\title{
PLANOS URBANOS LOCAIS: DEFINIÇÃO CONCRETA PARA A MOBILIDADE \\ E QUALIDADE AMBIENTAL URBANAS
}

Maria Elizabet Paez Rodriguez

Faculdade de Arquitetura

e Urbanismo

Universidade de São Paulo

São Paulo $\cdot 2013$

Exemplar revisado e alterado em relação à versão original, sob responsabilidade do autor e anuência do orientador.

O original se encontra disponível na sede do programa de Pós Graduação da FAU USP.

São Paulo o3 de dezembro de 2013. 


\section{PLANOS URBANOS LOCAIS: DEFINIÇÃO CONCRETA PARA A MOBILIDADE E QUALIDADE AMBIENTAL URBANAS}

Maria Elizabet Paez Rodriguez

Tese de Doutorado

Planejamento Urbano e Regional

Faculdade de Arquitetura

e Urbanismo

Universidade de São Paulo

orientador Prof. Dr. Emérito

Candido Malta Campos Filho

São Paulo $\cdot 2013$ 
Autorizo a reprodução e divulgação total ou parcial deste trabalho, por qualquer meio convencional ou eletrônico, para fins de estudo e pesquisa, desde que citada a fonte.

emailepaez@usp.br
Rodriguez, Maria Elizabet Paez

R696p Planos Urbanos Locais: definição concreta para a mobilidade e qualidade ambiental urbanas / Maria Elizabet Paez Rodriguez; orientador Candido Malta Campos Filho São Paulo, 2013

Tese (Doutorado - Programa de Pós-Graduação em Arquitetura e Urbanismo - Área de Concentração: Planejamento Urbano e Regional) - Faculdade de Arquitetura e Urbanismo da Universidade de São Paulo

$232 \mathrm{p}$.

1. Uso do Solo - 2. Planos Diretores

3. Áreas Metropolitanas - 4. Região Leste de São Paulo 5. Planos de Bairro

CDU 711.14 projeto gráfico capa+miolo Caroline Gabriel Pedro

imagem capa Francisco Gómez. Saconia-Dehesa de la Villa.

XII Congreso Mundial de la Union Internacional de Arquitectos, 1975, p.51 


\section{AGRADECIMENTOS}

Ao Professor Candido Malta Campos Filho e a todos os dedicados professores da Pós-Graduação da Faculdade de Arquitetura e Urbanismo da Universidade de São Paulo, por seus ensinamentos Aos funcionários da secretaria, da biblioteca e de apoio da Pós-Graduação da FAU, pelo profissionalismo e dedicação no trato com os alunos

Ao Bruno, pelo apoio inesperado

Ao Francisco, pela ajuda incansável

À Cristina, Vera, Suzana, Maria, Gisele e, principalmente, Caroline

Ao Raphael

Aos meus pais 
Na metrópole de São Paulo, o maior crescimento urbano se deu em direção ao Leste da cidade de forma irregular sob muitos aspectos. Atualmente vivem na Região Leste de São Paulo, quase quatro milhões de pessoas, com pouquíssima oferta de trabalho e de serviços públicos e privados de qualidade. A grande maioria dessa população é dependente do Centro Expandido para usufruir de bons serviços e da ocupação de postos de trabalho, mas com mobilidade urbana atualmente muito comprometida.

O objetivo desta tese é demonstrar que o planejamento urbano no Brasil para suas grandes cidades, tomando como exemplo São Paulo, cidade que tem sido pioneira em muitos aspectos nesse campo como em outros, não tem chegado a níveis conclusivos que permitam lidar com a principal problemática urbana: a de oferecer espaços públicos de qualidade enquanto áreas de convivência social através de Planos de Bairro, alcançando o tão necessário desenvolvimento urbano da região do extremo leste e outras regiões carentes do município de São Paulo.

Esta tese apresenta uma metodologia para a criação de Planos de Bairro sustentáveis e com qualidade urbana, através da conjunção do sistema de Transporte Público com a política de Uso e Ocupação do Solo, que possa oferecer ao habitante local trajetos curtos entre moradia e trabalho, escola e comércio e a possibilidade de caminhar e praticar atividades ao ar livre por seu bairro, em vias urbanas com qualidade ambiental.

Palavras chave: Uso do Solo, Planos Diretores, Áreas Metropolitanas, Região Leste de São Paulo, Planos de Bairro 
ABSTRACT

In São Paulo Metropolis, the largest urban sprawl felt towards the East Side of the city in an irregular way under all of the aspects. Nowadays, a population of almost 4 million people lives in the East Region of São Paulo, with a low level of employability offering and public and private services quality, with dysfunctional urban mobility.

The objective of this thesis is to demonstrate that urban planning in Brazil for this big cities, taking the example of São Paulo, city which has been a pioneer in many aspects in this field as in others, has not reached conclusive levels that allow to deal with its main urban problems: to offer quality public spaces as areas of social interaction by Neighborhood Urban Plans, reaching the much needed urban development of the extreme east and other needy areas of São Paulo City.

This thesis presents a methodology for the creation of sustainable Neighborhood Urban Plans with urban quality, through the conjunction of the Public Transportation System with a policy of Land Use, which can offer to the local inhabitant short displacement between home and work, school and commerce and the ability to walk and practice outdoor activities in his neighborhood, on environment quality full streets.

Key words: Land Use, Urban Planning Guidelines, Metropolitan Areas, São Paulo East Side, Neighborhood Urban Plans 


\section{RESUMEN}

En la metrópoli de São Paulo, el mayor crecimiento urbano ha tenido lugar hacia el Este de la ciudad de forma errática bajo muchos aspectos. Actualmente, viven en la Región Leste de São Paulo casi cuatro millones de personas, con muy poca oferta de trabajo y baja calidad en los servícios públicos y privados. La gran mayoría de esta población es dependiente del Centro Principal, Ilamado Centro Expandido para disfrutar de buenos servicios y para ocupación de puestos de trabajo, mas con movilidad urbana actualmente muy comprometida.

El objetivo de esta tesis es demonstrar que la planificación urbana en Brasil para sus grandes ciudades, tomando como ejemplo São Paulo, ciudad que ha sido pionera en muchos aspectos en ese tema como en otros, no ha tenido éxito en lograr niveles conclusivos que permitan lidiar con su principal problemática urbana: ofrecer espacios públicos de calidad mientras áreas de convivencia social bajo Planes de Barrio, logrando el tan necesario desarrollo urbano de la región del extremo leste de São Paulo.

Esta tesis presenta una metodología para la creación de Planes de Barrio sostenibles y con calidad urbana, tras una conjunción del sistema de Transporte Público con una política de Uso e Ocupación de la Tierra, que pueda ofrecer al habitante local caminos cortos entre su morada y trabajo, escuela y comercio y con posibilidad de caminar por su barrio y practicar actividades al aire libre en calles urbanas con calidad ambiental.

Palabras clave: Uso y Ocupación de la Tierra,

Planes Urbanos, Areas Metropolitanas, Zona Leste de São Paulo, Planes de Barrio 
ÍNDICE

1 APRESENTAÇÃO

2 PROBLEMÁTICA

9 OBJETIVOS

9 HIPÓTESE

11 JUSTIFICATIVAS PARA O TEMA

18 ESTRUTURA DA TESE

20 METODOLOGIA DE TRABALHO

27 CAPÍTULO I

FUNDAMENTAÇÃO TEÓRICA

28

SÃO PAULO METRÓPOLE 1965: CAOS ANUNCIADO

CORREDORES METROPOLITANOS

ESPAÇO INTRAURBANO

ESPAÇOS URBANOS PARA VIVER

41 VIDA ENTRE EDIFÍCIOS: USANDO O ESPAÇO PÚBLICO

45 O IMPACTO DO TRÁFEGO NAS VIAS RESIDENCIAIS

54 TRANUS: MODELAGEM MATEMÁTICA PARA CÁLCULO DE CAPACIDADE DE SUPORTE

58 OS PLANOS DE BAIRRO

69 CAPÍTULO II

SÃO PAULO RUMO AO LESTE: SUA ESTRUTURAÇÃO URBANA

71 SÃO PAULO RURAL

73 A ESTRUTURAÇÃO URBANA NA ESCALA DA METRÓPOLE

74 A ESTRUTURAÇÃO URBANA DA REGIÃO LESTE PAULISTANA COMO CONJUNTO DE METRÓPOLE

79 OS NOVOS BAIRROS DA REGIÃO LESTE

86 ESPRAIAMENTO URBANO: MENSURAÇÃO E DEFINIÇÃO

87 SÃO PAULO: ESPRAIAMENTO URBANO CONTÍNUO 
CAPÍTULO III

RUMOS URBANÍSTICOS EM SÃO PAULO 1960/2012: DIRECIONAMENTO DA ESTRUTURAÇÃO URBANA ATRAVÉS DOS PLANOS URBANOS

PUB-PLANO URBANÍSTICO BÁSICO DE SÃO PAULO

PMDI-GSP: PLANO METROPOLITANO DE DESENVOLVIMENTO INTEGRADO-

GRANDE SÃO PAULO

PAITT-PROGRAMA DE AÇÃO IMEDIATA DE TRANSPORTES E TRÁFEGO

PLANO DIRETOR DO MUNICÍPIO DE SÃO PAULO 1985/2000

PLANO DIRETOR ESTRATÉCICO PARA O MUNICÍPIO DE SÃO PAULO 2002/2012

A MOBILIDADE URBANA EM SÃO PAULO

129 CAPÍTULO IV

CENÁRIO PLANEJADO PARA A REGIÃO LESTE PAULISTANA: PLANOS EM VIGOR

AS DIMENSÕES METROPOLITANAS DA REGIÃO LESTE PAULISTANA

GOVERNO DO ESTADO-PLANOS HIDRORRODOFERROVIÁRIOS

PARA A METRÓPOLE DE SÃO PAULO

140 GOVERNO MUNICIPAL:

PLANOS PARA O DESENVOLVIMENTO URBANO DA REGIÃO LESTE PAULISTANA

143 POLÍTICAS PÚBLICAS VERSUS PLANOS URBANOS

145 OPERAÇÕES URBANAS CONSORCIADAS

148 COMPLEXO VIÁRIO JACU PÊSSECO-NOVA TRABALHADORES

149 OPERAÇÃO URBANA CONSORCIADA RIO VERDE-JACU

160 CONCLUSÃO 
CAPÍTULO V

CARACTERÍSTICAS TERRITORIAIS, POPULACIONAIS E SOCIOECONÔMICAS DA REGIÃO LESTE PAULISTANA

173 PERFIL SOCIOECONÔMICO

173 EMPRECABILIDADE

175 EDUCAÇÃO E CULTURA

175 USO E OCUPAÇÃO DO SOLO ATUAL

177 O TECIDO URBANO ATUAL

178 TIPOLOGIAS DE TECIDO URBANO

179 O TRAÇADO VIÁRIO

180 PRINCIPAIS CENTRALIDADES

$180 \quad$ TRANSPORTE PÚBLICO

181 MEIO AMBIENTE

183 CAPÍTULO VI METODOLOGIA PARA DEFINIÇÃO DE DIRETRIZES PARA PLANOS DE BAIRRO COM A ADOÇÃO DE UNIDADES AMBIENTAIS DE MORADIA
183 A UTILIZAÇÃO DO TRANUS EM PLANOS DE BAIRRO
188 CONCEITUAÇÃO PARA OS PLANOS DE BAIRRO
190 PLANOS DE BAIRRO: O URBANISMO ANTES DA POLÍTICA
191 UNIDADE AMBIENTAL DE MORADIA-UAM
193 ROTEIRO PARA UM PLANO DE BAIRRO
197 LEVANTAMENTOS E PARÂMETROS
198 SISTEMAS DE TRANSPORTE PÚBLICO
199 LEVANTAMENTOS TERRITORIAIS
200 LEVANTAMENTOS POPULACIONAIS
200 LEVANTAMENTOS SOCIOECONÔMICOS 


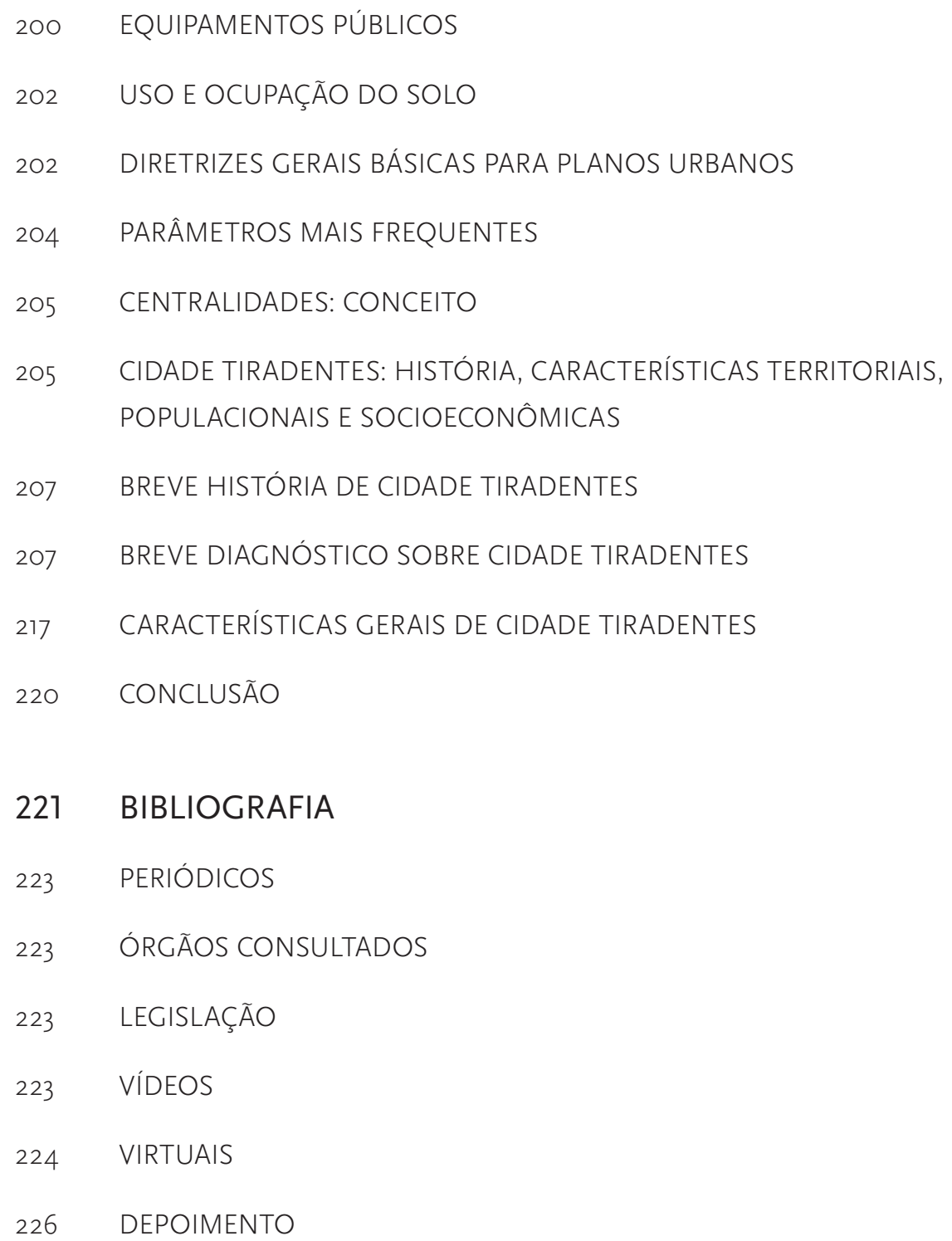

231 FIGURAS 


\section{APRESENTAÇÃO}

Esta é uma tese de doutoramento em Arquitetura e Urbanismo e área de concentração em Planejamento Urbano e Regional e tem como objetivo comprovar a inclusão nas políticas públicas de um planejamento local articulado ao mais amplo, municipal ou metropolitano, para obter-se o tão almejado equilíbrio e qualidade ambiental intraurbanos, ou seja, o planejamento de bairros em escala pontual de cada demanda por infraestrutura urbana, adotando-se de forma concreta a participação popular.

Em 1965, o urbanista Jorge Wilheim, em seu livro São Paulo Metrópole 65, detectou o que considerou como problemas urbanos típicos de uma metrópole e que já despontavam em São Paulo. (WILHEIM, 1965, passim) Segundo o autor, em 1965, São Paulo já estava em fase adiantada de metropolização e com uma população de cinco milhões de habitantes. Àquela altura, o autor já considerava a vida em São Paulo desumana para o cidadão e responsabilizava por isso o crescimento através de transformações espontâneas, o que chamaríamos hoje de crescimento desordenado.

Segundo análise do urbanista Candido Malta Campos Filho,

o denominado crescimento desordenado nada mais é que o resultado do entrechoque de interesses não suficientemente dirigido pelo poder público através de um planejamento urbano que atenda aos interesses da maioria de um lado, e de outro contemple, o capital produtivo e não o especulativo, seja ele financeiro, seja ele imobiliário. A análise do papel dos agentes produtores do espaço urbano, dos que usufruem da renda fundiária e dos consumidores das mercadorias imobiliárias, constituiu-se em um avanço teórico conquistado a partir da década de 1970 do século XX. (...) Naquela ocasião acreditavase de modo um pouco ingênuo que o planejamento por si só tudo resolveria, sem se considerar de modo suficiente as forças contrárias a ele. (...) Não considerando de modo suficiente esse entrechoque de forças sociais, pois na época as teorias disponíveis não abordavam de modo sistemático as forças sociais em presença na produção apropriação e consumo do espaço urbano, Wilheim credita ao planejamento urbano a solução dos problemas que serão enfrentados por uma suposta população de treze milhões nos próximos 35 anos da data da edição do livro. (informação verbal)'

O Município de São Paulo apresentou uma população de 9.600.696 habitantes em 1996, (IBGE) aproximadamente três milhões de habitantes a menos em relação aos treze milhões esperados pelas fontes consultadas por Wilheim. A forma encontrada para planejar o crescimento futuro dessa jovem metrópole foi criar-se seu primeiro Plano Diretor, o Plano Urbanístico Básico de São Paulo-PUB, contendo um conjunto de diretrizes para o desenvolvimento urbano e social, para a circulação, hoje chamada de mobilidade urbana, para os transportes e para os serviços públicos da metrópole São Paulo. O trabalho de diagnosticar a realidade socioterritorial de São Paulo foi executado pela Sociedade para Análises
1. Campos Filho. Depoimento à autora, 18 fev. 2013. 
2. Nos anos 1950, a SAGMACS, organização vinculada ao Mouvement Économie et Humanisme, dirigido pelo Padre Louis-Joseph Lebret realizou intensa pesquisa urbana com tônica social, política e econômica. (CESTARO, 2009, p.6)

3. O Centro Expandido está delimitado pelas marginais dos rios Pinheiros e Tietê e pelas Avenidas Salim Farah Maluf, Prof. Luis Inácio de Anhaia Melo, Juntas Provisórias, Tancredo Neves, Complexo Viário Maria Maluf, D. Affonso Taunay e Avenida dos Bandeirantes. Forma o Mini Anel Viário, utilizado também como referencial no rodízio de veículos semanal.

4. A Zona Leste 1 começa a partir do limite entre a Zona Central e os distritos de Belém, Brás, Pari, Mooca e Vila Prudente, incluindo também Água Rasa, Aricanduva,

Artur Alvin, Cangaíba, Carrão, Penha, Ponte Rasa, São Lucas, Sapopemba Tatuapé, Vila Formosa, Vila Matilde e Ermelino Matarazzo, totalizando dezoito distritos. A Zona Leste 2 inclui os distritos de Cidade Líder, Cidade Tiradentes, Guaianases, Iguatemi, Itaim Paulista, Itaquera, Jardim Helena, José Bonifácio, Lajeado, Parque do Carmo, São Mateus, São Rafael, São Miguel, Vila Curuçá e Vila Jacuí, totalizando quinze distritos.
Gráficas e Mecanográficas Aplicadas aos Complexos Sociais-SAGMACS, coordenado pelo Padre Lebret, do Instituto de Economia e Humanismo, com sede em Paris. ${ }^{2}$ Sem esse trabalho, teria sido impossível ao PUB atingir o nível de detalhamento a que se chegou. Lebret chegou ao nível de diagnosticar os déficits dos equipamentos em escala de bairro, ação provavelmente nunca mais repetida até o surgimento dos Planos Diretores Regionais de São Paulo.

Especialmente a partir da década de 1960, cresce a necessidade de deslocar massas de trabalhadores residentes a grandes distâncias das centralidades concentradoras de postos de trabalho em serviços e comércio diversificados e especializados. Além dos bairros dormitório das periferias, surgem as cidades dormitório na Região Metropolitana de São PauloRMSP, como Guarulhos, Santo André, Osasco e Mauá, e a crescente demanda por transporte público é ainda dependente de linhas de ônibus movidos a diesel. Esse panorama passa a ser visto como fato a combater.

As grandes distâncias entre o centro financeiro, econômico e cultural de São Paulo e os bairros populares resultantes da horizontalização descontrolada da mancha urbana do Município de São Paulo, principalmente em direção ao Leste, levaram os planejadores da cidade a implantar sistemas viários bidirecionais de longo percurso, voltados ao deslocamento diário dessas massas de trabaIhadores entre o Centro Expandido e as periferias, sem empreender o desenvolvimento qualitativo das urbanizações crescentes nas franjas da cidade.

A divisão territorial do Município de São Paulo possui 96 distritos, sob administração de 31 Subprefeituras em cinco Regiões: Centro, Norte, Sul, Oeste e Leste esta, subdividida recentemente em Região Leste 1 e Região Leste 2 devido à sua extensão e massa populacional. ${ }^{4} \mathrm{O}$ Mapa 1: Regiões, Subprefeituras e Distritos-Município de São Paulo
2009, tem por objetivo a fácil localização dos Distritos, Regiões e Subprefeituras ao leitor desta tese de doutoramento.

No decorrer deste trabalho, serão expostas as razões e argumentos que levaram à escolha da Região Leste 2 Paulistana-RLP2 como objeto de análise e o distrito de Cidade Tiradentes como exemplo para um roteiro para desenvolvimento de um Plano de Bairro. Mais adiante, outros mapas dedicados à Região Leste e com destaque para a RLP2 serão apresentados, demonstrando sua conexão e interdependência com o Centro Expandido e as características territoriais, populacionais e socioeconômicas necessárias ao estudo analítico da Região Leste Paulistana-RLP.

\section{PROBLEMÁTICA}

A problemática abordada nesta tese trata da falta de qualidade intraurbana nas periferias da Metrópole de São Paulo, que apresenta um caótico cenário urbano, principalmente em relação à mobilidade urbana de veículos, pessoas e cargas, comprometida pelas consequências das políticas públicas praticadas nas décadas passadas, como a opção pelo investimento na circulação de veículos sobre rodas, principalmente o automóvel em lugar do investimento em transporte público de qualidade e de acordo com a demanda.

Podem-se enumerar as questões urbanas com consequências negativas sobre praticamente todo o espaço urbano do município de São Paulo como o comprometimento crônico da mobilidade urbana, a baixa qualidade ambiental e o bem estar de sua população, causados pela ineficiência do transporte público em fase de esgotamento e obsolescência, as grandes distâncias a percorrer em transporte público e privado entre o local de moradia e local de concentração de oferta de empregos, o Centro Expandido, com a consequente baixa oferta de empregos qualificados 


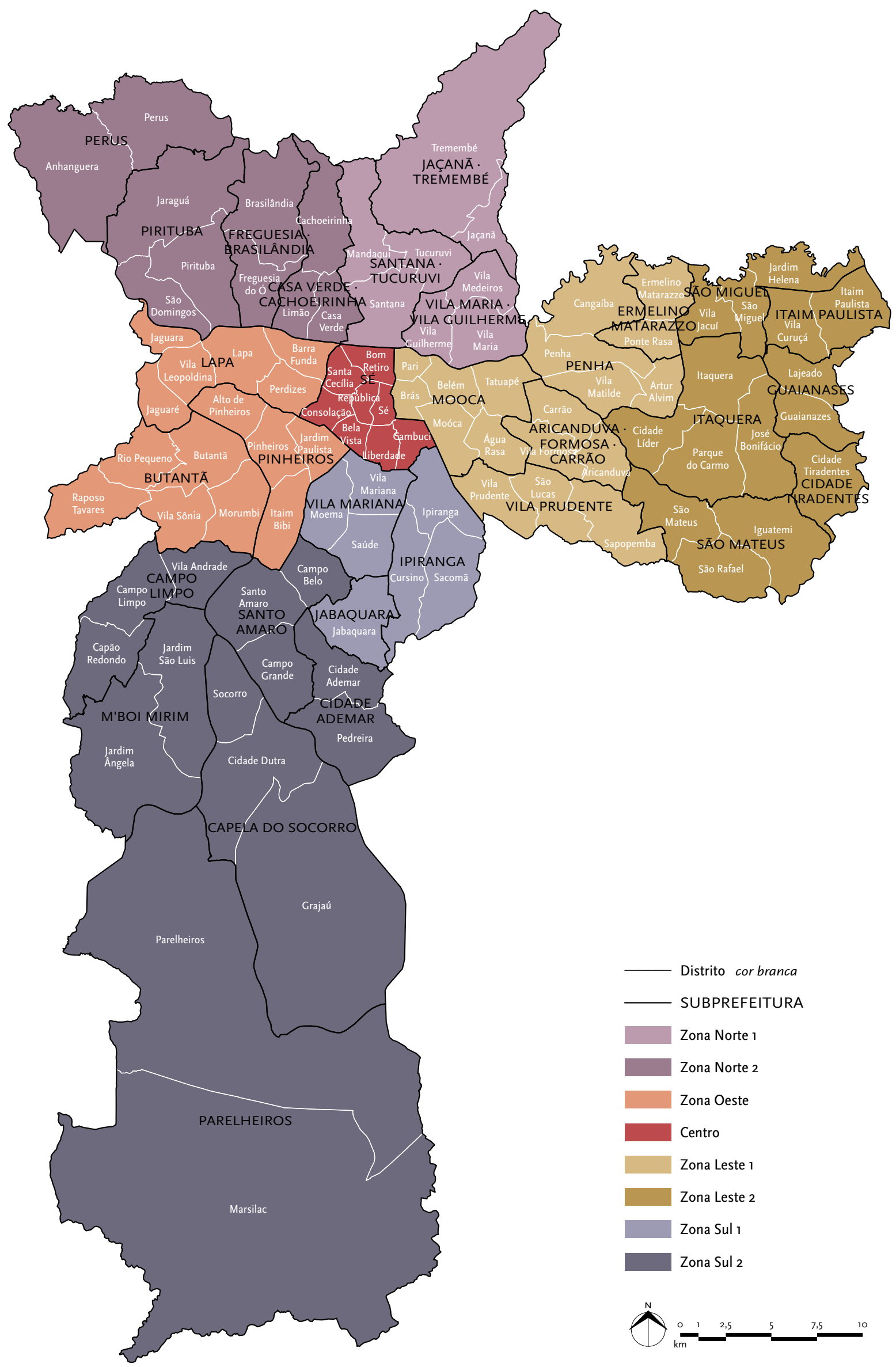

Mapa 1: Regiões, Subprefeituras e Distritos-Município de São Paulo 2009 PMSP/SEMPLA/Dipro 
5. A CPTM teve sua criação autorizada pela lei n. 7.861 , de 28 de maio de 1992, segundo a qual a nova companhia deveria assumir os sistemas de trens da Região Metropolitana de São Paulo, operados pela Companhia Brasileira de Trens Urbanos-

CBTU (Superintendência de Trens Urbanos de São Paulo-STU/SP e em 1996, a empresa assumiu a operação dos sistemas da FEPASA.

6. Vetor Sudoeste é termo utilizado por urbanistas para descrever o fato histórico ocorrido com a transferência da elite paulistana do distrito de Santa Ifigênia para os Campos Elíseos em fins do século XIX e posteriormente para o distrito de Higienópolis, fenômeno fruto da urbanização sanitarista. A partir daí, o mercado imobiliário se concentro em regiões do sudoeste da cidade. e em número suficiente próximo às moradias dos trabalhadores; a baixa oferta de serviços públicos nas regiões periféricas que obrigam seus habitantes a gerar novas e longas viagens em busca de serviços públicos, educação de nível superior, cultura; a falta de espaços públicos para a prática de esportes e lazer no espaço intraurbano, ou seja, nos bairros. Esses fatores em conjunto provocam os grandes e diários congestionamentos que degradam o meio ambiente e a qualidade ambiental das ruas e espaços públicos, desestimulando as atividades ao ar livre, gerando insegurança pública com o aumento da violência urbana e, consequentemente, a baixa produtividade do trabalhador paulistano e os incalculáveis prejuízos resultantes desse panorama urbano de início de século XXI.

Promover o desenvolvimento urbano de grandes áreas urbanas que se consolidaram a partir do modelo de urbanização colonial português representa um dos grandes desafios da atualidade para a administração pública nas regiões metropolitanas brasileiras, que depende da obtenção de verbas de valor altíssimo para promover reestruturações de grande porte, definitivas ou que apresentem metas mais duradouras.

A estruturação urbana da grande São Paulo ocorreu a partir de fatores como a ligação da Vila de São Paulo com a Corte Real, sediada na cidade do Rio de Janeiro, além da implantação de ferrovias para o escoamento da produção de café, como a São Paulo Railway, interligando o Porto de Santos à cidade de Jundiaí, na região cafeicultora e posteriormente rebatizada de Ferrovia Santos-Jundiaí. Hoje, essa ferrovia juntamente com a linha Central do Brasil, construída sobre o antigo Caminho da Corte, entre os municípios de São Paulo e Rio de Janeiro, faz parte do sistema ferroviário da Companhia Paulista de Transportes Metropolitanos- CPTM. Cogita-se agora, além do Trem de Alta Velocidade-TAV, um possível trem regional de média velocidade, ampliando a capacidade dessas interligações entre Jundiaí e São Paulo e a Metrópole a São José dos Campos, em um planejamento macro metropolitano que se inicia no âmbito da Secretaria de Transportes Metropolitanos do Governo do Estado de São Paulo. ${ }^{5}$

As duas ferrovias mencionadas acima em funcionamento no âmbito da CPTM têm seu início de percurso dentro do Centro Expandido de São Paulo e seguem em direção Leste, contribuindo de forma importante para a estruturação urbana histórica da Zona Leste desde o final do século XIX. Consequentemente, contribuiu de forma importante para a estruturação, a formação do tecido urbano e a mobilidade urbana da Região Leste. Mas, o desenho urbano adotado para a implantação desses sistemas rodoferroviários, de forma radial em relação ao centro principal e sem ligações transversais entre eles, delineou um grande espaço sem qualidade urbana ou desenvolvimento econômico, que é a RLP, objeto de estudo mais pormenorizado desta tese com foco nos planos locais. Esse grande espaço sem estruturação urbana, localizado entre a ferrovia Central do Brasil e o limite da cidade com os municípios de Santo André, Mauá e Ferraz de Vasconcelos, assim permaneceu até a implantação da Linha Leste do Metrô, paralelamente à ferrovia, mas que não foi suficiente para reestruturar todo esse imenso vazio urbano, diga-se assim

O crescimento de São Paulo contou com planos urbanos entre as décadas de 1960 e 2000 , especialmente o PUB, seguindo as tendências de ocupação, ou seja, a concentração de serviços de qualidade no Centro Histórico, Centro Novo e os novos centros financeiros do Vetor Sudoeste, palco principal da valorização imobiliária decorrente da concentração de investimentos públicos em infraestrutura urbana de boa qualidade. ${ }^{6}$

Exceções a essa tendência conservadora de manter o centro principal da metrópole como o grande polo 
de empregos encontramos em Lebret, que aponta em seu diagnóstico da SAGMACS as imensas desigualdades sociais inclusive enquanto equipamentos de comércio e serviços entre o centro da metrópole e seus municípios vizinhos e bairros periféricos do município paulistano, a serem resolvidas. Também Campos Filho em sua tese de doutoramento Um desenho para São Paulo: o Corredor Metropolitano como estrutura urbana aberta para a Grande São Paulo, de 1972, aponta, como diretriz básica para a solução da distância entre moradia e emprego e entre moradia e serviços e comércio urbanos de qualidade, a extensão gradativa de centralidades metropolitanas ao longo dos três eixos rodoferroviários paralelos aos três principais rios da metrópole e sua interligação futura por três arcos ou semianéis rodoferroviários.

Essas tendências, contraditórias entre si, são parcialmente mencionadas pela urbanista Sarah Feldman, que aponta duas lógicas de demarcação de zonas. A primeira foi o "respeito às tendências existentes" com, inclusive, o congelamento das zonas estritamente residenciais (especialmente, mas não apenas as da CIA City) e a segunda, que propôs uma "estrutura polinuclear para a grande parte da cidade," ou seja, o que seria um desrespeito às tendências, com todos os usos permitidos, exceto grandes indústrias. (FELDMAN, 2005, p.268) No entanto, afirmamos que Lebret, na Pesquisa SAGMACS do final de década de 1960, já apontava para a mescla existente de usos e o Zoneamento, finalmente aprovado em 1972, viria consagrar essa mescla através de zonas mistas aplicadas a cerca de $90 \%$ do espaço urbano de São Paulo.

Feldman cita o arquiteto Adiron Ribeiro, colaborador da Secretaria de Planejamento da Prefeitura de São Paulo durante a criação da Lei de Uso e Ocupação do Solo-LUOS, pioneira na estruturação de um zoneamento que vigorou de 1972 a $2002 .{ }^{7}$

As palavras de Adiron Ribeiro, sobre a principal meta da LUOS de 1972:

\begin{abstract}
Ela não se restringe a aspectos meramente físicos, mas envolve toda uma conceituação de organização social, toda uma conceituação de necessidades mínimas em termos de atendimento à população nos setores de serviços públicos, nos setores de lazer, nos setores de educação, nos setores de saúde etc. (Ribeiro, Adiron (1972) in Feldman, 2005 , p.265)
\end{abstract}

Segundo Feldman, a ideia central da LUOS de 1972 era a lei conter um modelo de cidade e perspectiva transformadora da lógica de ocupação do espaço. Mas, respeitar as tendências significou não entrar em conflito com os interesses do mercado imobiliário em relação ao zoneamento das áreas onde estavam os estoques de terrenos mais valorizados. (FeldMAn, 2005, p.265) À época, as tendências apontadas por Wilheim em 1965 continuavam as mesmas ou foram potencializadas após quase uma década de forte crescimento urbano e econômico em uma São Paulo que se encontrava em fase de subdesenvimento industrializado, conforme análise do economista Bresser Pereira. ${ }^{8}$

Formara-se uma Região Leste de altos índices de vulnerabilidade e baixos índices de qualidade urbana sem poder contar com a instalação de estabelecimentos e empresas que pudessem contribuir com grande oferta de postos de trabalho especializado, o que atrairia o interesse do mercado imobiliário e sua influência sobre setores da administração pública.

Nas décadas de 1960 e 1970, a produção de moradia para a população de baixa renda por parte do poder público ficou muito aquém da necessidade e os loteamentos ilegais e as construções precárias nas periferias do município permaneceram, mantendo muito baixa a qualidade ambiental para seus habitantes, considerando-se a moradia precária e as distâncias entre estas e os centros concentradores de postos de trabalho.
7. A lei n. 7805 , primeira lei geral de zoneamento do munícipio de São Paulo, limitou o Coeficiente de Aproveitamento-CA, a uma vez a área do terreno para quase toda a cidade, contrariando frontalmente o setor imobiliário. A fórmula de Adiron, na verdade introduzida na gestão de João Evangelista Leão pela lei n. 8001, foi um recuo a que essas forças o obrigaram a fazer, a ele e evidentemente à Prefeitura e, na sequência, à Câmara Municipal, instituindo um aumento significativo do CA com uma contrapartida supostamente benéfica de redução da Taxa de Ocupação-TO. Os prédios isolados no lote passavam a ser a tipologia preferencial do mercado imobiliário como ocorre até hoje, com a legislação aprovada pela lei n. 13885/04. (CAMPOS FILHO. Depoimento à autora, 18 fev. 2013)

8. O período industrial pode ser dividido em duas fases: a da Revolução Industrial Brasileira, entre 1930 e 1960 , e a de Subdesenvolvimento Industrializado, entre 1960 e 1980. (Bresser Pereira, 1982, p.13) 


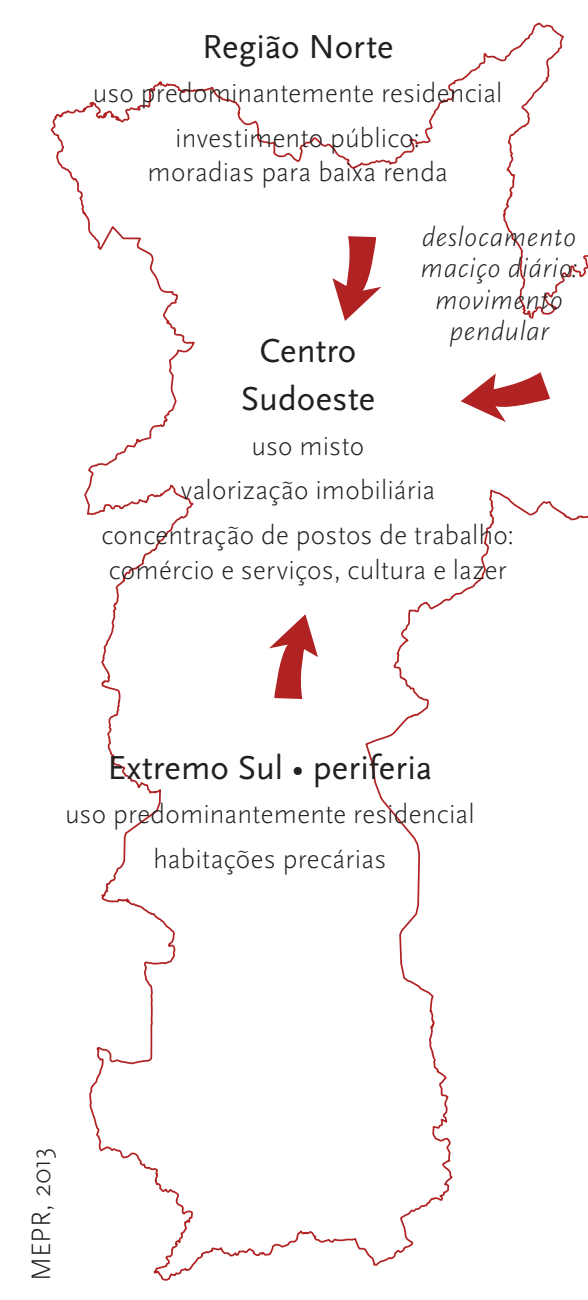

Figura 1: CenÁrio ocorrido ENTRE 1950 E 2010

uso do solo • investimento público - trabalho edificações. Percebe-se claramente a predominância do uso residencial, representado pelas cores bege e amarela, desde o extremo leste da mancha urbana até muito próximo do Centro Expandido, onde distritos como Tatuapé, Belém, Brás, Mooca, Vila Prudente e Água Rasa contam com mais equipamentos de qualidade para os usos comercial, serviços e institucionais para saúde e educação. Os distritos na área do extremo leste do município, nos limites com os municípios de Mauá e Ferraz de Vasconcelos, contam inclusive com grandes extensões de loteamentos irregulares e construções precárias, ou favelas, em áreas públicas invadidas e de controle ambiental. Ainda no Mapa 2, as cores de emprego" ao discutirmos os níveis de especialização de centralidades, no Capítulo IV, juntamente com a análise de mapas mais recentes com a distribuição de estabelecimentos e postos de trabalho pela mancha urbana de São Paulo, onde se conclui que o panorama de 2000 pouco mudou na última década.

A Figura 1: Cenário ocorrido entre 1950 e 2010, apresenta um diagrama esquemático do processo de concentração de postos de trabalho no Centro Histórico e no Vetor Sudoeste desde a década de 1950 e que ainda representa a realidade atual no Município de São Paulo. Como resultante, temos na primeira década do século XXI grandes áreas e regiões com uso misto, predominantemente residencial, com pouca oferta de serviços e comércio diversificados, estes concentrados há décadas no Centro Expandido, como mostra o Mapa 2: Uso do Solo Predominante-Distritos de São Paulo 2010 (p.8) que apresenta a distribuição de uso do solo predominante por quadra fiscal dos usos serviços, comércio, indústria, educação e saúde e comprova a predominância do uso residencial, de alto, médio e baixo padrão, este último altamente incidente na região do extremo leste do Município de São Paulo, o que comprova que o contingente de moradores é muito grande, apesar da menor verticalização das laranja e terra representam edificações de uso misto, com residências no pavimento superior e salões comerciais ou pequenas indústrias de transformação ou manutenção no andar térreo, modelo de ocupação datado da época da industrialização de São Paulo, no início do século XX, o que ainda garante o sustento de artesãos e trabalhadores autônomos, como chaveiros, serralheiros, vidraceiros e outros.

Fica evidente que o setor terciário não se desenvolveu de forma a absorver um contingente maior de mão de obra local nas regiões Leste e Norte do Município de São Paulo. Nem mesmo no distrito da Penha, ao longo da Linha Leste do Metrô, onde foram implantadas cinco estações de embarque, esses setores se desenvolveram em nível mais diversificado. A predominância é fortemente residencial com serviços e comércio de âmbito predominantemente local e algo diversificados.

Ao sul do distrito do Tatuapé, conhecido por seu desenvolvimento urbano a partir dos lançamentos imobiliários de alto padrão, as conhecidas ilhas de prosperidade, nas últimas duas décadas e no distrito de Vila Formosa, ocorre o mesmo fenômeno.

Deve-se levar para a Região Leste oferta de serviços e comércio mais especializados que o nível local de 
comércio, serviços e pequenas indústrias (oficinas) que já existe lá, porém em consonância com a massa de moradores e seu nível de renda, geradores de respectiva demanda por esses empregos mais especializados. Assim, as empresas que por lá se instalarem poderão contribuir com um número de postos de trabalho importante e com o poder de manter parte da população trabalhando em seu bairro, mais perto de sua residência, o que gera economia. A comparação deve ser feita analisando-se no Mapa 2: Uso do Solo Predominante-Distritos de São Paulo 2010 a incidência destes usos nas áreas dentro do Centro Expandido, mais precisamente em suas áreas centrais, que apresentam diferentes níveis de especialização e, no vetor sudoeste paulistano de desenvolvimento urbano, onde o nível de oferta inclui não somente o de âmbito local e o diversificado, como o diversificado sofisticado.

Durante a expansão em direção ao Leste do Município, os sistemas viários para transporte público de massa, implantados nas décadas de 1970 e 1980, ocorreram em áreas já urbanizadas consolidadas ou em consolidação. Exemplo disso foi a implantação da Linha Leste do Metrô em faixa paralela à linha ferroviária, proposto por Campos Filho quando este era o titular da Coordenadoria Geral de Planejamento-COGEP, na gestão do Prefeito Olavo Setúbal. (informação verbal) ${ }^{9}$

A partir da década de 1990, os sistemas viários para transporte público de massa têm sido implantados ora sobre áreas ainda pouco urbanizadas ou com baixa qualidade de urbanização, ora sobre sistemas já concretizados como, por exemplo, a implantação do Expresso Tiradentes, via exclusiva para ônibus, atualmente com oito quilômetro de extensão, com trecho sobre a laje que cobriu em parte o Rio Tamanduateí, na avenida do Estado, região centrosul do Município de São Paulo, e que seguirá em forma de VLT até o distrito de Cidade Tiradentes. ${ }^{10}$
Apesar do conhecimento por parte do poder público dos problemas urbanos que se tornavam crônicos desde a década de 1960, a administração pública de São Paulo não evitou que a concentração de serviços e comércio especializados ocorresse somente no Centro Histórico, Centro Novo e centralidades que se tornavam importantes para a economia, como a Avenida Paulista, Avenida Brigadeiro Faria Lima e outras, deixando de incentivar o desenvolvimento de outras regiões da cidade, como a Zona Norte, Zona Sul e Zona Leste, que em pleno início do século XXI ainda se mostram muito carentes em relação à oferta de empregos, comércio e serviços diversificados e especializados, além da falta de instituições culturais, atendimento de qualidade na saúde e educação públicas. O problema culmina na atual situação do transporte público de massa, que se encontra em estado de total esgotamento e, em consequência, oferece serviços de baixa qualidade, apesar da alta capacidade das linhas existentes de metrô e trens urbanos, da CPTM."

As secretarias municipal e estadual dedicadas ao planejamento urbano de São Paulo, tanto de visão setorial como as que visam sua integração, por décadas se dedicaram ao planejamento de estruturas viárias e de transporte público. Isso ocorreu na forma de produção predominante de grandes obras viárias no Centro Expandido, voltadas para a circulação da crescente frota de veículos e sistemas de transporte público conectando as periferias ao centro. Essas iniciativas refletem um único e principal propósito: grandes obras de engenharia desenhadas para transportar grandes massas de indivíduos de um ponto a outro da metrópole, diariamente, respondendo ao paradigma de que o Centro Expandido se incumbiria de prover postos de trabalho, serviços e comércio diversificado, especializado e qualificado ao restante da população, não residente nesse centro.
9. Campos Filho, Depoimento à autora, 12 out. 2012

10. O Expresso Tiradentes será um corredor exclusivo de ônibus com 31,8 quilômetros de extensão que, quando concluído, ligará o Parque D. Pedro II à Cidade Tiradentes, zona leste da cidade. O primeiro trecho, de oito quilômetros, inaugurado em 9 mar. 2007 pela Prefeitura de São Paulo, liga o Terminal Sacomã à Estação Mercado, no Parque D. Pedro II, Centro de São Paulo. (EMTu. Rede de Transporte: Expresso TiradentesSacomã. Acesso em 25 maio 2013)

11. O Metrô de São Paulo atingiu níveis de superlotação quando a ocupação indicava "níveis até 50\% acima do limite aceitável de conforto dos usuários," superando "redes de trilhos mais movimentadas do mundo, como Tóquio e Moscou." Segundo dados da própria Companhia do Metrô, a Linha Vermelha Leste-Oeste, a mais movimentada do sistema, passou de 7,5 para 9 passageiros por metro quadrado desde 2007 , "embora pela previsão devessem abrigar no máximo 6 passageiros por metro quadrado." Em matéria jornalística, o consultor Peter Alouche, com 30 anos de carreira no Metrô, afirma que, enquanto o metrô de Tóquio transportou média de 8,3 milhões de passageiros por quilômetro entre 2007 e 2008 , 0 metrô paulistano transportou em torno de 10 milhões de passageiros por quilômetro/ano, nesse mesmo período. Nessa mesma publicação, o Metrô atribui a alta no uso desse sistema à implantação do programa Bilhete Único e ao aquecimento da economia. (Pequeno, João. Viagem é até $60 \%$ mais demorada no pico. Folha de S. Paulo, 21 abr. 2008) 


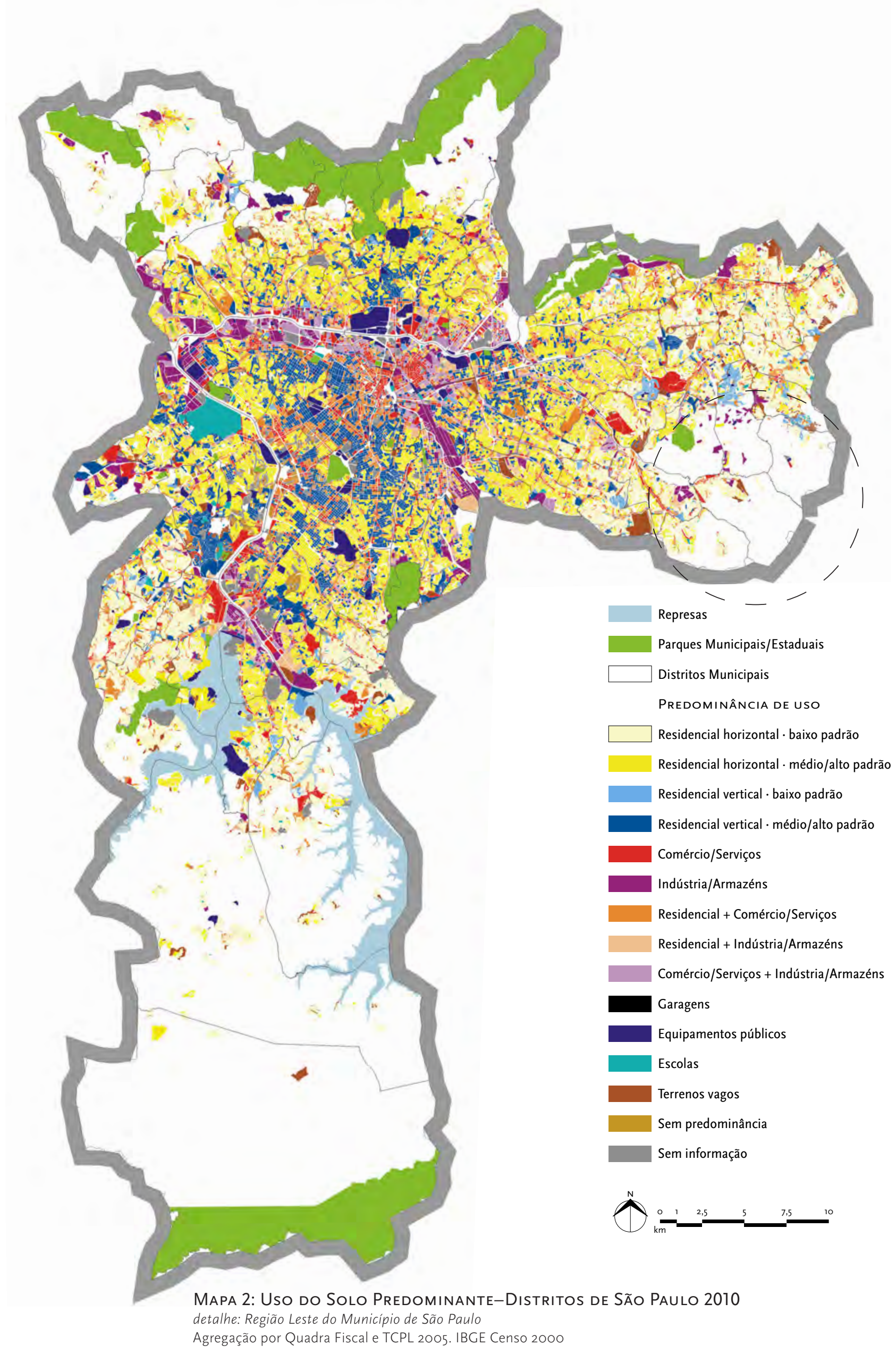




\section{OBJETIVOS}

O objetivo desta tese é comprovar que a requalificação urbana de áreas metropolitanas brasileiras que se estruturaram de forma irregular, inicialmente em torno de paradas de trens e ao longo dos caminhos de ligação regional e, posteriormente, com o preenchimento dos vazios deixados por uma urbanização desconexa, seja embasada em um planejamento local articulado o mais amplamente possível, onde se combinam técnicas que promovam um equilíbrio entre a oferta e a demanda por sistemas de circulação, tendo em vista a geração de viagens por atividades urbanas. Técnicas estas que eliminem ou reduzam os congestionamentos no tráfego de veículos públicos ou particulares, degradadores ambientais, a níveis aceitáveis. Deve-se quantificar, para isso, as variáveis envolvidas e desenvolver esse planejamento de modo articulado com um planejamento de bairros, que defina as soluções concretas a que os cidadãos têm direito. Enquanto a oferta de equipamentos sociais e infraestrutura urbana não for adequada, não se alcançará o objetivo de obterse espaços públicos de qualidade ambiental que promovam a convivência social produtiva, apanágio das cidades.

O planejamento urbano para as grandes cidades no Brasil não tem chegado a níveis conclusivos que permitam dar conta da problemática urbana em relação à qualidade ambiental acima mencionada. Para isso, faz-se necessário completá-lo com duas modalidades. Primeiramente, um cálculo de capacidade de suporte do sistema de circulação em relação às atividades distribuídas no território, reguladas em certa medida pela legislação urbanística e, depois da Constituição Federal de 1988, por políticas de desenvolvimento urbano orientadoras de planos diretores e por incentivos extrafiscais que visem fazer com que a cidade e a propriedade para fins urbanos cumpram função social. Em segundo lugar, um planejamento em escala local através de planos urbanísticos de intervenções localizadas em parcelas do espaço urbano, normalmente feitas por Operações Urbanas Consorciadas, mas também previstas através de Áreas de Intervenção UrbanaAIUs ainda não aplicadas, de modo articulado com os Planos de Bairro, como se definirá.

\section{HIPÓTESE}

Qualificar os espaços públicos visando promover neles a convivência social produtiva, que inclui também o desfrutar da cidade, o andar a esmo para descobrir suas qualidades, implica em dar concretude ao planejamento, ou seja, os planos devem deixar de ser apenas constituídos de diretrizes para enveredar-se na definição do que fazer, onde, quando e com que verba, concretude esta que deveria constituir qualquer plano.

Esta tese de doutoramento promove a aplicação de conceitos urbanísticos e metodologias desenvolvidas com o propósito de reestruturar áreas de tecido urbano em consolidação buscando requalificá-las a partir de uma readequação de uso do solo conjugada a uma política consistente de transporte público intraurbano e conectado ao Centro Expandido. Um plano conjunto de uso do solo e transporte público bem delineado e que permita ao habitante deslocamentos mais curtos entre moradia e trabalho, desafogará significativamente as vias hoje dominadas pelo automóvel particular, com consequente melhoria do meio ambiente e da qualidade de vida dos cidadãos que deles desfrutarem.

Consequentemente, a melhoria da infraestrutura urbana promove a requalificação de vias e áreas públicas e atrai o interesse dos habitantes e empreendedores locais que, por sua vez, promovem a melhoria de seus estabelecimentos e moradias. Não se pode esquecer que há a contrapartida negativa em relação à valorização do espaço urbano, que é 
12. As Operações Urbanas visam promover melhorias em regiões pré-determinadas da cidade através de parcerias entre o Poder Público e a iniciativa privada. Cada área, objeto de Operação Urbana, tem uma lei específica estabelecendo as metas a serem cumpridas, bem como os mecanismos de incentivos e benefícios. O perímetro de cada Operação Urbana é favorecido por leis que prevêem flexibilidade quanto aos limites estabelecidos pela Lei de Zoneamento, mediante o pagamento de uma contrapartida financeira. Este dinheiro é pago à Prefeitura, e só pode ser usado em melhorias urbanas na própria região. Uma lei de Operação Urbana pode conter concessões não onerosas, entendidas como um estímulo adicional à ocorrência de investimentos na área. Disponivel em <http://www.prefeitura.sp.gov.br/ cidade/secretarias/desenvolvimento_ urbano/sp_urbanismo/operacoes_ urbanas/index.php? $p=19525>$ Acesso em 20 fev. 2013. a expulsão de moradores locais de baixa e média renda que passam a não poder arcar com aumentos desproporcionais nos valores de aluguéis e tem que se deslocar para regiões onde o custo da moradia é mais baixo, uma vez que o transporte público não tem o preço de sua tarifa aumentada em função da distância. Mas, hoje, esse fato pode e deve ser mitigado a partir de instrumentos públicos baseados no Estatuto da Cidade e do Plano Diretor Estratégico para o Município de São Paulo.

No fim da década de 1990 e pouco antes da privatização da telefonia em São Paulo, o mercado de serviços apresentou grande expansão na área de Contact Center ou Call Center. A escassez, naquele momento, de infraestrutura de comunicações na maior parte da área urbana motivou as empresas de telemarketing e serviços de assistência via telefone a transferirem ou expandirem suas instalações para o Centro Novo, região entre o Vale do Anhangabaú e Consolação, que apresentava infraestrutura de comunicação com disponibilidade suficiente para atender a essa nova demanda, somada à grande oferta de transporte público, entre metrô e linhas de ônibus municipais. Caso dispusessem de infraestrutura e tecnologia de comunicações adequadas, as regiões Norte e Leste de São Paulo poderiam ter sido contemplados com a chegada desses blocos de postos de trabalho, uma vez que o contingente de trabalhadores dessas mesmas redes de serviços já é formado basicamente por moradores dessas duas regiões, evitando assim a deseconomia causada pelo deslocamento de massas de trabalhadores até o Centro Novo para trabalhar.

A implantação de planos de transporte público intraurbanos específicos para a essas regiões de São Paulo associados à reestruturação de uso do solo, na forma de Planos de Bairro, poderá oferecer aos habitantes locais trajetos curtos entre moradia e trabalho, moradia e escola e a possibilidade de caminhar por seu bairro, em direção ao trabalho, compras e serviços diversificados ou pontos de lazer, em vias urbanas com atividades ao ar livre.

A Região Leste de São Paulo tem população e demandas de dimensões nacionais, uma vez que concentra uma população de pouco mais de quatro milhões de cidadãos, ou seja, 35\% da população total do município, divididos entre 33 distritos, com área total de 29.171 hectares. (IBGE, Censo 2010) A pesquisa Origem/Destino-OD 2007, da Companhia do Metrô, aponta um total de 6.180.673 viagens produzidas e 6.178.510 viagens atraídas à Zona Leste. Uma região com dimensões e demandas de um país deveria apresentar também potencial para manter um maior número de habitantes onde residem a partir da oferta de postos de trabalho especializado e serviços de qualidade em educação, saúde, cultura e lazer.

O adensamento habitacional a partir da verticalização ao longo de corredores com a substituição de construções precárias de uso residencial, muitas vezes em áreas irregulares, permitirá a localização de áreas não ocupadas para a implantação de equipamentos públicos hoje rarefeitos na Zona Leste, como equipamentos para a prática de esportes, hospitais e postos de saúde. As grandes distâncias entre essa região da Metrópole e as principais centralidades existentes no Centro Expandido justificam um planejamento que permita o desenvolvimento urbano adequado da Região Leste e contribua para o equilíbrio urbano de toda a metrópole. Com a implantação da Operação Urbana Consorciada'2 Rio Verde-Jacu - OUC-RVJ, este é o momento adequado para seu desenvolvimento, mais precisamente a carente Região Leste 2, como vem sendo referenciada pelos técnicos dos órgãos públicos que, em função das dimensões da dessa região do município, foi dividida em Leste 1 e Leste 2.

Como solução para a inserção da Região Leste Paulistana de forma consistente como parte ativa e produtiva da metrópole, defende-se nesta tese a 
reestruturação intraurbana em escala local da região do extremo leste da capital, a partir de diretrizes gerais constitutivas de um plano urbanístico de uso e ocupação do solo, coordenado com uma reestruturação do sistema de circulação de veículos e de transporte intraurbano individual e coletivo e de espaços de circulação e usufruto do espaço público como lazer e cultura. Deve-se desenvolver esse planejamento também enquanto demandas habitacionais e de equipamentos sociais de serviços infraestruturais, de modo que, como cidadãos, seus moradores tenham possibilidade de acesso aos bens públicos a que têm direito, tanto em nível local como regional.

A solução acima pode ser ainda aplicada a todos os planos urbanos desenvolvidos para São Paulo como município e como metrópole, nas últimas quatro décadas, para entender a lógica de planejamento de nossas administrações públicas, guiadas também pela força da valorização territorial e o mercado imobiliário, especialmente por sua colaboração histórica na especulação imobiliária. Como observou Campos Filho, a especulação imobiliária exacerbou esse processo concentrador de comércio e serviços diversificados de alta qualidade nos bairros de maior poder aquisitivo e também contribuiu para um muito maior crescimento espacial com a prática de deixar vazias ou subutilizadas extensas áreas urbanas. (CAMPOS FILHO, 1989, passim)

O governo municipal e metropolitano de São Paulo vem introduzindo políticas públicas eficazes em diversas áreas da administração pública em geral, como as Operações Urbanas Consorciadas que introduzem a possibilidade de uma requalificação urbana de tecidos urbanos em vários aspectos: viário, uso do solo, social. Mas deve-se enfatizar aqui a introdução de instrumentos urbanísticos importantes, como os Planos de Bairro, como completadores dos planos urbanos, que têm sido mais generalistas quanto à escala das proposições, especialmente no que tange aos equipamentos comunitários, a exemplo do Plano de Bairro de Perus, na Zona Noroeste da cidade, cujo projeto e plano de diretrizes foram desenvolvidos com a coordenação técnica do urbanista Candido Malta Campos Filho e equipe, com a utilização de metodologia própria por ele definida, que tomaremos como base para nossas propostas de plano local por sua pertinência, conforme será mais bem exposto adiante.

\section{JUSTIFICATIVAS PARA O TEMA}

Alta vulnerabilidade, baixa empregabilidade e crescimento populacional sem o devido suporte em educação e qualidade habitacional são os problemas crônicos da Região Leste Paulistana-RLP. Seu desenvolvimento urbano é primordial e já tem a atenção da administração pública voltada para essa importante questão, pelo menos desde os anos 80, com a aprovação de um grande distrito industrial ao longo da Estrada do Pêssego pela legislação do zoneamento. (Zona 7 em 1981) No entanto, as iniciativas públicas para obtê-lo não deram ainda resultados satisfatórios. Ainda que tardiamente, na última década, planos mais efetivos como a OUC-RVJ associada à nova via Jacu Pêssego de interligação metropolitana do ABCD a Guarulhos, cuja implantação está sendo terminada, passaram a viger. A OUC$\mathrm{RV}$ ), associada a um novo eixo ou arco de interligação entre os corredores metropolitanos do Tietê, Tamanduateí e Pinheiros, como propôs Campos Filho em 1972, será detalhada no Capítulo IV. ${ }^{13}$ Excluir grandes regiões dos planos urbanos ou deixar de aplicar as propostas definidas nesses planos contribui para a queda gradual da qualidade ambiental das cidades e metrópoles ao redor do mundo, mais fortemente em metrópoles que não deem a devida atenção à oferta de transporte público adequado e bem dimensionado às demandas.
13. Como desenvolvido em sua tese de doutoramento e reproduzido em seus livros Cidades Brasileiras: seu controle ou o caos (1989) e Reivente seu Bairro (2003). 
Cidades com padrão de urbanização espanhola ou portuguesa na América Latina não têm sistema rodoviário ou vias destinadas aos veículos sobre pneus com dimensões para suportar altos volumes de veículos, mesmo com as prioridades dadas nos últimos 50 anos, de fato, para a sua ampliação, contrariando as políticas públicas que enfatizaram nesse mesmo período a necessidade de investimentos predominantes em sistemas de transporte público bem dimensionados, como ocorre em Buenos Aires, capital Argentina, cujos habitantes contam com bom sistema metroviário.

A concentração de postos de trabalho no Centro Expandido de São Paulo e, consequentemente, a carência crônica de empregos mais diversificados na Região Leste, onde predominam os empregos ditos locais, obriga a população economicamente ativa residente nessa periferia a se deslocar em trechos de quinze quilômetros, em média, do local de moradia ao local de trabalho ou estudo. (Metrô, 2007, Pesquisa OD).

A baixa qualidade dos serviços oferecidos no transporte público ou a carência de sistemas adequados a cada demanda, inevitavelmente, leva a classe média a optar pelo uso do transporte particular, o automóvel. O uso prioritário do transporte individual e o volume atual da frota de veículos existente em São Paulo produzem congestionamentos diários que comprometem a qualidade ambiental, a qualidade de vida e a economia da cidade.

O desenvolvimento da região do extremo leste de São Paulo deve ser adotado como plano urbano prioritário pela prefeitura, de forma a recriar, dentro do tecido consolidado ou em consolidação da RLP, uma área com qualidade urbana em todos os usos, tanto o residencial, como o comercial, o de serviços em geral e destacadamente, os serviços de saúde e de educação, que sejam compatíveis com a demanda por eles, de modo a dar-lhes base econômica, sejam eles públicos ou privados. Essa não é uma questão simples como muitos imaginam, pois sempre haverá uma competição entre as centralidades existentes que podem se desenvolver e as novas centralidades que se pretenda implantar. Essa questão será discutida mais adiante no Capítulo IV.

A partir da ideia aqui defendida de que a qualidade urbana só é alcançada quando planos urbanos de reestruturação de Uso do Solo vêm acompanhados de políticas de transporte público adequadas à região que se deseja reestruturar ou corrigir, esta tese defende o re-estudo dos modelos de circulação de veículos e pedestres nas vias existentes e os sistemas de transporte público local que permitam a mobilidade intraurbana justificando essa reestruturação e, consequentemente, viabilizando o desenvolvimento urbano e econômico a partir do surgimento de serviços e comércio mais diversificados e especializados do que os existentes, além de outros usos indispensáveis à qualidade urbana, como os industriais ou para-industriais, como os centros de logística fora do tecido urbano e ao longo de sistemas rodoferroviários. O desenvolvimento econômico da região que traga oportunidades de trabalho com crescimento profissional promoverá mobilidade social e certo nível de inclusão social almejada pela população da RLP.

Existe amplo consenso entre especialistas sobre as relações causais entre a forma ou estruturação urbana e o desempenho do sistema de transportes. Os efeitos desses dois fatores se alimentam e retroalimentam entre si, resultando que o segundo molda a cidade enquanto o primeiro tem influência direta nas demandas de transportes. (...) Os elementos da forma ou estrutura urbana, a saber, densidades de população e empregos e suas localizações - atividades, bem como suas dimensões e os tecidos urbanos existentes, impactam as demandas de deslocamento e o funcionamento do sistema de transportes. 
Inversamente, os componentes do sistema de transportes - desempenho da oferta em termos de custo e tempo das viagens influenciam os preços do mercado imobiliário e, portanto, a distribuição das atividades na cidade. (GESP-STM. 2009, p.17)

Deve tal política e consequente planejamento urbano serem produzidos a partir da análise do sistema de circulação que inclua o traçado rodoviário existente (constituído pelo sistema viário em sua hierarquia de funcionamento e a dosagem de tipos de vias, praticada em atendimento aos veículos de transporte individual e aos de transporte coletivo, além dos veículos de carga sobre pneus), assim como o ferroviário, entendendo-se como tal as linhas de metrô pesado e leve assim como os trens da CPTM que paulatinamente estão atingindo o padrão metroviário. Esse levantamento incluirá assim o uso real do solo que dependeu basicamente do poder estruturador do sistema de circulação, em face da demanda dos cidadãos distinguida por camadas de níveis de renda. Esse levantamento será realizado utilizando-se técnicas e conceitos urbanís ticos baseados nas distâncias reais comparando-as com as distâncias-limite a percorrer caminhando, em ônibus, vans e outros tipos de deslocamento. Adotou-se o conceito de Unidade de Vizinhança como Campos Filho desenvolveu em seus livros Cidades Brasileiras: seu controle ou o caos (1999) e Reinvente seu Bairro (2003) e aplicou no Plano de Bairro de Perus, com a denominação por ele proposta de Unidades Ambientais de Moradia. A partir desse conceito, adotou-se o de Ilhas de Tranquilidade pela qual se busca a transformação das áreas mistas existentes entre as diversas vias estruturais em unidades de vizinhança, de modo a conferir-lhe qualidade ambiental com oferta de comércio e serviços de abrangência apenas local, que contribua para a desejada tranquilidade de um bairro residencial. No entorno, situado nas vias de interligação dessas ilhas e a uma conveniente distância a pé, devem se situar os serviços e o comércio diversificados de qualidade e até os empregos industriais compatíveis com os bairros de moradia ao lado das indústrias. O conceito de Plano de Bairro já aplicado em São Paulo no distrito de Perus representa a última etapa de requalificação urbana resultante da reestruturação de transporte público e usos, ainda ausente no planejamento de 95 dos 96 distritos existentes de São Paulo, à exceção do Plano de Bairro do distrito de Perus, já mencionado. ${ }^{14}$

O conjunto de mapas temáticos a seguir é apresentado para que se tenha um panorama inicial das condições urbanas da RLP. Foi extraído da publicação Olhar São Paulo: Contrastes Urbanos, da Secretaria Municipal de Planejamento da Prefeitura de São Paulo-SEMPLA (2008), e apresenta uma síntese sobre a cidade, situando o município no contexto metropolitano em três quadros analíticos: demográficos, econômico e social, "este último focado especialmente nos grupos populacionais mais expostos à situação de pobreza ou de vulnerabilidade social." (SEMPLA, 2008, p.15)

O Mapa 3: Taxa de crescimento anual da população-Município de São Paulo 1991/2006 apresenta as taxas de crescimento populacional entre 1991 e 2005 no Município de São Paulo. Apesar da falta de infraestrutura urbana básica suficiente para o atendimento às populações do extremo leste da cidade, os distritos de São Rafael, Cidade Tiradentes e Iguatemi, dentro da área tracejada à direita, estão em segundo lugar em crescimento populacional, equiparando-se aos distritos de Parelheiros e Marsilac, ambos da região do extremo Sul. Os distritos com maior crescimento situam-se no extremo noroeste do mapa: Anhanguera e Perus. Observe-se que bairros ou distritos centrais continuam a perder habitantes, apesar da infraestrutura urbana completa de que dispõem.
14. A experiência prática contou com participação popular detectada no Plano de Bairro, segundo desejo popular constatado por votação formal e por aprovação por lei do bairro Branca Flor em Itapecerica da Serra, o pioneiro em todo Brasil, e a votação popular do Plano de Bairro de Perus. Campos Filho. Depoimento à autora, 15 mar. 2013. 


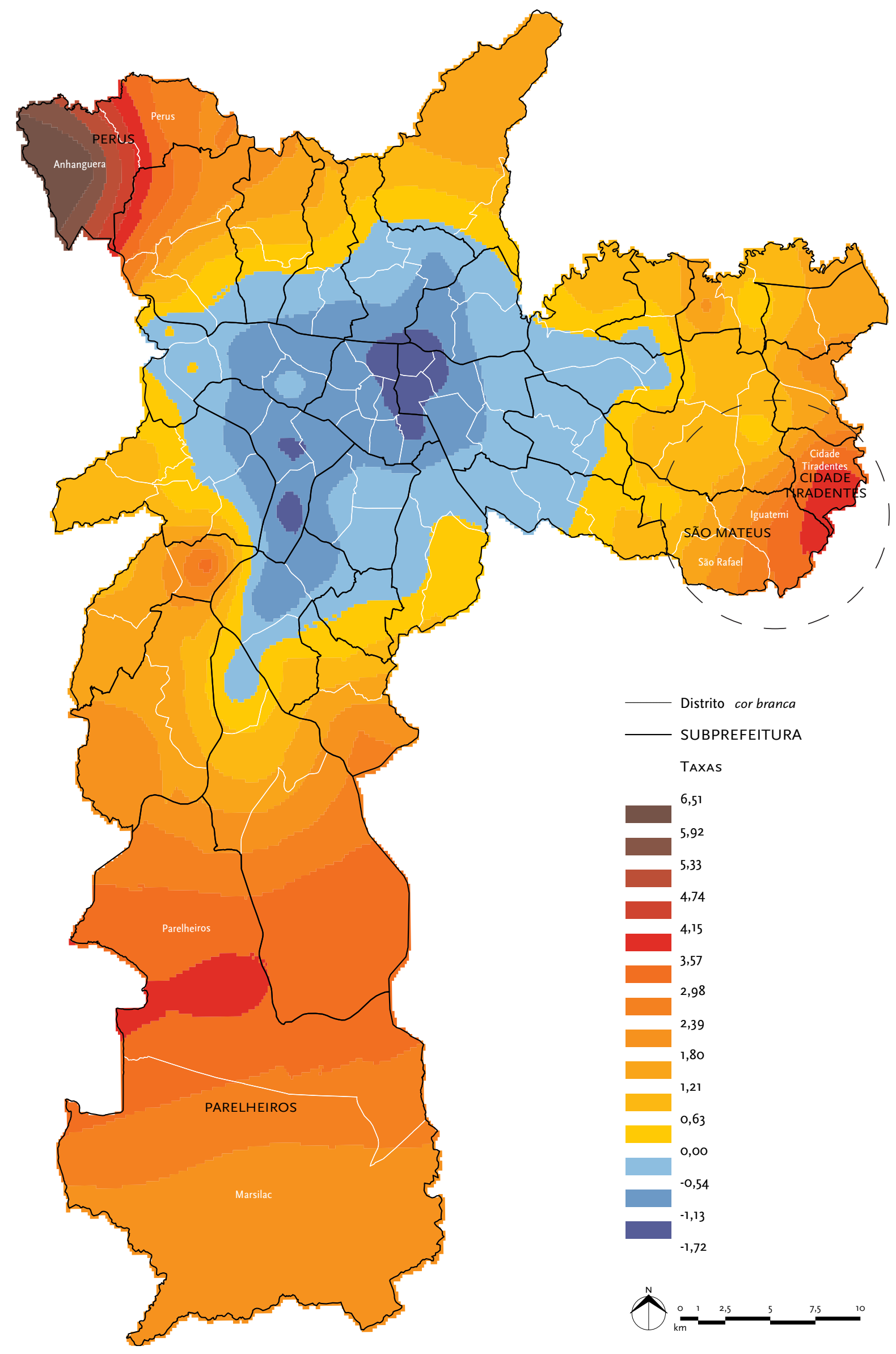

Mapa 3: TAXa de Crescimento anual da população-Município de São Paulo 1991/2006 IBCE, Censos 1991 e 2000, SEMPLA/DIPRO, Estimativa populacional para 2005 


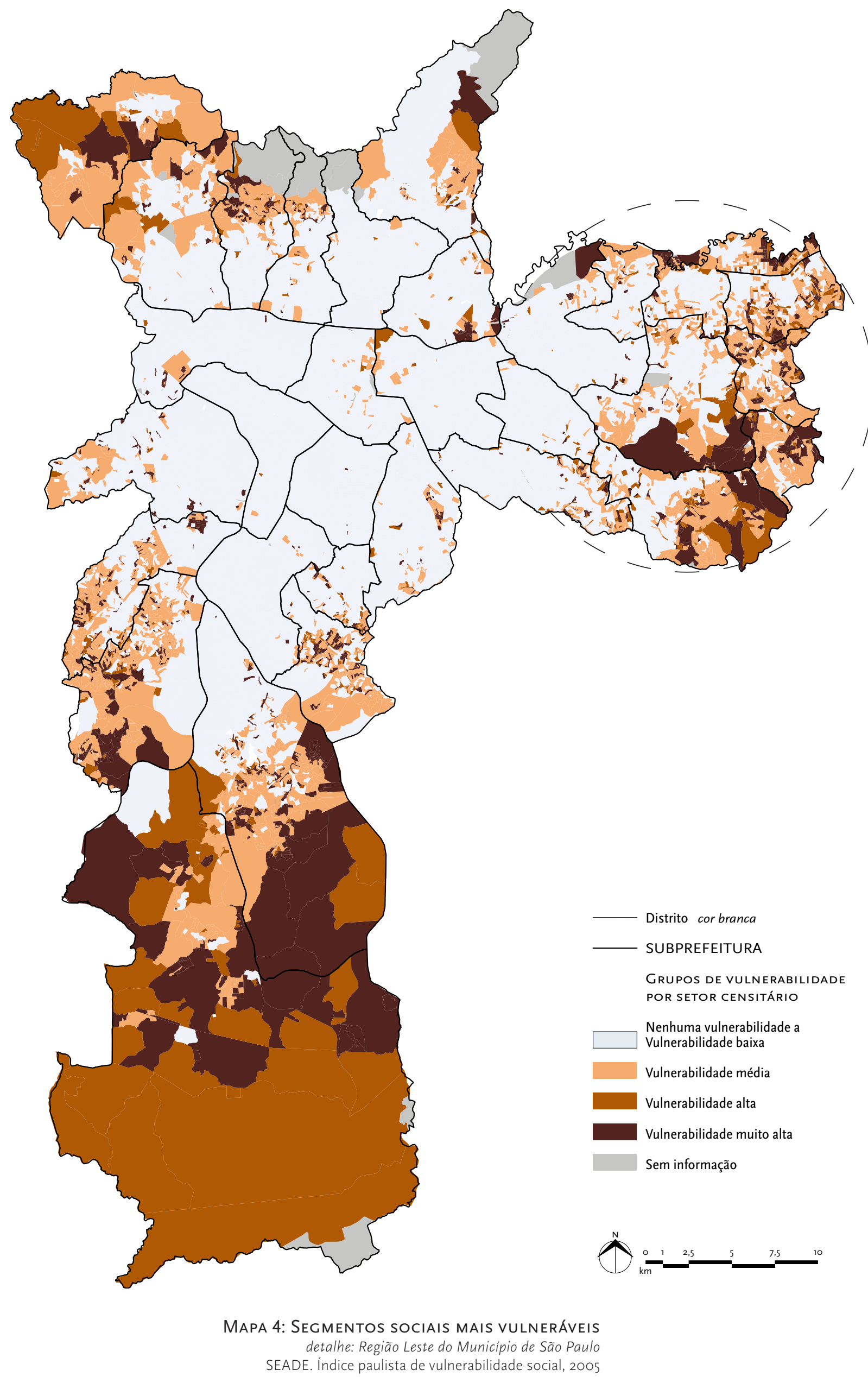


O Mapa 4: Segmentos sociais mais vulneráveis (p.15) apresenta a classificação por grupos do grau de vulnerabilidade social, segundo dados de 2000. A região do extremo Leste de São Paulo, dentro da área tracejada, através de uma avaliação visual, pode ser considerada altamente vulnerável, necessitando de intervenções urgentes, assim como o setor noroeste da cidade. O extremo sul apresenta a pior situação pela extensão do território e, por estar em áreas de mananciais invadidas e irregulares, transforma-se em outro grande desafio à administração pública, uma vez que lá residem quase um milhão de pessoas de baixa renda e vivendo em condições de insalubridade.

Justifica-se a escolha da RLP como estudo de caso com o propósito de eleger uma região periférica da cidade que sirva de exemplo para o desenvolvimento de metodologia para a criação de planos urbanos locais a partir de cálculos de capacidade de suporte. Fica claro nos mapas acima que a Região Leste, assim como outras grandes áreas de São Paulo, concentra dois graves problemas relacionados à população local: a baixa renda - que os obriga a viver em áreas não apropriadas por prescindirem de infraestrutura urbana básica ou por estarem irregulares por questões fundiárias - conjugada ao crescimento populacional acima da média registrada no município. Ou seja, famílias populosas, em situação de vulnerabilidade, estabelecidas em áreas carentes de equipamentos públicos, em número dissonante do número de moradores.

Segundo a publicação Contrastes Urbanos 2, Quadro Social,

São Paulo, assim como os demais grandes centros urbanos brasileiros, tem assistido à permanência de elevados níveis de heterogeneidade socioeconômica em sua população, apesar de estar em curso no país, desde o início da década, um processo de redução na desigualdade de renda, apontado por pesquisas e levantamentos realizados por instituições como o IBGE ou o IPEA. Situações de riqueza e de pobreza em marcante contraste moldam uma das principais características da cidade e se expressam na fragmentação do espaço urbano ou em suas denominadas desigualdades sócio-territoriais. (SEMPLA, 2008, p.25)

Ainda, segundo a publicação Contrastes Urbanos 1, Quadro Demográfico,

\begin{abstract}
A representação das taxas anuais de crescimento demográfico no período 1991/2005, para unidades territoriais intraurbanas no Município de São Paulo, mostra em detalhes a contraposição existente entre áreas da cidade que têm apresentado redução de população a um ritmo significativo (taxas inferiores a $-1,5 \%$ ao ano em distritos como Pari, Brás e Sé) e áreas periféricas em que o crescimento ainda ocorre a taxas elevadas (superiores a 3\% ao ano em distritos como Anhanguera, Perus, Parelheiros, Grajaú, Cidade Tiradentes e Iguatemi). De modo geral, nota-se que a tendência à perda de população, que se manifestou primeiramente em quatro distritos centrais de São Paulo (Bom Retiro, Brás, Pari e Belém), por ocasião do Censo Demográfico de 1980, ampliou-se desde então para um vasto conjunto de distritos que extrapolam a região central do município, atingindo, a leste, áreas como Penha e Vila Matilde; a oeste, Lapa e Jaguara; ao norte, Tucuruvi e Vila Medeiros; ao sul, Socorro e Santo Amaro. (SEMPLA, 2008, p.15)
\end{abstract}

Os Mapas 5 a 7: Empregos formais segundo setor de atividade 2004 trazem a distribuição de empregos por setor, onde se pode ver a carência de postos de trabalho na Região Leste, objeto de aplicação do plano urbano com foco nas condições locais proposto por esta tese. As três imagens representam a distribuição das atividades econômicas da Indústria, Serviços e Comércio no perímetro urbano do Município de São Paulo, em 2004, segundo a SEADE. Nelas, se vê que as atividades mencionadas estão distribuídas de forma rarefeita na região do extremo Leste, se comparadas à sua alta concentração 


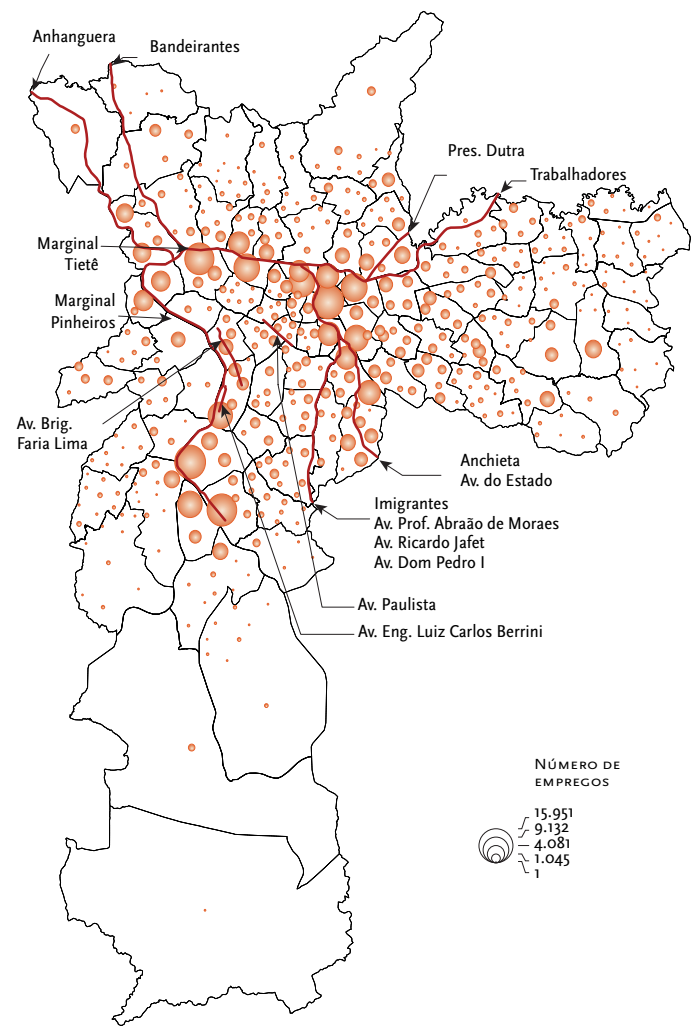

MAPA 5: INDÚSTRIA

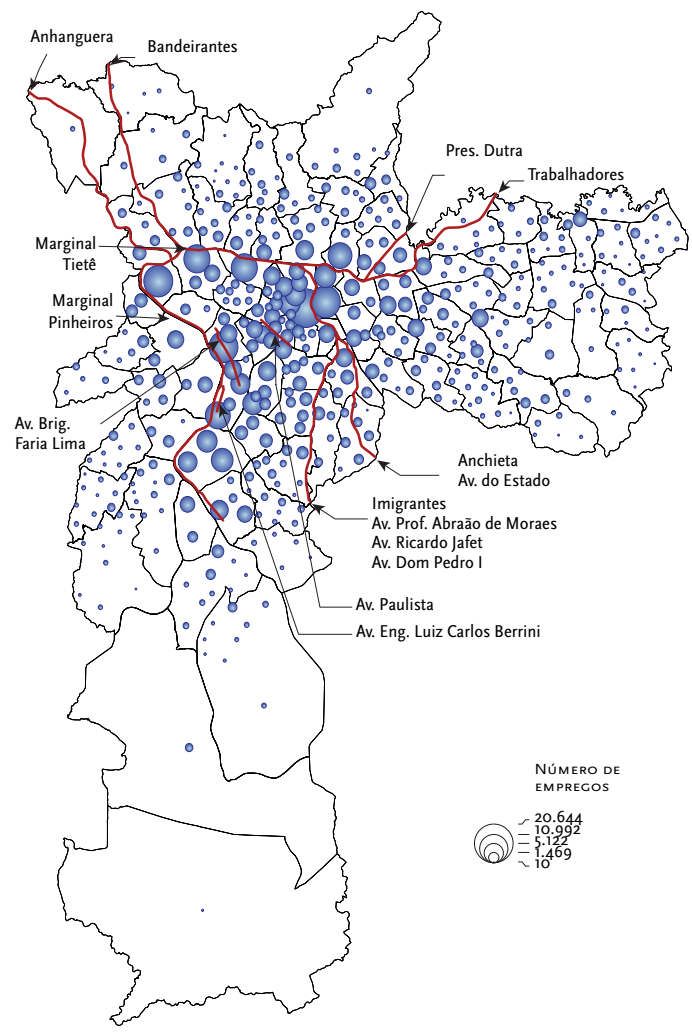

MAPA 6: COMÉRCIO

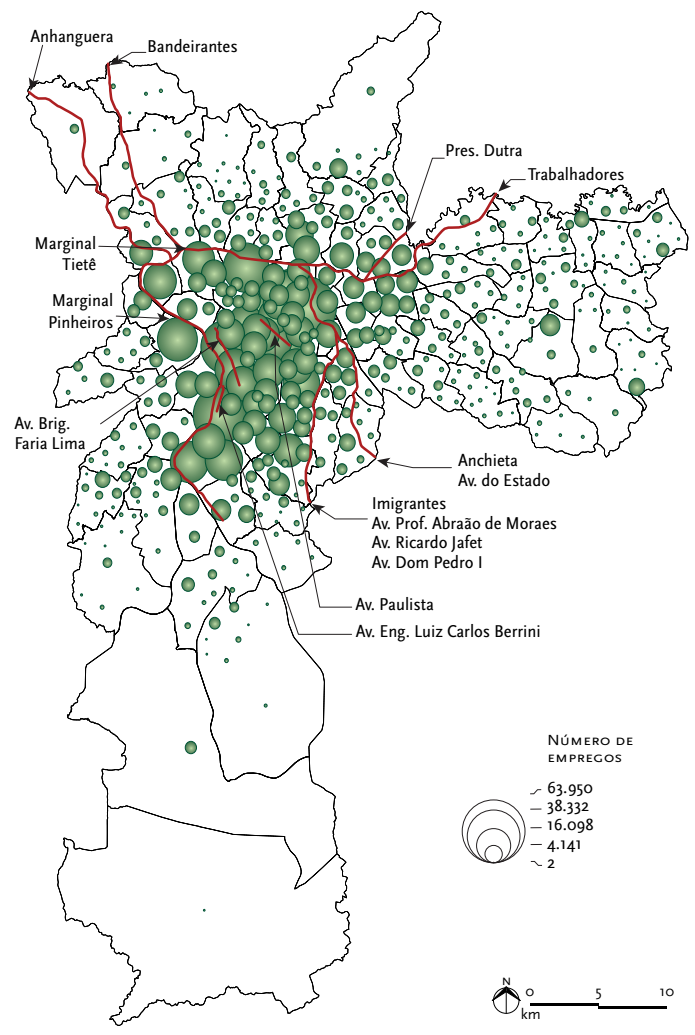

MAPA 7: SERVIÇOS 
no Centro Expandido. Há ainda que se considerar que os estabelecimentos existentes provavelmente não têm potencial de empregabilidade alto para absorver a mão de obra residente na região. O conceito de maior equilíbrio entre a oferta e a demanda de empregos na RLP voltará a ser discutido no Capítulo V. As mesmas imagens mostram a carência de estruturas viárias no extremo Leste.

Os três elementos, vulnerabilidade, crescimento populacional acima da média e distribuição desigual de oportunidades de empregos qualificados, justificam, portanto a proposição aqui defendida da necessidade premente de plano urbano que impulsione o desenvolvimento urbano da RLP, que não se atenha a diretrizes gerais, mas que focalize as condições urbanas locais. Sem a provisão de suficiente infraestrutura de serviços urbanos em seu sentido amplo e à altura da demanda por tipo e quantidade, as qualidades ambientais desejadas para áreas carentes não se concretizarão.

\section{ESTRUTURA DA TESE}

Após a Apresentação da tese onde estão detalhados a Problemática, Objetivos, Justificativa e Hipótese, esta tese é estruturada por cinco capítulos, como segue.

No Capítulo I apresenta-se a fundamentação teórica da estruturação urbana de metrópoles com os conceitos e metodologias desenvolvidas por urbanistas, sociólogos e técnicos em sistemas urbanos, especialmente de transporte, para justificar a linha de trabalho e o tema principal, ou seja, o desenvolvimento urbano de regiões metropolitanas consolidadas ou em consolidação a partir dos planos urbanos locais, os Planos de Bairro, cujo conjunto de diretrizes urbanas deve partir da reestruturação de uso do solo conjugada a uma política de reestruturação viária e de circulação de veículos e pedestres, embasados por cálculos de capacidade de suporte. Esse conjunto de diretrizes, aplicável às metrópoles brasileiras com questões similares, aborda a problemática urbanística e social intraurbanas para promover o desenvolvimento local em todos os aspectos: territorial, socioeconômico e cultural.

Os estudos, pesquisas e conceitos encontrados nas publicações de autores como a jornalista norteamericana Jane Jacobs, os arquitetos e urbanistas Jan Gehl, da Dinamarca, Donald Appleyard, dos EUA, e os urbanistas brasileiros Jorge Wilheim, Raquel Rolnik e Candido Malta Campos Filho, este fundamentado especialmente em Juergen Langenbuch e em Manuel de Solà-Morales, formam o conjunto básico de teorias estudadas e aplicadas no desenvolvimento desta tese de doutoramento em Planejamento Urbano e Regional.

O livro A estruturação da Grande São Paulo (1971), escrito pelo geógrafo Juergen Langenbuch, serviu para conhecerem-se quais foram as primeiras e mais importantes centralidades da região em estudo e os bairros-dormitório correspondentes e como estas se formaram e se desenvolveram a partir da oferta de acessibilidade oferecida pelos vários meios de transporte disponíveis em cada período histórico, com uma visão de duração temporal ampla desde a fundação dos núcleos urbanos na bacia do Alto Tietê, o berço da metrópole. Ainda, como essas transformações tecnológicas nos meios de transporte afetaram a oferta de acessibilidade e como estas contribuíram para seu crescimento urbano, permeado por loteamentos irregulares, invasões de áreas e planos urbanos não direcionados ou metas não atingidas, criando grandes áreas negligenciadas pelo poder público durante décadas.

$\mathrm{Na}$ abordagem do tema do crescimento desordenado da cidade, selecionou-se o livro do urbanista Jorge Wilheim, que participou diretamente na elaboração de planos urbanos para São Paulo e que fez uma análise urbana de São Paulo em 1965, pouco anterior 
à época da produção do primeiro PUB, abrangendo todos os setores em que atua o poder público para a cidade, feito em 1968. O diagnostico SAGMACS, embora também abrangente como o PUB e anterior a ele, não chega a ser um plano, pois apresenta recomendações mais próprias de uma política de desenvolvimento urbano. Mas sem ele, o PUB não teria conseguido abranger a amplitude que atingiu.

Em seguida, estuda-se o trabalho do urbanista Candido Malta Campos Filho sobre os Corredores Metropolitanos propostos em sua tese de doutorado e no Plano Metropolitano de Desenvolvimento Integrado-PMDI, desenvolvidos em 1972 e 1971 respectivamente, uma vez que estes já apontavam para uma solução para o sistema viário e de transporte público à altura das necessidades atuais, como veremos detalhadamente mais adiante.

O espaço intraurbano foi abordado principalmente a partir da obra de Flávio Villaça, urbanista e estudioso dos espaços intraurbanos e sua evolução urbana. Será ainda considerada a contribuição de Campos Filho quando, a partir dos trabalhos do arquiteto e urbanista espanhol Manuel de Solà-Morales, desenvolve uma análise das configurações produtivas imobiliárias e seus agentes na produção, apropriação e consumo do espaço urbano, e também analisa a lógica da estruturação da hierarquia das centralidades.

Áreas urbanas consolidadas e que devem conter os espaços públicos necessários para as atividades ao ar livre e a vida nas ruas, são a temática abordada por Gehl, Appleyard e Jacobs, que buscaram modelos e padrões positivos ocorridos nas cidades do capitalismo avançado, especialmente na Dinamarca e nos Estados Unidos da América do Norte.

Recortar soluções viáveis para a melhoria ambiental pós-impacto do excesso de veículos em vias de áreas predominantemente residenciais, caso da RLP, foi o objetivo da inclusão dessas contribuições. São estudos e soluções aplicáveis na proposição da reestruturação de uso e ocupação do solo, um dos objetivos desta tese.

O Plano de Bairro de Perus, no Município de São Paulo, de autoria de Campos Filho, e os bairros El Pozo del Tío Raimundo e SACONIA-Dehesa de la Villa, ambos da década de 1970 em Madrid, Espanha, são exemplos na condição de breves estudos de caso, formando um conjunto de três tipos diferentes de planos de bairro.

No Capitulo V Características territoriais, populacionais e socioeconômicas da Região Leste Paulistana discorre-se sobre a estruturação urbana de São Paulo na escala da metrópole e na escala da Região Leste Paulistana como parte do conjunto da metrópole. O estudo do crescimento urbano da RLP permitiu definir-se a área de aplicação da metodologia e dos conceitos urbanos descritos no Capítulo I. O histórico de transformações de seu traçado rodoferroviário'5 e a conjugação desses sistemas ao longo do tempo histórico de desenvolvimento da metrópole paulistana vai configurando as centralidades metropolitanas regionais e locais para ater-se, provisoriamente, a apenas três níveis de sua hierarquia. Essa análise permitiu avançar no estudo das tendências de sua transformação e, assim, na eventual redefinição do Uso do Solo.

O Capítulo III apresenta os planos urbanísticos desenvolvidos para o Município de São Paulo desde a década de 1960 até 2012 , com o objetivo de tomar conhecimento de suas diretrizes principais e como estes dispuseram sobre a crescente Região Leste. Faz-se uma análise breve das propostas e diretrizes principais apresentadas nesses planos urbanos desenvolvidos até 2002, ano da publicação do Plano Diretor Estratégico para o Município de São Paulo. O objetivo dessa leitura foi localizar as principais ideias de cada um comparando-os em busca de tendências explicativas para o cenário urbano atual no perímetro urbano de São Paulo. O estudo desses planos urbanos serviu
15. As rodovias são entendidas aqui como aquelas utilizadas por veículos sobre pneus, como automóveis, ônibus e caminhões. As ferrovias, como aquelas que utilizam veículos sobre trilhos, como os bondes, os trens de subúrbio que vêm, nas últimas décadas, se transformando em metrôs pesados, com grande capacidade de transporte de passageiros (de quarenta a oitenta mil passageiros por hora e por sentido), e os metrôs leves, estes sendo os Veículo Leve sobre TrilhosVLT, com capacidade em torno de vinte mil passageiros por hora e por sentido. As faixas rodoviárias preferenciais e as exclusivas para trânsito de ônibus vêm, mais recentemente, configurando um sistema de capacidade até vinte mil passageiros por hora e por sentido. 
para concluir-se como essa produção de rodoferrovias teve influência na mobilidade dentro do atual tecido urbano do Município de São Paulo, relacionando os usos Habitação, Comércio e Serviços, estes dois últimos como local de trabalho. Um segundo objetivo foi destacar de cada um dos planos como os sistemas de transporte foram planejados e comprovar se houve a tendência de se implantar sistemas viários de grande porte, tanto para transporte público de massa como para a circulação de veículos, priorizando-se o deslocamento de automóveis particulares. A pesquisa foi feita a partir das publicações oficiais do Estado e do Município, na forma de planos diretores e outros instrumentos do gênero. Trata, finalmente, da mobilidade urbana na cidade de São Paulo, dos trajetos a que os seus habitantes estão submetidos para deslocar-se de um ponto ao outro para realizar suas atividades cotidianas e a tendência de implantação de grandes obras viárias.

No Capítulo IV descrevem-se as políticas públicas dos governos de estado e municipal em vigor para essa extensa região. Inicia-se o capítulo situando-se a RLP em relação à RMSP-Região Metropolitana de São Paulo, em seguida faz-se uma comparação de índices populacionais e territoriais com a Metrópole de São Paulo, passando-se a uma análise da RLP e de seus distritos.

No Capítulo V faz-se uma análise das características territoriais, populacionais e socioeconômicas da RLP, com o objetivo de expor seu cenário atual, além do detalhamento da análise realizada para determinar a região de estudo e a escolha de um distrito na RLP a título de exemplo para ilustrar a metodologia de desenvolvimento de Planos de Bairro que conjugam diretrizes urbanas de Uso do Solo e Transporte Público para a conquista de qualidade ambiental urbana.

No último capítulo, trata-se da conceituação dos planos urbanos locais, os planos de bairro, e a metodologia utilizada para levantamentos e quantificações necessárias para o desenvolvimento desse tipo de plano. Neste capítulo descreve-se a metodologia para análise e definição da área-objeto de estudo, dentro da RLP com ênfase na dimensão local, ou seja, por distrito, aplicando-se, em seguida, o conceito da distância máxima a percorrer entre o local de moradia e a via estrutural mais próxima. Descreve-se também a escolha do sistema TRANUS, aperfeiçoado em 2009 pela FUPAM sob a coordenação técnica do arquiteto e Urbanista Candido Malta Campos Filho, intitulado Montagem e avaliação de um cenário equilibrado para o desenvolvimento urbano de São Paulo através de uma estratégia combinada de transporte e uso do solo, e um Roteiro para Planos de Bairro ilustrado por características territoriais, populacionais e socioeconômicas do distrito de Cidade Tiradentes, inserido na Região Leste 2 de São Paulo mas excluído do recorte territorial da Operação Urbana Consorciada Rio Verde-Jacu. Um diagnóstico sobre esse distrito finaliza o Capítulo VI. Encerra-se este último capítulo com uma conclusão sobre como o TRANUS, aliado ao Plano de Bairro, possibilita que se definam os controles imprescindíveis do processo de produção, apropriação e consumo do espaço urbano de modo a que se obtenha a qualidade ambiental que estimule a convivência social produtiva no espaço.

\section{METODOLOGIA DE TRABALHO}

Para o desenvolvimento de metodologia para proposição de diretrizes para planos de bairro, mostrar-se-á, inicialmente, em linhas gerais, como o espaço urbano se estrutura com base em metodologia desenvolvida pelo geógrafo Jurgen Langenbuch. Na sequência, serão apresentadas as diretrizes em que se basearam planos feitos para São Paulo para mostrar até onde chegaram, tendo em vista o objetivo citado de qualificação dos espaços públicos urbanos, enquanto dependentes do ambiente gerado pela circulação 
urbana. Em seguida, será mostrada a problemática especifica da RLP, escolhida por sua precariedade como estudo de caso. Será apresentado, como parte da metodologia, o cálculo da capacidade de suporte do sistema de circulação face ao uso do solo, como os planos de bairro que, atuando conjuntamente, podem desenvolver diretrizes no nível da estruturação urbana local da região do extremo Leste do município de São Paulo, nomeada neste trabalho de Região Leste 2 Paulistana, e avaliar sua contribuição para a uma qualificação urbana mais efetiva do que tem sido praticado no planejamento urbano paulistano, restrito a diretrizes mais gerais de planos diretores regionais, especialmente dos espaços públicos como espaços de convivência social.

Em sequência, se demonstrará até onde cada plano elaborado envolvendo o município de São Paulo, avançou no sentido de planejar a qualidade dos espaços públicos urbanos. Nesse sentido, avaliandose a contribuição de Campos Filho com a tese dos corredores urbanos como principais ordenadores da estruturação urbana com base no transporte coletivo na região metropolitana paulistana, onde se destacam os Corredores Metropolitanos que estão sendo paulatinamente adotados pelo planejamento metropolitano (PMDI 1972) e municipal de São Paulo PDE da lei n. 13.430 em 2002, completado pela lei 13.885 em 2004, como a DIAGONAL SUL, e pela atual gestão municipal o Arco do Futuro. (2013)

A seguir, serão apontadas as contribuições dos que pensam criticamente as cidades contemporâneas, como organizar os espaços públicos de uma cidade através da contribuição de Gehl, Appleyard e Jacobs.

Mostrar-se-á que a estruturação urbana planejada ou induzida por ações aparentemente desconectadas de uma visão de conjunto previamente conhecida que oriente decisões pontuais, seguem, de um lado, uma lógica topográfica associada à rede hídrica na definição dos traçados das vias de ligação por terra ou por água e, de outro, que as tecnologias de transporte que vão se alterando com o tempo, aumentando as velocidades com que se transporta pessoas e mercadorias e a capacidade de carga das mesmas, vão condicionando ao longo dos séculos e décadas o surgimento ao longo dessas vias e, especialmente, nos pontos de pouso ou de mudança de tecnologia de transporte, a aglomeração de atividades produtivas, ou de comércio e serviços e consequentemente de moradia, que, a partir de certo tamanho mínimo, denominamos de urbanas .

O utilizador sistemático dessa metodologia que estudou a estruturação para o caso da região metropolitana de São Paulo, ou Grande São Paulo, foi o geógrafo Jurgen Langenbuch. Essa estruturação urbana deve ser lida em suas várias escalas: desde a metropolitana, passando pela municipal, e pelo gigantismo do município de São Paulo, com seus quase doze milhões de habitantes em 2013, subdividido em região centro, norte, sul, leste e oeste. Neste caso, para demonstrar-se a tese, através do estudo de caso de uma região significativa, se utilizará o método de apontar como essa carência se faz presente, de modo exemplificativo.

Buscar-se-á avaliar em uma região carente escolhida a sua aplicação, a Região Leste do Município de São Paulo, através do estudo de como se deu a sua estruturação urbana e a problemática resultante da baixa qualidade dos espaços urbanos decorrentes da urbanização desregrada que predominou até agora na maior parte dos bairros surgidos, até mesmo quando resultantes de planejamento público, como é o caso da Cidade Tiradentes.

Uma vez analisada a região escolhida em seu conjunto, proceder-se-á uma análise mais detalhada da mesma, a Região Leste 2, onde justamente se busca, há pouco mais de trinta anos, (1981) obter-se uma reestruturação com a ampliação da oferta de empregos associada a um distrito industrial e uma 
centralidade de uso diversificado de interesse metropolitano a meio caminho entre o ABCD e Guarulhos e seu aeroporto internacional. Essa política urbana em curso há mais de três décadas, se intensificou nos últimos dez anos através de uma ação conjunta da Prefeitura de São Paulo com a Operação Urbana Consorciada Rio Verde-Jacu (gestão Marta Suplicy) e do Governo do Estado (gestão AlckminSerra) com a ligação tipo Anel Viário do Rodoanel, a Avenida Jacu Pêssego-Nova Trabalhadores, possivelmente servida por sistema de transporte de massa de passageiros sobre pneus ou sobre trilhos.

Mostrar-se-á a eficácia da utilização de um cálculo definitivo da capacidade de suporte do sistema de circulação em relação ao uso do solo, ou seja, a distribuição das atividades reguladas pela ação estatal, o desequilíbrio resultante entre oferta e procura por meios de circulação, não apenas na região escolhida como em toda a metrópole, afeta diretamente a qualidade dos espaços públicos como vias e praças enquanto espaço de circulação de veículos, mas especialmente de pedestres, comprometendo-se a mobilidade urbana como um todo.

Um planejamento que privilegie de fato o uso do transporte coletivo passa a ser assim uma prioridade também nos espaços de bairros populares como o da região leste 2 escolhida como área de estudo. Nela escolheu-se para uma maior pormenorização do planejamento local previsto pela Operação Urbana Consorciada Rio Verde-Jacu, um distrito de longa formação histórica na região: o de Cidade Tiradentes.

Será recomendada a ampliação da área da Operação Urbana de modo a abranger as áreas mais distantes dela situadas no município de São Paulo, a leste desta. Esse é um primeiro resultado de uma técnica de planejamento que possibilita uma melhor quantificação das variáveis como oferta de empregos de presença de moradores por faixa de renda e das viagens geradas em consequência, pela metodologia do cálculo da capacidade de suporte, do sistema ofertado de circulação no ano base - situação atual e, em um ano meta - definindo uma situação futura desejada ou planejada - de modo a resultar de sua aplicação a paulatina obtenção de maior equilíbrio entre oferta e demanda que resultará no alívio progressivo do tráfego nas vias. A redução desse desequilíbrio até a sua eliminação ou redução a níveis aceitáveis, é uma precondição para a obtenção de espaços públicos de qualidade ambiental estimuladores da convivência social prazerosa, criativa e inclusive como espaço de manifestações coletivas de reivindicações democráticas. Como demonstraram empiricamente Appleyard e Gehl.

Por fim apenas com o planejamento das desejadas Unidades Ambientais de Moradia-UAMs na escala de bairros e vilas segundo metodologia desenvolvida por Campos Filho, aplicada no Plano de Bairro de Perus no município de São Paulo, de modo articulado com o planejamento local mais amplo de uma região, como o de uma Operação Urbana ou como com os Planos Regionais Estratégicos do Plano Diretor de São Paulo, é que se consegue levar a uma concretude final o planejamento ou reestruturação de espaços intraurbanos de uma grande cidade.

\section{METAS A ATINGIR}

Um plano urbanístico deve ter anos-meta de implantação e um ano meta de durabilidade mediante as demandas que se pretendeu atingir considerando as projeções de crescimento, estabilização ou diminuição populacional por nível de renda.

As diferentes fontes de pesquisa utilizadas nesta tese têm anos de publicação diferentes, entre 2004 nas publicações de mapas e diretrizes por parte da Secretaria de Desenvolvimento Urbano da Prefeitura de São Paulo e 2010, ano do CENSO do IBCE. A mais recente Pesquisa Origem/Destino-OD 2007, 
do Metrô também foi utilizada na coleta de dados e índices úteis para o desenvolvimento desta tese.

O ano base indicado para a metodologia a ser apresentada para o Plano de Bairro é o ano de 2010, em função da disponibilidade de dados acima mencionados e o ano meta, 2030, pois se considera que 20 anos é um período factível para a implantação de planos urbanos.

O Mapa 8: Área para análise territorial na Região Leste Paulistana foi preparado sobre a ortofoto da região, acrescido das vias estruturais existentes $\mathrm{N}$, $N_{2}$ e N3, além dos sistemas de transporte público existentes e os futuros, planejados para atingir a meta de 2025. Será a ferramenta básica para aplicarse o conceito das distâncias máximas ou socialmente ideais para o deslocamento de pedestres desde seu local de moradia até o trabalho nas diversas formas de circulação: caminhando até o ponto de ônibus, em seguida embarcando em outro tipo de transporte, metrô, trem metropolitano e assim por diante.

No Capítulo V serão feitas análises de territorialidade, vulnerabilidade e perfil socioeconômico da população para determinar os distritos mais vulneráveis e urbanisticamente carentes, e selecionar um deles como exemplo para apicação de Plano de Bairro.

\section{A OBSERVAÇÃO IN LOCO: OS GRANDES SISTEMAS DE TRANSPORTE PÚBLICO ESTRUTURAIS EM SÃO PAULO}

A observação in loco do tecido urbano da região objeto que serve como exemplo para a proposição de um plano se mostrou importante, pois permitiu fazer-se um diagnóstico preliminar que indica que a implantação de sistemas rodoferroviários para transporte público de massa na região metropolitana de São Paulo tem ocorrido ora sobre áreas ainda pouco urbanizadas ou com baixa qualidade de urbanização, ora sobre erros já concretizados como, por exemplo, a implantação do Expresso Tiradentes, antigo Fura-Fila, sobre a laje que cobriu em parte o Rio Tamanduateí, na região sudeste do município de São Paulo. As intervenções no tecido urbano paulistano, ocorridas principalmente nas décadas de 1970 e 1980, frequentemente não vieram acompanhadas de melhoria urbana no entorno, apesar de ser essa uma diretriz básica de qualquer plano urbanístico.

Equipamentos públicos de grande porte, como estações de transbordo de sistemas sobre trilhos e de transporte público urbano sobre pneus, se implantados sem os devidos cuidados urbanísticos, fracionam o tecido urbano preexistentes, inibindo as atividades de convivência social e mesmo o comércio e serviços instalados nas ruas. Foram esquecidas as praças; nas vias faltam espaços de parada nas calçadas com largura e fluxo de pedestres e veículos, mobiliário urbano adequado, inclusive paisagismo de espécies vegetais e jorros d'água que sejam promotores do usufruto de qualidade ambiental e de simples contemplação da vida.

Vários casos negativos, enquanto qualidade ambiental urbana, foram observados em diferentes regiões da cidade de São Paulo: na Zona Sul, as estações Socorro e Santo Amaro, ambas as linhas pertencentes à rede Companhia Paulista de Transporte Metropolitano-CPTM e a estação Giovanni Gronchi da Linha 5 Lilás do Metrô, de superfície, pertencente ao Terminal João Dias e localizada na avenida João Dias. Nessas estações de transbordo a circulação de pedestres existe, a acessibilidade para pessoas portadoras de necessidades especiais foi devidamente prevista, em atendimento às normas. Mas, até que o pedestre alcance as "portas das estações," as áreas destinadas à circulação de pedestres no seu entorno não apresentam qualquer qualidade ambiental, com raras exceções. 


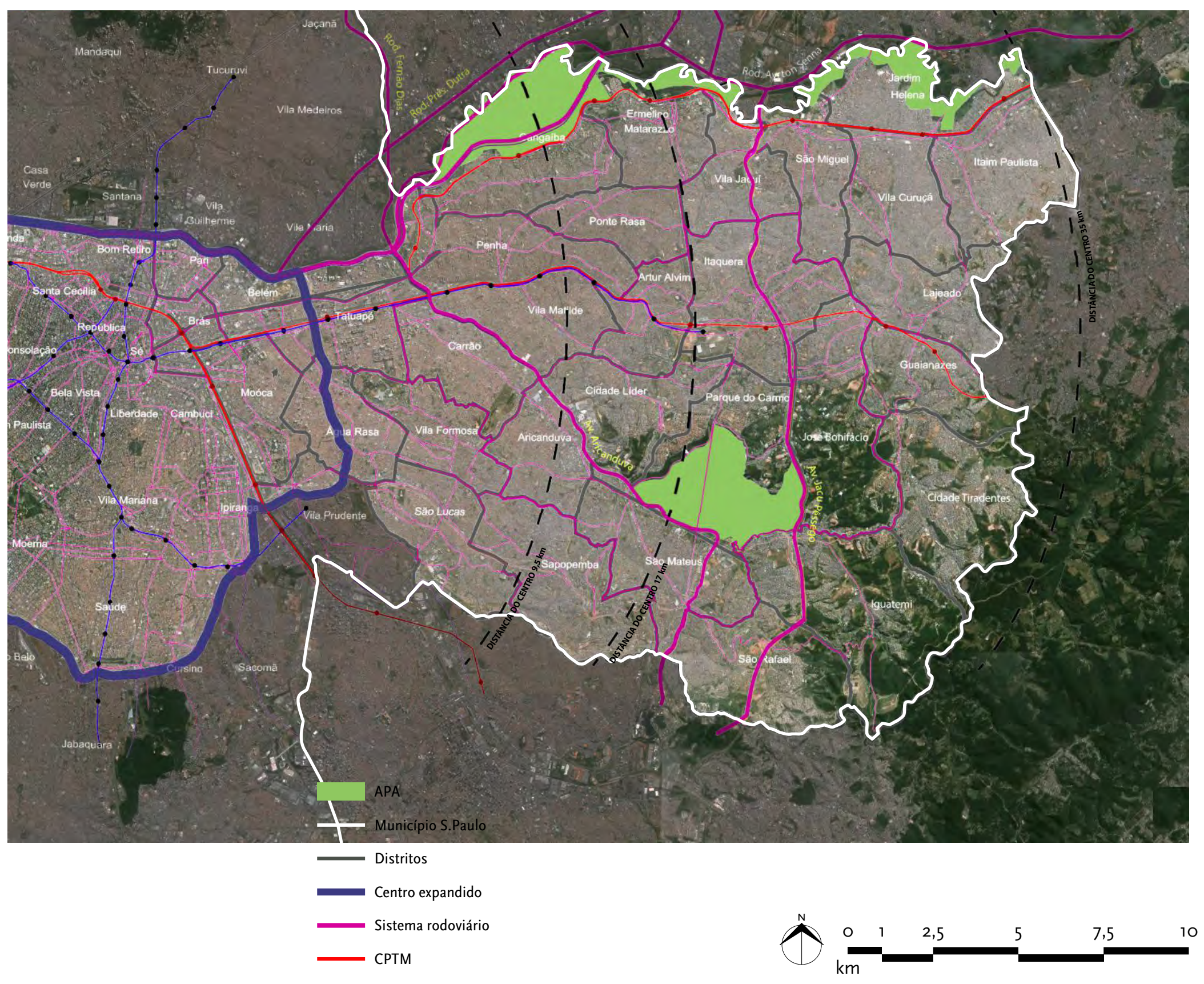

Mapa 8: Área para análise territorial na Região Leste Paulistana

Região Leste, Rodoferrovias, Operações Urbanas. Montagem sobre ortofoto GoogleEarth 2013 
$\mathrm{Na}$ Zona Leste, foram visitadas algumas estações do Metrô Leste, da Linha 3 Vermelha: estações Carrão, Vila Matilde, Arthur Alvin e Corinthians-Itaquera. A exemplo do que se verificou na Zona Sul, os sistemas de transporte público de massa também formaram barreiras urbanas em função dos poucos acessos ou longos trechos a caminhar dentro destes entre conexões. O que ocorre no conjunto formado pela ferrovia de trem metropolitano da CPTM, antiga Central do Brasil, existente desde o fim do século XIX, é diferente das vias que tiveram seu tráfego ampliado com ou sem ampliação de seu espaço físico, constituindo, com o grande fluxo de veículos, a citada barreira de difícil transposição em nível por pedestres e mesmo por veículos de duas ou quatro rodas. As ferrovias se anteciparam por muitas décadas ao desenvolvimento urbano em seu entorno. Assim, ao invés de barreiras, as ferrovias foram estruturadoras do tecido urbano ao seu redor, como muito bem demonstrou Langenbuch com os chamados "subúrbios estação." No entanto, muitas vezes, avenidas paralelas foram sendo implantadas, como Rangel Pestana e Celso Garcia de um dos lados da ferrovia Central do Brasil e, muitas décadas depois, do outro lado da ferrovia e na sua tangente, a Radial Leste. Assim, viadutos e passarelas para pedestres foram erguidos para a interligação dos dois lados, que se desenvolveram com certa autonomia devido a essa estruturação histórica. Posteriormente, com a implantação da Linha Leste do Metrô, paralela ao leito da ferrovia e tirando partido do seu baixo custo, conforme a tese dos Corredores Metropolitanos de Campos Filho, pode-se argumentar que se formou uma barreira arquitetônica conflitante com a escala humana. Na verdade, essa pseudo barreira desconhece a estruturação histórica que criou uma lógica própria de vida urbana de cada um dos lados, que deve ser conhecida e respeitada. Inadvertidamente, os usuários dos automóveis que convivem com os congestionamentos crescentes passam a ver a ferrovia na superfície como uma barreira a ser eliminada.
Segundo Campos Filho,

É a lógica imobiliária que quer valorizar o lado menos valorizado em busca de um ganho especulativo que está por detrás desse conceito de barreira urbana no caso das ferrovias. No entanto, consideramos que as verdadeiras barreiras são as avenidas, quando superam os limites ambientais do número de veículos por faixa por sentido, as verdadeiras barreiras a serem solucionadas quando ainda possível. (informação verbal) ${ }^{16}$

A visitação a esses pontos selecionados em regiões extremas da cidade, a título de exemplo, possibilitou assumir a posição do pedestre, habitante, trabalhador, turista que depende dos transportes públicos para se locomover e vivenciar seu dia a dia. As imagens não mostram a verdadeira dimensão das distâncias que o habitante deve percorrer entre um ponto de desembarque e de novo embarque, mas conseguem ilustrar a dificuldade de circulação e travessia nos arredores desses pontos.
16. Campos Filho. Depoimento à autora, 1 mar. 2013. 

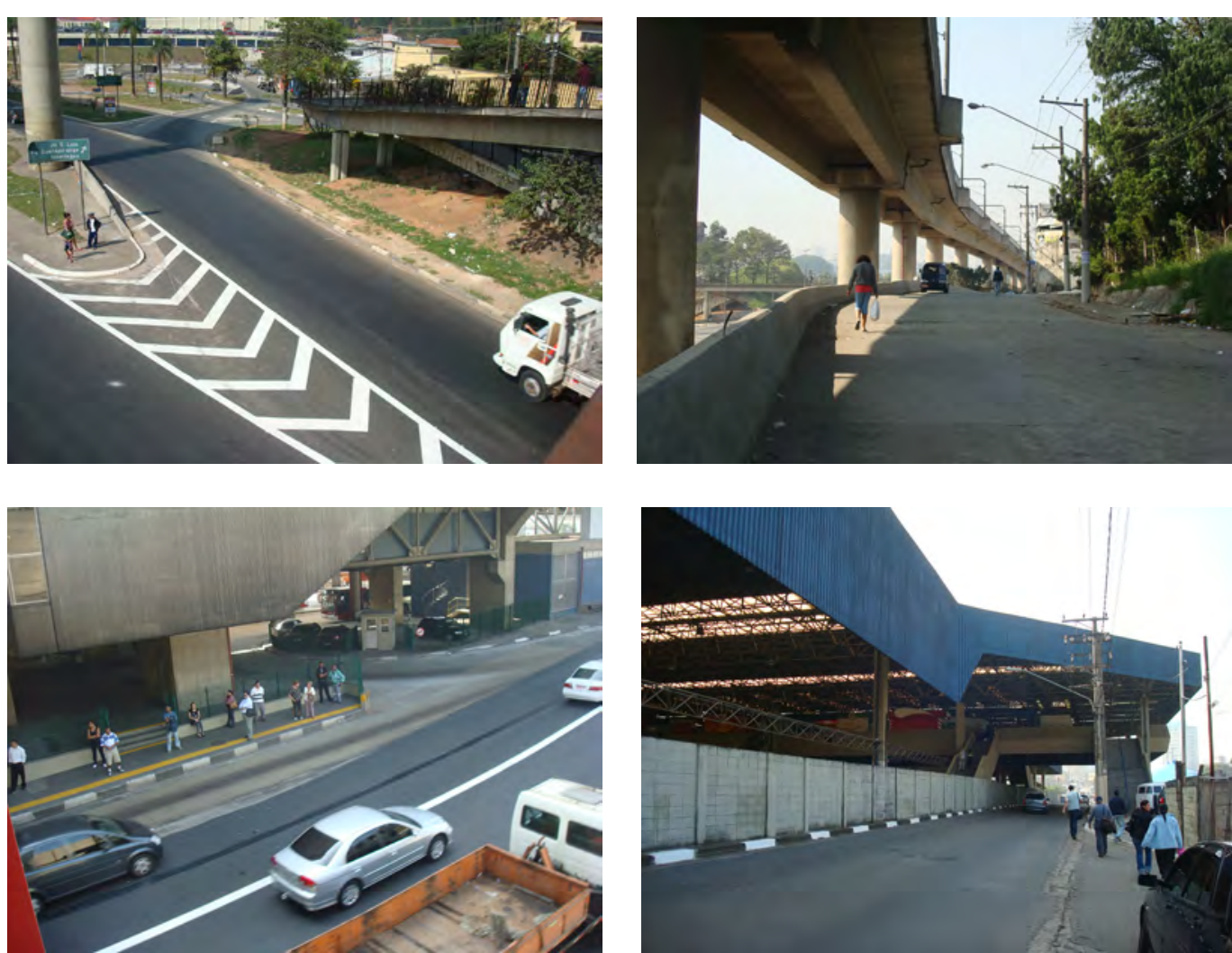

Figuras 2 a 5: Terminal JoÃo Dias

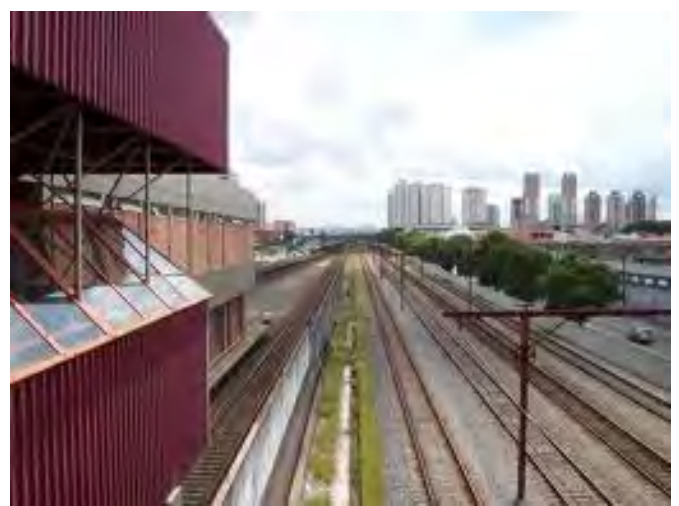

Figuras 8: ESTAÇÃo CARRÃo

linha Leste Vermelha do Metrô

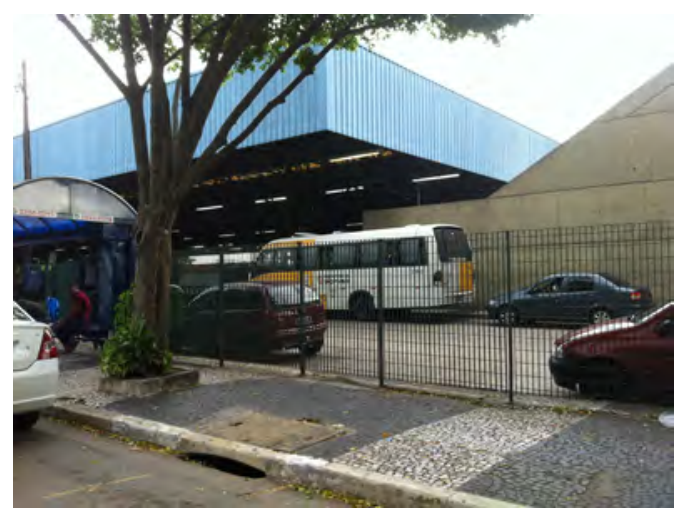

Figuras 11: estaçÃo Linha Vermelha linha Leste Vermelha do Metrô

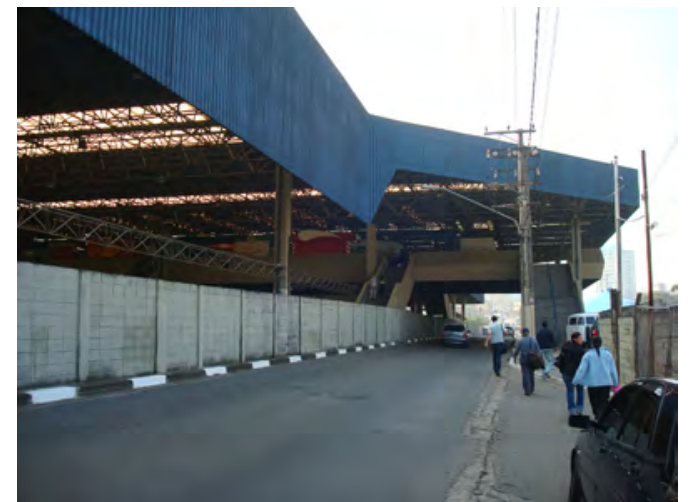

Figura 6: Terminal Santo Amaro

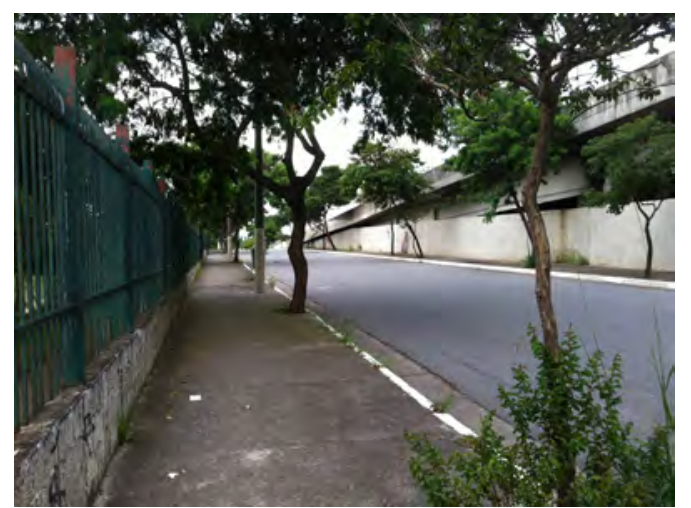

FIGURA 9: VIA PARALELA À L. Vermelha linha Leste Vermelha do Metrô

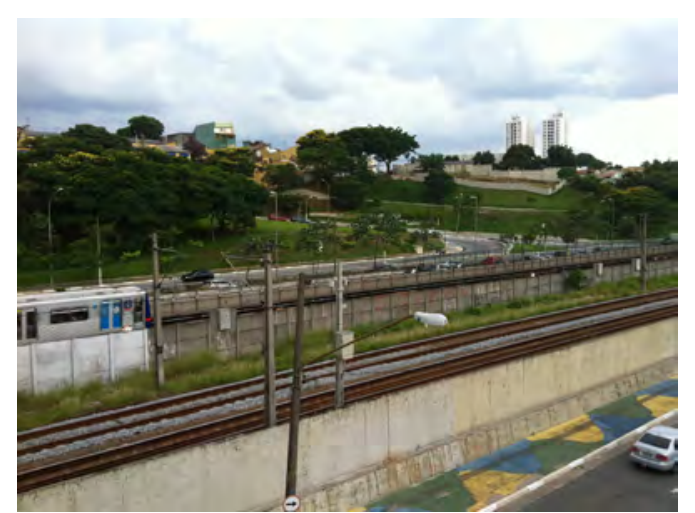

Figura 12: linha Leste Vermelha do Metrô
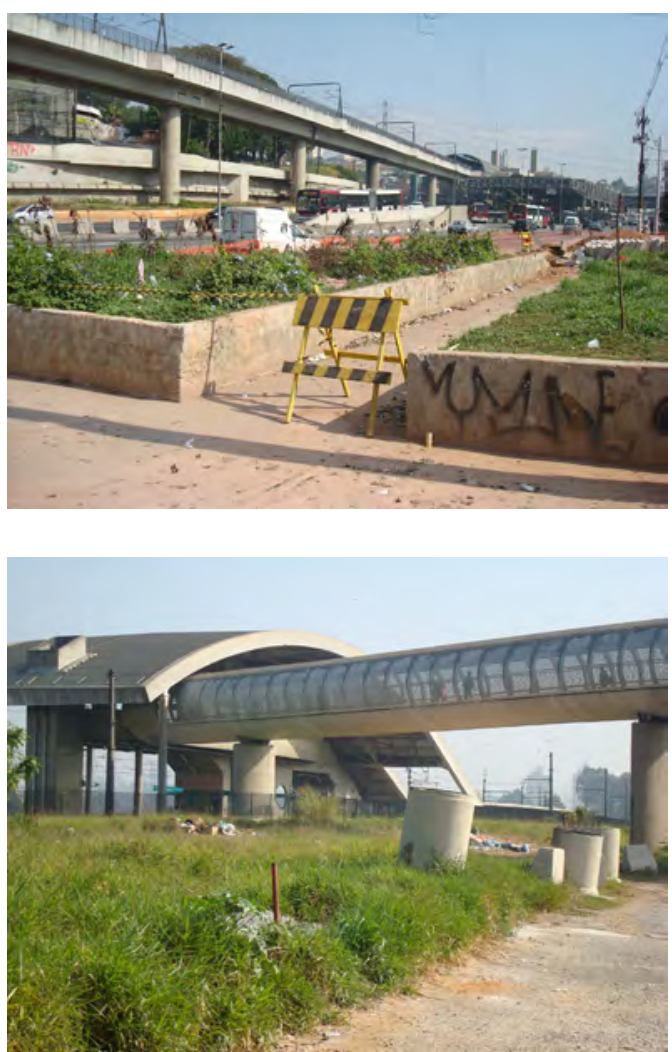

Figura 7: EstaçÃo SOCORRo CPTM

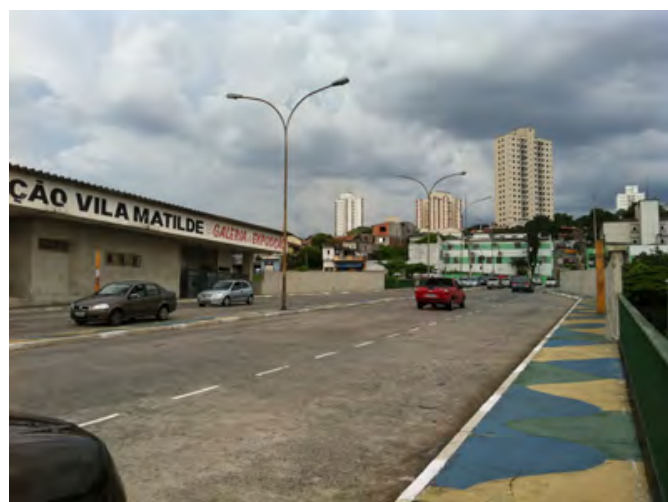

Figura 10: Estação Vila Matilde linha Leste Vermelha do Metrô

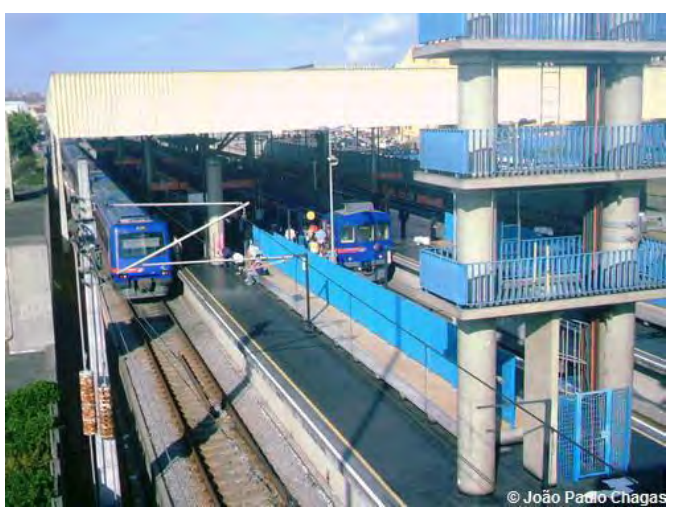

Figura 13: Estação Guaianases CPTM 


\section{CAPÍTULO I}

\section{FUNDAMENTAÇÃO TEÓRICA}

Esta tese está embasada nos estudos, pesquisas e conceitos encontrados nas publicações de autores como a jornalista norte-americana Jane Jacobs (1961), o urbanista italiano Jorge Wilheim (1965), o geógrafo Juergen Langenbuch (1971), os arquitetos e urbanistas Jan Gehl (1971), da Dinamarca, e Donald Appleyard (1981), dos EUA, e os urbanistas brasileiros Raquel Rolnik (1997), Flávio Villaça (1998) e Candido Malta Campos Filho. (1972, 1989 e 2003) As teorias e conceitos adotados contribuíram, primeiramente, como forma de levantamento da condição urbana atual encontrada nas cidades brasileiras e, em segundo lugar, para localizar falhas buscando a definição de metodologias capazes de não reproduzi-las no planejamento urbano municipal ou metropolitano, especialmente no que se refere à qualificação ambiental do espaço público com vistas à promoção da convivência social produtiva.

Historicamente, o processo de estruturação da metró pole paulistana foi demonstrado por Langenbuch, e muito bem detalhado através dos prismas políticos e históricos por Rolnik e resultante de intensa pesquisa histórica. Langenbuch contribuiu com o Capítulo I/ São Paulo rumo ao leste: sua estruturação urbana desta tese, onde se apresenta a evolução urbana da região leste de São Paulo. Para fundamentar a busca por modelos e padrões positivos ocorridos e poder, a partir deles, recortar soluções viáveis para fundamentar esta tese, foram selecionados os trabalhos de Jacobs, Gehl e Appleyard, nessa ordem. Para melhor entender o processo que permitiu a horizontalização da metrópole paulistana e dele depreenderem-se quais foram os equívocos redundantes no planejamento urbano ou na falta deste, selecionou-se o livro do urbanista Jorge Wilheim, um dos urbanistas que mais participaram do início do planejamento urbano desta grande metrópole, publicado em 1965. No entanto, a contribuição de Wilheim nas questões relativas à produção do espaço urbano, apropriação da renda fundiária associada ao consumo das mercadorias imobiliárias não havia ainda sido elaborada, em razão da época em que foi escrita. O trabalho de Wilheim foi complementado pela teorização de Campos Filho, exposta em seus livros Cidades Brasileiras: seu controle ou o caos (1989) e o Reinvente seu Bairro (2003), com textos de apoio e análises desenvolvidas na disciplina que ministra no curso de pós-graduação da FAUUSP, Teoria do Planejamento e do Desenvolvimento Urbano.

Esses autores foram eleitos para fundamentar teórica e tecnicamente a produção de diretrizes visando planejamento urbano com pretensões de não reincidir em falhas anteriores e propor soluções alinhadas com as necessidades de uma população alijada do "bem morar," com foco específico na qualidade ambiental dos espaços públicos de convivência social, incluindo as vias de circulação. A contribuição de Campos Filho (1972), específica para a região metropolitana paulistana, proporcionará o conhecimento das questões urbanas crônicas sem atrelamento ou quaisquer amarras com a política urbana que não esteja comprometida com soluções definitivas e que não mais sacrifiquem o habitante da Região 
19. U.S. traffic calming manual, por Reid Ewing e Steven Brown. Disponível em <http://trafficcalming.org/ history/>. Acesso em 8 jun. 2013.

17. Disponível em <http://trafficcalming. org/history/>. Acesso em 8 jun. 2013

18. Administração Federal de Vias Expressas (EUA)

20. Jorge Wilheim participou do Plano Diretor do Município de São Paulo 1985/2000, no cargo de Secretário Municipal de Planejamento da gestão Mário Covas e, posteriormente, no mesmo cargo, durante a formulação do Plano Diretor Estratégico do Município de São Paulo 2002/2012, em 2002

21. O Município de São Paulo apresentava uma população de 9.600 .696 habitantes em 1996 pouco mais três milhões de habitantes a menos em relação aos treze milhões esperados. (IBGE)
Leste, já tão privado de qualquer qualidade urbana. Finalmente, em busca de conhecimento em relação às grandes metrópoles brasileiras, lançou-se mão da obra de Flávio Villaça (1998), urbanista e estudioso dos espaços intraurbanos e sua evolução, atualmente já na forma de áreas urbanas consolidadas e que devem, segundo Jan Gehl, conter os espaços públicos necessários para as atividades ao ar livre e a vida nas ruas.

Como o modelo de plano urbano local que se deseja propor está dentro de um tecido urbano consolidado e em consolidação na periferia de São Paulo, onde o controle de tráfego é quase inexistente, o conceito Traffic Calming serve também de referência, com o propósito de trazer tranquilidade às ruas também na periferia.

O conceito Traffic Calming começou como um movimento na Europa no fim da década de 1960, contemporaneamente aos estudos do dinamarquês Jan Gehl e às análises críticas ao planejamento urbano da norte-americana Jane Jacobs. Moradores da cidade holandesa de Delft transformaram suas vias em vias habitáveis e amigáveis aos pedestres ao impedir ali o tráfego. Na década seguinte, surgiram na Europa, as vias de velocidade baixa, com limite de $30 \mathrm{~km} / \mathrm{h}$. Na década de 1980, aplicaram-se os princípios do traffic calming em vias estruturais intermunicipais em pequenas cidades da Alemanha e Dinamarca, além do tratamento de vias arteriais e suas áreas de influência, principalmente na Alemanha e França. Nos EUA, uma versão do traffic calming foi aplicada nas décadas de 1960 e 1970 em Berkeley, Califórnia e Eugene, no estado do Oregon. Um estudo nacional sobre traffic calming foi realizado nos EUA em 1980 com o objetivo de conhecerem-se as preferências dos residentes em relação ao tráfego, os dados sobre velocidade e revisou leis. ${ }^{17}$

Em 1998, a Federal Highway AdministrationFHWA ${ }^{18}$ promoveu outro estudo, transformado em um manual, que apresentou um leque de medidas de diminuição de tráfego além das vias residenciais e das normas públicas oficiais. ${ }^{19}$

Como ferramenta essencial para requalificar o espaço intraurbano de um plano de bairro a desenvolver, serão adotados os estudos e conceitos para a criação de planos de bairro de Campos Filho, especialmente o planejamento da complementação dos equipamentos e o conceito de unidade de vizinhança atualizado para a realidade das cidades brasileiras. (CAMPOS FILHO, 2003)

\section{SÃO PAULO METRÓPOLE 1965: CAOS ANUNCIADO}

Como ponto de partida para o Capítulo I, lançou-se mão das análises do urbanista Jorge Wilheim (1965) antes da formulação do Plano Urbanístico Básico de São Paulo-PUB e em função de sua participação como urbanista na formulação de dois planos diretores para São Paulo: em 1985 e em 2002. ${ }^{20}$ Nessa publicação, o urbanista oferece como preâmbulo para a elaboração do PUB dados sociais e outros elementos estatísticos que, em conjunto, demonstravam em 1965 o crescimento espantoso de São Paulo e sua importância para a região e o país.

Segundo Wilheim, em 1965, São Paulo já está em fase adiantada de metropolização e com uma população de cinco milhões de habitantes. Àquela altura, o autor já considera a vida em São Paulo desumana para o cidadão e responsabiliza, por isso, o crescimento através de "transformações espontâneas," o que chamaríamos hoje de crescimento desordenado. (WILHEIM, 1965, P.5) Wilheim credita ao planejamento urbano a solução dos problemas que serão enfrentados por uma suposta população de treze milhões nos 35 anos seguintes à data da edição do livro. ${ }^{21}$

A forma encontrada para planejar o crescimento futuro dessa jovem metrópole foi criar-se seu primeiro 
Plano Diretor. Alegando que à época os profissionais careciam de "experiência coletiva em urbanismo" e com "dispersão de informações," partiu-se para uma coletânea de subsídios - aqui com significado de contribuição na forma de dados e informações. (WILHEIM, 1965, p.10)

Curiosamente, Wilheim se desculpa por embrenharse no campo de trabalho de sociólogos e historiadores, refugiando-se na falta de estudos urbanos completos e atualizados especializados em São Paulo.

Atualmente, pesquisas desenvolvidas para trabalhos em planejamento urbano devem contar com elementos desenvolvidos por sociólogos, economistas, historiadores e geógrafos, pela complexidade das questões urbanas, sociais e econômicas encontrada nas metrópoles brasileiras.

Wilheim discorre sobre o "rápido crescimento a partir de 1980" e sobre premissas como "a função histórica da cidade e a situação da região paulistana quando do advento da estrada de ferro," sistema indutor do crescimento urbano à época e que, sem dúvida, foi fator importante na definição da morfologia e tecido urbanos. (WILHEIM, 1965, p.9)

Em sua pesquisa demográfica, Wilheim demonstra que o crescimento geométrico da população começa a dar sinais de decréscimo mais acentuado nos distritos do centro como Belenzinho, Brás, Mooca e Sé, com crescimento negativo; Barra Funda, Bom Retiro, Jardins e Cerqueira César, com crescimento de 2 a 4\%; Aclimação, Penha de França, Butantã e Ibirapuera, dentre outros, com crescimento de 4,1 a 16\%. (WILHeIM, 1965, p.15) Franco sinal do deslocamento de populações inteiras para a periferia, onde os loteamentos clandestinos e irregulares com baixo custo da terra atraíam moradores que já não podiam pagar os aluguéis em seus antigos bairros.

Wilheim prossegue mostrando que, em 1960, já era de conhecimento dos pesquisadores e planejadores que havia tendências e demandas por infraestrutura e por equipamentos urbanos em (sub) distritos como Santo Amaro, Casa Verde, Mooca, Lapa, Tatuapé, Jardim América, Vila Maria, dentre outros, que apresentavam densidades de vinte a cem habitantes por hectare. O autor informa que a concentração de domicílios era um dado importante para a distribuição de novos centros habitacionais e de equipamentos urbanos e importante indicador de tendência de ocupação do solo. (WILHEIM, 1965, p.16/17)

Lançando mão das "tendências de ocupação do solo" detectadas, o autor apresenta então algumas conclusões como a definição da Região Metropolitana, limitada pela Serra da Cantareira ao norte e nordeste, as grandes represas ao sul e a Serra do Mar a sudeste, sendo estes limites grandes obstáculos físicos que levariam a mancha urbana a estender-se na direção do Vale do Paraíba a nordeste e na direção dos municípios do chamado ABCD a sul e a sudeste, com ocupação ao longo da Via Anchieta. (WILHEIM, 1965, p.17)

A segunda conclusão leva o autor a afirmar que, em 2000, a população municipal estimada então em treze milhões de habitantes, levaria a região metropolitana a "alcançar as fraldas da Serra do Mar, constituindo-se então uma imensa conurbação São Paulo-Cubatão-Santos, qual cidade alta e baixa, separadas por uma área verde." (WILHEIM, 1965, p.17)

A terceira conclusão de Wilheim é que o "fenômeno nacional de urbanização crescente" provocaria adensamento da região já definida com o preenchimento dos vazios ainda existentes. (à época)

A quarta conclusão do autor sugere que o adensamento era desejável para melhoria da eficiência dos serviços públicos e que deveria ser incentivado, com o devido planejamento, para que este fosse mais veloz e menos aleatório, com a criação de novos centros de atração urbana, como pontos de polarização: nos centros mais indicativos da tendência de 
ocupação do solo registrada, como Vila Maria, Casa Verde, Itaim, Ipiranga, Vila Prudente, dentre outros, e "as áreas ainda desocupadas como as várzeas do Tietê;" nos centros de atração comercial existentes em distritos como Brás, Pinheiros, Lapa, Penha e outros, e nos centros de atração flutuante "em cujo redor se processa um adensamento considerável," como Alto da Mooca, São Miguel, Itaim Paulista, Pari e Água Rasa. (WILheIM, 1965, p.18)

A quinta e última conclusão a que chega o autor é o surgimento de áreas de distritos desertas à noite $\mathrm{e}$ feriados, com a expulsão de seus habitantes em função da mudança de uso residencial para comércio e serviços em distritos como Centro Histórico, Santa Ifigênia, Bom Retiro e Brás, já na década de 1960. (WILHeIM, 1965, p.18)

Wilheim leva em consideração as dificuldades de adaptação do sistema viário à complexa metropolização em curso e soma a isso os problemas a vencer, como vazios urbanos, topografia acidentada e o grande problema dos loteamentos clandestinos ou espontâneos, altamente responsáveis pela horizontalização da mancha urbana aliada à total e histórica falta de iniciativa e eficácia do poder público na produção de moradias para a população de baixa renda, da especulação imobiliária e da ausência do planejamento urbano. (WILHEIM, 1965, p.18)

Em seguida, Wilheim apresenta dados sobre a entrada de veículos comerciais e de passageiros vindos de rodovias como Via Anchieta, Via Anhanguera, Via Dutra, Raposo Tavares e Estrada do Oeste. Os dados apresentados incluem não somente a origem dos veículos como também os distritos de destino. A maior tendência entre estradas registrada pelo autor era da Via Anhanguera para a Via Anchieta. (WILHEIM, 1965, p.20/22)

Wilheim afirma que a superposição de problemas era agravada pela ausência de planejamento urbano e resultava em uma "rede viária acidental, de vazão já agora insuficiente, percorrida por transportes deficientes e com perspectivas graves se persistir a dinâmica do organismo paulistano." (WILHEIM, 1965, p.23)

Wilheim apresentou, a seguir, conclusões à guisa de problemas existentes, como a predominância do Centro Histórico na atração de trabalho, ausência de criação de outros centros urbanos, a necessidade de criação de vias diametrais que não passassem pelo Centro Histórico e "a intensidade do tráfego ligando a Via Anhanguera às demais vias, exigindo a interpretação do sistema viário chamado tangencial como sendo, na realidade, um esquema viário urbano e não perimetral." Aqui o autor considera que o sistema batizado na época de tangencial não poderia ser assim chamado, uma vez que o tráfego gerado passava pela área urbana do município. (WILHeIM, 1965, 24)

Wilheim passa a tratar dos "pontos de encontro" de São Paulo. Os pontos de encontro nas cidades são tema abordado neste trabalho para ilustrar a importância da vida e atividades ao ar livre e, consequentemente, a qualidade que estes espaços deveriam apresentar. Espaços públicos ao ar livre devem surgir em decorrência do bom desenho urbano, com vias definidas para o volume de pedestres e veículos adequado à formação de tecido urbano completo e que acolha o habitante em lugar de afastá-lo. Wilheim reconhece que o "coração da cidade" se forma a partir do uso das áreas públicas ao ar livre, como praças e ruas, e que é ele que dá caráter a uma cidade. (WILHEIM, 1965, p.26)

A grande concentração de serviços e equipamentos públicos ou privados no Centro Expandido até o fim do século XX, quando o mercado imobiliário se volta para outras áreas da cidade que ainda apresentam estoques de áreas e altos coeficientes de aproveitamento, criou centralidades e localizações valiosas em um ciclo vicioso de localização e 
valorização, excluindo os distritos e regiões mais distantes, que, menos valiosas, atraíam menos ou quase nenhum investimento.

Apesar da distância entre distritos periféricos e o Centro Expandido e sem traçar comparações, uma valorização local se foi instalando, surgiram novas centralidades com serviços e comércio diversificados, muitas vezes sem o devido controle de uso e ocupação do solo, criando áreas valorizadas no espaço intraurbano em consolidação dentro de regiões metropolitanas mais carentes.

Quanto ao controle do uso e do abuso do solo urbano, o avanço tem sido mais lento. A renda da terra, isto é, o valor que assumem os imóveis no mercado imobiliário capitalista, depende de como o mercado imobiliário capitalista está organizado. É conhecido pela teoria econômica o grau elevado da não substituição da gleba ou do lote urbano, isto é, cada lote localizado no espaço intraurbano apresenta características próprias quanto às vantagens locacionais, sejam elas paisagísticas (como a proximidade a uma praia, a encosta de um morro, a beira de um rio), sejam decorrentes das características da distribuição das redes de infraestrutura urbana, especialmente a viária e de transporte (CAMPOS FILHO, 1989, P.19)

Com os olhos do mercado imobiliário voltados para as regiões onde há estoques de terrenos, a especulação imobiliária alcança agora distritos mais distantes do Centro, elevando o preço da terra e dos imóveis, além dos valores dos aluguéis, expulsando para mais longe os trabalhadores de baixa renda. Isto pode explicar o recente crescimento populacional em áreas periféricas da Capital, como mostrado no Mapa 39: Projetos e Operações Urbanas (p.151) em distritos muito carentes com população de baixa renda, poucas oportunidades locais e trajetos muito longos entre local de moradia e local de trabalho ou serviços e comércio especializados. Juntando-se a isso o fato de que ocorreu um esvaziamento populacional do centro da cidade, processo aparentemente em reversão, pode-se concluir que ainda há expulsão dos mais pobres para áreas mais distantes e o crescimento populacional em São Paulo registrado entre os Censos de 2000 e 2010 ocorreu concentrado nas regiões do extremo sul, extremo leste e extremo noroeste da Capital. Além disso, e como comprovado pelo Instituto de Pesquisa Econômica Aplicada-IPEA, o espraiamento da mancha urbana de São Paulo continua no extremo sul da cidade, nas ocupações das áreas de mananciais. Detalhes da pesquisa do IPEA estão no Capítulo // desta tese.

\section{CORREDORES METROPOLITANOS}

Anteriormente à sua participação como diretor do PMDI 1971 e à elaboração de sua tese de doutorado em 1972 (desde 1965) o arquiteto e urbanista Candido Malta Campos Filho apresentou o conceito de corredores urbanos e, dentre eles, os de escala metropolitana, como se vê em publicação da Revista Acrópole n. 356 de novembro de 1968 e em publicação da FAUUSP de 1978 A Grande São Paulo: trabalhos e entrevistas de 1965 a 1973. Em 1970 e 1971 desenvolveu o conceito dos corredores metropolitanos quando de sua orientação na elaboração e como diretor do PMDI. Um trabalho de levantamento do processo histórico da chegada e da saída das indústrias ao longo das ferrovias que cortam a metrópole detectou um movimento de periferização, e foi então elaborado de modo pioneiro, com especial participação do arquiteto e urbanista colombiano Guillermo Londoño. (informação verbal) ${ }^{22}$

Ainda em 1970 e 1971, Campos Filho propôs, de fato, a partir de seus estudos, um plano de Corredores Metropolitanos para a Grande São Paulo no bojo do PMDI. Portanto, o fez desde o início da década de 1970, (CAmpos Filho, 1972) apenas dois anos após a publicação do PUB de São Paulo, produzido em 1969 pela Prefeitura do Município de São Paulo, e do PMDI GSP, produzido pelo Governo do Estado
22. Campos Filho. Depoimento à autora, 4 mar. 2013. 
23. Como já afirmado, o conceito de corredores urbanos está presente em Langenbuch em A estruturação da Grande São Paulo (1971) sem que ele assim os houvesse denominado. Não é, portanto, de autoria de Campos Filho. Consta de extensa bibliografia, como presente em muitos planos urbanos especialmente norte americanos. Arturo Soria Y Mata, urbanista espanhol, propôs cidades lineares ou como corredores urbanos no fim do século XIX.

24. Exposta no capítulo 3 de sua tese, especialmente conforme metodologia adotada à página 90. Campos Filho, 1972. de São Paulo em 1970. A seguir, em sua tese de doutoramento na FAUUSP em que se tornou um de seus primeiros doutores, desenvolveu o conceito de corredores metropolitanos, apresentando, em sua defesa, teorias sociais que analisavam o fenômeno urbano, basicamente oriundas da sociologia funcionalista norte americana que havia conhecido em Berkeley, onde obteve seu titulo de mestre em planejamento urbano e regional, em 1971.

\section{Citando Campos Filho:}

\begin{abstract}
A crescente tomada de consciência de que uma cidade é um conglomerado espacial de sistemas de produção e vida social que apresentam um grau de conectividade ou interdependência que se poderia também dizer crescente. Essa crescente interdependência decorre de cada vez maior especialização de funções que ocorrem com o desenvolvimento socioeconômico e que tem como "habitat" mais propício as grandes cidades. (CAmpos Filho, 1972, p.22)
\end{abstract}

Para desenvolver o conceito dos Corredores Metropolitanos, ele compara os modelos do PMD e do PUB, ambos aplicando um traçado viário em malha ortogonal sobre os eixos rodoferroviário em malha basicamente ortogonal sobre eixos viários de traçado radioconcêntrico existentes. O PUB adota uma malha realmente ortogonal, deixando de lado qualquer referência ao sistema hidrográfico e topografia de vales correspondente. Já o PMDI, por influência de Campos Filho, adota o traçado viário radioconcêntrico existente inclusive pelas vias marginais de seus três grandes rios, Tietê, Pinheiros e Tamanduateí, complementado por novos sistemas em anéis ou arcos.

Esses eixos estruturadores rodoferroviários possibilitam delimitar claras regiões potencialmente autossuficientes até certo ponto. Assim, nas regiões entre esses eixos, um centro de comércio e serviços de âmbito local associado a outros pouco mais diversificados mas sem especializações tem condições econômicas de se estabelecer. O comércio e serviço mais especializado é característica do setor terciário de âmbito regional. Decorre assim uma estruturação urbana com base em um processo histórico de desenvolvimento no entorno de corredores urbanos em suas várias escalas em substituição à metrópole do tipo "área urbana desestruturada ou 'o acampamento' - aglomerado de bairros e vilas." (CAMPOS FILHO, 1972, p.XXII) ${ }^{23}$

Campos Filho propôs também a implantação de linhas de Metrô paralelas formando feixes de linhas onde as estações ficariam até um máximo de 250 metros distantes uma da outra para, "distribuir mais uniformemente o poder polarizador de cada estação, uniformizando a acessibilidade ao longo do corredor e reduzindo as distâncias de deslocamento entre estação-e destino final e vice-versa." Desse modo, as linhas paralelas e justapostas na mesma faixa de domínio e até sobrepostas, se a demanda justificar, possibilita alcançar altas densidades dada a capacidade de suporte do sistema de circulação de passageiros assim criada. (CAMpos FILHO, 1972)

Em sua análise, ${ }^{24}$ Campos Filho comparou dois modelos bem distintos: um conceito "puro" de vias expressas e um conceito "puro" de corredores de metrô. O primeiro é um modelo de malha ortogonal de vias expressas voltadas para o uso exclusivo de automóveis, conformando bolsões urbanos entre elas, ou seja, uma estrutura urbana correspondente à concepção de vida urbana dispersa (o modelo “ideal" de Los Angeles, EUA) e é claramente aplicável a sociedades e comunidades que organizam seu cotidiano vinculado ao uso de automóveis particulares. O segundo, o conceito "puro" de corredores de metrô, cuja estrutura urbana corresponde à concepção de vida urbana compacta, (modelo "ideal" dos Corredores Metropolitanos aplicado ao caso de São Paulo) conforme metodologia de levantamento empírico-teórico do sociólogo Max Weber, que tem por objetivo libertar o cidadão da dependência do 
automóvel para seu deslocamento e acesso a serviços, trabalho, educação, lazer etc. (CAMPOS FıLнo, 1972, p.XXVI)

\section{Obviamente, a escala dos Corredores}

Metropolitanos deve ser complementada por corredores de menor escala. Isso porque, com base nos estudos de Langenbuch para a formação histórica da região metropolitana paulistana, os corredores urbanos de menor escala que os ferroviários e depois os metroviários foram formados primeiro pelos bondes e mais tarde também pelos ônibus, até que foram os bondes completamente desativados. Hoje em dia cogita-se adotar o modelo de bondes modernos como sistemas de transporte de massa de média capacidade, chamados também de Veículos Leves sobre Trilhos-VLT. Assim, se busca reservar faixas para eles ou para ônibus, gerando os corredores exclusivos para o transporte coletivo, ou quase exclusivos, quando compartilhados com táxis ou com veículos do sistema público de segurança como ambulâncias, policia, de transporte de valores e bombeiros. É exatamente o segundo modelo apontado pelo autor, o dos corredores urbanos em suas várias escalas sendo a mais ampla a dos corredores metropolitanos, que se irá adotar como uma das ferramentas para fundamentar o plano desta tese, intitulada Planos Urbanos Locais: definição concreta para a mobilidade e qualidade ambiental urbanas, com ênfase em sua dimensão local.

A proposta de Campos Filho para os Corredores Metropolitanos tem como elementos rodoferroviários e geográficos principais três vales, três ferrovias e as vias marginais para veículos sobre pneus, formando três Corredores Metropolitanos principais: o do Rio Tamanduateí, que corre ao lado da Ferrovia Santos-Jundiaí, hoje operada pela CPTM enquanto transporte de passageiros e por concessionária para o transporte de carga; o do Rio Tietê, tendo a antiga ferrovia Central do Brasil com seus dois ramais, situada no interior de seu vale, embora a certa distância de seu leito, para fugir das periódicas inundações, que foram encampados pela CPTM como transporte de passageiros e por concessionária para o transporte de cargas; o do Rio Pinheiros, tendo ao lado a antiga Estrada de Ferro Sorocabana, que tem ramal que corre em sua margem direita também encampada pela CPTM para o transporte de passageiros e concessionária para o transporte de cargas; além de um quarto corredor metropolitano, com ferrovia de carga em parte já implantada entre Mauá e Suzano e planejado para implantação futura, de mais um trecho em forma de anel ao longo do Rodoanel em seu tramo norte, completando um arco rodoferroviário. (CAMPOS FILHO, 1972, p.XXV) Os Corredores Metropolitanos de Campos Filho compõem um plano estrutural de abrangência regional, considerando na aplicação de sua proposta a macrorregião, a polarização externa e o relacionamento regional em direção aos estados da federação vizinhos ao Estado de São Paulo. (CAmpos FILHo, 1972, p.VI, VIII)

A partir da comparação entre PUB e PMDI, Campos Filho apresenta no desenvolvimento do PMDI três conceitos urbanísticos: o Conceito 1 ou Agregação de Propostas Parciais, o Conceito 2 ou Corredores Metropolitanos, e o Conceito 3 ou PUB. (CAmpos FILHO, 1972, p.XIV)

A seguir, a Figura 14: Conceito 1-Agregação de propostas parciais do PMDI apresenta uma estrutura que resulta em irradiação a partir do centro principal para outras centralidades, com malha viária ortogonal sobre o tecido urbano existente à época.

A Figura 15: Conceito 2-Corredores Metropolitanos, do PMDI, apresenta uma estrutura que interliga os Corredores Metropolitanos propostos, criando centralidade ao longo desses corredores, com malha viária radioconcêntrica sobre o traçado viário. Este conceito, que propõe uma "descentralização concentrada," com circulação de grandes volumes de 


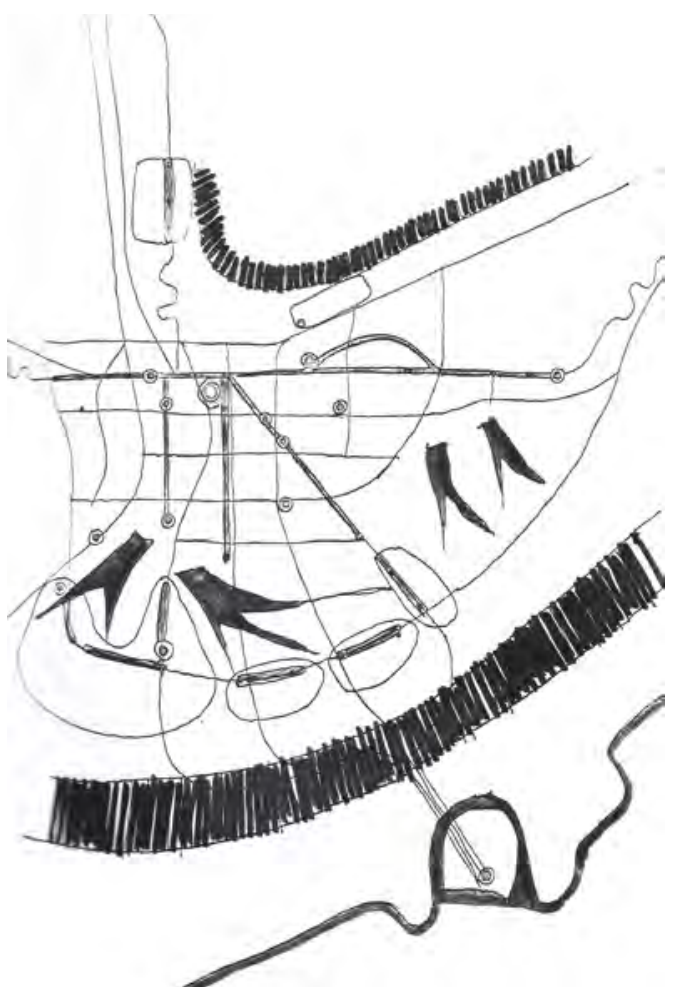

FIGURA 14:

CONCEITO 1-

AGREGAÇÃo dE PROPOSTAS PARCIAIS

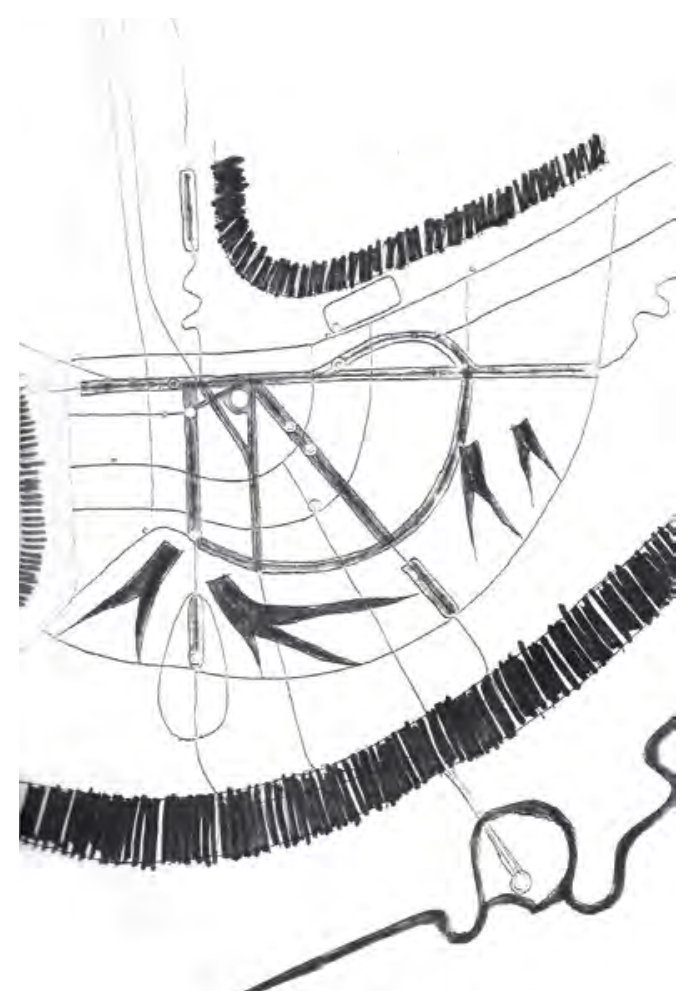

FIGURA 15:

Conceito 2-Corredores Metropolitanos

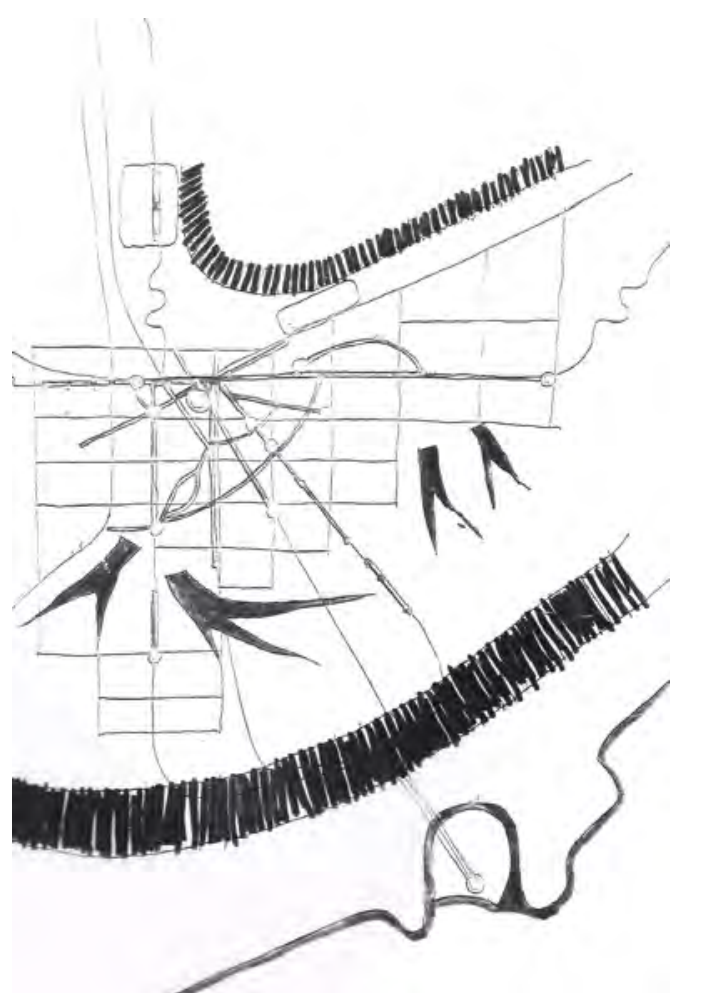

FIGURA 16:

CONCEITO 3-PUB veículos concentrada nas vias estruturais de ligação e pequenas centralidades nas grandes áreas intraurbanas, distribui e concentra usos fora do centro principal. Este conceito engloba a proposta do PUB como uma etapa intermediária. (CAMPOS FILHO, 1972, p.XIX) O Conceito 2 de Campos Filho, que conta com uma política de transportes como coadjuvante, é proposto como plano urbanístico em três fases: na primeira fase, o autor propôs a construção de vias expressas e, menos intensamente, as linhas de metrô; na segunda fase, o autor espera que as vias expressas tenham atingido o seu ponto ótimo de serviço e, na terceira fase, a oferta de metrô cresceria ao longo dos corredores e a oferta de vias expressas seria limitada entre esses corredores.

(CAmpos Filho, 1972, p.XXI)

Por último, a Figura 16: Conceito 3-PUB apresenta uma estrutura que resulta em interligação, com maIha viária ortogonal sobre o tecido urbano existente. (CAmpos FILHo, 1972, p.XV/XVII)

Campos Filho adota o Conceito 2 como base para seu plano urbano de corredores metropolitanos, conforme se vê na Figura 17: Sistema viário centro expandido com o detalhamento viário-estrutural proposto para 1990, "coerente com o sistema viário metropolitano e macrorregional. Foi o que recomendou como um de seus 


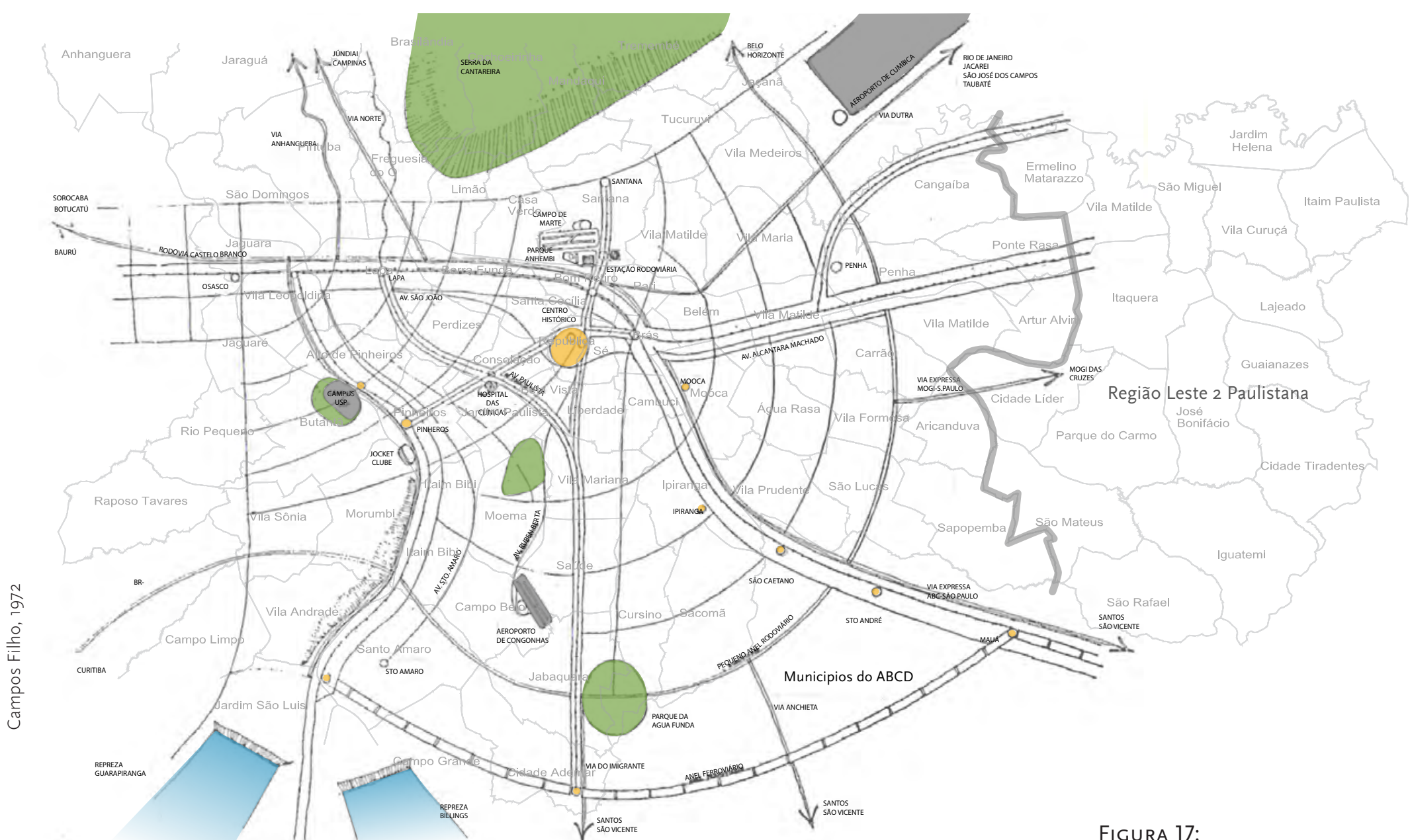

EXPANDIDO

diretores e adotado pelo PMDI." (CAmpos FILHo, 1972, p.XXV)

Na Figura 17, Campos Filho resume em poucos traços um esquema conceitual de plano para desenvolvimento urbano baseado em uma nova rede rodoferroviária estrutural, na condição de indutora da qualidade em tecido urbano consolidado e em consolidação. Este esquema contribuiria para a sustentabilidade de toda a cidade, estancando o crescimento urbano que por fim ocorreu. Campos Filho, assim como outros urbanistas na década de 1970, se opôs a continuidade da horizontalização desmesurada da mancha urbana em direção ao Leste na intensidade ocorrida ou em direção ao Sul.

É de se destacar a firme oposição do urbanista Sergio Zaratin no âmbito do PMDI que se opôs ao crescimento previsto pelo PUB na direção de Parelheiros, em plena região de preservação de mananciais, redirecionando-o para a região leste, mais propícia para o crescimento urbano do que a sul, em função de ali se situarem as principais bacias manancias da metrópole, as represas Billings e Guarapiranga. ${ }^{25}$
25. Campos Filho. Depoimento à autora, 4 mar. 2013. 


\section{ESPAÇO INTRAURBANO}

O conceito de espaço intraurbano do urbanista Flávio Villaça será outro instrumento agregador de conhecimento para o desenvolvimento conceitual desta tese, com ênfase na dimensão local. (VıLLAçA, 1988)

A partir do estudo de seis metrópoles brasileiras (São Paulo, Rio de Janeiro, Belo Horizonte, Porto Alegre, Salvador e Recife), Villaça pretende "entender as localizações intraurbanas, a constituição e o movimentos do espaço intraurbano [das metrópoles brasileiras] - entendido como uma estrutura territorial." (VILLAÇA, 1988, p.11) O autor apresenta seu estudo como essencial para entender-se a formação do tecido urbano nas metrópoles brasileiras e suas resultantes em áreas centrais ou periféricas e quais são as reais diferenças e semelhanças entre as seis metrópoles acima mencionadas que se formaram sob os mesmos aspectos sociais, econômicos, históricos e políticos e sob o mesmo modo de produção. (VILLAÇA, 1988, p.11)

É importante citar o que Villaça destaca como objetivos de sua pesquisa:

1. Detectar traços e movimentos comuns a todas as estruturas territoriais analisadas; daí a importância da história territorial e da análise comparativa de várias metrópoles. Por exemplo, o que há de comum entre a distribuição territorial das classes sociais, além da óbvia distinção entre centro e periferia? A chamada "decadência" do centro principal é um processo comum a todas as nossas metrópoles. Qual sua fonte? Em que consiste na realidade? Qual sua essência? Que relações há entre o "centro principal" e outros elementos das estruturas territorial e social?

2. Relacionar os movimentos da estrutura territorial com os das estruturas sociais (latu senso) e - o que é bem mais difícil - vice e versa. Veja este exemplo: que papel desempenham as classes sociais na estruturação territorial urbana? Qual o papel que sua segregação espacial desempenha na dominação política? E na ideologia urbana? Em que consiste e como se dá essa dominação política através do espaço urbano? Que participação tem o espaço produzido em Copacabana sobre os valores e estilo de vida de seus moradores e dos cariocas da zona Sul em geral?

3. Relacionar entre si os movimentos dos diversos elementos das estruturas territoriais urbanas os vários bairros, o centro urbano, a estrutura de transportes etc. - e com os de outras estruturas articuladas. (VILLAÇA, 1988, p.12)

As hipóteses de Villaça para estas questões servirão para a análise da evolução urbana da RLP de forma a entender e aceitar a condição urbana histórica das periferias paulistanas na proposição, nesta tese, de metodologia para um plano urbano local ambientado nessa região. A macroárea de estudo para a proposição de um plano urbano local corresponde a uma ampla área dentro da Região Leste de São Paulo, a chamada Leste 2, próxima aos limites da cidade com os municípios do extremo leste da RMSP: Itaquaquecetuba, Poá, Ferraz de Vasconcelos, Suzano, Ribeirão Pires e Mauá. A proximidade com esses municípios demandaria por um plano urbano rodoferroviário de cunho regional, do ponto de vista técnico do planejamento urbano praticado nas últimas cinco décadas. Esta tese pretende viabilizar, e dito de um modo muito simplificado, uma "cidade dentro da cidade," interligada ao centro principal e outras centralidades que já oferecem uso mais diversificado, mas o mais autossuficiente possível para que o habitante tenha a opção de cruzar a cidade ou não, em direção ao trabalho e aos serviços e comércios mais sofisticados do que os oferecidos localmente. Isso porque o mercado imobiliário já define os denominados usos locais sem que haja a necessidade de uma intervenção pública pontual para obter essa localização. Tratase de criar uma área com qualidade urbana que atraia esses usos mais especializados que ofereçam tanto os empregos que se deseja assim como os serviços 
e o comércio correspondentes. Também indústrias e serviços de logística que podem envolver algum tipo de transformação industrial, como o da reembalagem de mercadorias do atacado para o varejo, deverão ser objeto de atração. Esse objetivo deverá ser buscado independentemente de uma via estrutural de alto volume de tráfego ou de transporte de massa, embora esse tipo de eixo tenha um papel essencial na reestruturação regional que se busca. Por esse motivo, a análise do espaço intraurbano de Villaça é tão importante para esta tese.

Em relação ao termo intraurbano, Villaça explica que ele foi utilizado para diferenciar o espaço urbano regional do espaço urbano local, apesar de considerar uma redundância desnecessária, acreditando que a expressão espaço urbano está mais vinculada atualmente ao espaço regional. Villaça menciona outras expressões correlatas e muito utilizadas pelos acadêmicos em Urbanismo: estrutura urbana, estruturação urbana, reestruturação urbana, e concluiu que, assim como a expressão espaço urbano, essas expressões só podem se referir ao espaço intraurbano, e acredita que obras intituladas por Reestruturação urbana de (nome de lugar) ou Reestruturação do espaço urbano em (nome de lugar) podem levar a um entendimento diferente do pretendido. Aos interessados na semântica das expressões utilizadas em publicações acadêmicas, recomenda-se a leitura desse capítulo do livro de Villaça pela riqueza e útil contribuição ao perfeito entendimento de conceitos e planos urbanos. (VILLAÇA, 1988, p.18-20)

O autor concluiu que a grande diferença entre espaço regional e espaço intraurbano deriva dos transportes e da comunicação:

Quer no espaço intraurbano, quer no regional, o deslocamento de matéria e do ser humano tem um poder estruturador bem maior do que o deslocamento da energia ou das informações. A estruturação do espaço regional é dominada pelo deslocamento das informações, da energia, do capital constante e das mercadorias em geral - eventualmente até da mercadoria força de trabalho. O espaço intraurbano, ao contrário, é estruturado fundamentalmente pelas condições de deslocamento do ser humano, seja enquanto portador da mercadoria força de trabalho - como no deslocamento casa/trabalho -, seja enquanto consumidor - reprodução da força de trabalho, deslocamento casacompras, casa-lazer, escola etc. Exatamente daí vem, por exemplo, o enorme poder estruturador intraurbano das áreas comerciais e de serviços, a começar pelo próprio centro urbano. Tais áreas, mesmo nas cidades industriais, são as que geram e atraem a maior quantidade de deslocamentos (viagens), pois acumulam os deslocamentos de força de trabalho - os que ali trabalham - com os de consumidores - os que ali fazem compras e vão aos serviços. (VILLAÇA, 1988, p.20)

A clara descrição e análise dos espaços da cidade feita por Villaça fundamentam esta tese de forma muito abrangente e confirmam a problemática que envolve a Região Leste, tema que tratamos aqui, onde milhões de pessoas deixam suas moradias em direção às centralidades paulistanas para trabalhar e desfrutar de serviços de alta qualidade, quando podem pagar por eles.

Villaça prossegue apresentando conceitos e teorias de David Harvey em relação à apropriação do espaço por automóveis, pessoas, objetos e edifícios e como o trabalho "útil e concreto produz valores de uso em determinados lugares." ${ }^{26}$

O autor aborda, em seguida, o tema da localização urbana que, segundo ele, é determinada por dois atributos: uma rede de infraestrutura (vias, redes de água, esgotos, pavimentação, energia etc.) e a possibilidade de transporte de produtos de um ponto a outro, de deslocamento de pessoas e de comunicação.

Dentre essas possibilidades, a de deslocamento do ser humano (para os locais de trabalho, de compras, de serviços, de lazer etc.) dominará a estruturação do espaço
26. Esse, a princípio, não é tema para esta tese. (HARVEY, David (1982) in VILLAÇA, 1988, p.22) 
27. Jaramillo, Samuel. Las formas de produción del espacio construído en Bogotá. Bogotá: CEDE/ Universidad de Los Andes, 1980

28. Campos Filho. Notas da disciplina Teoria do Desenvolvimento e do Planejamento (Área: Estruturas ambientais no curso de Pós-graduação da Faculdade de Arquitetura e Urbanismo da USP, em 2002 intraurbano, já que, entre os deslocamentos de matérias e os do ser humano, dominará o último. Por outro lado, a necessidade de deslocamento do ser humano dominará as de comunicação na estruturação do espaço intraurbano pois, como vimos, o custo das comunicações por fax, telefone ou televisão é praticamente o mesmo em qualquer ponto do espaço urbano. (VILlaçA, 1988, p.23)

Segundo Villaça, há de se considerar a acessibilidade como fator mais vital na produção de localizações do que a disponibilidade de infraestrutura, até mesmo quando a infraestrutura não está disponível mas há acessibilidade, a terra pode ser considerada urbana, e ele reforça que a recíproca não é verdadeira. (VILlaçA, 1988, p.23)

O estudo da produção do espaço urbano ou produção do espaço, como preferem alguns autores, foi muito bem conceituado por Jaramillo (1980, apud Pradilla, 1982, p.149/212)27 e pelo urbanista Campos Filho (informação verbal) ${ }^{28}$ que tratam das quatro formas de produção do espaço (autoconstrução, encomenda, capitalista e estatal ou pública) e que, segundo o entendimento de Villaça, se referem ao espaço regional, uma vez que segundo ele,

Os produtos específicos resultantes da produção do espaço intraurbano não são os objetos urbanos em si: as praças, as ruas ou os edifícios, mas suas localizações. A produção de edifícios ou de conjuntos de edifícios - A Noite, o Martinelli, Barra da Tijuca, Copacabana, o Jardim América ou a Avenida Paulista etc. - enquanto objetos urbanos certamente é produção de espaço. Entretanto o é tanto quanto a produção de cadeiras, árvores ou canetas. A produção dos objetos urbanos só pode ser entendida e explicada se forem consideradas suas localizações. A localização é, ela própria, também um produto de trabalho e é ela que especifica o espaço intraurbano. Está associada ao espaço intraurbano como um todo, pois refere-se às relações entre um determinado ponto do território urbano e todos os demais. (VILLAÇA, 1988, p.24)
Em continuação, Villaça aborda tema do estudo das formas urbanas e as especificidades do espaço intraurbano, os bairros, as direções do crescimento, a forma da mancha urbana, verticalização e densidades. O autor afirma que esse estudo deve considerar a localização de cada objeto, seja ele um edifício ou uma via, no espaço, como um ponto, relacioná-lo com os outros pontos e, por fim, entender o porquê da escolha de um ponto em lugar de outro na produção daquele determinado objeto. (VILLAÇA, 1988, p.24)

Villaça informa que apesar dos estudos dos espaços regionais e planetários, como por exemplo os desenvolvidos pela Escola Francesa de Regulação, "não se desenvolveu, nas últimas décadas, nenhuma corrente de pensamento voltada para os processos socioespaciais intraurbanos mais significativos e muito menos para as conexões entre as transformações das esferas socioeconômicas e as espaciais," correntes essas que poderiam se referir não somente "aos efeitos das transformações sobre o espaço," mas "também ao oposto, isto é, as transformações espaciais sobre a esfera socioeconômica, muito menos frequentes." (VILLAÇA, 1988, p.25)

Nossa análise do espaço intraurbano de seis metrópoles nacionais mostra que a lógica básica de seus espaços pouco se alterou nos últimos cem anos, por mais que, nesse período, o capitalismo brasileiro tenha se alterado, seja nacionalmente, seja em distintas regiões do país. Claro que, se, por exemplo, o neoliberalismo faz aumentar o desemprego e a pobreza, as áreas pobres de nossas cidades aumentarão. Essa explicação é tão verdadeira e óbvia quanto pobre. No nível intraurbano é fundamental entender como essas transformações são filtradas em nossa sociedade e traduzidas em estruturação e reestruturação - e não apenas em alteração do espaço urbano. (VILLAçA, 1988, p.27)

Campos Filho acrescenta a essa análise a importante distinção que faz entre as instituições que 
refletem o capitalismo da acumulação primitiva e o da reprodução ampliada, mostrando que os agentes da produção, apropriação e consumo do espaço urbano mesclam os dois modos de organização capitalista, um arcaico e outro avançado, respectivamente, tendo como referência a apropriação da renda fundiária e a produção. (informação verbal) ${ }^{29}$

As lutas urbanas se explicam em maior parte como resultado da disputa por sua apropriação. No capitalismo dito avançado, com a clara predominância das estruturas institucionais da reprodução ampliada da acumulação capitalista, a denominada "especulação imobiliária" passa a ser controlada com a propriedade cada vez mais pública do solo. Esta nada mais é do que a produção e apropriação da renda fundiária por quem não a produziu. Com o seu progressivo controle, na medida em que o capitalismo da reprodução ampliada se torna hegemônico em relação à da acumulação primitiva, as cidades se tornam mais humanas por se tornarem menos desiguais, mais bonitas e sustentáveis quando as sociedades que as abrigam conseguem um domínio sobre ela, como se vê especialmente no mundo escandinavo no norte da Europa. O Brasil se encontraria em uma determinada etapa desse capitalismo combinado como muitos autores têm analisado, inclusive Francisco de Oliveira, com seu Ornitorrinco. (informação verbal) ${ }^{30}$

Essa contribuição de Campos Filho é seminal para que se compreenda as políticas públicas de combate à especulação imobiliária conforme aponta a constituição federal de 1988 assim como o Estatuto da Cidade de 2001.

\section{ESPAÇOS URBANOS PARA VIVER}

Para se proporem diretrizes ou uma política orientadora para um plano de bairro, para uma nova cidade ou para a requalificação de uma área com tecido urbano consolidado e de baixa qualidade é preciso ter claro o que se quer como resultado. Áreas urbanas de qualidade devem apresentar uso misto em suas variantes de mescla, conforme o desejo de seus moradores, densidade de uso do solo adequada à infraestrutura urbana disponível e a planejada. Um dos fatores principais é a conformidade da qualidade no uso residencial com as diferenças culturais e de nível aquisitivo, evidenciadas pela participação do cidadão na definição do uso e dos serviços disponíveis e com a menor dependência que se consiga do automóvel.

Áreas ao ar livre, espaços públicos e equipamentos urbanos devem, em conjunto, estimular atividades necessárias e opcionais e as consequentes atividades sociais ao ar livre, conforme a classificação de Jan Gehl, que se verá adiante. Quando as duas últimas acontecem com maior frequência, significa que a condição do espaço físico é boa e convidativa à permanência ali, em vez da "expulsão" do usuário do espaço e seu deslocamento para outro espaço mais confortável. (GEHL, 1971, p.11)

A vida nas ruas ou a falta dela foi analisada por Jane Jacobs (JACOBS, 1961) e Jan Gehl, (GeHL, 1971) cujos conhecimentos utilizamos aqui com o objetivo de entender essa forma de habitar a cidade, quais são os cenários ideais e quais as causas da crescente reclusão de seus habitantes em suas moradias. A pesquisa de Gehl é contínua até a década de 2010, mas, como ele declara, a essência das análises e conclusões é a mesma desde a primeira edição, em 1971.

Na década de 1980, Donald Appleyard (AppleyARD, 1981) analisou três tipos de vias em São Francisco, na Califórnia, EUA, para conhecer o impacto do tráfego na vida dos moradores dessas vias, qual a frequência e tamanho do deslocamento desses habitantes a partir de suas casas até os serviços ofertados nas vias e o relacionamento com outros vizinhos.

Jane Jacobs decanta a cidade "ideal" como aquela que apresenta espaços públicos de qualidade, seguros, com vida nas ruas, com habitantes zelando uns pelos outros pelas simples atividades
29. CAmpos FILHO. Depoimento
à autora, 12 mar. 2013 . 30. IBIDEM. 
de estar na rua, olhar a rua, "ser os olhos da rua." Independentemente de sua postura radicalmente contrária ao planejamento urbano e às reurbanizações vigentes à época de sua publicação, ela apresenta uma valiosa crítica à produção do espaço urbano na forma de conjuntos habitacionais que não têm vida socialmente rica nos espaços entre edifícios e suas vias e que culminam por estigmatizar seus habitantes:

\begin{abstract}
Mas veja só o que construímos com os primeiros vários bilhões (de dólares): conjuntos habitacionais de baixa renda que se tornaram núcleos de delinquência, vandalismo e desesperança social generalizada, piores do que os cortiços que pretendiam substituir; conjuntos residenciais de renda média que são verdadeiros monumentos à monotonia e à padronização, fechados a qualquer tipo de exuberância ou vivacidade da vida urbana; conjuntos habitacionais de luxo que atenuam sua vacuidade, ou tentam atenuá-la, com uma vulgaridade insípida; centros culturais incapazes de comportar uma boa livraria; centros cívicos evitados por todos, exceto por desocupados, que têm menos opções de lazer do que as outras pessoas; centros comerciais que são fracas imitações das lojas de rede suburbanas padronizadas; passeios públicos que vão do nada a lugar nenhum e nos quais não há gente passeando; vias expressas que evisceram as grandes cidades. Isso não é reurbanizar cidades, é saqueá-las. (JACOBS, 1961, p.2)
\end{abstract}

Jacobs alerta que os problemas aventados no parágrafo acima se estendem por outras cidades norte-americanas além de Nova York, como Chicago, Boston, Filadélfia, São Francisco etc., vítimas do "raciocínio econômico da reurbanização atual," que classifica como embuste. (Jacobs, 1961, p.3) A autora classifica as cidades como "um imenso laboratório de tentativa e erro, fracasso e sucesso, em termos de construção e desenho urbano," com grandes somas à disposição, mas que produzem tanto praças convidativas e seguras às crianças como praças idênticas que têm exatamente o efeito contrário. (JACOBS, 1961, p.5)

Para Appleyard, Jane Jacobs faz um ataque à urbanização e planejamento residencial modernista, defendendo a diversidade da cidade antiga e clamando pela volta da vida nas ruas urbanas com os olhos dos moradores sempre alertas, criando espaços sempre seguros, contraponto aos modernos conjuntos habitacionais, onde ninguém teria tempo de cuidar dos outros. (Aplleyard, 1981, p.3) Appleyard faz uma crítica a Jacobs, ao acreditar que esta defende seu ideal de ambiente urbano, o bairro de Greenwich Village, sem ater-se ao tráfego local. Ela argumenta que o tráfego cresceu após a implantação de uma highway, defendendo que o tráfego atrai a si mesmo. (JACOBS, Jane (1961) in ApPLEYARD, 1981, p.3) Gehl também é um defensor de modelos de cidades do passado, onde os espaços públicos estão tão inseridos no tecido urbano que proporcionam ao habitante maiores possibilidades de vida ao ar livre e às atividades sociais decorrentes. Ele cita, inclusive, exemplos de antigos núcleos medievais em cidades da Europa. (GehL, 1971, p.38)

Jacobs não credita aos automóveis nenhuma responsabilidade pela queda na qualidade dos espaços públicos e, consequentemente, da qualidade de vida, mas sim à ineficiência de planejadores que "não sabem o que fazer com os automóveis nas cidades porque não têm a mínima ideia de como projetar cidades funcionais e saudáveis - com ou sem automóveis." (JACOBS, 1961, p.6)

Assim como muitos urbanistas e planejadores brasileiros, Jacobs defende a "diversidade de usos mais complexa e densa" nas áreas urbanas, evitando o que Gehl chama de áreas desertas em fins de semana: áreas que sofreram alteração de uso residencial para comercio e serviços, com a perda de seus habitantes. (JACOBS, 1961, p.13) 


\section{VIDA ENTRE EDIFÍCIOS: USANDO O ESPAÇO PÚBLICO}

O dinamarquês Jan Gehl, cuja pesquisa aborda a vida nas ruas, apresenta um ensaio sobre a cidade de Copenhagen da década de 1970, capital de seu país natal, classificando espaços e vias urbanas em relação à qualidade apresentada nesses meios físicos e a resultante no uso das ruas para a prática de atividades variadas por parte de seus habitantes e as atividades sociais decorrentes. Sua análise pode se apresentar como complementar às de Jane Jacobs. (GeHL, 1971)

A primeira versão do livro de Gehl foi publicada em 1971 com o propósito de colocar e apontar alguns pontos da arquitetura funcional e do planejamento das cidades que dominaram aquele período, década de 1970. O propósito do livro foi analisar a qualidade de vida nos espaços entre edifícios e determinar e classificar a frequência da ocorrência das atividades externas nesses espaços, demonstrando que esses espaços têm dimensões importantes para a arquitetura, o urbanismo e o planejamento urbano e devem ser tratados com cuidado. (GehL, 1971, p.7)

O cenário geral que serviu para a produção deste livro é a cidade de Copenhagen, na Dinamarca, e segundo o autor, um dia comum em uma rua comum apresenta pedestres nas calçadas, crianças brincando próximas à porta de suas casas, pessoas sentadas em bancos de jardim, praticantes de corrida e prestadores de serviços como carteiros e mecânicos em plena atividade. Essa mistura de atividades externas é influenciada por uma série de condições. O meio físico é um dos fatores. As atividades externas e o grande número de condições físicas que o influenciam são objeto do livro do autor. (GEHL, 1971, P.9)

O autor divide as atividades nas ruas em três categorias: atividades necessárias (Necessary activities), atividades opcionias (Optional activities) e atividades "resultantes" ou sociais ("Resultant" activitiesSocial activities). (GEHL, 1971, p.9/12)

Pode-se fazer um paralelo com a classificação tradicional dos usos nas leis paulistanas. Atividades necessárias são os nossos serviços e comércio de âmbito local, ou seja, as compras diárias, a frequência escolar, o transporte publico. O autor destaca em seu trabalho as atividades dos habitantes, sem enfatizar a prestação de serviços, atividades comerciais ou profissionais. Em geral, o autor relaciona as atividades necessárias e diárias ao caminhar, ao pedestrianismo, dispensando o uso de veículos. O autor lembra que as necessárias atividades em grupo ocorrem e dependem unicamente das condições do espaço físico, onde o participante tem menos independência e opção de escolha.

Gehl destaca como atividades opcionais aquelas que somente ocorrem se o habitante o desejar e se as condições climáticas e físicas externas o permitem. São atividades como sair para tomar ar fresco, contemplação da vida nas ruas ou tomar sol em bancos de jardim. Essas atividades ao ar livre estão particularmente conectadas com o planejamento do espaço físico porque as atividades de recreação são especialmente prazerosas se praticadas em áreas públicas e dependem especialmente das condições físicas do espaço público. (GeHL, 1971, p.9)

Quando o meio externo apresenta baixa qualidade, somente as atividades estritamente necessárias ocorrem. Quando o espaço externo apresenta qualidade urbana, as atividades necessárias ocorrem na mesma frequência, ou seja, elas têm o tempo de duração equivalente às condições físicas externas presentes. O espaço urbano público com alta qualidade encoraja as pessoas a saírem às ruas, parar, sentar, comer, jogar etc. Em ruas e espaços urbanos com baixa qualidade, somente um mínimo de atividades ocorre, mantendo-se a população 
confinada em suas casas. Com bom tempo e boa qualidade urbana, a área externa ganha um espectro de atividades muito maior. É claro que o autor se refere ao clima como fator externo influenciador do uso das ruas, uma vez que o ensaio foi realizado na cidade de Copenhagen na Dinamarca, país do norte europeu, onde as estações do ano são bem definidas com invernos rigorosos e baixíssimas temperaturas. (GeHL, 1971, p.11)

Gehl relaciona a qualidade do meio físico à necessidade da atividade e afirma que, quanto maior a qualidade do meio físico, mais atividades externas ocorrerão, ou seja, se o meio físico é pobre em qualidade, o número de atividades necessárias externas ocorrem em número médio e as atividade opcionais são muito poucas. Se o meio físico é bom, as atividades necessárias aumentam muito pouco, por já serem necessárias, enquanto que as atividades opcionais aumentam de forma significativa e as atividades sociais decorrentes aumentam na ordem de $300 \%$.

O autor define como atividades sociais todas as atividades que dependem da presença de outras pessoas no espaço público, como crianças conversando ou brincando, atividades comunitárias diversas e contatos passivos, ou seja, simplesmente ver e ouvir outras pessoas. Os espaços são jardins, balcões, edifícios públicos, locais de trabalho etc., mas somente as atividades que ocorrem em espaços públicos é que foram consideradas na pesquisa de Gehl. (Geht, 1971, p.12)

Atividades sociais ocorrem espontaneamente como consequência direta de indivíduos movendo-se e permanecendo no mesmo espaço e isso implica que atividades opcionais ou necessárias sejam resultantes da conexão entre esses indivíduos no espaço público. (GeHL, 1971, p.12)

Os tipos de atividades sociais variam de acordo com o contexto. Em ruas residenciais, áreas próximas a locais de trabalho ou de escolas, onde um determinado número de pessoas têm interesses e experiências em comum, as atividades sociais que ocorrem nesses espaços públicos são saudações e cumprimentos, conversas, discussões e isso as faz descobrir e desenvolver seus interesses em comum pelo simples motivo de se verem com frequência. Já nas centralidades urbanas de maior diversidade e de uso mais intenso no nível superior da hierarquia em que se organizam, as atividades sociais tendem a ser mais superficiais, quando a maioria das pessoas mantém apenas contatos passivos, vendo e ouvindo um grande número de desconhecidos. Mesmo assim, essa simples atividade pode ser muito atraente. (GeHL, 1971, p.13)

Em uma interpretação livre, a atividade social ocorre toda vez que duas pessoas estão juntas no mesmo espaço. Olhar e ouvir um ao outro, encontrar, já configura uma forma de contato, uma atividade social, e pode ser a semente para outras formas de atividades sociais mais profundas.

Esse tipo de relação social é importante no planejamento do espaço físico. Mesmo que o espaço físico não influencie diretamente a qualidade, conteúdo e intensidade dos contatos sociais, os arquitetos e planejadores urbanos podem interferir na possibilidade dos encontros, no ver e ouvir outras pessoas, possibilidades que têm qualidade em si mesmas e se tornam importantes como experiência e viabilizam relações sociais mais profundas. O plano de fundo da pesquisa de Gehl é encontrar as possibilidades e oportunidades para ver e ouvir outras pessoas. Outra razão para a pesquisa dessas atividades é precisamente entender que a presença de outras pessoas, atividades, eventos, inspiração e estímulos compreendem uma das mais importantes qualidades do espaço público de modo geral, comprovando que a presença de pessoas nos espaços públicos Ihes empresta qualidade urbana. (GeHL, 1971, p.13)

Ao observar-se uma via comum, com pedestres indo e vindo, crianças brincando próximo a suas casas, 
pessoas sentadas em bancos e degraus, carteiros, mecânicos trabalhando, grupos conversando, pode-se perceber o quanto as atividades necessárias, opcionais e sociais ocorrem num padrão perfeitamente entrelaçado. Pessoas, andam, se sentam, conversam. Atividades funcionais, sociais e de recreação ocorrem em todos os tipos de combinações. Esta análise do tema atividades ao ar livre não começa com uma simples, limitada categoria de atividades. (GeHL, 1971, p.9, 14) Segundo Gehl, a vida entre edifícios não é meramente o trânsito de pedestres ou atividades sociais ou de recreação, mas compreende todo um espectro de atividades que se combinam para formar espaços comunitários significativos e atraentes nas cidades e em áreas residenciais. Tantos as atividades necessárias, funcionais, como as opcionais, de recreação, foram por ele longamente examinadas em diferentes contextos. Já as atividades sociais e suas relações para formar o tecido urbano receberam atenção consideravelmente menor. (GEHL, 1971, p.14)

Segundo Gehl, oportunidades de encontro e atividades diárias em espaços públicos de uma cidade ou área residencial permite a qualquer um se reunir, ver e ouvir outros e ter a experiência de conhecer e ver outras pessoas se comportando em diversas situações. O tímido "ver e ouvir" deve ser considerado em relação a outras formas de contato e como parte de um amplo espectro de atividades sociais, do simples contato sem compromisso até as relações complexas e com envolvimento emocional. (GEHL, 1971, p.15)

Gehl classifica a intensidade de contato das atividades ao ar livre a partir de baixa intensidade, onde ocorrem os contatos passivos (ver e ouvir), localizados na parte inferior da escala, passando para os contatos casuais, conhecidos, amigos até amizades próximas, sendo estas a de maior na escala de intensidade de contato. Ele enumera oportunidades relacionadas ao simples encontrar, "ver e ouvir," ponto de partida para interações complexas como contatos de nível tímido, possibilidade para manutenção de contatos já estabelecidos, fonte de informação sobre o mundo social externo e, por último, fonte de inspiração e de outras experiências estimulantes. (GeHL, 1971, p.15)

A partir dessa etapa do livro, Gehl passa a fazer um refinamento dos seus conceitos e graus de contatos entre pessoas, a descrever essas atividades sociais através de um prisma mais sociológico das ocorrências da vida nos espaços públicos, de forma a fundamentar suas teorias. O autor procura demonstrar, por exemplo, a partir de gráfico, qual o tempo gasto em espaços públicos por crianças de zero a seis e de sete a catorze anos durante a semana e aos domingos, quais são as atividades e as preferências na vida ao ar livre. (GEHL, 1971, p.25) O autor apresenta uma foto onde várias pessoas admiram dois jovens dançando e afirma que ninguém para defronte a bancos ou lojas conceituadas, apenas poucas pessoas param em vitrines para olhar brinquedos e fotos, mas, de longe, um grande número de pessoas para e observa outras pessoas e eventos. (GEHL, 1971, p.28)

O trabalho desenvolvido por Gehl pode ser relacionado ao trabalho de Appleyard. Como descrito no item 6 deste capítulo, Appleyard é autor de um estudo histórico, internacionalmente conhecido, que avaliou os efeitos da deterioração de vias em função da intensidade do tráfego e o consequente grau de confinamento dos moradores a partir do estudo de três ruas residenciais com intensidades de tráfego diferentes - leve, moderado e intenso - na cidade de São Francisco. Quando discorre sobre o estudo de Appleyard, Gehl destaca que, nas vias de baixo tráfego de automóveis, um grande número de atividades ao ar livre era observado. Crianças brincavam nas calçadas e na rua, degraus e entradas das residências eram largamente utilizados para estar ao ar livre e uma vasta rede de contatos de vizinhança, o oposto ocorrendo nas vias com muito tráfego. (GEHL, 1971, p.34/35) 
37. Rothenburg ob der Taubert, uma bem preservada cidade medieval ao sul da Alemanha. Cidade de Martina Franca, na Apúlia, ao sul da Itália. GeHL, 1971, p.38)

32. Gehl se refere aqui aos subúrbios da década de 1960 que se disseminaram nas cidades planejadas americanas, com morfologia urbana específica e de baixa densidade e que, por estarem implantados a longas distâncias dos centros urbanos, alteraram sensivelmente a forma de contato ou interação entre os seus habitantes e os espaços públicos nessas novas áreas residenciais. Pode-se também estabelecer um paralelo com as áreas periféricas das metrópoles brasileiras, com suas construções precárias que, distantes dos centros urbanos e absolutamente carentes de espaços públicos com ou sem qualidade, contam com suas ruas e vielas para as atividades sociais ao ar livre.
Em outro exemplo, Gehl apresenta um projeto de urbanização de uso residencial com duas áreas implantadas, ambas entre 1973 e 1975, em Copenhagem. A maior área apresenta tipologia superior em relação ao desenho urbano e na distribuição dos espaços privados e semiprivados ao ar livre, com quintais privados e pequenos pátios frontais semiprivados. A menor área, cerca de $40 \%$ do tamanho da primeira e que não apresenta desenho urbano tão equilibrado quanto a anterior, apresenta apenas quintais privados aos fundos das residências. Em uma avaliação das atividades ao ar livre em ambas as áreas, realizada em um sábado no verão de 1980/1981, o autor concluiu que as atividades ao ar livre ocorreram em proporção 35\% maior na área mais bem planejada. Os pátios frontais semiprivados implantados representaram um fator de substancial diferença nas atividades ao ar livre. (GEHL, 1971, p.36)

Gehl apresenta duas cidades europeias, Rothenburg ob der Taubert, na Alemanha, e Martina Franca, na Itália, ${ }^{31}$ e compara a relação entre o traçado urbano do núcleo medieval com o traçado urbano mais recente de cada uma delas, analisando as atividades ao ar livre dos espaços públicos em cada traçado. Conclui que, nos núcleos medievais, os espaços urbanos estão excepcionalmente bem relacionados com as atividades ao ar livre em função de sua qualidade espacial. Segundo o autor, as áreas urbanas mais recentes não apresentam o mesmo grau de uso dos espaços públicos ao ar livre por serem projetados em áreas muito largas, muito compridas ou muito retas. No exemplo da cidade italiana, ele conclui que

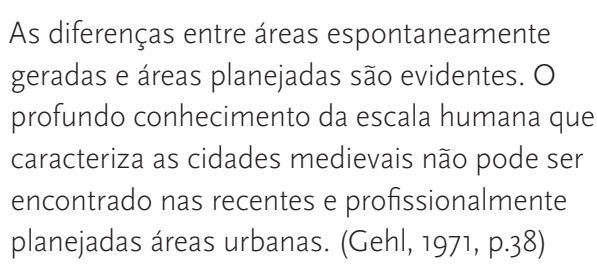

As diferenças entre áreas espontaneamente geradas e áreas planejadas são evidentes. $\bigcirc$ profundo conhecimento da escala humana que caracteriza as cidades medievais não pode ser encontrado nas recentes e profissionalmente planejadas áreas urbanas. (Gehl, 1971, p.38)

Gehl passa a discorrer sobre as tendências arquitetônicas e as ideologias de planejamento urbano, sobre o que não pretendemos discorrer aqui. (GEHL, 1971, p.39)
Para Gehl, os modelos atuais das relações sociais urbanas, contam com novos elementos como os subúrbios ${ }^{32}$ e equipamentos eletrônicos, como televisão e computadores e que representam uma nova forma de interação entre os indivíduos de uma cidade. Os relacionamentos sociais diretos nas áreas públicas podem ser hoje em dia substituídos pelos relacionamentos indiretos na forma de apreciação passiva de imagens e experiências alheias ocorridas em outros lugares. (GEHL, 1971, p.49)

Para Gehl, o automóvel possibilitou substituir a participação em atividades sociais espontâneas por deslocamentos para encontrar amigos ou atrações pré-selecionadas. Apesar disso, diversas possibilidades de participação em atividades sociais foram perdidas. Gehl alerta para as mudanças ocorridas na formação familiar atual. O tamanho da família média, como na Escandinávia, onde a média de pessoas por família é de 2,2 pessoas, e a demanda por espaços ao ar livre cresce também conforme a nova estrutura familiar, onde há menos crianças e jovens e uma crescente população idosa com boa saúde e que ainda tem dez, vinte e até trinta anos de vida pós-aposentadoria para usufruir. (GEHL, 1971, P.5O)

Gehl informa que, em todas as partes do mundo, centros de cidades dominadas pelo automóvel têm visto muitas de suas ruas transformadas em vias de pedestres, resultando em aumento das atividades nesses espaços públicos em função dos novos padrões de vida nas ruas determinados pelos novos conceitos de vida urbana. Ele cita a cidade de Copenhagen, que começou a sofrer essas mudanças a partir de 1962, tendo várias ruas revertidas para vias de pedestres. O autor afirma que os espaços públicos em vias residenciais são áreas necessárias e sua busca óbvia inclui desde uma pequena rua residencial até uma grande praça central. (GEHL, 1971, P.50)

Segundo o autor, críticas, reações e visões relativas à melhoria das condições de vida e cidades formam 
a base para a análise da estrutura física necessária para a vida entre edifícios. O autor não propõe como ponto de partida nenhum programa incompreensível ou ambicioso, mas sim um conceito básico, onde a vida cotidiana, as situações corriqueiras e os espaços onde essas atividades ocorrem formam o centro das atenções e esforços e se expressam em três modestos mas abrangentes requisitos para os espaços públicos, que são: condições desejáveis ao ar livre para as atividades necessárias, condições desejáveis para as atividades opcionais e de recreação e, por último, condições desejáveis para as atividades sociais. (GeHL, 1971, p.51)

Gehl considera que a capacidade dos indivíduos se moverem segura e facilmente, a capacidade de permanecer na cidade e nas áreas residenciais, a capacidade de desfrutar espaços, edifícios e a vida urbana e a capacidade de conhecer e permanecer com outras pessoas são fundamentais para projetos de boas cidades e de bons edifícios hoje, assim como no passado. Para o autor, esses requisitos básicos não podem ter importância superestimada e devem ser vistos como demadas modestas por estruturas urbanas melhores e mais úteis para as atividades diárias mas, por outro lado, estruturas urbanas bem planejadas para a vida entre os edifícios e para atividades comunitárias são, em qualquer circunstância, uma qualidade valiosa e independente e, talvez, um começo. (GeHL, 1971, p.51)

\section{O IMPACTO DO TRÁFEGO NAS VIAS RESIDENCIAIS}

Jacobs considera que a rua deve contar com os habitantes para cuidar dela e Gehl relata e classifica a vida nas ruas e quais são os mecanismos para mantê-la e evitar a reclusão de seus habitantes. Gehl faz um cruzamento entre a qualidade das ruas e as condições climáticas para classificar a intensidade da vida nos espaços públicos entre edifícios e nas ruas, o que é válido até os dias de hoje. O autor nos oferece instrumentos para criar panoramas suaves, mas passa ao largo de outras questões, como o uso das praças públicas em comícios e protestos.

Para Appleyard, pessoas vivem e viverão nas ruas. (APPLEYARD, 1981) É nas ruas que as crianças desco-

brem o mundo e vizinhos se encontram; as ruas são centros sociais das cidades, ponto de encontro de manifestações e palco de repressões. São também canais de acesso e transporte, ruidosas com carroças e cavalos e gritos dos cocheiros, contaminadas por esterco, lixo e lama, onde estranhos invadem e criminosos agem. As ruas sempre foram palco desse conflito, da vida versus mobilidade; moradores versus viajantes; vida nas ruas versus ameaça de morte. Lidar com esse conflito é o foco da análise de Appleyard. (ApPlEYARD, 1981, p.1) Segundo o autor, no século XIX, as ruas não eram melhores na Europa e EUA do que na Roma antiga: as ruas tinham tráfego e ruído incessante, pessoas não saíam desacompanhadas à rua e ladrões agiam. À noite, o risco de ser atingido por dejetos lançados das casas à rua era grande. No século XIX, as ruas dos EUA e Europa ainda continham lixo e lama e poças insalubres aos moradores. (APPLEYARD, 1981, p.1)

Nos primeiros anos do século XX, Londres tinha ruas pavimentadas, mas sujas; Nova York possuía casas em sobrados, acima de comércios, e massas de crianças e lixo nas ruas; São Francisco possuía ruas largas sem pavimentação com calçadas de madeira, não raramente ocupadas por cavalos ou carruagens. Nesse mesmo século, as ruas limpas e pavimentadas estimularam o automóvel, que invadiu para sempre, de um modo geral, as ruas. Segundo o autor, o planejamento moderno discute os perigos do tráfego nas ruas desde o início do século XX. (Appleyard, 1981, p.2)

Appleyard menciona, como contraponto, o surgimento do movimento Cidades Jardim, que buscava 
ruas seguras através do cul-de-sac, quadras residenciais e unidades de vizinhança, com acessos pedonais seguros até a escola, e que tentou separar o uso residencial do comercial, evitando o convívio com os incômodos provocados pelas atividades comerciais e industriais. Com o crescente número de carros, os seguros espaços verdes dão lugar a estacionamentos e ruas para circulação de autos. (Appleyard, 1981, p.3)

Appleyard informa em seu livro que, em 1963, o inglês Colin Buchanan produziu importante relatório governamental, Traffic in Towns (Tráfego nos centros urbanos), onde documentou problemas mas atevese mais às soluções: introduzir o conceito de "áreas ambientais," onde o ambiente tinha prioridade na preocupação. Muitas cidades produziram planos para suas "áreas ambientais." Entretanto, nos anos seguintes a preocupação passou a ser o transporte em virtude da necessidade de canalizar o tráfego por enormes vias expressas a fim de criar "áreas ambientais." Segundo Appleyard, Buchanan não era contra o tráfego, percebeu que era inevitável e decidiu organizá-lo. (AppleYARD, 1981, p.3/4)

Uma sociologia empírica passa a olhar o conjunto da rua puramente como fenômeno sociológico, mantendo como primeiro interesse o papel do encontro face a face praticado pela vizinhança nas redes sociais de moradores da cidade (APPLEYARD, 1981, p.4) e que é defendido por Jacobs.

Ainda segundo Appleyard, em 1968, Herbert Gans também acusa Jacobs de engajamento na "falácia do determinismo ambiental" quando argumenta que os desenhos das ruas e das habitações possam por si só trazer diversidade à vida nas ruas. (APPLEYARD, 1981, p.4)

O autor relata as conclusões de outros estudiosos:

Marc Fried (1961) e Gerald Suttles (1968) descreveram a natureza da vida nas ruas em cortiços e bairros de operários de Boston e Chicago. Mais recentemente, Sidney Brower
(1977) concluiu que havia mais recreação nas ruas que nos parques de Baltimore. Esses estudos se iniciam com a primazia da vida das ruas nas vizinhanças de baixa renda e detalham a interrelação entre território público e privado, considerando a rua como mediador entre a comunidade e o mundo privado da família. Nenhum dos estudos, à exceção do de Brower, mencionam tráfego ou outros incômodos ambientais, apesar de Suttles descrever o papel das principais vias comerciais, o "domínio impessoal" dos bairros miseráveis de Chicago, onde poucos se aventuram à noite. (...) Preocupações ambientais começaram a surgir apenas recentemente, a partir de estudos que consideram a satisfação residencial como um todo. Uma ampla série de qualidades foi relatada, incluindo a casa propriamente dita, privacidade, manutenção das relações de vizinhança, aparência, status social, adaptação às crianças e ruas bem pavimentadas. Curiosamente, o tráfego não foi considerado um problema importante nesses estudos. Uma das razões pode ser a concentração das pesquisas sobre ambientes suburbanos ou novos conjuntos habitacionais, onde a circulação de veículos é frequentemente planejada para ter baixa velocidade ou baixo volume. Outra razão é o modo como os resultados são categorizados nas diferentes pesquisas [a falta de padronização na classificação dos resultados de tráfego, que hora aparece como "atividade de rua " ora como "ambiente externo"]. (...) O estudo 1973 US Housing Survey, publicado em 1975, baseado em entrevistas com 53.800 entrevistados (...) [reporta que] $46 \%$ consideraram o ruído das ruas como característica indesejável de sua vizinhança, e $29 \%$ consideraram indesejável o tráfego intenso. (...) Tráfego foi, portanto, considerado problema muito mais difundido que o crime, apesar deste ocupar as manchetes da mídia. (...) Nas cidades centrais, 34\% reclamaram do tráfego intenso, $51 \%$ do barulho das ruas e $22 \%$ dos crimes nas ruas. (...) Talvez o problema mais crítico seja o alto índice de crianças feridas ou mortas pelo trânsito de veículos. (Appleyard, 1981, p.4/5)

Appleyard segue contando que, a partir de 1973, cidadãos europeus e norte-americanos começaram a se opor ao trânsito de veículos, protestos geralmente 
ocasionados por acidentes recentes. Os esforços para controlar os efeitos negativos do tráfego de veículos fora do continete americano foram mais eficientes. Em 1975, em Paris, ocorreu entre os países participantes da Organização para Cooperação Econômica e Desenvolvimento a conferência Melhores cidades com menos tráfego, e foram estudados os casos de cidades como Bolonha, Cingapura, Nothingham, Uppsala, Munique, Besançon e Nagoya, que haviam se tornado pioneiras em novas maneiras de tornar habitável a cidade. (APpleyard, 1981, p.9)

Segundo Appleyard, a proteção e criação de ruas com vida não é simplesmente uma questão de aumentar seu conforto, porque elas têm outras funções. Mediadora entre o lar e o mundo exterior, lugar onde crianças crescem, aprendem a se confrontar com estranhos e outros espaços sozinhas, a rua deve ser um receptivo e configurar um espaço razoavelmente seguro onde a criança possa explorá-la, manipulá-la e usá-la como cenário para toda uma sorte de atividades. As ruas têm significado pessoal e social para adultos e idosos, já que simboliza a posição de um sujeito no mundo quase tanto quanto a casa em que ele vive, e as relações sociais que acontecem na rua, seu potencial de aproximar a vizinhança e a vida na rua são importantes valores urbanos quando desejados. Mas, segundo Appleyard, não devemos romantizar a vida na rua a ponto de se tornarem objeto de total proteção. Algumas coisas que ocorrem nas ruas são também ameaçadoras e antissociais. (APPLEYARD, 1981, p.9)

Appleyard afirma que as cidades devem acolher sua população. Devem-se procurar maneiras de tornar as vizinhanças capazes de se comportar como "paraísos de descanso" depois de um dia de trabalho, ao invés de sítios ruidosos, sujos e enfumaçados. (Appleyard, 1981, p.10)

Appleyard propõe a criação e manutenção de ruas habitáveis e com vida a partir de: 1 . Entendimento profundo do que ocorre nas áreas residenciais, quem vive lá, os problemas específicos de diferentes grupos e as mudanças em andamento; 2. Variedade de estratégias para criar ruas mais habitáveis e vizinhanças mais protegidas para aliviar ou compensar as condições onde o tráfego é inevitável; 3. Programas participativos efetivos que informem e estimulem os afetados pelas mudanças no tráfego a se envolverem no processo de planejamento; 4. Métodos confiáveis e relevantes de avaliação dos custos e benefícios das mudanças entre diferentes populações e grupos de interesses. (APPLEYARD, 1981, p.10)

Segundo Appleyard, há importantes questões a estudar em assuntos pertinentes ao planejamento em transportes:
Se, por exemplo, todos os bairros residenciais de uma região metropolitana são protegidos do trânsito pesado, o sistema viário principal provavelmente será sobrecarregado. Devemos aumentar a capacidade dos grandes sistemas viários ou iniciar uma política generalizada de restrição ao trânsito que provoca congestionamentos, com todas as consequências negativas que cada uma das opções traz? E quantas pessoas desejarão ou concordarão em mudar para o transporte coletivo? Estas são as novas questões no planejamento de transportes. (APPLEYARD, 1981, p.11)

Em linhas gerais, o estudo de Appleyard tem duas vertentes: explorar como é viver em ruas com diferentes graus de tráfego, que se encontra na Parte 1, que é inteiramente devotada à descrição de como é viver nas ruas, e encontrar caminhos para transformar mais vias em seguras e habitáveis, no conteúdo da Parte 2, que descreve esforços para criar mais ruas habitáveis. Na Parte 3 , encontra-se uma série de estratégias que podem ser úteis mais adiante para esta tese, na análise do tecido urbano da Região Leste de São Paulo, especialmente a Região Leste 2, e na proposição de diretrizes nesta tese. (Appleyard, 1981, p.11) 


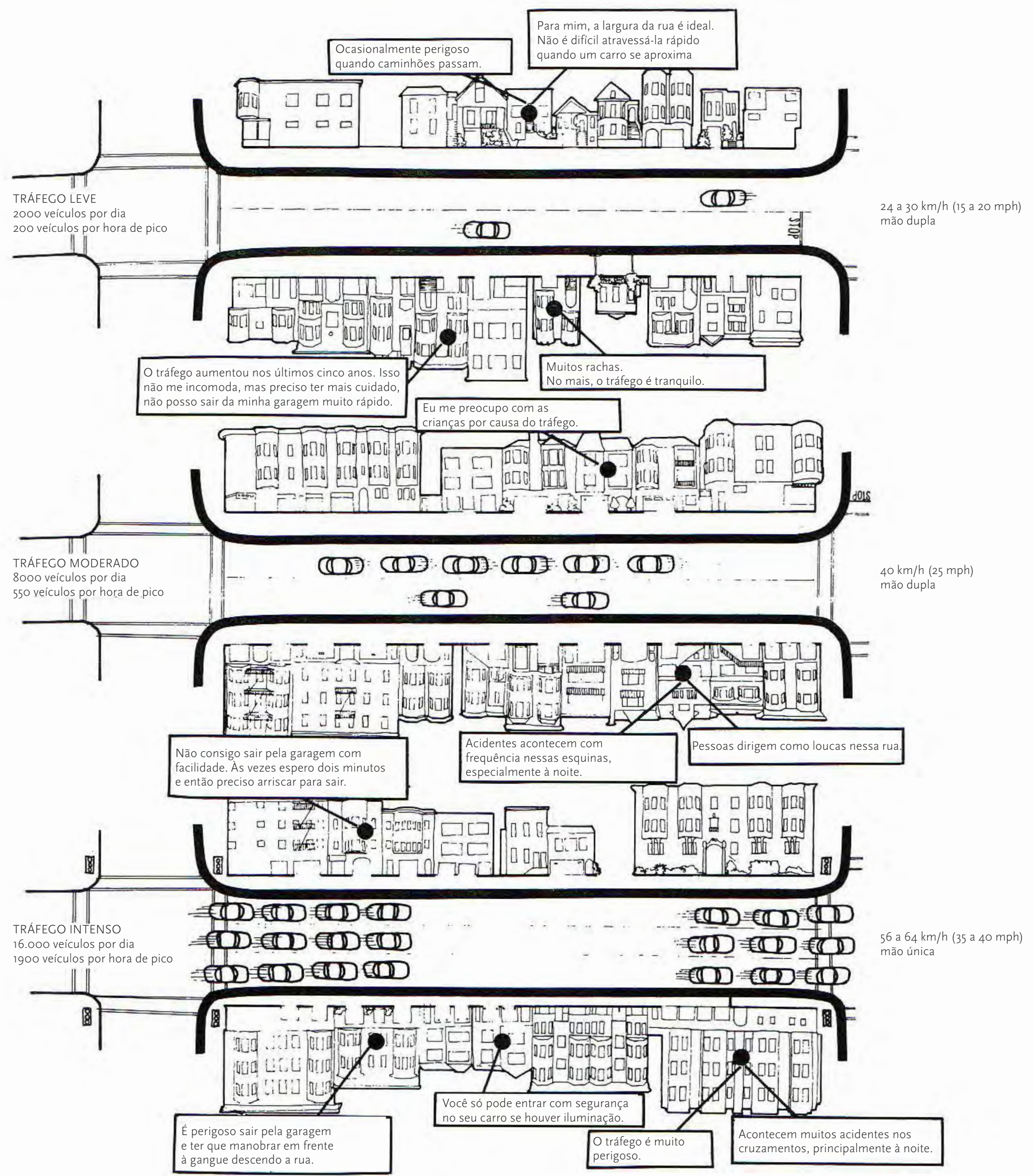

Figura 18: PeRiculosidade Por NíVel de tráfeGo Appleyard, 1981, p.17 


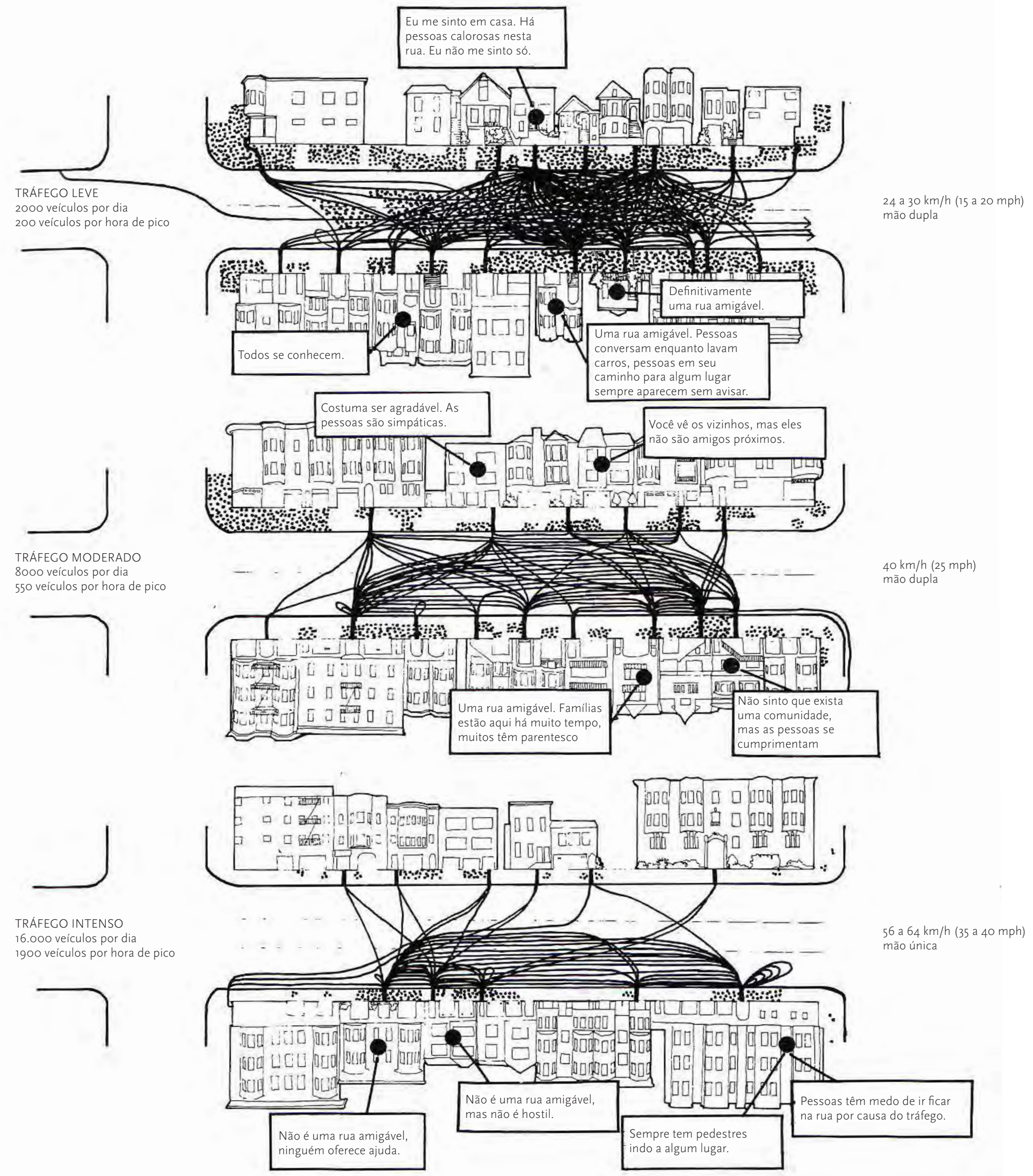

FIGURA 19: ReLACIONAMENTO DE VIZINHANÇA POR NíVEL DE TRÁFEGo linhas indicam onde as pessoas dizem ter amigos e conhecidos

pontos indicam onde as pessoas dizem se encontrar

Appleyard, 1981, p.21 


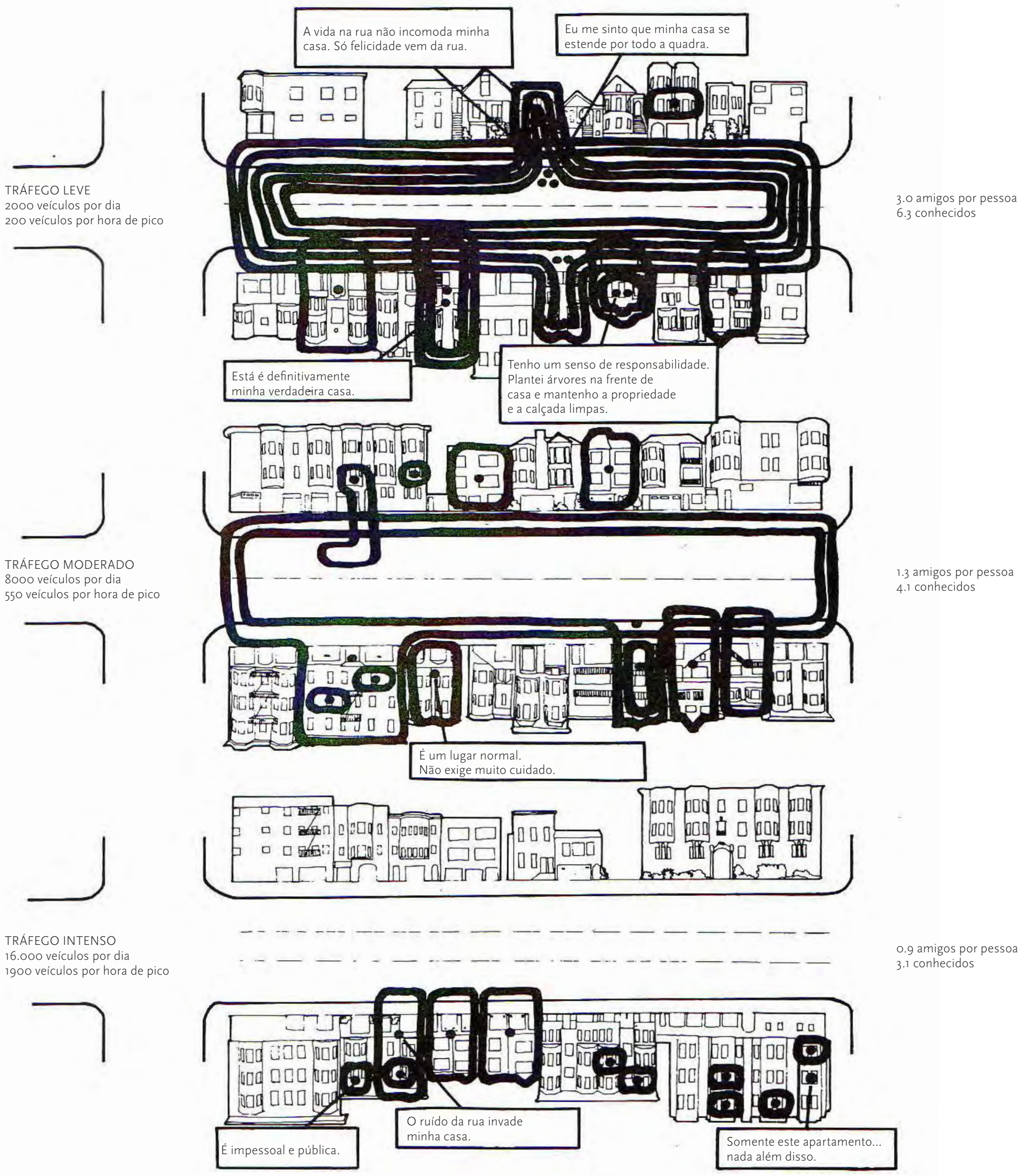

Figura 20: EXTENSÃo do LAR NO ESPAÇO URBANO POR NíVEL DE TRÁFEGO linhas indicam áreas onde as pessoas dizem se sentir em casa

Appleyard, 1981, p.23 
Appleyard usou como estudo piloto, três ruas de San Francisco, na Califórnia, USA, onde, em 1969, a administração pública iniciou um Projeto de Desenho Urbano, com duração de dois anos. O primeiro ano foi dedicado a um levantamento do meio-ambiente de San Francisco, incluindo pesquisa quantitativa e entrevistas em cada quadra da cidade, produzindo uma classificação em uma escala de um a cinco de várias características visíveis: a quantidade de vegetação, a qualidade da vista, o grau de manutenção, a variedade nas tipologias das fachadas e a distinção entre outras quadras da rua. A distância entre uma quadra e um espaço aberto foi também considerada. Características como condições climáticas e o incômodo causado pelo tráfego foram descartadas por sua subjetividade. (APpleyard, 1981, p.15)

Ao mesmo tempo, um levantamento comportamental foi feito para explorar os valores ambientais imbuídos em cada grupo da população da cidade, o que resultou em avaliações interessantes sobre cada via, mas tendo como principal preocupação o tráfego. Segurança nos cruzamentos de vias foi o problema ambiental mais preocupante, seguido muito proximamente pela preocupação com a manutenção e a carência de espaços abertos. (Appleyard, 1981, p.15)

Appleyard seleciona três vias residenciais com as mesmas características, idênticas na aparência, mas bem diferentes em relação ao volume de tráfego. Foram classificadas como vias de tráfego intenso, moderado e leve, considerando-se o fluxo diário de $15.750,8.700$ e 2.000 veículos, respectivamente. A via com tráfego intenso, de mão única, tinha semáforos sincronizados que encorajavam velocidade acima de $70 \mathrm{~km} / \mathrm{h}$. As vias de tráfego moderado e intenso estavam conectadas, $3 \mathrm{~km}$ adiante, a uma via do tipo freeway (via urbana expressa, sem semáforos), que contribuía com considerável número de veículos em circulação nas vias com tráfego moderado e intenso. As três quadras estudadas apresentavam habitantes de classe social e renda familiar homogêneas, havendo contraste na composição das famílias, tempo de residência e propriedade dos imóveis. A via de tráfego leve era predominantemente uma rua familiar, com muitas crianças, sendo $50 \%$ dos moradores proprietários das casas e a média de tempo de residência encontrada foi de 16,3 anos. No outro extremo, a via de tráfego intenso não tinha praticamente crianças em sua quadra. Era habitada basicamente por pessoas solteiras de todas as idades e algumas pessoas de idade avançada. A média de tempo de residência era de 8 anos e os moradores eram locatários, na grande maioria, com aluguéis 30\% maiores aproximadamente que na via de tráfego leve. As três vias estudadas estavam localizadas próximas ao comércio, serviços locais e equipamentos comunitários. (APPLEYARD, 1981, p.16)

Problemas com o tráfego foi consenso nas três vias estudadas, especialmente na via de tráfego intenso e em relação à velocidade dos veículos. A via de tráfego leve apresentou problemas de outra natureza: a tendência de atrair veículos estranhos à vizinhança, que não respeitavam a sinalização e, com isso, representavam uma ameaça à segurança das crianças brincando na rua. Todos os grupos entrevistados classificaram as vias de tráfego leve como seguras, as vias de tráfego moderado, nem seguras nem inseguras e as de tráfego intenso como inseguras. Depois do perigo apresentado pelo tráfego, os problemas que mais incomodavam foram ruído, vibrações, fumaça e lixo. A via de tráfego leve recebeu algumas poucas reclamações sobre eventuais ruídos. (Appleyard, 1981, p.16)

Nas páginas seguintes, as Figura 18, Figura 19 e Figura 20 representam as três vias estudadas e suas respectivas intensidades de tráfego e as observações de seus moradores sobre o impacto desse tráfego em seu cotidiano. As figuras demonstram a escala 
Figura 21: ANTES DOS IMPACTOS DO TRÁFEGO

FIGURA 22: IMPACTOS DA INTRUSÃO DO TRÁFEGO

FIGURA 23: SOLUÇÕES PARA ADAPTAÇÃO AOS IMPACTOS
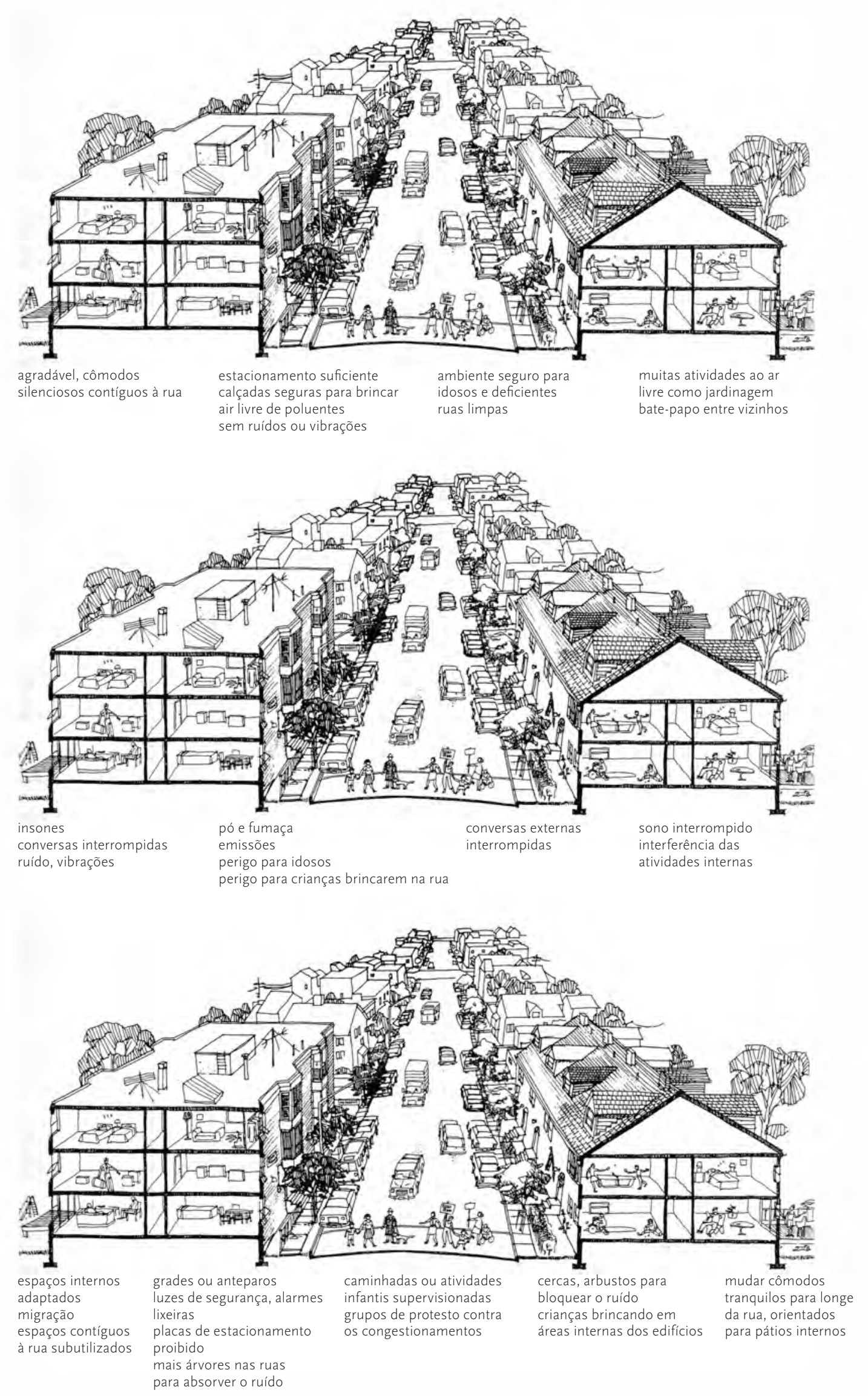
de risco nas três vias analisadas e as características básicas das tipologias das edificações existentes nas faces voltadas para cada via. Estão destacadas também as características do volume de tráfego em cada uma delas: velocidade desenvolvida pelos veículos, número de veículos/dia e sentidos de circulação. (APPlEYARd, 1981, p.17)

Appleyard aplicou uma série de questões aos moradores das três vias em relação ao quanto essas vias eram amigáveis, o número de amigos e conhecidos que possuíam e o lugar onde as pessoas se encontravam. A cada entrevistado foi apresentada uma foto dos edifícios correspondentes à sua rua e the foi solicitado apontar onde viviam seus amigos, parentes e conhecidos. Na rua de tráfego leve, os moradores apresentaram três vezes mais quantidade de amigos e duas vezes mais quantidade de conhecidos em relação aos moradores da rua de alto tráfego. (APPLEYARD, 1981, p.21)

A Figura 19: Relacionamento de vizinhança por nivel de tráfego (p.49) demonstra graficamente a interação entre a vizinhança e a visitação ocorrida, ou seja, os deslocamentos de uma casa a outra em função da amizade ou outro relacionamento. Nota-se que na via de tráfego leve os deslocamentos dos pedestres ocorrem principalmente cruzando-se a via, devido ao baixo risco. À medida que o risco aumenta os deslocamentos que necessitam de cruzamento da via diminuem e, na via de tráfego intenso há praticamente só situações onde o ponto de origem e o ponto de destino estão localizados no mesmo lado da rua, evitando-se cruzá-la, o que afeta diretamente o relacionamento social dentro da vizinhança, claramente demonstrado pelo número de amigos e de relacionamentos de cada morador que caem à medida que o risco cresce. (da via de tráfego leve à via de tráfego intenso) Os pontos que aparecem nas calçadas representam pedestres, de onde se conclui que a via de tráfego intenso reúne poucas pessoas nas calçadas, transformando-as em desérticas. (AppleyARD, 1981, p.21)

$\mathrm{Na}$ via de tráfego intenso, os moradores contavam com poucos ou nenhuns amigos, com baixa interação social, com aparente demonstração de solidão por parte dos entrevistados moradores dessa via, principalmente os idosos. No caso da via de tráfego moderado, a sensação passada pelos entrevistados foi de perda de qualidade de vida e de atividades ao ar livre em função do aumento do tráfego, "como se a comunidade estivesse à beira da extinção: Costumava ser uma rua agradável; o que antes ficava do lado de fora está agora recolhido dentro dos edifícios. Pessoas estão preocupadas com suas próprias vidas (...) não há mais amigos aqui perto." Mas, segundo a pesquisa de Appleyard, o número de amigos e conhecidos na via de tráfego moderado era somente pouco maior que na via de tráfego intenso. (APPLEYARD, 1981, p.22)

Na Figura 20: Extensão do lar no espaço urbano por nivel de tráfego, Appleyard demonstra a enorme diferença entre as áreas que os moradores da via de tráfego leve consideram como território de sua casa em relação à via de tráfego moderado e a diferença dramática entre a via de tráfego leve e a de tráfego intenso, onde é inexistente, na quase totalidade dos casos, território de rua reconhecido como relacionado à casa dos moradores.

As situações apresentadas por Appleyard mostram que a possibilidade de perda de raízes com a localidade onde o morador pode ter nascido e vivido por muitos anos, é imensa. O morador desmotivado, ou se enclausura ou se muda de endereço.

Appleyard prossegue demonstrando as atividades sociais que ocorreram em cada uma das três vias e seus volumes de tráfego correspondentes, sendo que na via com tráfego leve, as atividades sociais a que também se refere Gehl ocorrem: sentar-se no degrau da entrada de casa e conversar, visitar uns aos outros. Moradores declaram que apreciam a vida ocorrendo 
ao ar livre a partir das suas janelas, (APPLEYARD, 1981, p.25) como os "olhos da rua" de Jacobs.

Nessa primeira etapa de seu estudo, a conclusão do autor é a confirmação da expectativa:

O que este pequeno estudo nos diz? Primeiro, ele confirma algumas expectativas. O tráfego intenso realmente criou todo um espectro de problemas aos residentes: era perigoso, ruidoso e seus efeitos no sentido de comunidade e de posse da rua eram aparentemente devastadores. (...) Por outro lado, a vida na via com tráfego leve era de certo modo idílica. Moradores eram muito mais engajados na rua. A viam como seu próprio território. Suas crianças brincavam na calçada e na rua. Eles tinham mais amigos e conhecidos e estavam geralmente mais alertas a essas qualidades. O contraste entre as duas ruas era impressionante. De um lado, alienação, de outro, amizade e envolvimento. (AppleyARd, 1981, p.26)

Inicialmente, Appleyard fornece as ferramentas para o exame das vias às que se queira adicionar qualidade a partir do controle de tráfego e apresenta um modelo, graficamente representado em três imagens: via sem tráfego, a mesma via após a chegada do tráfego e, por fim, as medidas a serem tomadas para reverter esse quadro de impacto do tráfego e baixa qualidade urbana.

A Figura 21: Antes dos impactos do tráfego mostra a via residencial antes do aumento do tráfego, com moradias cujos cômodos estão sem ruído interno proveniente da rua; calçadas adequadas para o estacionamento de veículos e seguras para desfrutar; ambiente saudável e sem ruído; ambiente saudável para os idosos e calçadas livres para deficientes físicos; muitas atividades externas, como jardinagem e conversação entre vizinhos. (APPLEYARD, 1981, p.29)

A Figura 22: Impactos da intrusão do tráfego apresenta uma relação de problemas que ocorrem na mesma via do modelo: insônia, interrupção de conversas nas áreas internas e cômodos de frente para a rua sem uso; ruído e vibrações; poeira, emissão de fumaça, perigo para os idosos e para as crianças que brincam na calçada; interrupção de conversas na área externa; interrupção do sono e interferência nas atividades ao ar livre. (APpleyARD, 1981, p.29)

A Figura 23: Soluções para adaptação aos impactos aplica à mesma via hipotética os mecanismos e ações que podem mitigar a ação predatória do tráfego em vias residenciais ou mistas, ainda que alguns deles contemplem até mesmo a mudança de endereço para seus moradores, o que não deixa de ser uma expulsão. São eles: adaptação de espaços internos das moradias, migração interna à moradia e não utilização de cômodos frontais; instalação de anteparos e grades, luzes de segurança e alarmes, lixeiras, placas de estacionamento proibido, mais árvores nas ruas para absorver o ruído; caminhadas ou atividades infantis supervisionadas e grupos de protesto contra os congestionamentos; cercas, arbustos para bloquear o ruído, crianças brincando nas áreas internas dos edifícios; mudar cômodos tranquilos para longe da rua, orientados para pátios internos. (APPLEYARD, 1981, p.30)

Está claro que algumas soluções acima não são ideais nem desejadas pelos moradores, que precisam de outros recursos, financeiros e psicológicos, para promover uma mudança de endereço. E, quanto menor a renda do morador, menor a possibilidade de ocorrer uma mudança de endereço para um local com mais qualidade urbana. (APPLEYARD, 1981, P.30)

Na parte 3 de seu livro, Appleyard nos dá ainda outras ferramentas que serão consideradas na elaboração das diretrizes para um plano urbano local.

\section{TRANUS: MODELAGEM MATEMÁTICA PARA CÁLCULO DE CAPACIDADE DE SUPORTE}

Para melhor entendimento da metodologia de cálculo de capacidade de suporte para desenvolvimento 
de diretrizes urbanas para um determinado espaço urbano, aplicada nesta tese, é necessário fazer-se a apreciação da evolução das metodologias utilizadas em planejamento urbano até este início de século XXI, em tempo desta proposição.

Com a introdução da computação gráfica a partir dos anos 1990 em computadores de grande capacidade e baixo custo foram difundidas as técnicas de modelagem matemática para o planejamento econômico, social e territorial. ${ }^{33}$ Desde os anos 1970 passaram a ser desenvolvidos academicamente e a serem usados na prática governamental.

Em 1978, Marcial Echenique, arquiteto chileno e exímio matemático, com um grupo de pesquisadores ingleses na Universidade de Cambridge, Inglaterra, se apresentou em São Paulo, com abrangente currículo sobre um modelo matemático que, relacionando Uso do Solo e Transporte Urbano, criava uma ferramenta de planejamento urbano até hoje não ultrapassada embora aperfeiçoada. O urbanista e professor Candido Malta Campos filho, quando secretário de planejamento urbano do Município de São Paulo na gestão de Olavo Setúbal, tomou conhecimento do trabalho de Echenique e apoiou sua aplicação. Montou-se um grupo técnico-especialista para desenvolver os estudos que se tornariam pioneiros no Brasil, caso tivessem sido implementados. Compunham a equipe técnica formada, técnicos e integrantes da COCEP - que detinha uma equipe de planejamento de transporte e recomendava tal instrumento de planejamento justamente para fazer frente na interação entre uso do solo e transporte, Coordenadoria Geral de Planejamento, Cia. do Metrô, EMURB, EMPLASA e CET, esta recémformada. Apenas 30 anos depois, em 2008, na gestão de Alckmin, governador do Estado de São Paulo, e José Serra, prefeito do Município de São Paulo, essa metodologia é retomada e não por coincidência. Campos Filho é convidado pela Secretaria de Transportes Metropolitanos a coordenar tecnicamente um trabalho ainda pioneiro que planeja a estruturação urbana com modelo matemático protagonizado agora por um sucessor de Marcial Echenique, Tomás de La Barra, também arquiteto e também matemático. Agora, Tomás de La Barra oferece gratuitamente acesso pela Internet ao modelo matemático iniciado pelo grupo da Universidade de Cambridge, denominado TRANUS, uma abreviatura de Transporte e Uso do Solo, as duas variáveis básicas que combina. (informação verbal) ${ }^{34}$

A empresa Modelistica, desenvolvedora do sistema TRANUS desde 1982, o descreve em linhas gerais como um modelo de simulação sobre a localização de atividades, uso do solo e transporte, que pode ser aplicado tanto à escala regional quanto à escala urbana. É especialmente concebido para simular os efeitos prováveis de políticas e projetos diversos em cidades ou regiões e avaliá-los do ponto de vista social, econômico, financeiro, energético e ambiental. A mais notável característica do sistema TRANUS é a maneira verdadeiramente integrada em que são representados os principais componentes do sistema urbano ou regional, tais como a localização e interação de atividades, o mercado imobiliário e o sistema de transportes. Todos esses componentes estão inter-relacionados de forma explícita e claramente com base numa teoria integral desenvolvida para essa finalidade. Assim, o fenômeno da circulação de pessoas e bens é explicado por relações econômicas e espaciais entre as atividades que as geram. Por sua vez, a acessibilidade do sistema de transporte afeta a forma como as atividades interagem umas com as outras, a sua localização no espaço e influenciam o sistema imobiliário. A avaliação econômica também é parte integrante da formulação teórica e do sistema de modelagem, fornecendo-se todas as ferramentas necessárias para a análise de políticas e projetos. (Modelistica, 2007, p.1)

Um cálculo em nível metropolitano com ênfase no Município de São Paulo tem a finalidade básica de avaliar a capacidade de suporte do sistema de
33. As origens da análise espacial partem do trabalho de Von Thürnen, no ano 1826, que criou a escola chamada microeconomia espacial. Desta escola, o sistema TRANUS leva os conceitos fundamentais da economia espacial e a renda da terra. A segunda linha de pensamento, conhecida como gravidade e entropia, tem suas principais teorias nos trabalhos de Hansen (1959) e Lowry (1964), consideradas as primeiras por serem as mais relevantes dessa área de pesquisa. A essa primeira geração de modelagem em gravidade e entropia seguiu-se o trabalho de Wilson (1970), que não só introduziu princípios da máxima entropia para dele derivar um conjunto de modelagens espaciais, mas também apontou o caminho para modelagens de uso do solo associado às de sistemas de transporte. Wilson mostrou que sistemas urbanos regionais de transporte podem ser representados por uma única teoria inteligível e consistente. Este princípio e a abordagem da interação espacial compõem um importante componente do sistema TRANUS. Disponível em <http://cdn.bitbucket. org/apalala/tranus/downloads/ GeneralDescriptionTranus.pdf $>$ p.3. Acesso em 12 jun. 2013

34. Campos Filho. Depoimento à autora, 24 maio 2013. 


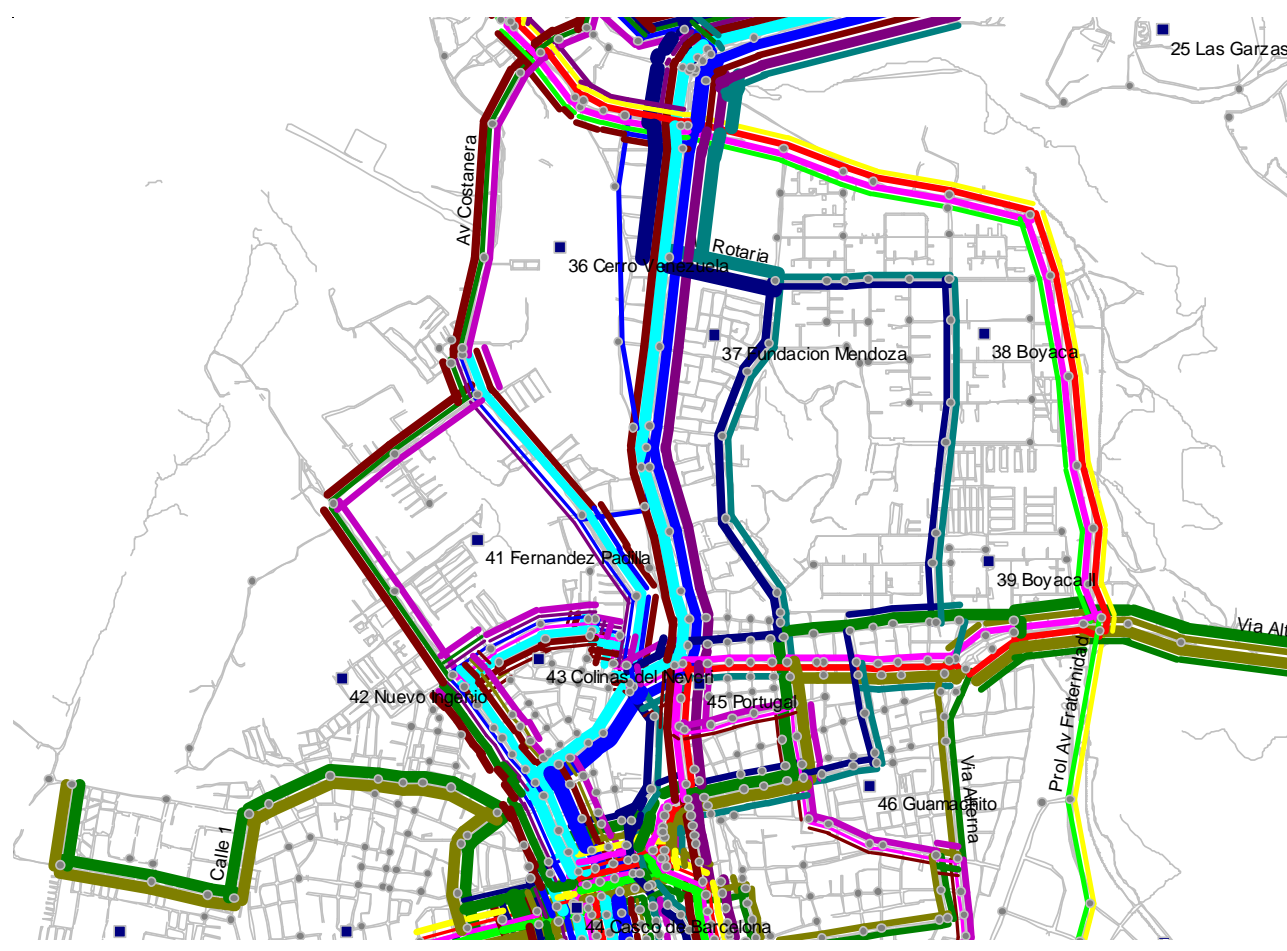

FIGURA 24: TRANUS-EXEMPLO DE APRESENTAÇÃo DE ROTAS NUM SIG

a ruas são representadas por linhas de espessuras proporcionais à

capacidade necessária de cada rota (Anzoáteg, Venezuela)

Modelistica, 2007, p.22

35. Estabelece normas complementares ao Plano Diretor Estratégico, institu os Planos Regionais Estratégicos das Subprefeituras, dispõe sobre o parcelamento, disciplina e ordena - Uso e Ocupação do Solo do Município de São Paulo. (PMSP, 2013)

36. Campos Filho. Depoimento à autora, 24 maio 2013

37. A Operação Urbana Consorciada Rio Verde-Jacu foi criada pela lei n. 13.872 de 12 de julho de 2004 , como parte de um programa que propõe a mudança da região pelo desenvolvimento econômico e social, visando à melhoria das condições gerais dessa região e da população residente. Articulada ao Programa de Desenvolvimento da Zona Leste, tem por objetivo criar condições para a atração de investimentos geradores de emprego e renda e incentivar a instalação de atividades industriais e de prestação de serviços na região, especialmente os destinados à formação e capacitação profissional. Disponível em <http://www.prefeitura.sp.gov. br/cidade/secretarias/habitacao/ plantas_on_line/legislacao/index. php? $p=10572>$. Acesso em 5 jun 2012. circulação em relação às atividades distribuídas no território a partir de políticas públicas de Transporte e Uso do Solo definidas basicamente pelos planos diretores municipais.

Segundo Campos Filho, o planejamento metropolitano de transportes de passageiros através do PITU 2025, com ênfase no Município de São Paulo, teve ano meta de 2025 e ano base 2005, este último sendo o do PDE do Município de São Paulo, então em vigor pela lei n. 13.430/04. O Ano Base neste caso foi o de 2005. A adoção formal de um ano meta implicaria na substituição do Quadro 8 da lei n. 13.885/04 que institui os potenciais construtivos máximos por distrito no Município de São Paulo. ${ }^{35}$

Segundo o coordenador técnico e professor Candido Malta Campos Filho, não houve tempo hábil para a utilização da Pesquisa OD 2007 do Metrô, principal fonte de dados a ser utilizada e de periodicidade de publicação de 10 anos. Só esse fato justificaria sua utilização. Por outro lado, novas linhas de transporte de massa sobre trilhos foram e estão sendo definidas para área mais carentes que ainda não haviam sido atendidas como bem assinala Campos Filho, especialmente para a Região Leste. Um cálculo atualizado foi entregue recentemente à Prefeitura Municipal de São Paulo para que ela o examine. Desse modo, ainda não existe um cálculo atualizado publicamente acessível para quaisquer anos base e anos meta. (informação verbal) ${ }^{36}$

\section{A RLP foi contemplada com a Operação Urbana} Consorciada Rio Verde-Jacu - OUC-RVJ, ainda não regulamentada e, portanto sem plano urbanístico definido, o qual está sendo elaborado enquanto se desenvolve esta tese. Como não foram publicadas as diretrizes urbanísticas da OUC-RVJ em tempo de serem utilizadas para a elaboração desta tese, as diretrizes urbanísticas a propor neste trabalho serão desenvolvidas a partir do macrozoneamento definido quando da elaboração inicial da OUC-RVJ pela PMSP, em 2003, sob o comando do econo mista Branislav Kontic, lotado excepcionalmente no Gabinete da então Prefeita Marta Suplicy, ${ }^{37}$ conforme será visto no Capítulo IV.

Em Reinvente seu Bairro, o urbanista Candido Malta Campos Filho sintetiza muito bem o ambiente urbano e a qualidade que devemos oferecer na proposição de diretrizes para um plano urbanístico para uma região metropolitana ou área metropolitana, quando apresenta seu conceito de Unidade Ambiental de Moradia: moradia, trabalho, serviços e qualidade urbana no mesmo local

O conceito de unidade ambiental de moradia (...) consagra essa diretriz como unidade territorial de um estilo de morar, pelo qual as energias físicas e emocionais gastas na luta pela vida durante o trabalho são recompostas no espaço de morar, propiciada essa recomposição pela tranquilidade do local onde se mora. (CAMPOS FILHO, 2003, p.23) 
Em relação à localização dos serviços, Campos Filho ensina que:

\begin{abstract}
A proximidade espacial do comércio e dos serviços estará definida pelo mercado imobiliário, em grande medida, quando não houver planejamento publico ou privado interferindo nessa lógica, no que se refere àqueles que são oferecidos pelo setor privado. Aqueles que dependem da oferta pública ficarão na dependência de critérios públicos de localização de seus equipamentos de educação, saúde e lazer. (CAmpos Fıاнo, 2003, p.21)
\end{abstract}

Campos Filho classificou o espaço urbano da metrópole paulistana em quatro tipos básicos de macrorregiões: a do Centro Expandido consolidado; a de uma área adjacente em processo de consolidação; uma terceira área adjacente à segunda, constituída em geral por bairros periféricos em desenvolvimento; e uma quarta região, constituída por áreas de ocupação rarefeita ou não, que devem ter preservação ambiental caso não sejam necessárias para a expansão urbana. (CAMPOS FILHO, 2003, p.16) Adotando-se o conceito de cidade compacta, atendendo-se sempre limites ambientais e infraestruturais de capacidade de suporte, evita-se a expansão horizontal desnecessária, custosa para ser equipada e mantida, afora as modificações resultantes da ação antrópica constituída pela urbanização sobre o espaço mais natural que contribuiria para as mudanças climáticas. A partir do desenho esquemático de Campos Filho, com a localização dessas macrorregiões, pode-se localizar a área-objeto desta tese e classificá-la como fazendo parte de um tipo 3 adjacente ao tipo 4, ou seja, bairros periféricos em desenvolvimento ao lado de área com preservação ambiental, como demonstrado na Figura 25: Tipos básicos de Macrorregiões na Metrópole de São Paulo.

Campos Filho tem, da década de 1980 em diante, partido do menor para o maior, ou seja, parte da moradia como foco em seu método de avaliação do espaço, num caminho diametralmente oposto ao que normalmente se pratica no planejamento urbano de grandes metrópoles brasileiras, como ele mesmo praticou como diretor do PMDI e em sua tese de doutoramento. Parte do princípio do que é necessário no entorno imediato da moradia, como comércio e serviços de âmbito local, depois o diversificado e, por fim, o especializado, de menor frequência, semestral ou anual, e que podem ficar localizados mais distantes da moradia do habitante em hipótese. Segundo o autor, "essa abordagem pela frequência de demanda tem a qualidade de colocar a questão da mobilidade urbana em foco, que é o maior problema urbano da cidade." (CAMpos FILHO, 2003, p.17)

Segundo, Campos Filho,

Nas grandes cidades, o automóvel exige que o sistema viário seja de grande porte, com grandes avenidas e até vias expressas. Essas avenidas e vias expressas, verdadeiros canais de tráfego, passam a dividir o espaço urbano em verdadeiras ilhas. Ora, essas ilhas, se tratadas urbanisticamente de forma conveniente, podem ser transformadas em bairros autônomos, as unidades de vizinhança, que devem, segundo propõe, no entanto, erroneamente o urbanismo globalizante contrário à grande cidade, reproduzir, tanto quanto possível, a qualidade de vida das pequenas cidades. Para isso, por essa doutrina contrária à grande cidade, essas ilhas deveriam ter a maior autonomia possível, quanto à oferta de empregos e serviços para seus moradores. Não é preciso tomar essa direção equivocada. A unidade de vizinhança é compatível com a vida metropolitana, se a entendermos apenas como o local de moradia com seus serviços básicos. Essa pequena cidade dentro da grande cidade, que é em geral chamada pelos urbanistas de unidade de vizinhança, na realidade concreta das cidades é o que chamamos de bairro, com uma população que pode variar de cerca de 5 a 80 mil habitantes. (CAmpos FiLHo, 1989, p.88)

Ao assim abordar o tema, Campos Filho volta-se para as questões da organização espacial a nível local, seja nos bairros onde predomina a moradia, seja nas

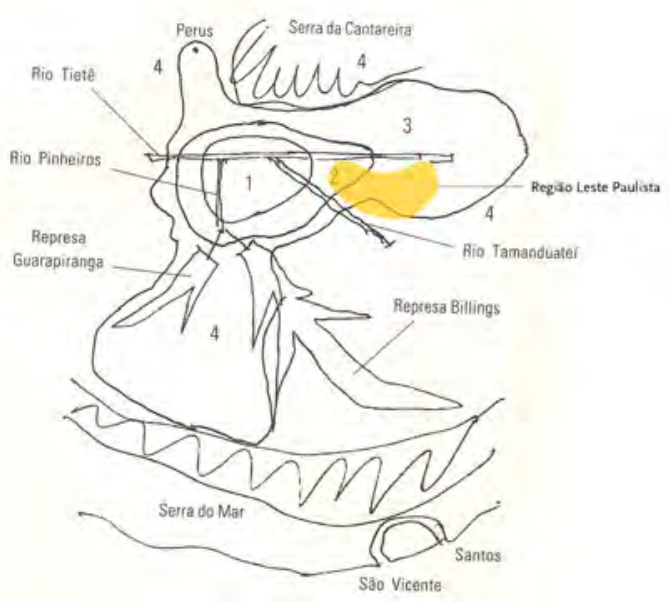

FIGURA 25: TIPOS BÁSICOS DE MACRORREGIÕES NA Metrópole de São Paulo Campos Filho, 1972, p.16

1 Centro Expandido-CE consolidado

2 área adjacente ao CE em processo de consolidação

3 área adjacente à segunda, de bairros periféricos em desenvolvimento

4 áreas de ocupação rarefeita ou não, com preservação ambiental 
centralidades. Faz assim convergir o planejamento urbano para as abordagens mais próprias do urbanismo ou do desenho urbano, que inclui o paisagismo.

Sintetizando-se a teoria de Campos Filho, pode-se concluir que este pretende a organização da cidade a partir de unidades territoriais "com ruas internas de tráfego apenas local, com pouco ou nenhum tráfego de passagem," passando gradativamente a equipar esse tecido urbano com níveis de equipamentos e ofertas de serviços, comércio, educação, lazer e cultura mais intensos, conforme a capacidade das vias de absorver o tráfego gerado nesse tipo de ambiente urbano, distanciando dos locais mais tranquilos de moradia o ruído e incômodos produzidos nessas centralidades de níveis variados. A organização das unidades territoriais pretendida deve atender à preferência demonstrada pelos moradores em função de seus valores culturais. Os equipamentos de atividades ao ar livre estarão mais próximos às moradias, juntamente com os serviços de âmbito local quando em bairros predominantemente ou exclusivamente residenciais. Mas, também as centralidades com uma maior mescla de usos, com atividades de maior especialização que as de âmbito local, devem oferecer essas amenidades do bom viver para os moradores que tiverem a preferência de nelas habitar. (CAmpos FILHO, 2003, p.19/22)

Campos Filho, no que se refere às macrodiretrizes de planejamento urbano de uma região, defende uma coerência entre as normas que definem o que se pode construir em cada parcela do território e a capacidade de suporte do sistema de circulação. Essa coerência a ser definida pelo Plano Diretor passa pelo cálculo da demanda para poder definir o tipo de sistema de transporte, especialmente o que deve ser o prioritário, adequado ao conjunto de unidades territoriais ambientais dessa nova organização da cidade, de forma a protegê-las do excessivo volume de tráfego, de modo a que se regule e se monitore a qualidade ambiental desejada, como preconizam também Appleyard e Gehl, como vimos. Esse é um método a adotar-se no capítulo final desta tese. (CAmpos FILHO, 2003, p.34/35)

\section{OS PLANOS DE BAIRRO}

Os Planos de Bairro têm por objetivo a qualificação do espaço através do conceito de Unidade Ambiental de Moradia-UAM com a provisão de equipamentos sociais e melhoria e atualização da infraestrutura. Eles devem ser implantados de forma sustentável, propondo transporte público conveniente e dentro da demanda, além de equipamentos urbanos adequados para que esse bairro possa dar condições de moradia a seus habitantes, com emprego para todos sem excluir o direito de escolha de ir e vir aos centros mais sofisticados da metrópole a que pertencem.

Para desenvolverem-se diretrizes urbanas com objetivo de reestruturação ou requalificação urbana em escala local, os chamados Planos de Bairro - complementares aos Planos Diretores Regionais, preparados pelas Subprefeituras de São Paulo, que se restringem à sua abrangência regional, não definindo demandas - é indicado que se utilizem cálculos de capacidade de suporte do sistema de transporte público, como os modelos matemáticos pormenorizados no item anterior, no que se refere à definição dos parâmetros de Uso do Solo e transporte, equivalente ao que tange à população futura a ser acrescida, diminuída ou mantida. Há também a possibilidade de utilizar-se o método da lotação, ou seja, quantos novos habitantes poderão ser assentados em um determinado terreno ou gleba a partir do que é permitido pela LUOS, ou seja, o Coeficiente de Aproveitamento de cada lote disponível. Uma terceira hipótese é adotar-se o crescimento de acorodo com os padrões urbanísticos e populacionais existentes.

Os Planos de Bairro podem ser realizados a partir de três diferentes tipos de desenvolvimento, de acordo com classificação criada para esta tese. Os primeiros são os planos locais mitigadores, ou seja, são planos 
urbanos locais desenvolvidos sobre um tecido urbano consolidado mas que ainda apresentam diversas carências socioeconômicas, como moradias adequadas e equipamentos públicos suficientes para atender a um ano meta, e que, assim, apresentam diretrizes mitigadoras, causadoras do mínimo possível de impacto no tecido urbano local e sua vizinhança e no cotidiano de seus habitantes, com o mínimo de expulsões destes para lugares mais longínquos, onde se preservam o máximo de elementos urbanos que são marcos referenciais locais ou são referencias culturais para essa população local. É o caso do Plano de Bairro de Perus, em São Paulo e de autoria de Campos Filho, arquiteto e urbanista e pesquisador no assunto há 25 anos.

O segundo tipo é o plano de bairro de reconstrução, quando uma área totalmente desprovida de infraestrutura urbana e composta basicamente por moradias de construções precárias quase inabitáveis, - segundo as referências locais e culturais, que fique claro - têm seu tecido urbano totalmente substituído por edificações de qualidade, implantadas em terrenos com qualidade ambiental, como é o caso do bairro espanhol chamado El Pozo Del Tío Raimundo, que teve seu crescimento a partir de 1950, sua reconstrução entre 1970 e 1976 e contou com intensa participação popular em parceria com a administração pública municipal. Essa notória participação popular ocorrida em El Pozo e em Perus comprovam que o atendimento às demandas locais feita de forma estudada e calculada tem como resultado a aceitação popular pelo fato de terem suas reivindicações ouvidas e concretizadas.

O terceiro tipo apresentado aqui como estudo de caso é o bairro SACONIA-Dehesa de La Villa, ao norte de Madrid, capital da Espanha. Esse é um tipo de plano de bairro que partiu de uma área totalmente vazia, uma grande gleba de 42 hectares, que continha apenas uma residência de tipologia arquitetônica típica de Madrid e que foi preservada pelos incorporadores, permitindo assim que um tecido urbano totalmente novo fosse implantado. É um exemplo da década de 1970, de produção imobiliária capitalista para o mercado e não necessariamente direcionado para famílias de baixa renda, como se verá adiante. Houveram contrapartidas como a construção, equipamento e a posterior doação de áreas públicas já incorporadas como as escolas e outros centros cívicos para uso de seus moradores.

Ainda em Madrid, há outros casos em que famílias de baixos recursos vivendo em condições precárias para os padrões daquele país foram realocadas em conjuntos de edifícios residenciais verticais com qualidade ambiental, moradias de oitenta a cem metros quadrados e, o que é mais importante, construídas exatamente na mesma vizinhança em que viviam, sem impacto socioeconômico importante. Um exemplo é o residencial dentro do Barrio Concepción, a poucos quilômetros do Parque El Retiro, onde se chega caminhando a pé. Nos terrenos remanescentes foram construídos edifícios de classe média alta, ao lado dos antigos moradores do bairro, com lojas de serviços e comércio de âmbito local.

\section{O Plano de Bairro de Perus: mitigação}

Conforme descrito no início do item 7 deste capítulo, temos os tipos de planos de bairro mitigador, reconstrutor e os planos desenvolvidos pela inciativa privada para o mercado. No exemplo que se segue, o Plano de Bairro de Perus seguiu o modelo mitigador, com larga participação popular.

Campos Filho desenvolveu de forma completa para a Prefeitura de São Paulo um plano urbanístico para o distrito de Perus, iniciado em 2008 e finalizado em 2009, intitulado Plano de Bairro de Perus. O trabalho é apresentado a partir de esclarecimentos sobre a inserção de um Plano de Bairro no processo do planejamento municipal, passando a um conjunto de proposições para o sistema de circulação com novos terminais de transporte coletivo, sendo um ferroviário; um novo Centro de Logística 


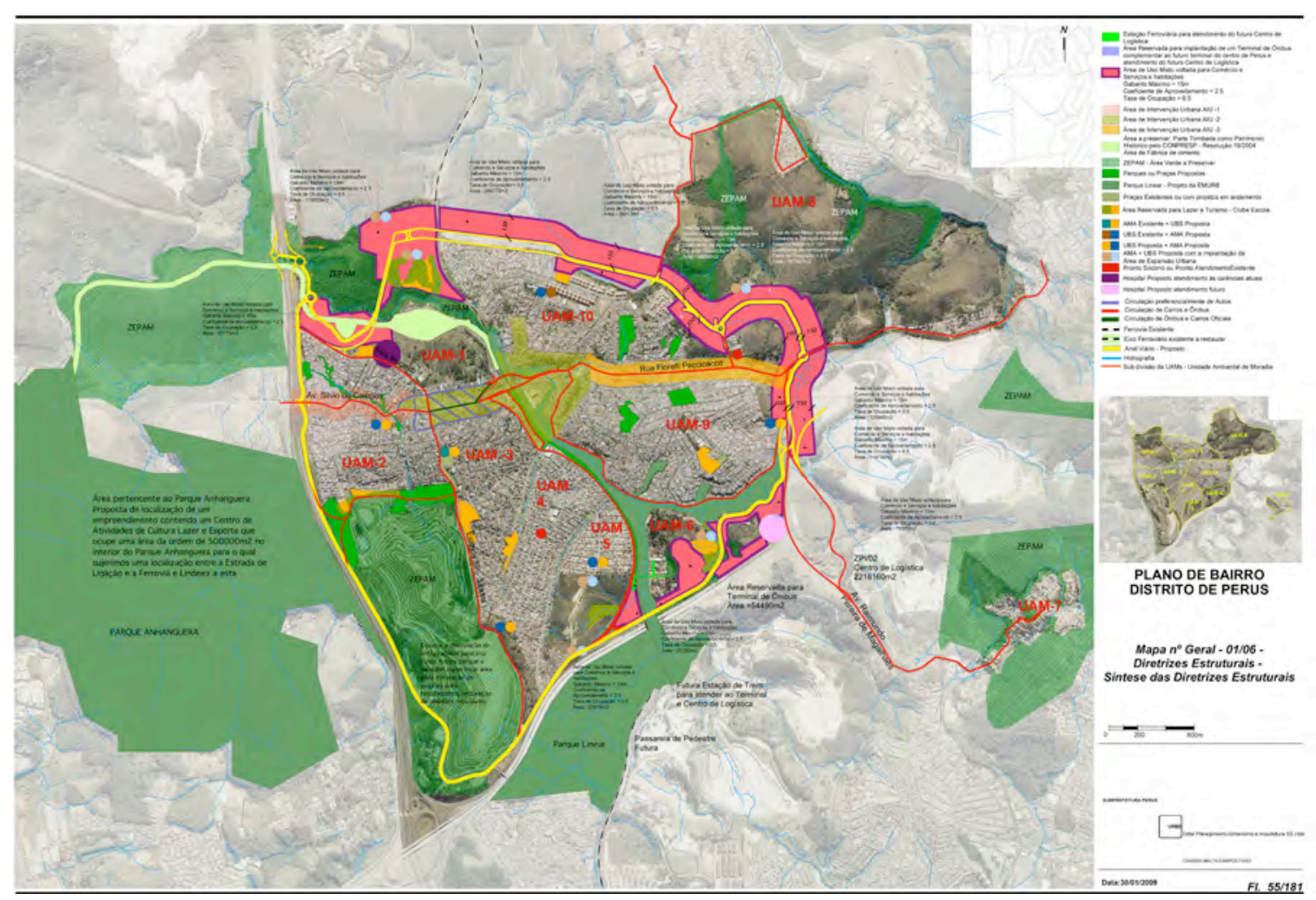

Mapa 9: Plano de Bairro de Perus-Síntese das diretrizes estruturais

Mapa 10: Plano de Bairro de Perus-Diretrizes para o anel viário e sua envoltória AiU-11

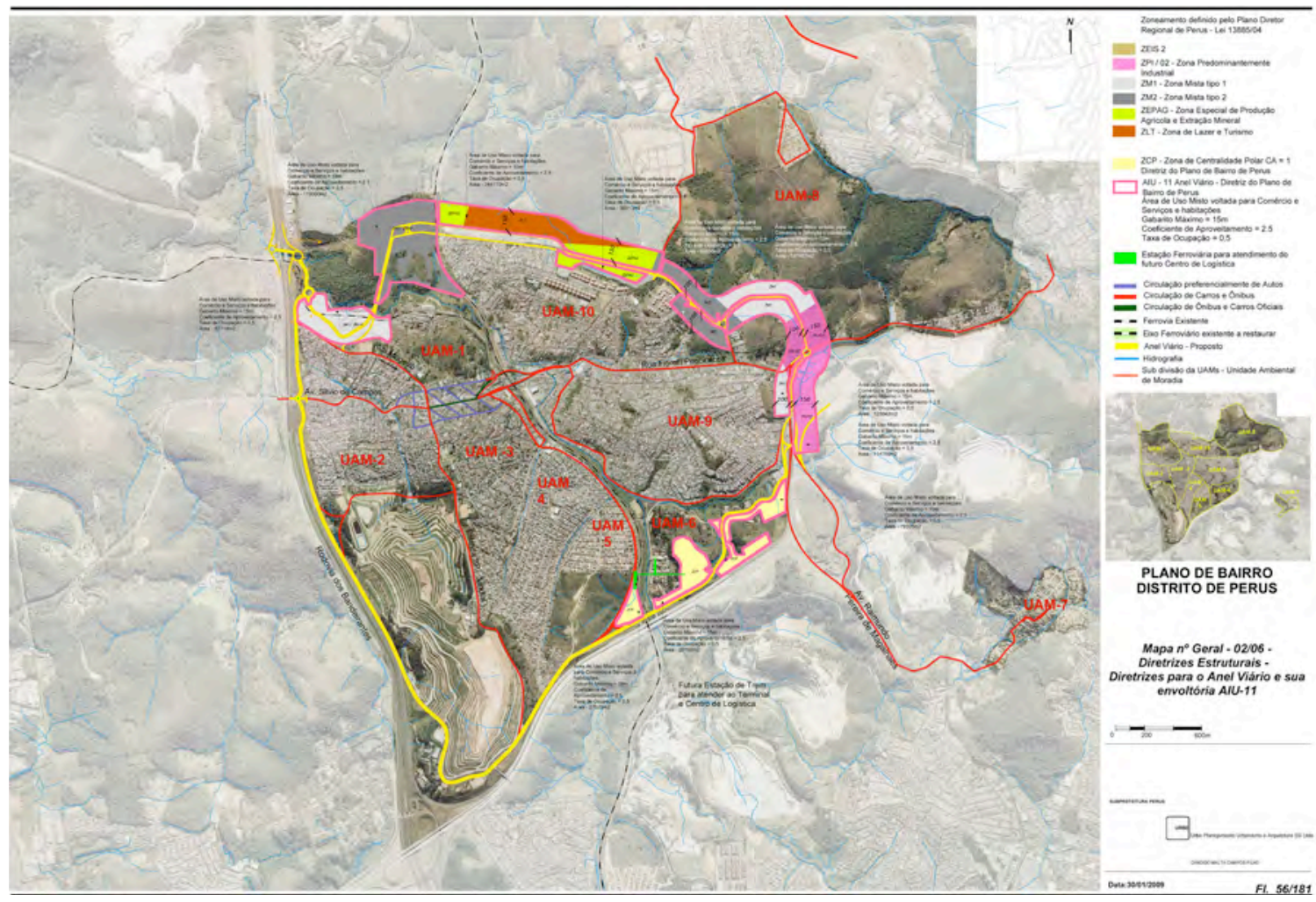




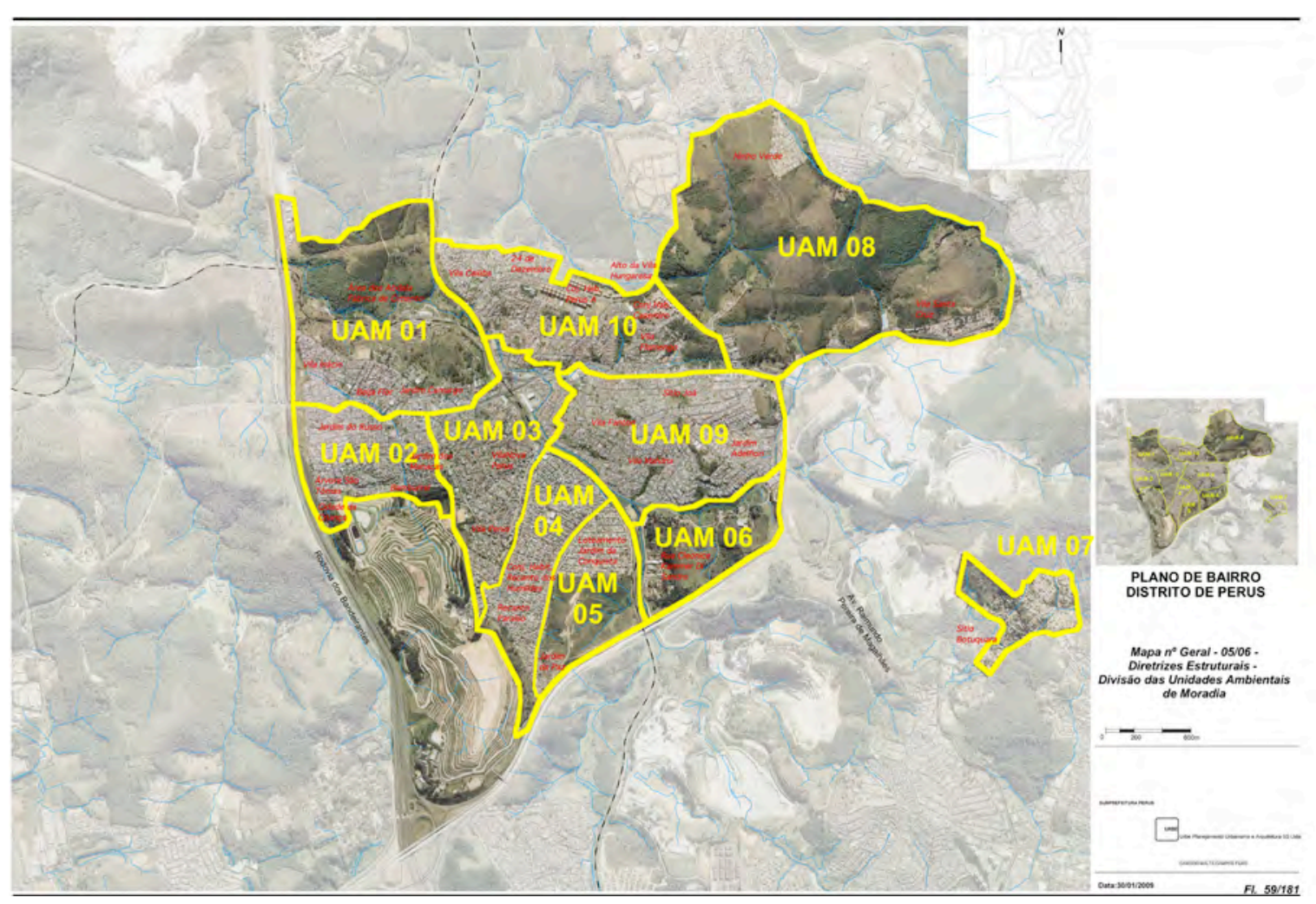

Mapa 11: Plano de Bairro de Perus-Uams

Mapa 12: Plano de Bairro de Perus-Detalhamento AiU 2

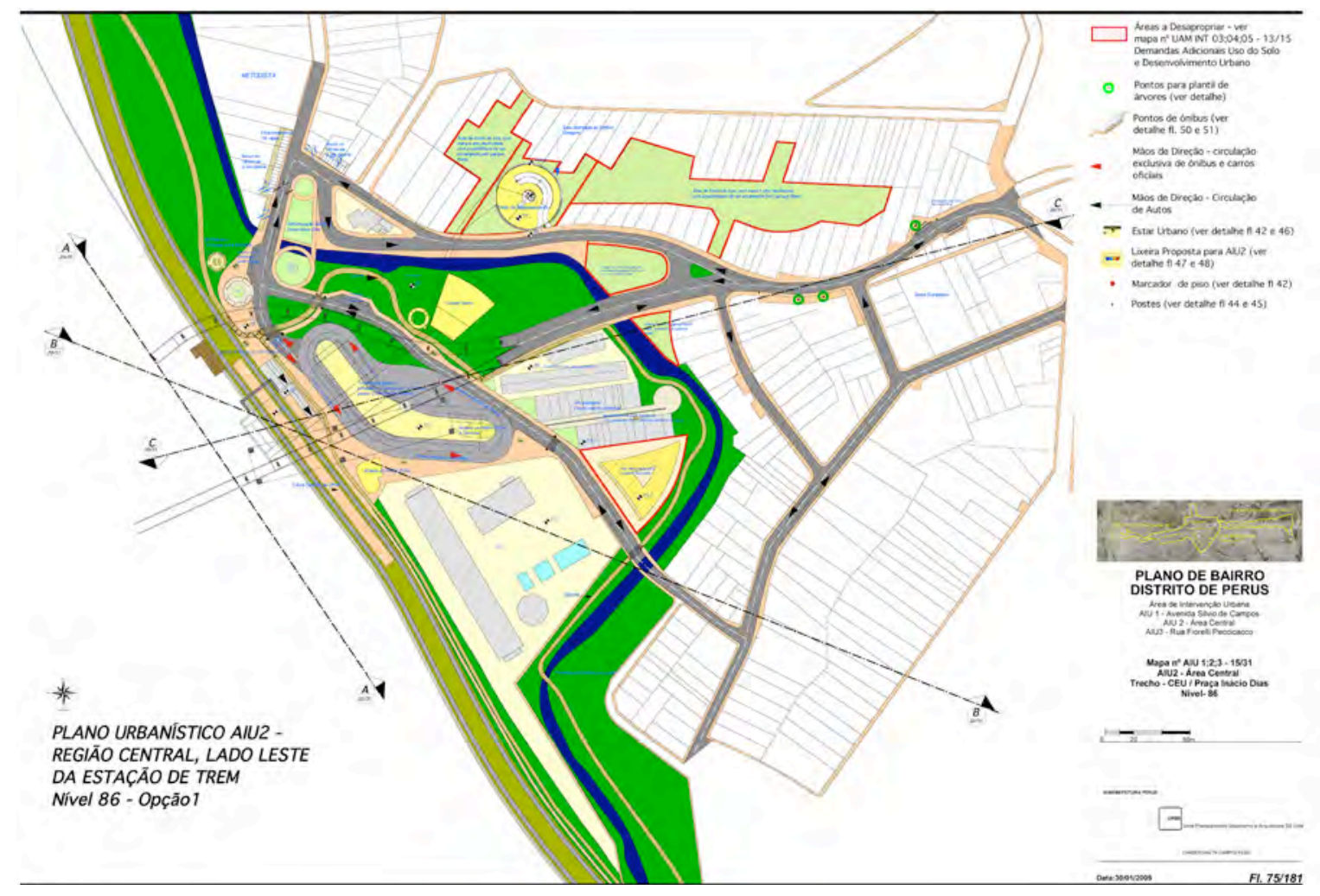


38. Campos Filho. Depoimento à autora, 5 mar. 2013. em substituição a um distrito industrial previsto no Plano Regional para a Subprefeitura de Perus e pormenorizado pelo plano de bairro; diretrizes de crescimento urbano que possibilitem até a duplicação de seus cerca de 120 mil habitantes, com oferta de empregos pela implantação do Centro de Logística; questões gerais relacionadas com sustentabilidade e controle de resíduos sólidos; implantação de um parque linear de grande amplitude ao longo do Ribeirão Perus como incremento ao existente Parque Anhanguera, de porte metropolitano e com represamento de suas águas para a eliminação de enchentes periódicas; resguardo e desenvolvimento de centralidades de âmbito local como parte das unidades ambientais de moradia; a proteção de uma paisagem característica de "mar de morros" tendo como ápice o Pico do Jaraguá e o desenvolvimento do turismo atraído por essa paisagem; proteção do meio ambiente e transformação gradativa do Aterro Sanitário Bandeirantes em parque, com a transformação do resultante gás metano em energia elétrica, produzindo qualidade ambiental e créditos de carbono; controle dos níveis de trânsito para a garantia das qualidades ambientais desejadas; requalificação do centro principal com a definição de um sistema de circulação de veículos trinaria, uma inovação urbanística; prédio-ponte sobre o terminal ferroviário, entrelaçando os dois lados do centro histórico de Perus; criação de equipamentos para educação com uma Faculdade de Tecnologia-FATEC, dois hospitais gerais para a saúde, além de equipamentos para cultura, esporte e lazer, para todo o conjunto do distrito e para cada uma das dez unidades ambientais de moradia em que este foi subdividido, de modo a criar-se "ilhas de tranquilidade," com demanda dimensionada tanto para o déficit verificado no ano base como para atender a demanda futura estimada resultante da expansão urbana, cuidadosamente definidos inclusive com sua localização; regularização fundiária de assentamentos populares merecedores de sua legalização e propostas para parcelamento e uso do solo em intervenções urbanas previstas pelo Plano Regional do tipo operações urbanas, como a já prevista para a desativada e historicamente preservada Fábrica de Cimento Perus.

Segundo descrição do próprio autor do Plano de Bairro de Perus, delimitaram-se dez Unidades Ambientais de Moradia-UAMs e, para cada uma delas, foram analisados dados socioeconômicos levantados por pesquisa sóciodemográfica dita quantitativa, por pesquisa do "bairro que queremos" (com consulta popular) dita qualitativa e por levantamento da infraestrutura urbana instalada e dos equipamentos existentes, inclusive as vagas ofertadas nas áreas de saúde, educação, cultura, esporte e lazer. Propõe-se, inclusive, a criação de um dispositivo legal, à semelhança do existente para a implantação de vias e demais equipamentos infraestruturais, denominado Lei de Melhoramentos, que reserva áreas privadas a serem desapropriadas para esse fim. Tal dispositivo é um tipo de zona que se propôs denominar Zona de Reserva de Área-ZRA. Foram analisadas as áreas de risco com a definição de áreas prioritárias de ação pública, visando dar segu rança aos moradores sujeitos a desmoronamentos e inundações. Por fim, o Plano de Bairro do Distrito de Perus apresenta o Orçamento Público das

Diretrizes de Conjunto para o Distrito de Perus e também para cada uma das Unidades Ambientais de Moradia, tanto no que se refere aos investimentos necessários assim como de seu custeio decorrente e programas de desenvolvimento comunitário e de gestão do Plano de Bairro. Em seu conjunto de mais de 170 pranchas, o projeto urbano para o distrito de Perus aborda todo e qualquer tema relacionado com o tecido urbano local, seus habitantes, suas necessidades e expectativas. (informação verbal) ${ }^{38}$

Nas palavras de Campos Filho,

Nenhuma necessidade que constitua um direito do cidadão deve deixar de ser planejada em seu atendimento público. A 
sua transformação em lei complementando - Plano Regional é o instrumento jurídico garantidor legal dos direitos a serem respeitados pelo Poder publico em suas três esferas de governo: federal, estadual e municipal. Isso porque o Plano Diretor, por determinação constitucional, é o único instrumento que obriga a coordenação do planejamento e, consequentemente, da ação entre essas três esferas de governo. Como sabemos que sem essa convergência de esforços governamentais não haverá solução a vista para os problemas enfrentados pelos cidadãos em sua vida nas cidades, percebe-se quão estratégico se tornou o Plano Diretor após sua revitalização pela Constituição Federal de 1988 em seu artigo 182. Assim, o Plano de Bairro como completador dos Planos Diretores, alcançando em seus pormenores o atendimento das carências mais sentidas pelos cidadãos em seus locais de moradia, deverá, com sua implantação progressiva em todo o Brasil, dar ao planejamento urbano uma compreensão de sua finalidade pelo cidadão comum. Com isso, deverá deixar os arquivos dos documentos pouco requisitados pela maioria dos habitantes urbanos que têm ignorado o seu papel. Do contrário, continuará a ser objeto de interesse apenas do setor imobiliário, assim como das classes médias que possuam entre seus integrantes técnicos capazes de defender seus interesses. O processo democrático com que é elaborado contribui firmemente para essa tomada de consciência de sua importância pelo cidadão comum. As assembleias abertas a todos interessados amplamente convocados por panfletagem e outros meios, assim como a notícia da convocação que chega aos 5\% das moradias amostradas para a pesquisa quantitativa como a qualitativa, ampliam o nível de informação da população em geral que, através do "boca a boca," alcança um nível inédito de mobilização popular. Mais nas vilas mais carentes do que nas de classe média como é de se esperar. (informação verbal) ${ }^{39}$

Campos Filho teve como colaboradores, além das pessoas que compareceram individualmente, as associações de moradores e outras entidades representativas das comunidades. $\mathrm{O}$ arquiteto e urbanista
Roberto Mônaco muito contribuiu para a elaboração do Plano Regional Estratégico da Subprefeitura de Perus - PRE-Perus, aprovado pela lei n. 13.885/04, e foi por seu intermédio e do arquiteto Nabil Bonduki, vereador e relator dos projetos de lei que deram origem ao assim denominado Plano Diretor Estratégico para o Município de São Paulo e sua lei complementar para a regulamentação dos planos regionais por Subprefeitura, que os Planos de Bairro, como nova tipologia de planejamento local foi introduzido na legislação ordenadora do uso do solo do Município de São Paulo. (informação verbal)40

\section{El Pozo del Tío Raimundo: reconstrução}

A participação popular das comunidades interessadas e residentes em áreas eleitas para receber um plano de bairro é vital para que sejam respeitadas as diferenças culturais e de renda da população local. Um exemplo ocorrido fora do Brasil, em Madrid, capital da Espanha, é o bairro Pozo Del Tío Raimundo, habitado basicamente por migrantes de baixa renda, provenientes da província de Andaluzia, ao sul do país e, posteriormente, da região da Mancha, ao sul da provícia de Madrid.

A participação popular nesse plano de bairro, por assim dizer, foi fundamental para o sucesso do bairro ou urbanización, como os espanhóis costumam chamar os bairros novos, criados para abrigar famílias provenientes de bairros menos qualificados ou expansões urbanas formadas por conjuntos habitacionais de média renda nos arredores das grandes cidades.

El Pozo del Tío Raimundo é um bairro do distrito de Puente de Vallecas, ao sul da capital Madrid, situado entre o bairro de Palomeras e a ferrovia entre Madrid e Barcelona por um lado e, pelo outro, Entrevías-San Diego. Ao extremo norte deste bairro, hoje, localiza-se a estação ferroviária El Pozo, do Entorno Madrid, que teve inauguração na década
39. É o que afirma Campos Filho enquanto coordenador do Plano de Bairro de Perus e atestam os documentos que comprovam as votações formais de cada ponto ou diretriz decidida. Ibidem. 40. Ibidem
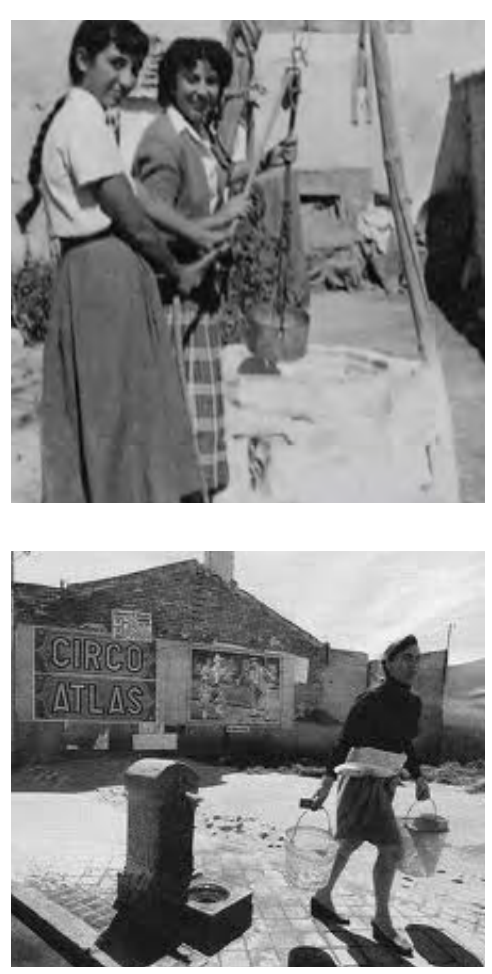

FIGURAS 26 E 27: O POÇO QUE DEU NOME AO BAIRRO 


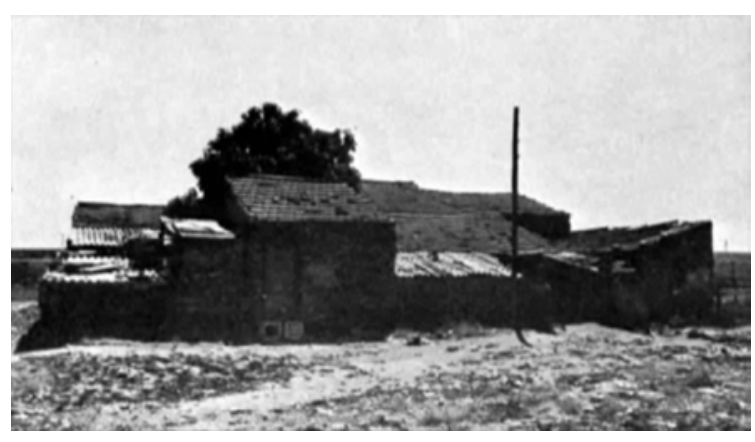

FIGURA 28: ESTÁBULO DA PROPRIEDADE RURAL CAMBRONERAS QUE ORIGINOU A OCUPAÇÃo

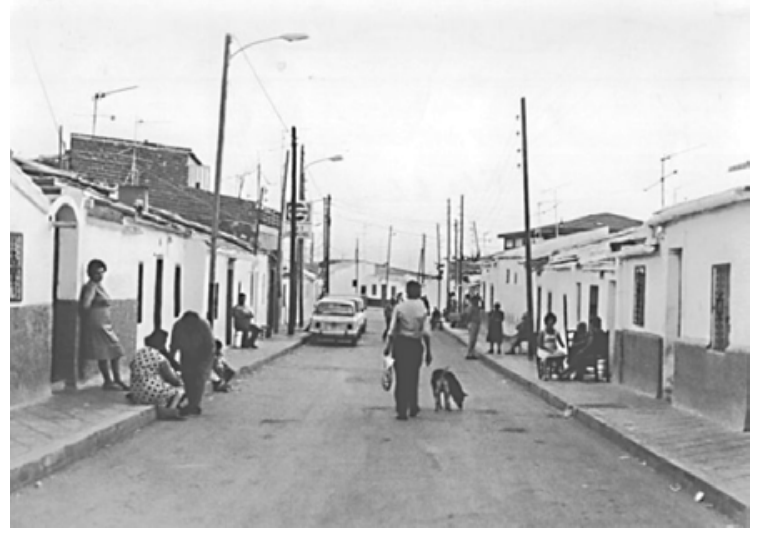

FIGURA 29: MORADIAS PRECÁRIAS-CHABOLASPOUCO ANTES DA REQUALIFICAÇÃO DO BAIRRO
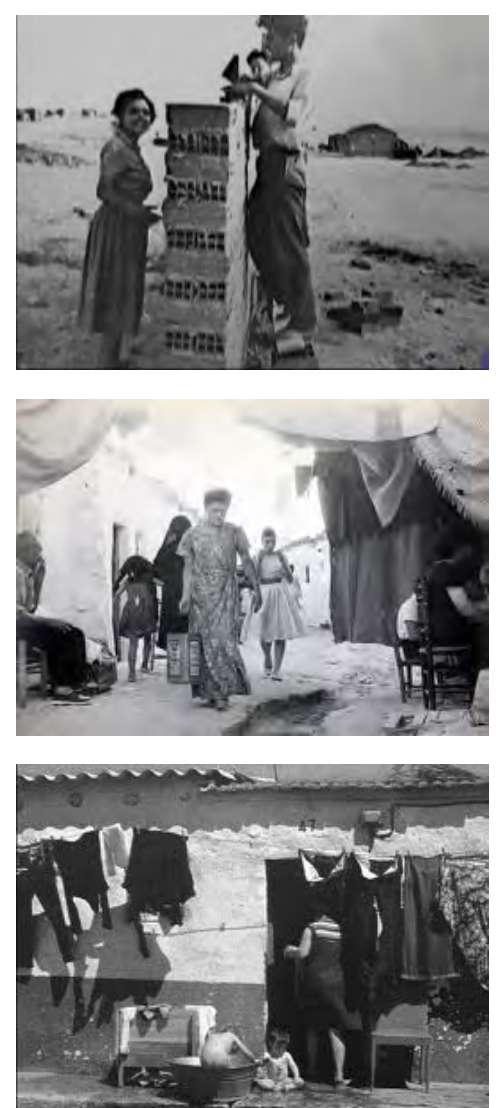

Figuras 30, 31 e 32: Construção E USO DAS CHABOLAS

Figura 33: El Pozo del Tío Raimundo-localização (em azul) vizinho ao Parque de Entrevías e cercado por rodoferrovias estruturais e transporte público Google Maps, maio 2013

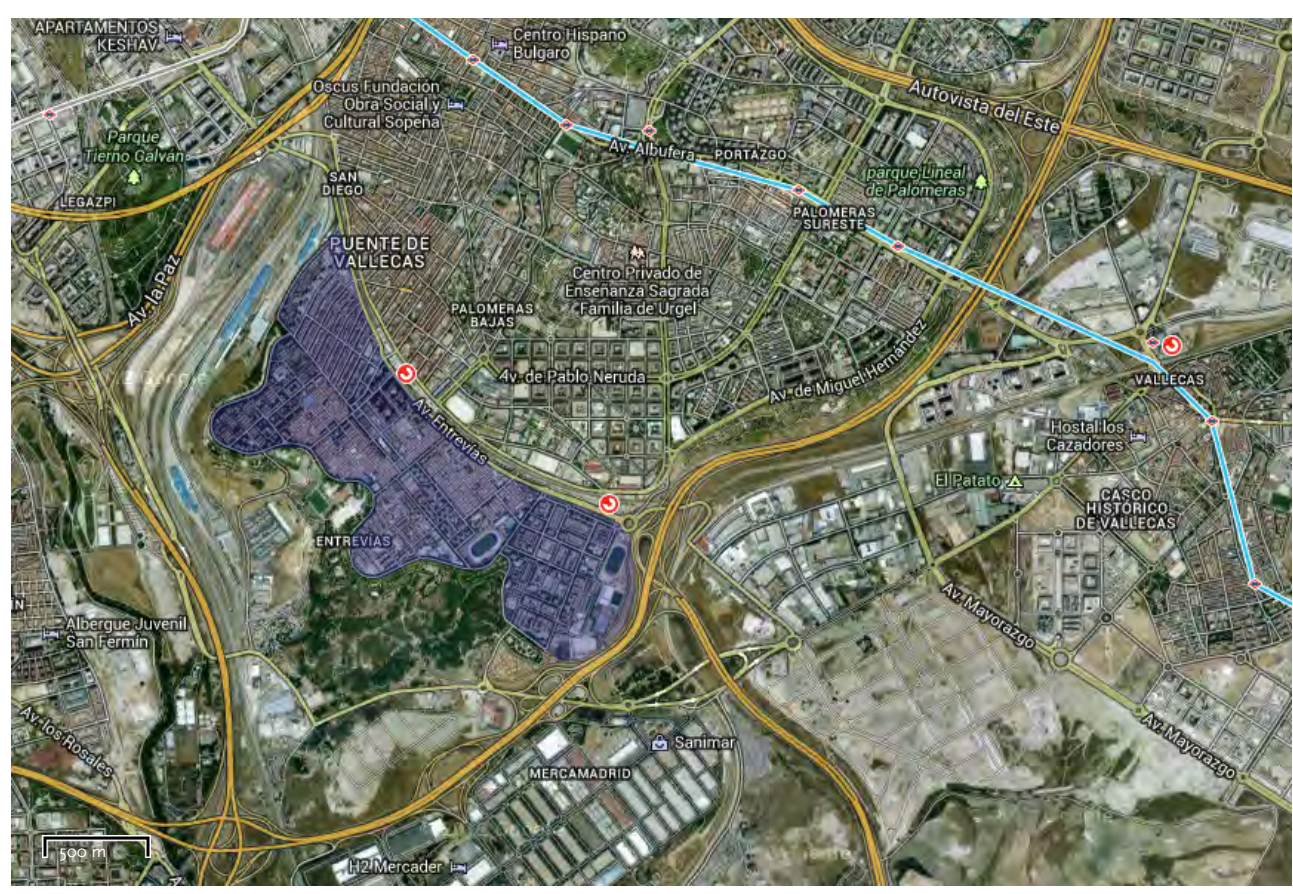

de 1990, posterior à criação das linhas do Corredor de Henares, bem como a de Santa Eugenia, já que se construiu paralelamente ao desenvolvimento do bairro, aumentando a mobilidade intraurbana e regional. (RAstrosdearquitectura, 2012. Acesso em maio 2013)

O bairro foi construído de forma precária com casas de barro e lata nos anos de 1950 e desprovido de qualquer tipo de infraestrutura. Os habitantes, que eram trabalhadores no segmento da construção civil, em sua maioria, começaram a realizar conexões clandestinas à rede de coleta de esgoto. A partir de 1955, ocorreu um ponto de virada neste bairro, com a chegada de alguns jesuítas, cujo máximo expoente foi José María de Llanos Pastor, que começaram a organizar os habitantes para a criação de um posto de saúde, uma cooperativa, instituições e escolas. Com o passar das décadas, a chegada de novos e muito diversos habitantes propiciou a esta zona de Madrid adquirir uma identidade moderna que a identifica dentro e fora da cidade. Muitos contribuíram com este objetivo, mas o trabalho do padre Llanos, chamado "padre vermelho," foi decisiva para transformar El Pozo e estender a seus habitantes a ideia de que "um mundo melhor é possível." (Construyendo..., d.d.)

O bairro Pozo del Tío Raimundo se desenvolveu em solo agrícola onde a primeira construção ocorreu em 1924, quando um migrante da província de Astúrias se instalou na propriedade rural chamada Cambroneras, nome que apelidava o terreno, junto à ferrovia. Construiu um estábulo e uma taberna e fornecia leite ao bairro de Vallecas. (RAstrosdearquitectura, 2012. Acesso em maio 2013)

No pós-guerra civil espanhol, a primeira moradia foi construída por um migrante que se estabeleceu de forma permanente no que ainda era um arrabalde. Pouco tempo depois, um morador, o 

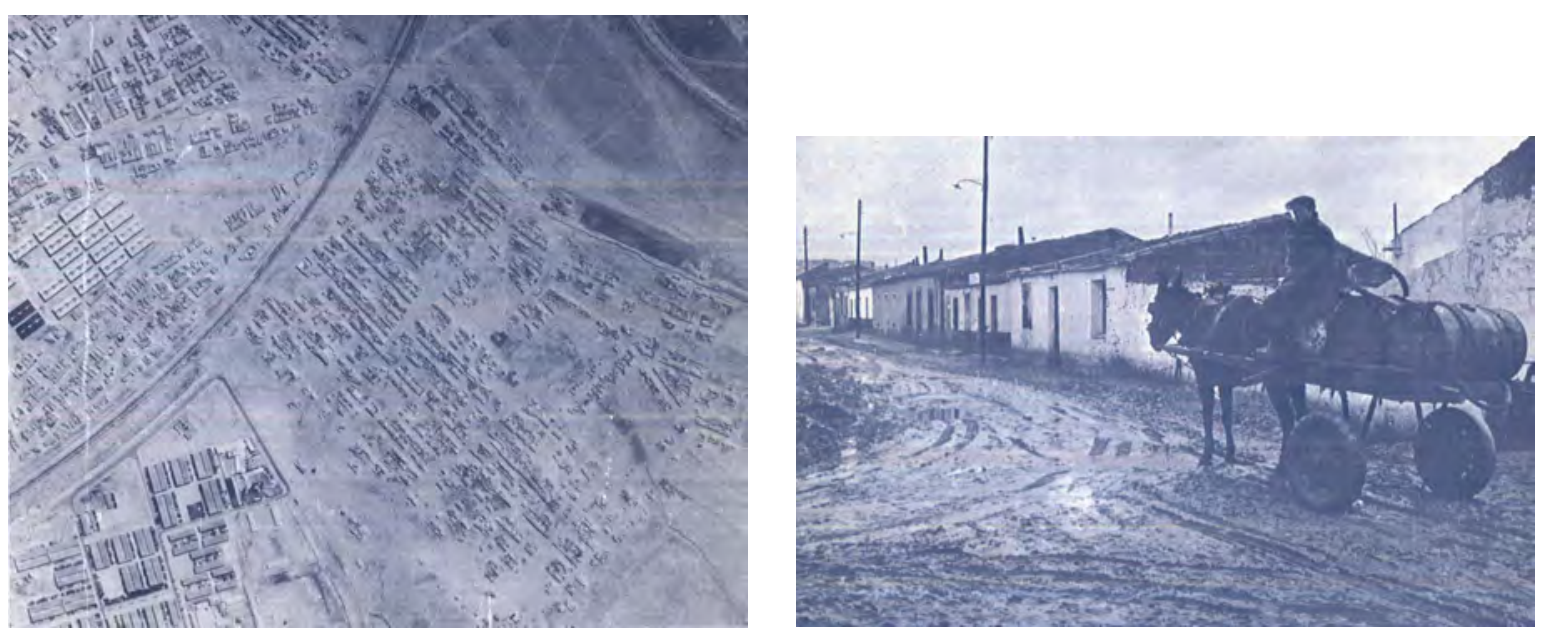

Figuras 34, 35 e 36: Fotos

AÉREAS DO BAIRRO, EM 1958, 1970 E 1976, RESPECTIVAMENTE

Figuras 37, 38 e 39: Situação DOS ACESSOS VIÁRIOS, ANTES DA REESTRUTURAÇÃo
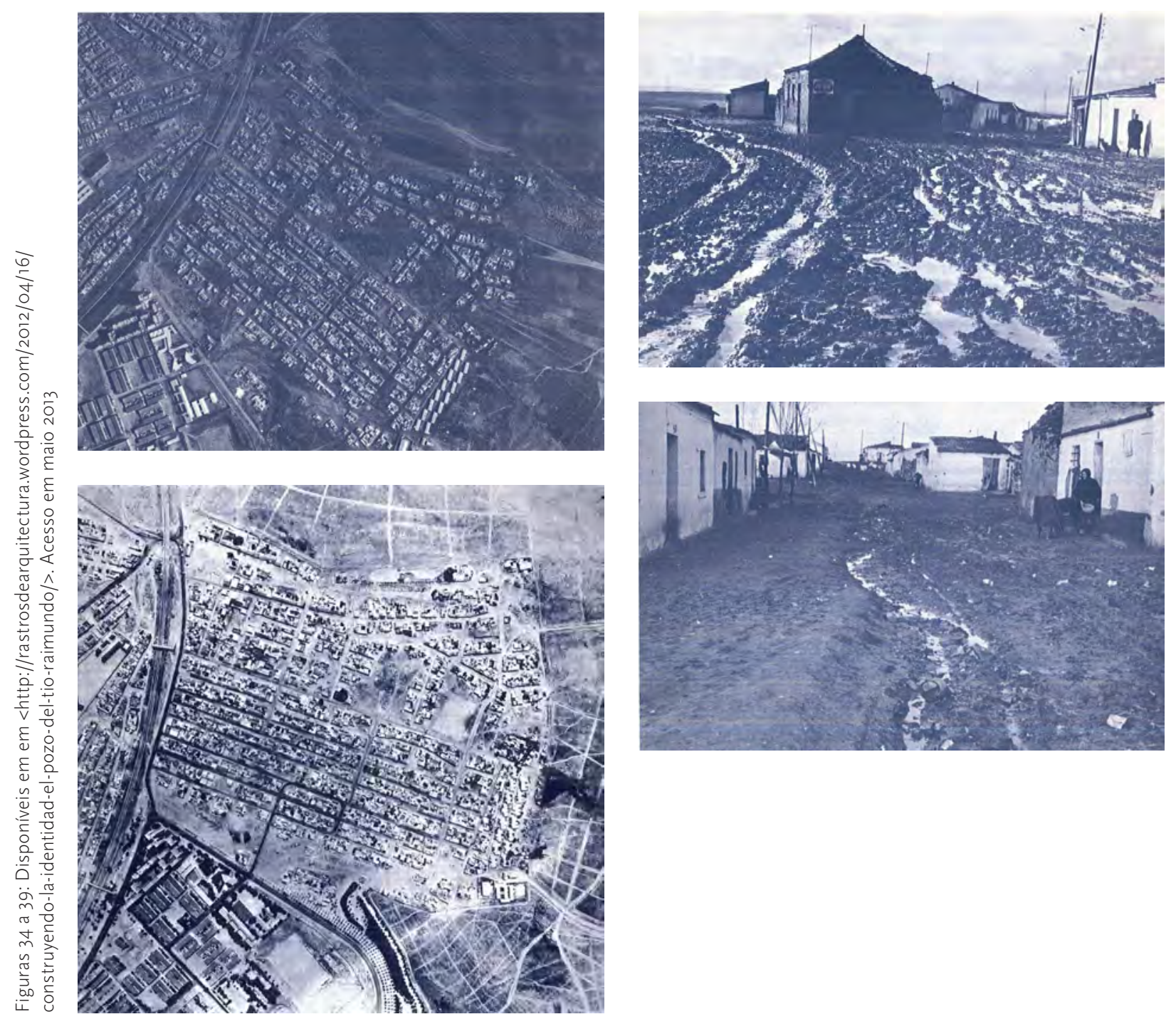
FIGURAS 40: O BAIRRO ANTES DA REESTRUTURAÇÃO

FIGURAS 41, 42 E 43: FOTOS AÉREAS DO BAIRRO, PRIMEIRA, SEGUNDA E TERCEIRA FASE DA REESTRUTURAÇÃO, RESPECTIVAMENTE
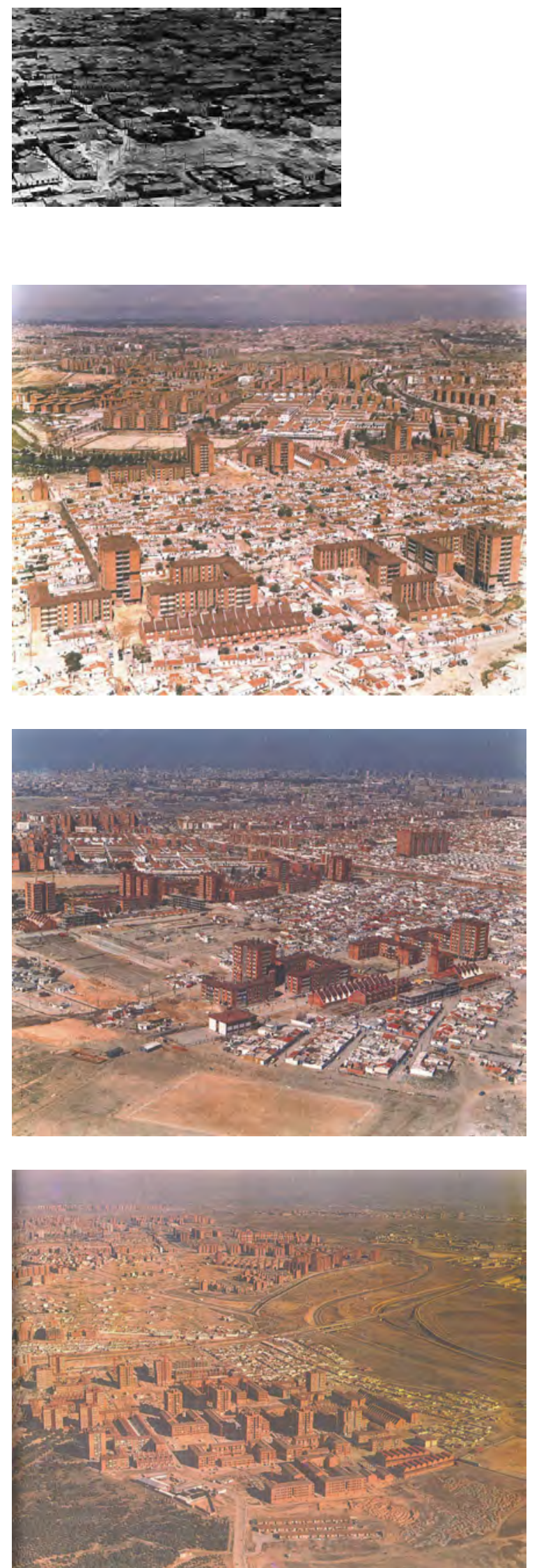

Tío Raimundo, construiu um poço de água, acontecimento que serviu para dar nome a esse novo bairro madrilenho. (RASTROSDEARQUITECTURA, 2012. Acesso em maio 2013)

A população de El Pozo se formou à base das migrações interiores que ocorreram na Espanha a partir dos anos 1940. Nos anos 1950, os trabalhadores agrícolas eram atraídos pela mecanização do campo. Em sua maioria, esses novos habitantes provinham das províncias de Andalucía, Extremadura y Guadalajara. (RASTROSDEARQUITECTURA, 2012. Acesso em maio 2013)

Os assentamentos se produziram inicialmente em um terreno de lamaçal e começaram a proliferar na área as moradias precárias na forma de autoconstrução, conhecidas por chabolas, e que eram apelidadas de "flores de luna" pois se erguiam na clandestinidade da noite para o dia. O requisito para que a policia não mandasse demolir era que tivessem quatro paredes e que estivessem cobertas por um telhado. Certos fatores como haver crianças pequenas ou mulheres grávidas dentro da moradia eram decisivos para que essas construções não fossem demolidas. Para legalizar a moradia, o habitante pagava uma multa à polícia. Entre os anos de 1956 e 1966, o preço dos terrenos subiu $6000 \%$, valor que permaneceu até 1976, quando se parou de construir no bairro. Estas construções formaram una nova paisagem à medida que se iam instalando mais migrantes. (RASTROSDEARQUITECTURA, 2012. Acesso em maio 2013)

O ano de 1976 foi seu apogeu, pois em 28 de dezembro foi aprovado o Plan Parcial, plano urbano local elaborado pelos moradores em colaboração com a Gerencia Municipal de Urbanismo e a criação de uma sociedade integrada pelo Ministério da Moradia e a Prefeitura. Os trabalhadores trocaram suas moradias de trinta metros quadrados por apartamentos de cem metros quadrados, 
financiados a baixos juros por até 35 anos. Nas figuras da página anterior se demonstram as fases de implantação do plano urbano: 1958, 1970 e 1976. Em 1987, finalizaram-se as edificações que substituíram as casas precárias e com todos os habitantes reinstalados, as casas remanescentes foram demolidas e a imagem do bairro se consolidou para sempre. (RAstrosdeARQUitectura, 2012. Acesso em maio 2013)

Um documentário sobre a transformação do bairro foi produzido por Juan Vicente Córdoba, cineasta e morador da localidade.

Nas palavras do Córdoba,

\begin{abstract}
A partir de um barraco em El Pozo del Tío Raimundo, aquele arrabalde construído vertiginosamente nos anos $1950 \mathrm{com}$ "casas" de barro e lata que cresciam como "flores de luna" levantadas durante a noite, o "padre vermelho" Padre Llanos insuflou os imigrantes com sua ilusão utópica na busca da justiça e liberdade. Dias e anos de solidariedade, de rebeldia e de forjarse uma nova identidade sonhando com a crença de que, a partir do bairro, se poderia mudar o mundo. Como estas pessoas tomaram consciência de sua situação e, com sua força e coesão como grupo humano, empreenderam a transformação? (FLORES DE LUNA, 2008)
\end{abstract}

"Contamos com ternura (no longa-metragem) um relato de imigrantes," diz Juan Vicente Córdoba sobre seu documentário, que compara a emigração atual com a vivida pela Espanha nos anos de 1960. (Córdoba, 2008)

\section{SaConia-Dehesa de LA Villa: PRODUÇÃo IMOBILIÁRIA CAPITALISTA}

Além de El Pozo, outros exemplos de planejamento com resultante de grande qualidade em desenho urbano é a urbanização de Saconia-Dehesa de La Villa (Saconia-Pastagem da Vila), com 45 hectares aproximadamente, projeto dos arquitetos Antonio Perpiñá, Carlos de Miguel e Luis Iglesias, desenvolvido com o modelo Parceria Público Privada-PPP, em meados da década de 1970, e localizado a noroeste de Madrid. Os edifícios possuem apartamentos de $86 \mathrm{~m}^{2}$, com três dormitórios.

A urbanização ocorreu em área rural onde somente uma residência foi mantida, representante da tipologia construtiva de residências em Madrid, como visto nas fotos que se seguem. As fotos ao lado mostram a área antes da implantação do novo bairro.

O conjunto é composto por unidades de vizinhança, cada qual com sua escola de $1^{\circ}$ grau. Além disso, existem escolas de $2^{\circ} \mathrm{grau}$, um centro institucional principal, paróquia, instituição sindical, Instituto da Mulher, posto policial e o Parque de Dehesa de La Villa.

O total de moradias chegou a 1800 e o projeto foi desenvolvido com a união de três elementos: arquitetos, incorporadora e construtora e, basicamente, atendo-se à Lei de Uso e Ocupação do Solo local, conformando a produção capitalista para o mercado, que obteve os seguintes resultados positivos, segundo o incorporador:
1. Racionalização adequada da construção mediante a padronização tipológica de moradias, sem chegar à pré-fabricação; 2. Boa privacidade e unidades de vizinhança com personalidade própria; 3 . Perfeita separação do tráfego de veículos da circulação de pedestres (...); 4. Uma plena adaptação por parte dos residentes, estes provenientes de localidades diversas, constituindo uma verdadeira comunidade, ou seja, uma entidade viva social. (XII Congreso..., 1975, p.18)

FIGURA 44: LINHA DE BONDE QUE ATRAVESSAVA O CAMPO A SER OCUPADO

\section{Figura 45: "EL BURAK" única edificaçãono terreno antes da execução do projeto, preservada}

\section{FIGURA 46: VISTA DO CONJUNTO IMPLANTADO}
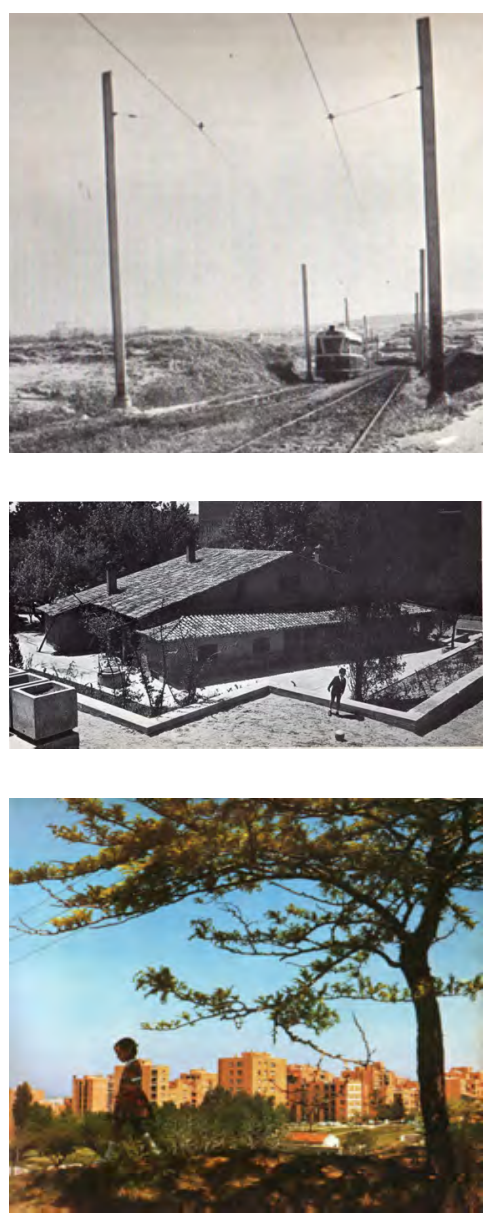

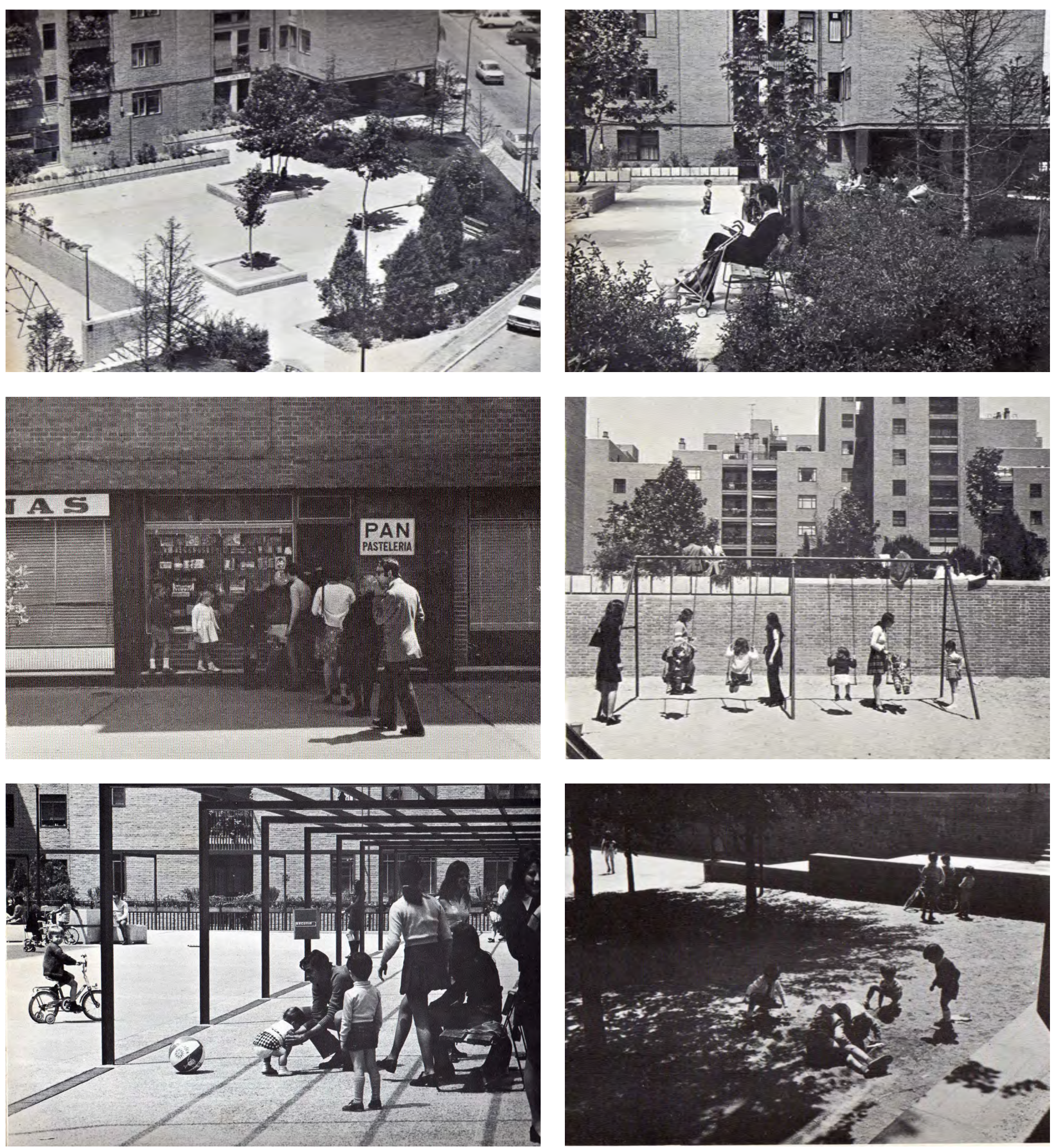

FIGURAS 47 A 52: IMPLANTAÇÃo E PÓS-OCUPAÇÃo do PROJeto SACONIA-DEHESA DE LA VILLA com pátios amplos e arborizados, comércio e serviços de âmbito local, escolas e equipamentos para crianças

XII CONGRESO...., 1975, p.28, 51 e 52 


\section{CAPÍTULO II \\ SÃO PAULO RUMO AO LESTE: SUA ESTRUTURAÇÃO URBANA}

São Paulo é conhecida pelo seu espraiamento ou horizontalização de sua mancha urbana de forma desestruturada com a verticalização no centro e a horizontalidade das periferias, o que contribuiu com grande parte dos problemas urbanos que vivenciamos hoje como o trânsito caótico, os grandes congestionamentos de veículos e os deslocamentos diários da população. As periferias paulistanas basicamente se formaram a partir de loteamentos irregulares e invasões de glebas vazias de propriedade privada ou pública, onde a produção de espaço urbano na forma de autoconstrução gerou aglomerações com construções precárias e sem infraestrutura.

Esse espraiamento se acentua em direção ao leste do município entre as décadas de 1950 e 1960, quando a extensão da mancha urbana ultrapassa o limite da área de proteção aos mananciais, ao sul da capital, fato que ainda prossegue neste início de século, de forma crônica nas também terras no entorno das represas Bilings e Guarapiranga, com urbanização esparsa que atinge os limites municipais entre São Paulo, Itanhaém e São Vicente, junto à Serra do Mar.

Para esta tese, procurou-se analisar a estruturação urbana da metrópole, detendo-se mais detalhadamente à estruturação da Região Leste Paulistana, tema desta pesquisa.
Para uma tese acadêmica envolvendo a estruturação viária e o crescimento urbano de uma região ou área metropolitana é preciso conhecer-se a evolução urbana surgida a partir da estrutura ferroviária em cidades industrializadas, como é o caso de São Paulo, pela importância que tiveram esses sistemas indutores de crescimento urbano, no transporte de mercadoria e escoamento de produtos após a crise do café e no início da industrialização, a partir da segunda metade do século XIX.

Pretende-se aqui demonstrar que na transição de cidade industrializada do fim do século XIX à metrópole de 8.493.226 habitantes no fim da década de 1970, (IBGE, 1980) São Paulo possuía uma grande região, a Leste, à espera por desenvolvimento urbano, enquanto a dinâmica econômica, social e cultural ocorria em seu redor, como segue.

Assim como afirmou Wilheim em seu livro São Paulo: Metrópole 1965, o planejamento de uma metrópole requer equipe multidisciplinar. Com ele concorda Langenbuch, que foi o geógrafo que estudou e descreveu com maestria a estruturação da Grande São Paulo, como era chamada a Região Metropolitana de São Paulo-RMSP, antes de sua oficialização, em 1973.

A administração pública de uma metrópole enfrenta 


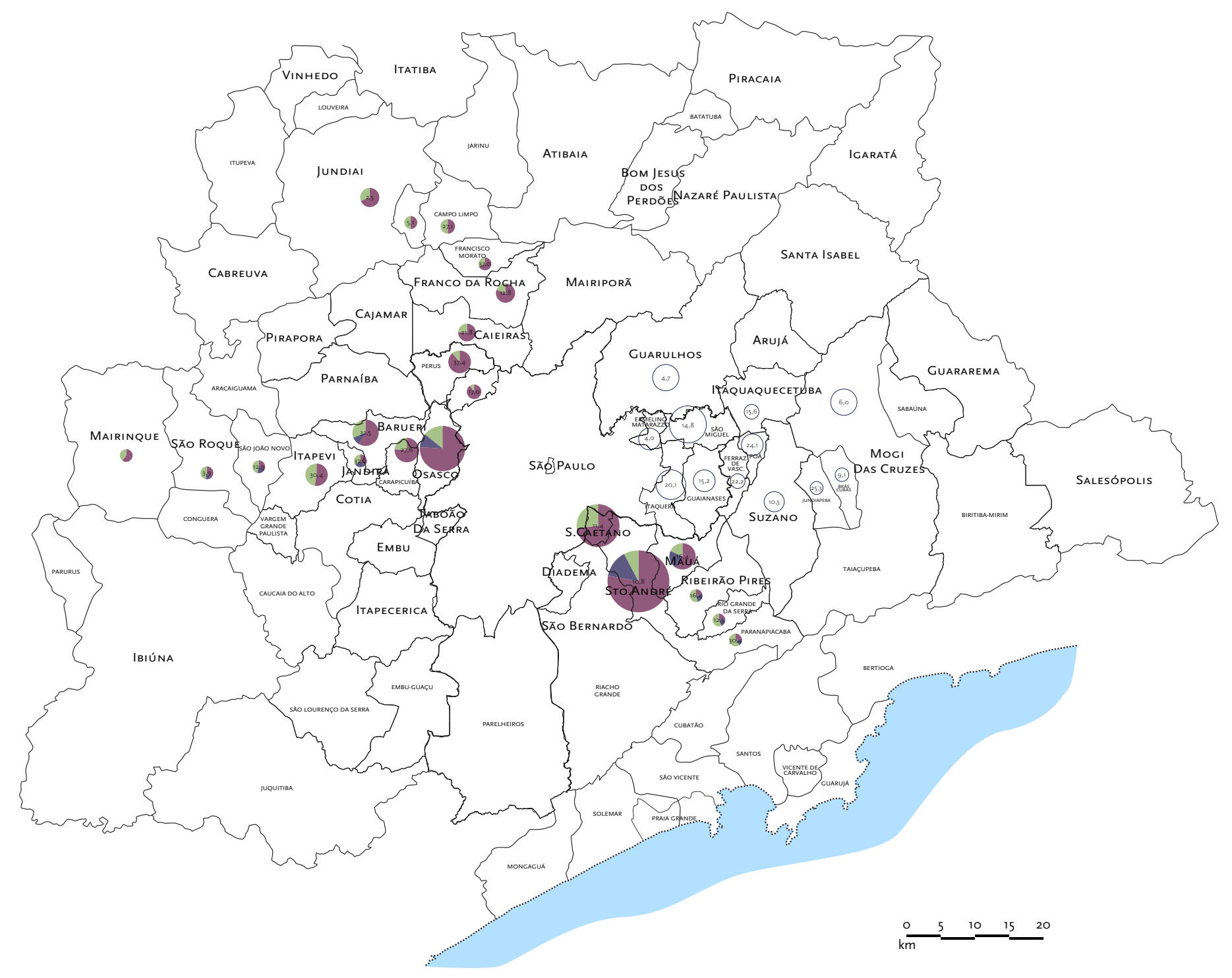

MÉDIA DIÁRIA DE EMBARQUE

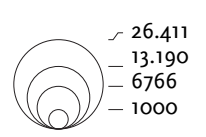

Passageiros destinados a Sãc Passageiros destinados aos $d$ Faixa de incerteza

Mapa 13: Arredores da cidade de São Paulo-Movimento pendular por trem Langenbuch, 1971, Encarte 
árduas tarefas. De um lado, cabe-lhe melhorar o que já existe, corrigindo pretéritas imprevisões e falta de planejamento, de outro lado, cumpre planejar para o futuro, evitando que erros outrora cometidos venham a se repetir e visando a um crescimento ulterior mais racional. Para tanto, o administrador precisa conhecer, de modo exato, a realidade presente, bem como estar a par das técnicas necessárias para atingir os objetivos supraenunciados. Assim é que os técnicos das mais diversificadas especializações, bem como cientistas que têm na cidade um objeto ou um campo de pesquisa, fornecem à administração pública - através de seus estudos - subsídios necessários à sua obra. Entre esses cientistas figura, obviamente, o geógrafo. (LAGENBUCH, 1971, p.1)

\section{O Mapa 13: Arredores da cidade de São Paulo-}

Movimento pendular por trem, elaborado por Langenbuch segundo sua interpretação e análise, mostra os municípios da Grande São Paulo e demonstra o movimento pendular de trabalhadores entre as cidades dormitório e São Paulo, local de concentração de postos de trabalho. ${ }^{41}$ Esses trabaIhadores se deslocavam em trens das redes federal e estadual, Rede Ferroviária Federal S/A-RFFSA e Ferrovia Paulista S/A-FEPASA respectivamente, no início da década de 1970

Langenbuch (1971) definiu a metrópole como organismo urbano extremamente complexo e peculiar e destaca fatos que caracterizam essa peculiaridade como: 1. Expansão urbana diversificada, ou seja, expansão horizontal por aglutinação (mais comum), por desdobramento que produz pequenos núcleos fora da cidade, por absorção de aglomerados rurais e de cidades próximas muito menores em razão de sua relação com a metrópole; 2. Estrutura funcional interna externamente complexa, com especialização de ramos comerciais; 3. Dicotomia entre cidade no sentido político-administrativo e cidade no sentido geográfico do termo; 4. Limites externos extremamente imprecisos, seja pelos contornos da área edificada e dos loteamentos não ocupados ou em fase de ocupação; 5. Arredores não urbanizados mas estruturados para fazer parte da metrópole. (LANGENBUCH, 1971, p.2)

Segundo Langenbuch, na década de 1970, "o grande organismo urbano hexamilionário se inscrevia entre as maiores metrópoles do planeta," superando a média em crescimento, uma vez que passou de modesto burgo com menos de vinte mil habitantes a metrópole de mais de seis milhões de habitantes. (LANGENBUCH, 1971, p.3)

Parte-se, neste breve estudo, da evolução urbana e estruturação rodoferroviária da Região Leste, mais detalhadamente a Região Leste 2 Paulistana, área foco de nosso estudo, desde meados do século XIX, quando "se verificaram importantes transformações nos arredores paulistanos, que precederam a metropolização iniciada a seguir." (LANGENBUCH, 1971, p.8)

\section{SÃO PAULO RURAL}

O perímetro da cidade, no último quartel no século XIX, compreendia extensas áreas rurais, as freguesias, que se localizavam tanto dentro dos limites municipais como os ultrapassavam. (Langenbuch, 1971, p.9) Em relação à população urbana de São Paulo, tanto Langenbuch (1971, p.9) como Singer (1974, p.58) atentam para a falta de precisão os números em função das freguesias não terem sido necessariamente consideradas. Singer indica os números de 27.900 habitantes em 1860 e, 31.385 habitantes em 1872 (1974, p.20) e Langenbuch indica uma população de
41. A Região Metropolitana da Grande São Paulo foi criada pela Lei Complementar Federal n. 14, de 8 de junho de 1973. A RMSP foi institucionalizada pela Lei Complementar Estadual n. 94, de 29 de maio de 1974. Mas sua efetiva implantação só se deu através do Decreto Estadual n. 6111, de 5 de maio de 1975, que regulamentou a Lei Complementar n. 94. Esse decreto criou e institucionalizou o denominado Sistema de Planejamento e Administração Metropolitana-SPAM. Estabeleceu o Conselho Consultivo Metropolitano de Desenvolvimento IntegradoConsulti, como unidade consultiva, e o Conselho de Desenvolvimento da Região Metropolitana da Grande São Paulo-Codegran. Foram então criados a Secretaria de Estado dos Negócios Metropolitanos-SNM, como unidade coordenadora e operadora, a Empresa Metropolitana de Planejamento da Grande São Paulo S/A-Emplasa, como unidade técnica e executiva, e o Fundo Metropolitano de Financiamento e Investimento-FUMEFI, como unidade financiadora. A Lei Complementar Estadual n. 144, de 22 de setembro de 1976, alterou episodicamente a primeira Lei Complementar Estadual n. $94 \mathrm{e}$ a Lei Estadual n. 1492, de 13 de dezembro de 1977, estabeleceu - Sistema Metropolitano de Transportes Urbanos e autorizou a criação da Empresa Metropolitana de Transportes Urbanos de São Paulo S/A-EMTU. Disponível em $<$ http://www.stm.sp.gov.br/index. php/rmas-de-sao-paulo/rm-de-saopaulo>. Acesso em 19 maio 2013. 
42. De autoria de Affonso Antonio de Freitas, publicado em Plan'História da cidade de São Paulo 1800-1874, São Paulo, 1914. (AzEvedo, 1958, p.87)

43. O Brasil adotou o regime da Federação de Estados em 1891, na $1^{\text {a }}$. Constituição Brasileira. "Dizia o art. $1^{\circ}$ da Constituição de 1891: 'A Nação brasileira adota como forma de Governo, sob o regime representativo, a República Federativa, proclamada a 15 de novembro de 1889, e constitui-se, por união perpétua e indissolúvel das suas antigas Províncias, em Estados Unidos do Brasil'." RABAT, 2002, p.9.

44. Os dados sobre a produção agrícola têm como fonte os cronistas e viajantes da época e mencionados por Langenbuch. (1971, p.19)

19.347 habitantes para a cidade em 1874 (1971, p.8) ocorrendo, portanto, uma grande discrepância.

Em relação às localidades ou bairros, alguns, como Santa Ifigênia, Luz, Liberdade e parte do Novo Centro, já apresentavam certo desenvolvimento como áreas urbanas em 1881, enquanto bairros hoje próximos ao centro como Moóca, Canindé, Bexiga, Santa Cecília e Bom Retiro, em meados do século XIX, ainda não existiam como tais, mas como áreas rurais. (LANGENBUCH, 1971, p.9) Era o cinturão verde da cidade de São Paulo.

Diversos cronistas e viajantes que descreveram o cinturão de chácaras que circundava São Paulo e são mencionados por Langenbuch como Manuel Aires de Casal, Auguste de Saint-Hilaire, Augusto Emilio Zaluar, Ernani Silva Bruno e outros, ficaram impressionados pelas ricas habitações de fazendas que "contribuíam singularmente para o embelezamento da paisagem." (Zaluar em LANGENBUCH, 1971 p.10) A expansão urbana já provocava o desmembramento de algumas chácaras a partir de meados do século XVIII e o conhecido Mapa das Chácaras determina um faixa de tempo entre 1769 e 1900 para a existência dessas propriedades rurais. ${ }^{42}$

\begin{abstract}
Analisando-se a localização dessas propriedades, constata-se que, esquematicamente, as chácaras formam um bloco relativamente compacto circundando a cidade, estendendo-se até os atuais bairros da Ponte Grande, Pari, Brás, Mooca, Cambuci, Vila Mariana, Jardim Paulista, Vila América, Santa Cecília, Barra Funda e Bom Retiro. Isoladamente, aparecem outras, sobretudo no quadrante leste. (LANGENBUCH, 1971, p.12)
\end{abstract}

Em relação à Região Leste Paulistana, podemos citar propriedades rurais que emprestam seus nomes, a distritos e vias importantes como Chácara do
Carrão (distrito do Carrão), sítio Aricanduva (distrito de Aricanduva), Chácara do Padre Adelino (rua Padre Adelino, no distrito Tatuapé).

Muitas propriedades rurais pertenceram aos aldeamentos indígenas e fazendas jesuítas, citando como exemplos ao Leste, Guarulhos (município desde 1906), Itaquaquecetuba (município desde 1953) e São Miguel (hoje distrito de São Miguel Paulista). (LANGENBUCH, 1971, p.14)

Nesses arredores rurais e agrícolas de São Paulo se produzia de forma importante a farinha de mandioca, componente da cultura indígena e da "agrícola caipira," em um total de $23 \%$ de toda a farinha produzida na Província, nome dado aos Estados da União até $1891 .{ }^{43}$ Produzia-se também 11\% da produção de feijão e 12\% da produção de aguardente e toda a produção de batata, mais precisamente em Santo Amaro, onde se concentraram os imigrantes alemães. A cultura do algodão atingiu 33\% da produção, ocorrendo tanto a nordeste em Mogi das Cruzes, como a noroeste, em Barueri. Em 1836, a cultura do café correspondia a 34\% de toda a produção da Província, em lavouras a noroeste (Chácara Anastácio) e a sudeste (São Bernardo). O açúcar era o principal produto na Província, teve expressão quase nula nos arredores de São Paulo e foi substituído pelo café no decorrer do século XIX.44

Os arredores paulistanos produziam para exportação, autoconsumo dos produtores, abastecimento da cidade de São Paulo e, manutenção e abastecimento das tropas com animais e gêneros alimentícios. (Langenbuch, 1971, p.22) Nos relatos dos cronistas mencionados por Langenbuch não se destacam quais eram os produtos agrícolas ou de rebanhos ocorridos nos arredores na Região Leste do Município, fato que já posicionava essa região de 
forma pouco participativa na economia da cidade e da Província, desde meados do século XIX.

O sistema de transporte nos arredores dependeu das tropas de burros, depois de cavalos e carros de boi até o advento da ferrovia, enquanto a navegação fluvial esteve geograficamente restrita em trechos dos rios Tietê e Tamanduateí. Em fins do século XVIII, o rio Pinheiros e seus dois afluentes, Grande e Pequeno, serviram de ligação entre São Paulo e Santos. (LanGenbuCH, 1971, p.25)

A propósito do rio Tietê, conta-nos Ernani Silva Bruno: "No Tietê, além da navegação por canoas ou pequenos barcos de transporte de areia, de telha e outros produtos, houve, em 1861, uma tentativa de navegação com barcos a vapor." Para seu desenvolvimento, chegou a se organizar uma companhia que obteve a concessão para estabelecer a ligação de São Paulo com Mogi pelo Tietê, "mas depois de feitas algumas explorações a empresa deixou de ir por diante." (Bruno em LanGenbuCH, 1971, p.26)

Langenbuch destaca a precariedade das estradas quando trata da circulação terrestre, predominantemente em tropas de burros. Vamos nos ater aqui aos caminhos voltados à Região Leste, seja partindo dela ou em direção a ela, com o objetivo de estabelecer sua relação histórica com a cidade sob o prisma econômico e social. Segundo Langenbuch, São Paulo, assim como o restante do Brasil, não conheceu a "fase da diligência," que antecedeu a ferrovia, como ocorrido em países europeus e nos Estados Unidos da América, exceção feita ao serviço entre São Paulo e Santos, insignificante, e entre a cidade e a Freguesia da Penha, em dias de festas religiosas. (LANGENBUCH, 1971, p.27)

\section{A ESTRUTURAÇÃO URBANA NA ESCALA DA METRÓPOLE}

A ferrovia chegou a São Paulo pelas mãos dos ingleses, que construíram a primeira ferrovia da Província em 1867, ligando o município de Santos, onde estava o Porto Marítimo, a Jundiaí, servindo para escoar a produção dos cafezais que se encontravam em maior concetração nesta região, e exportá-la.

Como dito anteriormente, tanto o Brasil como São Paulo passaram diretamente do carro de bois e das tropas de burros para o transporte por trem, sistema que determinou o crescimento urbano entorno a suas paradas, favorecendo o comércio e serviços nas freguesias da cidade de São Paulo e nas novas cidades que surgiram próximas à capital da Província.

Em relação às ferrovias em construção no interior de São Paulo, informa Langenbuch que

$$
\begin{aligned}
& \text { Profundas transformações iriam afetar o } \\
& \text { "cinturão caipira," que passa a ser cada vez } \\
& \text { mais organizado pela cidade, em função da } \\
& \text { cidade. Se o grande crescimento de São Paulo } \\
& \text { constitui o fato gerador de dita metamorfose, } \\
& \text { a ferrovia, novel meio de circulação, irá } \\
& \text { funcionar como fator do arranjo espacial da } \\
& \text { nova organização. (LANGENBUCH, 1971, p.97-98) }
\end{aligned}
$$

Segundo Langenbuch, as estradas de ferro desprezaram alguns conglomerados nos arredores paulistanos e apenas os maiores, Jundiaí e Mogi das Cruzes, foram levados em consideração no estabelecimento de ferrovias extra-regionais. "O povoado de Rio Grande (hoje cidade de Rio Grande da Serra) foi atingido por acaso pela estrada de ferro Santos a Jundiaí, simplesmente porque se situava ao longo do traçado geral da mesma. Trata-se de um caso excepcional." (LANGENBUCH, 1971, p.100) 
45. "Ferroanel: elemento chave da estratégia da intermodalidade proposta pelo Plano Diretor de Desenvolvimento de TransportesPDDT, o Ferroanel possibilitará o fechamento completo de um anel ferroviário no entorno da RMSP por meio de duas conexões ferroviárias: uma ao norte e a outra ao sul, conectando as malhas leste e oeste já existentes. A Secretaria dos Transportes conta com o PDDT, um instrumento de planejamento contínuo que, a partir de um diagnóstico do sistema atual, da identificação dos seus gargalos e pontos críticos estabelece as estratégias institucionais, de investimento e gestão, indicando as ações prioritárias das políticas públicas para o setor." Governo do Estado de São Paulo: Secretaria de Logística e Tranportes. Ações. Disponível em $<$ http://www.transportes.sp.gov. br/programas-projetos_/acoes. asp $>$. Acesso em 19 maio 2013.

46. Langenbuch apresenta mapa da Grande São Paulo, com um número de municípios segundo sua visão à época, que incluíam até municipios da Baixada Santista, conforme o Mapa 13: Arredores da cidade de São Paulo-Movimento pendular por trem (p.70). A região metropolitana oficializada em 1973 contou com pelo menos vinte municípios a menos no conjunto da RMSP em relação ao conjuto da GSP de Langenbuch.
De implantação mais recente, a ferrovia entre Rio Grande da Serra e Suzano pertencia ao sistema Central do Brasil na década de 1920 e está hoje nos planos de implantação do Ferroanel, da esfera federal, por ser um trecho coincidente com o traçado do futuro anel ferroviário do Governo do Estado de São Paulo, projeto ainda hoje sem previsão oficial para início e término de implantação. ${ }^{45}$

\section{O Mapa 14: Caminhos e ferrovias do século XIXX} mostra o traçado das ferrovias e caminhos que ligavam a Capital da Província de São Paulo às cidades menores, vilas, freguesias, aldeamentos e povoados. O círculo tracejado localiza a RLP para melhor compreensão e entendimento das vias e ferrovias que faziam a ligação desta com a capital, sua abrangência e importância. Nesse mapa pode-se ver a grande região localizada entre as ferrovias Central do Brasil, de 1889 e Santos Jundiaí, de 1867, a área da RLP. A estrada do Índio Tibiriça fazia a ligação entre a estrada em direção a Mogi das Cruzes e o Caminho do Mar, primeira estrada entre o planalto e o litoral, ligação que perdura até os dias de hoje, mas sem condições estruturantes por sua pouca capacidade de vazão.

\section{O Mapa 15: Caminhos e ferrovias do séc. XIX sobre} a GSP 1961 e RMSP 1973 (p.77), foi produzido, a título de comparação, sobrepondo-se Mapa 14 (p.75) ao mapa atual da RMSP, acrescido dos municípios que Langenbuch definiu como a Grande São Paulo à época da publicação de seu livro. Dessa forma, tem-se a Grande São Paulo em 1960, segundo Langenbuch, com aproximadamente 40 municípios, posteriormente subdivididos, sobre a qual está a RMSP oficial desde 1973, com 39 municípios, e os caminhos e ferrovias que propiciaram e induziram o crescimento urbano em São Paulo a partir do século XIX e nos municípios de seu entorno, seja da Grande São Paulo, seja da RMSP. De acordo com o Mapa 15 (p.77), o sistema ferroviário de meados do século XIX estruturou a RMSP, aliado ao sistema de caminhos, as vias, existentes à época, algumas calçadas com pedras em curtos trechos e outras apenas em chão batido. Conclui-se que a atual conformação da RMSP foi estruturada pelos caminhos e ferrovias que são hoje suas principais vias, estendidas após meados do século XIX e permeando os municípios circunvizinhos e conformadores da RMSP dos séculos 20 e $21 .^{46}$

\section{A ESTRUTURAÇÃO URBANA DA REGIÃO LESTE PAULISTANA COMO CONJUNTO DE METRÓPOLE}

Toda estruturação urbana brasileira se deu originalmente a partir dos caminhos abertos em qualquer foco urbano ou expansão de uma cidade, para caminho de tropas, carros de bois e posteriormente ferrovias. No caso da região leste da RMSP, e observando-se o Mapa 16: Arredores da cidade de São Paulo-Colônias oficiais 1875/1900 (p.78), pode-se ver que Poá, Suzano e Ferraz de Vasconcelos, que são municípios vizinhos imediatos de distritos da RLP, como Itaim Paulista, Lajeado, Guaianases e Cidade Tiradentes, já apresentavam focos urbanizados entre 1875 e 1900 . Esses municípios se formaram a partir das paradas dos trens da Ferrovia Central do Brasil, inaugurada na década de 1860. Entre São Paulo e Ferraz de Vasconcelos, as estações de paradas dos trens Itaquera e Guaianases induziram o surgimento dos distritos paulistanos com esses mesmos nomes.

Em relação ao município de itaquaquecetuba e São Miguel Paulista, este último também transformado 

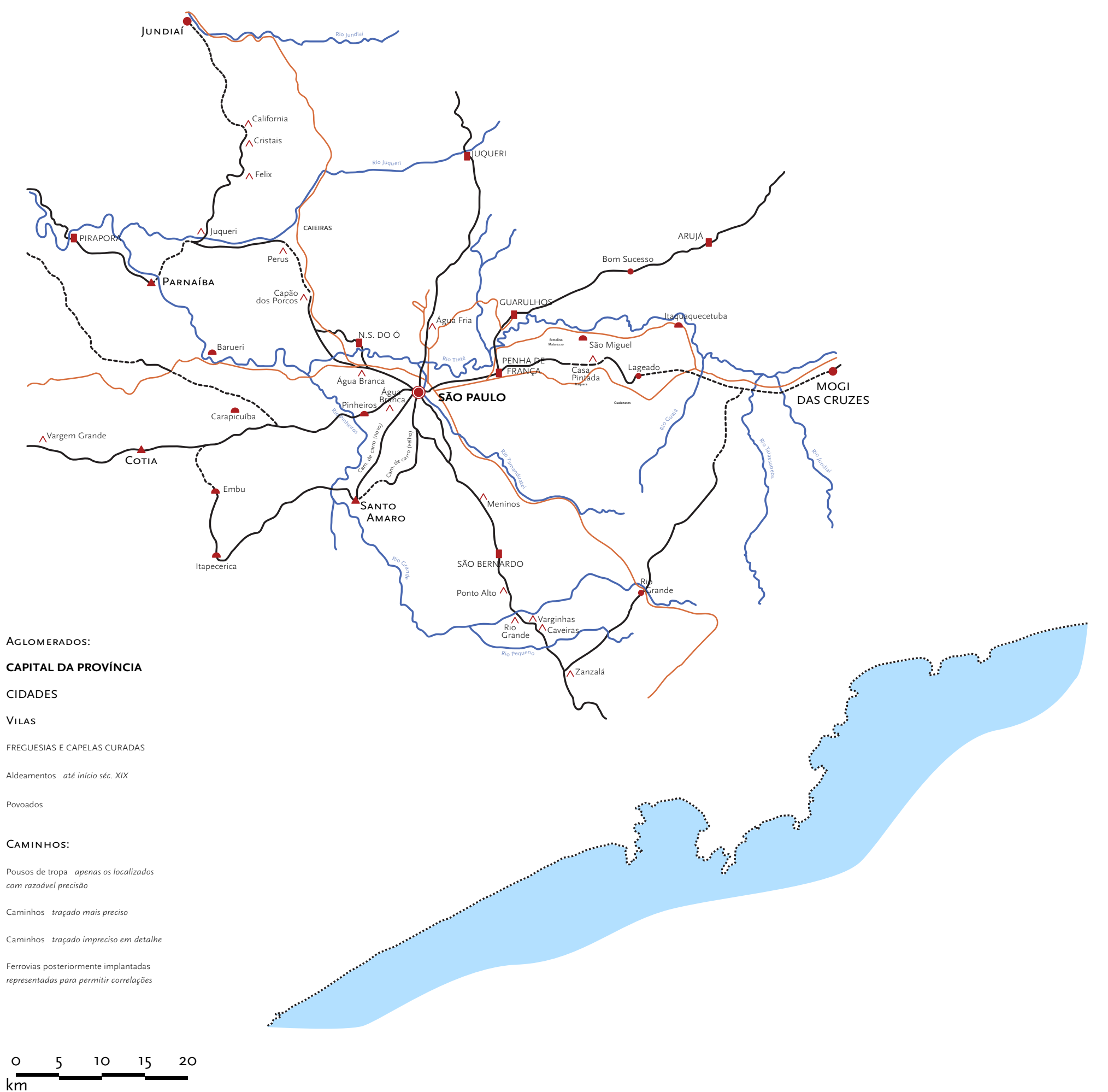

Mapa 14: CAminhos e ferrovias do século XIX tentativa de reconstrucão cartográfica Langenbuch, 1971, Encarte. Mapa base: Carta dos Excursionistas, 1923 


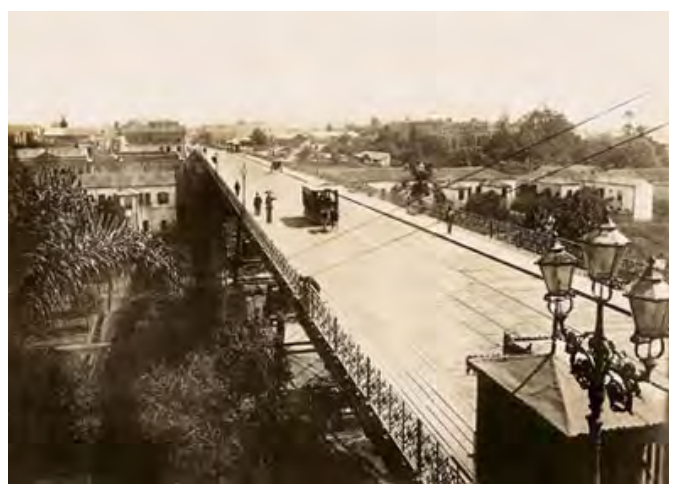

Figura 53: Viaduto do Chá

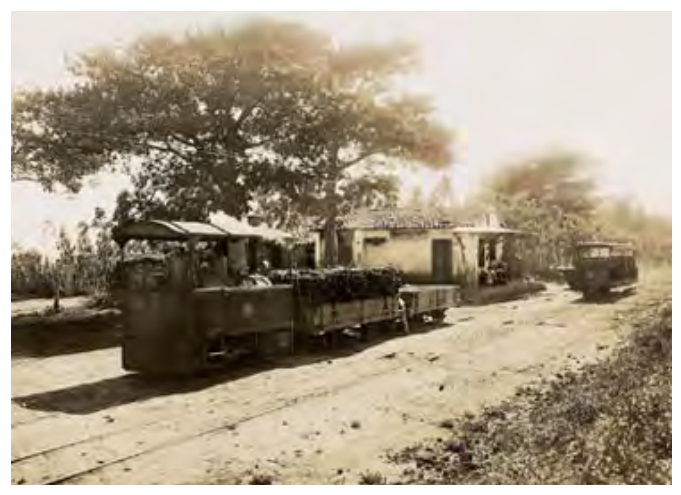

Figura 56: Primeiras ferrovias-Bonde

Figura 59: Ferraz de Vasconcelos
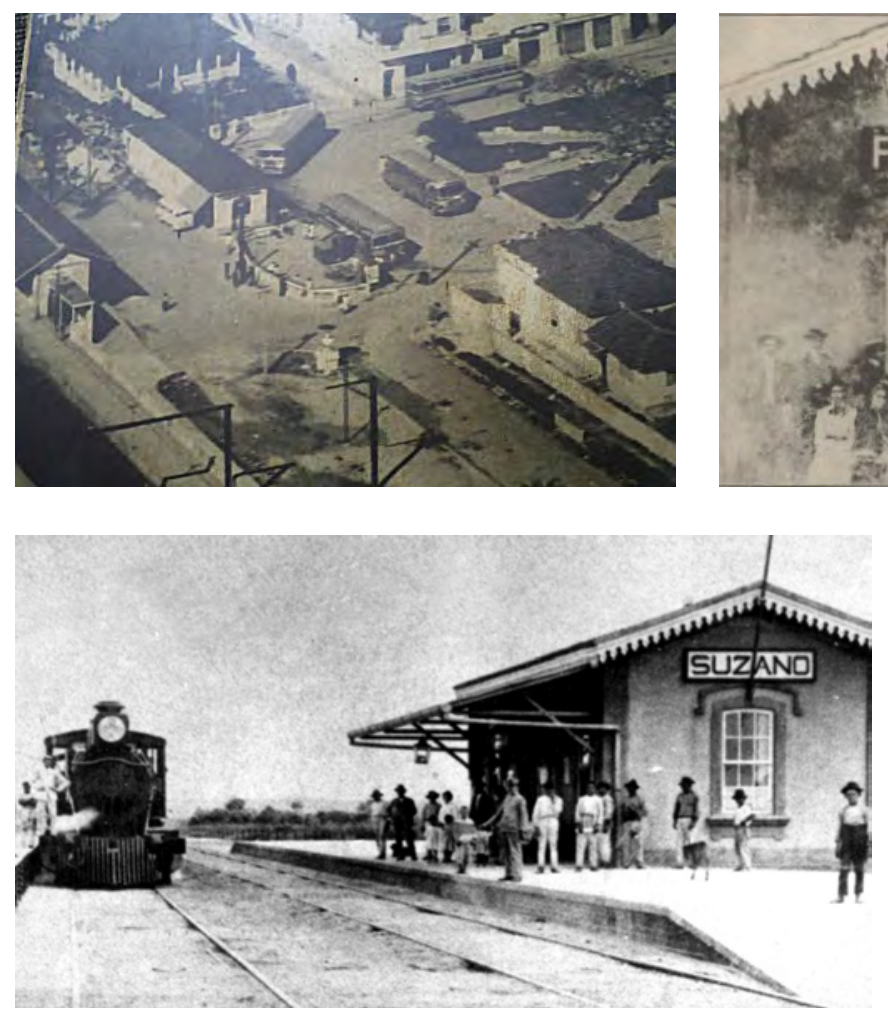

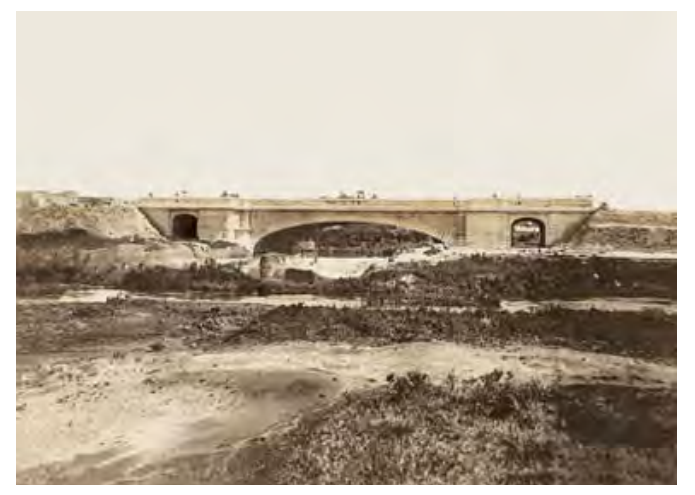

FIGURA 54: Ponte do CARMO

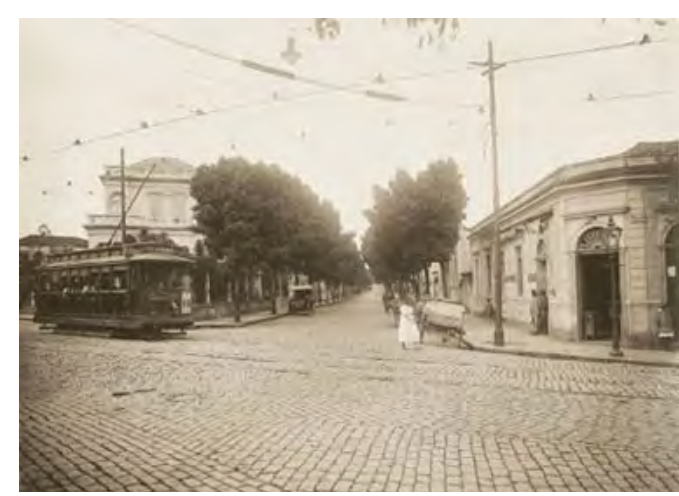

FIGURA 57: LINHA DE BONDE

Figuras 60: Estação de PoÁ séc. XIX

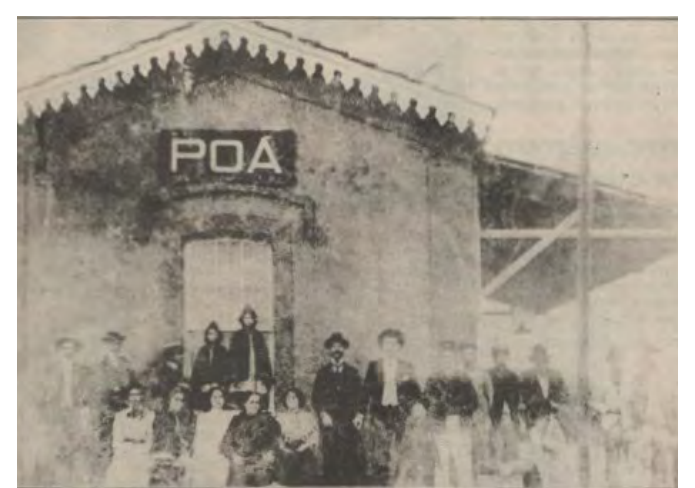

Figura 62: Estação de Suzano 1915

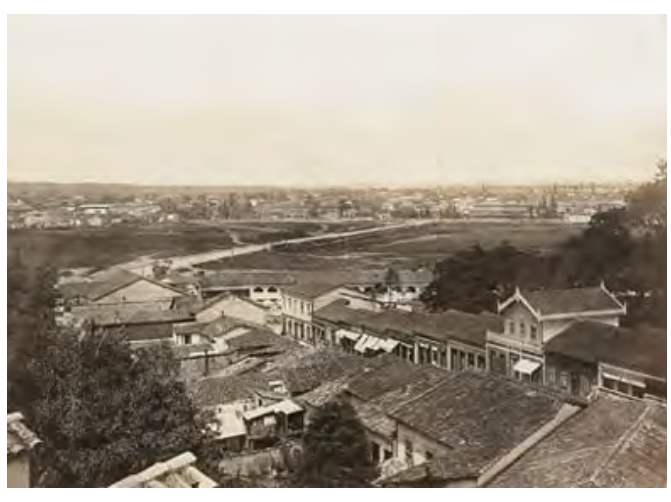

FIGURA 55: VAZIOS NA EXPANSÃO DA CIDADE

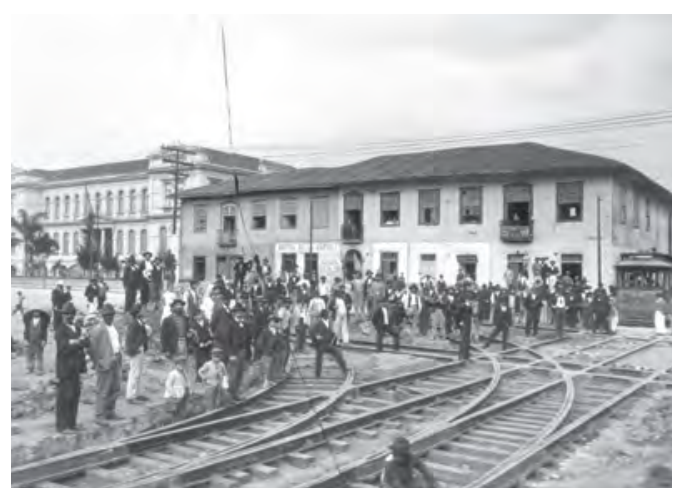

FIGURA 58: LINHA DE BONDE EM CONSTRUÇÃO

Figura 61: Estação de Itaquaquecetuba

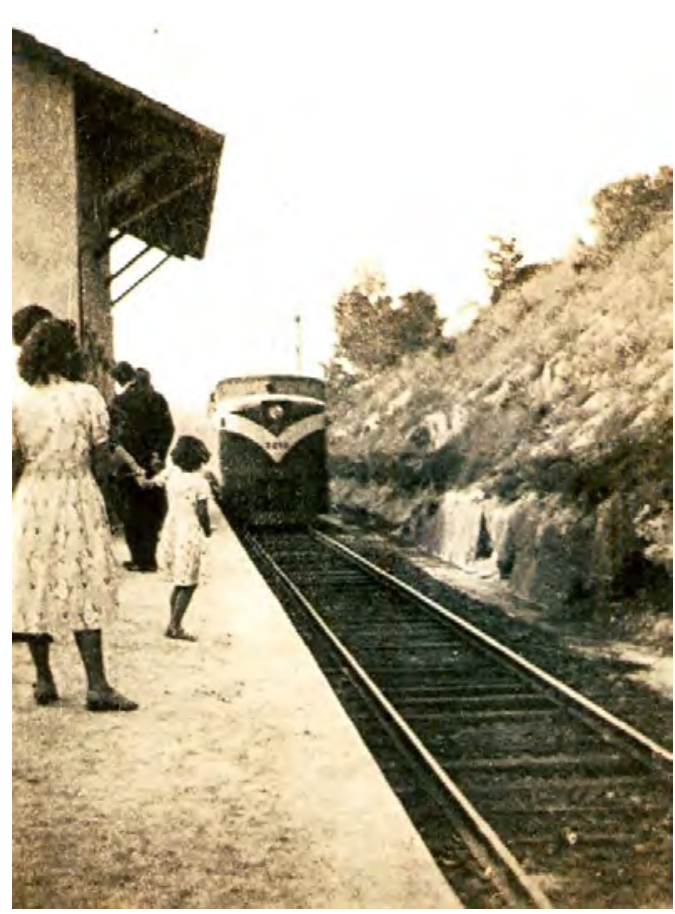


Capítulo II: São Paulo rumo ao leste-sua estruturação urbana

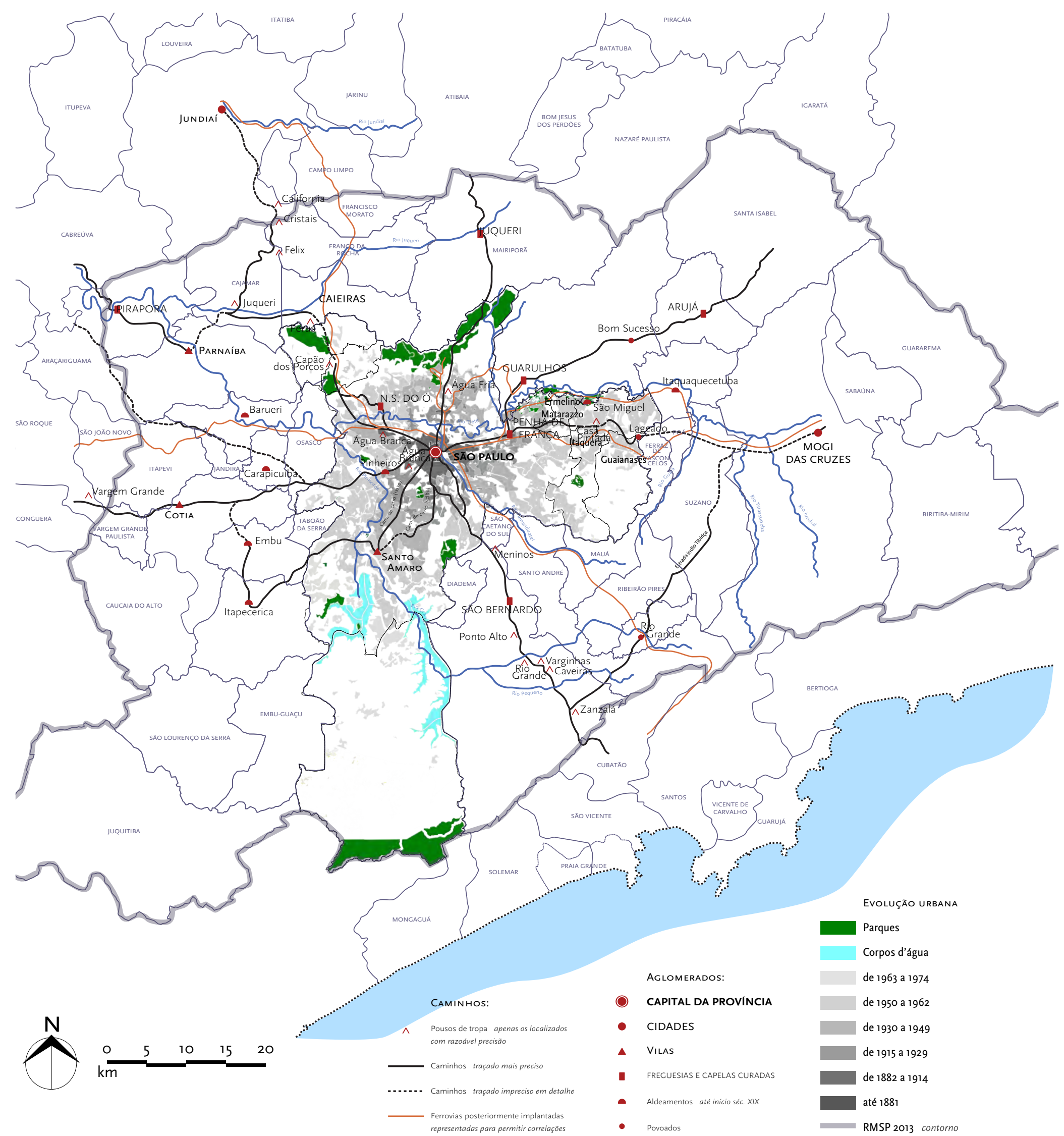

MAPA 15: CAMINHOS E fERROVIAS do SÉc. XIX SObRe A GSP 1961 e RMSP 1973 montagem sobre Langenbuch, 1971, Encarte 


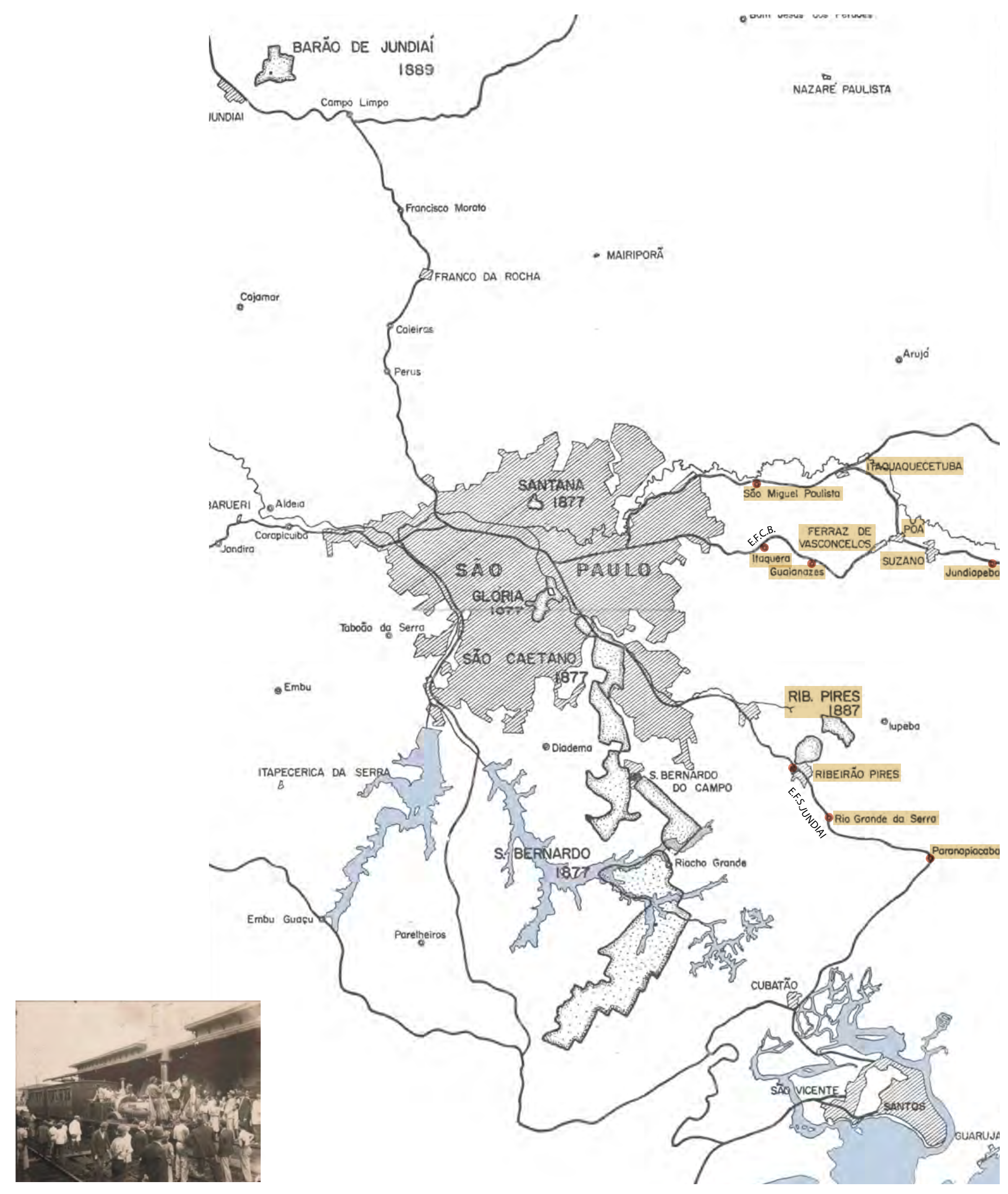

Figura 63: Estação Ferroviária de MoGI dAs CRUZES

Mapa 16: Arredores da Cidade de São Paulo-Colônias oficials 1875/1900

Langenbuch, 1971, Encarte 
posteriormente em distrito de são Paulo, tiveram seu surgimento e crescimento urbano devido à antiga estrada de rodagem entre Rio de Janeiro-São Paulo, hoje conhecida como Estrada Antiga São Paulo-Rio de Janeiro. O Mapa 16 (p.78) mostra ainda o crescimento urbano a sudeste de São Paulo, formando municípios como Ribeirão Pires, fundado em 1887, e aglomerados urbanos, como Rio Grande da Serra, até Paranapiacaba, vilarejo construído junto à estação de parada da Ferrovia Santos-Jundiaí, a Inglesa, construída pela Cia. Light, em 1867, com moradias para os funcionários da ferrovia. Seguindo-se pela mesma ferrovia, chega-se ao município de Santos, onde estava o Porto de Santos, onde era embarcado o café para exportação proveniente do noroeste do Estado, e a São Vicente. Cubatão e Guarujá já eram aglomerados urbanos em fins do século XIX.

O Caminho do Mar, estrada histórica de chegada a São Paulo a partir do Porto de Santos, está até hoje conectado aos municípios do leste do estado pela Estrada do Índio Tibiriçá, como se verá nos mapas 15, 22, 38 e 41. No caso do mapa 38, esta coincide com o canal artificial e as eclusas projetados a partir da represa de Taiaçupeba em direção sudoeste até a represa Billings.

A ligação entre os municípios de Mogi das Cruzes e Santos se dava pela estrada Índio Tibiriçá a partir do município de Suzano até estrada Caminho do Mar. (cf. Mapa 22: Arredores de São Paulo-ônibus urbanos intermunicipais 1965 (p.85)) A partir de Suzano e em direção ao Norte, caminhos não identificados por Langenbuch em sua tese, mas rapidamente identificáveis a partir de fotos aéreas e sem correlação precisa com o traçado anterior às obras viárias realizadas na região nas últimas décadas, conduziam os viajantes à Estrada ArujáItaquaquecetuba, permitindo conexões entre municípios do Leste da RMSP e o litoral e o Porto de Santos. As estradas mencionadas, Índio Tibiriçá, Estrada Santa Isabel, serviam como antigos caminhos de tropas, também entre a cidade de Mogi das Cruzes e a antiga vila ferroviária de Paranapiacaba, parada no alto da Serra do Mar dos comboios da ferrovia Santos-Jundiaí.

\section{OS NOVOS BAIRROS DA REGIÃO LESTE}

Analisando-se o Mapa 17: Planta geral da cidade de São Paulo 1897 (p.80) do ponto de vista do crescimento da Região Leste, é notável o crescimento urbano ao longo da ferrovia Central do Brasil, ligando São Paulo ao Rio de Janeiro, e ao longo da antiga estrada São Paulo-Rio de Janeiro, demonstrado pela análise do Mapa 14 (p.75) e Mapa 16 (p.78). Somandose a isso o desmembramento das chácaras e glebas em loteamentos, surge uma clara explicação para o início do crescimento de São Paulo rumo a leste: a planta preparada por Gomes Cardin, Intendente de Obras da cidade em 1897, mostra que este dá nome ao loteamento vila Gomes Cardin, provavelmente em terras de sua propriedade. Seguindo-se a lógica histórica da influência do mercado imobiliário no desenvolvimento urbano das cidades brasileiras até o fim do século XX, pelo menos, o surgimento desse loteamento exigiu do poder público a implantação de infraestrutura básica para atender aos novos moradores dessa localidade. O loteamento que originou a Vila Prudente, como outros na Região Leste, surgiu a partir da implantação da Ferrovia Santos-Jundiaí, estruturante, e era a ela conectado pelo caminho que hoje é a importante avenida Professor Luíz Ignácio de 


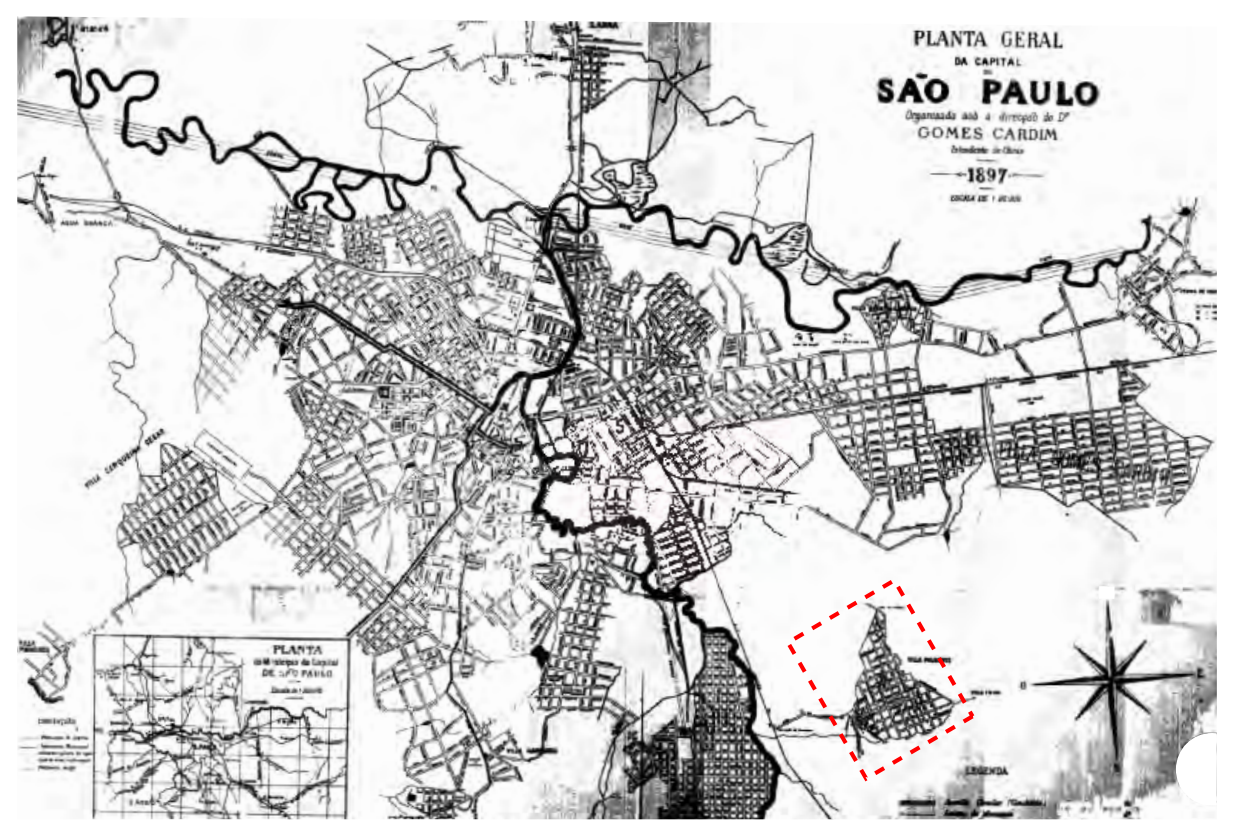

Mapa 17: Planta Geral da Cidade de São Paulo 1897

detalhe do loteamento da Vila Prudente; cf. planta abaixo

Comissão do IV Centenário da cidade de São Paulo-Plantas da cidade de São Paulo, 1954

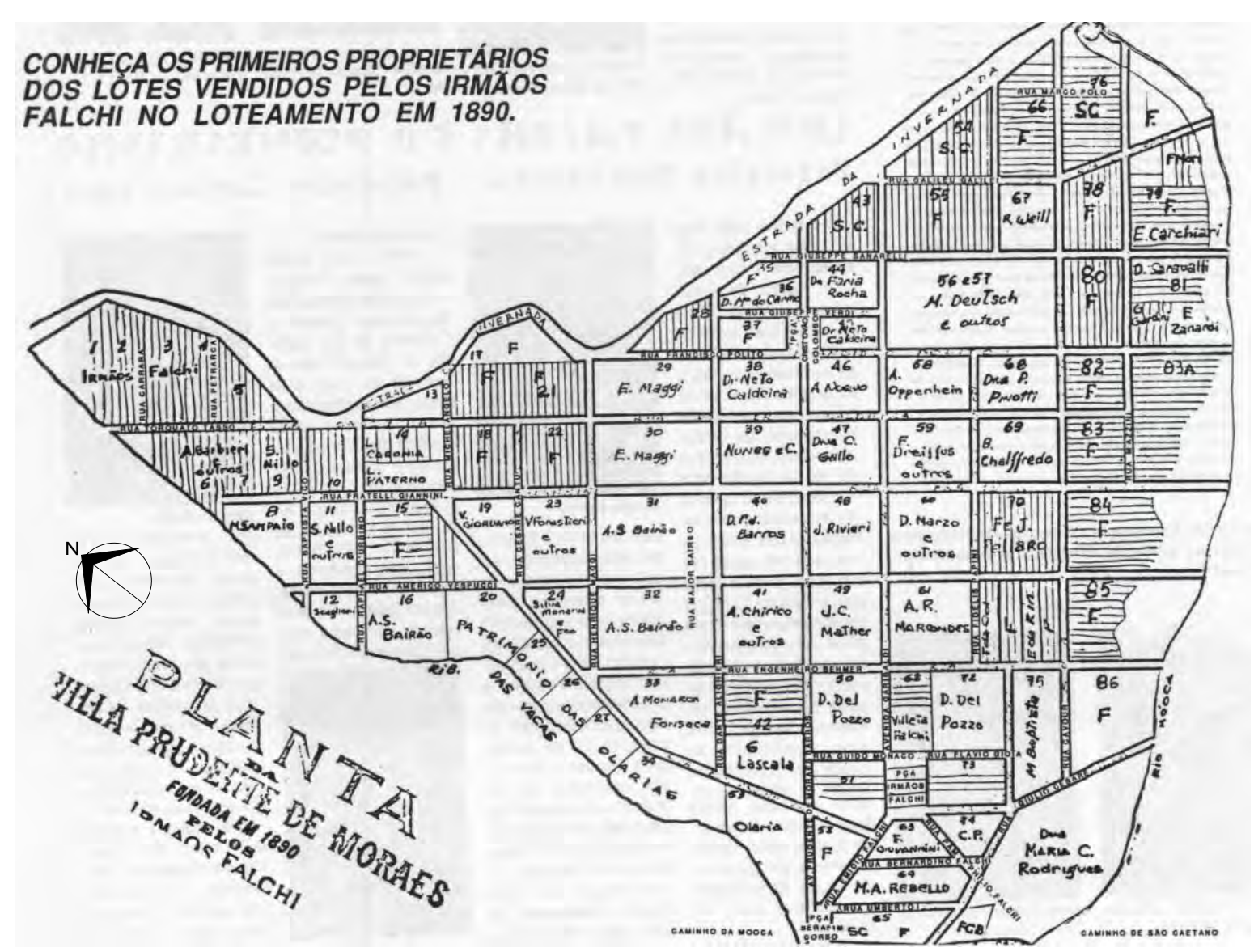

Mapa 18: Loteamento da Vila Prudente-Primeiros Proprietários

Disponível em <http://lemad.fflch.usp.br/node/354>. Acesso em 1 jun. 2013 


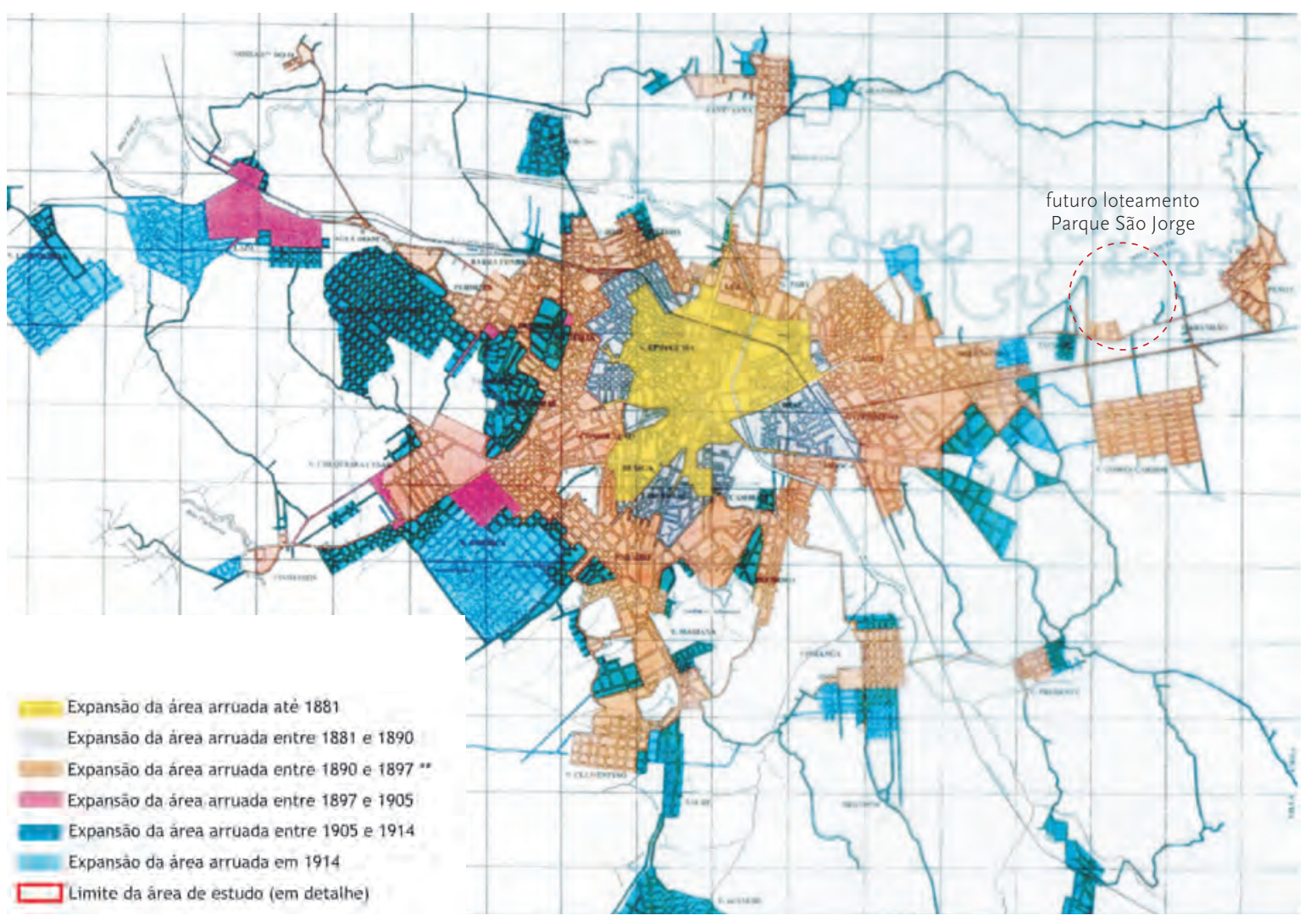

MAPA 19: EXPANSÃO DA

ÁREA ARRUADA DA CIDADE DE SÃo Paulo 1881/1914

montagem s/ Planta Geral da Cidade 1897

detalhe da localização do

loteamento Parque São Jorge

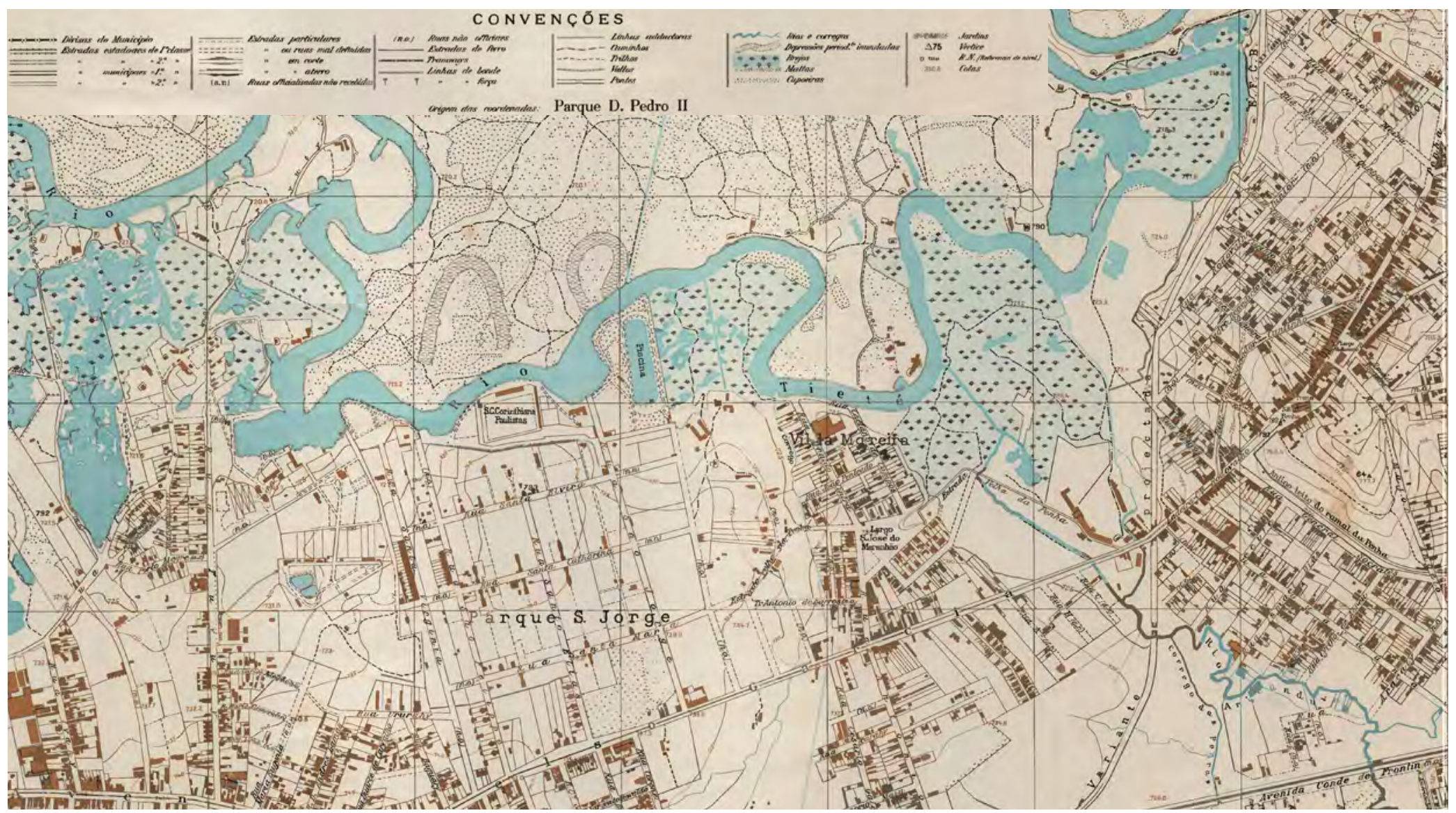

Mapa 20: LeVantamento topográfico do Parque São Jorge e entorno 1930-Sara Brasil (Det.)

PMSP. Sara Brasil S/A Mapa topográfico do município de São Paulo, 1930 
"Para concluir o que foi visto a propósito da evolução da cidade e arredores, durante o período 1915/1940, poderiamos em resumo destacar como espectos importantes os seguintes: 1. O espaço delimitado externamente pelos antigos bairros isolados tende se compactar através dos loteamentos que surgem entre eles e o núcleo ja compacto da cidade. É neste domínio urbano periférico que se verifica o maior crescimento demográfico. Não obstante, vários dos loteamentos, que ai surgem, permanecem, por ora, na fase de especulação imobiliária continuando a separar - ao invés de unir - bairros já estruturados; 2. No domíniio propriamente urbano surgem novas soluções: bairros jardins e o aproveitamento para fins residenciais de áreas com características de sítio, anteriormente rejeitadas para tal fim. O ersultado é positivo no caso do Pacaembu e negativo no caso das várzeas. (Vila Maria) (..) 4. São Paulo conhece uma verdadeira explosão da especulação imobiliária. Além dos loteamentos surtos no domínio propriamente urbano - entre os bairros á existentes - a especulação se volta com interesse nunca visto para os arredores paulistanos à época. Em torno da cidade surge um verdadeiro "cinturão de loteamentos residenciais suburbanos," que transcende os limites municipais, e compreende vastas extensões territoriais que por algum tempo ainda não serão necessárias à expansão urbana. (...)" (Langenbuch, 1971, p.176)

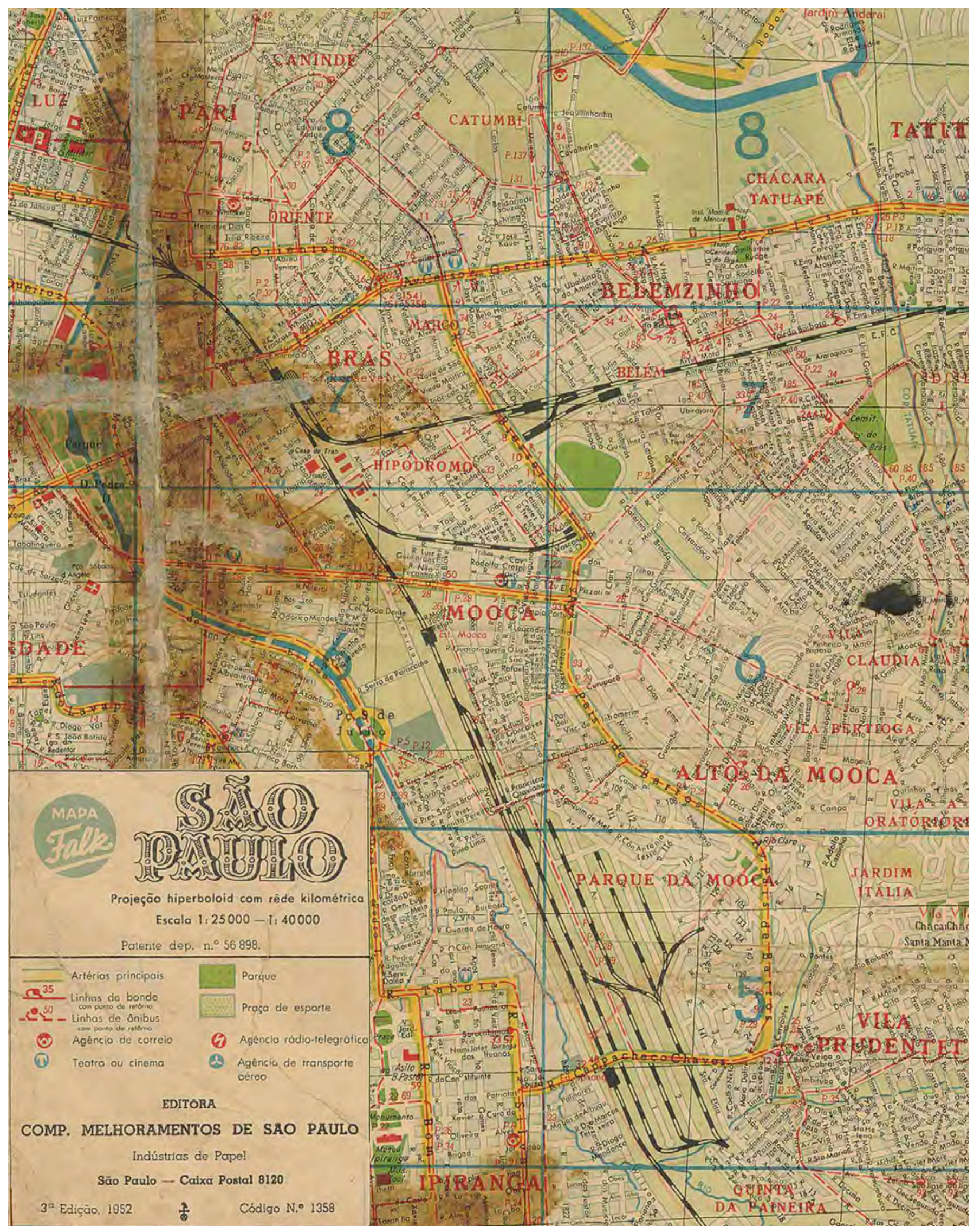

Mapa 21: Levantamento Viário de São Paulo 1952-Falk

Cia. Melhoramentos, 1952 


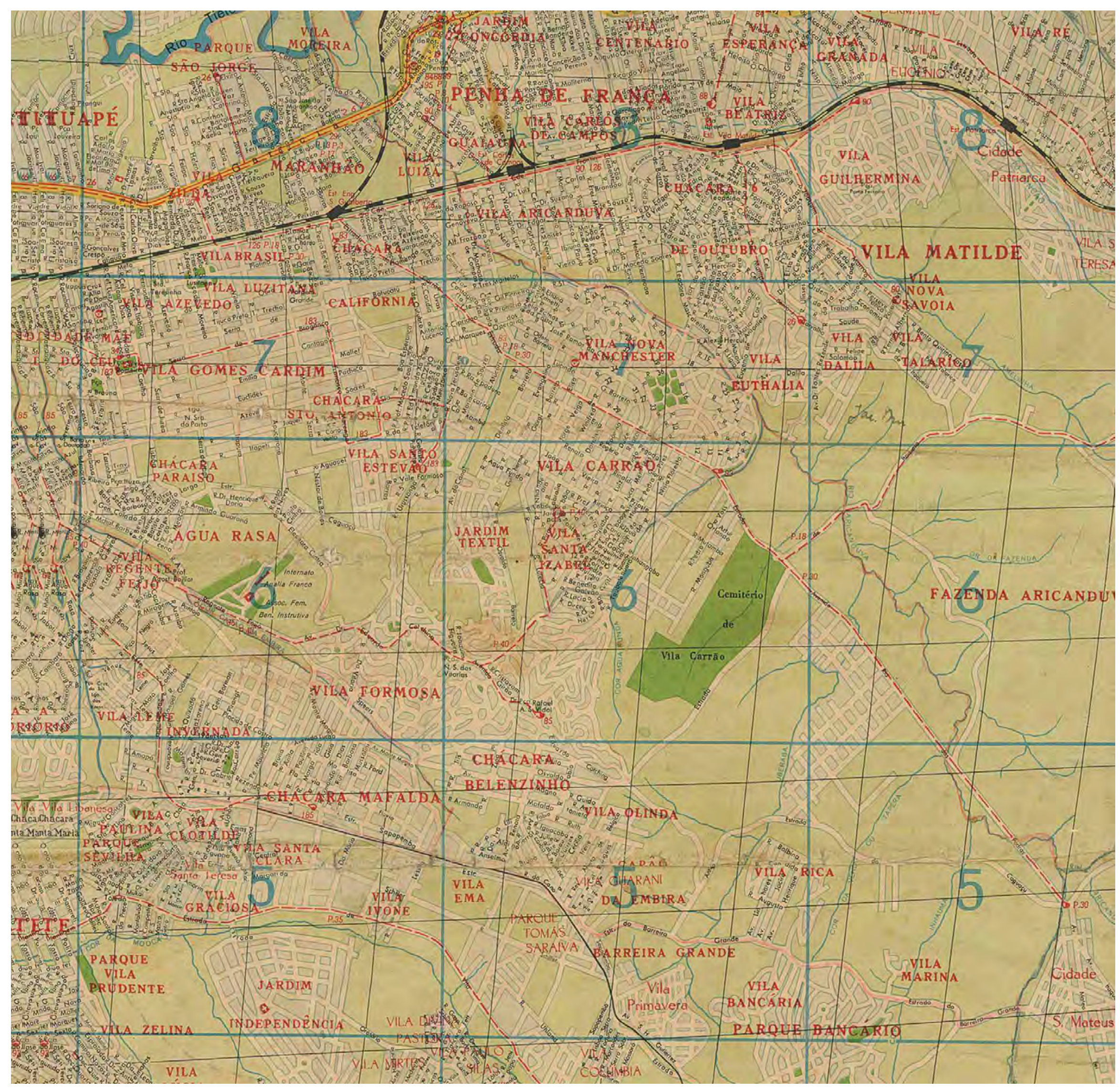


Anhaia Mello. O Mapa 19: Expansão da área arruada da cidade de São Paulo 1881/1914 (p.81) apresenta os loteamentos a partir da subdivisão de glebas e chácaras entre 1881 e 1914.

Não somente as ferrovias implantadas e os antigos caminhos do Centro às chácaras delinearam a mancha urbana paulistana. Também a proximidade com o rio Tietê e a ordem cronológica com que ocorreram as divisões de glebas em áreas menores por seus proprietários podem ser consideradas fatores influentes na expansão da cidade para leste.

O Mapa 22: Arredores de São Paulo-ônibus urbanos intermunicipais 1965 (p.85) traz a estruturação das linhas de ônibus intermunicipais, com grande concentração das linhas partindo do Centro para as periferias, sentido sudeste, aos municípios do ABC; sentido nordeste, aos municípios de Guarulhos e Rio de Janeiro principalmente à atual Região Metropolitana do Vale do Paraíba e Litoral Norte; sentido noroeste, onde hoje se localiza a Região Metropolitana de Campinas; e em direção oeste, para a Região Administrativa de Sorocaba.

O círculo tracejado em vermelho destaca uma imensa área delimitada desde a origem de São Paulo até a década 1965, sem as vias estruturais localizadas entre as ferrovias Central do Brasil (acima do círculo, como mostrado no mapa) e a Santos-Jundiaí. (abaixo) Os municípios a leste de São Paulo e parte da RMSP não tiveram conexão bem estruturada com a metrópole até aquele momento, ficando à mercê de vias coletoras utilizadas como estruturais para transitar veículos automotores na falta de sistema de transporte público que atenda a demanda ou, o que seria ideal, sem políticas públicas de desenvolvimento urbano e econômico específicas para esses municípios paulistas:
Poá, Ferraz de Vasconcelos e Mauá, municípios com economia desenvolvida. Outros Municípios como Suzano, Mogi das Cruzes foram beneficiados pela proximidade a rodovias como a Dutra e a ferrovia Central do Brasil, atual CPTM. Santo André e São Bernardo, a sudeste a partir do Centro de São Paulo, receberam as indústrias metalúrgicas de apoio às montadoras de veículos e teve em seu auge um parque industrial importante para a indústria brasileira.

O círculo marca a área dentro do perímetro urbano onde se encontram os distritos de Vila Curuçá, Lajeado, Guaianases, Cidade Tiradentes, Iguatemi, José Bonifácio, Itaquera, Cidade Líder e Artur Alvin, distritos dos mais carentes do município, na Região Leste 2 Paulistana. A leitura do Mapa 22 demonstra que a carência de transporte público era notável em 1965, e sua ausência colaborou com o atraso no desenvolvimento urbano da região. O mapa mostra as linhas de ônibus intermunicipais e, considerando-se que acima da elipse vermelha estavam os municípios de Poá, Ferraz de Vasconcelos, Suzano, estes também eram desconectados do acesso à metrópole. Moradores dos distritos de Cidade Tiradentes, Iguatemi, Lajeado, José Bonifácio e Guaianases, tinham dificuldades de se locomover para onde quer que fosse. O círculo tracejado em azul mostra a intersecção da estrada Índio Tibiriçá com Ribeirão Pires. Posteriormente, a Índio Tibiriçá foi prolongada até a histórica estrada Caminho do Mar, em Riacho Grande, que liga São Paulo e Santos, muito utilizada pela Corte de D. Pedro II. Em resumo, o habitante de municípios como Poá e Suzano ou de distritos como Guaianases e Itaquera, até a década de 1965, não podiam utilizar-se de caminho mais direto ao litoral mas deviam dirigir-se até o Centro Histórico de São Paulo para, então, tomar um ônibus até Santos. 


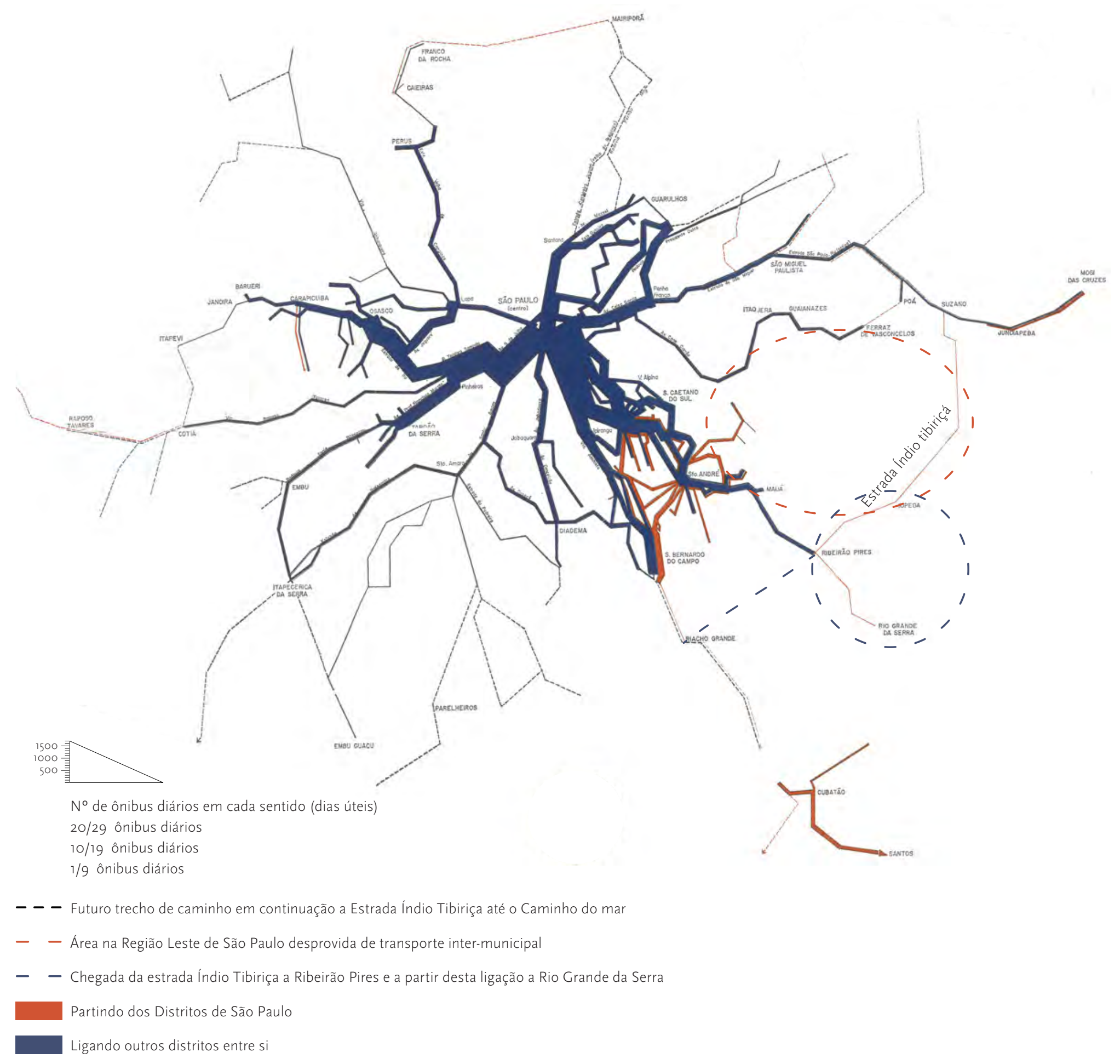

Mapa 22: Arredores de São Paulo-ônibus urbanos intermunicipais 1965

Langenbuch, 1971, Encarte observações efetuadas pela autora 


\section{ESPRAIAMENTO URBANO: MENSURAÇÃO E DEFINIÇÃO}

O espraiamento da mancha urbana em São Paulo é um dos principais fatores que contribuíram para os atuais grandes deslocamentos entre locais de trabalho e moradia a que está sujeita a população. É necessário esclarecer incialmente as diferentes definições e possíveis formas de ocorrência do espraiamento para, em seguida, apresentar as dimensões do fenômeno, que podem ser mensuradas.

47. Texto para discussão n. 1481 Publicação cujo objetivo é divulgar resultados de estudos direta ou indiretamente desenvolvidos pelo IPEA, os quais, por sua relevância, levam informações para profissionais especializados e estabelecem um espaço para sugestões. Vanessa Gapriotti Nadalin é técnica de Planejamento e Pesquisa da Diretoria de Estudos e Políticas Regionais, Urbanas e Ambientais-Dirur/IPEA. Danilo Camargo Igliori é professor doutor do Departamento de Economia da FEA USP e colaborador do Department of Land Economy da University of Cambridge.

\section{Segundo o estudo Evolução urbana e espraiamento} na Região Metropolitana de São Paulo, dos pesquisadores Vanessa Nadalin e Danilo Igliori, publicado pelo IPEA (2010, p.7) ${ }^{47}$

A literatura sobre o tema provém quase inteiramente dos Estados Unidos, onde o termo utilizado é urban sprawl. Parece simples e suficientemente fiel a tradução para "espraiamento urbano." No entanto, cabe mencionar como o termo vem sendo utilizado naquele país. A intensificação do uso do termo coincide com a mudança para o padrão atual e predominante de urbanização. Assim, uma definição utilizada por urbanistas e planejadores urbanos norteamericanos é: urbanização em baixas densidades, não planejada, dependente do automóvel, com alternativas construtivas homogêneas e esteticamente desagradáveis.

Em Anas, Arnott e Small (1998), o termo é mencionado como referente ao crescimento urbano que deixa espaços não utilizados em seu interior (leapfrogging). Os vazios poderiam até ser benéficos, se urbanizados no futuro a uma densidade superior à da urbanização presente.

Já segundo Glaeser e Kahn (2004), a definição de espraiamento já está completa, se trata apenas de duas características da estrutura urbana: a descentralização e a densidade. Estes autores afirmam que haveria uma divisão ao definir o espraiamento. Os trabalhos em economia urbana tenderiam a olhar para o fenômeno a partir da discussão sobre monocentricidade e policentricidade das cidades. O espraiamento urbano estaria identificado com as cidades policêntricas: descentralizadas, mas com subcentros densificados. Contraposta a essa visão, está a da estrutura urbana descentralizada e também pouco densa, sem menção à existência ou não de subcentros.

Com relação às alternativas de mensuração, (Galster et al., 2001) sistematizam as dimensões do fenômeno, indicando como medir cada uma das dimensões - que são oito e deveriam ser levadas em conta simultaneamente: densidade, continuidade, concentração, aglomeração, centralidade, nuclearidade, uso misto e proximidade.

Destas, este estudo seguirá a ideia de Glaeser e Kahn (2004), privilegiando o estudo de concentração e densidade. A densidade é a mais explícita dentre todas as definições: o espraiamento implica queda da densidade. Esta se refere à comparação da densidade residencial ou de empregos. Pode ser medida relativamente a áreas que são subdivisões do total da cidade, comparando-se, a área central com áreas distantes, por exemplo, mas também pode ser uma medida global de toda a cidade, comparando-se diversas cidades. Ainda é possível a análise da evolução da densidade média ao longo do tempo. Já a concentração da urbanização é uma medida relativa à localização do centro da cidade. $\mathrm{Na}$ hipótese de monocentricidade, a referência é o centro histórico. Já na hipótese de policentricidade, a medida é feita também com relação aos subcentros de emprego. Mas também levaremos em conta os vazios urbanos mencionados em Anas, Arnott e Small (1998). Portanto, definimos como espraiamento urbano o crescimento que é desconcentrado, não denso e que deixa vazios urbanos dentro da mancha urbana. 


\section{SÃO PAULO: ESPRAIAMENTO URBANO CONTÍNUO}

A referida publicação do IPEA afirma ainda: (NADALIN e IGLIORI, 2010, p.13)

A partir da revisão teórica feita acima, da motivação do tema dado na introdução e do rápido histórico da urbanização em São Paulo, é possível elencar os elementos que compõem o debate sobre se o espraiamento é socialmente desejável ou não. Os argumentos a favor se relacionam com a necessidade de mais espaço como uma imposição do crescimento populacional, e com a preferência do morador por mais espaço. Já os argumentos contra giram em torno do aumento do uso de automóveis, dos impactos no meio ambiente, dos custos de infraestrutura e degradação de áreas centrais históricas.

Como visto nas teorias de cidade monocêntrica, a fronteira de uma cidade se caracteriza por uma disputa de usos do solo: ganha quem puder ou estiver disposto a pagar mais. Assim, quando o uso urbano "vale" mais que o uso rural, a cidade avança espacialmente. Ou seja, lugares que têm terra de uso rural mais valiosa são cidades mais compactas (Brueckner, 2000). Mas por que motivo a terra urbana valeria mais que a rural? Existem alguns motivos plausíveis do ponto de vista econômico. O mais imediato é o crescimento da população, que gera necessidade de mais espaço para abrigar novos moradores.

Se incluirmos na análise a densidade e imaginarmos que a escolha do tamanho da moradia e, portanto, dos lotes, tem implicação direta no quão compacta a cidade é, então uma mudança nas preferências dos consumidores já é capaz de aumentar o valor da terra urbana na fronteira da cidade. Isto se verifica, por exemplo, se a população passa a preferir morar em casas térreas, com jardins e piscinas. No entanto podemos utilizar outro argumento: a não saciedade das preferências. O consumidor sempre prefere consumir uma quantidade maior de qualquer bem, desde que sua restrição orçamentária permita. Portanto, também sempre prefere mais espaço. Se essa característica é acompanhada de um aumento na renda das famílias, parece bastante legítimo que a cidade cresça de forma espraiada para acomodar esses anseios. Notemos que no modelo de cidade monocêntrica apresentado na seção 2 as famílias são idênticas e, portanto, escolhem o mesmo tamanho de lote em toda a cidade. Um efeito de mudança de preferências da família representativa, ou de aumento de renda, aumentaria o tamanho do lote para todas elas. Outras formulações desse modelo incorporam heterogeneidade dos agentes e determinam uma função de tamanho de lotes (Fujita, 1989) e, de acordo com as hipóteses com relação às preferências das famílias, é possível chegar a um equilíbrio com lotes maiores na periferia.

A década de 1960 é o auge da migração de grupos de trabalhadores da Bahia e norte de Minas Gerais para ocupar as vagas surgidas em São Paulo, na indústria automobilística e na indústria em geral. Outras frentes de trabalho também atraíram os migrantes nordestinos e a principal foi a construção civil. 0 Estado não mantinha uma política de produção ou subsídio à moradia para esses novos moradores e os loteamentos irregulares e clandestinos foram a solução encontrada pelos operários, que construíam barracos da forma como podiam. Os loteamentos eram criados no ritmo da chegada dos novos moradores, e a administração pública fechou os olhos a esse fenômeno que expandia a cidade rumo ao leste sem quaisquer critérios. Em consequência disso, a horizontalização ou espraiamento da mancha urbana se potencializa em direção ao leste e, posteriormente, ao sul da capital, até alcançar as áreas de mananciais.

Nadalin e Igliori definem e explicam o fenômeno da horizontalização de uma metrópole: 
48. A metodologia completa para a construção do Índice de Espraiamento está disponíve em <https://ipea.gov.br/agencia/ images/stories/PDFs/TDs/td_1481. pdf $>$. Acesso em 4 jun. 2013.
Definimos espraiamento urbano como o crescimento urbano que é desconcentrado, não denso e que deixa vazios urbanos dentro da mancha urbana. O fenômeno pode ser indesejável caso essas metrópoles não estejam crescendo naturalmente e sim crescendo mais do que deveriam. (NADALIN e IGLIORI, 2010, p.7)

A publicação analisa a evolução da área urbanizada, da densidade populacional e de empregos, e a evolução dos gradientes de densidade, entre os anos de 1962 e 2002, e chegam à construção de um índice de espraiamento. Segundo a publicação, "os resultados indicam que houve espraiamento, [no Município de São Paulo] no período mais recente analisado e que esse fenômeno se dá a partir da ocupação das periferias por população de baixa renda." (NADALIN e IGLIORI, 2010, p.8)

A pesquisa do IPEA relaciona as principais características do espraiamento para confirmar os fenômenos que são a periferização da população, menos acesso à infraestrutura urbana em função dos custos de se levar esta às regiões periféricas mais distantes e a consequente desigualdade social espacial. ${ }^{48}$

O despender de muito tempo em deslocamentos pendulares (casa-trabalho) reflete a extensão de viagens realizadas no modo individual: "O total de quilômetros rodados em todas as viagens para o ano de 1997 é de quase trezentos milhões, enquanto no ano de 2007 esse número é de mais de setecentos milhões - um aumento de 266\%. Já o número total de viagens no modo individual subiu $122 \%$. (Pesquisa OD em NAdALIN e IGLIORI, 2010, p.7)"

Outras características graves também levantadas pelos pesquisadores do IPEA, autores desse trabalho, são os efeitos negativos ao meio ambiente, na forma de desmatamento de cobertura vegetal entre os anos de 1991 e 2000 e ocupação por loteamentos clandestinos das áreas de mananciais na porção sul da RMSP - represas Billings e Guarapiranga. (Maricato em NADALIN e IGLIORI, 2010, p.8)

Assim, após o crescimento extensivo em direção ao leste, ocorre atualmente o espraiamento da cidade em direção ao sul, sem impedimentos eficazes, apesar das consequências já conhecidas pelos governos municipais.

\section{Essa é uma teoria que explica o urban sprawl} norteamericano. Não explica o espraiamento com loteamentos clandestinos e favelas periféricas e seus lotes mínimos, como, por exemplo, nas capitais brasileiras. Nos EUA o espraiamento é para classes média e alta, ao contrário do que acontece no Brasil e toda a América Latina. Aqui, as classes de renda mais alta preferem os prédios em altura para morar, o que faz subir os preços dos terrenos centrais, conforme comprovam as reclamações do SECOVI a respeito da falta de espaço para continuar a verticalizar as áreas mais centrais. Os loteamentos espraiados tipo Alphaville ainda são uma exceção polêmica em função do tecido urbano destacado, distanciado de certa forma, da realidade da cidade grande.

A ocupação das distantes periferias por populações de baixa e baixíssima renda impede, inclusive, que se aplique, na metrópole paulistana, a cobrança do transporte público em função da distância percorrida, medida injusta diante da realidade da concentração histórica de postos de trabalho dentro do Centro Expandido. 


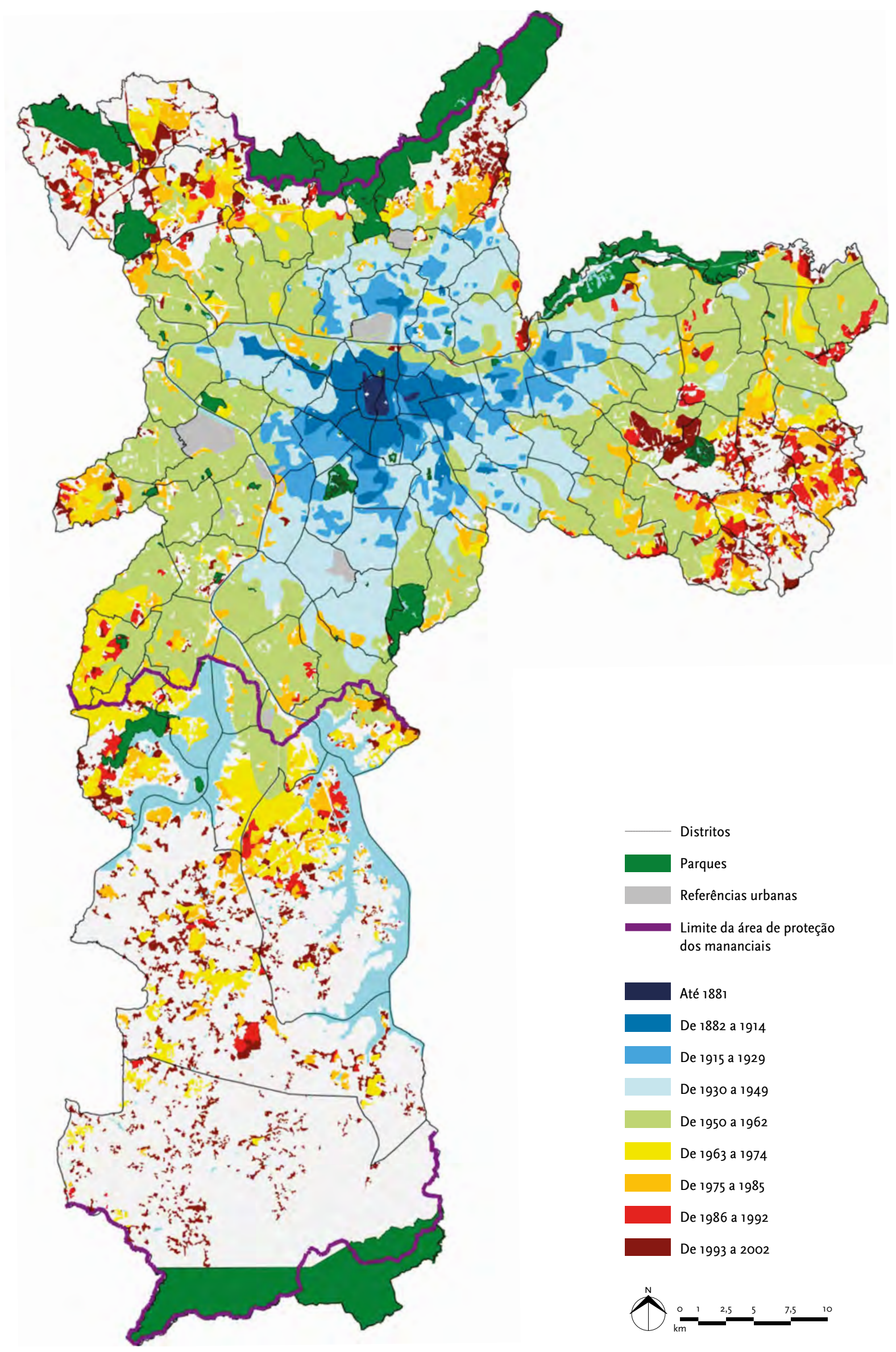

Mapa 23: Evolução do espraiamento em São Paulo até 2002

PMSP, SEMPLA 


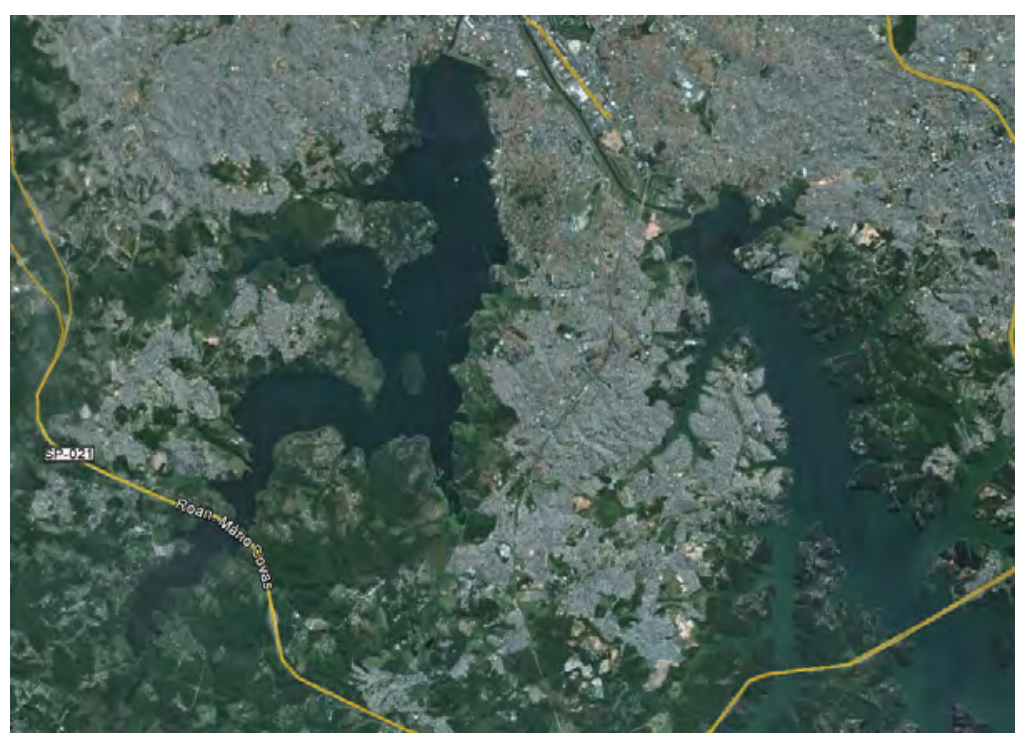

FIGURAS 64 A 66: INVASÃO DAS ÁREAS DE

mananciais ao sul do Município de São Paulo ortofoto mostrando a ocupação desordenada em

desacordo com os coeficientes de aproveitamento

e com a lei de proteção aos mananciais

"O Município de São Paulo representa um desafio quando se trata do mapeamento atualizado dos mais variados aspectos do meio físico, ambientais e socioeconômicos. A dinâmica urbana da metrópole tem provocado uma rápida desatualização das bases de dados existentes, sejam elas alfanuméricas ou espaciais." São Paulo (cidade)-SVMA, 2004. Disponivel em <atlasambiental. prefeitura.sp.gov.br/?id=7> Acesso em 28 jun. 2013.
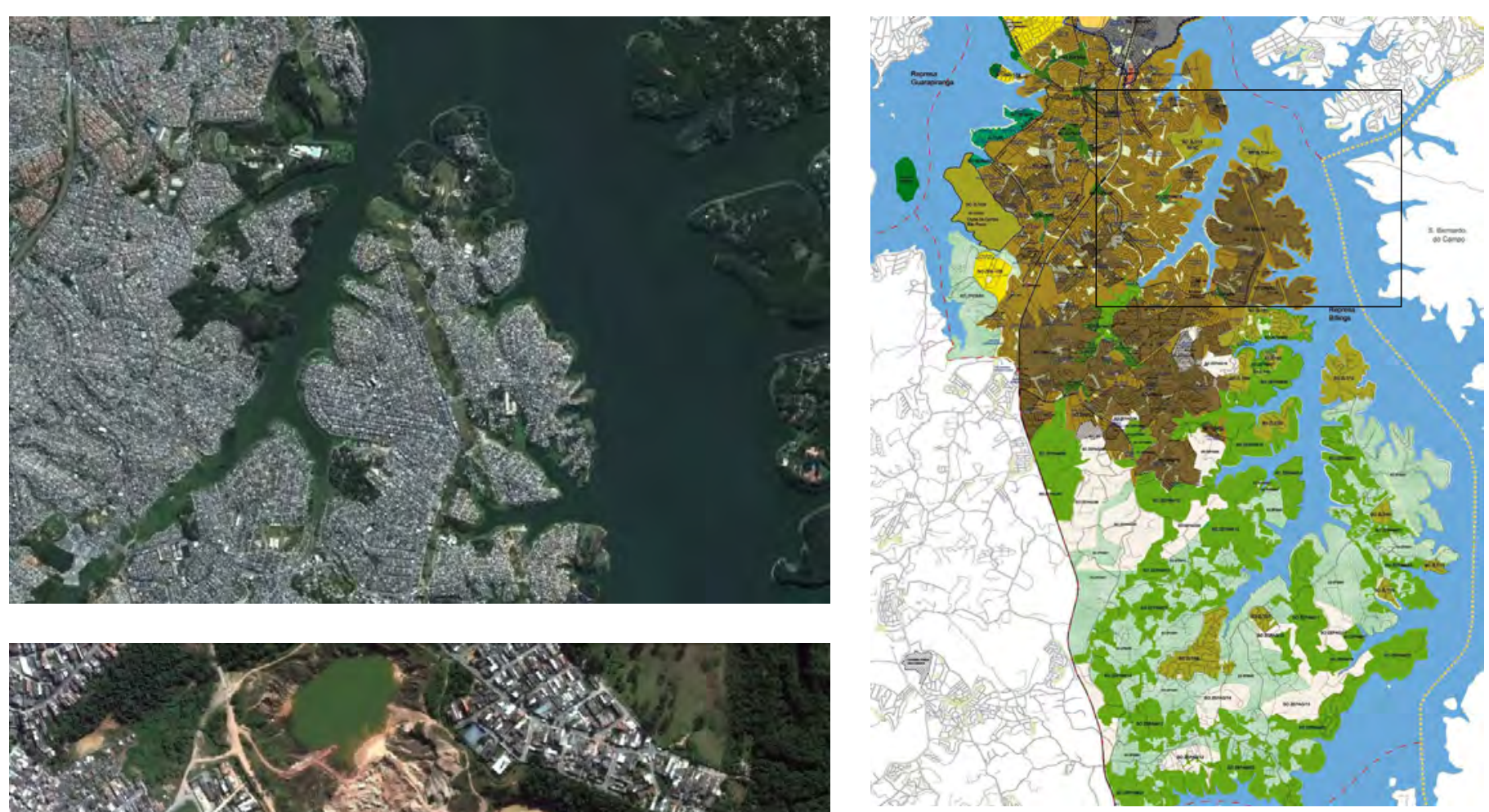

Figura 67: DETALHE do MAPA DE ZONEAMENTO do Plano Diretor Regional da Subprefeitura de CAPEla do Socorro

A figura acima mostra o trecho territorial entre as represas Billings e Cuarapiranga que, segundo a lei de zoneamento dessa Subprefeitura, compreende Zonas Especiais de Proteção Ambiental-ZEPAM, Zonas Estritamente Residenciais-ZER, (CA máx 0 1) Zonas de Proteção Agrícola e Extracão MineralZEPAG e Zona Especial de Preservação Cultural-ZEPEC,

A Figura 64 mostra, entretanto, que essas áreas já foram, em sua grande maioria, ocupadas de forma irregular, com agressões ao Meio Ambiente 


\section{CAPÍTULO III}

\section{RUMOS URBANÍSTICOS EM SÃO PAULO 1960/2012: DIRECIONAMENTO DA ESTRUTURAÇÃO URBANA ATRAVÉS DOS PLANOS URBANOS}

São Paulo é metrópole cuja urbanização ocorreu de forma pouco planejada para atender aos interesses dos habitantes de menor renda e que conta com uma população municipal de 11.379.114 habitantes, (IBCE, 2012) onde $18,9 \%$ dos domicílios tem renda familiar inferior a dois salários mínimos, na grande maioria localizados nas periferias da cidade, cujos moradores dependem de transporte público de massa para deslocar-se por muitos quilômetros de seu local de residência até o local de trabalho ou de estudo e para usufruir de serviços diversificados ou especializados. ${ }^{49}$ Denominados bairros dormitório, possuem populações de baixa renda com grande parte das famílias vivendo em situação de alta vulnerabilidade, concentradas nas Regiões Leste e Sul do Município de São Paulo..5

A estruturação viária e urbana de uma metrópole industrial pode ser classificada em pré-industrialização, durante a industrialização e pós-industrialização. $\mathrm{Na}$ fase pré-industrialização, o surgimento de vias estruturadoras que impulsionaram o crescimento urbano ocorreu para atender à economia extrativista, ao comércio e ao transporte de safras. A fase $d u$ rante industrialização procurou atender ao trânsito de produtos industrializados e utilizou as ferrovias existentes inicialmente, passando à construção de rodovias entre as cidades industrializadas e os portos marítimos. A fase pós-industrialização tem início quando as indústrias passaram a instalar-se ao longo das rodovias em busca da melhor logística para escoamento da produção e em função do tamanho das plantas que grandes indústrias exigem, como as montadoras de automóveis, a partir da década de 1960. É nesta fase que ocorreu o auge da implantação de novos sistemas de transporte público e circulação de veículos automotivos em vias planejadas a partir dos planos urbanos que também começaram a ser aprovados nas metrópoles industriais brasileiras. Em relação à estruturação rodoviária, esta foi a fase em que se tomaram as decisões mais importantes para o delineamento da mancha urbana, do traçado viário voltado aos veículos sobre pneus e circulação tanto de veículos de duas ou mais rodas como de seus habitantes a pé.

Neste capítulo, relacionam-se os planos urbanísticos já desenvolvidos para a cidade de São Paulo a partir da década de 1960. Tanto os formalizados pelo poder público como propostas contidas em teses acadêmicas consideradas relevantes. O objetivo é destacar de cada um dos planos os sistemas de transporte planejados para a área do centro expandido e para o restante do município para comprovar
49. IBGE/SEADE, 2010. Distribuição dos Domicílios por Faixas de Renda Familiar, segundo Distritos do Município de São Paulo. Salário mínimo de referência do Censo 2010: R\$510,00.

50. O Município de São Paulo não foi privado de planos urbanos no período aqui analisado, entre as décadas de 1960 e 2012, mas nem sempre os planos definidos foram implantados, parcial ou integralmente, e mesmo muitos o foram de modo pontual. Além disso, nem sempre esses planos se voltaram a áreas realmente carentes e que poderiam ter promovido o desenvolvimento urbano de muitas regiões municipais e metropolitanas. 
se houve tendência de se implantar sistemas viários de grande porte, tanto para transporte público de massa como para a circulação de veículos entre o centro e as periferias, priorizando-se o deslocamento de automóveis particulares.

Pretendeu-se registrar e comprovar também que, apesar da grande horizontalidade da mancha urbana à época, em função da chegada dos migrantes do nordeste do país que se instalavam nas periferias, e da especulação imobiliária produtora dos vazios urbanos, as concretizações das diretrizes e obras de qualidade urbana contidas nos planos urbanos aprovados foram sistematicamente direcionadas ao que se considera hoje Centro Expandido. Mais especificamente, foram direcionadas aos centros financeiro e comercial do município, inclusive para tentar diminuir os congestionamentos derivados da especulação fundiária associada com uma verticalização excessiva resultante de investimentos insuficientes em face de demanda por mais espaço rodoviário nessa região central decorrente de uma lei de zoneamento que não considerou - como ainda não considera - a capacidade de suporte instalada e por instalar do sistema de circulação, negligenciando os extremos da cidade na promoção da qualidade urbana. Uma área central histórica que se congestiona em seu sistema rodoviário e, por isso, é progressivamente abandonada e substituída por outra na sua expansão para o denominado Centro Expandido por falta de controles do adensamento em coerência com a capacidade de suporte do sistema de circulação, que deveria ter essa capacidade ampliada na medida da demanda adicional, coexiste simultaneamente com uma periferia cada vez mais extensa e muito pouco equipada. Um excesso de demanda e concentração de investimentos em serviços públicos nas áreas centrais da metrópole ou no seu entorno imediato, onde habitam, trabalham e produzem e usufruem da cultura, do esporte e do lazer as classes sociais mais abastadas, é, assim, acompanhada de seu corolário: uma escassez de investimentos em serviços públicos onde moram como podem as classes sociais empobrecidas.

A conclusão deste capítulo traz o resultado dessa produção rodoferroviária e sua influência na mobilidade dentro do atual tecido urbano da cidade de São Paulo, relacionando os usos habitação, cultura, comércio e serviços, locais de trabalho e locais de consumo. Também explica como a tendência à implantação de grandes obras rodoferroviárias pode ter comprometido a qualidade da mobilidade do habitante das periferias, fragmentando o espaço urbano por confinar o cidadão a um espaço mais restrito da metrópole e dificultando um uso mais diversificado e integrado, deixando para trás fragmentos de cidade sem definição clara e inúteis como espaços de lazer e descanso.

Inicialmente, fez-se um levantamento dos documentos oficiais produzidos, selecionados pelo potencial de contribuição a este trabalho. Também foram levantados os planos produzidos, as teses acadêmicas, como a de Campos Filho, (1972) e outros textos considerados mais relevantes, como o de Jorge Wilheim. Dos planos listados a seguir, foram destacados apenas quatro, em função da relação com o tema deste trabalho, sendo descartados de análise mais detalhada os planos urbanos que não foram oficialmente publicados, como o PDDI, aprovado por lei municipal supostamente em consonância com o PUB, enquanto mapas com definição clara das diretrizes territoriais, e o PAITT, voltado à gestão de tráfego e, por isso, não configurando um plano estruturante. 
Apesar de esta tese tratar dos planos urbanos num recorte temporal entre as décadas de 1960 e 2010, vale mencionar que, segundo Feldman, desde 1925, os planos urbanos consideravam que o embelezamento da cidade passava pelo sistema viário ou "plano geral de viação."

Segundo Feldman, durante a segunda gestão de Prestes Maia, entre 1961 e 1965, "desfaz-se o discurso do planejamento como função de governo."

As ideias de Planejamento como processo de articulação das várias divisões e dos vários níveis de governo, de pesquisa como ponto de partida para toda e qualquer definição de intervenção na cidade, de necessidade de um novo perfil de urbanista, perdem seus defensores no interior do setor do urbanismo, e o Plano de Avenidas se mantém como referência de atuação do executivo. O Departamento de Urbanismo passa a ser dirigido por Luiz Carlos Berrini Junior, engenheiro dos quadros da prefeitura que, no período de 1947 a 1961, está entre as figuras ativas do departamento, mas que defende claramente as ideias de Prestes Maia. (...) Segundo o engenheiro, não há necessidade de mais planejamento: o problema da cidade "não é falta de planejamento, mas sim de incrível atraso na execução de obras." Berrini faz a crítica das ideias de contenção do crescimento das cidades, qualificando-as de "interpretações messiânicas," de "reformas radicais urbanas," e defende a melhoria das cidades, "adaptando-as às condições atuais de vida." (...) Berrini defende a prioridade absoluta às obras da rede viária principal, a fim de constituir o "esqueleto" do plano urbanístico. (Berrini, Luis Carlos (1961) em FELDMAN, 2005, p.209-210)

Em relação às verbas e responsabilidade pela produção de planos e leis urbanas, Feldman descreve a criação do órgão municipal que permitiu a participação de empresas privadas no planejamento urbano da cidade de São Paulo:
Em 1964, cria-se o Serviço Federal de Habitação e Urbanismo-SERFHAU, que é regulamentado em 1966. Juntamente com o SERFHAU, cria-se um Fundo de Financiamento de Planos de Desenvolvimento Local Integrado, no Banco Nacional da Habitação para financiar os planos e estudos de desenvolvimento local integrado, mas a liberação de recursos fica condicionada à criação, pelas regiões e municipalidades, de órgãos permanentes de planejamento e desenvolvimento local. Ao mesmo tempo em que se condiciona a liberação de recursos a uma estrutura de planejamento, esta pode contratar a elaboração dos planos e estudos. Com essa concessão de verbas para o planejamento e abertura para contratação externa de planos, os órgãos de planejamento se multiplicam, assim como os planos e as empresas de consultoria, que passam a assumir a maioria dos planos elaborados nos anos 1960 e 1970, no país. (FELDMAN, 2005, p.216)

As empresas brasileiras que passam, com a criação do SERFHAU, a atuar na área de consultoria de planejamento urbano começam a se constituir no final dos anos de 1950, a maioria como empresas de engenharia do eixo Rio-São Paulo. (Feldman, 2005, p.229)

A inserção de arquitetos no mercado de trabalho ligado à elaboração de planos se amplia com a criação do SERFHAU. (FELDMAN, 2005, p.230)

Como dito no Capítulo I Fundamentação teórica, Jorge Wilheim analisa as questões atuais e projeta um cenário para São Paulo, onde reconhece e retrata os problemas urbanos da metrópole, usando o método da projeção linear e tendencial para estimar que a população cresceria a níveis importantes e que esse fato exigiria um planejamento desse crescimento, propondo a criação de seu primeiro Plano Diretor, o Plano Urbanístico Básico de São Paulo PUB, em 1969, desenvolvido por um grupo multidisciplinar, o Grupo Executivo de Planejamento-GEP.
51. "A organização de um órgão de atribuições específicas na esfera do urbanismo, centrado numa visão de plano geral e como instrumento de previsão ocorre, pela primeira vez, no governo municipal de São Paulo, em 1925 Nesse momento, cria-se a Seção de Cadastro e Urbanismo no interior da Diretoria de Obras e Viação, com a incumbência de elaborar o plano geral, organizar o cadastro, fixar e fiscalizar alinhamentos e nivelamentos, e tratar de 'todas as questões referentes ao problema do Urbanismo' (Lei Municipal n. 2898 de 10 de agosto de 1925). O plano, segundo o artigo $2^{\circ}$ da lei que cria a Seção, deve envolver 'um plano geral de viação, remodelação, embelezamento, melhoramentos, extensão e sistematização para regular o desenvolvimento e a vida da cidade.'" (Feldman, 2005, p.41) 
Segundo Feldman

(...) Com o GEP se viabiliza a elaboração do primeiro plano depois do Plano de Avenidas - o PUB. A mudança fundamental é que o plano não é elaborado nem por urbanistas ilustres, nem por técnicos vinculados, por décadas, ao setor de urbanismo. "O PUB é elaborado por uma ampla equipe multidisciplinar, montada e subcontratada por empresas privadas de consultoria." (FELDMAN, 2005, p.215)

52. Com o apoio de Jânio Quadros e de Carvalho Pinto, o brigadeiro José Vicente Faria Lima foi eleito prefeito da cidade de São Paulo, com 462.162 votos, para o período de 8 de abril de 1965 a 7 de abril de 1969 substituindo Francisco Prestes Maia. Disponivel em <http://www.cepam. sp.gov.br/index.php?option=com content\&task=view\&id=2\&Itemid=3>. Acesso em 19 maio 2013.

53. Assessoria em Planejamento S/A-ASPLAN. Empresa brasileira que participou da elaboração do PUB a partir da lei que permite que o planejamento urbano do município seja desenvolvido por consórcios de ou incluindo empresas privadas. Montreal, empresa do Rio de Janeiro fundada em 1950 e com os mesmos objetivos de produção de planos urbanos no Brasil. (Feldman, 2005, p.230)

\section{PUB-PLANO URBANÍSTICO BÁSICO DE SÃO PAULO}

Produzido em 1969 pela Prefeitura do Município de São Paulo, na gestão de Faria Lima, ${ }^{52}$ tendo como Secretário de Obras José Meiches, o PUB foi desenvolvido pelo GEP e pelo Consórcio Asplan Daly Montreal Willbur Smith. 53 Segundo Anelli, em seu artigo sobre mobilidade e urbanismo em São Paulo,

Evitando o desgaste de contratação de uma equipe norte-americana como ocorreu no caso de Robert Moses, o Prefeito Faria Lima aciona um conjunto internacional de empresas de consultoria, entre elas a brasileira ASPLAN. Cria ainda o Grupo Executivo de Planejamento diretamente subordinado ao prefeito para coordenar a elaboração do PUB, retirando essa atribuição do Departamento de Urbanismo, até então encarregado desse tipo de função. Entre os brasileiros da equipe técnica temos a presença de Joaquim Guedes e entre os consultores encontramos Celso Lamparelli. (ANELLI, 2007, 07.082)

Percebe-se a princípio que o desenvolvimento do primeiro Plano Diretor de São Paulo pretendeu considerar a opinião pública na forma de representantes de comunidades e outras organizações para a criação de "certas hipóteses urbanísticas novas" ou "maneira nova de encarar velhas realidades urbanas." (PUB, 1969, passim)
O prefeito de São Paulo à época, José Vicente Faria Lima, (1965 e 1969) entrega a administração pública a seu sucessor acompanhada do PUB, contendo um conjunto de diretrizes para o desenvolvimento urbano e social, a circulação, hoje chamada de mobilidade urbana, os transportes e os serviços públicos da Metrópole de São Paulo.

Em função da importância da época em que o PUB foi elaborado, com a recente chegada das montado ras ao Brasil, que contribuíram com seus empregos e provocaram o intenso êxodo rural da população oriunda de Minas Gerais, Bahia e outros estados do nordeste do Brasil, este será mais detalhado nas resenhas dos planos urbanísticos produzidos para São Paulo, a partir da década de 1960. Era o exato momento de se tomarem as medidas adequadas para ordenar-se a já caótica ocupação e transformar o crescimento urbano em desenvolvimento urbano, evitando-se a segregação espacial e social com a qual nos deparamos hoje, aparentemente sem solução ou com soluções polêmicas.
A sofisticação metodológica [do PUB] é nítida e torna este o mais abrangente plano produzido até então no Brasil. Não se limita ao urbanismo, levantando um conjunto amplo de dados para propor diretrizes nas várias áreas da administração pública. (...) A estrutura de mobilidade urbana é um aspecto fundamental da proposta. Mas ao contrário da proposta de Curitiba, o PUB dissocia a rede de transporte público de massa da malha de vias expressas. (ANeLLI, 2007, 07.082)

O relatório do PUB está dividido em: 1. Os problemas de hoje e o desafio de amanhã; 2. Principais objetivos; 3. Síntese das recomendações; 4. Análise do desenvolvimento urbano; 5. Plano em longo prazo; 6. Programa em médio prazo. (PUB, 1969, p.9) 


\section{PUB: OS PROBLEMAS DE HOJE E O DESAFIO DE AMANHÃ}

Em Os problemas de hoje e o desafio de amanhã, o relatório é iniciado com um pequeno texto sobre o rápido e intenso crescimento da população do município de São Paulo, tendo como causa conhecida o fenômeno do êxodo rural em busca de melhores condições de vida na crescente cidade industrial. Segundo o relatório, a maior metrópole do Brasil apresentou quadruplicação de sua população, de 1,3 milhões de habitantes para 5,8 milhões, em pouco mais de duas décadas, entre 1940 e 1969. (PUB, p.13) Declara ainda que a verba pública disponível para suprir as necessidades de infraestrutura básica ficou aquém da demanda, resultando em uma "profunda defasagem entre as necessidades da população e a capacidade de serviços oferecidos" e que a atual administração esteve empenhada, desde 1965, a "restabelecer o trinômio população, desenvolvimento e serviços urbanos" como meta e como compromisso com o futuro, uma vez que se estimava a duplicação da população do município em 1990 e quase a triplicação da população da Grande São Paulo. (PUB, 1969, p.13) Verificando-se os dados disponíveis na bibliografia consultada e nas fundações SEADE e IBCE, a população do município realmente duplicou entre 1965 e 1990. Já em relação à população da metrópole, esta teve um crescimento de $140 \%$ nesse período. ${ }^{54}$ As previsões da equipe técnica do PUB estavam corretas no tocante ao crescimento da população total, rural e urbana na metrópole de São Paulo.

Quando se refere à qualidade urbana, o relatório considera que em 1965 os "índices referentes ao nível de vida da população paulistana são superiores aos verificados na maioria das cidades brasileiras, embora ainda limitados se comparados com os de países mais desenvolvidos." Pode-se concluir que, se havia a comparação com "melhores cidades," a chance de acerto deveria ser alta, considerando-se que essas cidades eram realmente melhores.

As cidades consideradas para comparação com São Paulo foram Moscou, Tóquio, Paris, Londres e Chicago, e suas manchas urbanas em relação aos limites municipais e dos centros de cada uma delas. O relatório do PUB não faz qualquer análise em relação à mancha urbana de cada uma das metrópoles apresentadas como modelos, mas a utilização das imagens dessas capitais mencionadas no PUB é necessária para que se possam comparar as metrópoles mais adiante e poder obter conclusões importantes para nossa tese de doutoramento. Observando-se as imagens a partir da escala gráfica, é possível verificar que a área urbanizada de São Paulo em 1969 é equivalente à de Londres e à de Chicago, superior à mancha urbana de Paris e bem superior às manchas urbanas de Tóquio e de Moscou, esta a menor em área urbanizada.

A proporcionalidade entre as imagens foi mantida para uma rápida comparação visual das manchas urbanas de cada metrópole em 1965. Pode-se concluir que as áreas urbanizadas dessas capitais colocavam Chicago como a maior mancha urbana em 1965, seguida em ordem decrescente por Londres, São Paulo, Paris, Tóquio e Moscou.

É possível comparar, também nas imagens, a expansão urbana ocorrida entre os limites municipais e os limites da área urbanizada. No caso de Moscou, a mancha urbana não havia se expandido de forma consolidada para além do perímetro municipal, estando as cidades menores em torno de Moscou apenas conectadas através de vias regionais
54. Em 1963, a população do município de São Paulo era de 4.884 .900 habitantes (Villaça, 1978 em RoLnIK, 2003, p.165). Em 1990 a população do município chegou a 9.512.545 habitantes; em relação à Grande São Paulo (MSP), em 1960 a população atingira a marca de 4.739 .406 habitantes e provavelmente 6.439 .568 em 1965, aproximadamente. Em 1990, a Metrópole de São Paulo contabilizava 15.444.491 habitantes. (SEADE, IBGE e SEMPLA) 


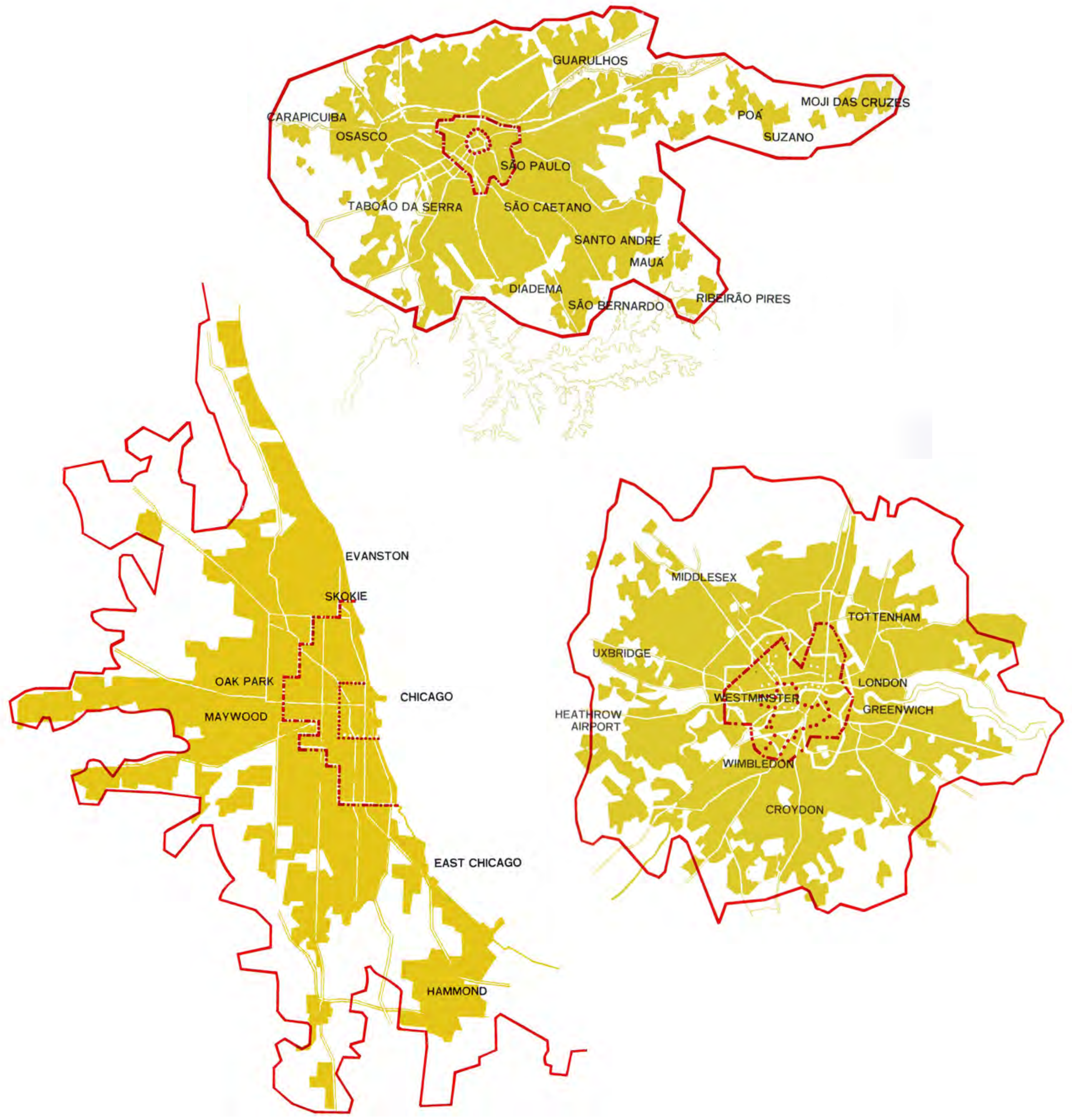



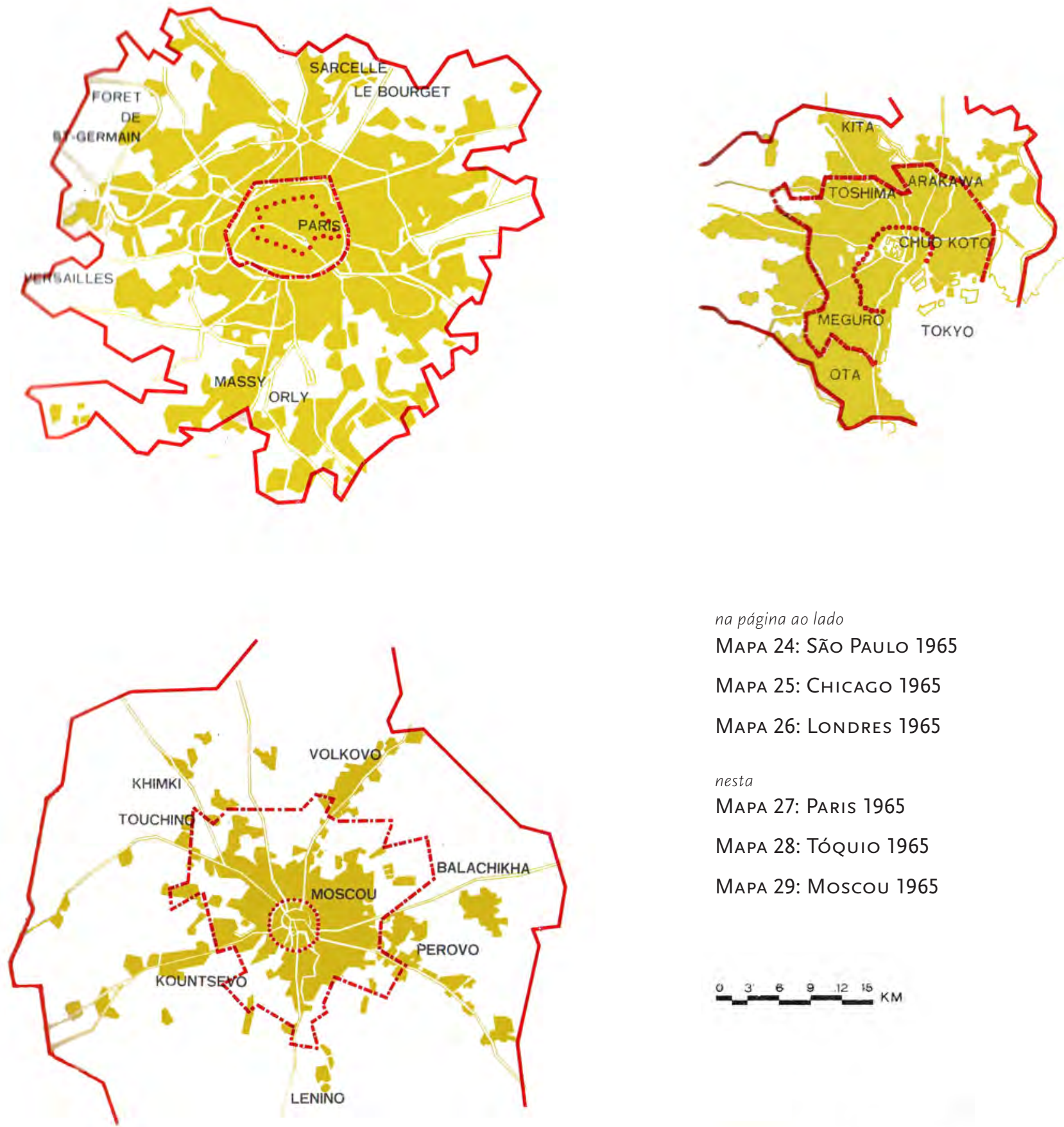

na página ao lado

MAPA 24: SÃo Paulo 1965

MAPA 25: CHICAGO 1965

MAPA 26: LONDRES 1965

nesta

MAPA 27: PARIS 1965

MAPA 28: TÓQUIO 1965

MAPA 29: MOSCOU 1965

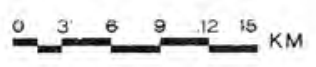

VIAS PRINCIPAIS CENTRO

--.- PRIMEIRO PERIMETRO URBANO
- EXTENSAOO DA AREA URBANIZADA AREA GERALMENTE URBANIZADA

comparação da Área urbanizada de São Paulo COM OUTRAS METRÓPOLES 
55. Os Centros Educacionais ou Clubes Municipais mencionados foram construídos em alguns distritosde São Paulo, como, por exemplo, Mooca, no espaço deixado pelo antigo Jockey Club de São Paulo, quando este foi transferido para Cidade Jardim, em 1941. Possuem quadras esportivas, piscinas, creches, biblioteca dentre outros edifícios da administração pública como subprefeituras, postos de saúd etc. (Rodricuez, 2006, p.43, 83) intermunicipais. Nas outras cidades mencionadas, a conurbação das manchas urbanas das capitais e das cidades menores em seu entorno já se encontravam consolidadas, formando centros metropolitanos, mais notoriamente em São Paulo e Chicago.

Em seguida, a pesquisa do PUB passa a enumerar índices da época, como a mortalidade, a mortalidade infantil e a expectativa média de vida do paulistano. Menciona índices educacionais e, o que é mais relevante para esta tese, índices urbanos, como saneamento básico, iluminação pública, coleta de lixo e vias pavimentadas. O relatório toca então num ponto nevrálgico para a qualidade de vida do paulistano de média e baixa renda, problema crônico que nos atinge até hoje: o transporte público e as longas jornadas no caminho entre casa e trabalho, somando inúmeras horas diárias, mensais e anuais, irrecuperáveis. Em fins da década de 1960, segundo relatórios do PUB, eram consumidas 2.450.000 horas diárias no deslocamento da população ao trabalho e de volta a casa. Chama a atenção para os loteamentos distantes, onde a instalação de infraestrutura urbana básica é inviável em função dos custos. Apesar disso, por décadas, a administração pública investiu na infraestrutura urbana para conectar o centro às periferias, o que provocou a horizontalização da mancha urbana, em lugar de investir em mecanismos que mantivessem ou reconduzissem os habitantes a locais não tão distantes.

O relatório passa a discorrer sobre a participação do município na distribuição de verbas federais e outros entraves político-administrativos para justificar as dificuldades financeiras no desenvolvimento urbano de São Paulo, cuja administração pública adota diretrizes orçamentárias para aumentar a arrecadação e viabilizar diversas obras necessárias ao "pleno funcionamento do complexo urbano." Por exemplo, a criação de "feiras modernas" em substituição às feiras livres, com dois objetivos: melhorar o trânsito e maior higiene. Se essa solução de remover as feiras livres teria efeito sobre o tráfego de veículos, não o saberíamos hoje, pois não foi adotada exceto por raras exceções, como a utilização, para esse fim, do estacionamento da Praça Charles Miller, defronte ao Estádio Paulo Machado de Carvalho, no Pacaembu. Também a construção de cinco novas Avenidas, projetadas há mais de 25 anos, a pavimentação de mil quilômetros de vias, a duplicação de vias iluminadas, além da implantação de equipamentos públicos, como doze creches e seis centros educacionais para jovens contendo equipamentos esportivos e serviços culturais e recreativos. ${ }^{55} \mathrm{~A}$ entrega de 1790 unidades residenciais e mais 7013 em construção são atribuídas àquela gestão. Outros equipamentos e serviços estavam presentes nas diretrizes do PUB como a construção de hospitais, a ampliação do serviço de coleta de lixo e os serviços telefônicos, que eram públicos na década de 1960, além de outros equipamentos culturais de importância para a cidade e seus habitantes.

Em relação aos sistemas de circulação rodoferroviários de transporte público, a Companhia Municipal de Transportes Coletivos-CMTC teve a frota renovada e aumentada em 1964, e "o sistema de trânsito rápido (Metrô) que vinha sendo cogitado para a cidade nos últimos quarenta anos, pôde ser estudado, projetado e iniciado em apenas dois anos."

Não há no relatório menção quanto à demanda por metrô e se a meta seria atingida e quando. Ao invés disso, cogita que São Paulo terá sua frota de veículos sextuplicada em apenas 25 anos, passando 
de quatrocentos mil para 2,4 milhões de veículos em 1990, e sugere que a extensão de vias para suportá-los deverá ser duplicada. ${ }^{56}$ Estimando que "o aumento de renda dos habitantes exigirá padrões mais elevados de todos os serviços." O relatório destaca o que já fora implantado pela administração do prefeito Faria Lima (gestão entre 1965 e 1969) e o que se configurava em diretrizes, como declarado no item O desafio. (PUB, 1969, p.14)

A recuperação do atraso nos serviços públicos e o atendimento das necessidades atuais exigiram esforços consideráveis da atual administração. O futuro de São Paulo reserva, no entanto, um desafio, maior ainda, à capacidade administrativa e à liderança política das autoridades. (PUB, 1969, p.14)

Resta verificar-se se realmente o atraso nos serviços públicos preconizados no PUB foram eliminados na totalidade, o que, no decorrer da tese em desenvolvimento, só será feito em relação aos sistemas viários de qualquer tipo, isto é, tanto os rodoviários como os ferroviários.

Como diretrizes principais, o relatório supõe o que teria sido um grande avanço urbanístico, a distribuição e o controle das densidades na área metropolitana com uma redistribuição regional do desenvolvimento para a Grande São Paulo, hoje Região Metropolitana de São Paulo, sugerindo a união de esforços do Município de São Paulo, do Governo Estadual e do Governo Federal para alcançar objetivos e encontrar soluções comuns, pela importância de São Paulo na receita pública do país, dentre outras coisas.

O PUB apresenta soluções adequadas aos problemas da cidade, prevendo uma concepção integrada do Município, na Área Metropolitana e uma distribuição de população, localização das atividades econômicas e um sistema de transportes e de serviços urbanos capazes de comportar, de modo apropriado, flexível e contínuo, o grande desenvolvimento urbano previsto. (PUB, 1969, p.17)

\section{PRINCIPAIS OBJETIVOS}

O item Principais objetivos do PUB, cujo "propósito geral é atender às necessidades e aspirações da população do Município de São Paulo, consubstanciadas em seis objetivos," quatro deles em relação ao desenvolvimento social e dois em relação ao desenvolvimento econômico:

- Ampliar as oportunidades de desenvolvimento individual e social: em síntese, a melhoria do ambiente urbano para toda a cidade; - Ampliar a disponibilidade de serviços urbanos de conforto: menciona-se aqui a demanda por serviços como telefone e "obras relacionadas primordialmente com o uso de automóveis particulares," uma vez que "crescerá a renda per capita;" • Ampliar as oportunidades de integração de grupos de imigrantes e de indivíduos marginalizados: preconizam-se aqui programas de educação básica e ensino profissionalizante além da melhoria das condições de moradia das famílias de baixa renda; - Ampliar as oportunidades de participação na comunidade: apesar do governo militar, pretendia-se que as comunidades participassem ativamente das decisões públicas em relação às suas demandas; - Maximizar as oportunidades de emprego: estímulo à iniciativa privada na geração de empregos e na habilitação da mão de obra; - Maximizar as oportunidades de aumento da renda regional: entende-se que o objetivo de elevação da renda per capita poderia elevar os níveis de arrecadação do município que em contrapartida proveria a população com "elevado nível de transporte, equipamentos públicos e outros serviços essenciais ao desenvolvimento das atividades produtivas" de forma regionalizada, reduzindo custos de transporte de passageiros e de carga. (PUB, 1969, p.19)
56. Embora as previsões do PUB sobre o incremento da frota automobilística e seus 840 quilômetros de vias expressas soassem exagerados à época, na verdade a previsão de 2,4 milhões de veículos do PUB se mostrou subestimada em cerca de 50\% face aos 3,4 milhões constatados pelos dados mostrados pela EMPLASA. Em 1990, São Paulo apresentava total de 3.376.324 veículos. (Secretaria do Estado da Habitação e Desenvolvimento Urbano-Empresa Metropolitana de Planejamento da Grande São Paulo. Sumário de Dados da Grande São Paulo 1990, p.225) Em 2011, a frota total se encontrava na casa dos sete milhões de veículos. (SEADE. Órgão da Secretaria Estadual de Planejamento e Desenvolvimento Regional do Estado de São Paulo) 
Até este ponto do relatório, a prioridade pelo uso do automóvel particular e outros veículos automotores fica latente, mostrando que a influência da indústria automotiva e petrolífera já contribuíra, irreversível e fortemente, para a disseminação da cultura do automóvel por São Paulo e pelo país. Justiça seja feita à indústria automotiva, que contribuiu para o desenvolvimento industrial de forma contundente e, consequentemente, para o desenvolvimento do país como um todo. Mas o equilíbrio entre o uso do automóvel e o investimento massivo em transporte coletivo rápido não poluente e com qualidade, como o metrô, teria sido uma melhor opção, do ponto de vista ecológico e sustentável. Era o momento do turning point.

\section{SínTESE DAS RECOMENDAÇÕES}

Em Sintese das Recomendações, apresentam-se as principais diretrizes para que em 1990, São Paulo tivesse controlado seus problemas urbanos, sociais e econômicos. Foram selecionadas as duas grandes áreas de atuação pública que estão diretamente relacionadas com a implantação de sistemas viários, para transporte público ou circulação de veículos em geral. Primeira grande área de atuação pública, segundo o PUB. (1969, p.21)

Desenvolvimento urbano, "abrangendo uso do solo e execução de grandes projetos de urbanização," onde as diretrizes propõem "a melhor distribuição da população e das atividades econômicas no país;" "melhor distribuição da população e do emprego no município e área metropolitana possibilitando proximidade entre locais de residência e de trabalho" e "permitir a operação de um sistema de transporte que proporcione alta mobilidade com mínimo de congestionamento de tráfego;" "orientar o desenvolvimento urbano para proporcionar a proximidade de indivíduos de estratos sociais diversificados" e "preservar e valorizar a paisagem regional, salientando as características locais específicas para enriquecer a qualidade do ambiente urbano." (PUB, 1969, p.21)

Nas diretrizes acima, encontram-se as Proposições, com itens que podem surpreender como,

\begin{abstract}
“manter e consolidar o centro de São Paulo como principal núcleo das atividades comerciais, de negócios e de administração, para o atendimento de toda a região metropolitana, expandindo-o de modo a incluir a Avenida Paulista como área de atividades comerciais, financeiras e outros serviços particulares, e a zona entre o centro atual e o Rio Tietê, nas proximidades da Linha Norte-Sul do Metrô, como área de atividades administrativas e culturais." (PUB, 1969, p.21, grifo nosso)
\end{abstract}

A afirmativa acima condena as populações moradoras de distritos distantes da Avenida Paulista ou do Centro Histórico a depender dessas duas centralidades para assuntos que poderiam ser tratados em locais alternativos. Em 1965, os distritos do extremo leste da cidade já existiam e exigiam o anteriormente mencionado sacrifício e consumo excessivo de horas em viagens de casa ao trabalho ou em busca de serviços de saúde, burocráticos, educação de nível elevado e cultura. A Avenida Paulista e o Centro Histórico sempre serão as principais centralidades, indubitavelmente. No entanto, previu-se uma outra ao sul, em Parelheiros, apesar de, em seguida, propor o desenvolvimento de Itaquera e de Santo Amaro com o provimento de infraestrutura urbana de qualidade por parte do Estado e de propor o desenvolvimento de Parelheiros com áreas para atividades culturais e recreativas, atingindo com isso a criação de cem mil postos de trabalho em serviços para atender a uma população estimada de um 
milhão a 2,5 milhões de habitantes em áreas de alta densidade a partir de desapropriações em área de mananciais - ação temerária e que não deveria ter sido oficializada como meta. Não se demonstra, entretanto, se esses serviços a serem oferecidos a essa população existiam ou seriam estimulados, nem ao menos que tipo de serviços seriam eles, uma vez que serviços e comércio de âmbito local não têm muita capacidade geradora de trabalho.

Segunda grande área de atuação pública, segundo o PUB:

Circulação e transportes, "abrangendo transportes coletivos, sistema viário, controle de tráfego e todas as medidas relativas aos vários sistemas de transportes," onde as diretrizes são: contribuir para a melhor distribuição da população e das atividades econômicas no país; promover distribuição mais equilibrada da população e do emprego no município e na área metropolitana, a fim de possibilitar maior proximidade entre os locais de residência e de trabalho e permitir a operação de um sistema de transportes que proporcione alta mobilidade com mínimo congestionamento de tráfego; assegurar a disponibilidade de terrenos que apresentem condições físicas e ambientais para futura utilização residencial, comercial, industrial e institucional. (PUB, 1969, p.29)

Além dos grupos de diretrizes contidas nos itens 1 e 2 acima, há diretrizes para Desenvolvimento Social onde se priorizam a saúde pública, habitação, educação, bem estar social, recreação e cultura; para Serviços Urbanos, onde se priorizam o saneamento básico, suprimento de energia, despoluição ambiental, comunicação, abastecimento e outros serviços públicos, e para a Administração Pública, onde se destacam diretrizes como "medidas legais administrativas e financeiras para permitir a realização do Plano (...)" (PUB, 1969, p.70)

\section{PUB-MODELOS}

O relatório do PUB apresenta sua fundamentação a partir da análise de fatores do desenvolvimento urbano ocorrido, como a evolução urbana do município, até a data do plano, como pano de fundo para a distribuição de sistemas viários regionais importantes na RMSP, como ferrovias e rodovias, tendências de crescimento da mancha urbana, evolução demográfica e socioeconômica etc.

O relatório apresenta ainda dois mapas da Grande São Paulo e seus municípios com a distribuição de postos de trabalho e a área onde vivem seus habitantes. No Mapa 30: Distribuição da população e do emprego 1965 (p.103) aparecem os pontos concentradores de postos de trabalho (círculos vermelhos preenchidos, segundo a legenda original) e a concentração da população de forma homogênea, sem detalhamentos (contornos vermelhos) distribuídos no município de São Paulo em 1965. Quanto maior o círculo preenchido ou o contorno, maior o número de postos de trabalho de habitantes em cada local marcado. Aparecem representadas ainda as represas Guarapiranga e Billings, ao sul da GSP, e parte do litoral.

O Mapa 31: Distribuição proposta da população e do emprego-Modelo 2 (p.103), também apresentado no PUB com a mesma forma de representação, propõe distribuição de empregos e população baseada no conceito urbano modelado a partir das "previsões referentes às necessidades de áreas para diversos usos, o que permitiu alterar as densidades inicialmente previstas." (PUB, 1969, p.71) Foi chamado de Modelo 2 e "foi preparado quando já eram conhecidas as sobrecargas do sistema de 
transportes, resultantes do Modelo 1," que, por sua vez, foi resultado da aplicação de "parâmetros a partir da quantificação de acordo com as tendências de crescimento." (PUB, 1969, p.68)

O que se pode depreender da análise dos mapas é que se propõe criação de postos de trabalho em áreas periféricas do município de São Paulo, ao sul e ao norte, como em Perus; acréscimo do número de postos no extremo leste da cidade e crescimento de postos no chamado vetor sudoeste, incluindo distritos como Pinheiros, Santo Amaro e Belezas. (atuais Jardim Ângela e Jardim São Luis) Nos distritos a sudeste, como Ipiranga e Saúde, a previsão contava com uma distribuição mais homogênea. Ao norte da cidade também se planejou um incremento de postos de trabalho acima do crescimento da população.

A proposta do PUB também se estende a todos os municípios da Região Metropolitana, com proposta de criação de empregos em municípios que no Mapa 30 não apresentavam postos de trabalho ou população demarcados.

Os Modelos 1 e 2 de estrutura urbana resultaram da análise pelo relatório de quatro conceitos esquemáticos de estrutura urbana, resumidos abaixo:

\section{Conceito Esquemático I - Tendencial,} com continuidade das tendências de desenvolvimento existentes, submetidas a certo controle e orientação: 1. Expansão das altas densidades residenciais, a partir do centro atual da cidade; 2. Estabelecimento de grandes corredores de alta densidade de uso misto ao longo das linhas do sistema de trânsito rápido; 3 . Ampliação dos centros das cidades existentes na Área Metropolitana, acentuando-se sua importância; 4. Estímulo à formação de novos centros comerciais para atender à população residente na periferia;
5. Limitação e controle do crescimento periférico. [Fundamenta o Modelo 1 do PUB]

Conceito Esquemático II - Corredor denso, com dispersão da população e dos empregos por toda Área Metropolitana: 1. Centros de atividades múltiplas, de comércio e serviços altamente concentrados, circundados por áreas residenciais de alta densidade e localizados dentro do município, ao longo de linhas do sistema de trânsito rápido; 2. Extenso sistema de espaços livres da Área Metropolitana, comportando ocupação de baixa densidade, parques recreativos e atividades agrícolas e servindo como faixa de separação entre os diversos núcleos urbanos; [Não utilizado para o PUB]

Conceito Esquemático III - Super concentração, com acomodação de todo o crescimento futuro nos limites da área urbanizada atual: 1. Máximo desenvolvimento dos terrenos vagos e construção de edifícios mais elevados na área urbanizada; 2. Desenvolvimento linear das principais atividades comerciais e de serviços dos grandes centros recreativos e culturais ao longo do Vale do Rio Tietê, na direção LesteOeste; 3. Desenvolvimento de densidades demográficas elevadas por toda a área urbana e especialmente ao longo das linhas do sistema de trânsito rápido. [Não utilizado para o PUB]

Conceito Esquemático IV - Estrutura urbana pró-automóvel, com grande proporção da população e dos empregos em serviços é distribuída numa área urbanizada consideravelmente ampliada: 1 . Composto por cinco centros sub-regionais de negócios e de atividades comerciais, circundadas por áreas residenciais de alta densidade, localizados na periferia e ligados ao centro metropolitano no sistema de trânsito rápido; 2 . Centro metropolitano ampliado, abrangendo áreas de alta densidade; 3 . Área de ocupação intensa provida de centros comerciais e de serviços organizados sob a forma de corredores de atividades múltiplas, ao longo das linhas do sistema de trânsito rápido, que partem do centro metropolitano e separado por usos residenciais de média densidade; 4 . Sistema 


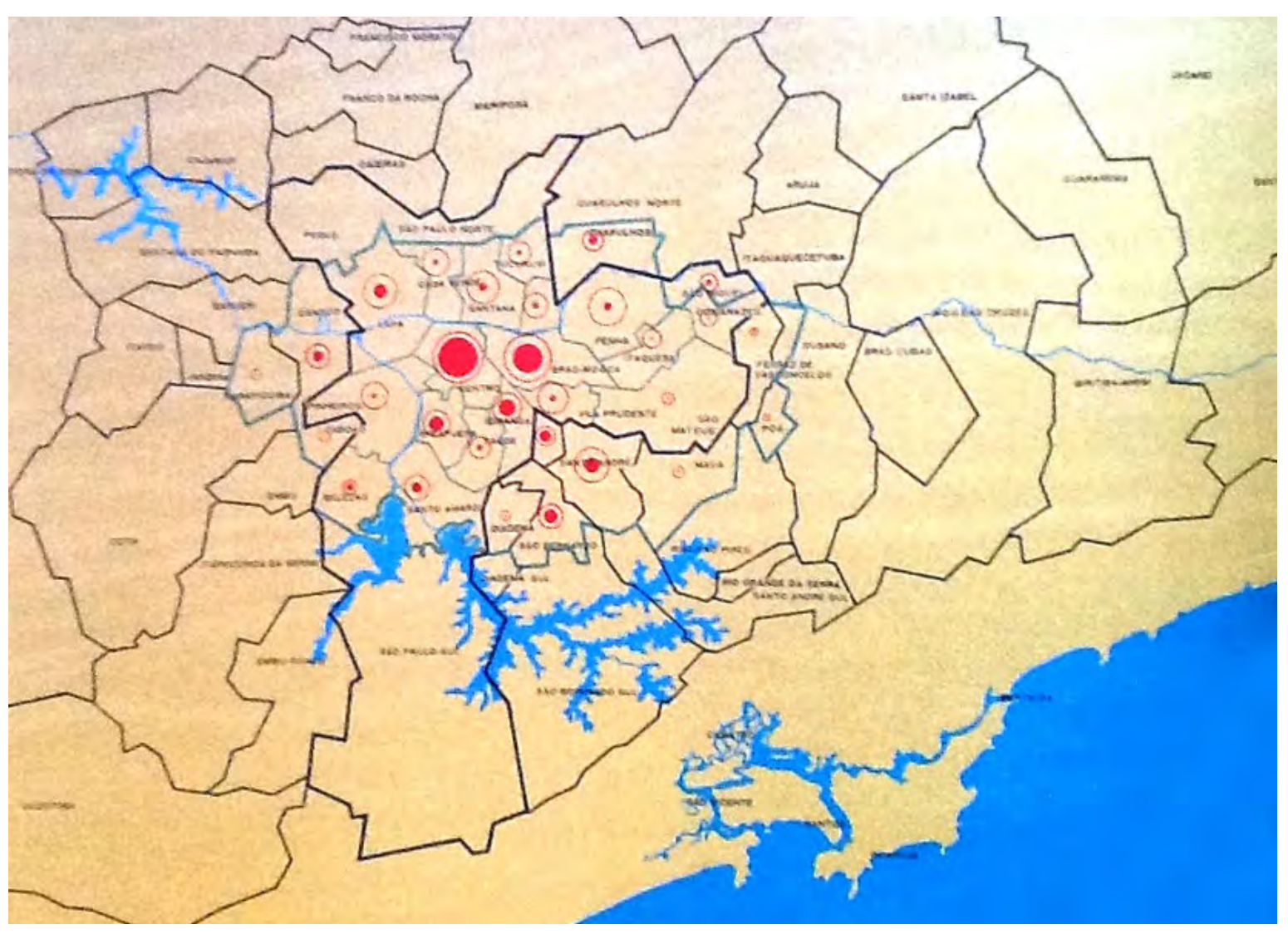

MAPA 30: Distribuição DA

POPULAÇÃO E DO EMPREGO 1965

PUB, 1969, P.70

MAPA 31: DistribUIÇÃo

PROPOSTA DA POPULAÇÃO E DO EMPREGO-MODELO 2

PUB, 1969, p.71

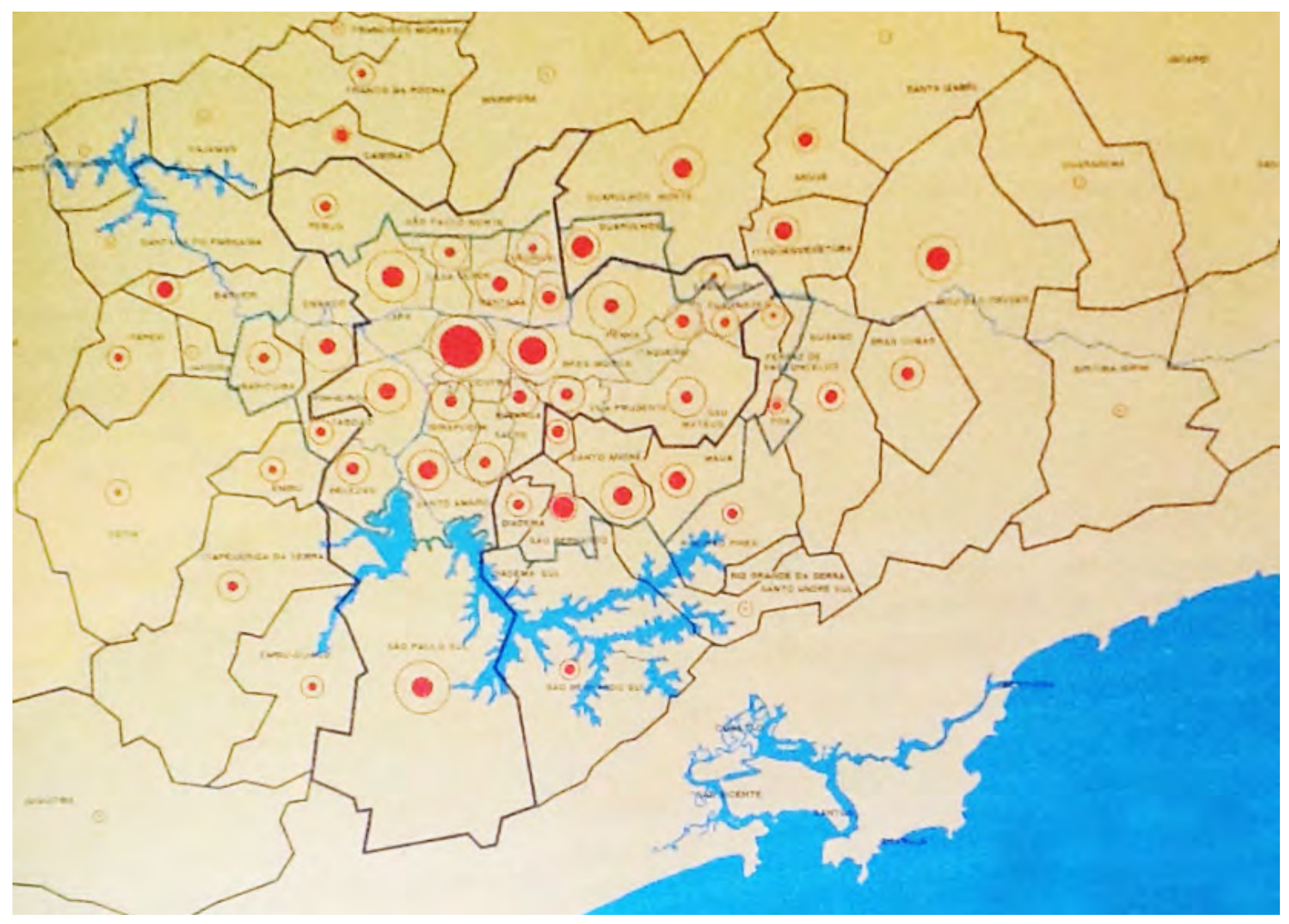

População

—_ Município de São Paulo Grande São Paulo 
adequado de vias expressas e de trânsito rápido para permitir alta mobilidade da população. [Fundamenta o Modelo 2 e sua variante, o Modelo 3, do PUB] (PUB, 1969)

Segundo Feldman,

Somente em 1967 será resgatado o discurso do planejamento como "processo permanente e dinâmico que deve ser implantado com flexibilidade para adequarse ao crescimento da cidade," conforme se pode ler na exposição dos motivos do decreto que cria o Grupo Executivo de PlanejamentoGEP. O GEP é criado como órgão transitório, diretamente subordinado ao prefeito. Tem por função reunir, analisar e coordenar os estudos, projetos e legislação existentes e os em andamento nas unidades especializadas da Prefeitura, ligados ao planejamento urbano, físico, econômico e social, em entrosamento com o Departamento de Urbanismo; coordenar e orientar as medidas pertinentes ao Plano Urbanístico Básico - pesquisas, diagnósticos, estudo e elaboração de diretrizes básicas de planos setoriais e projetos; superintender e orientar serviços contratados e fiscalizar seu cumprimento; estudar e propor convênios visando a cooperação, entrosamento e implementação de planos setoriais e regionais. Além dessas atribuições, cabe ao GEP acompanhar e fiscalizar os estudos e contratos do PUB e atuar como órgão implantador do mesmo, até a constituição de órgão próprio, o que o caracteriza como órgão transitório. (FELDMAN, 2005, p.212)

\section{PUB-BREVE CONCLUSÃo}

Com a visão urbanística demonstrada pelos urbanistas e técnicos, as diretrizes acima se implantadas à época, ou seja, em fins da década de 1960, poderiam ter contribuído para que o município desfrutasse de desenvolvimento urbano com mais qualidade em lugar do crescimento urbano conflituoso ocorrido. Em lugar disso, as equipes permanentes de técnicos da administração pública que tinham todos os meios para delinear um desenvolvimento urbano com mais qualidade, os indicadores e as análises, "em função de suas obrigações funcionais não puderam reagir às orientações governamentais e de alguns políticos à época, às pressões econômicas exercidas pelas montadoras de automóveis e pelas empresas petrolíferas, alterando prioridades e a melhor destinação de verbas públicas." (informação verbal) ${ }^{57}$

Segundo Feldman,

O PUB promove uma conexão direta de profissionais brasileiros com a prática do planning americano, seguindo o esquema sugerido pelo IAB - Instituto de Arquitetos do Brasil. Não mais a solicitação de um parecer de especialistas estrangeiros, como ocorreu com Robert Moses, e anteriormente com Bouvard, e não mais a consultoria para assuntos específicos, como o que ocorrera com Padre Lebret, mas a montagem de uma estrutura nos moldes do New York Regional Plan and its Environs, de 1920, em que consultores, especialistas e técnicos ligados a empresas privadas trabalham em conjunto, ao longo de um ano, financiados pelos governos brasileiro e americano..$^{58}$

Para Feldman, por um lado o PUB é o plano que mais se assemelhou às ideias preconizadas por Anhaia Mello, em fins de 1920, resultante de exaustivas pesquisas, além dos limites do município, envolvendo a Região Metropolitana e, por outro, a representação de que "um trabalho técnico exaustivo é suficiente para direcionar a atuação da prefeitura" (FELdmAn, 2005, p.237) e, menciona Villaça, para quem a "profusão de dados e recomendações denota o distanciamento entre o que chama de "super planos" e suas propostas e as possibilidades de sua implantação pelo poder público." (Villaça, 1999, em Feldman, 2005, p.237) Para Feldman, a grande 
importância do PUB é por ter sido este o primeiro plano para São Paulo que incorporou uma legislação de zoneamento, um dos elementos da Lei do Plano Diretor de Desenvolvimento Integrado-PDDI, produzido em 1971 pela Prefeitura Município de São Paulo na gestão de Figueiredo Ferraz, desenvolvido pela SEMPLA, e tendo como secretário municipal do planejamento o engenheiro Luiz Antonio Naves Junqueira, aprovado pela lei n. 7688 de 30 de dezembro de 1971.

Segundo Feldman, o PDDI foi o primeiro plano aprovado em São Paulo, após mais de 40 anos desde o Plano de Avenidas e é, segundo a autora, "a negação da concepção de Plano Diretor que o PUB representou: o plano composto por exaustivos diagnósticos e abrangentes a todos os aspectos da vida urbana." (FELDMAN, 2005, p.243)

Feldman relata que os responsáveis pelo plano não consideravam necessárias pesquisas e adotaram e admitiram como satisfatórios os estudos existentes do PUB em lugar de refazê-los e para não parar toda a administração durante dois anos. (Cerqueira Cesar, 1971, em FeLdman, 2005, p.243)

Segundo Feldman,

A lei n. 7805 que dispõe sobre a instituição do PDDI (...) é um agregado de elementos de naturezas diversas. A maioria dos 57 artigos que compõem a lei trata de princípios, definições, classificações. (...) A única coerência perceptível no plano é o fato de o plano se voltar, estritamente, a questões referentes ao uso do solo. Nesse sentido, pode-se afirmar que se aproxima do esquema do plano elaborado nos anos de 1950 pelo Departamento de Urbanismo. O esquema se constituía por três elementos para propiciar uma cidade descentralizada e hierarquizada: a circulação, o plano de uso do solo e a organização funcional, que deveriam se materializar por meio de vias expressas, do zoneamento e da utilização das unidades de vizinhança como unidade mínima de organização da vida urbana. (FELDMAN, 2005, p.248)

Segundo Feldman, por se tratar de um plano restrito ao planejamento físico-territorial, atuando genericamente nas questões pertinentes ao desenvolvimento econômico e social "O PDDI de 1971 é um plano que se restringe a uma lei acompanhada de um mapa, este último só possível de consulta ao processo que constitui a lei do plano." (Feldman, 2005, p.243)

Segundo Campos Filho, "O PDDI repetiu a contradição presente no PUB: estruturação radioconcêntrica adensadora do metrô no entorno de suas linhas versus estrutura em malha de vias expressas dispersadora dos usos urbanos como orientadoras do zoneamento, uma diretriz anulando a outra." Segundo ele, "o metrô foi incluído sem ter absorvido suas consequências de adensamento no entorno de suas estações, ou seja, fatores de estruturação na ordenação do uso do solo." (informação verbal)59
A falta de coerência dessas diretrizes contribuiu para a predominância final da lógica dispersadora dos veículos sobre pneus, especialmente dos automóveis e ademais, sem que se houvesse implantado o sistema de vias expressas, mesmo que posteriormente tenha reduzido pelo PMDI a 250 quilômetros, menos da metade de sua gigantesca amplitude, de 840 quilômetros, prevista pelo PUB. O que em muito se comentou é que, de fato, o PUB esperava que o metrô subterrâneo livrasse as ruas dos ônibus para que o sistema viário modelo Los Angeles pudesse receber os milhões de automóveis que se esperava, já que os consultores principais do PUB eram de Detroit e Los Angeles. O metrô havia sido desenhado por consultores alemães antecipadamente e com uma rede modesta atendendo apenas ao que hoje chamamos de centro expandido. (informação verbal) ${ }^{60}$
59. Campos Filho. Depoimento à autora, 5 maio 2012.
6o. Campos Filho. Depoimento à autora, 7 mar. 2013.




\section{PMDI-GSP: PLANO METROPOLITANO DE DESENVOLVIMENTO INTEGRADO- GRANDE SÃO PAULO}

Produzido no ano de 1970 pelo Governo do Estado de São Paulo, durante a gestão do Governador Roberto Costa de Abreu Sodré, tendo como Secretário de Estado dos Negócios da Economia e Planejamento Eurico de Andrade Azevedo, foi desenvolvido pelas empresas privadas ASPLAN S/A, GPI Ltda. e Neves \& Paoliello S/C Ltda.

A seguir, um resumo das principais diretrizes do novo plano urbano PMDI, que inclui os textos resumidos de membros da equipe de produção técnica e burocrática, com suas considerações a respeito dos objetivos do PMDI.

\section{ApresentaçÃo do PLANO E ASPECTOS ADMINISTRATIVOS}

Por Eurico de Andrade Azevedo, Secretário de Economia e Planejamento do Governo do Estado de São Paulo durante a gestão do Governador Roberto Costa de Abreu Sodré

A Grande São Paulo conta atualmente com uma população de 8,1 milhões de habitantes, que cresce $5,4 \%$ ao ano. Deverá atingir, seguramente, doze milhões em 1980, podendo alcançar dezessete milhões em 1990. (...) Seus problemas ultrapassam a área de ação das administrações locais, exigindo um tratamento global e integrado. Entre estes problemas, na Grande São Paulo, como nas demais áreas metropolitanas do mundo, um dos principais é o da organização administrativa. (...) A criação de uma entidade metropolitana, como órgão da administração estadual, sem ferir a autonomia dos Municípios, é a solução mais adequada, dentro de nossas normas constitucionais. Esta entidade poderá ser uma autarquia, uma Secretaria de Estado, ou até mesmo uma empresa com participação da União, do estado e dos Municípios. (...) Este órgão terá necessariamente as funções de: efetuar o planejamento da área; exercer as competências assumidas nos assuntos de interesse predominantemente metropolitano; superintender as atividades dos órgãos setoriais metropolitanos; coordenar as atividades de outros órgãos públicos que atuam na área; e compatibilizar as atividades do governo estadual e dos governos municipais da área metropolitana. (...) Como grande investidor na Região da Grande São Paulo, e como agente competente para a solução de seus problemas, cabe ao Governo do Estado a iniciativa no processo de solução de seus problemas. Tal é o propósito do PMDI, resultado de quatro anos de estudos desenvolvidos pelo GEGRAN-Grupo Executivo da Grande São Paulo, e que deverá orientar os empreendimentos governamentais na região da grande São Paulo. (PMDI, 1970, p.IX)

\section{AsPECTOS TÉCNICOS}

Por Antonio Cláudio Moreira, diretor do Gegran

A Grande São Paulo é constituída por 37 municípios, por onde se estende a área urbana contínua de São Paulo. Por isso, é entendida como uma única cidade, abrigando hoje oito milhões de habitantes, com previsão para doze em 1980 e dezessete milhões em 1990. É, hoje, uma grande metrópole, ao nível de Londres, Paris e Los Angeles. É área estratégica para o desenvolvimento do país, pois responde por $40 \%$ da produção industrial do Brasil. São Paulo arrecada, nesta área, mais de 60\% de sua receita orçamentária. O município de São Paulo, que é o polo de desenvolvimento da metrópole, tem $\circ 4^{\circ}$ orçamento da nação. Como se sente facilmente, os problemas da Grande São Paulo afetam toda a vida econômica do País. (...) A atividade inicial do GEGRAN, sob a coordenação do Dr. Helio Martins de Oliveira, foi a de coletar informações que o possibilitassem cumprir suas finalidades e, (...) em 1968, sob a direção do Engenheiro Salvador Eugênio Giammusso, publicou seus resultados sob o título "caracterização preliminar da Grande São Paulo," objetivando, com isso, proporcionar aos meios técnicos informações indispensáveis à compreensão da problemática da área. Nessa época, por iniciativa do GEGRAN, a Secretaria de Economia e Planejamento contratou serviços técnicos para elaboração de mapa-base da 
Capítulo III: Rumos urbanísticos em São Paulo 1960/2012

Grande São Paulo, de base cartográfica e de levantamento avaliativo da qualidade do ar na área metropolitana e respectivo diagnóstico preliminar do problema de poluição do ar. (...) o GEGRAN, em 1969, procurou ampliar seu conhecimento sobre a área, para tanto desenvolvendo estudos sub-regionais e estudos setoriais. (...) Para efeito dos estudos sub-regionais, a grande São Paulo foi dividida em sete sub-regiões, uma das quais é o município da capital. Este contou com estudos do PUB, realizado pela Prefeitura de São Paulo. As demais subregiões, seis, foram estudadas em separado pelo GEGRAN. Já as pesquisas setoriais diziam respeito a prognósticos demográficos, com base em modelo macroeconômico; o estudo do sistema básico de transporte; e à pesquisa do setor industrial, todos eles referindo-se à área da Grande São Paulo. Com base nesses trabalhos, cuidou o GEGRAN, em fins de 1969, da elaboração do PMDI. Para sua elaboração contratou-se os serviços de um consórcio de empresas de planejamento ASPLAN, GPI, Neves \& Paoliello, com a colaboração da SOTEPLAN e PADCO, esta de origem americana, por 3,95 milhões de cruzeiros, contando com financiamento de três milhões de cruzeiros do SERFHAU. (...) Diríamos, em síntese, que o PMDI alcançou as seguintes metas: 1. Identificou os principais problemas fora do controle dos governos locais, e que se situam principalmente nos setores de Saneamento, Transportes e Uso do Solo; 2. Propôs soluções a esses problemas, formulando diretrizes de longo prazo e medidas concretas de médio prazo - 1980; 3. Concebeu um mecanismo coordenador das atividades do Governo do Estado na área metropolitana, ou seja, a própria entidade metropolitana. (PMDI, 1970, p.XI)

\section{ObJetIVOS Do PMDI}

O PMDI teve objetivos econômicos, sociais e físicoterritoriais e "os estudos realizados para a elaboração do PMDI permitiram atingir um consenso técnico quanto aos objetivos a serem perseguidos, visando à satisfação das necessidades e aspirações da população metropolitana," como exemplos: econômicos, para redução das deseconomias de aglomeração, mediante melhor distribuição das atividades urbanas; sociais, para ampliar e distribuir de forma adequada a oferta de empregos, de modo a possibilitar o maior número de oportunidades e opções da população, e físico-territoriais, para assegurar maior mobilidade da população, proporcionando sistemas viários e de transportes capazes de atender às necessidades futuras. (PMDI, 1970, p.XVI)

Segundo Moreira, no setor de Transportes, o PMDI recomenda principalmente:

Implantação de um Sistema de Transportes Rápido de Massas para atender a 60\% das viagens, mediante aproveitamento do sistema ferroviário existente integrado com a linha norte-sul do Metrô, e construção do anel ferroviário; Implantação de um sistema de vias expressas (freeways) para atender ao transporte individual e de cargas, sistema este composto do Pequeno Anel Ferroviário, das rodovias norte, Anhanguera, Castelo Branco, Raposo Tavares, Regis Bittencourt, Imigrantes, Anchieta, São Paulo-Mogi, Dutra e Fernão Dias, e de duas vias expressas internas ao anel rodoviário, uma no sentido norte-sul ligando a Anchieta e Dutra, e outra no sentido leste-oeste ligando o ABC e Morumbi; Racionalização do sistema de trânsito e transportes coletivos, especialmente na área interna do pequeno Anel Rodoviário. (PMDI, 1970, p.XI)

\section{Ainda segundo Moreira, no setor de Estrutura}

Urbana, ou seja, de controle do uso do solo, o PMD recomenda principalmente:

Desestimular a expansão urbana na direção sul e sudoeste, reorientando-a especialmente em direção a leste (Mogi das Cruzes) e nordeste (Guarulhos); Estimular o desenvolvimento de novos centros de atividades terciárias em corredores ao longo do sistema ferroviário, capazes de absorver a expansão do setor terciário na metrópole e de viabilizar o sistema de transporte 
rápido de massas e, com pontos focais nas regiões de Osasco, Santo Amaro, ABC, Mogi, Itaquaquecetuba e Guarulhos; Preservar as áreas das represas e da Serra da Cantareira para recreação da população da Área Metropolitana. (PMDI, 1970, p.XVII)

Veremos adiante que tais diretrizes correspondem a um tipo de estruturação urbana densa de corredores metropolitanos proposta por Campos Filho em 1972 em sua tese de doutoramento pela FAUUSP. ${ }^{61}$

61. Campos Filho teve a oportunidade de promover o desenvolvimento dos estudos técnicos de levantamento de dados junto aos registros históricos da Junta Comercial e de mapas antigos, que confirmaram a oportunidade de ordenar a transformação urbana em curso pelo processo histórico de duração secular de saída gradativa das indústrias de localizações mais centrais para mais periféricas, ao longo das ferrovias e, mais tarde, ao longo do entorno das rodovias, como a Via Anchieta e a Via Dutra, que só agora está sendo reconhecido como a grande possibilidade de transformação urbana do Município de São Paulo, com um plano urbanístico chamado de Arco do Futuro baseado em conceito desde há muito tempo defendido por ele. (CAmpos FILHO. Depoimento à autora, 8 mar. 2013)

62. Disponível em <http://www. emplasa.sp.gov.br/emplasa/ empresa/aempresa.asp>. Acesso em 3 jun. 2013.

\section{EstratécIa do PMDI E O ÓRGÃo METROPOLITANO}

Adotando a perspectiva de que o planejamento da Grande São Paulo deva ser compreendido como um processo permanente e sistemático, em contínuo aperfeiçoamento, o PMDI apresenta um horizonte de trabalho conceitual de longo prazo, flexível a imprevistos e de contornos mais genéricos para conhecer e analisar a realidade com objetivos préfixados. (PMDI, 1970, p.XVI)

\begin{abstract}
A década que se inicia será um período fundamental para aperfeiçoar o processo de planejamento em todos os níveis. A importância das áreas metropolitanas, seus problemas e potencialidades para o País, vêm progressivamente merecendo a atenção do Governo Federal, podendo-se prever para o futuro próximo a disponibilidade de novos recursos institucionais, técnicos, humanos e financeiros. (PMDI, 1970, p.XVI)
\end{abstract}

Um dos pontos estratégicos para a implantação do PMDI foi a criação de um órgão metropolitano de planejamento para a comunicação entre os diversos órgãos atuantes na área, adotando a posição de coordenação dos três níveis do poder público. (PMDI, 1970, p.XVI) Esse órgão foi a Empresa Paulista de Planejamento Metropolitano
S/A-EMPLASA, criada em 1975, "um órgão vinculado à Secretaria Estadual de Desenvolvimento Metropolitano-SDM (...) para cuidar do planejamento da Grande São Paulo, - única região metropolitana então existente - a empresa tem hoje como foco de suas ações o território da Macrometrópole Paulista-MMP." Atualmente, a EMPLASA tem como campos de atuação, através da SDM, Diretrizes Estratégicas, Foco no Território, Institucional, Articulação e Viabilização, Bases do Planejamento, Planejamento e Projetos Urbanos. (EMPLASA) ${ }^{62}$

\section{INTERVENÇÃO PRIORITÁRIA}

O PMDI propôs como prioridade a intervenção estratégica em problemas que afetam a comunidade metropolitana como transporte coletivo, saneamento básico e controle do desenvolvimento urbano. Neste último tema, o controle da expansão horizontal desordenada mediante o adensamento das áreas periféricas, a descentralização do emprego, melhor distribuído em relação ao assentamento populacional, e provisão de áreas verdes e espaços abertos metropolitanos para recreação de massa e proteção contra a poluição de recursos naturais. (PMDI, 1970, p.XVI-XVII)

O PMDI propõe a integração macrorregional por estar o "desenvolvimento da Grande São Paulo vinculado ao desenvolvimento do Estado e do País," prevendo uma melhor distribuição da população e das atividades econômicas. (PMDI, 1970, p.XVII)

\section{Planejamento municipal}

Segundo o texto original do PMDI,

A assistência técnica e financeira para o desenvolvimento do planejamento integrado da Grande São Paulo completa a série de 
pontos estratégicos. O PMDI constituiria o quadro de referência básica para o planejamento municipal, permitindo que esse desenvolvesse os aspectos peculiares ao seu interesse segundo a estrutura metropolitana global. Obter-se-ia assim um sistema de planejamento integrado verticalmente e alcançando progressivamente todos os campos da atividade pública. Por sua vez a cooperação dos municípios poderá contribuir com a entidade metropolitana na adaptação e reformulação da estrutura metropolitana de modo a atender às peculiaridades das comunidades locais. (PMDI, 1970, p.XVII)

\section{Síntese e ReCOMENDAÇões do PMDI}

Por ser um plano voltado à entidade metropolitana, as diretrizes são orientações genéricas, podendo ser alteradas nas revisões periódicas do plano. (PMDI,

1970, p.XVII) Segundo seu texto de apresentação,

O programa metropolitano do PMDI compreende as diretrizes e preposições referentes aos setores estratégicos diretamente relacionados à atuação de entidade metropolitana, a saber: Desenvolvimento, Circulação e Transporte, saneamento básico e sistema Institucional." (PMDI, 1970, p.XVII)

Destacam-se aqui as diretrizes principais do PMDI e que se relacionam com o desenvolvimento da tese em elaboração:

DESENVOLVIMENTO URBANO

Diretrizes e Proposições:

1. Orientar a expansão do aglomerado metropolitano na direção Leste e Nordeste, onde se encontram os terrenos mais adequados à ocupação urbana, e restringir o crescimento nas direções Sul e Sudeste, a fim de proteger os recursos hídricos e recreacionais da grande São Paulo.
2. Promover o equilíbrio da distribuição do trinômio habitação-emprego-transporte através do desenvolvimento de centros terciários e áreas industriais descentralizadas, de locação de áreas prioritárias para a habitação e do estabelecimento efetivo de sistema integrado de transporte coletivo de massa.

3. Promover a integração do sistema financeiro de habitação com o planejamento metropolitano, com a execução de projetos nas áreas estratégicas para o desenvolvimento metropolitano nos eixos de urbanização preferencial, ao longo do sistema de transporte coletivo de massa.

4. Promover, através de incentivos à iniciativa privada, a realização de projetos de renovação urbana, principalmente nas áreas que deverão ser afetadas pela construção de grandes obras públicas.

\section{CIRCULAÇÃO E TRANSPORTES}

Diretrizes e Proposições:

1. Proporcionar níveis adequados de serviços de transportes a toda a Área Metropolitana, mediante o desenvolvimento de um sistema integrado regional, composto de metrô, ferrovias, ônibus e rede de vias expressas e arteriais, consolidando a Região em um conjunto econômico e social.

2. Intensificar o uso dos transportes coletivos dando prioridade ao desenvolvimento do sistema de transporte rápido de massa, para ser capaz de oferecer à população em geral acesso fácil a todos os pontos da Área e de atrair o maior número de proprietários de carros.

3. Promover a ampliação do sistema de transporte rápido metropolitano, mediante a utilização progressiva e prioritária das linhas ferroviárias inseridas na área urbanizada.

4. Concluir a linha Norte-Sul do Metrô, examinando a viabilidade de extensão ao Norte, na direção do Tucuruvi e Jaçanã. 
63. O Centro Metropolitano do PMDI refere-se ao que hoje chamamos de Centro Histórico.
5. Rever os programas e o traçado de novas linhas do Metrô, em face de um plano integrado de transporte de massa, considerando prioritário o sistema de metrô-ferroviário.

6. Projetar e implantar um programa prioritário de integração e aperfeiçoamento do sistema de trens de subúrbio, a fim de elevá-lo ao padrão de serviço de metrô, com prioridade para as seguintes linhas: Estrada de Ferro Santos-Jundiaí: trecho de Pirituba a Santo André; E. F. Sorocabana e E. F. Central do Brasil; E. F. Sorocabana: trecho de Santo Amaro à Lapa e interligação com a linha anterior. (PMDI, 1970, p.XVII)

As diretrizes acima estão conformes com o Conceito 2: Corredores Metropolitanos (p.34) do arquiteto e urbanista Candido Malta Campos Filho (1972), por ele desenvolvido na elaboração do PMDI, a seguir

1. Projetar e construir terminais de passageiros, possibilitando a integração dos vários sistemas de transporte com prioridade para implantar, junto a todas as estações de metrô e de ferrovias, terminais de ônibus e áreas de estacionamento adequadas.

2. Desenvolver e implantar programa imediato de controle de trânsito e de melhorias viárias, através da cooperação do Estado com a Prefeitura de São Paulo, a fim de aperfeiçoar, em curto prazo, as condições de transporte coletivo, de tráfego de veículos e de segurança das vias públicas na área interna ao Anel Rodoviário.

3. Controlar a provisão de espaços para estacionamento no Centro Metropolitano ${ }^{63}$ como parte da política de redução progressiva do uso de veículos particulares nessa área, à medida que se obtenham a integração e melhoria do sistema de transporte coletivo.

4. Outras diretrizes envolvendo aeroportos, anéis viários, rodovias a expandir ou novas rodovias. (PMDI, 1970, p.XVII)
Nas diretrizes acima, reconhece-se a origem do rodízio de veículos. A área chamada acima de área interna ao Anel Rodoviário é a área que chamamos hoje de Minianel Viário ou Centro Expandido.

\section{Saneamento básico e Sistema Institucional Metropolitano}

Na página XVIII do PMDI encontram-se também diretrizes e proposições para o saneamento básico da Grande São Paulo, que não serão detalhadas aqui por não estarem diretamente relacionadas ao tema geral da tese, que propõe uma metodologia para desenvolvimento de planos urbanos locais, no Capítulo VI

Segundo Campos Filho (1972), um dos diretores participantes do desenvolvimento do PMDI para Neves \& Paoliello,

Os conceitos de estruturação urbana analisados no PMDI foram o Conceito de Agregação de Propostas Parciais, o Conceito dos Corredores Metropolitanos e o Conceito do PUB - Plano Urbano Básico para São Paulo de 1969. Este adota o conceito $\mathrm{n}^{\circ} \mathrm{O} 2$ dos corredores Metropolitanos para o desenvolvimento de sua tese de doutorado com cálculos de potencial de ocupação e demanda para o ano de 1990 e contando (inclusive) com um anel ferroviário interligando as vias marginais dos três importantes rios do município: Pinheiros, Tietê e Tamanduateí. (Campos Filho, 1972, p.XIV, XVIII)

Ainda segundo Campos Filho em sua tese de doutorado de 1972:

Entretanto, quando de nossa participação no PMDI (em 1970), verificamos que a escolha do modelo de estrutura urbana a ser adotada para o ano meta (no caso 1990) tendia a ser o resultado de extrapolações puras e simples de tendências observadas no passado recente (5 a 10 anos) ou de escolhas baseadas por um 
lado nos valores predominantes na equipe técnica e pelo outro em uma combinação de valores desses técnicos com os dirigentes políticos ao qual o trabalho estava afeto. (...) Verificamos aí que era extremamente importante que, ao lado do desenvolvimento de técnicas que permitissem a extrapolação mais segura e pormenorizada das tendências "espontâneas" observadas, outras deveriam ser criadas e testadas que permitissem avaliar conceitos e modelos que se desviassem desse desenvolvimento "espontâneo." A técnica de análise de custos e benefícios que aqui será desenvolvida tem exatamente esse objetivo: o de aumentar a objetividade na avaliação de conceitos e modelos alternativos de estruturas urbanas. (CAMPOS FILHO, 1972, p.6)

Foi nesse contexto, utilizando o conceito weberiano dos "tipos ideais" que Campos Filho comparou quatro estruturas de tecidos urbanos típicos ideais para concluir que as estruturas urbanas com predominância de linhas de metrô de superfície organizadas em linhas paralelas que geram capacidade de suporte de altas densidades são as que apresentam a relação custo-benefício mais relevante do ponto de vista socioambiental. Essa conclusão será um dos pilares conceituais desta tese. (informação verbal) ${ }^{64}$

Constitui assim o PMDI, uma revisão profunda do PUB enquanto diretrizes urbanísticas, buscando eliminar a sua contradição interna de ao mesmo tempo preconizar um adensamento baseado no metrô e uma dispersão baseada no automóvel, como já analisado. Ao mesmo tempo em que significou a adoção de um planejamento metropolitano pelo governo estadual, o PUB, embora de visão metropolitana, havia sido encomendado pelo governo municipal de São Paulo.

\section{PAITT-PROGRAMA DE AÇÃO IMEDIATA DE TRANSPORTES E TRÁFEGO}

Produzido em 1971 pelo Governo do Estado de São Paulo durante a gestão de Laudo Natel, cujo Secretário Municipal de Economia e Planejamento era Miguel Colasuonno, foi desenvolvido pela Secretaria de Economia e Planejamento, pelo GEGRAN, pela Secretaria de Transportes e por empresas privadas como a ATCP, o GPI e a empresa norte-americana PADCO Inc., localizada em Washington. ${ }^{65}$

As diretrizes do PAITT não contribuíram para este trabalho, uma vez que, apesar de seu teor ser a gestão de tráfego, este não foi um plano estruturante, opostamente ao que se discute aqui, ou seja, de integrarse a Região Leste de São Paulo ao Centro Expandido como opção, e não como dependência obrigatória. Pode-se comprovar essa afirmação observando-se o Mapa 32: Linhas expressas de ônibus urbanos propostas e terminais de embarque, que prevê, à guisa de corredor de ônibus, o transporte de trabalhadores e estudantes a partir de "polos de concentração de transporte coletivo" em direção aos Centros Histórico e Novo. O plano previa basicamente cinco polos de embarque de passageiros em linhas expressas de transporte público rodoviário: dois na Região Leste, sendo um polo na avenida Radial Leste com os meios trem e ônibus urbanos, e outro a partir do distrito da Penha e utilizando a Marginal do rio Tietê e, nesse caso, o acesso até o Centro se daria pela avenida Cruzeiro do Sul. Para a Região Oeste da capital, o plano previa um polo de embarque na Lapa interligado à Marginal Tietê e esta à avenida Rudge. Para a Região Sul, planejaram-se dois polos: um nas proximidades do aeroporto de Congonhas, utilizando a avenida
64. Campos Filho. Depoimento à autora, 7 mar. 2013.

65. "Colaboradora internacional para fornecer consultoria a governos e clientes privados na África, Ásia, América Latina e Oriente próximo com pesquisa integrada, planejamento serviços de gerenciamento para o desenvolvimento urbano e rural." PADCO, 1981. Disponível em <http:// pdf.usaid.gov/pdf_docs/PNAAU150. pdf $>$. Acesso em fev. 2012. 


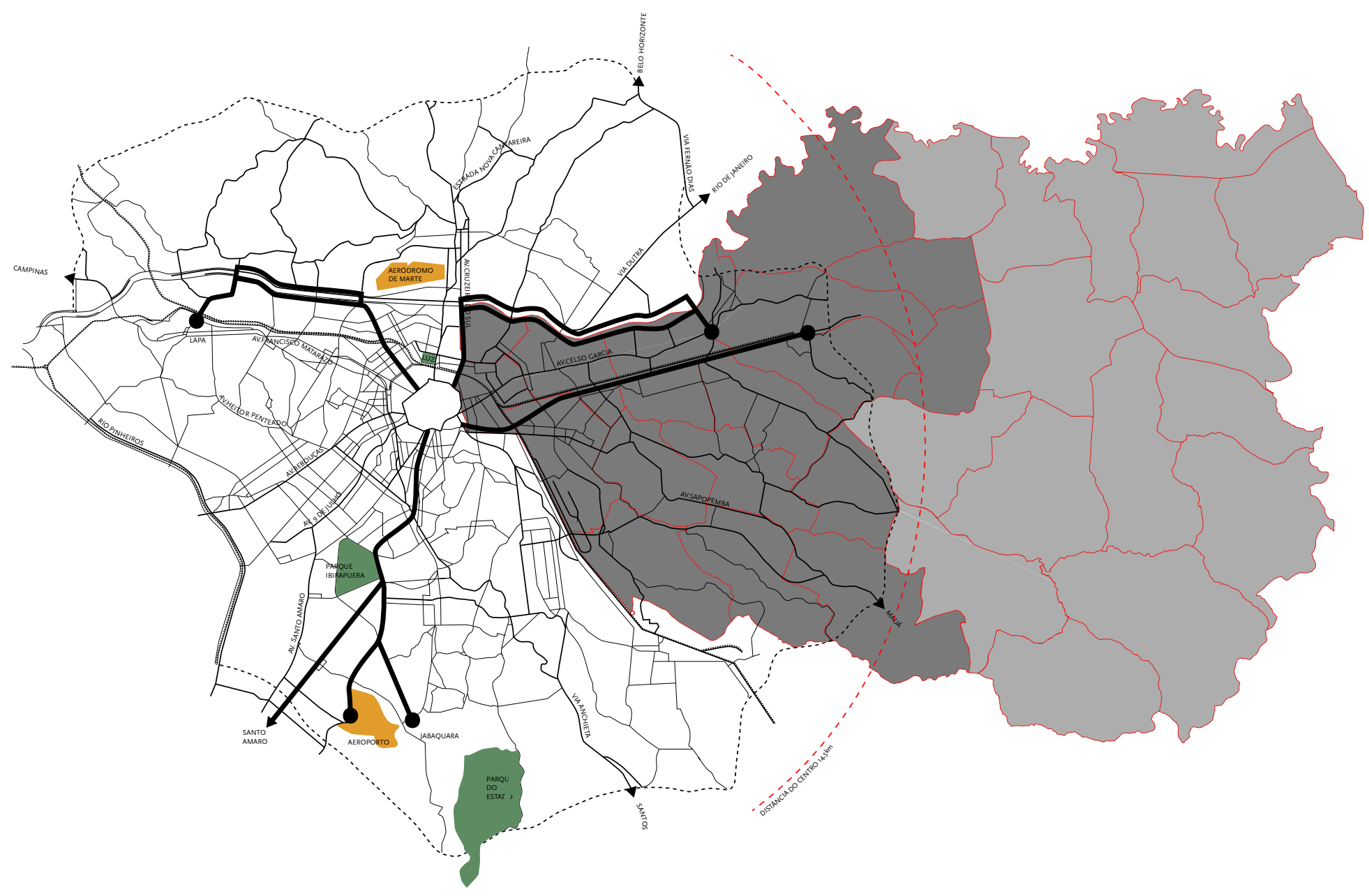

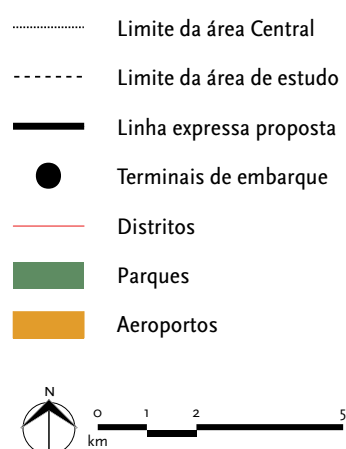

MAPA 32: LINHAS EXPRESSAS DE ÔNIBUS URBANOS PROPOSTAS E TERMINAIS DE EMBARQUE Governo de São Paulo. Programa de ação imediata de transportes e tráfego-PAITT, 1971. Redesenhado com inclusão da RLP 
Washington Luis, e outro no distrito do Jabaquara, utilizando a avenida Indianópolis, ambos interligando-se às avenidas Ruben Berta e 23 de Maio para acesso ao Centro. O mapa ainda apresenta uma linha expressa em direção a Santo Amaro sobre a avenida Vereador José Diniz, mas sem identificar um polo de embarque nessa região mais ao sul.

\section{O Plano de Governo 1980/1983}

Produzido em 1980 pela Prefeitura do Município de São Paulo sob a gestão de Reynaldo Emydio de Barros, foi desenvolvido pela COGEP, com o urbanista Candido Malta Campos Filho como Secretário coordenador do Planejamento.

Segundo Feldman, "em 1972, imediatamente após a aprovação do PPDI, é criada a COGEP." (FELDMAN, 2005, p.255)

O Departamento de Urbanismo terá partes de suas funções repassadas para a COGEP, em 1972, e somente virá a ser extinto em 1975, quando a Secretaria de Obras Públicas é substituída pela Secretária de Vias Públicas. (FELDMAN, 2005, p.213-214)

Segundo a lei, a COGEP é diretamente ligada ao gabinete do prefeito, e é concebida com poderes de "supersecretaria," com funções de coordenação e assessoria. Suas competências incluem a coordenação de atividades de planejamento dos órgãos municipais e entidades ligadas à prefeitura, elaboração de planos que envolvam mais de um setor municipal ou órgãos vinculados ao município, entrosamento com demais órgãos que tenham atuação ou influência na área do município; assessoria ao prefeito não assuntos relacionados com a implantação do PDDI, e proposição de medidas visando a participação da comunidade no processo de planejamento. (FELDMAN, 2005, p.255)

\section{Para Feldman, a COGEP introduz a Comissão de}

Zoneamento, para esclarecer dúvidas sobre a legislação encaminhando propostas de projeto de lei quando necessário, passo decisivo para a consolidação do zoneamento como principal instrumento de controle do uso e ocupação do solo. (FELDMAN, 2005, p.257)

Segundo Campos Filho,

O Plano de Governo na gestão de Reynaldo de Barros foi a primeira tentativa de dar concretude na escala do município de São Paulo, para um Plano de Metas de uma administração. Esse mérito, de ser pioneiro com o objetivo de comprometer uma administração com um plano de metas de governo, não the pode ser tirado. Foi publicado com uma tabela resumo e uma justificativa das prioridades adotadas. Definiu prazos e recursos para os projetos elencados, o que constituiu um avanço em dar transparência para uma administração pública. Teve ampla divulgação através da distribuição de 3000 exemplares entre os órgãos da administração municipal e estadual atuantes sobre a cidade. Receberam exemplares também as bibliotecas públicas de São Paulo assim como as organizações universitárias de ensino e pesquisa atinentes ao espaço urbano. (informação verbal) ${ }^{66}$

\section{SÉRIE POLÍTICAS GLOBAIS}

O conjunto de diretrizes O Planejamento Urbano em São Paulo: política global de desenvolvimento urbano e melhoria da qualidade de vida - Série Políticas Globais, foi produzido em 1981 pela Prefeitura Municipal de São Paulo, durante a gestão do prefeito Olavo Egydio Setúbal, e desenvolvida pela COGEP, tendo como Secretário Coordenador do Planejamento o arquiteto e urbanista Candido Malta Campos Filho.
66. Campos Filho. Depoimento à autora, 17 jun. 2013. 


\section{Políticas globais: Apresentação, segundo a COGEP}

Por Candido Malta Campos Filho, Secretário-

Coordenador de Planejamento da COGEP

Na apresentação do Volume 4 da série Políticas

Globais, a COGEP conclui que havia necessidade inadiável de se documentar a tomada de decisões pelo Executivo como condição básica de uma modernização e democratização de sua atuação, na solução dos problemas urbanos de sua competência e conclui também que o PDDI, em vigor desde à autora, 5 maio 2012.

1972, precisa de uma revisão substancial. O objetivo era fazer uma flexibilização conceitual do Plano Diretor, "transformando o seu caráter para o de uma constituição orientadora, em aspectos estratégicos ou estruturais, do desenvolvimento do Município de São Paulo, nas áreas de competência da Prefeitura." (COGEP, 1980, p.10)

Segundo Campos Filho, a partir de 1979, adotouse como estratégia na administração municipal o desenvolvimento de trabalhos que visam à globalização de uma visão setorial, praticada até o momento, mas com conhecimento profundo do modo de atuação das secretarias municipais, culminando-se numa integração intersetorial. (CAMPOS FILHO, 1980, p.4)

Segundo Campos Filho, a Série Políticas Globais pretendia juntar profissionais idealistas e pragmáticos para elaborar planos mais realistas que melhor atendessem às demandas da população. (informação verbal) ${ }^{67}$

Complementarmente, torna-se necessário desenvolver uma nova sistemática decisória que, ao invés de buscar no Plano Diretor toda orientação necessária para a tomada de decisões, o mantém como formulador das diretrizes mais estáveis politicamente e transfere para Conselhos Intersecretariais a tarefa da formulação de políticas menos permanentes, porque variáveis de administração para administração, em razão do próprio processo de desenvolvimento político em andamento, que cada vez mais permite uma abertura à participação das várias camadas da população no processo de planejamento urbano.

Ele deverá ser complementado por uma série de documentos de políticas setoriais subdivididos em dois grupos: o normativo e o executivo, que abrangerão setores de atuação concreta de cada uma das secretarias e empresas de economia mista que compõe a máquina administrativa municipal.

Documentos como esses que elaboramos cabem ser realizados especialmente no início e no final de cada gestão administrativa. No início, porque formulam o que se deseja realizar, e no final porque, a partir da experiência acumulada, apontam diretrizes para as administrações seguintes. A sua reavaliação anual permite a correção de rumos em face das condições cambiantes em cidades com o dinamismo socioeconômico e político de São Paulo.

A aceitação dessa sistemática não apenas possibilitará maior continuidade administrativa quando politicamente desejável, mas possibilitará ainda um debate técnico-político mais aberto e democrático, condição para se levar avante o difícil processo de humanização da cidade de São Paulo, por sua complexidade, através de seu desenvolvimento e melhoria da qualidade de vida de todos os seus habitantes. (COGEP, 1980, p.11)

\section{INTRODUÇÃO}

A principal característica deste documento reside na explicitação da lógica ou dos fatores que determinam a denominada "crise da cidade," articulada no plano 
social, institucional, financeiro, e da própria construção física do espaço urbano. Isto é, evitou-se, metodologicamente, contemplar a tradicional relação fastidiosa de carências urbanas, existentes e reais, em confronto com padrões ideais, mas aprender como de fato estas são produzidas na dinâmica socioeconômica da cidade e suas articulações internas e externas. Ao mesmo tempo, em lugar d e propor rol igualmente ideal de investimentos, obras e realizações curativas, intenta-se compreender o papel do setor público em atuação conjunta com a coletividade, nesta mesma dinâmica, com o objetivo de eliminar, deter ou restringir os principais focos geradores de patogenia urbana. Evidentemente, por este caminho se recorta e se explica a dimensão política do conjunto representado pela atividade urbana. (COGEP, 1980, p.11)

\section{A CRISE DA CIDADE E O PAPEL DA PREFEITURA, SEGUNDO A COGEP}

A Série Políticas Globais 4 apresenta cinco capítulos, como seguem, resumidamente. O primeiro capítulo procura "explicitar exatamente o entendimento que se tem da denominada crise:"

Admitindo-se que problemas urbanos sempre existiram, procura-se acentuar as dimensões diversas que adquiriram diante do crescimento econômico extremamente rápido e desigual após a década de 1950 e seu reflexo nas condições de vida presentes na cidade de São Paulo. A metropolização, o surgimento do mais importante patamar industrial e de serviços, bem como a enorme aglomeração de pessoas e mercadorias, criaram pressões sociais e econômicas e não encontraram condições objetivas e políticas de expressão. (COGEP, 1980, p.11)

\section{O segundo capítulo, Política de desenvolvimento} social:

(...) discute, através da ótica da negociação coletiva na gestão da cidade, os meios existentes e possíveis para o estabelecimento de uma política social abrangente no Município. Antes, porém, procura avaliar as relações existentes entre o quadro de vida urbana atual - produto de desigualdades, tensões sociais ou processos deteriorados das condições de vida da população - e uma prática de política social setorizada, comandada por visão tecno-burocrática tutelada e distante ou isolada das pressões que se avolumam no cotidiano das relações sociais.

O terceiro capítulo, Política institucional de ação regional:

(...) intenta indicar a redefinição do papel e do desempenho da Prefeitura diante dos problemas anteriormente analisados e explicitados da mesma forma em capítulos posteriores. Basicamente procura, através da análise da evolução do quadro institucional, apreender a capacidade dos diferentes setores da administração pública de agir como interlocutor das pressões coletivas no encaminhamento das decisões referentes à cidade. Isso poderia ser obtido mediante gestão democrática do aparelho institucional, a começar pelos canais diretamente relacionados com a população, - Administrações Regionais, por exemplo - incluindo-se a apresentação do debate e discussão pública das diretrizes e projetos elaborados pelos diferentes setores técnicos ou especializados da Prefeitura. Em contrapartida, a maior participação da população implica a distribuição coletiva de responsabilidades, bem como maior colaboração, através das diferentes associações representativas que se desenvolvem no Município. Analisando-se ainda as competências distribuídas pelos órgãos descentralizados, indicam-se algumas alternativas que visam o aperfeiçoamento do seu desempenho, contemplando-se a necessidade de integração e maior capacidade de decisão em cada unidade regional. Neste sentido, são consideradas as questões referentes à elaboração orçamentária, ao provimento de informações para o planejamento e aos mecanismos de consulta à população subjacente neste novo processo de gestão da cidade. (COGEP, 1980, p.11) 
O quarto capítulo, Política de produção e estrutura-

ção do espaço urbano:

(...) intenta buscar uma nova explicação para a produção do denominado "ambiente construído." Procura-se avaliar os efeitos deste espaço que sustenta os processos sociais, por um lado, como necessidade de reprodução do capital e, por outro, como quadro material de vida da própria população (...) contemplando a irracionalidade do processo e seus efeitos sobre a ação pública e sobre a população - principalmente de baixa renda. Significativamente, no curso desta análise, detecta-se a degradação social do espaço urbano, o desajuste entre a ocupação e os equipamentos das áreas urbanas, a expansão periférica onerosa e caótica, além da destruição acelerada do próprio patrimônio urbano conquistado. (COCEP, 1980, p.12)

O quinto capítulo, Política de recursos:

(...) procura analisar o processo de alocação de recursos para o custeio da operação e manutenção da cidade e o provimento de investimento para infra e superestrutura. Verifica-se que as despesas de custeio têm crescido a taxas pouco inferiores às das receitas próprias municipais. Entretanto, considerando-se as despesas correntes, indica-se que as receitas próprias do Município são insuficientes para cobrir até mesmo as despesas operacionais da cidade - ainda mais quando se adicionam investimentos maciços e contínuos necessários à eliminação de déficits acumulados ou destinados ao preparo da cidade para o futuro.

\section{Política de DESenVolvimento social, SEGUNDO A COGEP}

A partir da conscientização de que configuração sóciourbana de São Paulo está estruturada e relacionada às condições que regulam o sistema produtivo nacional e as forças sociopolíticas que atuam em seu território espacial e no processo de desenvolvimento capitalista, surge a estratificação social como espaço social com distinções e barreiras socioeconômicas e culturais crescentes. (COGEP, 1980, p.21)

\section{DiRETRIZES BÁSICAS DA COGEP}

O volume 4 da Série Políticas Globais: Política global de Desenvolvimento Urbano e melhoria da qualidade de vida, voltada para a política social, apresenta um corpo de diretrizes sócioadministrativas que tem "como objetivo de nortear a atuação do Poder Publico local na recuperação de sua dimensão de governo, como representante da cidade e com maximização de sua eficiência e eficácia administrativa." (COGEP, 1980, p.22)

São elas: 1. Organização e participação;

2. Descentralização participativa; 3. Nova postura do poder local; 4. Prioridade para as áreas críticas; 5. Reatualização da maquina administrativa; 6. Nova concepção de peças orçamentárias; 7. Produção do serviço coletivo com nova ótica social; 8.Critérios e padrões de atendimento; 9. Recursos humanos; e 10. Estudo sistemático da cidade. (COGEP, 1980, p.22-28)

Segundo Campos Filho,

O documento Política Global de Desenvolvimento Urbano e melhoria da qualidade de vida, de 1980, inaugurou uma nova visão do planejamento urbano focado no legado da desigualdade e dos mecanismos de sua produção, não apenas devido às políticas macroeconômicas, mas destacando os mecanismos relacionados à própria produção, apropriação e consumo do espaço urbano. Enfatizando as reações políticas envolvidas no processo, mostra as implicações institucionais de uma reestruturação administrativa para se alcançar os objetivos 
de dar voz e poder decisório às populações que têm sido excluídas dessa dinâmica em São Paulo. Destaca ainda, nesse processo de produção do espaço urbano, o papel central da especulação imobiliária, supervalorizando a área central, atraindo investimentos públicos rarefeitos no tecido urbano das áreas periféricas, produzindo um encarecimento dos serviços públicos e agravando a herança histórica dos déficits sociais. (informação verbal) ${ }^{68}$

Em 1981, na gestão do então prefeito Olavo Setúbal, tendo com o urbanista Campos Filho como Secretário Municipal de Planejamento Urbano, foi criada, através da lei n. 9300, a Zona Leste Industrial, com o propósito de gerar cerca de cem mil empregos ao longo da Estrada do Pêssego, coincidindo em grande parte com a área da Operação Urbana Consorciada Rio Verde-Jacu. (SEMPLA) ${ }^{69}$

\section{A Zona Leste à época apresentava ainda grandes} glebas rurais e pode receber assim o distrito industrial, mas a geração de empregos pretendida não ocorreu, pois a iniciativa atraiu poucas indústrias uma vez que não veio acompanhada de uma política adequada de transporte público e circulação intraurbanos além de melhor conexão do distrito industrial criado com o a região do $A B C D$, o Porto de Santos e com o Aeroporto de Guarulhos. A localização da Zona Industrial Leste não era atendida pela Linha Leste do Metrô, que ainda hoje se extende somente um pouco além da Estação Itaquera. A antiga ferrovia Central do Brasil, pertencente ao conjunto de sistemas de trens da RMSP, operados pela CBTU, hoje pertencente à CPTM também serve a região com seus trens de passageiros que vêm sendo transformados gradativamente em metrô de superfície, recentemente criando linhas paralelas expressas e, com isso, adotando as diretrizes preconizadas por Campos Filho de acréscimo de capacidade à medida que a demanda aumente a um custo muito baixo. Sem ligações rodoferroviárias com capacidade de suporte adequada, a logística à época era ineficiente, comprometendo a produção industrial e desestimulando a implantação de indústrias em maior número e com maior capacidade de absorção da mão de obra local.

O Mapa 33: Diretrizes de Estrutura Urbana é a representação gráfica das diretrizes propostas pela Série Políticas Globais, da COGEP. Numa rápida análise do mapa e de sua legenda, vê-se que não era esperado, em 1980, que as áreas de mananciais fossem ocupadas da forma precária como hoje estão. (cor marrom) A intenção, verificada pelo mapa, era de bloquear, nas áreas de mananciais, a urbanização. Mas, sabe-se que a ocupação dessas áreas às margens das represas já tem mais de vinte anos. Nas áreas periféricas, (cor roxa) a intenção era controlar e estruturar a expansão urbana.

\section{PLANO DIRETOR DO MUNICÍPIO DE SÃO PAULO 1985/2000}

Produzido em 1985 pela Prefeitura Município de São Paulo na gestão de Mário Covas, o Plano Diretor do Município de São Paulo foi desenvolvido pela Secretaria Municipal do Planejamento, com o arquiteto e urbanista Jorge Wilheim como Secretário Municipal do Planejamento e entregue ao final desse período. Não será detalhado aqui por não ter sido implantado de forma estruturante, pois não foi adotado por esse prefeito e pelos seguintes.
68. Campos FILHo. Depoimento à autora, 5 maio 2012.

69. A lei n. 9300 , de 24 de agosto de 1981, reorientou a ocupação da zona rural leste e oeste, propondo a sua divisão em cinco tipos (Z8100/1, Z8-100/2, Z8-100/3, Z8$100 / 4$ e Z8-100/5), com normas de Uso e de Ocupação do Solo que introduzem uma transição entre o uso urbano e o rural. Esta lei alterou as características da zona de uso Z7, criando parâmetros urbanísticos para essa nova zona de predominância industrial, cuja localização na Zona Leste tem por objetivo propiciar o aumento da oferta de emprego junto ao grande número de habitação popular, na sua maior parte implantado pela Companhia de Habitação de São Paulo-COHAB. (Sempla. Disponível em <http:// www.prodam.sp.gov.br/sempla/ zone.htm>. Acesso em 12 jun. 2013. 


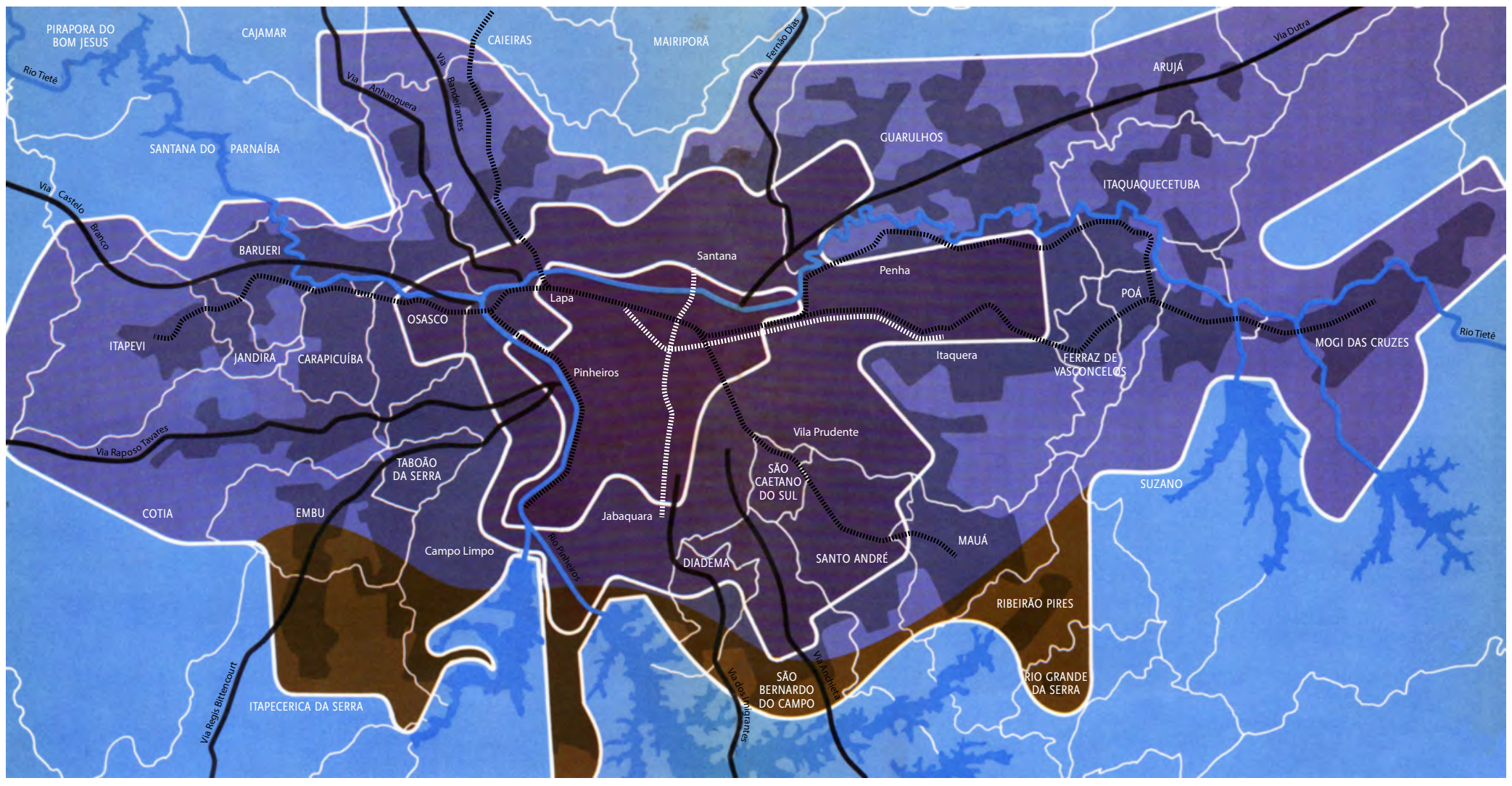

Área central controlar a verticalização manter a acessibilidade

Área intermediária completar a urbanização área preferencial de adensamento

Área periférica controlar e estruturar a expansão urbana

Área a bloqear a urbanização

Mancha urbana em 1977

Limite de município

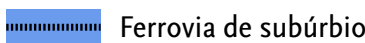

Metrô

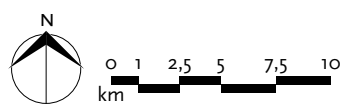

Mapa 33: Diretrizes de Estrutura Urbana

COGEP, Série Políticas Globais, 1980 


\section{PLANO DIRETOR ESTRATÉGICO PARA O MUNICÍPIO DE SÃO PAULO 2002/2012}

O ano de 2001 pode ser considerado como um marco para o urbanismo brasileiro. Foi em 10 de julho daquele ano que, após mais de dez anos de esforços de especialistas e políticos, finalmente se aprovou o Estatuto da Cidade, ${ }^{70}$ lei federal que tem por objetivo principal o resgate da função social da cidade conjuntamente com o da função social da propriedade de fins urbanos e, por consequência, o combate à especulação imobiliária, tanto a referente à constituída pela retenção especulativa dos vazios urbanos e outros conflitos urbanos característicos das metrópoles brasileiras. (GrazIA, 2002 apud OsÓRIO, 2002, passim)

Campos Filho teve importante participação na proposição e desenvolvimento do Estatuto da Cidade:

Um foco muito importante a ser ressaltado refere-se ao papel atribuído pela Constituição Federal ao Plano Diretor, de fazer com que a cidade e a propriedade para fins urbanos cumpram uma função social. O Estatuto da Cidade veio desenvolver os instrumentos com esse objetivo como alguns já predefinidos na mesma constituição como a urbanização compulsória, o IPTU progressivo no tempo e a desapropriação com títulos da dívida pública como punições aos proprietários que retenham sem uso minimamente adequados imóveis para fins urbanos visando obter valorização especulativa imobiliária. (informação verbal) ${ }^{71}$

\section{O Estatuto da Cidade vem como regulamenta-} dor dos "diversos instrumento de política urbana, vinculando-os ao Plano Diretor, bem como estabeleceu normas para sua elaboração participativa." 0 Estatuto da Cidade tem por objetivo também combater outros conflitos urbanos quanto à habitação popular no que se refere a sua sistemática localização em áreas de risco e em assentamentos ilegais as deficiências crônicas de saneamento básico, as enchentes periódicas prejudiciais a saúde e produtoras de perda de vidas, assim como de tempo por decorrentes congestionamentos e de bens patrimoniais e a ocupação urbana de áreas a serem protegidas de mananciais de água, característicos das metrópoles brasileiras. Assim, torna-se uma causa política fundamental do país a retomada de um planejamento urbano que contribua finalmente para solucionar essa problemática social de dimensões nacionais. (PDE 2002/2012, 2004, p.7)

O jurista e urbanista Edésio Fernandes sintetiza a lei com ênfase na questão da regularização fundiária, mas, como vimos, ela visa um objetivo muito mais amplo do que isso:

A nova lei tem quatro dimensões fundamentais, quais sejam: consolida um novo marco conceitual jurídico-político para o Direito Urbanístico; regulamenta e cria novos instrumentos urbanísticos para a construção de uma ordem urbana socialmente justa e includente pelos municípios; aponta processos políticos-jurídicos para a gestão democrática das cidades; e propõe instrumentos jurídicos para a regularização fundiária dos assentamentos informais em áreas urbanas municipais. (FERNANDES, 2002 apud Osório, 2002, p.8)

Assim como regulamentado pelo Estatuto da Cidade, a SEMPLA desenvolveu, com o arquiteto e urbanista Jorge Wilheim ${ }^{72}$ como Secretário Municipal do Planejamento, durante a gestão de Marta Suplicy, o novo Plano Diretor, o Plano Diretor Estratégico para o Município de São Paulo-PDE, aprovado pela lei n. 13.430 em 2002, retomando o planejamento urbano da metrópole de forma
70. Brasil. Lei n. 10.257, de 10 de julho de 2001. Estatuto da Cidade.

71. Campos Filmo. Depoimento à autora, 12 mar. 2013.

72. que publicou o já mencionado livro sobre a situação urbana da metrópole paulistana em 1965 , pouco antes da publicação do PUB para São Paulo WILHeIM, Jorge. São Paulo Metrópole 65: subsídios para seu plano diretor. São Paulo: Difusão Europeia do Livro, 1965. 
mais consistente do que vinha sendo praticado.

Aprovaram-se também as primeiras Operações Urbanas Consorciadas-OUC.

\section{PDE 2002/2012 SEGUNDO SEUS FORMULADORES}

Segue nota dos editores do PDE 2002/2012:

Este Plano Diretor Estratégico, inspirado pelos precedentes instrumentos democráticos e conscientes de que só mediante um pacto social se pode chegar à legitimidade por ele requerida, apresenta-se aqui como a grande fonte de informações sobre a cidade de São Paulo, que continua crescendo com a mesma energia do século XX. Para que desse crescimento se obtenha o melhor e se evite o pior, eis um documento imprescindível.

O Plano Diretor Estratégico para São Paulo de 2002/2012, segundo o urbanista Jorge Wilheim, Secretário Municipal de Planejamento Urbano na época da publicação do plano, considera que:

A aprovação do Plano Diretor Estratégico do Município de São Paulo em 2002 significou imenso avanço para a concretização das diretrizes de política urbana exemplares, despertando o interesse nacional e internacional. Até o momento, o público carece de uma publicação que explicite o processo e o produto resultante da implementação do planejamento urbano na gestão de São Paulo, quarta maior cidade do mundo.

(...) Ao manter uma visão generosa de São Paulo, o plano é ' 'diretor,' com metas de longo prazo (dez anos), e também 'estratégico,' com metas de curto prazo." Apresenta muitas inovações: permite a transferência de potencial construtivo de áreas de preservação para outras; cria dois níveis para o Coeficiente de Aproveitamento do solo (o básico e gratuito e o máximo, alcançável mediante outorga onerosa); prevê e provê, ao criar um fundo com os recursos orçamentários da outorga onerosa, destinado a melhorias urbanas; estimula o adensamento em áreas de intervenção lineares ou polares, notadamente no entorno das estações de transporte de massa; fornece critérios de zoneamento que consideram a cidade real e promove uma mistura de usos e atividades de molde a diminuir o custo do solo e a permitir menores distâncias na circulação de pessoas; define e localiza operações urbanas; cria um sistema permanente de planejamento do qual fazem parte conselhos de política urbana; gera planos de nível inframunicipal: o das Subprefeituras e finalmente o dos bairros.

O método de debate foi igualmente inovador. Após quarenta debates e ampla participação, podemos afirmar que, além dos sucessivos aperfeiçoamentos do texto, gerou-se uma "pedagogia da cidadania." Na sequência, a elaboração, o debate e a aprovação dos 31 planos das Subprefeituras e do zoneamento aprofundaram consideravelmente esse processo democrático de elaboração, sem perder a criatividade e a precisão técnica das propostas urbanísticas. (...) Considerando a natureza dos cidadãos e entidades participantes e interessados nesse processo de elaboração do Plano, assim como a diferença de interesses legítimos, por vezes conflitantes, o público alvo do presente texto é necessariamente diversificado. Entretanto cremos que os leitores terão em comum a consciência da importância de construir cidades justas e um desenvolvimento que implique qualidade de vida para todos. (WILHeIM em PDE 2002/2012, 2004, p.11)

Segundo análise de Campos Filho,

Como o citado Plano Diretor aprovado pela lei n. 13.430 de 2002 na verdade constituiuse quase apenas de conteúdos próprios de uma Política de Desenvolvimento Urbano, ficou para a lei n. 13.885 de 2004, dita complementar, a definição dos instrumentos indutores da reestruturação urbana. Essa lei, no entanto, instituiu alguns desses instrumentos, como a outorga onerosa do direito de construir, deixando para posterior definição o IPTU progressivo no tempo sobre 
imóveis subutilizados, o que ocorreu em 2011, por iniciativa do vereador José Police Neto. (informação verbal) ${ }^{73}$

Em 2004, o PDE sofreu sua primeira revisão e outra está em andamento sendo que se anuncia será levada a efeito durante o ano de $2013 .{ }^{74}$

\section{O Plano Diretor Estratégico aprovado em 2002} pela lei n. 13.430 não menciona os Planos de Bairro. Segundo Campos Filho, "como na verdade se trata de uma política de desenvolvimento urbano não é de estranhar essa omissão." É na lei n. 13.885, dita complementar ao Plano Diretor, mas que entendemos seja o embrião do Plano Diretor como já exposto acima, que é como pormenorização dos Planos Regionais que os Planos de Bairro são mencionados. As Operações Urbanas que exigem Planos Urbanísticos para serem implantadas, o que é outro tipo de plano local para isso definido. (informação verbal) ${ }^{75}$

Em função da proposição nesta tese de um plano de reestruturação de uso e ocupação do solo ser coordenada com uma política pública de reestruturação do sistema de transporte público, foi importante apresentar o Mapa 34: Rede Viária Estrutural (p.122), pertencente ao conjunto de mapas do PDE SP 2002/2012, destacando a Zona Leste de São Paulo, as vias estruturais existentes e os sistemas de transporte público, como corredores de ônibus planejados. Esta diretriz é uma das poucas definições próprias de um Plano Diretor que consta da lei n. 13.430 que o instituiu. Porém, como comentaremos mais adiante, tal diretriz não fez parte de um conjunto integrado de diretrizes de Uso do Solo, Transportes e Habitação. ${ }^{76}$

Vale para as diretrizes correspondentes ao transporte coletivo a mesma observação feita aqui para as do sistema viário. Desde logo se deve chamar a atenção para o fato de que um planejamento de transportes abrange muito mais questões do que a definição de traçado rodoviário e de linhas de transporte público, que em parte usam o mesmo sistema viário que os veículos sobre pneus como no caso do Município de São Paulo e, em parte sobre trilhos. A definição da dosagem desejada entre os diversos tipos de transporte é fundamental e para isso as tarifas e instrumentos de indução do transporte coletivo tem que ser discutidos e definidos como, aliás, vem acontecendo com o rodízio e os controles da intensidade do tráfego de veículos, questões básicas para a definição de diretrizes de transporte e uso do solo nas dimensões locais do objeto desta tese para a Região Leste 2. Nessa ordem de considerações e observando-se o mapa em escala maior é possível ver que o desenho de vias planejadas atravessa por vezes o traçado viário existente sem qualquer critério, entrando em conflito com o tecido urbano existente.

\section{As Centralidades Urbanas no PDE 2002/2012}

Como visto no Capítulo II, a estruturação da Região Metropolitana de São Paulo, a sua respectiva formação de vilas e bairros e centralidades locais e regionais, se deveu ao surgimento de caminhos e ferrovias de ligação regional entre o Centro Histórico e os municípios localizados ao redor da capital da província. Entre os caminhos e ferrovias em direção ao litoral do Estado, onde estava o Porto de Santos, e os caminhos e ferrovias que ligavam São Paulo ao Rio de Janeiro, onde estava a capital do país em meados do século XIX, cresceu o tecido urbano da Região Leste de São Paulo. Ao longo da primeira metade do século $X X$, outras vias surgiram
73. Campos Filho. Depoimento à autora, 12 mar. 2013.

74. É opinião de Campos Filho que a lei n. 13.430 deve ser vista como a que formulou a Política de

Desenvolvimento Urbano orientadora do Plano Diretor propriamente dito, como exige a Constituição Federal em seu artigo 182. O Plano Direto deve ser entendido, segundo ele, como a conjunção de vários planos setoriais como o do Uso do Solo definido em parte importante pela legislação urbanística (o macro e o microzoneamento e o código de edificações), pelo plano de transporte, pelo plano habitacional e pelo plano de saneamento básico, pelo menos Também devem constitui-lo os demais planos setoriais (educação, saúde, cultura, esportes, lazer), demandas crescentes da sociedade civil, com participação democrática para definição de prioridades. Aos Planos de Bairro constitui importante acréscimo como melhor se definirá adiante. A lei n. 13.885 deve ser entendida como um embrião de um plano diretor, ainda incompleto para ser encaminhado aos três níveis de governo em ação entrelaçada na solução progressiva dos principais problemas da cidade e da metrópole, com prazos e recursos estimados de investimento e custeio. Assim, vejamos o que o chamado PDE e lei complementa definem para a RLP. CAMPOS FILHO. Depoimento à autora, 5 mar. 2013.

75. Campos Filmo. Depoimento à autora, 5 mar. 2013.

76. O PDE limitou-se a exigir que tal integração fosse desenvolvida pelos órgãos de planejamento atuantes sobre a cidade (estaduais e municipais) e aprovada pela lei complementar, o que não ocorreu, pois a lei n. 13.885/2004 que teria de aprovar esse planejamento integrado repetiu a mesma exigência e, portanto, postergando-a sem que nenhum outro prazo fosse definido. Desse modo, até o momento desta tese, tal estudo integrado não foi apresentado à Câmara Municipal para deliberação, o que pode ocorrer na próxima revisão do $\mathrm{PDE}$, cuja validade expirou em 31 de dezembro de 2012 como estipulado pela lei inicial de 2002, ou seja, um prazo de vigência ou horizonte de planejamento de dez anos. Campos Filho. Depoimento à autora, 12 mar. 2013. 


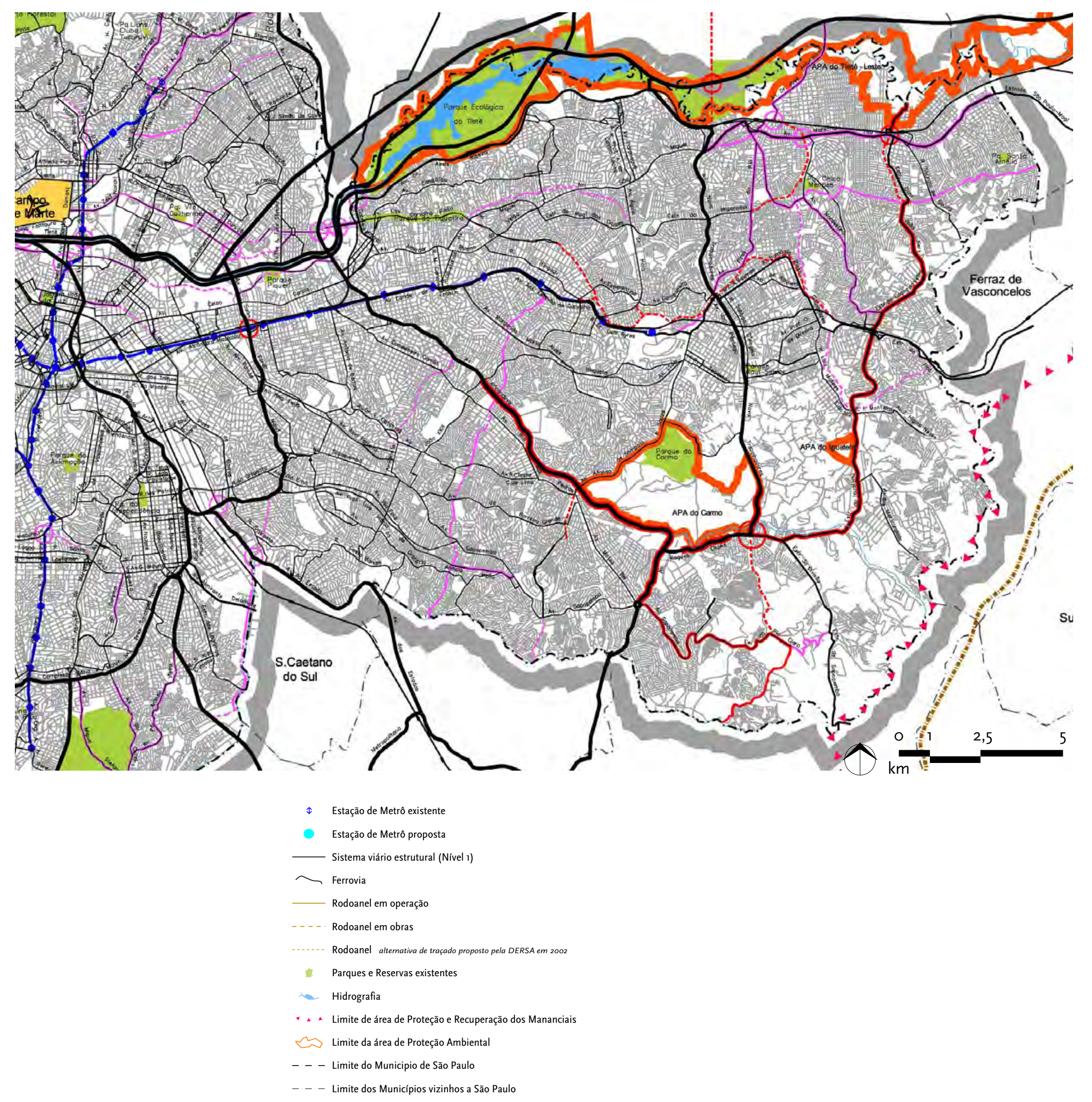

Mapa 34: Rede Viária Estrutural

PDE 2002/2012, Mapa 2 (det.) 


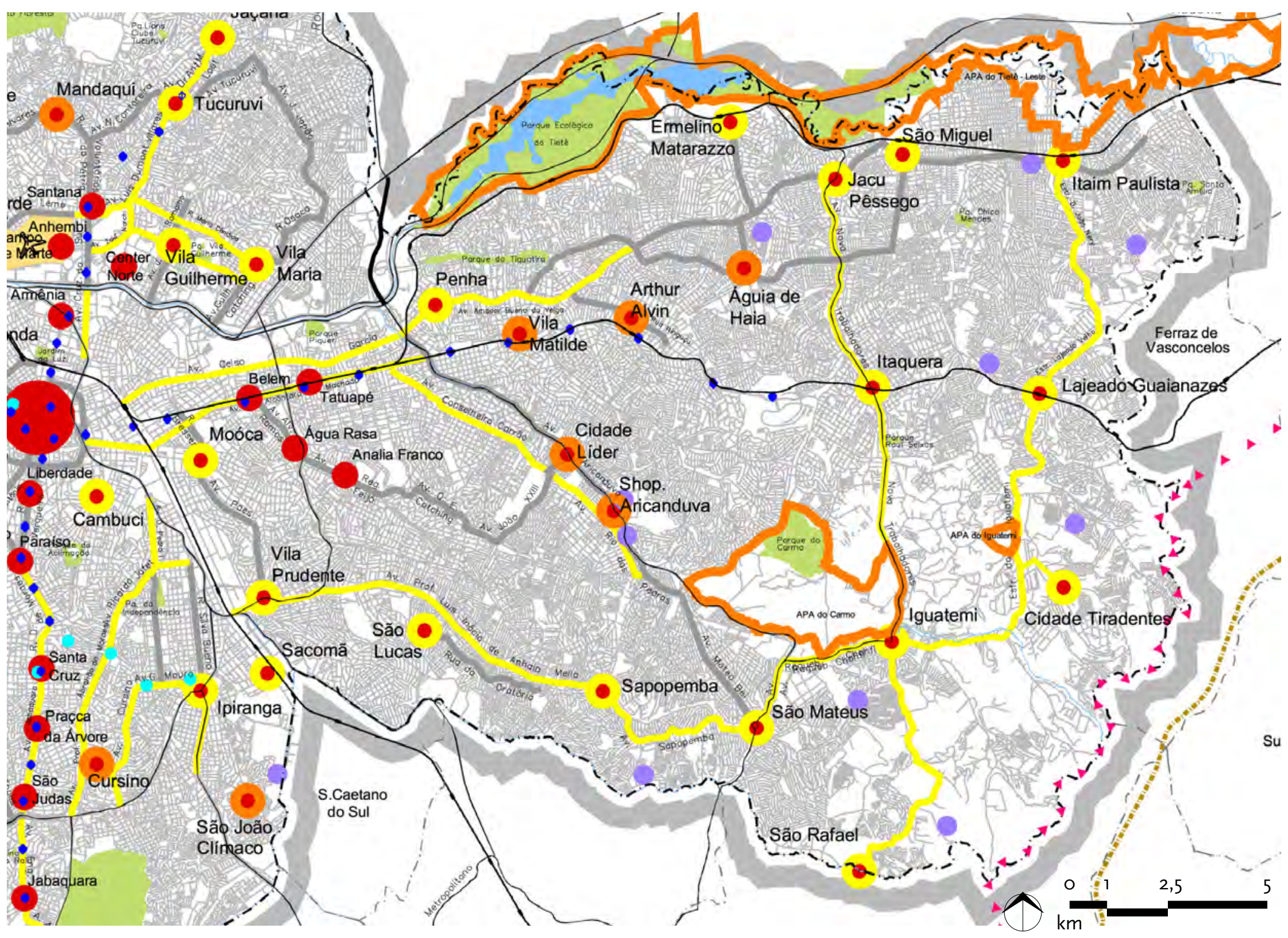

Centralidades Polares existentes estações, terminais e grandes estabelecimentos

- Centralidades Polares existentes a qualificar 2006

- Centralidades Polares existentes a qualificar 2012

- Centro de Educação Unificado-CEU

1. Parques e Reservas existentes

- Hidrografia

- $\Delta$ Limite de área de Proteção e Recuperação dos Mananciais

Limite da área de Proteção Ambiental

- - - Limite do Municipio de São Paulo

- - - Limite dos Municípios vizinhos a São Paulo

\begin{tabular}{|c|c|}
\hline \multicolumn{2}{|c|}{ Centralidades Lineares existentes vias estruturais e coletoras } \\
\hline $\begin{array}{l}\text { Av. Amador Bueno da Veiga } \\
\text { Av. Celso Garcia } \\
\text { Av. Conselheiro Carrão } \\
\text { Estr. D. João Nery } \\
\text { Estr. do Iguatemi } \\
\text { Estr. Lajeado Velho }\end{array}$ & $\begin{array}{l}\text { Av. Prof. Luis Inácio de Anhaia Mello } \\
\text { Av. Nova Trabalhadores } \\
\text { Av. Ragueb Choh fi } \\
\text { Av. Rio das Pedras } \\
\text { Av. Sapopemba }\end{array}$ \\
\hline Centralidades Lineare & \\
\hline $\begin{array}{l}\text { Av. Águia de Haia } \\
\text { Av. Alvaro Ramos } \\
\text { Av. Aricanduva } \\
\text { Rua Bresser } \\
\text { Av. Dr. Eduardo Cotching } \\
\text { Estr. do Imperador } \\
\text { Rua Itinguçu } \\
\text { Av } \text { ão XX|| }\end{array}$ & $\begin{array}{l}\text { Rua Mateo Bei } \\
\text { Estr. Mogi das Cruzes } \\
\text { Rua do Oratório } \\
\text { Av. Paes de Barros } \\
\text { Av. Pires do Rio } \\
\text { Av. Regente Feijó } \\
\text { Av. São Miguel }\end{array}$ \\
\hline
\end{tabular}

Mapa 35: Centralidades Polares e Lineares na RLP PDE 2002/2012, Mapa 4 (det.) 
e definiram os limites da capital do Estado com os municípios a leste desta.

Os sistemas rodoferroviários são indutores do crescimento urbano e, a partir daí, possibilitam o surgimento de centralidades, vias ou estações de embarque concentradoras de serviços e comércio diversificados. Centralidades são decorrentes da acessibilidade oferecida pelas vias estruturais em seus três tipos hierárquicos e pelas vias coletoras, onde se concentram serviços e comércio diversificados sofisticados ou especializados. As centralidades podem ser do tipo linear, quando esses serviços e comércio se encontram ao longo de um via urbana, ou do tipo polar, quando estes se concentram entorno de uma estação de transbordo de um sistema de transporte público de qualquer modal: metrô, trem metropolitano ou terminal de ônibus ou no cruzamento de duas vias.

A Região Leste conta com centralidades lineares e polares surgidas a partir da estruturação metropolitana estudada por Langenbuch como as avenidas Celso Garcia e Amador Bueno, ambas em continuidade à Rangel Pestana; rua do Gasômetro, avenidas Alcântara Machado, Mateu Bei, Carrão e Aricanduva; avenida Sapopemba, estrada do Pêssego e Nova Trabalhadores que juntas formam a avenida Jacu Pêssego-Nova Trabalhadores, dentre outras localizadas nos distritos do extremo leste e que constaram no PDE 2002/2012 como centralidades a dinamizar, como a estrada do Iguatemi, estrada do Lajeado Velho e estrada D. João Nery.

O Mapa 35: Centralidades Polares e Lineares na RLP (p.123) apresenta os dois tipos de centralidades, existentes e planejadas: centralidades polares, em torno de estações de transbordo de sistemas de transporte público e, centralidades lineares, ao longo de vias estruturais existentes. A legenda pressupunha para o ano meta de 2012 os seguintes cenários: 1. Centralidades Polares Existentes; 2. Centralidades Polares Existentes a Qualificar em 2006 e 2012; 3. Centralidades Lineares Existentes e, 4. Centralidades Lineares a Dinamizar, estas sem ano meta declarado. A readequação dos usos ao longo delas estimulará a chegada de outros estabelecimentos de serviços ou comércio diversificados e até especializados. A proposta de centralidades novas e existentes já incluía a nova avenida JacuPêssego-Nova Trabalhadores, mas ainda não previa na edição do mapa a criação da Operação Urbana Consorciada Rio Verde-Jacu, na Região Leste 2.

\section{A MOBILIDADE URBANA EM SÃO PAULO}

A tendência de implantação de grandes obras viárias para transporte público dentro e fora do centro expandido apresentada nos planos analisados até agora, em muito colaborou com o comprometimento da mobilidade urbana, principalmente a do habitante da cidade enquanto escala do pedestre, do ciclista e mesmo do motociclista, como hoje se percebe nitidamente. Com essa postura de planejamento e projeto seccionando o espaço urbano e dificultando as interligações entre os usos existentes ou por existir entre os seus dois lados, deixa para trás fragmentos de cidade sem definição clara e inúteis como espaços de lazer, descanso, de produção e trocas culturais ou, dito de outro modo, de convivência social produtiva. E a urbanidade do espaço, vista como sua capacidade de promover encontros sociais, vai sendo destruída paulatinamente, com um acréscimo do número de veículos 
sem proporção com a capacidade rodoviária, dando razão as criticas de Appleyard e Gehl.

A opção pelo modelo de transporte urbano sobre rodas definida na década de 1930 impôs ao nosso tempo presente um cotidiano muito dependente do transporte individual, desvinculado do transporte público, ou seja, os dois sistemas não se relacionam como deveriam, comprometendo a mobilidade e dificultando a possibilidade de convivência urbana. O uso prioritário do automóvel e o volume atual da frota de veículos existente em São Paulo e em outras metrópoles brasileiras produzem congestionamentos diários inaceitáveis, que comprometem a qualidade ambiental, a qualidade de vida e a economia da cidade.

Enquanto os investimentos públicos em infraestrutura eram destinados às regiões centrais de São Paulo, estas concentravam os postos de trabalho tanto para trabalhadores mais especializados quanto para trabalhadores de nível médio. Com a saída das indústrias, o setor de serviços se fortalece, gerando mais deslocamentos pendulares a longas distâncias entre periferias e centro.

Os investimentos fora do eixo centro-sudoeste se restringiram a habitação popular de produção doméstica ou autoconstruída em loteamentos irregulares ou por ocupação de terrenos públicos e privados. Destas, é mais comum a ocupação de terrenos ditos "da Prefeitura," que são, na verdade, ๙ do povo," obtidos através da doação obrigatória dos loteadores, resultando em uma inserção inadequada बु os conjuntos habitacionais de produção pública, a grandes distâncias na periferia urbana.

Aumentar as opções do morador de modo que esse cidadão possa caminhar por seu bairro, em direção ao trabalho, à escola ou pontos de lazer, deve ser um objetivo a ser perseguido.

Caminhar é a atividade mais importante da cidade. (...) Tanto pelo lado cultural, como pela sustentabilidade. (...) É por isso que Nova York é uma cidade vibrante. (...) O espaço público é importante para construir confiança entre as pessoas de todas as classes e etnias. (...) Quando toma a decisão de colocar o pedestre em primeiro lugar, você adota um ponto de vista. Você vê os problemas através dos olhos de um cidadão caminhando pela rua. (...) O muro da rua tem que ser feito do tecido dos prédios, com lojas no térreo, janelas nos primeiros andares. É preciso sentir que as extremidades da rua estão abertas para você. E que as pessoas estão olhando para você. (Alexandros Washburn em CASTRO, 2011, P.2)

\section{O CIDADÃO PAULISTANO A CAMINHO DO TRABALHO}

O panorama da mobilidade urbana avistado na metrópole de São Paulo é bem diferente do que seria adequado, a começar do fato de não se ter uma estação de Metrô a cada oitocentos metros de distância entre uma e outra, no máximo, de acordo com exemplos encontrados em cidades sem graves problemas de mobilidade. Paris tem uma estação de Metrô a cada quinhentos metros mas, em São Paulo, elas se apresentam com até dois quilômetros distância entre uma e outra, como no caso das estações Butantã e Morumbi, da Linha Amarela. Com a supressão da Estação Três Poderes, por exigência da comunidade de alta renda local, a distância a se percorrer caminhando entre essas duas estações será
FIGURA 68: ACESSO À Estação do Metrô Vergueiro boas condições de mobilidade, sem confilitos com grandes elementos estruturais de circulação
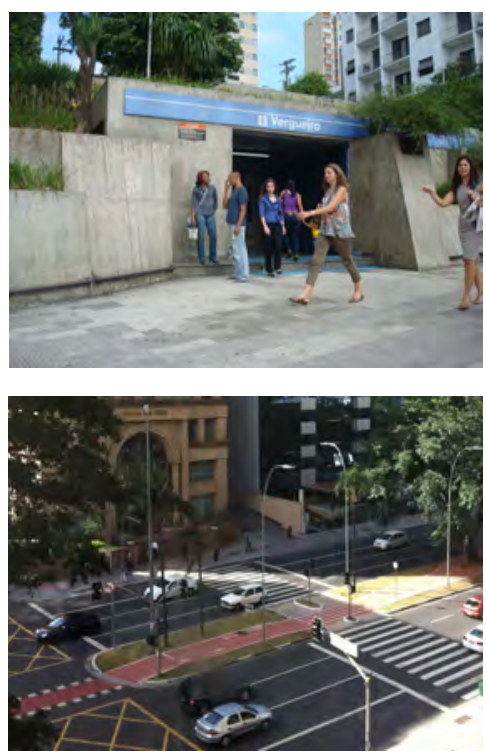

FIGURA 69: CICLOVIA NA Av. FARIA LIMA 

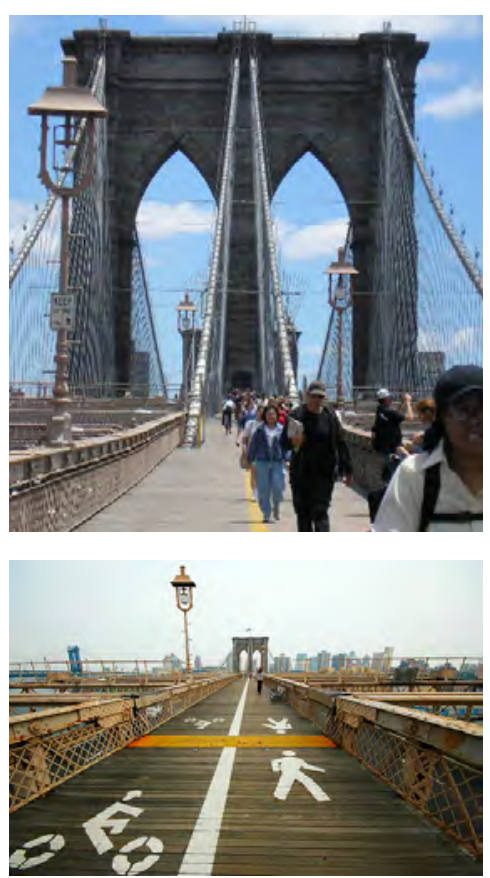

FIGURAS 70 E 71: FAIXAS

EXCLUSIVAS PARA PEDESTRES E PARA CICLISTAS NA BROOKLIN BRIDGE, NOVA YORK

o projeto previu a separação de autos, bicicletas e pedestres, de modo que toda a circulação ocorra em segurança

77. A falta de cultura no uso da bicicleta se reflete inclusive na escala da arquitetura, pois a estrutura interna dos edifícios é despreparada para receber os usuários de bicicletas. (armários permanentes, banheiros e paraciclos suficientes)

78. O trecho sul-oeste, ou "Ciclofaixa entre Parques," interliga os Pqs. do Povo, do Ibirapuera, das Bicicletas, Villa-Lobos e futuro Pa. Clube do Chuvisco $(22,5 \mathrm{~km})$. O trecho norte $(8,5 \mathrm{~km})$, liga a Praça Heróis da FEB à estação Parada Inglesa. O trecho leste $(14 \mathrm{~km})$ está implantado ao longo da Av. Gov. Carvalho Pinto, onde se situa o Parque Linear Eng. Werner Zuluaf-Tiquatira. N Av. Paulista, a Ciclofaixa liga a R. Consolação à Pça. Osvaldo Cruz. Esse trecho é interligado ao Centro através do eixo Vergueiro-Liberdade onde o percurso passa por pontos turísticos históricos. Na Região Sul, o trajeto até a região do Ibirapuera é feito a partir do eixo VergueiroDomingos de Morais-JabaquaraIndianópolis (19,2 km) passando pelo Pq. das Bicicletas. Disponível em: <http://www.ciclofaixa.com.br/ circuitos/>. Acesso em 8 jun. 2013 de 2700 metros, aproximadamente. Entre as Estações

Vila Sônia e Morumbi, ambas em construção, a distância a percorrer será de 1400 metros aproxima damente. Nem todos os trechos das linhas de Metrô em São Paulo apresentam essas grandes distâncias entre uma estação e outra. Na Linha Azul, primeira linha de metrô inaugurada em São Paulo, há somente quinhentos metros entre as estações Sé e Liberdade, dentre outros exemplos.

Nas metrópoles, a construção de sistemas viários para transporte de massa de grande porte, de superfície ou aéreos, pode gerar grandes distâncias a serem percorridas entre os acessos a locais de transbordo passando pelo cruzamento de vias ou alças de passarelas para transposição de vias ou ferrovias etc., além do limite aceitável para o pedestre, seja este saudável, idoso ou portador de necessidades especiais. Hoje no Brasil tardiamente, a necessidade de atendimento às normas de acessibilidade amparadas por leis municipais, estaduais e federais não é somente uma formalidade na aprovação de projetos de edificações em geral. Trata-se de uma conscientização de que pessoas portadoras de necessidades especiais e mobilidade reduzida fazem parte da sociedade brasileira em qualquer faixa da população, apenas não estavam, até há pouco tempo, devidamente inseridas no contexto em instalações públicas e semipúblicas, que devem receber adequadamente todo cidadão em seu direito de ir e vir adotando uma cultura da acessibilidade geral e irrestrita.

Nos últimos anos tem havido, por parte de algumas esferas da administração pública, o apoio ao ciclismo, inicialmente como prática de lazer, mas que tem recebido investimentos e implantação de infraestrutura para que se concretize como meio alternativo de transporte individual, o que tem gerado polêmica sobre a falta de segurança para ciclistas em uma cidade consolidada.77 Ciclovias, denominação dada às faixas permanentes, estão sendo aos poucos implantadas em toda a mancha urbana, algumas delas com destacada qualidade de projeto, como a ciclovia da avenida Faria Lima, na Região Oeste da cidade, como mostra a Figura 69: Ciclovia na Av. Faria Lima (p.125). Nessa via, um proejto de requalificação urbana implantou a ciclovia no canteiro central da avenida, preservando as calçadas, que foram adequadas à acessibilidade de pessoas com necessidades especiais, como piso tátil, rebaixamento do meio fio para acesso de cadeirantes além de outros detalhes pertinentes ao tema. Existem outras ciclovias na cidade de São Paulo, sendo que seu último e maior trecho, inaugurado em 2012, possui trinta quilômetors e interliga a ciclovia do rio Pinheiros com a ciclovia Parque Praia São Paulo, que contorna a Represa de Guarapiranga, no extremo sul da cidade. Existem também ciclofaixas não permanentes demarcadas no asfalto e liberadas aos ciclistas aos domingos e dias festivos, para lazer da população..$^{78}$

Nas Figuras 70 e 71: Faixas exclusivas para pedestres e para ciclistas na Brooklin Bridge, Nova York (p.126), EUA, observa-se um bom exemplo de projeto de acessibilidade, mobilidade e qualidade urbana em fins do século XIX: vias separadas para autos e vias para ciclistas, carrinhos de bebê e pedestres, com locais para descanso e contemplação.

Já na recente Ponte Octavio Frias Oliveira, mais conhecida como Ponte Estaiada, ligação entre a avenida Roberto Marinho (antiga Água Espraiada) e a Marginal Pinheiros, fica patente a irrelevância do pedestre e do ciclista no projeto, que têm ali 
circulação proibida, em favor do transporte privado, como mostra a Figura 73: Sinalização no acesso à ponte estaiada (p.127). Tampouco serve aos meios de transporte públicos. Comparada à Ponte do Brooklin, a Ponte Estaiada é uma prova de que, no século XXI, em São Paulo, ainda se privilegia o uso do automóvel numa cidade com cada vez menos poder de comportá-lo da forma como tem sido utilizado: como alternativa cotidiana a um sistema de transporte público com capacidade aquém do necessário. Se cidadãos não proprietários de automóveis particulares tivessem sido considerados no projeto dessa ponte, trabalhadores moradores do conjunto habitacional Cingapura existente do lado oposto do rio Pinheiros e em frente ao grande polo de empregos que é o entorno da avenida Luis Carlos Berrini, na região sul de São Paulo, poderiam optar por simplesmente caminhar até seu local de trabaIho, economizando tempo, dinheiro e ganhando em saúde e qualidade de vida.

As vias tradicionais, no geral implantadas pelo loteador, que, durante a observação in loco inicial, demonstraram que, apesar de sobrecarregadas de veículos particulares e de transporte coletivo, ainda representam espaços mais respeitosos à escala humana, onde o indivíduo circula por trechos menores entre seus objetivos de consumo, transbordo ou parada para descanso. A apropriação da via, da rua como espaço de convívio visando o encontro com troca cultural, de lazer e de contemplação deve continuar fazendo parte de nossa cultura e ser também uma prolongação do espaço de morar, segundo Jacobs, Gehl e Appleyard.

No contraponto, quando os sistemas construtivos mais utilizados para a implantação de transporte

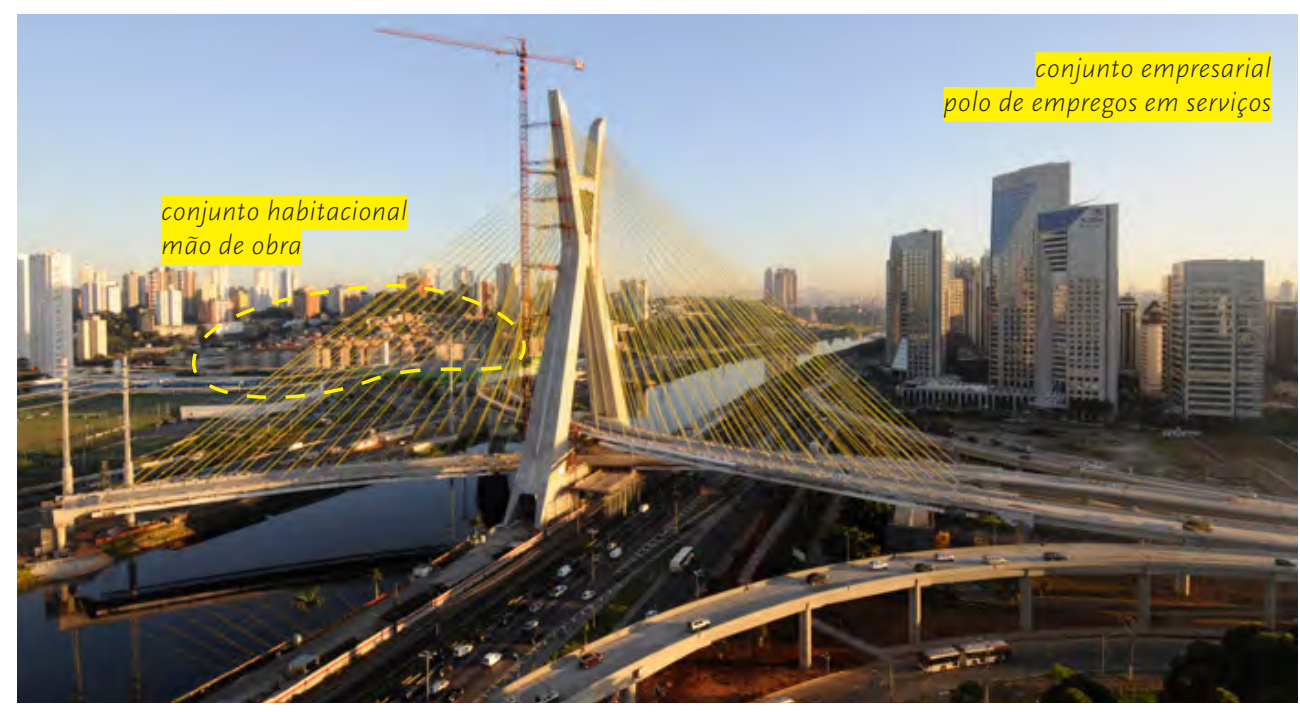

público de massa ocorrem na forma de grandes estruturas aéreas de concreto, provocam um conflito de escala entre a arquitetura monumental de algumas estações de transbordo e a humana, do habitante da cidade, que se torna ator secundário, perdendo importância para o pragmatismo de se ter um grande volume de pessoas embarcadas por minuto. Sistemas rodoferroviários de grandes proporções vêm cada vez mais gerando conflitos entre sua escala e a escala humana do cidadão caminhante ou do que se locomove sobre duas rodas, e impossibilitam quase totalmente a opção pelo pedestrianismo, especialmente por parte das camadas de baixa e média renda, embora todos sejam afetados por essa condição urbana.

Ainda, em São Paulo, o usuário dos grandes sistemas de transporte público circula entre um ponto de embarque e outro dirigido por passarelas, alças, passagens sob as estruturas de concreto de suporte para linhas de metrô aéreo, isto somado aos tempos de semáforos cada vez mais curtos ao cruzar largas avenidas. Nas vias expressas, esse "efeito barreira," como é denominado tecnicamente por seus estudiosos, como Appleyard, alcança um paroxismo

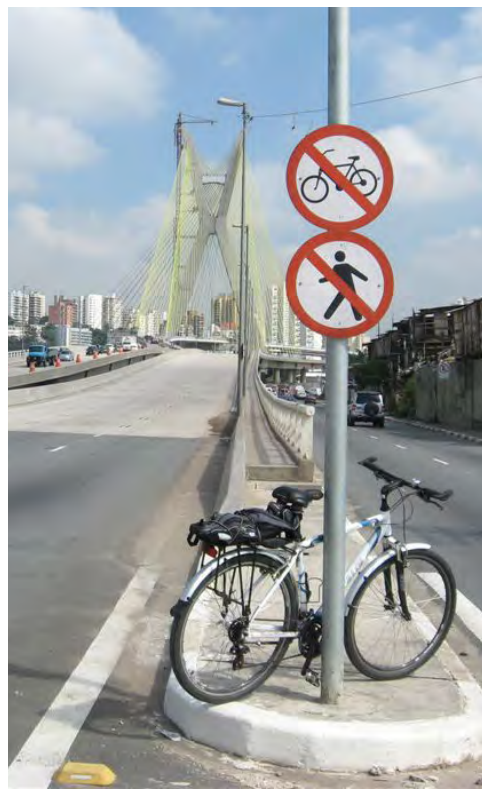

Figura 72: PONTE ESTAIAdA ineficácia para transposição do rio por trabalhadores sem automóveis

Figura 73: SinALIZAÇÃo No ACESSO À PONTE ESTAIADA proibiç̃ão de pedestres e ciclistas. obs: não circula na ponte nenhuma linha de transporte coletivo 
extremo: ao mesmo tempo, se a ele é permitido circular, movimentar-se, deslocar-se de um bairro a outro, cada vez menos the é permitido parar para contemplar ou descansar onde melhor the aprouver, pois os espaços públicos destinados à mobilidade raramente coexistem com espaços públicos de convivência social.

O uso do automóvel não pode ser ignorado, uma vez que é um dos tipos de transporte em um país de modelo de circulação sobre rodas, preferencialmente. A frota de veículos particulares em São Paulo cresce intensamente ano a ano, seja pelos incentivos fiscais do governo federal, que impulsionam as vendas de automóveis e outros veículos sem necessariamente objetivar a renovação da frota, como fez a Espanha há mais de uma década, seja pela incapacidade do transporte público de absorver de forma adequada um contingente de trabalhadores de classe média que, por um motivo ou outro, optam pelo transporte individual. Mas, o privilégio conseguido pelo automóvel produziu sistemas rodoviários de grande porte e capacidade de tráfego o que, segundo Campos Filho, fragmentou a cidade:

Nas grandes cidades, o automóvel exige que o sistema viário seja de grande porte, com grandes avenidas e até vias expressas. Essas avenidas e vias expressas, verdadeiros canais de tráfego, passam a dividir o espaço urbano em verdadeiras ilhas. Ora, essas ilhas, se tratadas urbanisticamente de forma conveniente, podem ser transformadas em bairros autônomos, as unidades de vizinhança, que devem, segundo propõe, no entanto, erroneamente o urbanismo globalizante contrário à grande cidade, reproduzir, tanto quanto possível, a qualidade de vida das pequenas cidades. (CAMPOS FILHO, 1989, p.88
Políticas públicas voltadas a uma melhor distribuição de postos de trabalho na mancha urbana paulistana aliada à implantação de conjuntos completos de equipamentos públicos em todas as regiões do município, principalmente onde estes se apresentam em carência, contribuirão para a diminuição dos deslocamentos pendulares entre as periferias e o Centro Expandido, descongestionando os sistemas de transporte público e as vias para veículos sobre rodas. Além disso, e principalmente, o investimento em transporte público de qualidade pode estimular o proprietário de automóvel a optar pelo primeiro.

O cenário relatado acima é perfeitamente realizável de forma concreta com delimitação de "ilhas de tranquilidade" no interior das UAMs, quando transformadas em bairros autônomos contando apenas com comércio e serviços locais de apoio à moradia, que são o tema principal desta tese na forma de metodologia para a proposição de conjunto de diretrizes para planos locais ou Planos de Bairro, tema abordado no Capítulo VI, onde se apresenta um Roteiro para Planos de Bairro.

Uma conclusão a respeito das políticas públicas que conformaram os planos urbanos governamentais aqui descritos encontra-se no Capítulo IV, onde se apresentou uma análise conjunta com as políticas públicas direcionadas à Região Leste Paulistana dos planos em vigor. 


\section{CAPÍTULO IV}

\section{CENÁRIO PLANEJADO PARA A REGIÃO LESTE PAULISTANA: PLANOS EM VIGOR}

Este capítulo aborda novamente o tema dos planos urbanos para a Capital, desta vez analisando os que estão em vigor tanto por parte do Governo do Estado como do Governo Municipal de São Paulo, e relacionando-os com a Região Leste Paulistana-RLP, o estudo de caso desta tese.

Primeiramente localizou-se a RLP na RMSP, da qual é parte integrante e por possuir localização estratégica entre esta e a Região Metropolitana do Vale do Paraíba, para, em seguida, discorrer sobre os planos em vigor tanto do Governo Estadual, com o Plano Integrado de Transporte Urbano-PITU 2025 e o Hidroanel Metropolitano, ambos de abrangência metropolitana, como do Governo Municipal, abordase a revisão do PDE 2002/2012 e a Operação Urbana Consorciada Rio Verde-Jacu, a maior OUC em extensão territorial já planejada para a reestruturação urbana de São Paulo, localizada em uma região urbanisticamente deficitária. Procurou-se destacar a influência da OUC-RV) na RLP, ainda que hipoteticamente, uma vez que as políticas públicas que nortearão a proposição de suas diretrizes urbanas estão ainda em nível preliminar, como publicado no edital ao qual se teve acesso. O objetivo dessa análise é demonstrar a necessidade de levar adiante concretamente os planos urbanos e não somente permanecer-se nas políticas públicas que os antecedem.

\section{AS DIMENSÕES METROPOLITANAS DA REGIÃO LESTE PAULISTANA}

\section{A Região Metropolitana de São Paulo-RMSP é} uma das Unidades Regionais que compõem a Macrometrópole do Estado de São Paulo.79 A RMSP está composta por 39 municípios e é o maior polo de riqueza nacional. Seu Produto Interno Bruto-PIB atingiu em 2008, 572 bilhões de Reais, o que corresponde a cerca de $57 \%$ do total do Estado de São Paulo.80

Os municípios que compõem a RMSP são: Arujá, Barueri, Biritiba-Mirim, Caieiras, Cajamar, Carapicuíba, Cotia, Diadema, Embu das Artes, Embu-Guaçu, Ferraz de Vasconcelos, Francisco Morato, Franco da Rocha, Guararema, Guarulhos, Itapevi, Itapecerica da Serra, Itaquaquecetuba, Jandira, Juquitiba, Mairiporã, Mauá, Mogi das Cruzes, Osasco, Pirapora do Bom Jesus, Poá, Ribeirão Pires, Rio Grande da Serra, Salesópolis, Santa Isabel, Santana de Parnaíba, Santo André, São Bernardo do Campo, São Caetano do Sul, São Lourenço da Serra, São Paulo, Suzano, Taboão da Serra e Vargem Grande Paulista. ${ }^{81}$

A RMSP apresentou, em 2012, segundo dados do IBCE, uma população total de 19.973.125 de
79. A RMSP foi instituída pela Lei Complementar Federal n. 14, de 1973 , e disciplinada pela Lei Complementar Estadual n. 94, de 1974. No entanto, sua existência legal e política dependeram da aprovação de uma lei estadual específica, de acordo com as regras da Constituição Federal de 1988, que atribuiu aos Estados a responsabilidade pela criação das regiões metropolitanas. O Projeto de Lei Complementar n. 6, de 2005 , aprovada no dia 13 de junho de 2011, pela Assembleia Legislativa, criou a RMSP preenchendo definitivamente o vazio institucional existente na mais importante concentração urbana do país. A nova lei busca promover o planejamento regional para o desenvolvimento socioeconômico e a melhoria da qualidade de vida, a proteção do meio ambiente, a integração do planejamento e da execução de funções públicas de interesse comum e a redução das desigualdades sociais e regionais. (GOVERNO DO Estado de São Paulo. Secretaria de Desenvolvimento Metropolitano)

8o. Idem.

81. Idem 


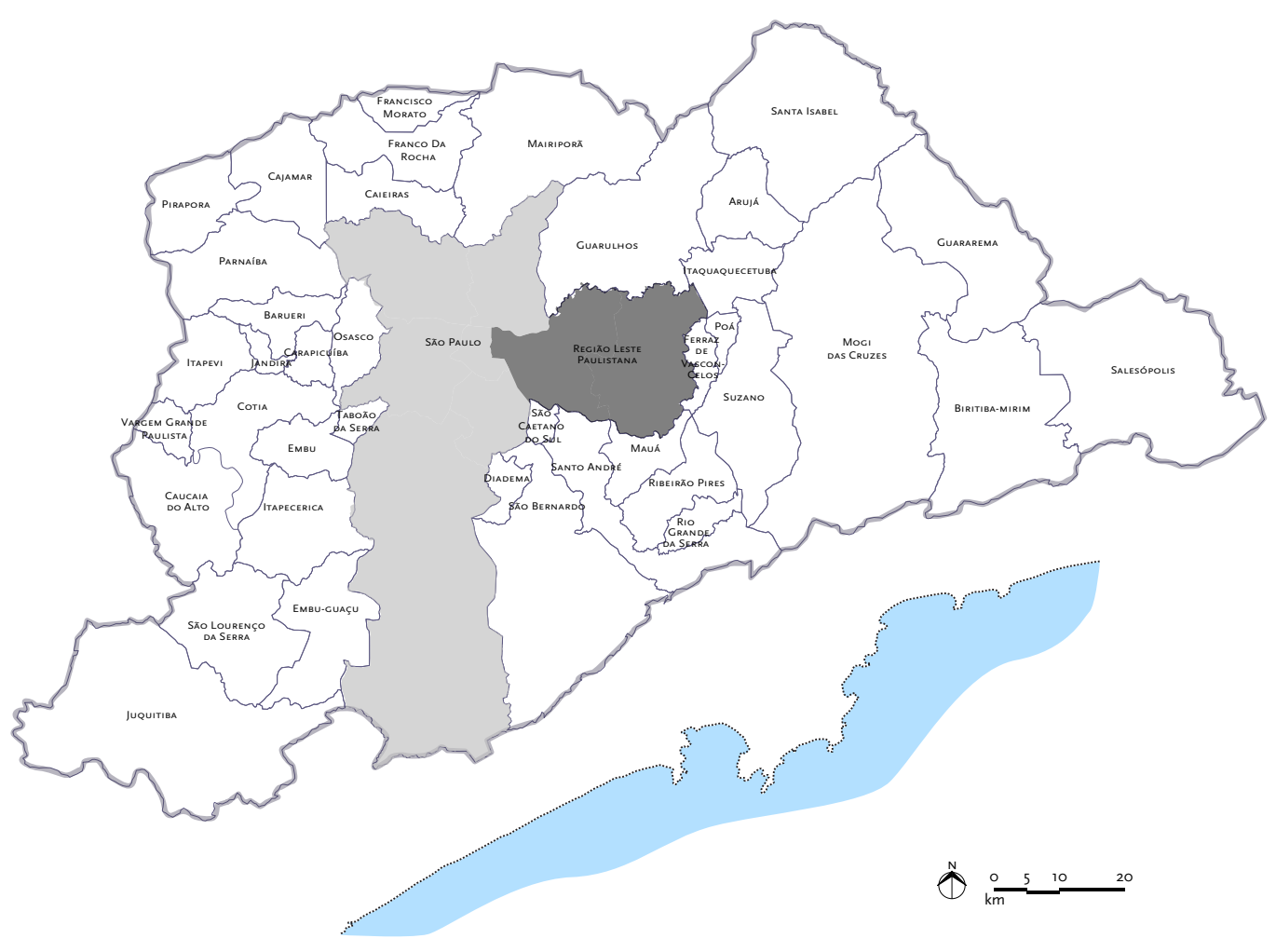

Mapa 36: Localização da RLP em São Paulo e na RMSP

MEPR, 2013

82. População dos distritos da Região Leste de São Paulo em 2012: Agua

Rasa com 84.870 habitantes:

Aricanduva com 89.162; Artur Alvim com 104.737, Belém com 45.577; Brás com 29.662; Cangaíba com 136.567, Carrão com 83.752, Cidade Líder com 127.541, Cidade Tiradentes com 213.623, Ermelino Matarazzo com 114.260, Guaianases com 104.521, Iguatemi com 130.374, Itaim Paulista com 225.181, Itaquera com 205.199, Jardim Helena com 134.696, José Bonifácio com 125.800, Lajeado com 165.182, Mooca com 76.961, Pari com 17.537, Parque do Carmo com 68.661, Penha com 128.136, Ponte Rasa com 93.515, São Lucas com 142.612, São Mateus com 155.168, São Miguel com 91.609, São Rafael com 145.884, Sapopemba com 284.749, Tatuapé com 92.875, Vila Curuçá com 149.307, Vila Formosa com 94.881 Vila Jacuí com 142.447, Vila Matilde com 105.125 e Vila Prudente com 104.427 habitantes. (IBGE, 2011)

83. População total dos municípios da Região Metropolitana da Baixada Santista. (SEADE/IBGE, 2012) habitantes e densidade demográfica de 2513,34 habitantes por quilômetro quadrado. Os municípios que compõem a maior metrópole brasileira têm populações totais que vão desde 14.272 habitantes, no caso de São Lourenço da Serra, a 11.379.114 habitantes, no caso da Capital do Estado, São Paulo. A variação tão grande não ocorre somente em relação ao número de habitantes, mas também em relação ao perfil socioeconômico dos municípios entre si e entre eles e a metrópole, não havendo uma relação direta entre número de habitantes maior ou menor e qualidade de vida urbana ou rural. ${ }^{82}$

Segundo Langenbuch, “a metrópole constitui um tipo especial de cidade, que se distingue das menores, não apenas por sua dimensão, mas por uma série de fatos, quer de natureza quantitativa, quer de natureza qualitativa". (Langenbuch, p.1) Metrópoles

são grandes aglomerações urbanas que contam com mais de um milhão de habitantes, em extensões territoriais proporcionais para comportar suas populações, com densidades demográficas muito variáveis, como por exemplo, a densidade demográfica de São Paulo, de 7383 habitantes por quilômetro quadrado e de Santos de apenas 1497, sendo este o município central da Região Metropolitana da Baixada Santista, com nove municípios associados: Bertioga, Cubatão, Guarujá, Itanhaém, Mongaguá, Peruíbe, Praia Grande, Santos e São Vicente. Juntos, esses nove municípios somam um total de apenas 1.696 .360 habitantes. ${ }^{83}$

Além de serem grandes conglomerados urbanos, as metrópoles brasileiras contam uma rede de sistemas rodoferroviários estruturais de escala regional que conectam essa metrópole aos municípios circunvizinhos em uma relação de dependência territorial, econômica e sócio cultural.

Em relação a São Paulo, não se trata mais de uma metrópole, mas, como já a denominara Langenbuch, falamos de uma macrometrópole, "cidade multimilionária que ultrapassara o tamanho ideal de uma cidade." (Langenbuch, 1971, p.1) E quando uma cidade ultrapassa seu tamanho ideal, isso ocorre em todos os sentidos, população, território urbano e demandas populacionais que, ao contrário do crescimento, passam a contar com menos equipamentos urbanos para atendê-las, cujo incremento acaba em descompasso com o crescimento urbano, gerando o caos, principalmente na mobilidade urbana.

O município de São Paulo e sua conhecida horizontalidade da mancha urbana apresenta densidade demográfica de 7393,32 habitantes por quilômetro quadrado, com população urbana de 11.379.114 
habitantes em 1521,10 quilômetros quadrados de área total. (SEADE/IBGE, 2012)

Conforme visto na Apresentação desta tese, em Justificativas para o tema, a publicação O/har São Paulo - Contrastes Urbanos (SEMPLA, 2005) traçou um perfil do município, com foco no tema das desigualdades socio territoriais onde as periferias paulistanas têm apresentado os maiores índices de crescimento populacional do município de São Paulo, como Jaguara ao norte, Iguatemi, ao leste e Parelheiros ao sul. (cf. Mapa 3 (p.14) $)^{84}$

O CENSO 2010 mostrou que o índice de crescimento populacional desses distritos já apresentou uma queda, mas ainda são as áreas de maior densidade demográfica e crescimento populacional do Município de São Paulo. Mais detalhes sobre o perfil populacional e socioeconômico da RLP e da área do estudo de caso encontram-se no Capítulo V.

\section{GOVERNO DO ESTADO-PLANOS HIDRORRODOFERROVIÁRIOS PARA A METRÓPOLE DE SÃO PAULO}

A problemática da Região Leste gira em torno do sistema de transporte urbano rodoferroviário, os movimentos pendulares diários praticados em escala municipal e regional que os habitantes dessa região realizam em função da concentração de postos de trabalho, serviços e comércios diversificados fora dela, dentro do Centro Expandido de São Paulo, e da busca e implementação de soluções em longo prazo, ou seja, com anos meta que justifiquem os investimentos, mitigando riscos de esgotamento das capacidades de suporte de transporte e circulação. Os governos do estado e do município vêm tratando o tema de forma conjugada. O plano vigente é o PITU 2025, sobre o qual se discorre a seguir. Rapidamente, se falará sobre o Hidroanel, ainda em estudo pelo Estado, e que contribuirá com o desenvolvimento da RMSP e da RLP.

\section{PITU 2025-TRANSPORTE URBANO INTEGRADO}

Produzido em dezembro de 2006 pela Secretaria de Estado dos Transportes Metropolitanos-STM e pela Coordenadoria de Planejamento e GestãoCPG, na gestão de Cláudio Salvador Lembo, teve diversos órgãos e instituições como participantes: Prefeituras da Região Metropolitana de São Paulo; Empresa Paulista de Planejamento Metropolitano S/A-EMPLASA; Consórcio Intermunicipal do Grande ABC; Companhia do Metropolitano de São Paulo-Metrô; Companhia Paulista de Trens Metropolitanos-CPTM; Empresa Metropolitana de Transportes Urbanos S/A-EMTU; Secretaria de Economia e Planejamento-SEP; Companhia de Engenharia de Tráfego de São Paulo - CET; Secretaria Municipal de Planejamento-SEMPLA; Empresa Municipal de Urbanização-EMURB; Companhia de Desenvolvimento Habitacional e Urbano do Estado de São Paulo-CDHU, e contou com a consultoria técnica da Secretaria Municipal de Transportes-SMT; São Paulo Transportes-SPTrans e da Fundação para Pesquisa Ambiental-FUPAM.

\section{SUMÁRIO EXECUTIVO}

Segundo o Sumário Executivo do Pitu 2025:

Pode-se dizer que o direito urbanístico no Brasil entrou em nova fase com a Constituição de 1988, o Estatuto da Cidade, cerca de treze anos depois, estabelece as diretrizes gerais da política urbana, esclarecendo que ela "não pode ser
84. Após a incorporação na Base Territorial das atualizações provenientes da coleta do Censo 2010, foi realizado, pelo IBCE, um reprocessamento dos valores das áreas territoriais, segundo a estrutura político-administrativa vigente na data de referência do Censo Demográfico-1 ago. 2010. A área do município de São Paulo passou de 1522,99 para 1521,10 quilômetros quadrados. Assim, estão provisoriamente indisponíveis os dados de distritos, a partir de 2010. A partir de agosto de 2008 os dados referentes à área dos municípios paulistas (e das regiões administrativas, de governo e metropolitanas, calculados pela soma das áreas municipais), divulgados nos sistemas de informação da Fundação Seade, têm como fonte a Resolução n. 5 do IBGE, de 10 de outubro de 2002, que toma como referência o quadro territorial vigente em 1 de janeiro de 2001. Até aquele mês, esses sistemas informavam os valores calculados pelo Instituto Geográfico e Cartográfico-ICC. (SEADE) 


\section{QUADRO 1}

Estratécias do PITU 2025-RMSP-MetAs de IMPLANTAÇÃo

Pitu 2025, Sumário Executivo, p.11

\begin{tabular}{|c|c|c|c|c|}
\hline \multirow[t]{2}{*}{ Projetos } & \multirow[t]{2}{*}{ Unidade } & \multicolumn{3}{|c|}{ Quantidade/Período } \\
\hline & & $\begin{array}{c}2006 \mathrm{a} \\
2012 \\
\end{array}$ & $\begin{array}{c}2013 \text { a } \\
2025 \\
\end{array}$ & $\begin{array}{r}2006 \\
2025 \\
\end{array}$ \\
\hline Metrô & $\mathrm{km}$ & 32 & 78 & 110 \\
\hline trem metropolitano & global & $\operatorname{sim}$ & $\operatorname{sim}$ & $\operatorname{sim}$ \\
\hline Expresso: trem aeroporto & $\mathrm{km}$ & 28 & o & 28 \\
\hline SIVIM·SVE & global & $\operatorname{sim}$ & O & $\operatorname{sim}$ \\
\hline EMTU·Troncalização & global & sim & $\mathrm{O}$ & $\operatorname{sim}$ \\
\hline Corredores Via Livre & $\mathrm{km}$ & $\mathrm{O}$ & 100 & 100 \\
\hline Corredores Passa Rápido & $\mathrm{km}$ & 27 & 83 & 110 \\
\hline Corredores Expresso Tucuruvi-Guarulhos & $\mathrm{km}$ & 21 & o & 21 \\
\hline Expresso ABD-CECAP & $\mathrm{km}$ & o & 24 & 24 \\
\hline Expresso Tiradentes & $\mathrm{km}$ & 32 & o & 32 \\
\hline Corredores urbanísticos & $\mathrm{km}$ & 10 & 100 & 110 \\
\hline SPTrans: Terminais & global & $\operatorname{sim}$ & $\operatorname{sim}$ & $\operatorname{sim}$ \\
\hline EMTU: Terminais • Pró-polos & un & 25 & o & 25 \\
\hline Terminais chave $\cdot$ Pró-polos & un & ○ & 15 & 15 \\
\hline sistema viário $\cdot$ estacionamentos $\cdot$ TNM & verba & o & $\operatorname{sim}$ & $\operatorname{sim}$ \\
\hline Pedágio urbano & global & 0 & $\operatorname{sim}$ & $\operatorname{sim}$ \\
\hline
\end{tabular}

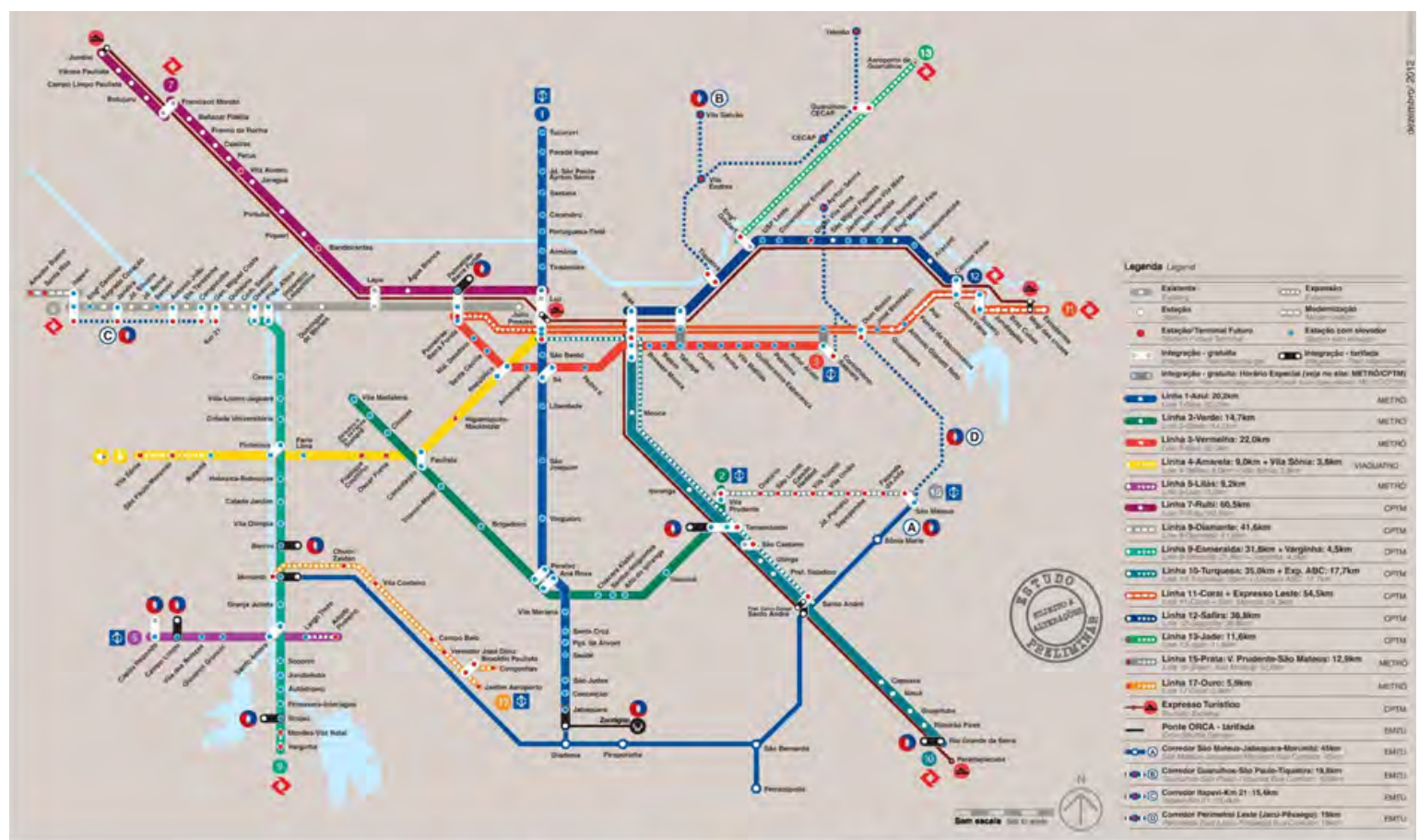

Figura 74: Rede de transporte Metropolitano 2014 Metrô, 2013 


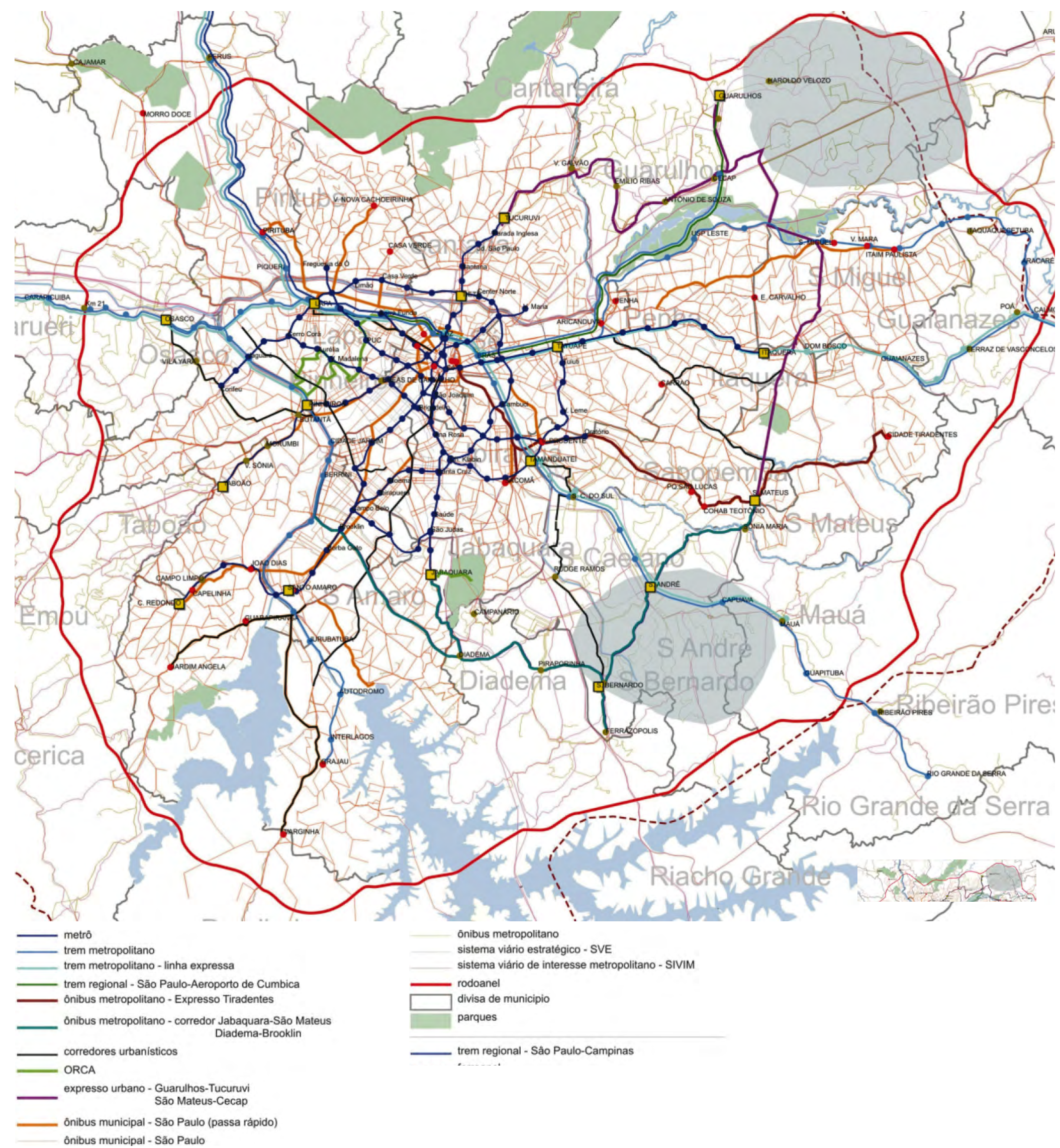


um amontoado de intervenções sem rumo. Ela tem uma direção global nítida: ordenar o pleno desenvolvimento das funções sociais da cidade e da propriedade urbana, de modo a garantir o direito a cidades sustentáveis.

Durante a elaboração da presente edição do PITU foi constatado, principalmente a partir dos dados do último censo, o agravamento do problema urbano representado por uma distribuição cada vez mais desequilibrada das atividades na cidade. Os empregos permanecem no Centro, que se esvazia demograficamente, enquanto cresce explosivamente a população na periferia. Em termos financeiros, passam a ocorrer maiores investimentos e maiores custos operacionais no serviço de transportes, sem aumento expressivo da receita, uma vez que a tarifa é única na maior parte da rede. Os usuários passam a esterilizar uma parte cada vez maior de seu dia útil no deslocamento e a economia do sistema de transportes é crescentemente deficitária.

Fica patente que o problema dos transportes não se resolverá exclusivamente como política setorial fechada em si mesma. E a visão de uma cidade mais sustentável, concebida no PITU 2020 e mantida nesta edição (ver Introdução) só será alcançada se houver apropriada interação de várias funções urbanas, regidas pelas correspondentes políticas públicas e dinamizadas pelas forças de mercado. Para obter esses resultados novas estratégias podem e devem ser mobilizadas, usando tecnologias e instrumentos mais poderosos. Dentre esses cabe destacar a demonstração da capacidade estatal de implementar concomitantemente mais de uma linha de Metro; o bilhete único; a criação do Comitê Diretor de Transporte Integrado reunindo os órgãos de transporte público urbano do Governo do Estado de São Paulo-GESP e da Prefeitura do Município de São Paulo-PMSP e a legislação de PPPs. (PITU 2025, p.6)

\section{ESTRATÉGIA E POLÍTICAS PÚBLICAS CONJUGADAS}

A nova estratégia do PITU soma ações de aumento da oferta com políticas de gestão da demanda e procura fazer uso desses instrumentos, envolvendo assim iniciativas que não se situam apenas na juris dição da Secretaria de Transportes Metropolitanos.

(PITU 2025, p.6)

O PITU 2025 propõe a adoção das Políticas Públicas Conjugadas à de transporte urbano de passageiros como: Política de Uso do Solo, Política Habitacional, Política de Logística Urbana de Cargas, Política de Financiamento Expandida, também de base fundiária e Política de Desenvolvimento. (PITU 2025, p.6)

\section{TRANSPORTE DE PASSAGEIROS}

O PITU busca transformar o sistema de transporte de passageiros em modelo com sustentabilidade e segurança, a chamada Estratégia Preferida de trans portes integrada com as diretrizes acima e combinada às outras específicas como: infraestrutura, medidas de gestão e políticas de preços e o financiamento do PITU 2025, com orçamento da monta de 48,676 bilhões de Reais. (PITU 2025, p.10)

O PITU 2025 é um Plano de Transporte completo com ano base 2005 em que a interação com o Uso do Solo foi completada por ocasião do trabalho Montagem e avaliação de um cenário equilibrado para o Desenvolvimento Urbano de São Paulo através de uma estratégia combinada de transporte e uso do solo, coordenado tecnicamente pelo urbanista Campos Filho como consultor da FUPAM para a elaboração desse relatório. Este trabalho calculou o potencial construtivo que deve ainda ser acrescentado ao conjunto da massa edificada para os distritos e bacias de tráfego, trabalho atualmente em elaboração pela SMDU.

O PITU 2025 dá suporte ainda ao transporte não motorizado, via Programa Pró-Polos, em sua 
configuração vigente e ampliada pelos Terminais

Chave, que procuram melhorar o deslocamento dos pedestres e ciclistas nas proximidades das estações e terminais. Além disso, ao privilegiar o adensamento em locais determinados, com uso misto, conjugado ao sistema de transportes, o PITU 2025 abre a oportunidade de criação de bolsões mais calmos, predominantemente residenciais, no tecido urbano remanescente. Nessas áreas deverá ser regulado com mais rigor o tratamento das calçadas e proposta a construção de ciclovias.

\section{HIDROANEL METROPOLITANO}

Além do PITU 2025 que planeja a integração dos sistemas rodoferroviários na RMSP, o Governo do Estado também tem desenvolvido um projeto para expandir o insipiente sistema de navegação no Estado de São Paulo. Em um país dependente de transporte de carga por sistemas rodoviários de uma maneira geral, o Hidroanel Metropolitano de São Paulo poderá expandir de forma produtiva uma modalidade pouco explorada no sudeste do Brasil, mas largamente usada em países Europeus e na região norte do país. Neste último caso, comunidades inteiras dependem da navegação pelos rios Amazonas e seus afluentes para obter mantimentos, medicamentos, utilidades domésticas em geral e, em muitas comunidades, atendimento médico, com equipes de saúde se deslocando por via fluvial para programas de prevenção de doenças, vacinações e acompanhamento do desenvolvimento de crianças, além das urnas eletrônicas de votação chegarem até eles por barcos dos cartórios eleitorais regionais e para transportar a produção agrícola local, dentre outros.
O projeto do Hidroanel Metropolitano está a cargo de empresa de consultoria privada em parceria com a Universidade de São Paulo e a Secretaria Estadual de Logística e Transportes-Departamento Hidroviário. ${ }^{85}$

Segundo o memorial descritivo do projeto apresentado pelo Governo do Estado,

\begin{abstract}
A hidrografia de São Paulo foi a principal estruturadora da metrópole: a cidade se estabeleceu em volta dos rios e utilizou intensamente seus recursos para o crescimento. No entanto, ao longo do rápido processo de expansão urbana, muitas transformações foram operadas na Bacia Hidrográfica do Alto Tietê reduzindo, por um lado, o espectro de usos dos rios na cidade e aumentando, por outro, as vulnerabilidades do complexo metropolitano. As consequências desse processo são sentidas no cotidiano de São Paulo: enchentes, alagamentos, dependência excessiva do transporte rodoviário e desarticulação logística e urbanística dos rios com a cidade. As águas superficiais se tornaram mais do que um problema hidráulico, elas são para São Paulo um problema fundamentalmente urbano. (GESP/FAUUSP, 2011, p.6).
\end{abstract}

Assim, o projeto do Hidroanel Metropolitano encon tra-se, em 2013, em fase de pré-estudos de viabilidade técnica, econômica e ambiental para execução das obras de infraestrutura de transportes, com levantamentos de tráfego, capacidade e mercado potencial, estudos de engenharia, socioeconômicos e ambientais, configurações e soluções associadas às diversas etapas de implantação e exame das soluções de intermodalidade no escoamento das cargas locais. ${ }^{86}$

Segundo o Governo do Estado de São Paulo, o Hidroanel é uma rede de canais navegáveis que conforma um anel hidroviário, composto por rios e
85. O Governo do Estado de São Paulo licitou em 2009 o Estudo de Pré-Viabilidade Técnica, Econômica e Ambiental do Hidroanel Metropolitano de São Paulo, através do Departamento Hidroviário (concorrência n. DH-008/2009), da Secretaria Estadual de Logística e Transportes, para apresentar as possibilidades técnicas, econômicas, ambientais e urbanísticas que viabilizam e justificam a implementação de um anel hidroviário na RMSP. Parceria da Planejamento em Transporte e Consultoria Ltda.-PETCON com a FAUUSP-Grupo Metrópole Fluvial. (GESTP/FAUUSP, 2011, p.6)

86. Disponível em <http://www. metropolefluvial.fau.usp.br>. Acesso em 21 jun 2013 
represas existentes na RMSP, e um canal artificial, totalizando 170 quilômetros de hidrovias urbanas. (GESP/FAUUSP, 2011, p.6)

\section{O Mapa 38 traz demarcados o Rodoanel Viário} com os trechos em construção - Trecho Leste -, os trechos construídos - Sul e Oeste -, e o trecho ainda em aprovação - Trecho Norte. Traz também a demarcação do futuro Ferroanel Metropolitano, também em fase inicial de estudos e que apresenta um trecho coincidente com o trecho de ferrovia existente entre Suzano e Rio Grande da Serra, a receber um sistema de VLT chamado Billings-Taiaçupeba.

\section{Objetivos do Hidroanel}

Os objetivos do Hidroanel Metropolitano são:

1. Articulação arquitetônica e urbanística com a consolidação de um território com qualidade ambiental urbana, nas orlas fluviais, que comporte infraestrutura, equipamentos públicos e habitação social, promovidos pelo Estado; 2. Estudos de projetos para a cidade que atribuam ao conjunto de rios e canais urbanos o papel de eixos referenciais para a constituição de uma urbanização planejada que considere a necessidade de parques, praças e bulevares fluviais. O interesse público do Hidroanel é formado por uma Política Nacional de Recursos Hídricos, uma Política Nacional de Mobilidade Urbana e uma Política Nacional de Resíduos Sólidos. (GESP/FAUUSP, 2011, p.6)

Os conceitos norteadores da navegação fluvial urbana são: 1. Portos de origem e destino localizados na área urbana; 2. A navegação fluvial em canais rasos e estreitos em águas restritas (confinadas entre barreiras, no caso, barreiras artificiais); 3. Ao transformar os principais rios da cidade em hidrovias, e considerando também suas margens como o espaço público principal da metrópole, o caráter público das águas de São Paulo é reforçado. Dessa forma, os rios urbanos, além de transformaremse em vias de transporte de cargas e passageiros, contribuem para a regularização da macrodrenagem urbana, abastecimento, geração de energia e lazer. (GESP/FAUUSP, 2011, p.6)

O transporte de passageiros no Hidroanel abrange travessias lacustres, o transporte público de passageiros e o transporte dedicado ao turismo e lazer. Este último já acontece no trecho navegável do rio Tietê, atividade que deve ser ampliada com a implantação do Hidroanel. O turismo fluvial tem o caráter educativo para a difusão da cultura da navegação e deve atender a demanda de deslocamentos a polos de turismo próximos da hidrovia e equipamentos flutuantes. (teatros, bibliotecas, etc.)

O projeto do Hidroanel, além de transformar o leito dos rios, requalifica suas margens de forma que a orla dos canais e lagos tornam-se potenciais espaços de lazer com parques e equipamentos urbanos. As eclusas, barragens e portos também são espaços de atração com caráter didático sobre o funcionamento do sistema hídrico e o gerenciamento dos resíduos sólidos. O grupo de pesquisa Metrópole Fluvial, da FAUUSP, sugere novos usos das margens para atividades de diversão e encontro, sendo esse caráter lúdico e funcional das águas elemento fundamental para a consolidação do Hidroanel Metropolitano. (GESP/FAUUSP, 2011, p.19)

O transporte público fluvial de passageiros deve estar integrado ao sistema existente de transporte púbico, garantindo a intermodalidade. A travessia lacustre, para o transporte de pessoas e veículos através de balsas, acontece atualmente na represa 

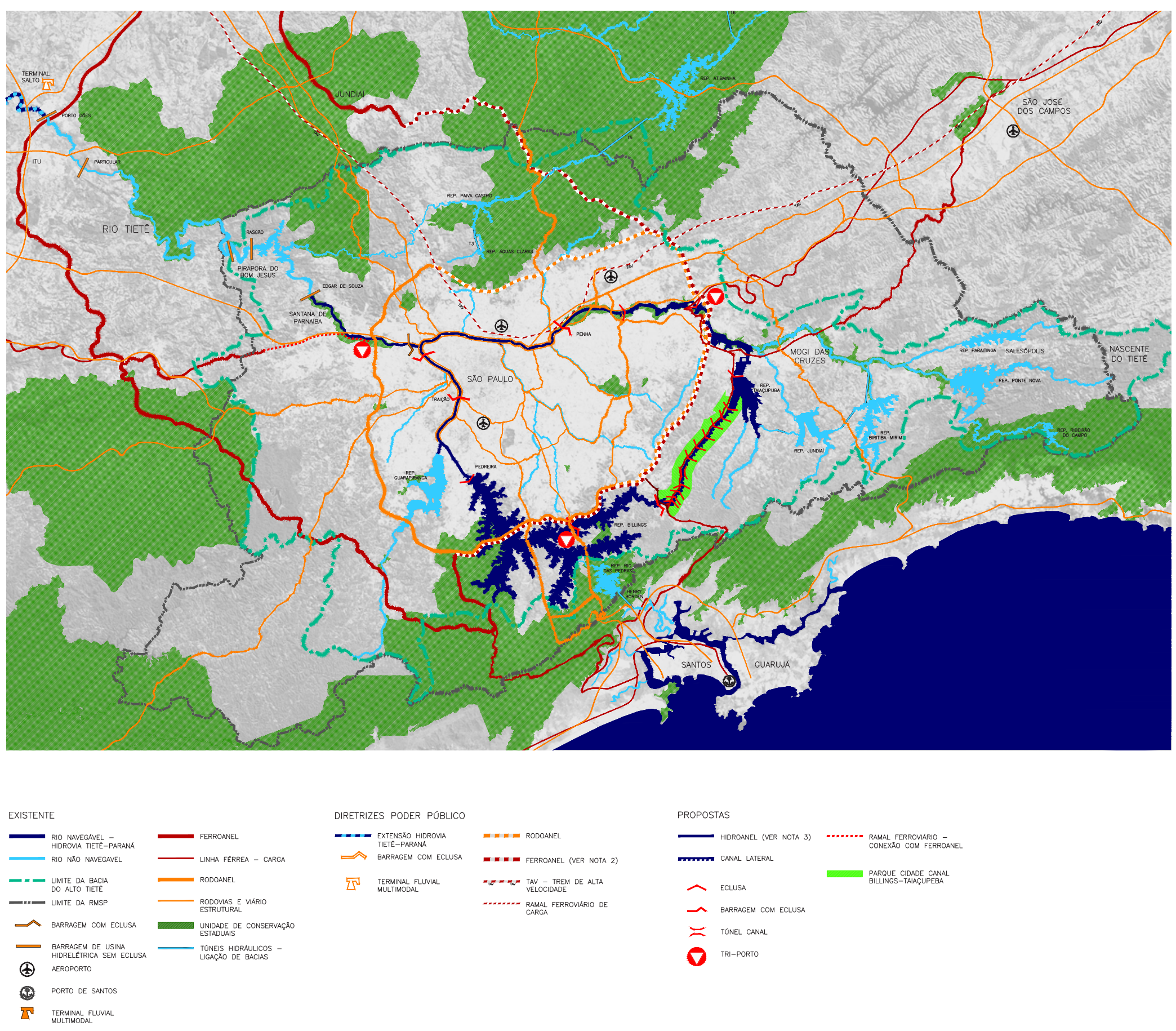


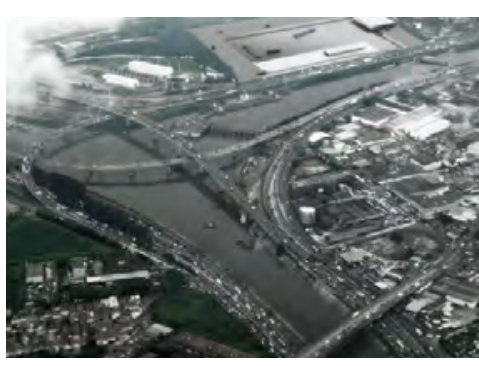

FIGURA 75: ECLUSA ENTRE RIOS PINHEIRO E TIETÊ

FAUUSP, Grupo Metrópole Fluvial, 2011

87. As barragens eram construídas desde a antiguidade com o intuito de reduzir os impactos dos períodos de estiagem. Assim, eram construídas barreiras artificiais para que pudessem ser armazenadas grandes quantidades de água provenientes das chuvas e da vazão caudal do rio em que a barragem se encontrava. O lago artificial formado por este armazenamento serve para diversos fins: irrigação, consumo humano, produção de energia, piscicultura, pesca, lazer, fornecimento de água para indústrias etc. Vale destacar que a construção de uma barragem deve passar por uma rigorosa fase de planejamento, pois a área em seu entorno sofrerá muitos impactos ambientais. Tal fato leva a necessidade de um rigoroso processo de licenciamento ambiental para sua construção. Ministério dos Transportes. Barragens e eclusas. Disponível em <http://www2. transportes.gov.br/bit/o4-hidro/barraeclu.html> Acesso em 21 jun. 2013

88. Até 2008, o Município de Guarulhos despejava 100\% de seu esgoto no Rio Tietê.
Billings e deve ter sua rede ampliada. (GESP/

FAUUSP, 2011, p.30)

\section{ETAPAS DE IMPLANTAÇÃO DO PROJETO}

O trabalho associa as etapas de implantação à noção de prazos - curtíssimo, curto, médio e longo para sua implementação. Os prazos são associados a gestões de quatro anos de administração Estadual, prevendo continuidade no desenvolvimento do projeto, com preparação de terrenos, execução dos projetos e condução das obras visando conclusão do Hidroanel Metropolitano na década de 2040.

(GESP/FAUUSP, 2011, p.20)

A navegação fluvial na RMSP depende de Eclusas, Barragens e Tri-portos, que são elementos na forma de instalações de infraesturura importantes para as conexões intermodais e transferência de cargas, resíduos sólidos e passageiros. Barragens e eclusas são construções, obras de engenharia hidráulica, feitas para solucionar dificuldades encontradas, por exemplo, em transpor desníveis dos cursos de água. Barragem é uma barreira artificial construída em um curso de água para retenção e represamento de grandes volumes de água. As eclusas funcionam como uma espécie de escada ou elevador para embarcações que desejam transpor um desnível num curso de água. ${ }^{87}$

Os Triportos são chamados assim devido às três funções que Ihes são atribuídas: triagem, processamento e destinação final, além do papel tri-modal que lhes cabem, interpolando os meios hidro, rodo e ferroviário. Para isso, suas localidades são definidas em entroncamentos das diferentes matrizes de transporte. Esses portos são o destino final de todas as cargas públicas. (cf. Figura 76) o Triporto é composto por usina de triagem, usina de processamento de materiais recicláveis, biodigestor e usina Termelétrica. Em razão dessas atividades, as áreas escolhidas para a implantação dos Triportos permitem a recuperação dos corredores industriais dos municípios de Osasco, Guarulhos e São Bernardo

- três municípios economicamente importantes para a RMSP. (GESP/FAUUSP, 2011, p.36)

\section{IMPORTÂNCIA DO HIDROANEL EM RELAÇÃO À Região Leste Paulistana}

Segundo o projeto do Governo do Estado, a obra do Hidroanel Metropolitano de São Paulo é uma possibilidade de ampla mudança na metrópole paulista, contribuindo para mitigar seus conhecidos problemas de crescimento desordenado, saturação do sistema rodoviário, desorganização logística, de seconomias e perdas, sociais e ambientais, incluin do as condições a que os rios foram submetidos, sem a manutenção adequada e recebendo esgoto de cidades inteiras, ${ }^{88}$ com contínuos e sérios problemas de enchentes. (GESP/FAUUSP, p.20).

Para os autores do projeto, o desenvolvimento da metrópole necessitará de uma ampla transformação dos seus rios. A obra do Hidroanel então poderá trazer benefícios diretamente para o rio, ao mesmo tempo em que as obras de adaptação são uma oportunidade de mudança da malha urbana, com a construção de referenciais públicos que podem contribuir para a urbanidade e crescimento ordenado da cidade, significam melhoras ambientais em seu entorno imediato, urbanas e econômicas na escala local e no que tange a funcionalidade e caráter de espaço público do próprio canal, a diretriz de intervenção e presença de equipamentos públicos são assim possibilidades de trazer eixos estruturadores, 
cuja influência na malha urbana, assim como o Hidroanel em sua navegabilidade, alcança os 39 municípios da RMSP. (GESP/FAUUSP, 2011, p.9)

Em relação ao nosso estudo de caso, Região Leste Paulistana e, aos municípios que mantém limites municipais com esta e estão dentro da área de influência do Hidroanel Metropolitano, podemos dizer que são vários os fatores que promoverão o desenvolvimento da Região Leste Paulistana e dos municípios do leste da RMSP. Como se vê na Figura 76: Triportos, Transportos e Ecoportos (p.139) no trecho Leste do Hidroanel existe um Triporto em Itaquaquecetuba, três Transportos e quatro ecoportos e as eclusas de São Miguel Paulista e Penha.

Segundo o projeto, o trecho 1 do canal do Rio Tietê entre a Eclusa da Penha e a UHE de Edgar de Souza permite uma articulação hidroviária entre as zonas leste e oeste da RMSP, uma vez que já é navegável, e, em curto prazo, a Eclusa de São Miguel deverá ser concluída em 2016, estendendo a navegação mais catorze quilômetros a montante do canal Tietê e abrangendo a Região Norte de São Paulo até o município de São Miguel Paulista. Em médio prazo (2019/2026), a primeira gestão do período de longo prazo deve ter como primeira obra a entrar em operação a Eclusa da Barragem de Taiaçupeba, em 2027.

\section{A CIDADE CANAL}

O projeto do Hidroanel inclui um lado arquitetônico fortemente estruturado no projeto urbano, transformando as margens do sistema hidroviário dos municípios que abrange, o que é um avanço após tantos anos de desrespeito aos nossos rios, área muito valorizadas nas cidades do primeiro mundo, como segue:

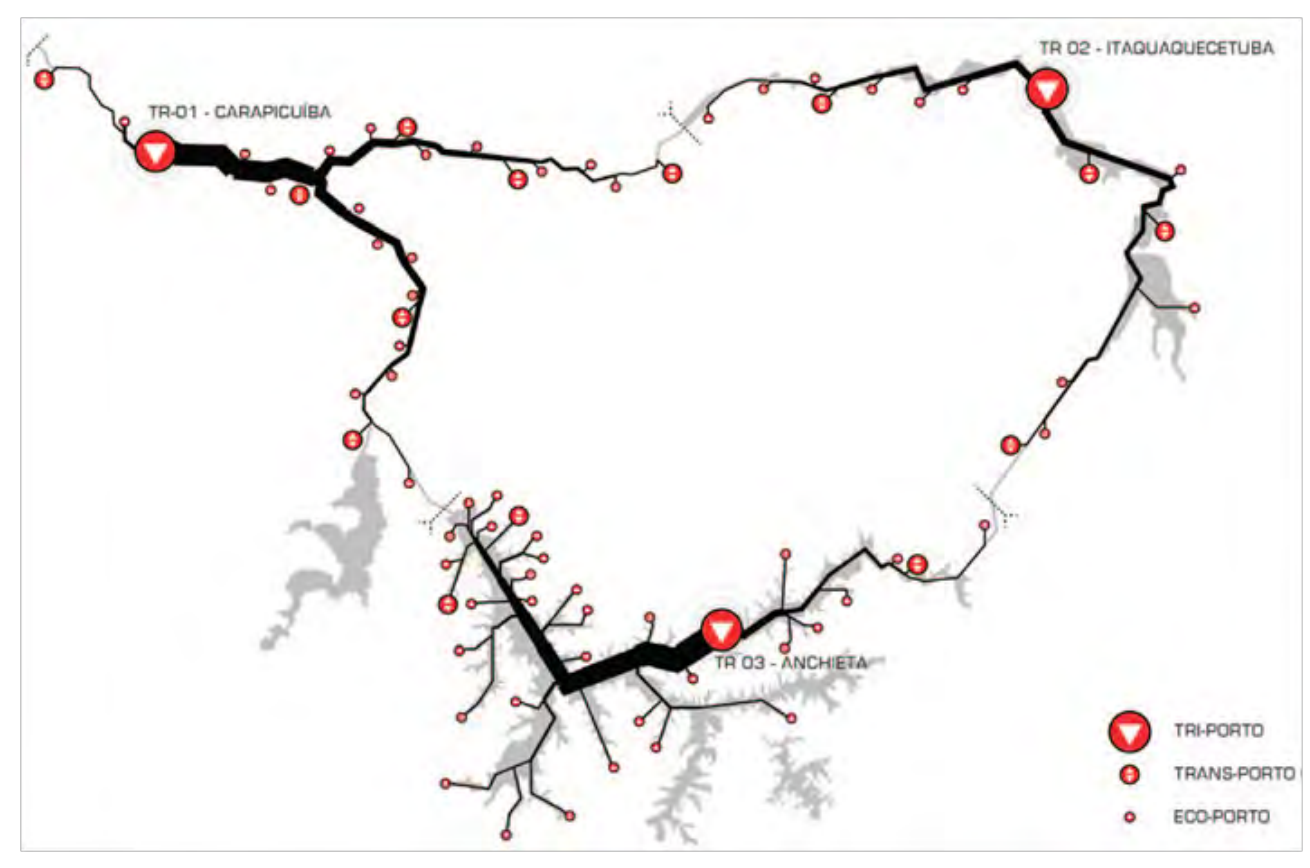

Figura 76: Triportos, TRANSPORTOS E ECOPORTOS FAUUSP, Grupo Metrópole Fluvial, 2011

O projeto da arquitetura do programa (elementos e edifícios que constituem a intervenção) da Cidade Canal é construído a partir do programa público de infraestruturas, equipamentos sociais e habitação social, articulados pelo canal navegável, que deve balizar a definição dos eixos estruturais de saneamento ambiental, mobilidade urbana e transporte público de cargas (primordialmente) e passageiros.

Os elementos construídos ao longo dos canais têm a função de integrá-los ao tecido urbano e destituí-los do papel que Ihe é intrínseco: um obstáculo natural. O planejamento adequado é responsável pela transposição modular do canal e pela consequente integração entre as duas margens e as cidades que se constroem a partir delas. Contribuindo para a integração entre as margens, as vias expressas de circulação rápida de automóveis é transferida para túneis ou diluída nas avenidas paralelas aos canais, para que nãohaja um segundo obstáculo, este bem mais agressivo, a ser transposto. Dessa forma, o planejamento consiste em conformar um sistema de áreas livres públicas através de espaços verdes contínuos, ou seja, uma rede de parques fluviais urbanos que permitam,além disso, o 


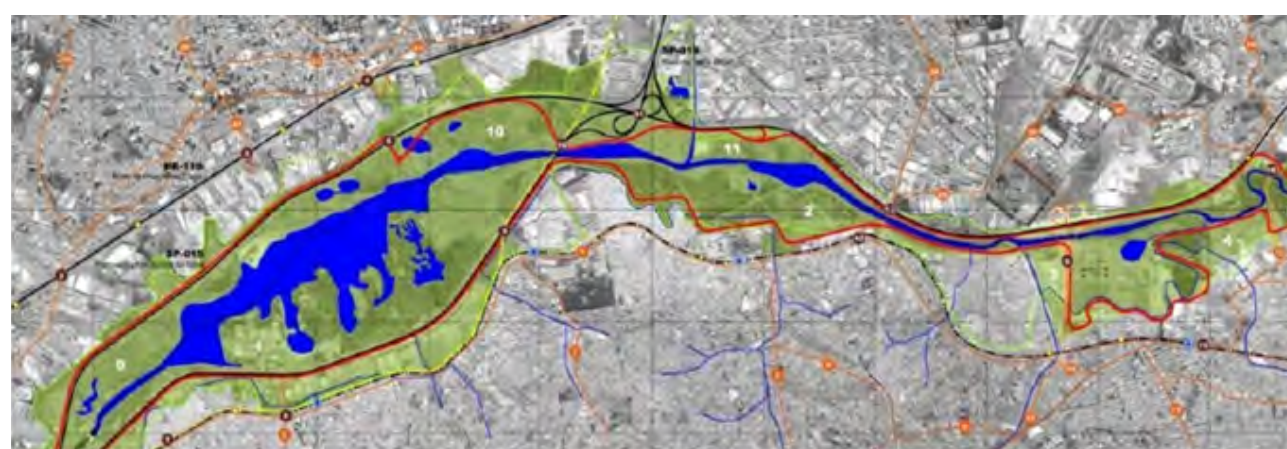

Figura 77: Projeto VÁrzeas do Tietê

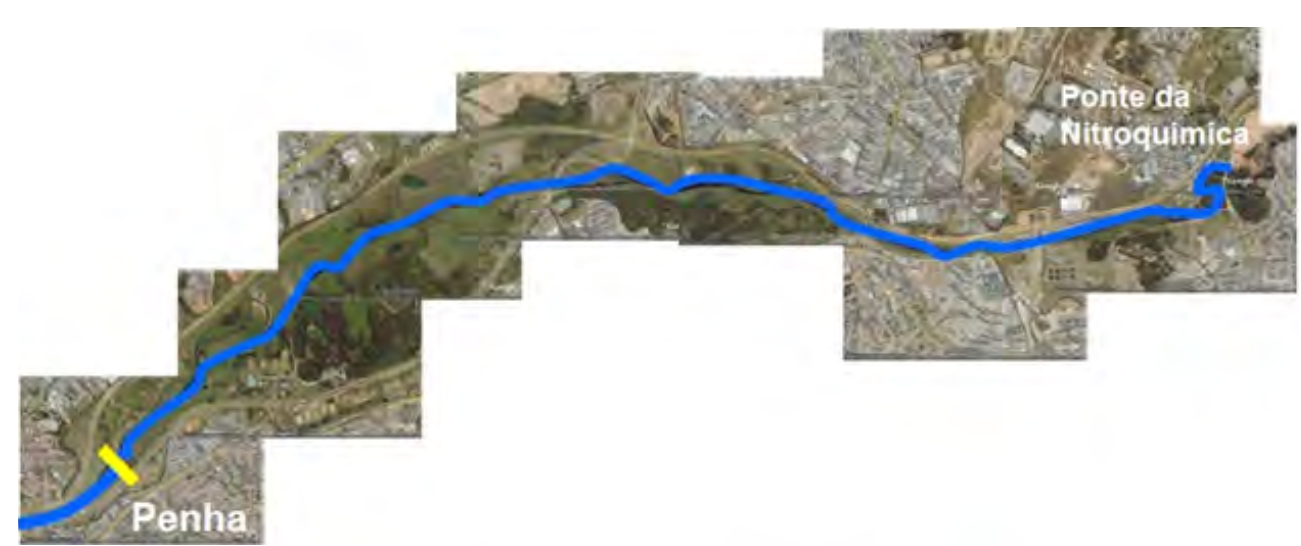

Figura 78: ECLUSA da PENHA extensão do trecho navegável: $\sim 14 \mathrm{~km}$

89. Disponível em <http://www. cidadespaulistas.com.br/cid/?c=507>. Acesso em 21 jun. 2013.
Trata-se do circuito turístico nomeado Circuito Turístico Caminho das Águas Nascentes, com abrangência em onze municípios da RMSP: Arujá, Biritiba-Mirim, Ferraz de Vasconcelos, Guararema, Guarulhos, Itaquaquecetuba, Mogi das Cruzes, Poá, Santa Isabel, Suzano e Salesópolis que guarda a nascente do Rio Tietê, principal atributo desse circuito turístico. Juntos, esses municípios tem uma popula ção de 2.936.437 habitantes, beneficiados por esse impulso econômico através do turismo das águas. (Associação dos Municípios de Interesse Cultural e Turístico- AMITUR) ${ }^{89}$

\section{GOVERNO MUNICIPAL: PLANOS PARA O DESENVOLVIMENTO URBANO DA REGIÃO LESTE PAULISTANA}

Neste início de século, as obras viárias em São

Paulo estão concentradas em grandes planos específicos como, por exemplo, o entorno do complexo público-privado formado pelos edifícios do estádio de futebol, um centro de compras do tipo shopping Center e um polo institucional da Prefeitura de São Paulo, localizados na Região Leste 2, dentro da Operação Urbana Consorciada Rio Verde-Jacu.

Aborda-se a partir daqui os planos urbanos vigentes por parte do Governo Municipal e, por esse motivo, ambiental, recursos naturais e histórico-culturais. preferiu-se discorrer sobre as diretrizes propostas pelo PDE para os sistemas rodoferroviários e para as centralidades no Capítulo III como visto, uma vez que o PDE 2002/2012 teve sua vigência finalizada em 31 de dezembro de 2012. (cf. Mapas 34 e 35 $(p .122))$

Além do Hidroanel, existem outros planos de integração regional entre municípios em relação ao lazer e turismo em cidades de mananciais e preservação

O projeto Várzeas do Tietê coincide com trecho do futuro projeto Arco do Futuro, preconizado pela Prefeitura de São Paulo e com seu trecho inicial, o Arco Tietê, já em processo de concurso para escolha de escritório de urbanismo que desenvolverá seu projeto urbanístico e planejamento urbano. (cf. Figuras 77 e 78 )

Preferiu-se aqui apresentar observações sobre sua revisão, em andamento, segundo declarado recentemente pela Prefeitura de São Paulo. O urbanista 
Campos Filho, que teve importante participação na criação e luta por aprovação de importantes leis urbanísticas federais, estaduais e municipais, nos empresta suas considerações a respeito.

\section{A Região Leste Paulistana no PDE $2002 / 2012$}

O urbanista Candido Malta Campos Filho, que propôs um plano de Corredores Metropolitanos para a Grande São Paulo do início da década de 1970 adotado do PMDI que ajudou a dirigir, como vimos, foi responsável técnico, a pedido do vereador José Police Neto, de São Paulo, pela segunda revisão do Plano Diretor Estratégico para São Paulo90 vigente desde 2002, diferente, segundo o urbanista, em muitos aspectos do PL 671 enviado pelo Poder Executivo para a Câmara Municipal. (informação verbal) $)^{91}$

Especialmente por não apenas manter todas as políticas sociais que aquele PL eliminava como por aprofundá-las ao inseri-las no contexto de obtenção de uma saúde urbana visando sua sustentabilidade como políticas transversais, uma inovação, segundo acredita, na metodologia de planejamento urbano no Brasil. Assim, Campos Filho considera uma boa política de desenvolvimento a que,

Introduz progressivamente diretrizes políticas baseadas nos conceitos de "sustentabilidade" (...) como uma questão estratégica hoje colocada como grande desafio para a humanidade para a manutenção da saúde, da vida, não apenas da humana, do planeta. (...) Para a sua implementação torna-se essencial a definição de políticas transversais que entrelacem as setoriais, especialmente no que se refere aos principais problemas a serem resolvidos. (...) Assim, desse modo, destacaram-se quatro problemas estratégicos: 1. Congestionamentos; 2. Enchentes;
3. Habitação popular; 4. Preservação dos mananciais. ${ }^{92}$

Desenvolver o conceito de equilíbrio urbano com base no conceito de cidade compacta ambientalmente sustentável, enfatizando a necessidade de vincular o potencial construtivo à capacidade de suporte da infraestrutura urbana através do cálculo da capacidade de suporte, devido já há pelo menos 10 anos, para obtermos não apenas uma cidade livre dos congestionamentos que a estrangulam e, ao contrário, desenvolvendo nela espaços de convivência social e comunitária no espaço dos logradouros públicos que depende da convivência civilizada no uso dos veículos nesses espaços e dos usos lindeiros. ${ }^{93}$

Recuperar o uso da rua como espaço de convivência social, mediante uma combinação de diretrizes de desenvolvimento econômico e social e melhoria da qualidade de vida; de circulação e transporte que eliminem o excesso de veículos acima da capacidade de suporte das vias consideradas conforme a qualidade ambiental para elas definida, controlandose o seu volume, tipo e velocidade. Com leitos carroçáveis e calçadas que propiciem a fluidez do tráfego de veículos e de pedestres, quando isso for possível e quando impossível (o que significa ruas com largura inferior a 6 metros) que se adote o conceito de rua compartilhada por veículos e pedestres, como em ruas estreitas e principalmente assegurem qualidade ambiental propiciadora do encontro de pessoas das diversas faixas etárias, da criança ao idoso com segurança, favorecendo com isso um ambiente de manifestação cultural, inclusive de esportes e lazer, própria de cada bairro de moradia e de suas centralidades, inclusive a centralidade maior e mais importante do centro histórico e de sua área expandida, sendo que a importância de tal diretriz é fundamental para uma cidade que presencia a transformação progressiva de suas ruas em simples canais de circulação perdendo com isso a sua urbanidade, que é a principal qualidade a ser oferecida por uma cidade. ${ }^{94}$

Partindo-se do princípio básico de que deve haver oferta de empregos qualificados dentro de distritos
90. Disponivel em <http://www. www.candidomaltacamposfilho. com.br/RevisaoPDE/RPDEOr. html>. Acesso em 18 mar. 2013

91. Campos Filho. Depoimento à autora em 12 mar. 2013.

92. Disponível em <http://www. www.candidomaltacamposfilho. com.br/RevisaoPDE/RPDEor. html>. Acesso em 18 mar. 2013. 93. Idem.

94. Disponível em <http://www. www.candidomaltacamposfilho. com.br/RevisaoPDE/RPDEor. html>. Acesso em 18 mar. 2013. 
5. Campos Filho considerou criticamente a proposta de revisão do Executivo consubstanciado no PL 671/2007, de modo a transformar a primeira na Política de Desenvolvimento Urbano orientadora do Plano Diretor e a segunda, no embrião do Plano Diretor, a ser completado com as políticas setoriais faltantes, mas de modo à inter-relacioná-las, conforme manda a Constituição Federal em seu artigo 182 de modo a cumprir-se efetivamente $\mathrm{o}$ ali estabelecido. A lei n. 13.340/2002, hoje denominada Plano Diretor Estratégico passa a ser denominada Política de Desenvolvimento Urbano Orientadora do Plano Diretor para adequá-la à constituição federa em seu artigo 182. (Depoimento à autora em 15 mar. 2013) urbanos com população economicamente ativa residente e em número suficiente para ocupá-los, em contrapartida deverá haver empresas e estabelecimentos com capacidade de absorção dessa mão de obra com diversos níveis de qualificação.

Para propor diretrizes para um plano urbanístico de desenvolvimento qualitativo para uma região urbana metropolitana, é necessário preparar-se um diagnóstico do cenário atual do ano base ou existente e a partir disso aplicar os conceitos definidos para obter parâmetros e produzir diretrizes que atendam as demandas ou complementem o panorama existente de forma funcional com os objetivos e com metas bem definidas, tanto territoriais como temporais e sempre que possível estimando a disponibilidade de recursos legais, institucionais e financeiros. Tendo em conta o crescimento populacional e a base econômica regional, desenhando cenários futuros planejados. Metodologicamente devemos comparar os cenários futuros planejados, se mais de um, com um cenário tendencial futuro que corresponderia à manutenção das políticas em curso que estão sendo realmente praticadas.

Há um processo de revisão do PDE definido pela lei n. 13.430/2002 em curso enquanto esta tese de doutorado esteve em elaboração.

Segundo Campos Filho,

O processo de revisão foi interrompido quando houve uma discordância pública entre a gestão municipal no poder naquele momento somada a setores da sociedade civil e da classe política que entenderam como não sendo democrática, a proibição presente em artigos do PDE que limitam a revisão a algumas diretrizes secundárias, impedindo a revisão das de maior amplitude.
Campos Filho produziu uma proposta de revisão ampla em 2008, liderando tecnicamente uma equipe de técnicos e políticos que revisaram o PDE 2002/2012 para o Município de São Paulo, aprovado pela lei n. 13.430/2002 conjuntamente com a lei n. $13.885 / 2004 . .^{95}$

Além da regulamentação da revisão do plano mencionada acima, Campos Filho considera como principais diretrizes que permearam o projeto substitutivo,

Tornar o texto da lei mais acessível à população; política de desenvolvimento urbano deverá estar sempre fundada na herança histórica única da cidade considerada e introduzir progressivamente diretrizes políticas, baseadas nos conceitos de sustentabilidade permeando as várias políticas, gerais e setoriais como uma questão estratégica hoje colocada como grande desafio para a humanidade para a manutenção da saúde da vida; atuação integrada entre o estado e a sociedade, (...) resultado de um pacto social que está sendo construído inclusive com a indústria, o comércio, os serviços e especialmente o setor imobiliário produtivo (...) através de uma convergência de esforços entre um nível federal, estadual, e municipais da região metropolitana; desenvolver o conceito de equilíbrio urbano com base no conceito de cidade compacta ambientalmente sustentável; recuperar o uso da rua como espaço de convivência social, mediante uma combinação de diretrizes de desenvolvimento econômico e social e melhoria da qualidade de vida; de circulação e transporte que eliminem o excesso de veículos acima da capacidade de suporte das vias consideradas conforme a qualidade ambiental para elas definida, controlando-se o seu volume, tipo e velocidade; promover a mixagem de usos do solo no território do município de modo a nas centralidades conseguirmos a maior mescla possível em função de seu nível de especialização; enfatizar a importância dos Planos de Bairro, como detalhadores dos Planos Regionais; enfatizar a importância 
democrática que significará a revisão dos planos regionais a partir da consulta popular distrito a distrito..$^{96}$

Campos Filho destaca quatro problemas estratégicos enfrentados na metrópole: congestionamentos, enchentes, habitação popular, preservação dos mananciais e afirma que "para resolvê-los será preciso desenvolver uma consciência crítica dos cidadãos através de uma progressiva ampliação e aprofundamento da educação formal e informal não apenas para os níveis infantil, básico, médio e superior mas ao longo de toda vida do cidadão." Segundo ele, "a escala dos problemas é de tal ordem que sua solução requer que o tempo seja medido em décadas." Em relação ao transporte, afirma que "o ano meta deste horizonte de tempo está sendo deslocado a cada cinco anos, constituindo desse modo que os planejadores mais lúcidos adotassem a feitura de planos como parte de um processo de planejamento a ser revisto e atualizado a cada cinco anos ou a cada gestão." 97

Campos Filho defende que o substitutivo a ser apresentado deveria, na ocasião em que o elaborou ser baseado em elementos da lei n. 13.430/2002, da lei n. 13.885/2004 e do projeto de lei n. 671/2007, além das contribuições das audiências públicas havidas e contribuições dos cidadãos colhidas ao longo da gestão da comissão de política urbana da qual participa. Diante das novas circunstancias políticas, afirma que "tal base não é mais necessária." No entanto, continua defendendo o projeto de lei que foi elaborado com sua coordenação como um bom ponto de partida para o debate que se inaugura neste inicio de 2013 para a revisão do denominado PDE que obrigatoriamente incluirá a lei complementar por se inter-relacionarem, como já exposto.
Deve ser destacado nessa proposta de revisão do Plano Diretor o fato de que nas duas leis revisadas são propostas diretrizes próprias de uma Política Orientadora de um Plano Diretor e de conteúdo mais específico enquanto metas a atingir com prazos distintos, os recursos administrativos e financeiros para atingir face à disposição de recursos e a definição do local de sua implementação. A conjunção entre Política e Plano já foi proposta por Campos Filho na Série Políticas Globais que desenvolveu na COGEP. Conjugar Política e Plano é dizer que o Plano transformado em Política passa a ser a Constituição da Cidade, em paridade ao artigo 182 da Constituição de 1988, onde a política deve ser a primeira orientação geral. $9^{8}$

\section{POLÍTICAS PÚBLICAS VERSUS PLANOS URBANOS}

Políticas públicas definem diretrizes e prioridades, mas de forma vaga, no máximo com um ano meta para implantação. Em relação às propostas definidas no PDE 2002/2012 para o sistema rodoferroviário, não foi possível obter informações sobre as ações que resultaram e se realizaram de forma concreta. Mesmo assim apresentaram-se no Quadro 2 as vias da Região Leste Paulistana que estavam na previsão de melhorias ou expansão no PDE com anos meta de 2006 e 2012.

Deve-se frisar que esta avaliação foi baseada na observação visual, uma vez que, como política pública e não plano urbano, a praxe para a realização de obras públicas é a abertura de uma licitação pública, com prazos exíguos para atendimento e sem o indispensável projeto executivo completo e compatibilizado com todos os conflitos que possam
96. Disponivel em <http://www. www.candidomaltacamposfilho. com.br/RevisaoPDE/RPDEor. html>. Acesso em 18 mar. 2013 97. Idem. 98. Idem. 


\section{QUADRO 2}

RenovaçÃo Viária Proposta no PDE 2002/2012-Ano meta 2006 Região Leste de Paulistana (PDE 2002/2012)

\begin{tabular}{|c|c|c|c|c|}
\hline Vias & $\begin{array}{l}\text { Tipo de intervenção } \\
\text { pelo plano }\end{array}$ & $\begin{array}{c}\text { Meta } \\
\text { conclusão }\end{array}$ & Plano & $\begin{array}{l}\text { Avaliação dos efeitos da } \\
\text { intervenção no tecido } \\
\text { urbano existente }\end{array}$ \\
\hline Av. Sapopemba & A melhorar & 2006 & PDE 2002 & Sem detalhes suficientes \\
\hline Estr. do Rio Claro & A melhorar & 2006 & PDE 2002 & Sem detalhes suficientes \\
\hline Av. Rio das Pedras & A melhorar & 2006 & PDE 2002 & Sem detalhes suficientes \\
\hline Av. Aricanduva & A melhorar & 2006 & PDE 2002 & Sem detalhes suficientes \\
\hline Estr. do Rio Claro & A melhorar & 2006 & PDE 2002 & Sem detalhes suficientes \\
\hline Av. Nova Trabalhadores & A melhorar & 2006 & PDE 2002 & Sem detalhes suficientes \\
\hline Av. Ragueb Chofi & A melhorar & 2006 & PDE 2002 & Sem detalhes suficientes \\
\hline Estr. do Iguatemi & A melhorar & 2006 & PDE 2002 & Sem detalhes suficientes \\
\hline Estr. do Lajeado Velho & A melhorar & 2006 & PDE 2002 & Sem detalhes suficientes \\
\hline $\begin{array}{l}\text { Entre Estr. do Rio Claro } \\
\text { e Av. Ragueb Chofi }\end{array}$ & $\begin{array}{l}\text { Abertura de via } \\
\text { Nova ligação }\end{array}$ & 2006 & PDE 2002 & $\begin{array}{c}\text { Não haverá interferência } \\
\text { evidente no tecido } \\
\text { urbano }\end{array}$ \\
\hline $\begin{array}{r}\text { Entre Av. Nova Trabalhadores } \\
\text { e Rodovia Pres. Dutra }\end{array}$ & $\begin{array}{l}\text { Abertura de via } \\
\text { Nova ligação }\end{array}$ & 2006 & PDE 2002 & $\begin{array}{c}\text { Cortará APA no } \\
\text { município de Guarulhos }\end{array}$ \\
\hline $\begin{array}{r}\text { Entre Av. Gov. Carvalho Pinto e } \\
\text { Estr. de Poá até divisa com município } \\
\text { Ferraz de Vasconcelos }\end{array}$ & $\begin{array}{l}\text { Abertura de via } \\
\text { Nova ligação }\end{array}$ & 2006 & PDE 2002 & $\begin{array}{l}\text { Conflito com tecido } \\
\text { urbano consolidado }\end{array}$ \\
\hline $\begin{array}{r}\text { Entre Av. Marechal Tito } \\
\text { e Estr. Dom João }\end{array}$ & $\begin{array}{l}\text { Abertura de via } \\
\text { Nova ligação }\end{array}$ & 2006 & PDE 2002 & $\begin{array}{l}\text { Conflito com tecido } \\
\text { urbano consolidado }\end{array}$ \\
\hline Av. Marechal Tito & A melhorar & 2012 & PDE 2002 & Sem detalhes suficientes \\
\hline Av. Dr. José Artur Nova & A melhorar & 2012 & PDE 2002 & Sem detalhes suficientes \\
\hline Av. Nordestino & A melhorar & 2012 & PDE 2002 & Sem detalhes suficientes \\
\hline Av. São Miguel & A melhorar & 2012 & PDE 2002 & Sem detalhes suficientes \\
\hline Av. Pires do Rio & A melhorar & 2012 & PDE 2002 & Sem detalhes suficientes \\
\hline $\begin{array}{r}\text { Entre Av. Marechal Tito } \\
\text { e Estr. Dom João }\end{array}$ & $\begin{array}{l}\text { Abertura de via } \\
\text { Nova ligação }\end{array}$ & 2006 & PDE 2002 & $\begin{array}{l}\text { Conflito com tecido } \\
\text { urbano consolidado }\end{array}$ \\
\hline $\begin{array}{r}\text { Estr. do Imperador até Av. Dr. José } \\
\text { Artur Nova }\end{array}$ & $\begin{array}{l}\text { Abertura de via } \\
\text { Nova ligação }\end{array}$ & 2012 & PDE 2002 & $\begin{array}{l}\text { Conflito com tecido } \\
\text { urbano consolidado }\end{array}$ \\
\hline $\begin{array}{r}\text { Av. Gov. Carvalho Pinto até } \\
\text { Av. Águia de Haia }\end{array}$ & $\begin{array}{c}\text { Abertura de via } \\
\text { Nova ligação }\end{array}$ & 2012 & PDE 2002 & $\begin{array}{l}\text { Conflito com tecido } \\
\text { urbano consolidado }\end{array}$ \\
\hline $\begin{array}{r}\text { Av. Dr. Eduardo Cotching } \\
\text { e Av. Aricanduva }\end{array}$ & $\begin{array}{l}\text { Abertura de via } \\
\text { Nova ligação }\end{array}$ & 2012 & PDE 2002 & $\begin{array}{l}\text { Conflito com tecido } \\
\text { urbano consolidado }\end{array}$ \\
\hline $\begin{array}{l}\text { Av. Nordestino entre a } \\
\text { Estr. do Lageado Velho e a divisa com } \\
\text { município de Ferraz de Vasconcelos }\end{array}$ & A melhorar & 2012 & PDE 2002 & $\begin{array}{l}\text { Conflito com tecido } \\
\text { urbano consolidado }\end{array}$ \\
\hline Av. Sapopemba e Av. Aricanduva & $\begin{array}{c}\text { Abertura de via } \\
\text { Nova ligação }\end{array}$ & 2012 & PDE 2002 & $\begin{array}{l}\text { Conflito com tecido } \\
\text { urbano consolidado }\end{array}$ \\
\hline $\begin{array}{r}\text { Av. Aricanduva e } \\
\text { Av. Gov. Carvalho Pinto }\end{array}$ & $\begin{array}{c}\text { Abertura de via } \\
\text { Nova ligação }\end{array}$ & 2012 & PDE 2002 & $\begin{array}{l}\text { Conflito com tecido } \\
\text { urbano consolidado }\end{array}$ \\
\hline $\begin{array}{l}\text { Entre limite de município com Santo } \\
\text { André e Avs. Luis Inácio de Anhaia } \\
\text { Melo, Barreira Grande, Rio das Pedras }\end{array}$ & $\begin{array}{l}\text { Trechos alternados de } \\
\text { abertura de via e melhoria } \\
\text { dos trechos existentes }\end{array}$ & 2012 & PDE 2002 & $\begin{array}{l}\text { Conflito com tecido } \\
\text { urbano consolidado }\end{array}$ \\
\hline
\end{tabular}


surgir como a abertura de novas vias ou elementos viários sobre tecidos urbanos consolidados, o que se verificou no Mapa 34: Rede Viária Estrutural (p.122). Normalmente os editais de licitação solicitam preços de execução de projetos e de execução de obras, o que sempre gera aditivos, mais ou menos justos, pois é muito grande o risco de subdimensionamento de custos se estes são avaliados sobre um estudo preliminar.

\section{OPERAÇÕES URBANAS CONSORCIADAS}

Até aqui se discutiram os planos urbanísticos governamentais em escala metropolitana e municipal na forma de plano diretor municipal. Passase agora à escala regional, mais precisamente às Operações Urbanas Consorciada-OUC e às Áreas de Intervenção Urbana-AIU, ambas operações urbanísticas em escala regional. Defende-se aqui que somente com a combinação de dois instrumentos de planejamento, ou seja, um planejamento regional que quantifica as variáveis de uso do solo e transporte de modo coerente entre si via TRANUS e o planejamento dos bairros concretizando o planejamento de modo a completá-lo de modo concreto é que se alcança a qualidade de vida desejada inclusive e principalmente nos espaços públicos. OUC e AIU podem conter planos de bairro ou vice e versa, quando um plano de bairro propõe por exemplo, uma AIU inserida em seu recorte.

Para viabilizar a renovação de todo o espaço urbano de São Paulo, a administração pública tem lançado mão de instrumentos urbanísticos e da parceria público privada para, inicialmente, planejar intervenções urbanas em grandes extensões do tecido urbano, priorizando duas vertentes: os planos de cunho econômico, alinhado com as tendências urbanas instaladas e os de cunho social e qualitativo, aplicável a regiões mais carentes do município. As OUC são os atuais instrumentos urbanísticos adotados com prioridade para levar adiante a melhoria ambiental de São Paulo, enquanto município e também como metrópole, uma vez que em função dos recortes dessas operações urbanas, podem-se promover alterações na mobilidade urbana e social também dos municípios pertencentes à RMSP, especialmente os que recebam influência das mesmas.

Operações Urbanas Consorciadas são intervenções pontuais realizadas sob a coordenação do Poder Público e envolvendo a iniciativa privada, empresas prestadoras de serviços públicos, moradores e usuários do local, buscando alcançar transformações urbanísticas estruturais, melhorias sociais e valorização ambiental. As OUC visam promover melhorias em regiões pré-determinadas da cidade através de parcerias entre o Poder Público e a iniciativa privada. Cada área objeto de Operação Urbana tem uma lei específica estabelecendo as metas a serem cumpridas, bem como os mecanismos de incentivos e benefícios. O perímetro de cada Operação Urbana é favorecido por leis que preveem flexibilidade quanto aos limites estabelecidos pela Lei de Zoneamento, mediante o pagamento de uma contrapartida financeira. Este dinheiro é pago à Prefeitura e só pode ser usado em melhorias urbanas na própria região. Uma lei de Operação Urbana pode conter concessões não onerosas, entendidas como um estímulo adicional à ocorrência de investimentos na área. No caso de polos geradores de tráfego, exige-se uma contrapartida ao empreender na forma de melhorias viárias para absorver o fluxo excedente de veículos 
99. PMSP. Secretaria de Desenvolvimento Urbano. Disponível em <http:// www.prefeitura.sp.gov.br>. Acesso em 6 jun. 2013 100. Campos filho. Depoimento à autora em 14 mar. 2013

101. Campos Filho. Depoimento à autora, 12 mar. 2013. gerados pelo empreendimento. Nesse instrumento, o Poder Público deve delimitar uma área e elaborar um plano de ocupação, no qual estejam previstos aspectos tais como a implantação de infraestrutura, nova distribuição de usos, densidades permitidas e padrões de acessibilidade. ${ }^{99}$

As Áreas de Intervenção Urbanística-AIU aprovadas no bojo do PDE e sua lei complementar são uma variante das operações urbanas consorciadas.

Segundo análise de Campos Filho,

\section{O objetivo implícito a ser perseguido por} esse instrumento é o de mediante planos urbanísticos de intervenção urbana, como nas OUC regradas pelo Estatuto da Cidade, reordenarem menos a estrutura e mais o tecido urbano de determinada região. Não sendo as OUC regradas pelo Estatuto da Cidade, não estão sujeitas a investirem os recursos que possam ser obtidos pela venda de direitos de construir com origem na diferença entre os potenciais construtivos básicos e os adicionais definidos em lei. Podem servir assim ao objetivo de redistribuir a renda fundiária produzida por ela mesma para outras áreas ou regiões do município. Servirão assim para a redução das desigualdades sociais. As OUC sendo obrigadas pelo Estatuto da Cidade a investirem a totalidade dos recursos obtidos através da outorga onerosa dos direitos de construir que forem para isso definidos, contribuem para se combater a desigualdade social apenas porque evitam que se utilize os recursos provenientes da arrecadação de demais impostos e taxas do orçamento na mesma medida que utilizem os recursos provenientes da mesma outorga onerosa. Assim são dois instrumentos progressistas, ao evitarem e mesmo poderem eliminar se corretamente definidos, a utilização de recursos orçamentários pra as reurbanizações. Tendo sido uma prática comum essa a da utilização de recursos orçamentários para investimentos públicos reestruturadores urbanos por mais de cem anos, no Brasil, sem que tivesse sido possível a implementação da contribuição de melhoria, esses gastos públicos os quais ao valorizarem o entorno eram os produtores da renda fundiária auferida pelos proprietários lindeiros, sempre foi um instrumento que esses proprietários utilizaram para obter as valorizações imobiliárias resultantes, que Campos Filho, corretamente denomina de especulação imobiliária decorrente do investimento público. Para que se cumpra a função social da propriedade para fins urbanos como prescreve a Constituição Federal em seu artigo 182, é essencial combater esse tipo indevido de ganho fundiário. (informação verbal) ${ }^{100}$

Atualmente existem OUC em vigor como as OUC Faria Lima e Água Espraiada, Centro e Água Branca e as futuras, ainda em fase de aprovação pelo poder público ou em fase de discussão em diferentes instâncias de aprovação. São elas as Operações Urbanas Lapa-Brás, Mooca-Vila Carioca e Operação Urbana Eixo do Tamanduateí, sendo estas três últimas partes da Operação Urbana Diagonal Sul e localizadas ao longo da ferrovia entre Santos e Jundiaí.

Agora na recém-iniciada gestão de Fernando Haddad como prefeito de São Paulo, em janeiro de 2013, se menciona uma proposta ainda não sancionada pelo PDE, a ser revisto possivelmente durante 2013, de reformulação das operações urbanas e áreas de intervenção urbanística, situadas ao longo das ferrovias paralelas aos rios Tiete e Pinheiros e ao longo da ligação rodoviária Jacu Pêssego, no chamado Arco do Futuro. Por estar ainda em debate publico e técnico tais reformulações de diretrizes serão consideradas enquanto proposições ainda sujeitas a aprovação dos poderes competentes. (informação verbal) $^{101}$

As diversas OUCs existentes aprovadas, em implantação e em estudo se apresentam desconectadas entre si dentro do perímetro urbano paulistano, por 
serem intervenções pontuais, como proposto na origem. Mas, recentemente, a nova administração municipal divulgou novo plano de integração metropolitana, batizado de Arco Tietê, primeira etapa do Plano Urbanístico denominado Arco do Futuro, propondo uma reestruturação urbana a partir de uma continuidade estrutural e urbana entre as diversas operações Urbanas consorciadas, demonstrado no Figura 79: Arco do Futuro-Arco Tietê em evidência e o restante das manchas, OUC mencionadas acima, além de novas a propor ao longo do Rio Tietê, compondo todo o Arco do Futuro.

Segundo texto oficial da Secretaria Municipal de Desenvolvimento Urbano-SMDU, ${ }^{102}$

A proposição do Arco Tietê como uma unidade territorial se justifica na medida em que se apresenta como espaço de intersecção de dois eixos estruturantes do desenvolvimento urbano da cidade de São Paulo: as operações urbanas consorciadas Diagonal Norte e Diagonal Sul, previstas pelo Plano Diretor Estratégico do Município de São Paulo (art. 225 da Lei nº 13.430/2002), e o território do Arco do Futuro, que se propõe como novo eixo de estruturação do desenvolvimento urbano da cidade de São Paulo. O espaço urbano do perímetro do Arco Tietê contém relações complexas que articulam escalas urbanas e econômicas de abrangências do local ao regional, que devem necessariamente ser consideradas na análise deste território

Tem-se, como exemplo, um conjunto de projetos de mobilidade com interferência direta no perímetro considerado: o projeto implantação do Trem de Alta Velocidade -TAV, a cargo da Agência Nacional de Transportes Terrestres; o projeto de implantação dos trens regionais, sob-responsabilidade da CPTM; a expansão da rede metroviária dentro do município de São Paulo, incluindo suas novas linhas e estações da Companhia do Metropolitano e considerando inclusive possíveis diretrizes de enterramento das

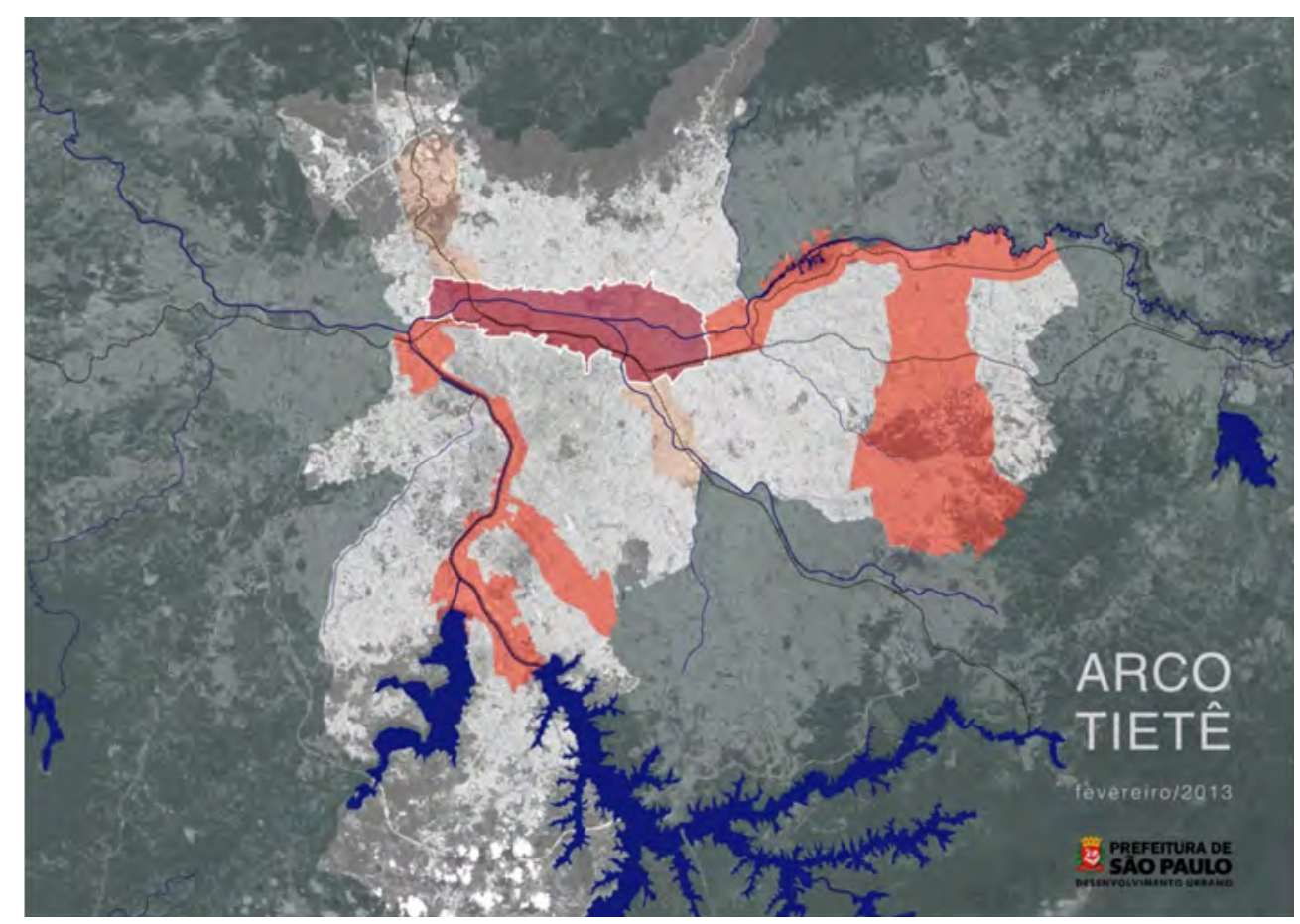

FIGURA 79: Arco do FUtURo-Arco TIETÊ EM EVIDÊNCIA PMSP/SMDU, 2013

linhas; o plano de melhoramentos viários instituídos pelo Plano Diretor Estratégico do Município de São Paulo (Lei Municipal n. 13.430/2002) e dos Planos Regionais Estratégicos, (Lei Municipal n. 13.885/2004) a rede de corredores de ônibus municipais, a cargo da Secretaria Municipal de Transportes. Podem-se considerar outras propostas, relativas ao meio ambiente, como o plano de macro drenagem da bacia do Alto Tietê, a cargo do Governo do Estado de São Paulo.

Os estudos de viabilidade do Arco Tietê devem levar em conta a condição estratégica desse território, tanto no sentido do espaço intraurbano, quanto no macrometropolitano e regional, a fim de orientar um desenvolvimento urbano mais equilibrado do ponto de vista social, econômico e ambiental para a cidade de São Paulo. Neste sentido deve considerar como sendo quatro os setores prioritários para a elaboração dos estudos: 1. Econômico; 2. Ambiental; 3. Mobilidade e Acessibilidade; 4. Habitacional; que devem orientar elementos estruturadores da transformação urbana do perímetro considerado.
102. PMSP-SMDU. Disponívelem<http:// www.prefeitura.sp.gov.br/cidade/ secretarias/desenvolvimento_urbano/ noticias/index. php? $p=142556>$. Acesso em 13 abr. 2013. 

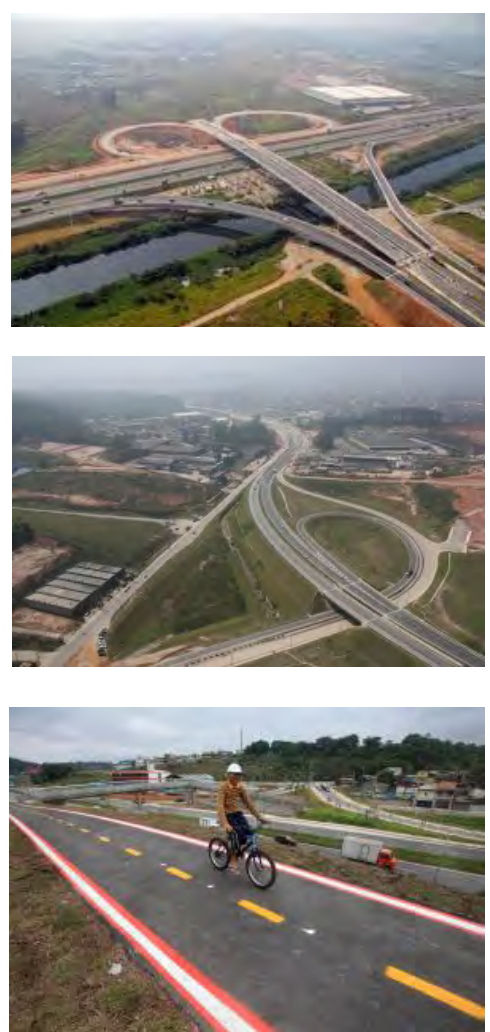

FIGURAS 80 A 82: COMPLEXO VIÁRIO JACU PÊSSEGO-Nova TRABALHADORES

o projeto incluiu uma ciclovia
A RLP, com extensão e população equivalentes as de uma capital europeia, por razões práticas foi dividida em duas, Região Leste 1 e Região Leste 2, tendo sido esta última selecionada para receber a OUC Rio Verde-Jacu. O propósito aqui é analisar e fazer uma crítica ao recorte territorial de abrangência da OUC-RVJ, ou seja, o porquê de sua forma e como foi a escolha dos distritos que nela estão incluídos, além da conceituação das macrozonas apresentadas no edital de licitação do projeto.

A área de localização e recorte da OUC-RVJ merece uma análise própria para esta tese, uma vez que deverá ser fortemente reestruturada em razão da nova oferta de acessibilidade em curso de implantação resultante do eixo viário que funcionará como caminho mais curto entre o Rodoanel e o Aeroporto Internacional André Franco Montoro, mais popularmente conhecido como Aeroporto de Guarulhos. Essa posição estratégica lhe dá excepcional poder transformador urbano na Região Leste 2. Em virtude disso, a área a leste dela, excluída da operação urbana, mas que é uma das mais carentes de São Paulo, merece ser incluída na área de estudo em desenvolvimento nesta tese, conforme será demonstrado neste capítulo, na análise do tecido urbano elaborada para a proposição de reestruturação de transporte e circulação dentro do espaço intraurbano moldado a partir dos sistemas viários implantados na região nas últimas cinco décadas.

A estruturação ocasionada pela Avenida Jacu pêssego-Nova Trabalhadores e sua importante ligação entre o município de Guarulhos e o ABCD paulista tem interrelação direta com a OUC-RV), pois uma é o embasamento estrutural da segunda. É importante discorrer sobre alguns dados históricos e colhidos no Portal da Secretaria de Desenvolvimento Urbano

da Prefeitura de São Paulo, como segue:

\section{COMPLEXO VIÁRIO JACU PÊSSEGO- NOVA TRABALHADORES}

A Avenida Jacu Pêssego-Nova Trabalhadores é hoje um importante eixo rodoviário do município de São Paulo. Segundo o texto oficial sobre a construção desse eixo viário, a Prefeitura de São Paulo informa que:

O primeiro trecho foi inaugurado em 1996, na gestão do prefeito Paulo Maluf. Nessa época, era apenas uma via local, entre os bairros de São Miguel, Itaquera e São Mateus. A obra interliga o trecho Sul do Rodoanel com a Avenida Jacu Pêssego, possibilitando melhor mobilidade no transporte de passageiros e cargas, através da consolidação do corredor de tráfego do Rodoanel Sul (no município de Mauá) com a Avenida Jacu Pêssego e rodovias Ayrton Senna e Dutra (município de Guarulhos), como também de toda Zona Leste de São Paulo. A via será uma alternativa enquanto o Trecho Leste do Rodoanel não for concluído.

Em 27 de junho de 2008 foi concluído o prolongamento da Av. Jacu-Pêssego (lado norte) com extensão aproximada de 2,1 quilômetros, entre a Av. Frei Fidelis Mota (final da Rua Dr. Assis de Ribeiro) e SP. 070 Rodovia Ayrton Senna da Silva (altura do km 23), permitindo uma ligação direta entre a rodovia e a avenida, garantindo uma integração maior e mais rápida com a região central da cidade, a Marginal Tietê e os municípios a leste da Região Metropolitana de São Paulo.

O Complexo Jacu Pêssego foi inaugurado em 16 de outubro de 2010 compreendendo a primeira etapa do empreendimento, com 13,6 quilômetros com três faixas de rolamento de cada lado, um canteiro central de seis metros, calçadas, guias, sarjetas e baias para parada de veículos a cada quilômetro, sinalização, iluminação, elementos de segurança e paisagismo. Foram executados também 
20 viadutos, um túnel sob os dutos da Petrobras e quatro passarelas provisórias para possibilitar a travessia de pedestres.

Em março de 2011 foi retomada a segunda etapa, compreendendo a conclusão das obras do Complexo Juscelino Kubitschek (JK) incluindo viadutos e alças de transposições das linhas da CPTM e Avenidas João Ramalho e Alberto Soares Sampaio, bem como do trecho que antecede a alça de chegada do Rodoanel trecho Sul na avenida Papa João XXIII. Também foi retomada a construção de três vias Marginais (extensão: 4,6 quilômetros), nos seguintes locais: Marginal COHAB nos dois lados (extensão: 2 quilômetros); Marginal entre o trevo da Ragueb Chohfi e viaduto São Rafael (extensão: 2,1 quilômetros); Marginal entre o viaduto Pedro de Medeiros e Av. Sapopemba (extensão: 0,5 quilômetros). A conclusão da segunda etapa se deu em 2011. ${ }^{103}$

\section{OPERAÇÃO URBANA CONSORCIADA RIO VERDE-JACU}

A partir da análise do edital de diretrizes básicas para o desenvolvimento do plano para a OUC-RV], vê-se que esta tem como pano de fundo a readequação urbana de cunho social e não voltada ao mercado imobiliário, o que poderá ser uma forma de mitigar a expulsão dos moradores e frequentadores da região como resultado do inevitável "enobrecimento" de áreas distritais metropolitanas ou como o termo em inglês, a gentrification. ${ }^{104}$ Assim, podemos afirmar que esta operação urbana, com esse cunho social, é diferente das demais aprovadas para o município de São Paulo até o momento.

Como harmonizar os Planos de Bairro com os planos urbanísticos das Operações Urbanas é a questão a ser tratada com profundidade necessária para que se leve a cabo a tese defendida aqui, de estender o planejamento urbano regional até o
Planejamento em escala local, na forma de planos de bairro, onde efetivamente se delineiam as demandas a partir da consulta pública em paralelo ao trabalho técnico de levantamentos de índices socioeconômicos e territoriais e os cálculos de capacidade de suporte entre transporte público e uso do solo, utilizando-se o sistema TRANUS, posteriormente aperfeiçoado pelo trabalho da FUPAM, já mencionado anteriormente na fundamentação teórica e que será detalhado na metodologia sugerida no Capítulo VI a seguir.

A ação de definir-se a delimitação de uma área ou recorte espacial para aplicação de uma OUC, mostrou-se uma ação complexa em função não somente do porte da região, mas também em função do projeto da Operação Urbana Consorciada Rio VerdeJacu estar ainda em andamento durante o período de desenvolvimento desta tese, por urbanistas paulistanos contratados para esse fim. ${ }^{105}$

A OUC-RVJ encontra-se em fase de desenvolvimento e o que se tem em mãos para análise e alinhamento com este plano são as diretrizes básicas e um mapa de setores de uso e ocupação do solo desenvolvido pela Secretaria de Desenvolvimento Urbano da Prefeitura de São Paulo, que divide a área da OUC em quatro tipos de setores e usos. (cf.

Mapa $40($ (p.152))

A OUC-RVJ faz parte de um conjunto de OUC que redefinirão grande parte do tecido urbano no Centro Expandido, Zona Norte, Zona Sul e Zona Leste, como mostra o Mapa 39 (p.151). Foram denominadas Operações Urbanas Reagrupadas as OUCs Lapa-Brás e Mooca-Vila Carioca (números 1 e 3, localizadas ao longo do perímetro do Centro Expandido e dentro dele) e OUC-RVJ. (número 2)
103. O valor previsto de investimento no empreendimento é de 2,14 bilhões de Reais, sendo 1,48 bilhão Reais para as obras brutas e 660 milhões de Reais referentes a reassentamentos, desapropriações, projeto, gerenciamento, supervisões, compensações ambientais e obras complementares, entre outros. Foram criados dois novos parques municipais em São Paulo: Parque Jardim da Conquista e Parque Guabirobeira. Em ambos, além da preservação da natureza, será possível encontrar opções de lazer da população em geral. PMSP. Operação Urbana Consorciada Rio Verde-Jacu... p.5. Disponível em <http://www.prefeitura.sp.gov. br/cidade/secretarias/upload/ chamadas/ouc_rvj_tr_1308775998. $\mathrm{pdf}>$. Acesso em 18 mar. 2013.

104. Gentrification, do termo em inglês gentry, que dá nome à camada social logo abaixo da realeza, portanto, com alto poder aquisitivo e que pode custear a alta de custos de se viver em áreas valorizadas acima do razoável. É usado para ilustrar o fenômeno da expulsão de moradores de locais que, uma vez requalificados, se tornam caros tanto no custo de vida

105. A Operação Urbana Consorciada Rio Verde-Jacu foi criada pela lei n. 13.872 , de 12 de julho de 2004 , como parte de um programa que propõe a mudança da região pelo desenvolvimento econômico e social, visando à melhoria das condições gerais da região e da população residente. Articulada ao Programa de Desenvolvimento da Zona Leste, tem por objetivo criar condições para a atração de investimentos geradores de emprego e renda e incentivar a instalação de atividades industriais e de prestação de serviços na região, especialmente os destinados à formação e capacitação profissional. (PMSP/SMDU) 
106. PMSP. Operação Urbana Consorciada Rio Verde-Jacu.. p.5. Disponivel em <http://www. prefeitura.sp.gov.br/cidade/ secretarias/upload/chamadas/ ouc_rvj_tr_1308775998.pdf>. Acesso em 18 mar. 2013.

107. Em relação à política de incentivos seletivos, deve ser mencionada a edição da lei n. 14.654/2007, complementada pela lei $\mathrm{n}$. 14.888/2009, que propôs um novo perímetro para aplicação dos incentivos fiscais, focando sua aplicação nas áreas de centralidades e ao longo dos eixos estruturais viários e de transporte coletivo. Dentre os investimentos públicos realizados, merece destaque à complementação da Av. JacuPêssego-Nova Trabalhadores, eixo da Operação Urbana Consorciada. O prolongamento Av. Jacu Pêssego-Nova Trabalhadores ao norte já se encontra implantado e a conclusão da obra até o limite do município de Mauá estava prevista para 2012. Ibidem, p.6.
As principais características da OUC-RVJ, coletadas a partir do documento oficial publicado pela prefeitura de São Paulo para divulgar os objetivos esperados da implantação dessa operação urbana, são:

Dentre as Operações Urbanas vigentes no município, a OUC-RVJ é a que apresenta maiores desafios, tanto pelas características da região que se pretende transformar e amplitude de seu perímetro como por sua estratégia de combinar um plano de desenvolvimento econômico e social às propostas de transformações estruturais em seu território. É a primeira Operação Urbana Consorciada proposta na cidade com vistas ao desenvolvimento econômico, buscando a melhoria das condições de vida de sua população, através do incremento da oferta de empregos, da capacitação profissional e da melhoria da qualidade ambiental da região. ${ }^{106}$

Ainda segundo a publicação em relação à OUC-RV), a administração pública justifica a tomada de recursos para viabilizar essa operação urbana:

\begin{abstract}
Vai, portanto, além da criação de mecanismos e aplicação direta de instrumentos urbanísticos e tributários que tenham por fim arrecadar recursos de imediato. Ao contrário, é bastante ambiciosa nos seus objetivos, propondo-se a criar condições de desenvolvimento cuja consequência deve ser a melhoria dos índices de Desenvolvimento Humano, não apenas dessa região, mas do município como um todo. ${ }^{107}$
\end{abstract}

\section{O Mapa 40: OUC-RVJ Setores/Macrozoneamento} mostra os setores de Uso e Ocupação do Solo determinados pela PMSP como base para o plano urbanístico que será detalhado pelos técnicos contratados. São quatro setores principais: CS-setor de comércio e serviços; CSI-setor de comércio, serviços e indústria; SM-setor de usos mistos; e o setor de urbanização controlada MPA-macroárea de proteção ambiental.
A Operação Urbana Rio Verde-Jacu, aprovada no bojo do Plano Diretor de 2002 para o município de São Paulo, estimula a chegada de indústrias em seu plano de uso e ocupação do solo preliminar, mas, pela localização ao lado da APA do Carmo, deverão ser indústrias ecologicamente sustentáveis.

O recorte espacial da Operação Urbana Consorciada Rio Verde-Jacu localiza-se no extremo Leste de São Paulo, mas a delimitação eleita não coincide com o limite leste do município de São Paulo, excluindo uma grande parte do extremo leste, formada pelo conjunto dos distritos Jardim Helena, Itaim Paulista, Vila Curuçá, Lajeado, Guaianases e Cidade Tiradentes, áreas urbanas e carentes em vários sentidos, com muitas glebas irregulares sob o ponto de vista fundiário e classificadas como setores muito vulneráveis pela administração pública.

A conformação da OUC-RVJ se dá ao longo da Avenida Nova Trabalhadores e Avenida Jacu Pêssego, que atuará como trecho Leste do Rodoanel enquanto este trecho da obra não estiver finalizado.

Em relação às áreas lindeiras à OUC-RVI, a prefeitura de São Paulo considera que haverá reflexo de ganho em qualidade urbana no entorno da operação, o que é significativo para esta tese de doutoramento:

A par dessas ações, com base nas diretrizes de desenvolvimento urbano constantes do PDE, para reestruturação e requalificação da porção leste do município, a Administração Municipal vem amadurecendo outras proposições e intervenções na Região Leste do Município, como a proposta do Polo Institucional junto à Estação Itaquera do Metrô e a proposta para a reestruturação do Polo Econômico Leste. Com estas iniciativas, o caráter 


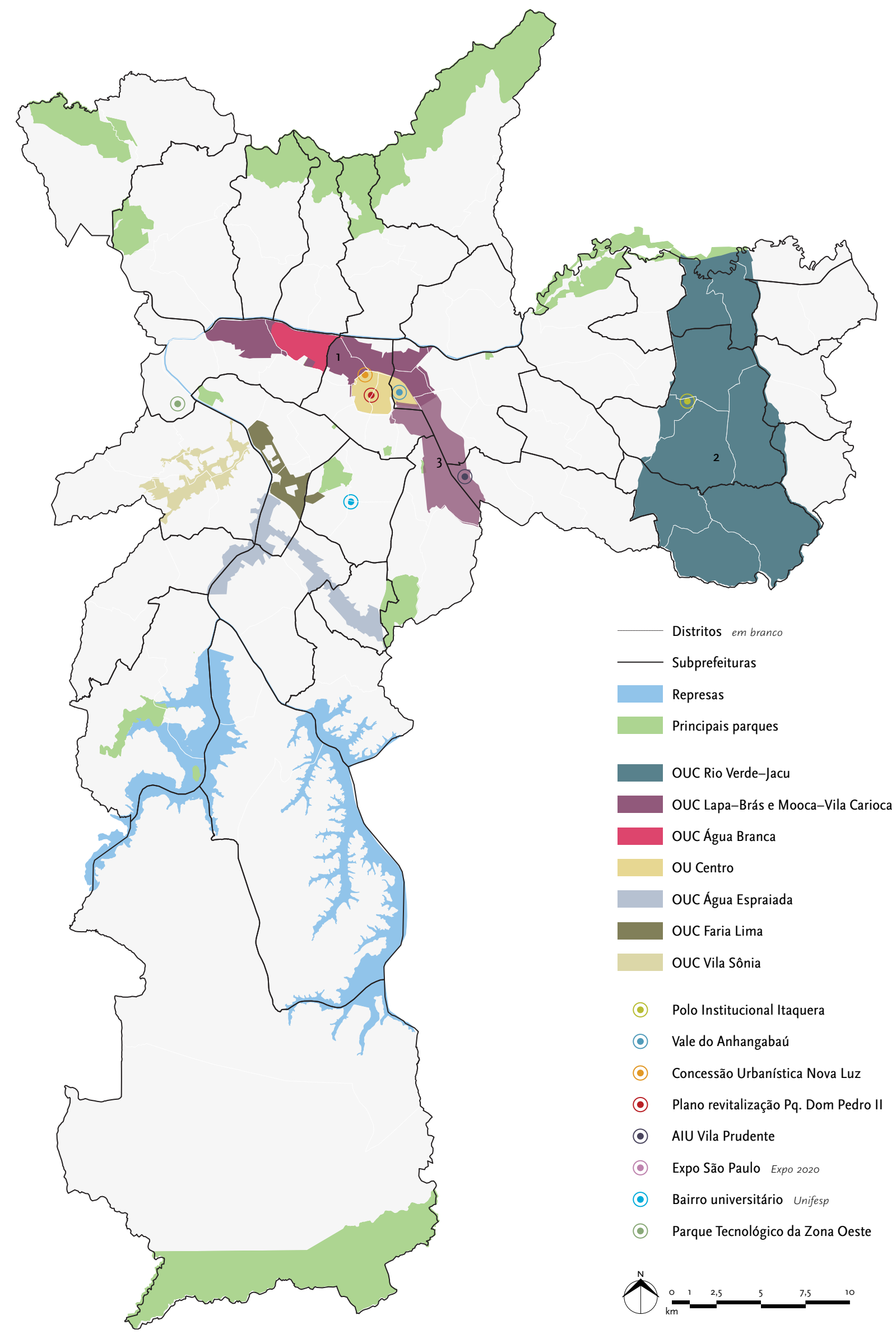

Mapa 39: Projetos e Operações Urbanas 


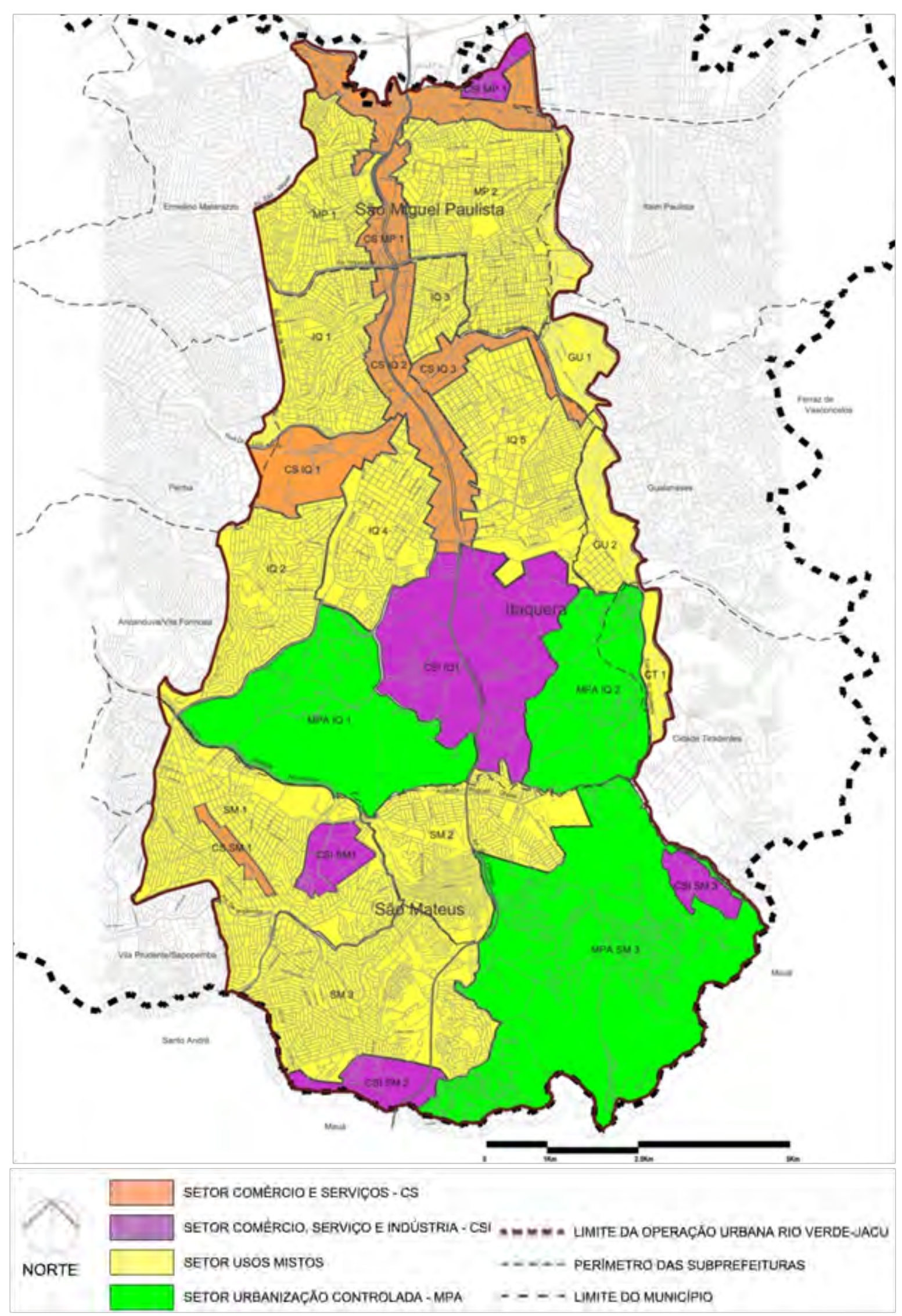

Mapa 40: OUC-RVJ Setores/Macrozoneamento

PMSP/SMDU, 2013 
regional de Itaquera é consolidado como centro polarizador (catalisador ou irradiador) dos investimentos públicos na região para reestruturação urbana a ser empreendida e amplifica os efeitos destas ações para as Subprefeituras do entorno. ${ }^{108}$

\section{DiRETRIZES MUNICIPAIS PARA A OperaÇÃo Urbana Consorciada Rio Verde-Jacu}

Em documento publicado pela prefeitura de São Paulo em seu site oficial, destacaram-se as principais diretrizes formuladas pela Secretaria Municipal de Desenvolvimento Urbano para o projeto a contratar, como:

Os vencedores desenvolverão e detalharão, em cooperação com as equipes técnicas da Prefeitura, os planos urbanísticos das operações. Terão, também, de produzir estudos de impacto ambiental, estudos de capacidade de suporte da infraestrutura de circulação, estudos econômicos e um plano de comunicação para cada operação. Entre os principais objetivos a serem alcançados pela Operação Urbana Rio Verde-Jacu, destacamos a promoção, no longo prazo, da renovação urbana da região estruturada pelo eixo da av. Jacu Pêssego (cujo prolongamento foi concluído em 2010), importante ligação viária entre o $A B C$, $\circ$ Porto de Santos (Rodoanel) e Guarulhos (rodovia Airton Senna), o incremento da atividade econômica na zona leste, incentivando a capacitação profissional e a geração de empregos. A intenção é aproveitar a proximidade do Polo Institucional com o Polo Industrial de Itaquera, que terá suas atividades incrementadas. E ao mesmo tempo, promover a requalificação ambiental por meio do aumento de parques e áreas verdes na região, a melhoria do sistema de drenagem e o incentivo à construção de habitações de interesse social. ${ }^{109}$

A prefeitura de São Paulo, em seu documento oficial de licitação dos projetos e planos, programas e projetos urbanos para a OUC-RV], apresenta um diagnóstico da área abrangida para a aplicação da OUC, com dados socioeconômicos, de infraestrutura urbana e oportunidades de trabalho dentre outros, como segue: ${ }^{110}$

A região da Operação Urbana Consorciada Rio Verde-Jacu está localizada na Zona Leste do Município, incluindo áreas das regiões administrativas de São Miguel Paulista Itaquera e São Mateus, cortadas pela antiga Estrada do Pêssego, atual complexo viário Jacu Pêssego-Nova Trabalhadores.

Estendendo-se sobre um território de aproximadamente 11.283 hectares e concentra cerca de 1.320.138 habitantes, o que representa cerca de $11,7 \%$ da população total residente na cidade (11.245.983 habitantes), conforme censo IBGE 2010. A população projetada para 2020 , considerando uma taxa de crescimento 2000/2010 de 0,98\% a.a., é de 1.163.997 habitantes. Embora o conjunto da região Rio Verde-Jacu apresente como tendência geral uma redução nas taxas de crescimento, é uma região de forte crescimento populacional, formada por distritos populosos.

Segundo a Relação Anual de Informações Sociais-RAIS 2007, aproximadamente $48 \%$ dos empregos formais da área da Operação Urbana estão nos grupos de serviços administrativos, nos serviços em geral e vendedores do comércio em lojas e mercados, atividades pouco complexas. Cerca de $24,5 \%$ dos empregos formais relacionam-se a atividades pouco complexas de produção de bens e serviços industriais (incluindo construção civil) e apenas 5\% estão relacionados a atividades complexas da produção de bens e serviços. Quanto à distribuição de empregos por estabelecimento da área da OUC-RVJ, esta é maior na indústria de transformação, observandose a seguinte proporção: 7 empregos por estabelecimento comercial, 12,79 empregos por estabelecimentos de serviços e 18,53 empregos por estabelecimento industrial. (sendo de 84.868 o total de empregos formais na área da OUC-RV], representando 2,72\% do total de empregos formais da cidade)
108. PMSP. OUC Rio Verde-Jacu. Termo de referência... p.7.

109. Ibidem, p.3.

110. Ibidem, p.3-4 
FIGURA 83: OUC-RVJ • POLOS INSTITUCIONAL, TECNOLÓGICO E ECONÔMICO

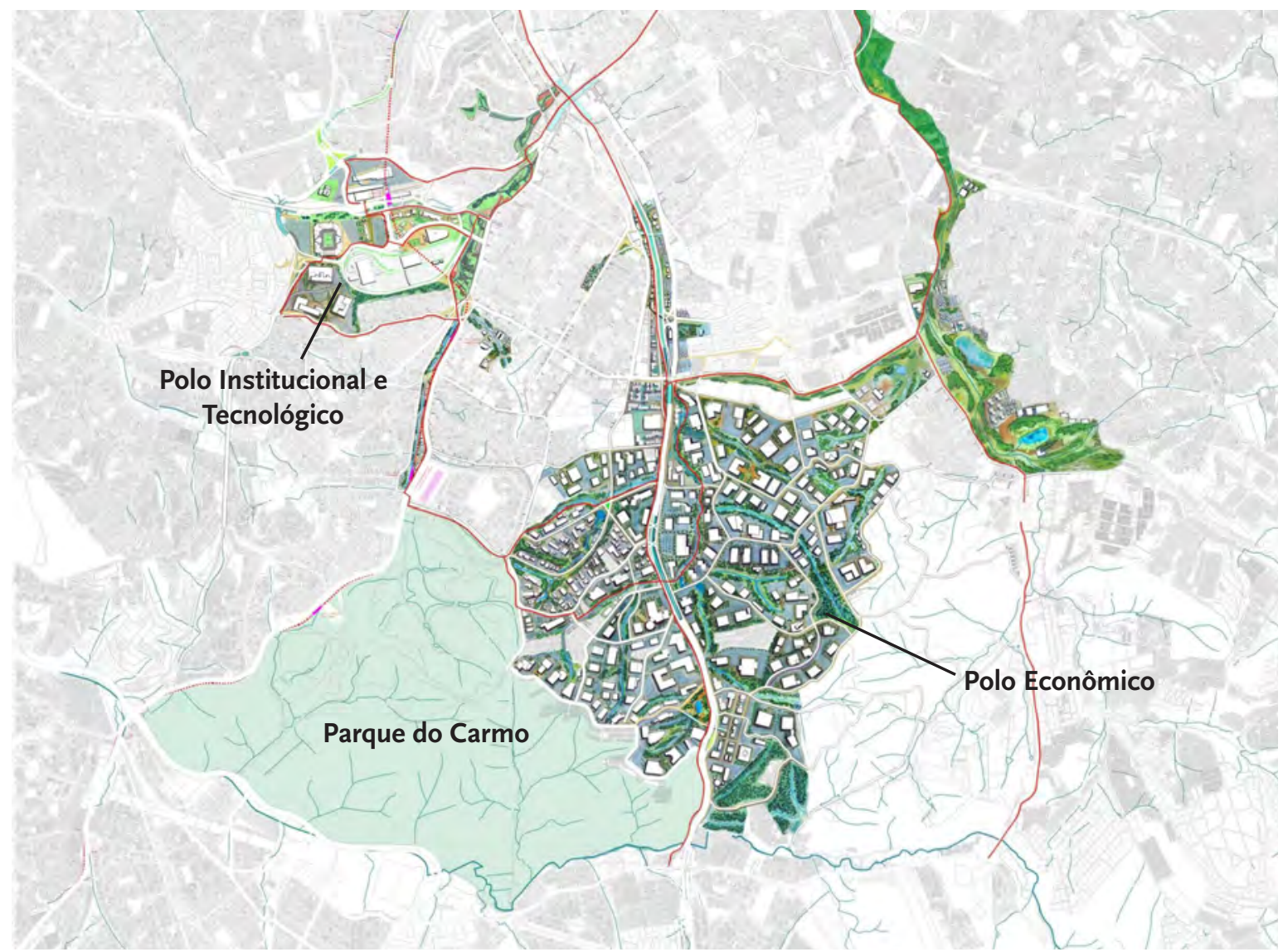

Assim, não obstante apresente um contingente populacional expressivo em relação à população da cidade, a região da Operação Urbana Consorciada Rio Verde-Jacu apresenta deficiências quanto às oportunidades de emprego na própria região. Essa situação obriga a população a deslocamentos diários em direção à área central, sobrecarregando a infraestrutura já insuficiente, refletindo-se de forma negativa na qualidade de vida de seus moradores.

Com poucas oportunidades de emprego, a região caracteriza-se como "bairro dormitório," gerando forte demanda em relação ao transporte coletivo direcionado ao Centro e aos parques industriais de Guarulhos e $A B C$. Esta demanda é concentrada nos horários de início e final do dia, com ociosidade nos demais horários. Obviamente tal situação tem reflexos negativos sobre a qualidade de vida dessa população, gerando também impactos na infraestrutura das áreas mais centrais.
As características físicas da região e a as condições de ocupação do território também não favorecem o desenvolvimento econômico e social e a melhoria da qualidade de vida. No que concerne ao sistema viário, identificase uma malha de vias coletoras de baixa capacidade e desarticulada, que dificulta a acessibilidade, a circulação e impede a formação de centralidades.

O sistema viário de São Paulo caracteriza-se por ser predominantemente radial, polarizado pela área central, o que implica problemas de articulação entre as várias áreas do município. A rede viária tornou-se insuficiente para o atendimento das necessidades geradas pelas relações de atividades dentro do município, principalmente as relações referentes a viagens entre residência e emprego. A insuficiência da rede viária é gritante nas áreas periféricas, onde houve expansão acelerada da cidade nestas últimas décadas, com o assentamento residencial de baixo padrão, principalmente nas regiões Norte, Sul e Leste, 
sem a necessária implantação de um sistema de transporte coletivo que atenda esta demanda. Nestas áreas, apesar das melhorias já efetuadas, a necessidade de ampliação da malha viária ainda é flagrante, não só para o desempenho operacional do tráfego, como para oferecer outras possibilidades de articulação urbana.

A afirmação sobre a situação da rede viária acima está correta uma vez que as obras planejadas para expansão e melhoria da rede viária propostas no PDE 2002/2012, cujas metas de realização previstas em duas etapas, 2006 e 2012, não foram atingidas na maioria dos casos. A relação de obras previstas está listada no Quadro 2 (p.144).

\begin{abstract}
Além disso, a região, embora densamente ocupada, tem baixa disponibilidade de áreas permeáveis, o que agrava os problemas de drenagem existentes na região. Portanto, não sem razão, a região tem sido alvo de vários estudos e proposições para o desenvolvimento econômico da Zona Leste. A proposição de instrumentos urbanísticos e econômicos, além de uma série de intervenções físicas para a Zona Leste do Município, justifica-se frente à sua localização estratégica do ponto de vista da região metropolitana e da cidade, se não somente por suas características específicas, que apontam para a necessidade de ações efetivas do poder público."'
\end{abstract}

O conjunto dos distritos excluídos do recorte da OUC-RV) (Jardim Helena, Itaim Paulista, Vila Curuçá, Lajeado, Guaianases e Cidade Tiradentes) possui uma população total de 987.787 habitantes e território de 10.131,13 hectares (IBGE 2010). Essa população vive em condições muito precárias no que se refere a qualidade urbana e ambiental, seja por falta de equipamentos públicos com capacidade de atendimento ao número de habitantes de acordo com a faixa etária, seja pelas condições precárias de moradia. Mais detalhes sobre as características territoriais e socioeconômicas dessa população serão tratados no Capítulo V desta tese.

\section{CRITÉRIOS PARA DELIMITAÇÃo dA OUC RIO VERDE-JACU}

A Operação Urbana Consorciada Rio Verde-Jacu é a maior OUC em extensão já proposta para o perímetro urbano de São Paulo. Interfere de forma importante na definição de um recorte espacial como estudo de caso nesta tese, pelo impacto a gerar na região em todos os sentidos: uso do solo, transporte, circulação, adensamento, verticalização, mobilidade social de classes, atração de empresas, criação de postos de trabalho, meio ambiente, desenvolvimento urbano e a valorização imobiliária.

Fez-se necessária uma análise crítica da OUC-RV) em relação a como esta foi delimitada. Quais foram os critérios dessa delimitação que corta a Região Leste 2 alcançando os limites do município nos extremos norte e sul dessa região, praticamente criando uma outra região leste, a do extremo leste? Por que não se incluiu nesse recorte as áreas até as franjas da cidade em seu limite leste com os outros municípios da RMSP? Por que seu perímetro de recorte inclui distritos inteiros em lugar de abranger setores censitários? Não seria outro o melhor formato para dar corpo à OUC-RVJ, de forma mais arredondada que vertical, formando uma massa central de atração para os distritos em seu entorno?

O Mapa 41 (p.157) representa o recorte territorial oficial previamente definido para a OUC-RVI pelo edital publicado e o Termo de Referência. Basicamente, ele secciona a Região Leste 2 em duas partes, pois exclui seis distritos dessa área,
111. PMSP. Concorrência n. 01/2011/ SMDU (Edital), p.4. Disponível em: <http://www.prefeitura.sp.gov. br/cidade/secretarias/upload/ chamadas/edital_1310218121. pdf $>$. Acesso em 18 mar. 2013. 
localizados no extremo leste da cidade. Da mesma forma não se considerou o distrito de Cidade Líder e Ermelino Matarazzo, ambos fazendo parte da RLP 2. Quais foram os motivos à época da divisão para que ambos os distritos mencionados não fossem incluídos na RLP 1? Uma das razões deve ter sido o número de distritos da RLP 1: 17, sobrando 15 para a RLP 2.

Fazendo-se uma correlação do distrito de Cidade Líder com a cidade de São Paulo, Cidade Líder apresentou população de 126.512 habitantes, área territorial de 10,20 quilômetros quadrados e densidade demográfica de 12.403 habitantes por quilômetro quadrado, bem acima da média de São Paulo que é de 7.458 habitantes por quilômetro quadrado. O crescimento populacional em Cidade Líder em quinze anos foi de $17,24 \%$, enquanto São Paulo teve crescimento de 7,85\% no mesmo período. (cf. Quadro 4 (p.168))

A partir do grande eixo estruturador da Região Leste que é o Complexo Viário Jacu Pêssego-Nova Trabalhadores, o primeiro entendimento que se tem é que a partir desse importante eixo que faz a ligação entre Guarulhos e o $A B C D$, toda sua extensão deve ser considerada como indutora na instalação de novos serviços e comércio de grande porte, indústrias, hospitais, centros de compras. Há, aparentemente, uma lógica nessa organização territorial da OUC, mas ainda assim ficaram seis distritos carentes excluídos do plano urbanístico e que estão localizados entre municípios da RMSP que não necessariamente tem capacidade de ofertar postos de trabalho aos moradores do seis distritos excluídos.

Aplicando-se o conceito dos 5,5 quilômetros de um eixo estruturador até o local de moradia de um habitante dentro de um espaço intraurbano como deslocamento máximo conforme detalhado no Capítulo III e demonstrado na Mapa 41 em tracejado, sendo cinco quilômetros a leste e e outros cinco a oeste da avenida Jacu Pêssego-Nova Trabalhadores. Constata-se que aproximadamente mais da metade do território dos seis distritos fica a uma distância bem maior que esta, o que os obrigaria a deslocarse por uma trecho muito acima do desejado para ocupar um posto de trabalho dentro da OUC-RVJ.

A próxima etapa desta análise do recorte territorial da OUC foi montar um novo recorte a partir dos sistemas rodoferroviários existentes na região e em expansão, como se viu no item 1 deste capítulo. (PITU 2025)

O Mapa 42 apresenta um recorte alternativo definido a partir dos eixos estruturais com aplicação do conceito dos $5 \mathrm{~km}$ aproximadamente e de forma a formar uma área territorial mais central, o que não se mostrou eficaz, uma vez que os distritos a extremo leste continuariam excluídos, o mesmo para Iguatemi, ao sul da mancha. Deslocando-se a mancha mais à direita, a OUC abrangeria também distritos da $\mathrm{RLP}$ 1, que, como já dito, são mais próximos ao Centro Expandido e, por esse motivo, acabam por ter mais oportunidades a uma distância menor e menos crônica que os distritos da RLP2.

No Mapa 42, sugere-se um recorte territorial alternativo para a OUC-RVJ, com população de 1.062.107 habitantes e densidade demográfica média de 11.998 habitantes por quilômetro quadrado, estruturada a partir das linhas de metro e da CPTM do centro ao leste, pelo Complexo Viário Jacu Pêssego-Nova Trabalhadores e pela Avenida Aricanduva que, por sua vez, faz a ligação entre as rodovias Dutra, 


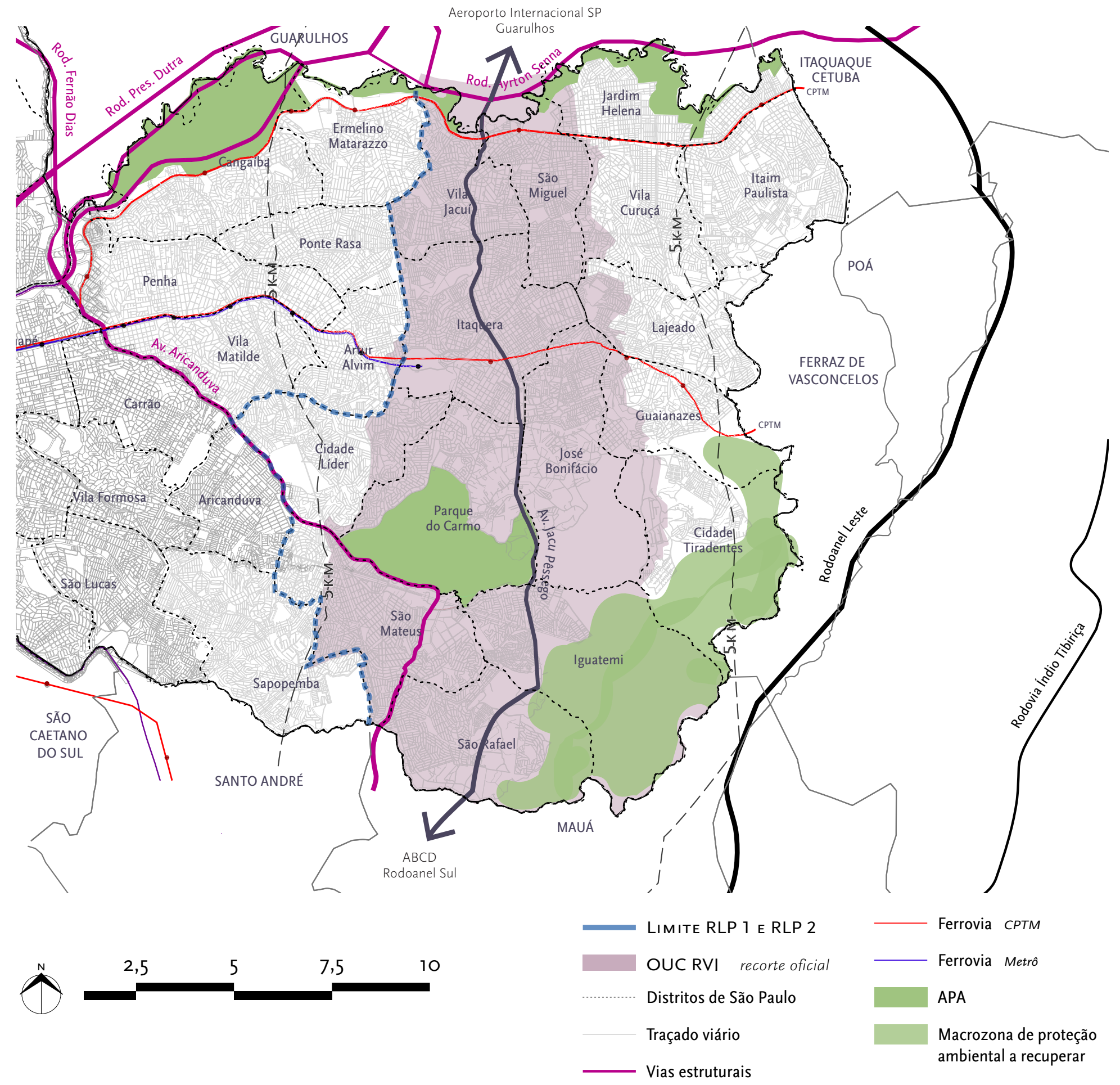

MAPA 41: OUC-RV] RECORTE TERRITORIAL OFICIAL MEPR, 2013 
Fernão Dias e Ayrton Senna. Considerando-se que a enorme área em verde representando APAs - e que, na realidade, estão tomadas por invasões irregulares formadas por moradias precárias, seus moradores podem ser transferidos para moradias em edifícios multifamiliares nos mesmos locais onde moram hoje. A área mais distante da OUC proposta nesta opção ficaria a 7,5 quilômetros da borda desse pano urbanístico, o que seria uma grande desvantagem por tudo o que já observamos aqui, mas o distrito de Itaim Paulista, o mais distante poderia ser atendido por uma AIU própria ou um Plano de Bairro, como o proposto e aprovado para o distrito de Perus, já detalhado no Capítulo I. Este recorte proposto mantém uma faixa entorno de toda a operação urbana aproximadamente homogênea em parte da RLP 1 (três distritos) e em grande parte da RLP 2 (12 distritos) onde se propõem a implantação de planos de bairro com urbanização controlada, como vimos propondo aqui em continuidade às políticas públicas definidoras de diretrizes gerais.

Para corrigir a forma do recorte territorial oficial da OUC-RVI, definida principalmente em função do grande eixo estruturador, restou fazerem-se dois ajustes importantes a esse formato: incluir o distrito de Cidade Líder pertencentes à RLP2, de forma a que este usufrua dos benefícios a serem propostos pelos desenvolvedores do plano urbanístico OUC-RV]; a segunda e mais importante alteração foi incluir os seis distritos do extremo leste, para desta forma não criar uma terceira área na Região Leste e proporcionar-Ihes todos os benefícios que uma OUC de cunho social poderá trazer no âmbito socioeconômico e de localização. Esta é a proposta para o recorte territorial da OUC-RVJ, ou seja, que esta abranja todos os quinze distritos da RLP2.
Cria-se o recorte territorial proposto alternativo 1. Mais detalhes sobre as características territoriais, populacionais, crescimento da população e empregabilidade dos quinze distritos da RLP2 e também da $R \mathrm{LP}_{1}$, para melhor compreensão do aqui exposto estão no Capítulo V.

Três opções para a conformação territorial da OUCRVJ, estão aqui apresentadas, sendo 1. A delimitação oficial como diretriz básica no concurso de escolha do escritório de urbanismo para desenvolver o planejamento urbano e o projeto urbanístico dessa grande operação urbana: Mapa 41 (p.157); 2. a primeira alternativa aqui sugerida para discussão e que apresenta um formato mais centralizado dentro da Região Leste Paulistana: Mapa 42; e, 3. a segunda opção, uma conformação derivada da que foi proposta preliminarmente pelo corpo técnico e consultores da Prefeitura de São Paulo, incluindo-se os distritos da RLP 2 excluídos da conformação original: Mapa 43, como já explicado acima.

Mas, para esta tese, a melhor forma para o recorte territorial para receber a Operação Urbana Consorciada Rio Verde-Jacu é a próxima, demonstrada no Mapa 44: OUC-RVJ recorte territorial proposto alternativo 3. Esta é uma conformação que tem uma área territorial bem superior à forma oficial, mas justificável a partir dos seguintes argumentos:

1. Operações Urbanas Consorciadas devem ter as dimensões territoriais equivalentes ao plano urbanístico desejado e à demanda existente por requalificação ou reestruturação urbana;

2. Está contida em um polígono formado por sistemas rodoferroviários estruturais como a Marginal Tietê, rodovia Ayrton Senna seguindo 

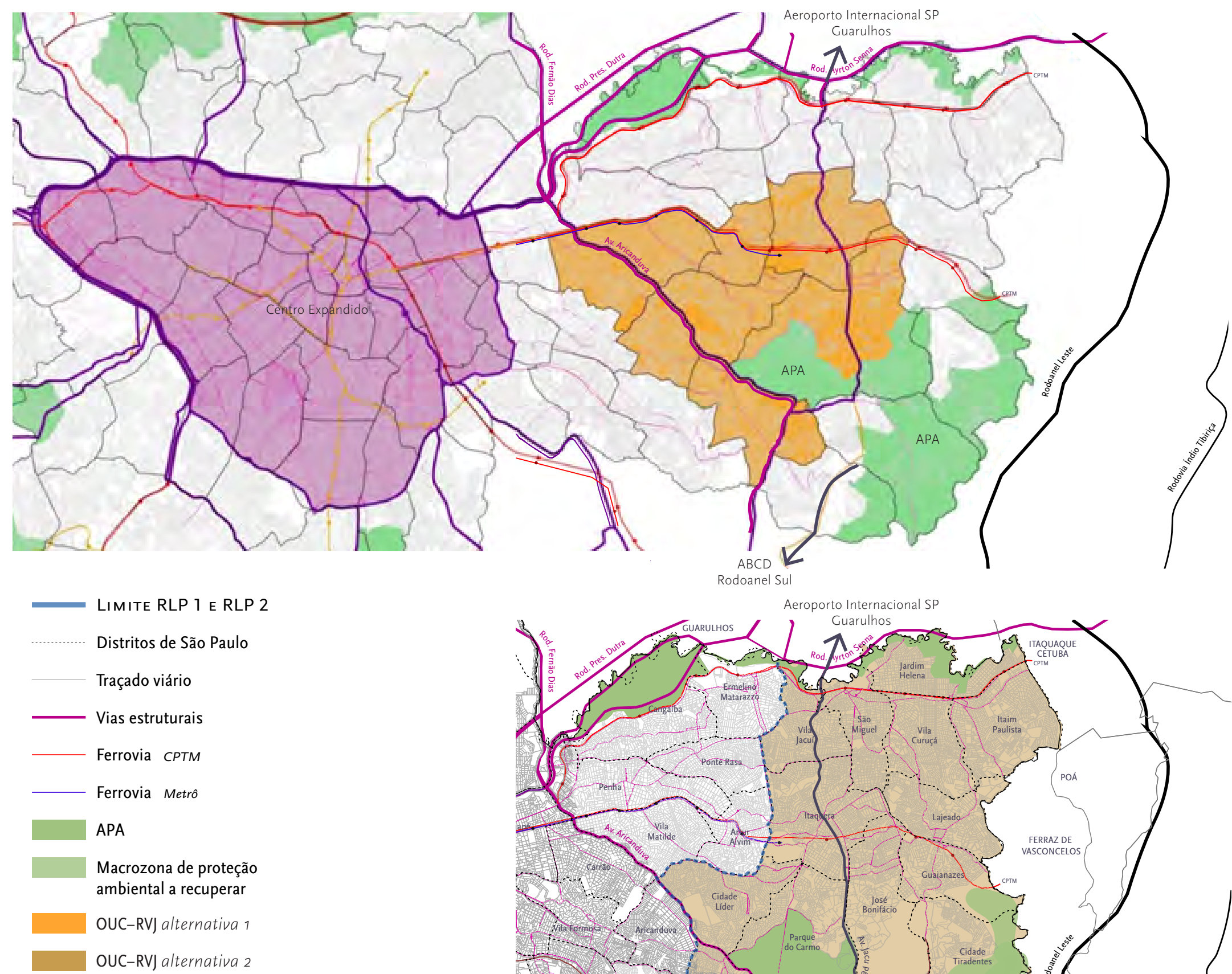

MAPA 42: OUC-RVJ RECORTE TERRITORIAL PROPOSTO

ALTERNATIVO 1

MEPR, 2013

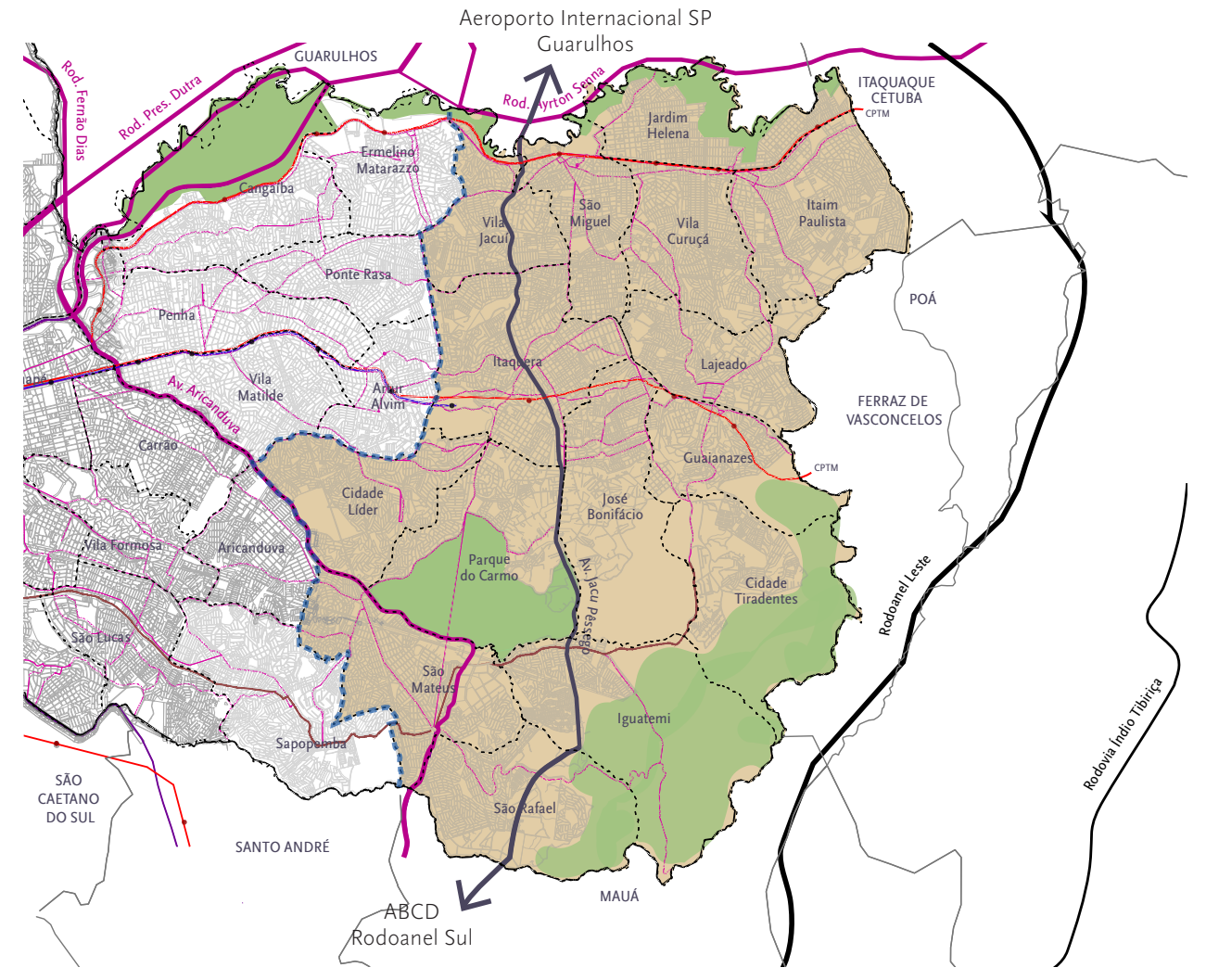

MAPA 43: OUC-RVJ RECORTE

TERRITORIAL PROPOSTO

ALTERNATIVO 2

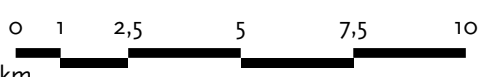


pelos limites municipais entres São Paulo e os municípios de Itaquaquecetuba, Poá, Ferraz de Vasconcelos, Mauá, Santo André e São Caetano, seguindo pela via estrutural avenida do

Oratório, Luis Inácio de Anhaia Melo, avenida Sapopemba, estrada da Barreira Grande, avenida Manuel F. Pires, avenida Arraias do Araguaia, chegando à avenida Aricanduva e fechando-se o polígono na Marginal do Rio Tietê;

3. Inclui todos os distritos da RLP 2, sem exceção, e inclui alguns distritos da RLP 1, os mais carentes ou menos beneficiados pela proximidade ao Centro Expandido como Vila Matilde, Penha, Ponte Rasa, Artur Alvin, Cangaíba e Ermelino Matarazzo;

4. Da mesma forma que o recorte oficial para a OUC-RVI, esta nova conformação contém a principal via estruturadora, o Complexo Viário Jacu Pêssego-Nova Trabalhadores, principal ligação entre Guarulhos e os municípios do ABCD;

5. Dentro do distrito de Sapopemba, existe uma importante centralidade, a avenida Mateu Bey;

6. Dentro do recorte territorial para a OUC-RVI proposto aqui, está incluído o Expresso Tiradentes, VLT com estação final em Cidade Tiradentes, um dos dois distritos mais carentes do RLP2 2, como se verá no Capítulo VI.

O distrito de Cidade Tiradentes, assim como os distritos de Iguatemi e Guaianases, contém áreas importantes de preservação ambiental, atualmente invadidas em grandes extensões por aglomerações de moradias precárias, cujos moradores podem e devem ser transferidos para novas edificações residências do tipo HIS em áreas de ZEIS a propor na OUC-RV), uma vez que existem diversos terrenos vazios, como se verá no Capítulo VI. Isto faz de Cidade Tiradentes, o nosso distrito exemplo na apresentação da Metodologia para elaboração de planos urbanos a partir do calculo de capacidade de suporte.

\section{CONCLUSÃO}

O Brasil ainda não adota postura firme concreta de combate ao uso escessivo do automóvel em detrimento do transporte público apesar do cenário de esgotamento do sistema rodoviário das metrópoles brasileiras. O cidadão vive ensimesmado e sem a real consciência de seus deveres como parte de um coletivo. Cedeu à cultura do automóvel por imposição, por incapacidade de reagir e enlevado ante a fantasia que esse meio de transporte ainda provoca como sonho de consumo. Precisamos dos automóveis nas metrópoles brasileiras onde ainda não se provê à população com sistemas de transporte público de qualidade e criamos grandes congestionamentos diários onde a população deixa parte de seu valioso tempo.

Surge uma dicotomia urbana contemporânea: morar perto do trabalho elimina o enfrentamento do trânsito no dia a dia, mas impede que o habitante possa escolher morar em vizinhanças sem ruído ou fumaça do tráfego intenso, mas distantes do local de trabalho. Conforme nos mostrou Appleyard, vias com tráfego intenso ou até mesmo moderado afastam as pessoas das ruas, desestimulando as atividades ao ar livre e consequentemente diminuindo a ocorrência das atividades sociais ao ar livre como demonstrou Gehl. O estudo de Appleyard 


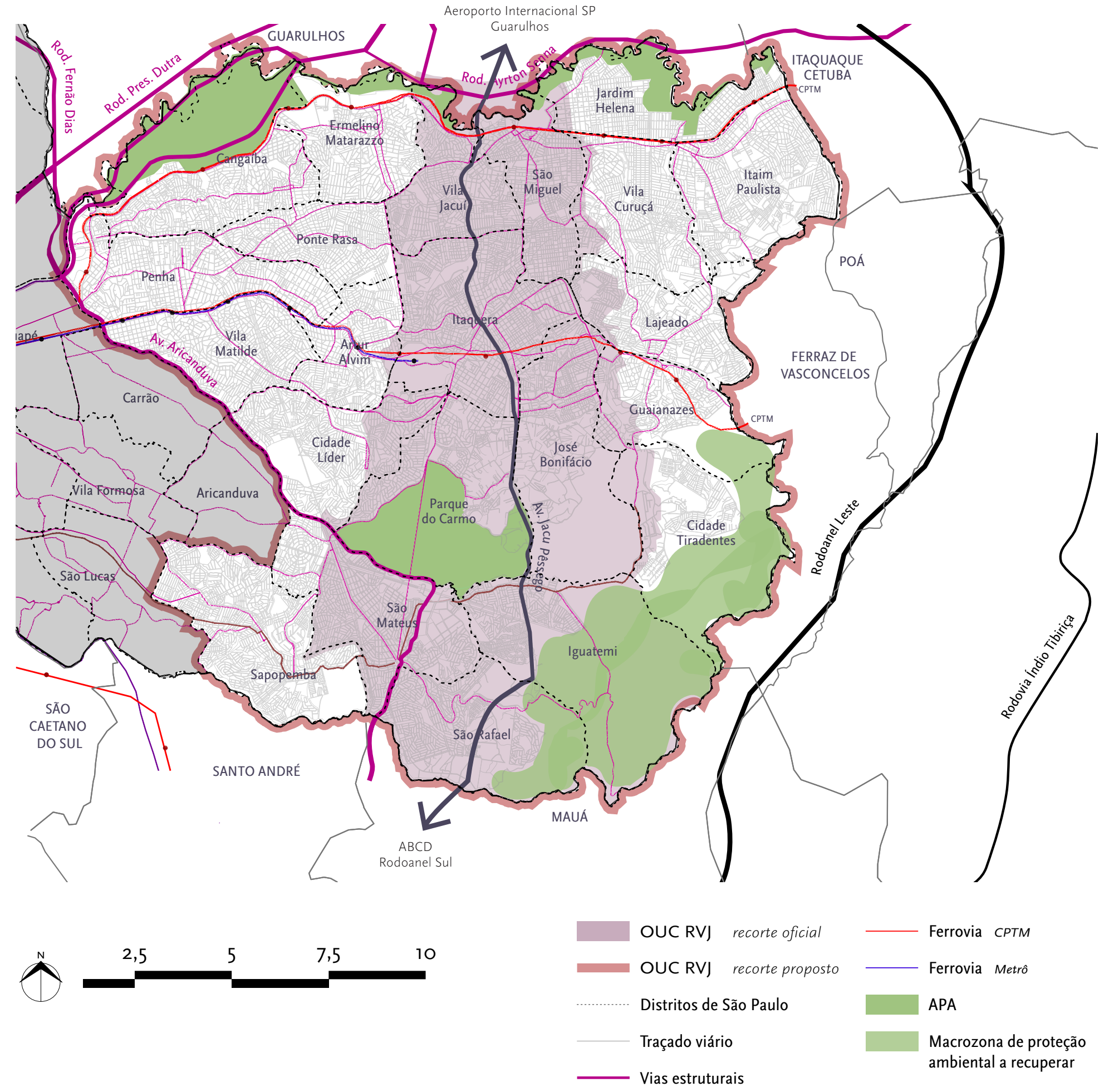

MAPA 44: OUC-RV] RECORTE TERRITORIAL PROPOSTO ALTERNATIVO 3 MEPR, 2013 área total $163,5 \mathrm{~km}^{2}$ população 2.132.976 hab 
demonstrou que nas ruas residenciais com tráfego leve, seus moradores consideram a rua como parte de suas casas, sentimento que vai diminuindo à medida que se passa à via de tráfego moderado e à de tráfego intenso, onde seus moradores consideram que sua casa é somente seu apartamento.

Quando Jacobs critica a produção de moradias na forma de habitações em bloco, sua crítica se dirige ao planejamento urbano voltado ao uso residencial, o que não é o foco desta tese. Conjuntos habitacionais sem qualidade e que não possibilitam ou estimulam as atividades sociais a que se refere Gehl, foram uma das ações da administração pública da metrópole de São Paulo, nas últimas seis décadas, juntamente com a implantação de estações de metrô nos extremos da cidade com linhas que partem do centro, extensões de vias coletoras existentes que transformadas em estruturais roubaram qualquer possibilidade de qualidade urbana ao longo destas.

As diretrizes para adequar uma região existente em uma metrópole como São Paulo deverão considerar os alertas de Jacobs como alertas e não verdades absolutas e, deverão aplicar as conclusões de Appleyard sobre o real impacto do excesso de tráfego de veículos em vias residenciais, de forma a reformulação do sistema viário como um todo resulte em ruas que estimulem as atividades sociais e recreativas em espaços públicos.

A tese de Campos Filho pode ser vista como uma forma de atribuir qualidade a tecidos urbanos sem qualidade da seguinte forma: a partir do fracionamento existente e provocado pela implantação de grandes vias, para veículos ou trens, reestruturar essas áreas de forma a torná-las sustentáveis.
Temos que considerar, no entanto, as diferenças entre tecidos em áreas centrais lineares ou polares onde a mistura de usos acontece entre comércio e serviços diversificados incluindo as indústrias não poluentes e, os usos de moradia e, os bairros residenciais com uso exclusivo, mas com comércio e serviços de apoio à moradia a uma distância conveniente, se possível de acesso a pé.

A dispersão de usos que o automóvel propicia possibilita que usos diversificados se mesclem ao uso moradia no mesmo tecido urbano. Com isso, esses bairros passam a ter características de tecidos urbanos centrais. causando conflitos com a vizinhança. (informação verbal) ${ }^{112}$

Transformar tecidos urbanos consolidados em áreas com qualidade ambiental e funcional é um grande desafio em qualquer parte do mundo, mas sem dúvida deve ser feito com critérios que priorizem a condição humana, sua escala em relação às metrópoles e a qualidade necessária para a sustentabilidade urbana, como os Planos de Bairro.

O recorte temporal deste trabalho inicia-se na década de 1960, indo até a década de 2010. Na primeira década desse período determinado, várias rodoferrovias estruturais foram projetadas e implantadas dentro da área urbana do Município de São Paulo, concentradamente no Centro Expandido.

A elaboração do PUB abordou a participação democrática, a melhor distribuição de postos de trabalho na mancha urbana com o objetivo de diminuir os deslocamentos da população trabalhadora em direção ao Centro Histórico e Centro Novo e as mais recentes centralidades à época, Avenida Paulista e Avenida Brigadeiro Faria Lima. Mas, pecou ao definir que o centro financeiro e de serviços de excelência 
na saúde e na educação deveriam ser estimulados a se concentrar nas centralidades já tão bem estruturadas, perdendo a oportunidade de realmente criar centralidades com qualidade.

Segundo avaliação de Campos Filho, há uma exceção, com a qual aqui se concorda: a centralidade regional proposta para a região de Parelheiros. Situada em plena região dos mananciais foi um grande equivoco técnico, corrigido em seguida pelo PMDI que, ao invés do crescimento urbano para essa região situada ao Sul, redirecionou as diretrizes para a Região Leste de São Paulo, o que acabou ocorrendo de modo predominante. E são as consequências desse redirecionamento para o leste da metrópole o objeto desta tese de doutorado, que aborda a qualidade e estruturação urbana específica da Região Leste 2. Porem, a lei de proteção aos mananciais do entorno de Parelheiros, acusada de elitista por muitos, acabou sendo desrespeitada por loteamentos e ocupações irregulares. ${ }^{113}$

A nova legislação que a substituiu, com leis específicas primeiramente para a represa de Guarapiranga e, na sequência, para a represa Billings, peca, segundo Campos Filho, por não impor reais limites à sua urbanização, embora pareça fazê-lo, o que deverá provocar a sua perda como manancial metropolitano, dentro de certo período de tempo."14

Em seguida, aprova-se o PDDI, o qual define basicamente como foco à implantação da Lei de Uso e Ocupação do Solo, em 1972, que vigorou por 20 anos, até 2002, com a aprovação do novo plano urbano, o Plano Diretor Estratégico 2002/2012 para o Município de São Paulo e da lei de zoneamento complementar, dois anos depois. (leis n. $13.430 / 2002$ e n. $13.885 / 2004$ )
Segundo Feldman, a elaboração do PDDI definiu a LUOS de 1971 e de 1972 (leis n. 7688/1971 e 7805/1972) que vigorou até a aprovação do PDE 2002/2012, sem dar a devida atenção às questões ligadas ao desenvolvimento econômico e social, renegando as diretrizes do PUB de 1969. (FELDMAN, 2005, p.248)

Para Campos Filho, pelas razões que já resumimos, especialmente o erro de propor criar uma centralida de regional periférica, que correta enquanto tal, mas incorreta enquanto na região dos mananciais ao sul da metrópole, o PUB não é um bom plano, preferindo o PMDI, que redefiniu corretamente a direção leste como a mais adequada para receber esse crescimento e onde ajudou a definir o conceito de Corredores Metropolitanos, analisados nesse plano e por terem função estruturante em relação à Região Metropolitana de São Paulo.

O PUB e o PMDI, assim como PDE 2002, promulgaram e propuseram a descentralização do emprego, melhor distribuído em relação ao assentamento populacional e provisão de áreas verdes e espaços abertos metropolitanos para recreação de massa. Neste último caso, ao contrário das propostas adotadas nas cidades norte-americanas e europeias, onde o parque é próximo das áreas residenciais, diferente de nossos modelos, onde a "recreação em massa" exige do habitante que percorra longas distâncias até para desfrutar de um singelo passeio no parque.

Pode-se observar no PDE 2002/2012 que nos distritos paulistanos com menor fator de área verde por habitante e com consequente maior temperatura na superfície do território, como Brás, Pari, Mooca e Cambuci, não se previu nenhuma criação de áreas
113. Considerou-se elitista pela proposital baixa densidade atribuída à área durante a LUOS de 1972, onde - Coeficiente de Aproveitamento era muito baixo, em lotes de área mínima de cinco mil metros quadrados. N.A.

114. Porque só se volta a cuidar da poluição derivada dos esgotos domésticos, deixando sem monitoramento e limitação aquela derivada de uma poluição difusa não retirável pelo sistema de captação e tratamento de esgotos nem por nenhum processo técnico conhecido que tenha viabilidade econômica. Campos FILHO. Depoimento em 12 mar. 2013. 
verdes de pequeno ou médio porte, apenas os Parques Lineares previstos no PDE, que não estão ainda claramente definidos ou normatizados, ao longo dos cursos d'água e de avenidas e ferrovias existentes.

Desde 1965 vem-se alertando para o descomunal crescimento desordenado da mancha urbana em direção ao extremo leste da cidade e, até hoje, século 21, as massas de trabalhadores se deslocam por horas em sistemas de transportes coletivos que, quando finalmente implantados, já estão obsoletos, seja em relação à tecnologia, seja em razão da demanda reprimida.

No PMDI, viu-se que as propostas estruturantes de transporte e desenvolvimento urbano para a RMSP, se implantadas poderiam ter eliminado ou, pelo menos, mitigado o fluxo de trabalhadores que se desloca ao centro e outras zonas desenvolvidas de São Paulo para trabalhar. Pessoas ainda saem de São Miguel Paulista para trabalhar no extremo sul do município, pela péssima distribuição de oportunidades de trabalho na região do extremo leste paulistano. Um Corredor Metropolitano ao longo do Rio Tietê e as ferrovias que correm em paralelo teria levado empregos, serviços e comércio, além de indústrias nos últimos 50 anos à RLP.

O PITU 2025, no Mapa das Centralidades Propostas, propõe uma centralidade polar em Itaquera, que receberá o novo estádio de futebol, para atender à Copa do Mundo de Futebol, o que certamente será o motor propulsor do desenvolvimento urbano em seu entorno e com grande influência na Região Leste. Resta esperar que esse desenvolvimento urbano não se limite à produção imobiliária para o mercado focada na valorização imobiliária mas sim para proporcionar qualidade de vida e opções de escolha do local de trabalho próximo à moradia do trabalhador ou dependente de um sistema de transporte público mais eficiente em todos os sentidos. Mas, somente essa centralidade será suficiente para atrair empresários prontos a oferecer serviços de qualidade à classe média enraizada na RLP?

Conhecer os planos urbanos para São Paulo de 1960 a 2010, incluindo-se o PMDI, um plano de âmbito metropolitano e o estudo de capacidade de suporte feito a partir dele, terminado em 2009 e coordenado tecnicamente por Campos Filho, teve como objetivo tomar ciência, entender e aceitar, para poder planejar com outros olhos, agregando todas as definições e diretrizes apropriadas já apresentadas nesses planos estudados, sem adotar dados anteriores como verdades absolutas.

Ainda não temos em São Paulo, um exemplo de plano urbanístico de reestruturação de Uso e Ocupação do Solo conjugado ao um plano de transporte público a partir da adoção do cálculo de capacidade de suporte com o objetivo promover o desenvolvimento urbano e social de uma área urbana em escala local e transformá-la em uma pequena cidade dentro de uma grande cidade. Essa é a proposta desta tese de doutoramento, onde se procurou reunir as experiências dos autores citados neste capítulo para elaborar a parte final da tese que propõe uma plano urbano, batizado de metodologia para desenvolvimento de diretrizes para Planos de Bairro a partir do cálculo da capacidade de suporte. 


\section{CAPÍTULO V \\ CARACTERÍSTICAS TERRITORIAIS, POPULACIONAIS E SOCIOECONÔMICAS DA REGIÃO LESTE PAULISTANA}

Neste capítulo, apresenta-se uma breve análise do tecido urbano e das características socioeconômicas e populacionais da região em estudo com o propósito de conhecer o cenário atual de seus distritos, em um total de 33 e destes, eleger um distrito como exemplo para ilustrar a metodologia para elaboração de diretrizes para planos urbanos.

Nos mapas que representam graficamente índices socioeconômicos foi sobreposto o recorte territorial da OUC-RVI com o objetivo de demonstrar a necessidade de inclusão dos distritos do extremo leste em um plano urbanístico dessa monta.

Dos 96 distritos do Município de São Paulo, a

Região Leste Paulistana agrupa 33 distritos. Sua extensão territorial é de 326,80 quilômetros quadrados e faz limites com outros municípios da RMSP, como Guarulhos, Itaquaquecetuba, Ferraz de Vasconcelos, Mauá, Santo André e São Caetano. (IBGE/SEADE, 2012)

A Região Leste Paulistana por si só tem proporções territoriais e populacionais de região metropolitana, mas condiç̧̃̃es urbanas muito aquém do que seria aceitável para um vilarejo, em função da falta de várias das peças importantes que compõem a cidade ideal: casa, escola, hospital, trabalho, local de compras diárias próximo à casa, comércio e serviços de âmbito local e frequência diária, lazer, cultura, meio ambiente preservado ou pouco poluído, infraestrutura básica completa e segurança urbana e, centralidade com serviços e comércio diversificados.

O Mapa 36: Localização da RLP em São Paulo e na RMSP (p.130) mostra a divisão político-administrativa da RMSP e, em destaque à área total da Região Leste Paulistana em relação à RMSP, demonstrando que sua extensão territorial é comparável aos maiores municípios da RMSP, exceto o município de São Paulo, o maior em área. Fazendo-se uma rápida comparação entre a Região Leste e os municípios da RMSP, temos Guarulhos, a oitava maior economia do país, com 318,68 quilômetros quadrados e 1.220.653 habitantes, praticamente a mesma área territorial que a Região Leste de São Paulo, mas menos de um terço de sua população total. ${ }^{115}$ Outros municípios, como Cotia, Mairiporã, Santa Isabel e Biritiba-Mirim, têm áreas territoriais bem próximas, mas sem economias locais representativas como no caso de Guarulhos, cujo perímetro municipal inclui o Aeroporto Internacional de São Paulo ou Aeroporto de Cumbica. Já Mogi das Cruzes, com área total de 712,67 quilômetros quadrados, e população de 387.260 habitantes, tem porte econômico
115. Guarulhos é um dos 39 municípios da RMSP, região economicamente mais importante do Brasil. É a segunda cidade com maior população do Estado de São Paulo e a $12^{\text {a }}$ mais populosa do Brasil. Graças a diversos fatores como forma de ocupação, políticas públicas e localização, Guarulhos se tornou um centro estratégico de distribuição e logística. Localizada na confluência de estradas que ligam São Paulo

ao Rio de Janeiro, abriga também o maior aeroporto da América Latina, no qual está o maior terminal de cargas do país. Guarulhos é hoje a $8^{a}$ cidade mais rica do Brasil, com uma produção que representa mais de $1 \%$ do Produto Interno Bruto (PIB). A cidade recebeu, nas últimas décadas, diversos grupos populacionais que chegaram em busca de oportunidades de emprego e moradia. A ocupação errática levou à construção de um ambiente marcado por fortes demandas. Resolver as questões sociais exige vontade política, instrumentos democráticos e participação popular. Disponnível em <http://www.guarulhos. sp.gov.br/index. php?option=com content $\&$ view $=$ article $\& i d=46 \&$ Itemid=34>. Acesso em 21 jun. 2013. 
QUADRO 3: TERRITÓRIO E POPULAÇÃO

SEADE/IBGE 2010

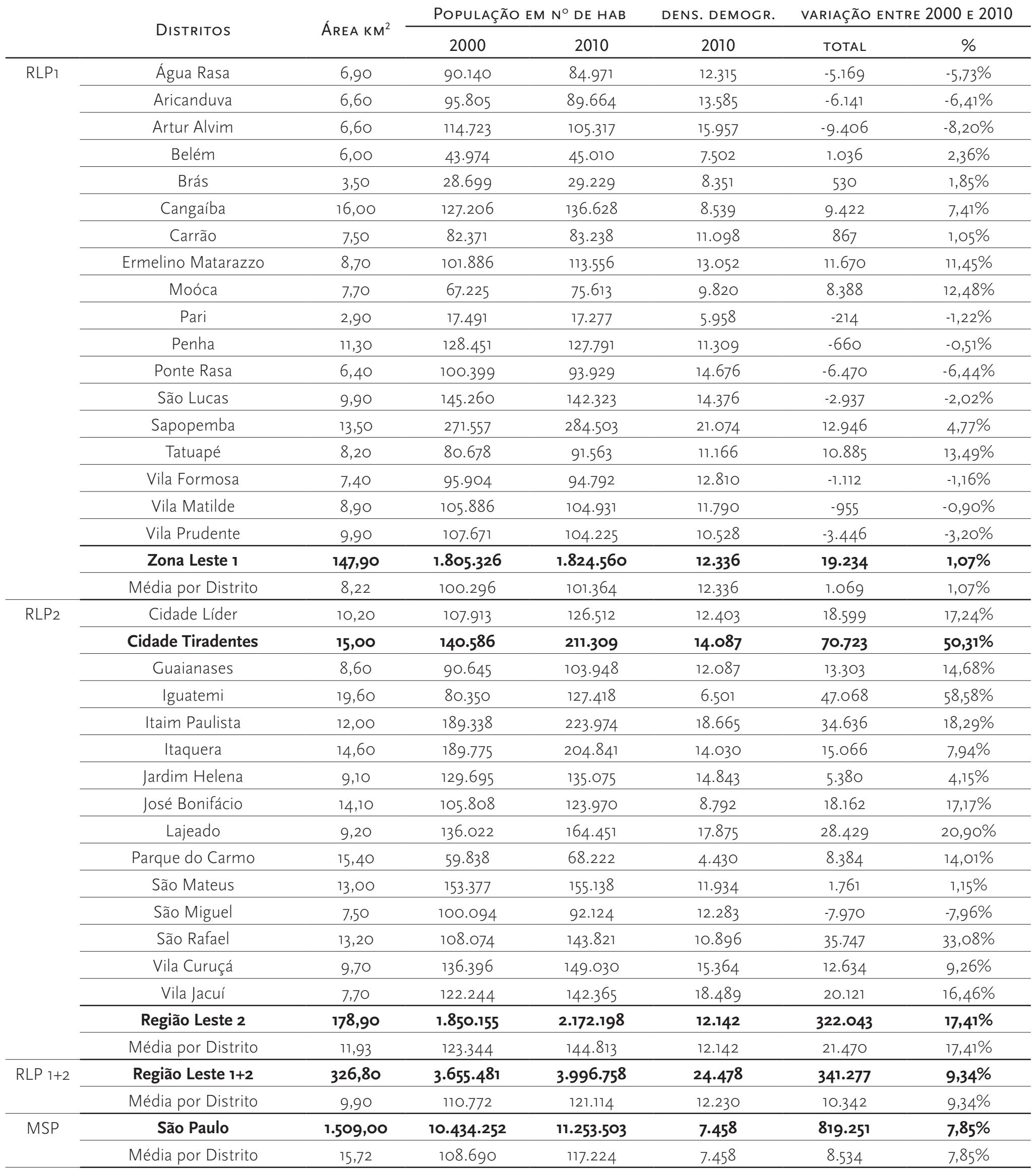


significativo em função das Universidades e indústrias, além de contar com outros segmentos induzidos por estes e complementares à economia desse município, como serviços, comércio, hospedagem, produção de moradias para estudantes e professores etc.

As características territoriais e populacionais completas de todos os municípios da RMSP estão detalhadas no Quadro 3: Território e população, que apresenta dados populacionais e territoriais de cada um dos 39 municípios que compõem a RMSP. Em uma rápida abordagem dos dados coletados, tem-se a RMSP onde a densidade demográica é de $2.474,69$ habitantes por quilômetro quadrado e onde a população rural é de apenas 0,12\% da população total, de 19.667 .558 habitantes, segundo o Censo 2010 do IBGE. Na RMSP, os municípios com as menores taxas de densidade demográfica, abaixo de cem habitantes por quilômetro quadrado, apresentam os piores índices de saneamento básico, exceção feita a Salesópolis, município que guarda a nascente do Rio Tietê e que apresenta índice de atendimento em esgoto sanitário em torno de $85,05 \%$. Contraditoriamente, os municípios que concentram áreas de proteção a mananciais ainda estão longe de atingir pelo menos 90\% de coleta de esgoto sanitário.

Como mencionado na Hipótese desta tese, à exceção de algumas ilhas de prosperidade situadas em distritos da Região Leste mais próximos ao Centro Expandido, ou dentro deste, a RLP apresenta índices de qualidade e desenvolvimento urbanos muito baixos, considerando-se as necessidades mínimas básicas para uma vida digna, como as condições gerais de moradia, mobilidade intraurbana e regional, de empregabilidade, cultural, atendimento médico e principalmente cuidados de prevenção com a saúde da população local. São áreas muito extensas e vulneráveis, com difícil conexão com o Centro Expandido seja na forma de transporte público, seja a partir de transporte individual, uma vez que os sistemas viários tem apresentado alto patamar de esgotamento tanto na qualidade como na capacidade de suporte.

Como mencionado na Apresentação desta tese, em função de sua extensão, população e demandas, e por questões políticas talvez, a RLP foi recentemente dividida pelo Governo Municipal em duas, Leste 1 e Leste 2. A Região Leste 1 começa a partir do limite entre a Região Central e os distritos de Brás, Pari, Belém, Mooca e Vila Prudente, incluindo também Água Rasa, Aricanduva, Artur Alvin, Cangaíba, Carrão, Penha, Ponte Rasa, São Lucas, Sapopemba, Tatuapé, Vila Formosa e Vila Matilde, totalizando dezoito distritos. A Região Leste 2 inclui os distritos de Cidade Líder, Cidade Tiradentes, Guaianases, Iguatemi, Itaim Paulista, Itaquera, Jardim Helena, José Bonifácio, Lajeado, Parque do Carmo, São Mateus, São Rafael, São Miguel, Vila Curuçá e Vila Jacuí, totalizando quinze distritos. Os 33 distritos da RLP são administrados por onze Subprefeituras: Aricanduva, Cidade Tiradentes, Ermelino Matarazzo, Guaianases, Itaim Paulista, Itaquera, Mooca, Penha, São Mateus, São Miguel e Vila Prudente, como pode ser visto no Mapa 1: Regiões, Subprefeituras e Distritos-Município de São Paulo 2009 (p.3)

Em algumas instâncias, os distritos em São Paulo são ainda subdivididos em bairros, nomenclatura em desuso, mas que faz parte da cultura paulistana como referência de localidade, inclusive para 


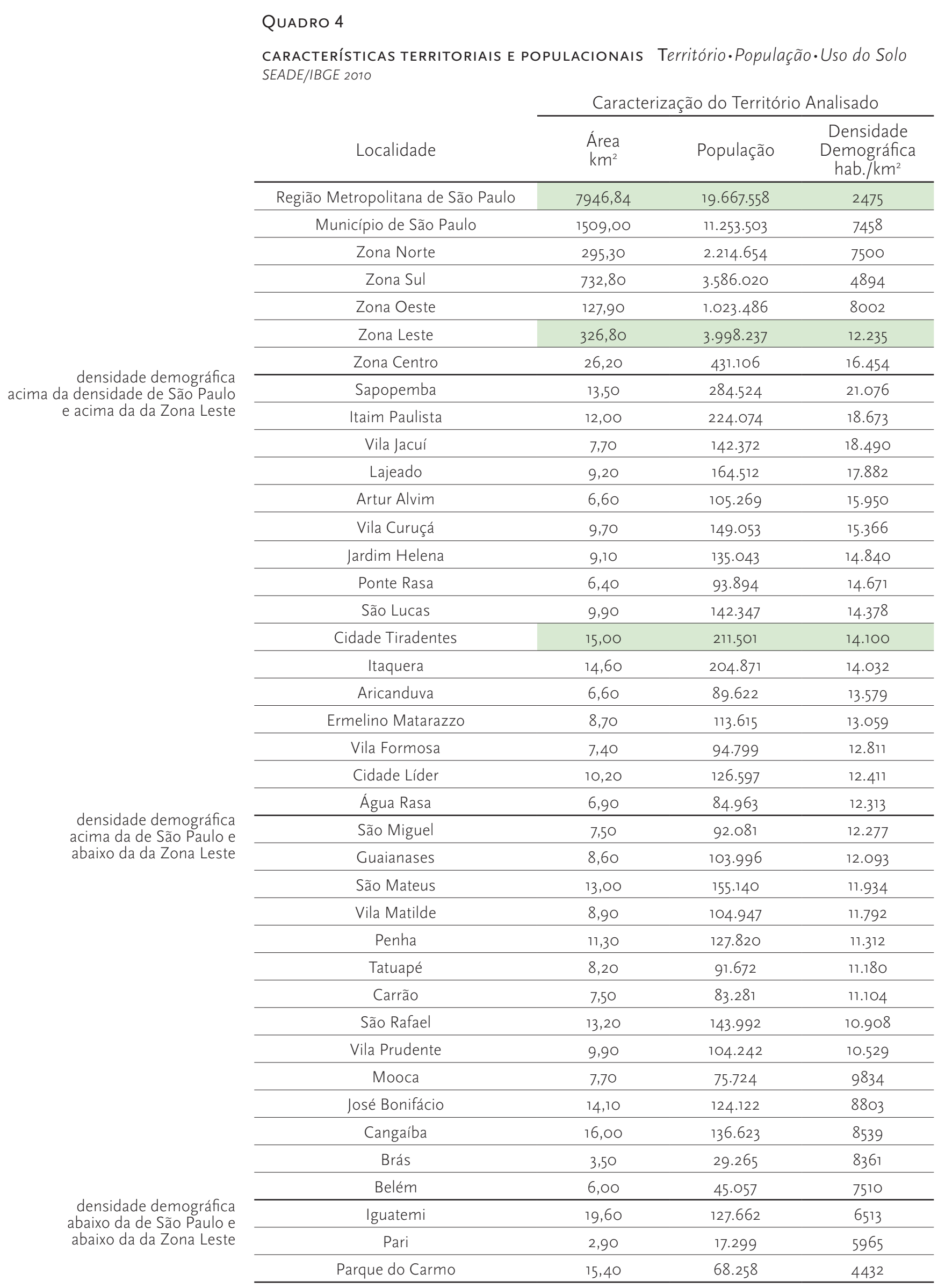


os institutos de pesquisa, como IBGE e Fundação SEADE, que ainda utilizam o termo oficialmente para muitos outros municípios paulistas e brasileiros, exceto São Paulo e outros municípios brasileiros, cujas administrações públicas municipais não mais o adotam. Exemplos: O distrito da Penha está subdividido em Penha, Ticoatiara e Vila Esperança; o distrito de Ermelino Matarazzo está dividido em Ermelino Matarazzo, Parque Buturussu e USP Leste II, esta última, subdivisão recente; o distrito de Cangaíba está subdividido em Cangaíba, Engenheiro Goulart, Rui Barbosa e USP Leste I. Alguns distritos da Região Leste estão divididos em até quatro Regiões, nomenclatura adotada pela Pesquisa OD 2007, outros em três Regiões, outros em duas Regiões. Já o distrito de Cidade Tiradentes é o único que não está territorialmente subdividido. A hipótese que pode explicar a territorialidade única apesar de sua grande população segundo dados do SEADE/IBGE é por ser um dos distritos da Capital que mais tem crescido em população e a formação histórica de seu tecido urbano com praticamente duas tipologias de edificações residenciais: residencial vertical de alta densidade no lote e residencial de gabarito baixo, um ou dois andares, na grande maioria formada por moradias de baixa ou baixíssima qualidade, sem centralidades de qualquer nível qualitativo. A produção de moradias no distrito de Cidade Tiradentes teve o Estado como produtor da maioria dos conjuntos habitacionais e, as moradias unifamiliares de gabarito baixo (térreas ou assobradadas) na grande maioria são produto de autoconstrução ou por mutirões organizados entre amigos ou grupos comunitários.

Em números absolutos, a RLP tem uma população total hoje de 4.042 .865 habitantes ou 35,52\% da população total de São Paulo, de 11.379.114 habitantes em 2012. Apresentando densidade demográfica de 13.050 habitantes por quilômetro quadrado, em média, cada distrito da Região Leste Paulistana contribui com 1,07\% da população total da capital. Isolando-se os distritos da Região Leste, resta uma média de 0,98\% para cada um dos distritos restantes, mesmo que a população nas áreas centrais esteja mais adensada que nas periferias. Os distritos da Região Oeste representam 9,09\% da população total da capital, os da Região Sul representam 31,86\% e os da Região Norte 19,67\%. A região Central da capital contribui com 3,83\% da população. ${ }^{116}$

Para entender a variação da densidade demográfica na Região Leste Paulistana é preciso avaliar os dados territoriais e populacionais específicos dos distritos que compõem todo o município de São Paulo, em um total de 96 distritos municipais, sob a administração de 31 Subprefeituras. Assim, foi montado o Quadro 4: características territoriais e populacionais Território. População. Uso do Solo, com um resumo das características territoriais populacionais de São Paulo, a título de comparação com a Região Leste, por Região e com os índices para o município como um todo. Este quadro especifica as características básicas de território, a população dessa região, e mostra quais são as densidades demográficas comparativas entre RMSP, Município de São Paulo, Regiões e distritos da RLP. É nas periferias onde se encontram os tecidos urbanos com construções de baixo gabarito, ou seja, um, dois, três e quatro andares, na maioria dos casos construções que ocupam quase todo o terreno disponível, chegando a um Coeficiente de Aproveitamento-CA, de quase quatro vezes a área do terreno, onde vivem famílias numerosas, sem condições de ventilação natural
116. O IBGE apresenta a população total para o município de São Paulo em 2012, mas não o faz para as regiões leste, sul, norte, oeste e centro. Tanto a população atual da Região Leste de São Paulo quanto a participação de cada uma delas em percentual atualizado aqui demonstrados foram conseguidos de forma estimada através de projeção linear partindo-se do CENSO 2010. 
e insolação mínimas. Dessa forma, o crescimento demográfico localizado em distritos com população de baixa renda explica a alta densidade demográfica nas periferias horizontalizadas. Como visto no Mapa 3: Taxa de crescimento anual da populaçãoMunicípio de São Paulo 1991/2006 (p.14), as taxas mais altas de crescimento populacional registrado no último Censo estão localizadas nos extremos da cidade ao Leste, ao Sul e Noroeste da Capital. Considerando-se o esvaziamento populacional registrado nas últimas décadas no Centro Histórico e Centro Novo, o aumento da população total em São Paulo entre os Censos de 2000 e 2010 e, as condições precárias de moradia nas periferias onde o crescimento populacional foi maior, pode-se afirmar que as famílias pobres na Região Leste 2 vivem amontoadas, dispondo de menos de seis metros quadrados por habitante, em média.

Apesar de alguns distritos da RLP como Água Rasa, Aricanduva, Artur Alvim, Cangaíba, Ponte Rasa, Jardim Helena e São Miguel terem apresentado esvaziamento populacional entre 2009 e 2010 , conforme mostrado Quadro 4, o restante deles apresentou crescimento populacional, sendo que a maior taxa em 2010, de 2,32\% ao ano ocorreu no distrito de Iguatemi, ao sul da Região Leste 2, ficando o distrito de Cidade Tiradentes com uma taxa de 1,1\% ao ano Ambos tem populações altas como visto no quadro: 211.309 habitantes em Cidade Tiradentes e 127.418 habitantes em Iguatemi, em 2010. (SEADE/IBGE)

Observando-se o Mapa 3: Taxa de crescimento anual da população-Município de São Paulo 1991/2006 (p.14), vê-se que a taxa de crescimento anual de ambos caiu de uma faixa entre 3,57\% a.a. e 1,21\% ao ano para taxas entre $2,32 \%$ e 1,1\% como dito acima.
O Mapa 3 (p.14) demonstra ainda alta na taxa de crescimento populacional de alguns setores da capital, mesmo que a taxa de crescimento da população como um todo tenha apresentado queda no último Censo do IBGE. Uma das regiões mais pobres e desprovidas na RLP 2, os distritos de Cidade Tiradentes e Iguatemi, apresentam as maiores taxas de crescimento. Sua localização ao lado da área de preservação ambiental leva a crer que essa população poderá ser estimulada a transferir-se para dentro da OUC-RVJ, uma das diretrizes propostas pela Prefeitura de São Paulo no edital de diretrizes apresentado. Esse mapa apresenta a distribuição do crescimento populacional no território, o que possibilita que se conclua que os maiores crescimentos nesses dois distritos aconteceram, até 2008, junto ao limite de são Paulo com os municípios de Ferraz de Vasconcelos e Mauá. A área da RLP 1 marcada com a cor azul, apresenta crescimento populacional negativo em 2008 de -0,54\% ao ano, em média, conforme o mapa em questão, mas esse fenômeno teve seu início há mais tempo, na década de 1990, conforme registros do IBGE/SEADE, mais precisamente na pesquisa de 1996. Entre esse ano e 2010, os distritos de Vila Matilde, Vila Prudente, Vila Formosa, Penha, Água Rasa e Parque São Lucas, pertencentes à RLP 1 e portanto mais próximos ao Centro Expandido, apresentaram queda em suas população residente. Artur Alvin, na RLP 1, também apresentou uma perda de $8 \%$ em sua população nesse período, mas este distrito se encontra muito distante do $C E$, mais precisamente no limite entre a RLP 1 e a 2, o que o torna uma exceção entre os distritos mais carentes da periferia da Região Leste. (SEADE/IBGE)

Na RLP 2 apenas o distrito de São Miguel apresentou queda, de $8 \%$ aproximadamente, em sua 
população residente, representando outra exceção, uma vez que o restante dos distritos da RLP 2 apresentaram crescimento populacional. As taxas de crescimento acumuladas nesse período de quinze anos da pesquisa variaram entre taxas de ganhos insignificantes como 0,9\% ao ano, na Vila Matilde, praticamente uma estagnação e, altas taxas como $33 \%$ de crescimento em São Rafael, 50\% em Cidade Tiradentes e 58\% em Itaim Paulista, os três distritos já bem populosos: São Rafael com 108.074 habitantes em 1996 e 143.821 em 2010, Cidade Tiradentes, com 140.586 e 211.309 em 2010 e, Itaim Paulista, com 189.338 habitantes em 1996 e 223.974 habitantes em 2010. (SEADE/IBGE)

O que se pode observar também é que tanto as perdas como os ganhos foram, na maioria dos casos gradativos ao longo do período entre 1996 e 2010, exceção feita a Cidade Tiradentes que cresceu $10 \%$ a.a. entre 1996 e 2000, um dos distritos mais carentes e populosos da Região Leste Paulistana. (SEADE/IBGE).

Analisando-se os dados de crescimento populacional comentados sob o prisma do mercado imobiliário fica claro o processo de adensamento propiciado por essa atividade. Dois casos podem ser destacados para ilustrar o tema: os distritos Mooca e Tatuapé que tiveram perda populacional entre 1996 e 2001 e retomaram seu crescimento em 2001. No caso do Tatuapé, a inauguração do centro de compras Shopping Center Anália Franco, em 1999, polo gerador de postos de trabalho e indutor de serviços e comércio em seu entorno que certamente em muito contribuiu para a retomada do crescimento populacional. O Jardim Anália Franco, localidade onde se encontra o centro de compras, já estava consolidado como uma ilha de prosperidade em meio ao Tatuapé, com a produção de imóveis residenciais e de serviços em empreendimentos verticais de alto padrão que acabaram por encorajar um estabelecimento desse porte, cuja área de lojas foi ampliada em 2009. ${ }^{17}$

No caso da Mooca, 2001, ano de sua retomada do crescimento populacional antecipara o ano da aprovação do novo Plano Diretor Estratégico para o Município de São Paulo, que iniciava a gradativa diminuição do Coeficiente de Aproveitamento na área urbana da cidade e que direcionou os lançamentos imobiliários aos bairros onde ainda havia estoques a preços ainda não tão inflacionados.

\section{Outros fatores externos também promoveram a} retomada de crescimento, ainda que modesta e sem significar ainda um adensamento populacional em distritos centrais e menos a Leste como Brás e Belém: as campanhas da administração pública para atrair habitantes ao Centro Histórico e Centro Novo de São Paulo podem ser consideradas um deles. Outro fator muito importante foram os valores dos aluguéis, baixos à época em que a população voltou a se estabelecer nesses distritos, em processo de revalorização. E, com o aumento da procura, provavelmente esses aluguéis já estão mais altos atualmente. A Operação Urbana Centro e Luz também concorrem antecipadamente para essa valorização.

O Gráfico (p.172) ilustra o movimento populacional descrito acima, com as maiores e menores taxas de perda e ganho populacional nos distritos de São Paulo.

Com o objetivo de confirmar as afirmações e colocações feitas no capitulo IV, em relação ao formato
117. O Shopping Anália Franco foi inaugurado em 1999 e hoje apresenta 99, $4 \%$ de sua ABL contratada. O Shopping é frequentado por $79 \%$ das classes A e B, e está localizado na Região Leste da cidade de São Paulo, uma das regiões com maior concentração populacional e de maior crescimento nos últimos anos. Disponível em <http:// multiplan.infoinvest.com.br/ptb/133/ Multiplan_ComunicadoaoMercado_ expansE30ShoppingAnaliaFranco_O2. 10.07.pdf>. Acesso em 15 jun. 2013. 

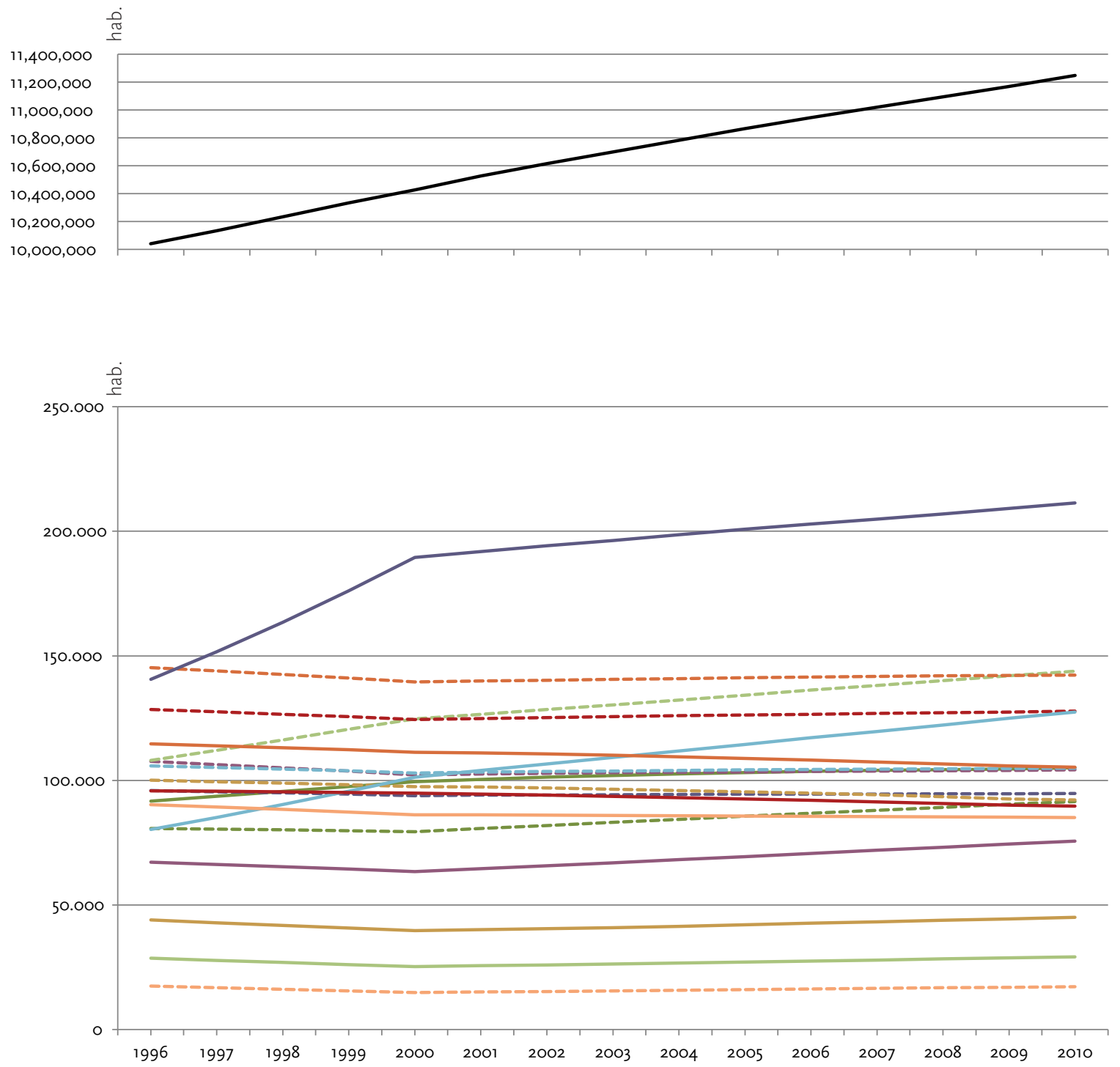

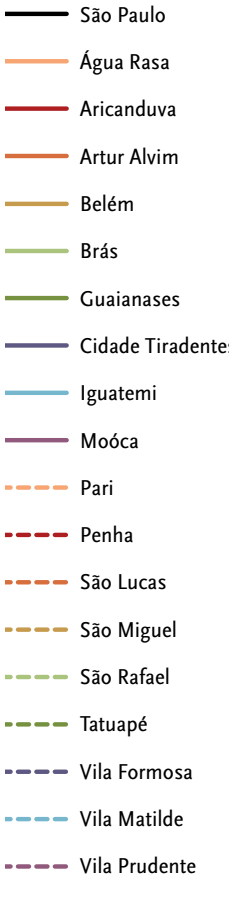

Gráfico: Variação da população no Município de São Paulo (DISTRItos) 
do recorte territorial definido pela administração pública no edital da contratação dos projetos e que espera-se aqui seja revisto, adicionou-se aos mapas a seguir, o recorte espacial da OUC-RVJ sobreposto à RLP para enfatizar a relação dos distritos do extremo leste e que não foram incluídos nessa recente operação urbana consorciada.

\section{PERFIL SOCIOECONÔMICO}

As taxas de crescimento tem sido altas nos distritos da Região Leste Paulistana, bem como em outros distritos da periferia de São Paulo, como visto na apresentação desta tese. Juntando-se alto crescimento populacional na faixa de baixa renda a áreas de baixa qualidade urbanística e infraestrutura muito aquém do mínimo, surgem os segmentos sociais vulneráveis.

O Mapa 4: Segmentos sociais mais vulneráveis (p.15), mostra as áreas Segmentos Sociais Vulneráveis em São Paulo. Na Região Leste 2., novamente o distrito de Cidade Tiradentes aparece como um dos distritos mais carentes do município. Observe-se que toda a área leste da OUC-RVJ apresenta a maior parte de seu território classificada como vulnerabilidade média, alta e muito alta.

Observa-se que as áreas de preservação ambiental como a APA do Parque do Carmo e as MPAs ou Setores de Urbanização Controlada, onde existem urbanizações em áreas irregulares e favelas, localizadas nos distritos de São Rafael, Iguatemi, Cidade Tiradentes, Guaianases, Lajeado, Vila Curuçá, Itaim Paulista e Jardim Helena, os seis últimos excluídos da OUC-RV], como analisado no Capítulo IV.

\section{EMPREGABILIDADE}

Os Mapas 5 a 7: Empregos formais segundo setor de atividade 2004 (p.17) mostram a distribuição de estabelecimentos comerciais, industriais e de serviços no município de São Paulo. Os mapas não estabelecem uma classificação de potencial de empregabilidade desses estabelecimentos o que deve ser verificado nos dados oficiais de institutos de pesquisa na área econômica. A concentração de estabelecimentos e empresas no centro Expandido à esquerda dos mapas vai gradativamente diminuindo em direção ao limite Leste do município. Pode-se observar no mapa da vulnerabilidade comparado aos mapas de empregabilidade, que o distrito Iguatemi, o que menos apresenta estabelecimentos é também um distrito com alta incidência de segmentos sociais vulneráveis, além de ser uma área de urbanização controlada a partir das diretrizes da OUC-RV).

A população total da Região Leste publicada pela Pesquisa OD/2007, era de 3.595.835 habitantes em 2007. Em 2013, a população total da Região Leste de São Paulo é de 4.042 .865 cidadãos, segundo o Censo 2010 com aplicação de projeção linear. Em relação à empregabilidade, a taxa de desemprego no Município de São Paulo hoje é de 10,2\%. A taxa de pessoas empregadas que residem em São Paulo é de $66,7 \%$ em relação aos empregos formais. A População Economicamente Ativa no Município de São Paulo é de 6.021.196 de pessoas.118

O Quadro 5 traz todos os tipos de emprego e as quantidades ofertadas na RLP, segundo a Pesquisa OD 2007, da Cia do Metrô.

Na Região Leste inteira, a taxa de empregabilidade é de $0,29 \%$, considerando-se a população total e
118. PesquisadeEmpregoe DesempregoPED, RMSP. SEADE. Tabelas 2/4/18. Edição n. 327. Fev. 2012. 
QUADRO 5

EMPREGABILIDADE NOS DISTRITOS DA RLP Metro, Pesquisa OD 2007

EMPREGOS POR SETOR

\begin{tabular}{|c|c|c|c|c|c|}
\hline DISTRITO & $\begin{array}{c}\text { ZONA OD } \\
2007\end{array}$ & SECUNDÁRIO & TERCIÁRIO & OUTROS & TOTAL \\
\hline Água Rasa & $46 / 47 / 48$ & 9.007 & 40.166 & 95 & 49.268 \\
\hline Aricanduva & $201 / 202$ & 8.969 & 18.905 & $\mathrm{O}$ & 27.874 \\
\hline Artur Alvim & $205 / 206$ & 2.177 & 24.885 & O & 27.062 \\
\hline Cangaíba & $170 / 171 / 172 / 173$ & 7.606 & 27.062 & $\mathrm{O}$ & 34.668 \\
\hline Carrão & 197/198 & 9.834 & 33.819 & $\mathrm{O}$ & 43.653 \\
\hline Cidade Líder & $207 / 208 / 209$ & 3.748 & 34.991 & O & 38.738 \\
\hline Cidade Tiradentes & 217 & 3.292 & 24.309 & $\mathrm{O}$ & 27.601 \\
\hline Ermelino Matarazzo & $174 / 175 / 176$ & 9.329 & 24.709 & $\mathrm{O}$ & 34.038 \\
\hline Guaianazes & $215 / 216$ & 1.709 & 21.351 & $\mathrm{O}$ & 23.060 \\
\hline Iguatemi & $218 / 219$ & 8.005 & 18.183 & 135 & 26.323 \\
\hline Itaim Paulista & 194/195/196 & 8.018 & 37.381 & $\mathrm{O}$ & $45 \cdot 399$ \\
\hline Itaquera & $181 / 182 / 183 / 184$ & 8.764 & 47.650 & 1.445 & 57.859 \\
\hline Jose Bonifácio & $213 / 214$ & 6.112 & 14.593 & $\mathrm{O}$ & 20.705 \\
\hline Lajeado & $192 / 193$ & 3.361 & 30.051 & $\mathrm{O}$ & $33 \cdot 412$ \\
\hline Parque Do Carmo & $210 / 211 / 212$ & 6.075 & 13.297 & $\mathrm{O}$ & $19 \cdot 372$ \\
\hline Penha & $167 / 168 / 169$ & 7.195 & 53.724 & $\mathrm{O}$ & 60.919 \\
\hline Ponte Rasa & $177 / 178$ & 4.058 & 26.188 & $\mathrm{O}$ & 30.246 \\
\hline São Lucas & $240 / 241 / 242$ & 6.319 & 23.456 & 0 & $29 \cdot 775$ \\
\hline São Mateus & $247 / 248 / 249 / 250$ & 11.416 & 39.617 & $\mathrm{O}$ & 51.032 \\
\hline Sao Miguel & $185 / 186 / 187$ & 3.679 & 40.332 & $\mathrm{O}$ & 44.011 \\
\hline São Rafael & $220 / 221$ & 2.884 & 18.592 & $\mathrm{O}$ & 21.476 \\
\hline Sapopemba & $243 / 244 / 245 / 246$ & 7.830 & 47.154 & $\mathrm{O}$ & 54.985 \\
\hline Tatuapé & $163 / 164 / 165 / 166$ & 11.945 & 85.932 & 538 & 98.414 \\
\hline Vila Curuça & 190/191 & 1.417 & 31.579 & 0 & 32.996 \\
\hline Vila Formosa & $199 / 200$ & 5.423 & 30.260 & 0 & 35.683 \\
\hline Vila Jacui & $179 / 180$ & 5.910 & 29.443 & $\mathrm{O}$ & $35 \cdot 352$ \\
\hline Vila Prudente & $237 / 238 / 239$ & 12.215 & 33.389 & 0 & 45.603 \\
\hline Região Leste & Total & 176.295 & 871.017 & 2.212 & $1.049 \cdot 524$ \\
\hline
\end{tabular}


o número de empregos da Pesquisa OD/2007. No extremo Leste temos as maiores taxas de crescimento populacional, o que exige desenvolvimento urbano e social. A população economicamente ativa que vive na Região Leste é composta por 1.704.858, o que representa $31 \%$ do PEA do município de São Paulo. Estima-se em 904.089 os trabalhadores desempregados na metrópole. Desses, 358.282 vivem na Região Leste, ou seja, 40\% dos trabalhadores desempregados do município. Entre os empregados da Região Leste no setor formal, 33\% estão na indústria de transformação e $41 \%$ no setor de serviços."19

Observe-se que nas duas Regiões que correspondem à localização da Universidade de São Paulo, a USP Leste 1 em Cangaíba e a USP Leste 2 em Ermelino Matarazzo, só foram considerados postos de trabalho no setor secundário em uma das divisões, a USP Leste 1, onde se agruparam todos os postos de trabalho das duas divisões.

\section{EDUCAÇÃO E CULTURA}

Diversos programas culturais atendem à RLP, mas somente programas menores se comparados com apresentação de grandes musicais, grandes orquestras, peças teatrais. Na RLP há somente três Teatros públicos (ver características de Cidade Tiradentes no capítulo VI), programas de leitura com pontos fixos, mas que não são bibliotecas completas e por Onibus-biblioteca.

\section{USO E OCUPAÇÃO DO SOLO ATUAL}

O Mapa 45: Cortiços e loteamentos irregulares 2006 apresenta a realidade na questão fundiária da Região Leste de São Paulo: a quantidade de áreas irregulares, na forma de territórios invadidos, cortiços ou loteamentos irregulares existentes na região objeto desta tese e onde se propõem um plano urbanístico voltado para o desenvolvimento sócio econômico como prioridade. Apesar de o mapa ser de 2006, o crescimento populacional sem programas concretos de assentamentos de famílias em áreas forma áreas de baixa qualidade ambiental urbana que podem ser vistas em ortofotos ou visitas in loco, comprovando-se que a situação ainda é a mesma em 2013. O Mapa 45 localiza também as favelas na RLP. Observe-se que a incidência de favelas (ou assentamentos precários, formados por construções precárias em número superior a cinquenta moradias, na classificação técnica oficial) segue um padrão de distribuição por toda a Região Leste do perímetro urbano, com maior incidência na área MPA da OUC$\mathrm{RV}$ e dispersas pelos distritos no entorno desta.

Comparando-se este mapa à ortofotos da Região Leste vê-se que o mapa não apresenta grande parte da área de favelas, portanto não representando portanto a realidade local.
119. PMSP. Disponível em <http://www. prefeitura.sp.gov.br/portal/a_cidade/ urbanismo/zona_leste/index. php? $p=362>$. Acesso em 28 mai. 2013. 


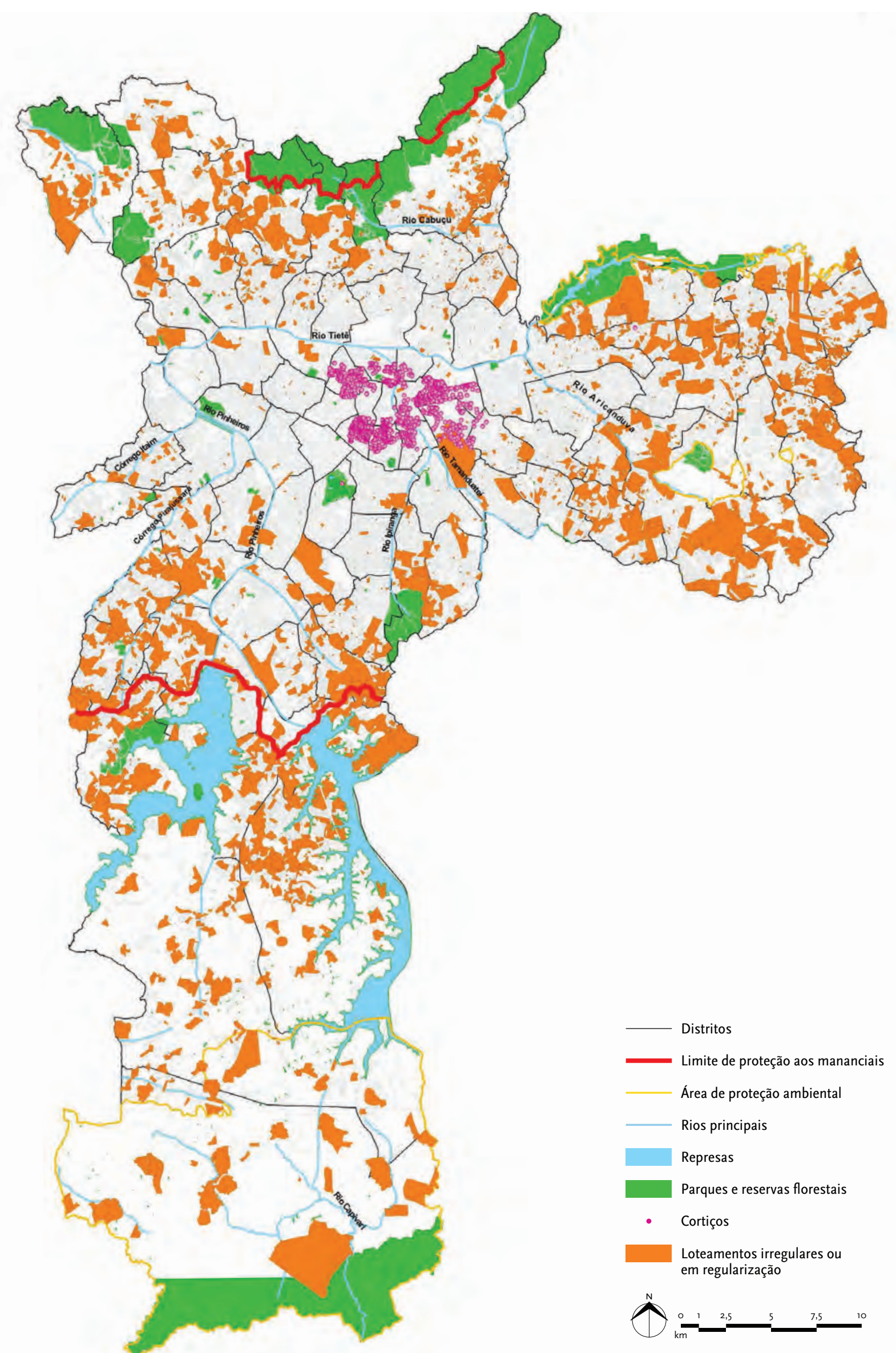

MAPA 45: CortiçOS E LOTEAMENTOS IRREGulares 2006

PMSP. Cadastro Unificado SEHAB/COHAB/CDHU; SEHAB/RESOLO 2006 


\section{O TECIDO URBANO ATUAL}

A visitação em 2012 e 2013 à Região Leste a título de reconhecimento de área e definição tanto da área de estudo como do distrito eleito como base para desenvolvimento de metodologia para planos de bairro, foi essencial para melhor entender as dinâmicas locais, seja de circulação de pedestres, seja do ponto de vista socioeconômico e cultural, já levantados em suas tendências macroestruturais pelos estudos de estruturação urbana histórica de longo prazo. O que para alguns pode parecer uma convivência caótica entre vias carregadas de veículos, estabelecimentos variados sem coerência arquitetônica entre si (o que não há também centralidades chamadas "nobres" nas cidades brasileiras), pode significar o lar para outros indivíduos, o local onde estão, família, amigos, escolas, igrejas e facilidades inclusive. Enfim, onde foram lançadas suas raízes e isso deve ser respeitado. A requalificação urbana ou viária não precisa ser excludente e sim usar dos resultados de análises do tecido urbano e conclusões coerentes com o espaço urbano onde se há de

Parte da metodologia utilizada para preparar o diag. nóstico da Região Leste 2 para localizar as caracterís ticas dos tipos de tecido urbano existentes foi a separação dessas características em aspectos negativos e aspectos positivos encontrados com o objetivo de mitigar impactos aos habitantes locais em uma reformulação de uso do solo e viária. Para localizar esses dois grupos característicos, antes se fez uma análise dos tecidos urbanos existentes, dos sete distritos selecionados após a análise da área pré-definida pela prefeitura municipal de São Paulo para a Operação Urbana Rio Verde Jacu: Itaim Paulista, Cidade Líder, Cidade Tiradentes, Guaianases, Ermelino Matarazzo, São Mateus e Vila Curuçá.

Observando-se a aerofotogrametria da região, em uma análise preliminar, destacam-se muitos vazios urbanos e construções aparentemente precárias, mas as vias com traçado irregular são quase todas asfaltadas, com raras exceções. O gabarito de ocupação é muito horizontal e o uso do solo é predominantemente residencial, com algumas incidências localizadas de galpões industriais ou para armazenamento. Os equipamentos públicos para esporte e lazer são muito poucos e as áreas verdes em praças são raros. O traçado viário é irregular, com vias em geral estreitas de cerca de 10 a 12 m de largura descontinua, mesmo quando são coletoras e estruturais, com quadras de diversos tamanhos, algumas muito grandes, levando o pedestre a caminhos mais longos. O transporte público atende com estações de metrô e trens metropolitanos localizados ao longo da antiga EF Central do Brasil, hoje CPTM, em seus dois ramais e linhas de ônibus municipais e metropolitanas, direcionadas basicamente para o Centro Expandido.

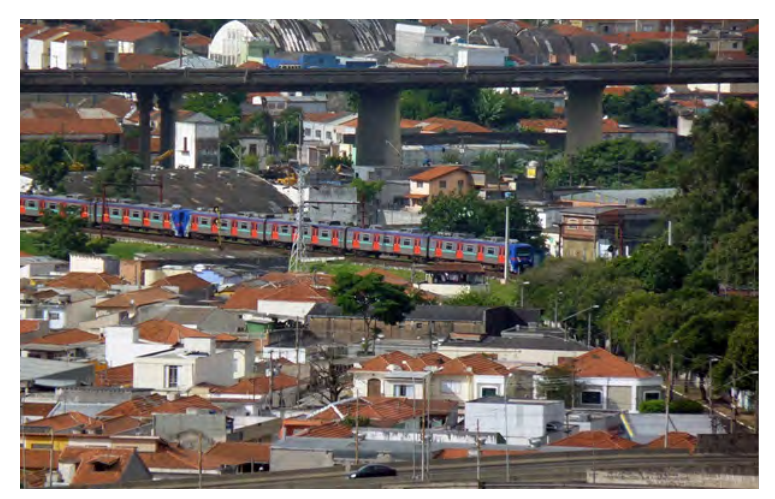

FIGURA 84: COMPOSIÇÃo DA CPTM SOB O VIADUTO Aricanduva, em SÃo Paulo 


\section{TIPOLOGIAS DE TECIDO URBANO}

A seguir, algumas tipologias de tecido urbano encontradas na RLP, a partir de ortofotos.

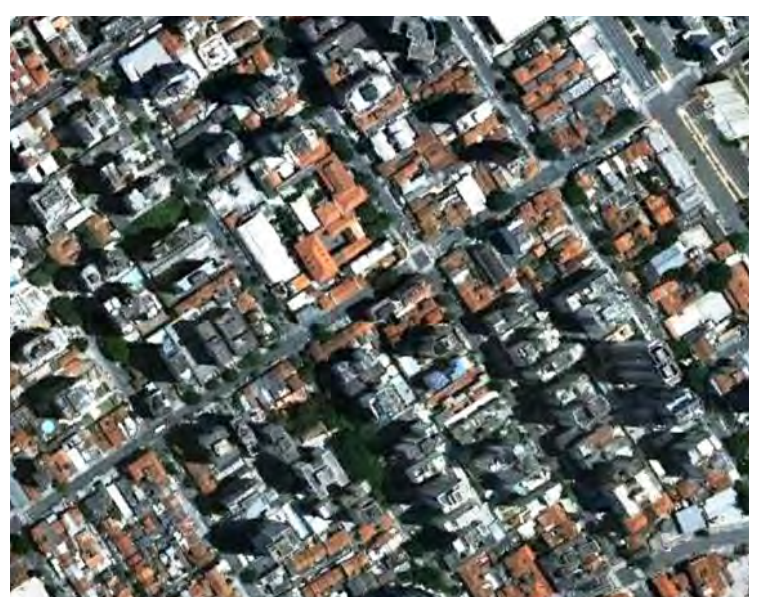

FIGURA 85: TIPO 1-TECIDO MISTO COM TRAÇADO ORTOGONAL E VERTICALIZAÇÃO MÉDIA

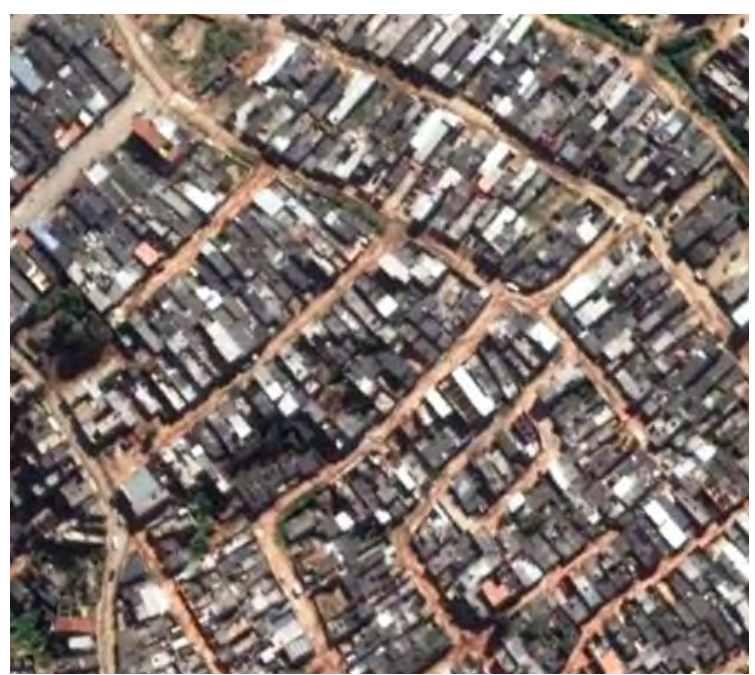

FIGURA 87: TIPO 2-USO PREDOMINANTEMENTE RESIDENCIAL COM TRAÇADO IRREGULAR E BAIXA VERTICALIZAÇÃO

Uma área de favela, com vias sem calçmento, baixo gabarito alta densidade populacional, como verificado no Mapa 2 (p.8).

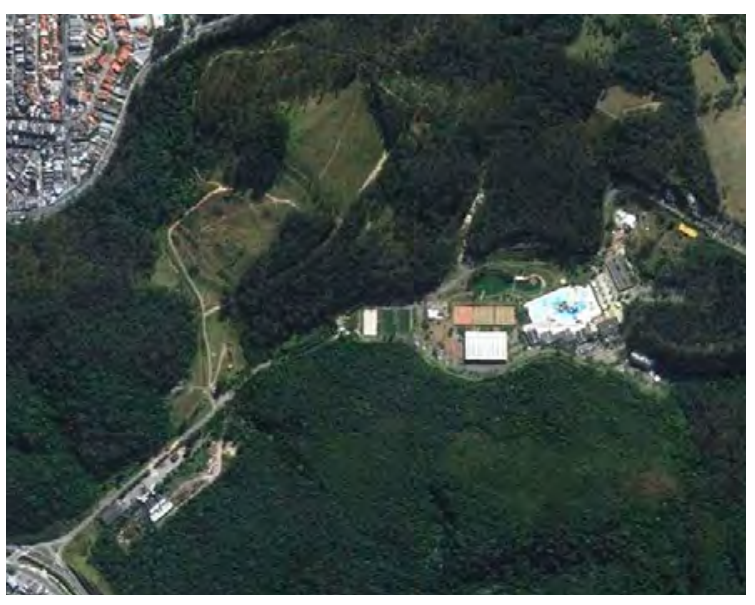

FIGURA 86: TIPOLOGIA 3-USO INSTITUCIONAL/ EQUIPAMENTO URBANO

Tecido em torno do Clube do Carmo, equipamento público para o esporte e lazer que está inserido em área verde: traçado orgânico e uso institucional público, gabarito baixo.

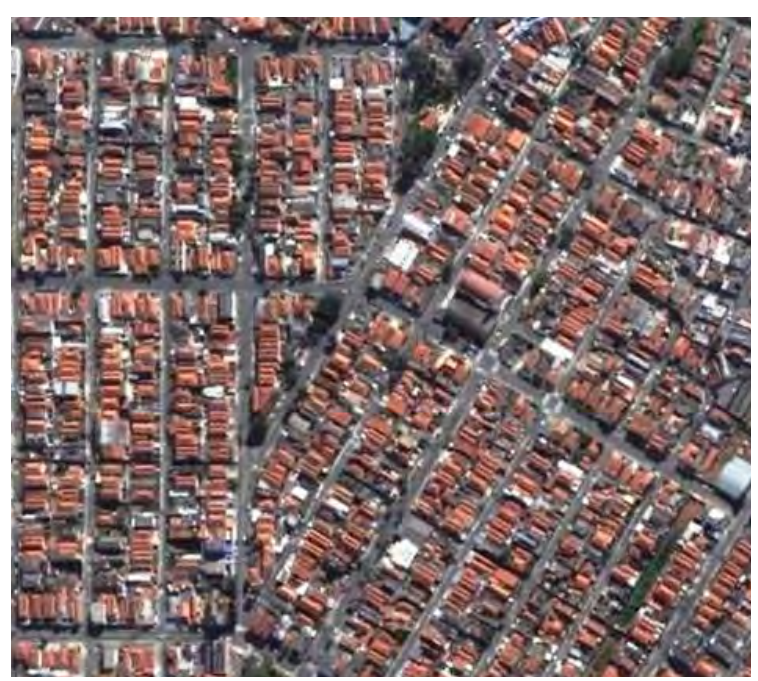

FIGURA 88: TIPOLOGIA 4-USO

PREDOMINANTEMENTE RESIDENCIAL

área residencial, com vias asfaltadas de traçado viário ortogonal proveniente de diferentes loteamentos, baixo gabarito e alta

densidade populacional, comprovada pelo Mapa 2 (p.8) e dados do CENSO 2010/IBGE. A tipologia construtiva de sobrados com telhado cerâmico aponta o uso residencial. 


\section{O TRAÇADO VIÁRIO}

O conjunto de vias rodoferroviárias do Município de São Paulo está hierarquicamente classificado em vias locais, vias coletoras e vias estruturais, estas classificadas por sua vez em e níveis: N1, N2 e N3. Na Região Leste Paulistana existem os três níveis de estruturais:

\section{AS VIAS ESTRUTURAIS}

As propostas viárias do Plano Diretor Estratégico para São Paulo e com ano meta 2012 e, portanto expirado e em fase de revisão estão listadas no Quadro 2: Renovação Viária Proposta no PDE 2002/2012-ano meta 2006 (p.144).

Este quadro apresenta uma listagem das vias que se pretende melhorar ou criar no PDE 2002, na Região Leste da capital, complementada por observações quanto às interferências no tecido urbano consolidado. O PDE definiu duas etapas para a execução dessas melhorias: 2006 e 2012. As melhorias estão classificadas no PDE 2002 como Via a Melhorar ou Abertura de Via/Nova ligação, ambos os tipos de intervenção previstos para as duas etapas: 2006 ou 2012, dependendo da via e que pode ser verificado na tabela montada a partir da análise visual do Mapa O2 do PDE - Rede Viária Estrutural.

Segundo o Plano Diretor Estratégico 2002, as ruas são classificadas em estruturais, coletoras, locais, ciclovias e vias de pedestre. (Governo de São Paulo. PDE2002/2012. Seção II-art. 110)

As Vias Estruturais, independentemente de suas características físicas, estão subdivididas em três níveis: Vias Estruturais N1: aquelas utilizadas como ligação da Capital com os demais municípios do Estado de São Paulo e com os demais estados da Federação; Vias Estruturais N2: aquelas, não incluídas no nível anterior, utilizadas como ligação com os municípios da Região Metropolitana e com as vias do $1^{\circ}$ nível; Vias Estruturais $N_{3}$ : aquelas, não incluídas nos níveis anteriores, utilizadas como ligações internas no Município. As demais vias do Município, não estruturais, são as que coletam e distribuem o tráfego internamente aos bairros e estão classificadas em quatro tipos: 1. Coletoras; 2. Vias locais; 3. Ciclovias; 4. Vias para pedestres.

A partir da observação Mapa 34: Rede Viária Estrutural (p.122), do Plano Diretor Estratégico para São Paulo 2002/2012, percebe-se que as diretrizes propostas para a melhoria e requalificação de algumas vias na Região Leste Paulistana foram classificadas por este trabalho para representar com mais exatidão o seu efeito sobre o tecido urbano consolidado e em consolidação.

Segundo Campos Filho em sua proposta de revisão do PDE 2002/2012, é parte da Política a tipificação das vias. Já o Mapa o2 do PDE 2002 assim como a tabela de intervenção nas vias acima é parte do que se entende deve ser um Plano Diretor. (informação verbal) ${ }^{120}$

A área delimitada com linha vermelha tracejada assinala a grande área à direita do recorte territorial oficial da OUC Rio Verde Jacu, área muito carente e tema de uma das questões aqui colocadas: como as diretrizes da OUC-RVJ contribuirão para o desenvolvimento urbano e a inclusão das famílias socialmente vulneráveis que lá vivem?
120. Campos Filho. Depoimento à autora, 12 mar. 2013. 


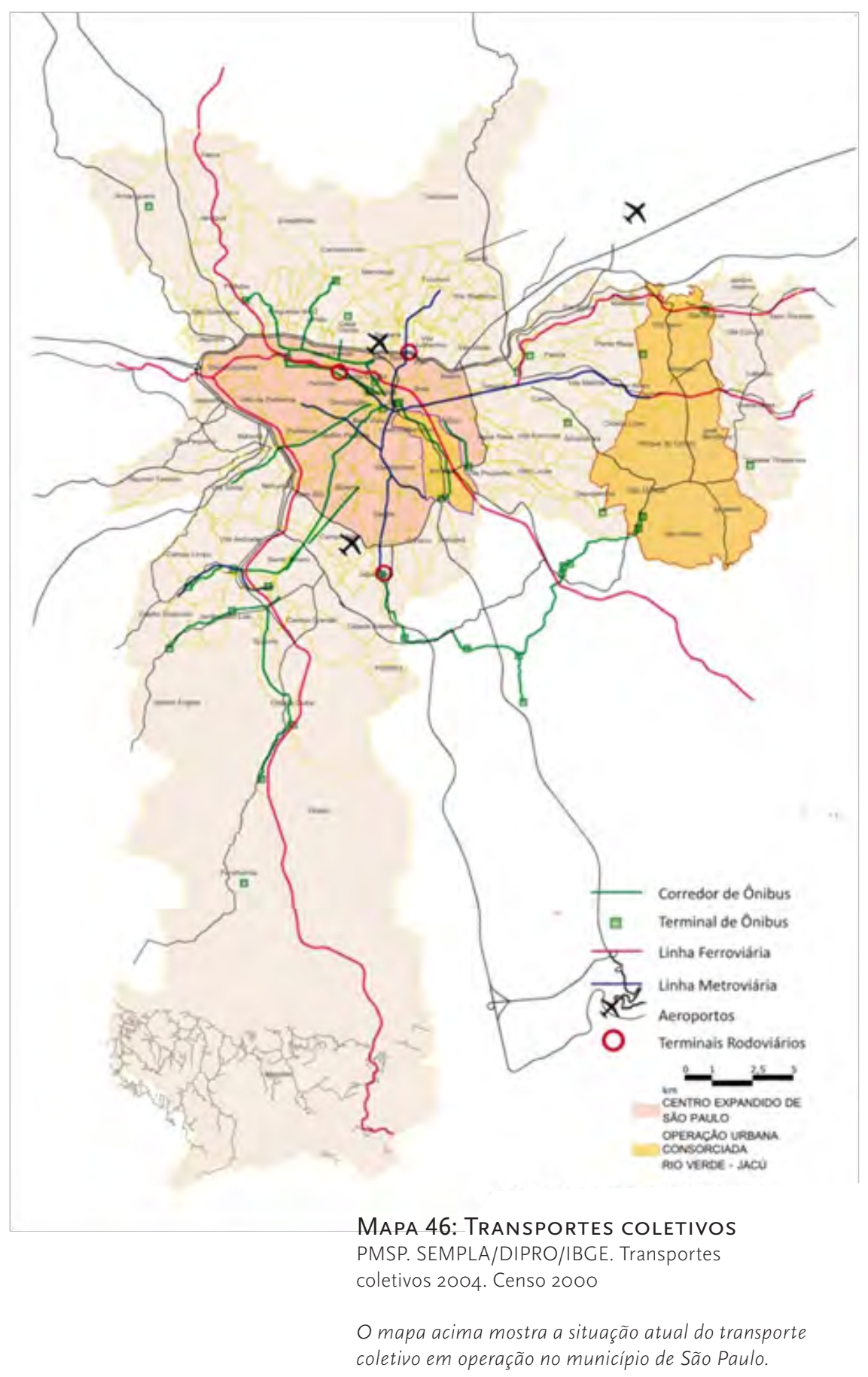

coletivo em operação no município de São Paulo.
Como essa área e sua população local serão beneficiados pela OUC-RVJ é questão a responder analisando os mapas a seguir, enquanto diretrizes municipais inseridas no PDE, obtidos na publicação digital Município em Mapas, Séries Temáticas Contrastes Urbanos e Dinâmica Urbana, e resultantes da aplicação gráfica de dados de institutos de pesquisa levantados entre 2004 e 2006

\section{PRINCIPAIS CENTRALIDADES}

Conforme visto no capítulo III, o Mapa no. 35, p. contém a lista de centralidades dentro da RLP, tanto as existentes como as centralidades a dinamizar, conforme declarado no PDE 2002/2012.

Mas, pode-se afirmar que outras centralidades existem, estão em formação ou se formarão, dependendo dos rumos que se propuserem nas requalificações urbanas que ocorrerão de hoje em diante na metrópole de São Paulo, uma vez que as condições urbanas atuais levam ao clamor por melhorias imediatas, principalmente no transporte público.

\section{TRANSPORTE PÚBLICO}

A carência de transporte público em toda a metrópole de São Paulo tem a Região Leste como o ponto crônico, superando somente a região Sul em população e distâncias de deslocamentos diários. É sentido pela população a cada dia de seu cotidiano que envolve deslocar-se até $30 \mathrm{~km}$ de seu local de moradia ao local de trabalho.

Haja vistas ao cenário diário das condições de lotação nos trens metropolitanos da CPTM que tem como ponto de partida municípios do Leste do Estado como Ferraz de Vasconcelos e até Mogi das 
Cruzes, onde grandes contingentes de trabalhadores se deslocam ao Centro Expandido de São Paulo para trabalhar.

As composições vindas de Mogi das Cruzes, Ferraz de Vasconcelos e Poá já chegam às estações de Calmon Viana e Guaianases, esta dentro do município de São Paulo totalmente lotadas, nos horários de pico da manhã, tornando impossível ao trabalhador conviver com uma realidade diária com trajetos de até 3 horas de duração entre moradia e local de trabalho. O Quadro 5 (p.174) apresenta a distribuição de empregos por setor nos distritos da Região Leste e entre as Regiões de cada um deles, como explicado acima.

O Mapa 46: Transportes coletivos mostra a localização das vias a abrir e a melhorar listadas na tabela anterior e as estações do Metrô Leste-Linha Vermelha, além das intervenções pontuais.

É clara a carência no transporte público de massa eficiente na região, além de vias com maior capacidade de suporte no espaço intraurbano existente, compreendido pela linha de trem metropolitano da CPTM, entre Jundiaí e o Grande ABC, pela Linha Leste do Metrô e pelo limite Leste da cidade, formando uma grande área triangular onde há necessidade de vias estruturais na forma de corredores de ônibus interligando os dois sistemas principais: CPTM e Metrô.

\section{MEIO AMBIENTE}

As áreas verdes são apenas duas com capacidade de absorção de águas pluviais e para lazer da população - Parque Ecológico do Tietê, ao longo do rio de mesmo nome e o Parque do Carmo, na APA do Carmo. O restante da área urbana está totalmente impermeabilizado por asfalto nas vias e outros tipos de calçamento em calçadas e áreas privadas, elevando a temperatura de superfície e comprometendo o conforto ambiental. As maiores temperaturas de superfície ocorrem no Brás e Mooca, distritos da Região Leste 1, junto à Região Central da capital. 
Este quadro traz um

detalhamento do consumo de território por uso residencial e não residencial, comparando-se os dados do Município de São Paulo com a Região Leste Paulistana e com o distrito de Cidade Tiradentes, eleito como exemplo ilustrativo da metodologia do Capitulo VI

\section{QUADRO 6}

ANÁLISE COMPARATIVA DAS CARACTERÍSTICAS TERRITORIAIS E POPULACIONAIS comparativo município de São Paulo e RLP SEADE/IBCE 2010/PMSP

TERRITÓRIO ANALISADO

\begin{tabular}{|c|c|c|c|c|}
\hline \multirow[b]{2}{*}{ TIPO DE DADO INFORMADO } & \multirow[b]{2}{*}{ UNIDADE } & \\
\hline & & $\begin{array}{c}\text { MuNicíPIO de } \\
\text { SÃo PAULO }\end{array}$ & RLP & $\begin{array}{c}\text { CIDADE } \\
\text { TIRADENTES }\end{array}$ \\
\hline \multirow{2}{*}{ População total } & habitantes & 11.253 .503 & 3.998 .237 & 211.501 \\
\hline & $\%$ & $100 \%$ & $35,53 \%$ & $1,88 \%$ \\
\hline \multirow{2}{*}{ Área territorial } & $\mathrm{km}^{2}$ & $1.509,0$ & 326,8 & 15,0 \\
\hline & $\%$ & $100 \%$ & $21,66 \%$ & $0,99 \%$ \\
\hline \multirow{2}{*}{ Densidade habitacional } & habitantes $/ \mathrm{km}^{2}$ & 7.458 & 12.235 & 14.100 \\
\hline & $\%$ & $100 \%$ & $164,05 \%$ & $189,07 \%$ \\
\hline \multirow{2}{*}{ Nº de domicílos } & totais & 3.574 .286 & 1.214 .027 & 60.740 \\
\hline & $\%$ & $100 \%$ & $33,97 \%$ & $1,70 \%$ \\
\hline \multirow{4}{*}{$\mathrm{N}^{\circ}$ de lotes } & vagos & 2.163 .025 & $589 \cdot 504$ & 3.962 \\
\hline & residenciais & 642.333 & 192.639 & 20.543 \\
\hline & não residenciais & 2.922 .026 & 824.733 & 25.070 \\
\hline & totais & 5.727 .384 & 1.606 .876 & 49.575 \\
\hline \multirow{4}{*}{ Área de terrenos } & $\mathrm{m}^{2}$ vagos & 284.850 .898 & 93.544 .992 & 562.387 \\
\hline & $\mathrm{m}^{2}$ residenciais & 223.031 .379 & 59.727 .805 & 1.170 .919 \\
\hline & $\mathrm{m}^{2}$ não residenciais & 592.416 .753 & 178.820 .128 & 2.291 .061 \\
\hline & $\mathrm{m}^{2}$ totais & 1.100 .299 .030 & 332.092 .925 & 4.024 .367 \\
\hline \multirow{3}{*}{ Área construída total } & $\mathrm{m}^{2}$ residenciais & 173.865 .458 & 46.220 .465 & 1.060 .966 \\
\hline & $\mathrm{m}^{2}$ não residenciais & 449.539 .164 & 115.028 .044 & 1.243 .627 \\
\hline & $\mathrm{m}^{2}$ totais & 623.404 .622 & 161.248 .509 & 2.304 .593 \\
\hline \multirow{3}{*}{ Área construída por lote } & $\mathrm{m}^{2}$ residenciais & 271 & 240 & 52 \\
\hline & $m^{2}$ não residenciais & 154 & 139 & 50 \\
\hline & $\mathrm{m}^{2}$ totais & 175 & 158 & 51 \\
\hline \multirow{2}{*}{$\begin{array}{r}\text { Área construída por } \\
\text { domicílio }\end{array}$} & $\mathrm{m}^{2}$ residenciais & 49 & 38 & 17 \\
\hline & $\%$ & $100 \%$ & $78,27 \%$ & $35,91 \%$ \\
\hline \multirow{2}{*}{$\begin{array}{c}\text { No de pessoas } \\
\text { por domicílio }\end{array}$} & residenciais & 3,15 & 3,29 & 3,48 \\
\hline & $\%$ & $100 \%$ & $104,60 \%$ & $110,60 \%$ \\
\hline \multirow{2}{*}{$\begin{array}{r}N^{\circ} \text { domicílios } \\
\text { por lote }\end{array}$} & residenciais & 5,56 & 6,30 & 2,96 \\
\hline & $\%$ & $100 \%$ & $113,25 \%$ & $53,14 \%$ \\
\hline \multirow{3}{*}{$\begin{array}{l}\text { Coeficiente de } \\
\text { Aproveitamento }\end{array}$} & $\mathrm{m}^{2}$ residenciais & 0,780 & 0,774 & 0,906 \\
\hline & $\mathrm{m}^{2}$ não residenciais & 0,759 & 0,643 & 0,543 \\
\hline & totais $(\div)$ & 0,764 & 0,676 & 0,666 \\
\hline & Obs. (*) o C.A. não & גi terrenos vago & & \\
\hline
\end{tabular}


CAPÍTULO VI

\section{METODOLOGIA PARA DEFINIČ̃̃O DE DIRETRIZES PARA PLANOS DE BAIRRO COM A̧ ADOÇÃO DE UNIDADES AMBIENTAIS DE MORADIA}

O objetivo desta tese de doutoramento é demonstrar que o planejamento urbano para reestruturação de áreas metropolitanas deve ocorrer em uma combinação de dois níveis finais do planejamento urbano: o de escala regional, como os Planos Diretores Estratégicos, e o de escala local, como os Planos de Bairro. Para que este planejamento urbano tenha uma eficácia concreta ao atribuir qualidade ambiental ao ambiente urbano, devem-se adotar metodologias de planejamento que quantificam as ofertas e demandas de modo a que se equilibrem. Elaborar o planejamento urbano com o objetivo de quantificar essas relações sociais permite que este se torne concreto, objetivo, deixando de ser um plano vago, de diretrizes gerais, que na verdade não são planos, são políticas de desenvolvimento urbano.

A partir dos conceitos teóricos estudados no Capítulo I, desenvolveu-se metodologia para a proposição de conjunto de diretrizes específico para um Plano de Bairro. A adoção dos conceitos urbanísticos ocorreu a partir da escala metropolitana até a escala local, ou seja, a escala bairro.

A Região Leste 2, que quase coincide com a área da Operação Urbana Rio Verde-Jacu, foi escolhida como estudo de caso e, por esse motivo, se propôs que a OUC-RVJ fosse ampliada, incluindo os seis distritos do extremo leste de São Paulo pelos critérios descritos no Capítulo IV. Uma área menor, o distrito de Cidade Tiradentes, foi adotada como exemplo ilustrativo desta Metodologia para propor Diretrizes para Planos de Bairro com a adoção da UAM. Não se pretendeu apresentar aqui um plano de bairro para esse distrito, mas sim a metodologia e o roteiro de como fazê-lo.

Metodologia para Planejamento de Planos de Bairro, Sistema TRANUS, Planejamento Urbanístico para um Plano de Bairro e o Roteiro para um Plano de Bairro serão os termos e expressões utilizados neste texto, ora em diante mencionados de forma resumida como Metodologia, TRANUS, Planejamento e Roteiro. Em seguida, se falará do modelo matemático de cálculo de capacidade de suporte sugerido para o desenvolvimento de planos de bairro.

\section{A UTILIZAÇÃO DO TRANUS EM PLANOS DE BAIRRO}

O uso de modelos matemáticos para o cálculo da capacidade de suporte do sistema de transporte 
21. "Com o processo de avaliação no TRANUS estima-se o efeito da aplicação de certas políticas (planos ou projetos) no decorrer do tempo, baseados em indicadores de benefícios socioeconômicos. sistema apresenta a distribuição dos benefícios entre os diversos atores sociais envolvidos. Nenhum processo de avaliação terá a última palavra sobre as vantagens ou desvantagens de um determinado projeto, desde que os elementos de julgamento sejam múltiplos e de natureza diversa. Portanto, TRANUS estima e apresenta uma ampla variedade de indicadores que proporciona a simulação e os resultados podem ser combinados com outros fatores considerados relevantes." (Modelística, 2007, p.29) público é instrumento indispensável para desenvolver diretrizes em uma área ou bairro que se pretenda requalificar, como já foram mencionados no Capítulo I, como parte da fundamentação teórica desta tese, e no Capítulo III, onde se mostrou e discutiu a eficácia dos planos urbanos governamentais para a metrópole de São Paulo e sua eficácia ou objetividade em relação à RLP. Neste caso, o uso do modelo matemático em questão, o TRANUS, teve seu uso e aplicação autorizados pelo governo mas, lamentavelmente, não foi levado adiante, apesar do imediato interesse por parte dos técnicos envolvidos no planejamento da cidade à época. Esses modelos matemáticos de modelagem e cálculo da capacidade de suporte do sistema de transporte público associados ao uso do solo devem ter prioridade como etapa inicial ao se desenvolver planos de bairro. Uma vez que os parâmetros do Cenário Atual e para o Cenário Desejado são calculados por esses modelos, suas resultantes fundamentam tanto as diretrizes urbanísticas a se propor para um plano local ou de bairro como o projeto urbano que deve se seguir ao conjunto de diretrizes aprovadas.

O uso do Sistema TRANUS é um processo metodológico na forma de modelo matemático para cálculo de capacidade de suporte utilizando como parâmetros principais dados socioeconômicos, populacionais e territoriais associados à oferta de transporte público em uma determinada área onde se pretende promover expansão urbana com provisão de moradias, seja sob responsabilidade do Estado, seja em uma Parceira Público Privada-PPP.

O Sistema TRANUS é um modelo matemático que trabalha com os parâmetros dos dois cenários, o atual e o desejado, futuro, no ano meta em que se deseja ter o plano urbano implantado, permitindo, assim, avaliarem-se políticas públicas que mantém tendências no sentido da continuidade da aplicação das políticas em vigor, implícitas (sem cálculo) ou explícitas, e avaliarem-se conjuntamente as políticas que visem alterar as que estejam em vigor ou torná-las mais efetivas.

Deve-se reiterar novamente que esta tese visa demonstrar como tornar mais efetiva a política de gerar melhor qualidade e condições de vida para a população moradora da Região Leste, levando a elas não apenas emprego, mas todos os equipamentos sociais que a atenda, combinando um planejamento mais estruturado do Uso do Solo e Transportes, com um planejamento local que, basicamente, vise completar a urbanização com todos os equipamentos sociais e de infraestrutura urbana a que todos os cidadãos têm direito, inclusive reduzindo a necessidade de deslocamento na metrópole na ida para o local de trabalho e para usufruir de serviços e comércio urbanos que necessite.

Fundamentalmente, buscou-se demonstrar que, para isso, é indispensável uma modelagem matemática que, simulando políticas públicas e a atuação do mercado imobiliário, consiga avaliar cenários possíveis que quantificam a distribuição no território das famílias por faixa de renda, de modo equilibrado, com a capacidade de suporte do sistema de circulação. Desse modo, para um determinado ano meta, escolhe-se o cenário desejado. Esse cenário conterá as informações sobre qual deverá ser a demanda futura a partir do ano base para todos os equipamentos sociais e para a infraestrutura urbana. Com base nesta informação, torna-se possível definir de forma quantificada a localização dos equipamentos sociais. ${ }^{121}$ 
A demanda assim localizada, por exemplo, por Zona OD ou por distrito, será a base para o desenvolvimento de Planos de Bairro.

Nos Planos de Bairro são utilizados conceitos de estruturação urbana que remetem para o conceito das Unidades de Vizinhança. No livro Cidades Brasileiras: seu controle ou caos (1989) e em Reinvente seu Bairro, (2003) Campos Filho justifica sua utilização atualizada na reestruturação de bairros, de vilas que os constituem, mesmo que sejam aglomerações resultantes de loteamentos de origem ilegal, inclusive favelas.

\section{O modelo TRANUS pode ser utilizado na escala} metropolitana, na escala municipal, na escala regional como, por exemplo, a Região Leste, e na escala local como, por exemplo, em um plano de bairro. Segundo a empresa Modelística, desenvolvedora do sistema TRANUS em sua forma atual,

A simulação do sistema TRANUS pode ser usada em áreas urbanas detalhadas, áreas e regiões metropolitanas, estados ou províncias, em nível Nacional ou até mesmo em regiões formadas por vários países. (Modelística, 2007, p.2)

Para a escala local, entram os Planos de Bairro articulados com os cálculos do TRANUS. Ainda segundo a Modelística,

A gama de políticas e projetos que podem ser geradas pelo sistema é muito ampla. Políticas de uso do solo podem ser associadas a projetos de transportes de diversas modalidades e avaliadas em conjunto. Uma lista completa das possibilidades do sistema seria muito extensa, mas as seguintes podem servir como guia: planos de desenvolvimento urbano, controles sobre os usos do solo, impactos de projetos urbanos específicos, como indústrias, condomínios residenciais ou shopping centers, planos de desenvolvimento regional, planos e estímulos para a construção de moradias, programas de proteção ambiental ou proteção de áreas especiais, novas estradas ou melhoria de existentes, reorganização do sistema de transporte público, (novas rotas, tarifas etc.) corredores exclusivos de ônibus e redes de integração, (Bus Rapid Transit-BRT) sistemas de transporte coletivo de massa, (metrô, Light Rail-LRT etc.) com tarifas integradas, vias expressas com pedágios urbanos ou regionais, faixas exclusivas para veículos de alta ocupação, (High Occupation Vehicles HOV) restrições à circulação de veículos, políticas de tarifação, como taxas sobre combustível ou estacionamentos, park-and-ride, ${ }^{122}$ (pedágios urbanos seletivos) reabilitação de vias expressas e políticas de manutenção de estradas, projetos ferroviários ou melhoria das redes existentes, novas instalações portuárias ou realocação das existentes, realocação dos aeroportos de carga e passageiros. (Modelística, 2007, p.2-3)

Para um plano local com o uso do TRANUS, dentre as possibilidades acima, e se selecionar principalmente e basicamente os cálculos para planos de urbanização, controles sobre os usos do solo, impacto dos projetos industriais ou residenciais, planos e estímulos para a construção de moradias, programas de proteção do ambiente através do controle sobre as áreas especiais, reorganização do sistema de transporte público (novas rotas, tarifas etc.), faixas exclusivas de ônibus (BRT), sistemas de transporte coletivo (metrô, LRT etc.) com tarifas integradas, faixas exclusivas para veículos para circulação em hidrovias, como os HOV, (hovercraft) restrições à circulação de veículos, dentre outras.

\section{O Sistema TRANUS associado ao Plano de Bairro} possibilita que se definam os controles imprescindíveis do processo de produção, apropriação e consumo do espaço urbano, de modo a que se obtenha a qualidade ambiental que estimula a convivência social produtiva no espaço. São os controles, por
122. Estacionamentos para transporte particular em periferias ou subúrbios conjugados a sistemas de transporte público, reunindo-se as pessoas que, de outro modo, estariam cada uma em seu carro, engrossando o congestionamento urbano. 
123. Campos Filho. Depoimento à autora, 21 jun. 2013. exemplo, das viagens geradas pelo transporte particular e coletivo nas vias do sistema viário principal como também pelo sistema segregado sobre trilhos. Esse controle resulta da modelagem TRANUS, que utiliza os parâmetros por Zona OD. Existem 320 Zonas OD no município de São Paulo e 460 para na RMSP. As variáveis são compatíveis com os números citados de Zona OD. Para o distrito de Cidade Tiradentes temos uma Zona OD somente.

Segundo Campos Filho,

$$
\begin{aligned}
& \text { Como os Planos de Bairro vão ser } \\
& \text { desenvolvidos mais detalhadamente do que } \\
& \text { o que o TRANUS permite, estuda-se como } \\
& \text { pormenorizar o TRANUS, o que poderia } \\
& \text { ser denominado "TRANINHO" semelhante } \\
& \text { ao apelido dado para o pormenor do MUT, } \\
& \text { que foi o de "Mutinho". Como ainda tal } \\
& \text { pormenorização não é operacional, os dados } \\
& \text { obtidos pelo TRANUS são utilizados para } \\
& \text { cálculos simplificados que estimam a relação } \\
& \text { entre oferta e demanda na escala intradistrital. } \\
& \text { (informação verbal)'23 }
\end{aligned}
$$

\section{Cenários para Modelo Tendencial e o Modelo Desejado}

Após a escolha de uma área urbana em escala local para o desenvolvimento de conjunto de diretrizes para um Plano de Bairro, devem ser considerados vários e importantes fatores inicialmente, como o Ano Base e o Ano Meta de atendimento de todos os objetivos desejados ou de grande parte deles. O Ano Base pode ser anterior ao ano em vigor, por razões práticas, pois regularmente os dados socioeconômicos, territoriais e populacionais não se econtram imediatamente atualizados.

O Ano Meta deve atingir um período tal que possibilite as transformações desejadas, evitando que este
Ano Meta passe sem que tenham sido atendidos os objetivos pretendidos ou realizadas as obras necessárias à expansão urbana pretendida, como ocorreu com o Plano Diretor Estratégico para o Município de São Paulo. Atingido o Ano Meta de 2012, caducou sem que se tenha realizado grande parte das propostas por ele pretendidas e, apesar de terem ocorrido as revisões dos Planos Regionais 2004, o Ano Meta para o PDE continuou o mesmo. Deve-se, por isso, considerar um Ano Meta vinte anos após o Ano Base, como horizonte de tempo mínimo.

O Ano Base apresenta um Cenário Atual com características e dados populacionais, territoriais e socioeconômicos que refletem as condições atuais do espaço urbano a reestruturar ou expandir, estando essas informações disponíveis nos órgãos públicos, como as secretarias das prefeituras municipais e dos governos estaduais, ou em órgãos de pesquisa, como IBGE, SEADE e outros mais específicos na área de transporte, por exemplo. Fica claro então que o Ano Base conta com um Cenário Atual, com os parâmetros acima listados já disponíveis.

No caso do Ano Meta, existem duas possibilidades de cenários a considerar para efetuar-se um cálculo de expansão e reestruturação urbana para um plano de bairro: o Tendencial e o Desejado. Como dito anteriormente, o Cenário Tendencial mantém as políticas públicas como a lei de zoneamento em vigor, LUOS, e o Cenário Desejado propõe uma alteração dessas políticas.

No Cenário Tendencial, utilizam-se parâmetros como Coeficiente de Aproveitamento-CA, ou seja, o potencial construtivo fixo por lote do início da política pública que o dimensionou, muitas vezes sem cálculo, até que uma nova LUOS seja promulgada, 
o que não tem data definida, segundo o que se tem praticado em São Paulo. Exemplo disto, o PDE expirado, coloca a cidade e o mercado imobiliário em uma situação de falta de diretrizes pode-se assim dizer.

O útimo PDE 2002/2012, expirado, determinou, além do CA máximo por lote, os estoques distritais em duas categorias de uso: residencial e não residencial, que engloba serviços, comércio, institucional, esporte, lazer e cultura e até o industrial, quando assim o permite a LUOS, aprovado pela lei n. 13.385 que estabeleceu no Quadro VIII do PDE, um estoque de solo criado, ou seja, o direito de construir além do CA Básico com o pagamento de outorga onerosa. Esses estoques foram calculados com base nas tendências do mercado imobiliário pelos 10 anos seguintes. Ou seja, não se considerou cálculo com base na capacidade de suporte do sistema de circulação.

Os estoques, principalmente os de uso residencial, já estão esgotados em vários distritos da Capital. Paradoxalmente, o CA ainda existe, mantendo o direito de construir do lote, mesmo que não haja estoque disponível, colocando-o em situação de vazio urbano, ou seja, propriedade urbana que não cumpre sua função social. Mas, não precisa ser assim, caso a LUOS determinasse dentro dos estoques distritais, um CA mínimo de 20\% fixo por lote e que não fosse disponibilizado ao primeiro que o requisitasse, somente ao proprietário do lote. Dessa forma, o proprietário do lote sempre poderia construir o equivalente a $20 \%$ da área do terreno, cumprindo sua função social e ficando livre de sanções legais.

O problema avistado é que quando há um potencial construtivo definido por lote na região, em se somando os direitos de cada lote, o resultado fica além do estoque distrital, porque não foram utilizados instrumentos como o TRANUS para se calcular a capacidade de suporte, como recomendamos aqui. Até mesmo os estoques das operações urbanas são independentes do CA permitido no lote e, no caso dessas operações, pode-se pagar pelo solo criado, através da compra desse direito na forma de Certificados de Potencial Adicional de Construção-CEPAC. ${ }^{24}$

Esse é o cálculo elaborado através da capacidade de lotação definida por uma política pública baseada no potencial construtivo. É fato que a revisão do PDE 2002/2012 de São Paulo precisa ser publicada imediatamente. Revisão ou novo PDE, para não se repetirem os erros do anterior, e com um Ano Meta mais distante que o primeiro: 2030.

No cenário tendencial, em relação aos planos de transporte público e melhorias viárias propostas pelo PDE 2002/2012 para a RLP, as políticas públicas mudam antes de se ter atingido os objetivos de adensamento ou reestruturação urbana, ou grande parte deles. Ambos os cenários são influenciados pelo mercado imobiliário, que depende das políticas de governo e costuma influenciar o mesmo em relação a leis urbanas, em um processo de causação circular, nem sempre o melhor para o cidadão.

Para um melhor desenvolvimento de cálculos para expansão e reestruturação urbana, sugere-se aqui que ambos os cenários sejam utilizados, a título de comparação entre as políticas que estão sendo praticadas e as propostas pela tese, embasando-se, assim, mais fortemente a definição de diretrizes em atendimento às demandas da população local, beneficiada por essa política urbana do Plano de Bairro.
124. CEPAC são valores mobiliários emitidos pela PMSP, através da SP URBANISMO, utilizados como meio de pagamento de Contrapartida para a outorga de Direito Urbanístico Adicional dentro do perímetro de uma OUC. Cada CEPAC equivale a determinado valor de metro quadrado para utilização em área adicional de construção. As emissões de CEPAC são regidas pelas determinações contidas na Instrução 401 da Comissão de Valores MobiliáriosCVM, que regulamenta a emissão dos títulos, as responsabilidades pelo acompanhamento das OUCS e indica a forma de exercício dos direitos assegurados pelos CEPAC, que são negociados em oferta pública primária em leilão e que podem ser negociados livremente no mercado secundário, até que sejam vinculados a um lote dentro do perímetro da OUC. Os recursos obtidos com as distribuições públicas de CEPAC destinam-se exclusivamente ao pagamento das Intervenções aprovadas pelo Grupo de Gestão. A Caixa Econômica Federal é responsável pela fiscalização do emprego dos recursos e pelo acompanhamento das referidas Intervenções, assegurando a suficiência e veracidade das informações prestadas pelo Município ao mercado. PMSP. Cepac. Disponível em <http:// www.prefeitura.sp.gov.br/cidade/ secretarias/desenvolvimento urbano/sp_urbanismo/ cepac/index.php? $\mathrm{p}=19456>$. Acesso em 13 jun. 2013. 
O Cenário Desejado deve, de preferência, considerar um Ano Meta definido por um prazo mínimo que permita a alocação de verbas governamentais ou o estabelecimento de PPP para viabilizar a implantação das diretrizes dispostas no plano proposto.

Para definirem-se as expansões urbanas desejadas, tanto no Cenário Tendencial como no Cenário Desejado, deve utilizar-se do sistema TRANUS, uma vez que a entrada de dados tem a mesma destinação mas gera, para comparações, resultados diferentes, mais realistas para o Tendencial que para o Desejado.

\section{CONCEITUAÇÃO PARA OS PLANOS DE BAIRRO}

A problemática decorrente da relação entre três fatores como longas distâncias a percorrer versus localização de empregos, comércio e serviços versus localização de moradia encontrada nas periferias da metrópole de São Paulo, só pode ser corrigida a partir da elaboração de planos locais em sequência aos Planos Diretores Regionais. Este é o objetivo desta tese: uma metodologia para Planos de Bairro estruturados pela conjunção dos temas Transporte Público e Uso do Solo, como política pública de reestruturação urbana de áreas consolidadas ou em consolidação.

Esse conjunto de diretrizes tem como principal eixo estruturador o traçado viário existente e sua hierarquia de uso, ou seja, vias estruturais $\mathrm{N}_{1}, \mathrm{~N}_{2}$ e $\mathrm{N}_{3}$ e vias coletoras conforme classificação oficial em São Paulo, além do número e localização de estações de transbordo dos diferentes tipos de transporte público e da verificação da capacidade de suporte dessas vias. Para isso, sugere-se o modelo desenvolvido e publicado pela FUPAM sob o título de
Montagem e Avaliação de um Cenário Equilibrado para o Desenvolvimento Urbano de São Paulo através de uma estratégia combinada de transporte e uso do solo, modelo aperfeiçoado do TRANUS, de cujo conteúdo foram destacados os pontos mais importantes.

Segundo o texto da publicação,

Existe amplo consenso entre especialistas sobre as relações causais entre a forma ou estruturação urbana e o desempenho do sistema de transportes. Os efeitos desses dois fatores se alimentam e retroalimentam entre si, resultando que o segundo molda a cidade enquanto o primeiro tem influência direta nas demandas de transportes. (...) Os elementos da forma ou estrutura urbana, a saber, densidades de população e empregos e suas localizações - atividades -, bem como suas dimensões e os tecidos urbanos existentes, impactam as demandas de deslocamento e o funcionamento do sistema de transportes. Inversamente, os componentes do sistema de transportes - desempenho da oferta em termos de custo e tempo das viagens influenciam os preços do mercado imobiliário e, portanto a distribuição das atividades na cidade. Em tese, esses elementos devem ser considerados sob todos os seus aspectos constitutivos. Por exemplo, uma rede de transportes cuja infraestrutura física é adequada para atender a uma determinada demanda e provocar efeitos favoráveis na cidade pode ter seus efeitos atenuados ou mesmo anulados por tarifação inapropriada ou por fragmentação institucional que iniba a gestão conjugada da rede e as integrações. (Governo de São Paulo, 2009, p.17)

Em relação às políticas conjugadas e ao complexo tecido urbano de São Paulo, destaca-se:

Embora sejam conhecidos o significado e o alcance das relações entre as políticas de uso do solo, transportes, habitação, meio ambiente e desenvolvimento, é extremamente complexo o desafio de usar tal conhecimento em situações concretas, especialmente em metrópoles como a de São Paulo, para estabelecer seu diagnóstico e formular e 
implantar propostas para direcionar ou redirecionar o desenvolvimento. Assim, não obstante as dificuldades, devem-se traduzir as aspirações por uma cidade mais sustentável, já declarada em nível técnico ou político, mediante a adoção de linhas apropriadas de política urbana, a serem computadas no presente trabalho. (Governo de SÃo Paulo, 2009, p.21)

Em relação ao adensamento da mancha urbana:

Tais diretrizes podem ser expressas como segue:

Adensamento seletivo: $\mathrm{O}$ adensamento da cidade deve se realizar prioritariamente ao longo dos corredores de transporte, em áreas de intervenção urbana (AIUs) e Operações Urbanas Consorciadas (OUCs) existentes ou a estabelecer

Condicionantes do adensamento: $\mathrm{O}$ adensamento deve ser coerente com a capacidade de suporte da infraestrutura existente ou planejada, evitando a criação de pressões que provoquem congestionamentos, acidentes e poluição e seus efeitos deletérios sobre a qualidade de vida. A disponibilidade de potencial construtivo deve ser correlacionada com a capacidade de suporte. (Governo de São Paulo, 2009, p.21)

Em relação à empregabilidade:

Balanceamento empregos / habitações: É desejável que seja estabelecido o balanceamento possível entre a localização de empregos e habitações, aproximando uns de outros - para todas as classes de renda - evitando o descompasso histórico que vem provocando exatamente o fenômeno oposto e o consequente alongamento dos deslocamentos. Além disso, deve ser vigorosamente estimulado o uso misto, sobretudo nas áreas lindeiras aos corredores de transportes. (Governo de São Paulo, 2009, p.21)
Em relação à política habitacional para a baixa renda, destaca-se:

Subsídio habitacional para os grupos de baixa renda: Devem ser instituídas políticas públicas de proteção aos mais pobres, para viabilizar os objetivos de balanceamento referidos no tópico anterior, uma vez que, na ausência dessas medidas, a valorização imobiliária provocada pela melhoria da infraestrutura tende a expulsar esses grupos sociais para a periferia. Contenção da área urbanizada, embora de difícil implementação, não deve ser permitida a expansão da mancha urbana da região metropolitana de São Paulo para além de seus atuais limites, seja para proteger áreas ambientalmente sensíveis, seja para evitar a queda da densidade populacional, que tem efeitos negativos sobre a sustentabilidade urbana. Financiamento complementar de base fundiária. (Governo de SÃo Paulo, 2009, p.21)

Em relação à captação de recursos, destaca-se:

Devem ser explorados os mecanismos do Estatuto da Cidade e do Plano Diretor para captar parte da mais valia imobiliária e internalizá-la no setor de transportes: As diretrizes urbanísticas devem ensejar a criação de valor imobiliário via projetos de revitalização urbana de áreas selecionadas, com apoio de novos instrumentos legais e administrativos que permitam a mobilização de todas as propriedades existentes nessas áreas.

Alocação das externalidades aos automóveis: As políticas expostas nos itens anteriores devem ser complementadas por medidas que aloquem aos automóveis a totalidade dos custos dos deslocamentos do transporte individual. (Governo de SÃo Paulo, 2009, p.21)

Em relação à eficácia da metodologia:

As orientações contidas nas diretrizes acima devem ser consideradas sempre no 
seu conjunto, uma vez que só apresentam resultado pleno se funcionarem em bloco. A efetividade de qualquer diretriz será reduzida ou comprometida caso alguns dos componentes do conjunto não seja implantado. (Governo de São Paulo, 2009 , p.21)

Em relação à aplicação de método similar em outras cidades, destaca-se que:

\begin{abstract}
Essa assertiva é confirmada pela experiência internacional. Vejam-se, por exemplo, as conclusões do estudo da Comissão Europeia "Planning and Urban Mobility in Europe" relatório final - set. 2005 , resumidas a seguir: 1. Estratégias integradas de transporte e uso do solo são mais eficientes do que estratégias isoladas; 2. Aumento ou requalificação da oferta deve ser combinado com administração da demanda; 3 . As estratégias de uso do solo - aumento de densidade e uso misto só terão sucesso se em paralelo for reduzida a atratividade do transporte individual; 4. Quando as medidas acima descritas não foram implementadas em sua totalidade, como um bloco integrado, as políticas que visaram aumentar a afluencia ao transporte coletivo e o desenvolvimento urbano em torno das estações tiveram pouco. (Governo de São Paulo, 2009)
\end{abstract}

\section{PLANOS DE BAIRRO: O URBANISMO ANTES DA POLIITICA}

A proposição de Diretrizes Urbanas é atribuição das Políticas Públicas, mas geralmente são vagas e a implantação concreta destas depende dos planos urbanísticos. As Políticas Públicas devem ser seguidas de cálculos de capacidade de suporte e estes de planos urbanos em quaisquer escalas, como mencionado no início deste capítulo.
Os Planos Regionais devem ser apresentados já com a definição das áreas, distritos ou bairros onde se deve planejar, projetar e implantar planos urbanos locais, ou seja, onde se deve praticar o urbanismo. É por esse motivo que esta metodologia faz a distinção entre as três etapas.

A Metodologia de Planejamento para Planos de Bairro é formada por duas etapas importantes: o Cálculo da Capacidade de Suporte e o Planejamento Urbanístico para um Plano de Bairro.

A síntese desta tese é o alcance de qualidade urbana em escala local através do uso do TRANUS e da criação de UAMs, que não se restrinjam ao fornecimento de moradias e equipamentos urbanos em quantidade e tipos adequados, mas sim a criação de espaços públicos com qualidade no entorno dos agrupamentos de moradias e em todos os espaços públicos de uso produtivo, para lazer, circulação e contemplação, os espaços de estar, como bem conceituado por Campos Filho em seu Plano de Bairro de Perus.

Um Plano de Bairro deve partir das resultantes obtidas através dos cálculos do Sistema TRANUS que, como já dito anteriormente, é um sistema matemático para o cálculo, por exemplo, da distribuição de habitações e empregos no espaço de acordo com a oferta de transporte urbano.

O Plano de Bairro deve utilizar as conclusões do TRANUS, onde se introduziram parâmetros do Cenário Atual como especificidades da população e fatores socioeconômicos como faixas de renda familiares ou per capita atuais, e os parâmetros para o Cenário Desejado. 


\section{UNIDADE AMBIENTAL DE MORADIA-UAM}

O conceito das UAMs, utilizadas por Campos Filho em seu Plano de Bairro de Perus, foi definido, segundo ele como:

(...) unidade territorial de um estilo de morar, pelo qual as energias físicas e emocionais gastas na luta pela vida durante o trabalho são recompostas no espaço de morar, propiciada essa recomposição pela tranquilidade do local onde se mora. (...) a tranquilidade encontra-se hoje conflitando com o uso cada vez mais intenso dos veículos, que provocam a degradação ambiental do espaço do uso coletivo. (...) e conjuntamente empurram os cidadãos para trás de grades e paredes e trancas e sistemas cada vez mais sofisticados de alarme e supervisão, isolando os cidadãos entre si. (Campos Filho, 2003, p.23-24)

Localizadas nos espaços intraurbanos entre vias estruturais rodoferroviárias ou que, no papel de centralidades de serviços e comércio diversificado, separam áreas de uso predominantemente residencial das áreas mais ruidosas e expostas ao tráfego de veículos. A Figura 89, de autoria de Campos Filho, expõe, dentro de sua simplicidade, o conceito de UAM ou Ilha de tranquilidade.

Desse modo, podemos dizer que, provavelmente, a maioria das pessoas que vive nas cidades gostaria de ter um espaço mais tranquilo para morar, podendo dispor de opções de ambientes mais intensos e agitados, quando isso é desejado ou inevitável. A organização da cidade em unidades ambientais de moradia de qualidade variada propicia essa diversidade ambiental. (Campos Filho, 2003, p.24)

Na delimitação de UAM, cujo objetivo é transformar o tecido intraurbano em ilhas de tranquilidade, adotam-se também os conceitos estudados e criados por Gehl e Appleyard, vistos no Capítulo I, que têm como prerrogativa a segurança nas ruas, tanto para a população como um todo como para os idosos, crianças e pessoas com necessidades especiais

Cabe ao elaborador do Plano de Bairro determinar onde estão as vias estruturais, as centralidades e os equipamentos públicos existentes, determinar as distâncias adequadas de acesso a centralidades caminhando ou com uso de um transporte público.

A participação das comunidades e seus representantes no planejamento de seu bairro é fundamental para lograrem-se os resultados almejados e, com isso, mostrar ao cidadão comum a efetividade do planejamento na solução dos problemas de seu local de moradia. Com o planejamento participativo chegando a esse nível de concretude, confere-se a ele um grau de credibilidade que não pode ser alcançado por um planejamento genérico de boas intenções ou só concreto para as classes médias, que pouco precisam da ação pública em seus bairros, apenas de um zoneamento que controle sua qualidade e de um sistema de circulação que the garanta a tranquilidade quando a mesma é desejada.

Pelo Plano de Bairro e as UAMs dele decorrentes, são organizados os ambientes urbanos de modo a oferecer proximidade com o comércio, serviços e indústrias, como emprego e como atividades urbanas de apoio ao cidadão para a sua vida urbana de trabalho, cultura, lazer e esporte, com as distâncias reduzidas de modo a estimular trajetos de pedestres ou ciclistas, com distâncias máximas de um quilômetro, que na média seja de até quinhentos metros. Ao mesmo tempo, definem-se ilhas de tranquilidade em meio às UAMs, onde devem estar ou serem

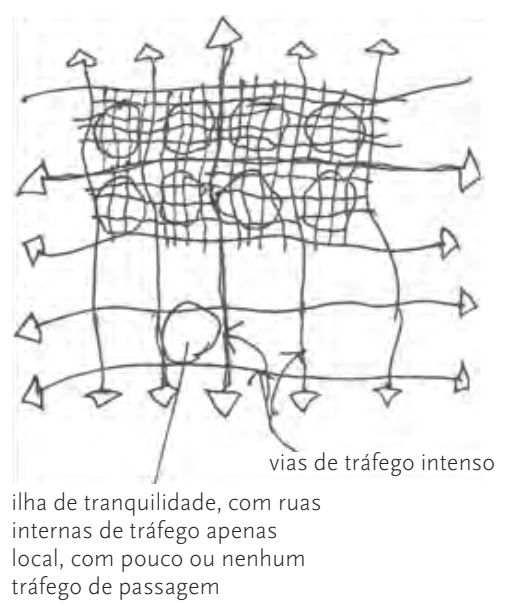

FIGURA 89: ILHAS DE TRANQUILIDADE esquema Campos Filho, 2003, p.23 
localizados os equipamentos sociais como creches, escolas de ensino infantil e fundamental e, postos de saúde com acesso seguro a idosos, mães com crianças pequenas e outros tipos de indivíduos mais frágeis.

Ao mesmo tempo em que são levantados os equipamentos existentes, com suas vagas oferecidas ocupadas e, eventualmente, ociosas, para a população atual de um determinado ano base escolhido, são previstas as vagas a serem oferecidas e sua localização através da Reserva Legal de Áreas, um instrumento novo de planejamento, muito necessário de ser criado, para uma população futura estimada. Com isso, garante-se a qualidade ambiental das vias a serem tranquilizadas quando no interior das UAMs, por medidas de traffic calming preconizadas por Gehl e Appleyard.

Os que preferem um ambiente mais dinâmico e mesmo ruidoso o encontrarão nas vias com comércio e serviços diversificados nas centralidades regionais ou no entorno das UAMs, por onde deve preferencialmente circular o tráfego de veículos, inclusive coletivos, vias essas que têm o papel de interligação entre os bairros. São elas que atraem naturalmente o comércio e serviços, pela potencial clientela que por elas passem. Corresponde assim a uma lógica positiva do mercado imobiliário. Se, no entanto, o seu dimensionamento enquanto de um lado o potencial construtivo a ser permitido construir e a capacidade viária e do transporte coletivo é feito por planejamento que integre uso do solo e o transporte, como com o obtido com a modelagem propiciada pelo TRANUS, fica garantido o equilíbrio entre oferta e procura dos meios de mobilidade urbana, mesmo com a restrição do tráfego de passagem pelo meio das UAMs.
Ao mesmo tempo, o cálculo da capacidade de suporte do sistema de circulação de um determinado local de acordo com seu zoneamento legal irá estimar com a melhor metodologia disponível, que é o TRANUS, a população que deverá morar ali, no prazo adotado pela definição de um ano meta como horizonte de planejamento. Defende-se que esse horizonte de planejamento seja suficiente para que se resolva - ou pelo menos que se avance significativamente nesse sentido - para os principais problemas urbanos enfrentados. Conforme Campos Filho afirma, e tendo como base o planejamento de transportes metropolitanos, esse prazo, no caso de São Paulo metrópole, incluindo todos os outros 38 municípios mais que a conformam, deve ser de, no mínimo, vinte anos.

Na ausência dessa estimativa do crescimento populacional regional, deve ser adotada a lotação máxima permitida pela legislação urbanística, no caso de se avaliar a existência de um potencial de transformação dos tecidos urbanos predominantes pela ação do mercado imobiliário, do poder público ou da combinação das duas ações. É também necessário consultar a população democraticamente pela metodologia participativa dos mesmos Planos de Bairro, conforme adotada em Perus, que deve concordar com a transformação, sendo conscientizada de que esse plano pode eventualmente expulsá-la devido à gentrificação resultante.

Estudos de tipologias urbanísticas consideradas de melhor qualidade ambiental que possam substituir as existentes deverão ser uma nova problemática a ser instaurada no planejamento urbano brasileiro, quando for superada a fase mitigadora atual, como propõe Campos Filho, exemplificado por seu Plano de Perus. 
Uma ação transformadora para padrões superiores aos existentes, por mudança radical dos tecidos urbanos existentes de origem irregular ou ilegal por outros resultantes de planos urbanísticos de qualidade ambiental em que aumente significativamente a quantidade e qualidade dos espaços públicos, já foi conseguida na Espanha, com um exemplo emblemático de planejamento urbano participativo reestruturador, El Pozo del Tio Raimundo, na periferia de Madrid e apresentado no Capítulo I desta tese como breve estudo de caso junto ao Plano de Perus e ao bairro de SACONIA-Dehesa de la Villa.

O urbanista Candido Malta Campos Filho defende que em algumas décadas será possível essa mudança de paradigma:

Será uma nova e mais completa reforma urbana da que está em curso, De qualquer modo a metodologia que se quer aqui demonstrar ser necessária na fase mitigadora, mais necessária se fará na etapa reestruturadora que se anuncia em um futuro, com data difícil de definir. (informação verbal) $^{125}$

\section{ROTEIRO PARA UM PLANO DE BAIRRO}

Antes de entrarmos no roteiro, deve-se dizer que se pode começar a proposição de diretrizes a partir do TRANUS ou de um Plano de Bairro, com os levantamentos populacionais e socioeconômicos do Cenário Atual utilizando para tal o Método da Lotação, ou seja, o número de famílias ou habitantes que podem ser transferidos para um determinado espaço formado por certo número de metros quadrados construídos, permitidos pela Lei de Uso e Ocupação do Solo-

LUOS, ou Lei de Zoneamento, como é popularmente conhecida. Mas, é preferível iniciar-se pelo TRANUS, cuja resultante é a distribuição de moradias no território disponível em relação à oferta de postos de trabalho e de transporte público.

Este Roteiro para um Plano de Bairro, ou Roteiro, como será chamado aqui, tem uma estrutura de ordem cronológica e funcional em relação a todo o processo que envolve um Plano de Bairro, desde os aspectos técnicos até os aspectos político burocráticos. Está composto de doze passos, chamando-se a atenção para o quinto, a Preparação da Proposta, que tem duas fases de trabalho: o Planejamento

Urbano e o Urbanismo. Sem diminuir a importância de ambas, diferenciam-se essas duas vertentes do trabalho do planejador urbano, uma vez que nem todos se dedicam ao urbanismo como desenho urbano, ou seja, o detalhamento dos parques, o desenho da praça, da calçada adequada, passarelas seguras para a transposição de vias ou cursos d'água, além de outros elementos do mobiliário urbano.

\section{PASSO}

\section{Delimitação das Unidades Ambientais de MORADIA}

Em resumo, as UAMs são áreas ou minicidades, delimitadas a partir da conformação urbana do distrito pelas vias estruturais rodoferroviárias e da estruturação do Plano de Bairro pretendido.

\section{PASSO}

\section{LEVANTAMENTO SOCIOECONÔMICO E DEMOGRÁFICO DA POPULAÇÃO ATUAL}

O levantamento socioeconômico e demográfico da população atual deve ser levantado via formulários ou IBGE, SEADE etc. Os levantamentos são os da população total e por faixa etária. Esses dados, entretanto, podem não ser precisos, e se deve então
125. Campos Filho. Depoimento em 18 jun. 2013 
utilizar métodos mais trabalhosos como a contagem domícilio a domicílio.

\section{PASSO \\ LEVANTAMENTO DA OFERTA ATUAL DOS EQUIPAMENTOS SOCIAIS}

Deve-se fazer um levantamento completo dos equipamentos públicos existentes, contemplando o número de vagas ocupadas e ociosas, para calcularse a demanda por equipamentos complementares. Equipamentos públicos são as edificações produzidas e administradas pelo Estado, tais como escolas municipais, creches, hospitais, UBSs - popularmente ainda chamados de postos de saúde - e postos especiais, como as AMAs, além da infraestrutura urbana básica. Esses dados devem ser levantados junto à administração pública como a Prefeitura Municipal e as Secretarias Municipais de cada área e junto às Subprefeituras responsáveis pela administração de determinado distrito ou bairro onde se im. plantará um plano urbano local. Alguns equipamentos são produzidos e administrados pelo Governo do Estado, como as escolas estaduais. Além da informação obtida via administração pública, na falta desta, deverá ser realizado um levantamento de campo, como dito no item anterior.

\section{$4^{\circ}$ PASSO}

AsPIRAÇÕES DAS COMUNIDADES: O "BAIRRO QUE QUEREMOS"

Levantamento das aspirações das comunidades através de questionário preparado para uma pesquisa de campo multidisciplinar e que abranja todas as possibilidades relacionadas ao plano de um bairro.

No levantamento feito por questionário por amostragem, uma em vinte casas é escolhida para a pesquisa, o que dá credibilidade científica ao plano. Na oportunidade da apresentação do Plano de Bairro, o modelo de pesquisa utilizado facilita a aprovação do plano em assembleias, pois já é sabido pelas lideranças da comunidade que este contempla as demandas expostas.

\section{$5^{\circ}$ PASSO}

Preparação de PROPOSTA URBANÍSticA PARA um Plano de Bairro

\section{O PLANEJAMENTO URBANÍSTICO}

Um grupo multidisciplinar de planejadores prepara uma proposta com base nos levantamentos científicos e a base cientifica mais importante é o conceito de UAM definido no $1^{\circ}$ Passo deste roteiro. Para a preparação do Plano, é necessário já ter-se a população futura, calculada pelo TRANUS ou pela lotação permitida pela LUOS. O Planejamento do Plano de Bairro envolve:

1. Definição dos déficits infraestruturais atuais e futuros;

2. Definição da localização ou conformação das ithas de tranquilidade dentro do espaço urbano local destinatário do Plano de Bairro a partir das vias interligadoras das vilas e bairros, onde se concentra o comércio e os serviços;

3. Definição da demanda por vagas nos equipamentos sociais para a população atual e a população futura;

4. Localização dessas vagas onde devem ser implantadas e a consequente reserva de áreas e terrenos quando necessários (direito de preempção ou tipo novo de zona denominada especificamente para esse fim, como por 
exemplo, a denominação de Campos Filho em Perus: Zona de Reserva de Área);

5. Definição de demanda por habitação popular enquanto moradia e a localização de sua oferta;

6. Definição de loteamentos e favelas a regularizar;

7. No caso de uma OUC estar contida no bairro ou vice e versa, deverá a proposta considerar a interação entre eles;

8. Alterações eventuais do Zoneamento - em casos de transição entre leis de zoneamento devem-se considerar as condições dessa transição e suas implicações ou postergações, a exemplo do que correu no início do PDE MSP, quando os coeficientes de aproveitamento foram diminuindo progressivamente ano a ano, enquanto projetos aprovados na lei anterior tinham seu direito adquirido de construir;

9. Alterações eventuais do sistema de circulação, que inclui o viário e o sistema de transporte coletivo;

10. Equalização da drenagem territorial;

11. Correção das áreas de risco;

12. Coleta e destinação do lixo com programas de reciclagem.

\section{O URBANISMO}

A disciplina Urbanismo inicia seu trabalho para um plano de bairro em seguida às resultantes e definições obtidas pela disciplina Planejamento Urbano. Os urbanistas não especializados em planejamento urbano desenvolvem o projeto urbano - em lugar do desenho urbano, derivado da tradução livre do anglicismo urban design, que significa projeto e não desenho. Itens que compõem o desenho urbano:

1. Desenho urbano para melhorias em geral;

2. Criação e detalhamento do desenho urbano para parques e praças;

3. Em terrenos de relevo acentuado, a proposição de sistemas funiculares para a mobilidade de pessoas e cargas deve ser considerada;

4. Melhoria do espaço urbano para comércio e serviços: calçadas acessíveis, estacionamentos, faixas exclusivas para VLT;

5. Desenho universal ou adequação para a acessibilidade de pessoas com necessidades especiais idosos e em vias de circulação de pedestres;

6. Projeto e detalhamento de ciclovias, ciclofaixas, paraciclos e bicicletários;

7. Arborização de vias para aumentar o grau de sombreamento e diminuir a temperatura de superfície, quando muito alta;

8. Vias compartilhadas entre o pedestre e $\mathrm{O}$ veículo em vias estreitas, com menos de dez metros de largura, comuns em áreas históricas e periféricas;

9. Inclusão de sistemas de transporte do tipo BRT ou LRT que contribuam com a mobilidade urbana; neste caso, não se trata de planos de bairro do tipo mitigadores em função dos custos de implantação e das interferências físicas decorrentes;

10. Detalhamento de Áreas de Intervenção UrbanaAIU, que incluem o bairro ou vice e versa. 
Este quinto passo do Roteiro para um Plano de Bairro deve incluir também outros dois itens importantes em sua elaboração: a história do bairro e o orçamento para a implantação do plano desejado.

\section{A HISTÓRIA}

A história de um bairro deve considerar fatos de importância local que deram nome ao bairro e suas variações ao longo do tempo e fatos singelos, como o primeiro morador, a primeira igreja, o primeiro loteador, a primeira escola, os marcos referenciais e moradores que contribuíram com as melhorias conseguidas. O levantamento da história de uma localidade ajuda no desenvolvimento de uma identidade para os moradores do bairro, reforçando o seu enraizamento ao local onde nasceram. Só haverá sucesso se o plano de bairro for defendido por quem ama o local que escolheu para viver, trabalhar e se desenvolver socialmente.

\section{O ORÇAMENTO E PRAZO}

A elaboração do orçamento para implantação de um plano de bairro além de contemplar o planejamento financeiro dessa requalificação urbana, cria uma conscientização do cidadão de quanto custará seu "novo bairro" e como este será mantido dentro das condições esperadas.

O orçamento para um plano de bairro deve ser composto por duas planilhas: a primeira com o valor detalhado e quantificado do investimento e a segunda com o custeio, ou seja, quanto custa pelo período determinado, a manutenção, operação e os recursos humanos envolvidos para que os equipamentos urbanos, sistemas de transporte e dos espaços públicos mantenham a qualidade mínima necessária. O prazo de implantação está diretamente ligado ao custo de implantação e ao custeio, uma vez que a implantação de um plano de bairro é executada em fases. O prazo de implantação pode ficar em aberto a menos que se tenha planejado um Ano Meta viável.

\section{$6^{\circ}$ PASSO}

\section{ApresentaÇÃo e debate EM ASSEMbleias ABERTAS}

Apresentação e debate com a comunidade em assembleias abertas e portanto democráticas são indispensáveis. Como os planos foram embasados nas aspirações, demandas, desejos e pesquisas de campo, junto às comunidades, a aprovação se torna mais fácil e, se necessário, se deve fazer mais de uma assembleia para total esclarecimento.

\section{Diferentemente dos Planos Diretores Regionais} onde, historicamente, não se consultavam as lideranças comunitárias antes da sua elaboração, sendo estes apresentados a elas depois de já terem sido elaborados e, portanto, apresentariam maiores as dificuldades para alterações e ajustes.

\section{PASSO VOTAÇÃO FINAL DAS PROPOSTAS}

A votação das propostas deve ocorrer em continuidade ao processo democrático em que os planos locais foram desenvolvidos, ou seja, ouvindo-se as comunidades locais e considerando suas aspirações de forma realista e concisa.

\section{$8^{\circ}$ PASSO}

\section{AsSEMBleia FinAL DE FECHAMENTO DO PLANO}

Uma vez aprovado o plano, uma assembleia final de fechamento deve ser agendada de forma a oficializar o momento e criar um cronograma de 
acompanhamento da implantação do plano após sua aprovação: publicação, licitação, acompanhamento da legitimidade das licitações e, por fim, o início e o prazo de implantação de suas fases.

\section{PASSO}

\section{Elaboração do Projeto de Lei e Relatório Final Expositivo do Plano de Bairro}

Em função das dificuldades conceituais de elaboração dos projetos de lei envolvendo consultores jurídicos, dentre outros, estes não podem contar com a participação popular de forma tão aberta como nas primeiras apresentações e levantamentos junto a ela.

\section{$10^{\circ}$ PASSO}

\section{Remessa À SubPrefeitura}

O projeto de Lei deve ser então encaminhado à Subprefeitura administradora do distrito ou bairro em questão e esta, por sua vez, deve encaminhá-lo aos órgãos centrais de planejamento da cidade.

\section{$11^{\circ}$ PASSO}

Remessa do Projeto de Lei da Prefeitura à CÂmara Municipal, COM VISTAS À aprovaçÃo

\section{$12^{\circ}$ PASSO}

\section{Aprovação pela Câmara de Vereadores}

A última providência é a aprovação do Projeto de Lei pela Câmara de Vereadores e sua inclusão no Plano Diretor Regional da Subprefeitura a que pertence o distrito que abrange o bairro.

\section{LEVANTAMENTOS E PARÂMETROS}

Além dos sistemas rodoferroviários para transporte público, prioritário na entrada de dados no Sistema
TRANUS, os cinco grandes grupos de levantamentos são: 1. O territorial, que inclui as áreas construídas e em terrenos vazios, quantificadas em quilômetros quadrados, a tipologia de tecido urbano, combinação entre uso do solo atual, traçado viário e o gabarito das edificações, o que leva a uma grande diversidade de tipologias em uma mesma área de estudo, além dos espaços disponíveis para atividades ao ar livre; 2. O levantamento populacional, que envolve a população total, rural e urbana, a população por faixa etária, por sexo e todas outras características necessárias conhecer para elaborar um plano de diretrizes urbanas; 3 . O levantamento socioeconômico, que inclui o nível de escolaridade da população residente, a renda familiar, a População Economicamente Ativa-PEA, moradora do espaço urbano em estudo e a quantidade de empregos no local; 4 . O levantamento completo dos equipamentos públicos existentes; 5. Levantamento de características ligadas ao meio ambiente, como percentual de moradias atendidas pela rede de saneamento básico, recolhimento e destino do lixo produzido no local, terrenos contaminados a remediar, fontes poluidoras, salubridade dos corpos de água do território.

$\mathrm{Na}$ falta de informações e dados, devem-se realizar pesquisas de campo que podem ser três: 1. Demográfica, complementando a do IBGE se necessário, por amostragem de 5\% da população, ou seja, uma a cada vinte residências são convidadas a responder o questionário. Um Plano de Bairro para o Município de São Paulo com planejamento para um determinado futuro deve fazer a projeção de crescimento populacional para um ano meta. Por exemplo, pode-se adotar o ano meta do Plano Integrado de Transporte Público Urbano-PITU 2025, de abrangência metropolitana; 2. Territorial, completando informações 
que não estão nas pesquisas oficias, como por exemplo, uso do solo lote a lote e, no caso do uso misto no lote, qual é o uso em cada andar da edificação;

3. Expectativas da população em relação ao seu bairro como participação efetiva - "o bairro que queremos," a partir de um questionário pré-definido pelo planejador.

\section{SISTEMAS DE TRANSPORTE PÚBLICO}

As informações sobre os sistemas rodoferroviários para transporte público a serem inseridas no sistema TRANUS são: tipo de transporte, considerando-se os diferentes modais - Metrô, trens metropolitanos, linhas de ônibus coletivos e até sistemas de vans, número de linhas, tipos de estações de embarque, terminais de ônibus, estações de transbordo, número de linhas de ônibus coletivos e seus itinerários, intervalos de tempo entre um carro e outro, capacidade de transporte dos veículos e, o mais importante, a localização territorial e a distância entre uma estação de embarque e outra.

Para o cálculo de capacidade de suporte, o transporte público deve ser dividido em dois tipos: o sistema

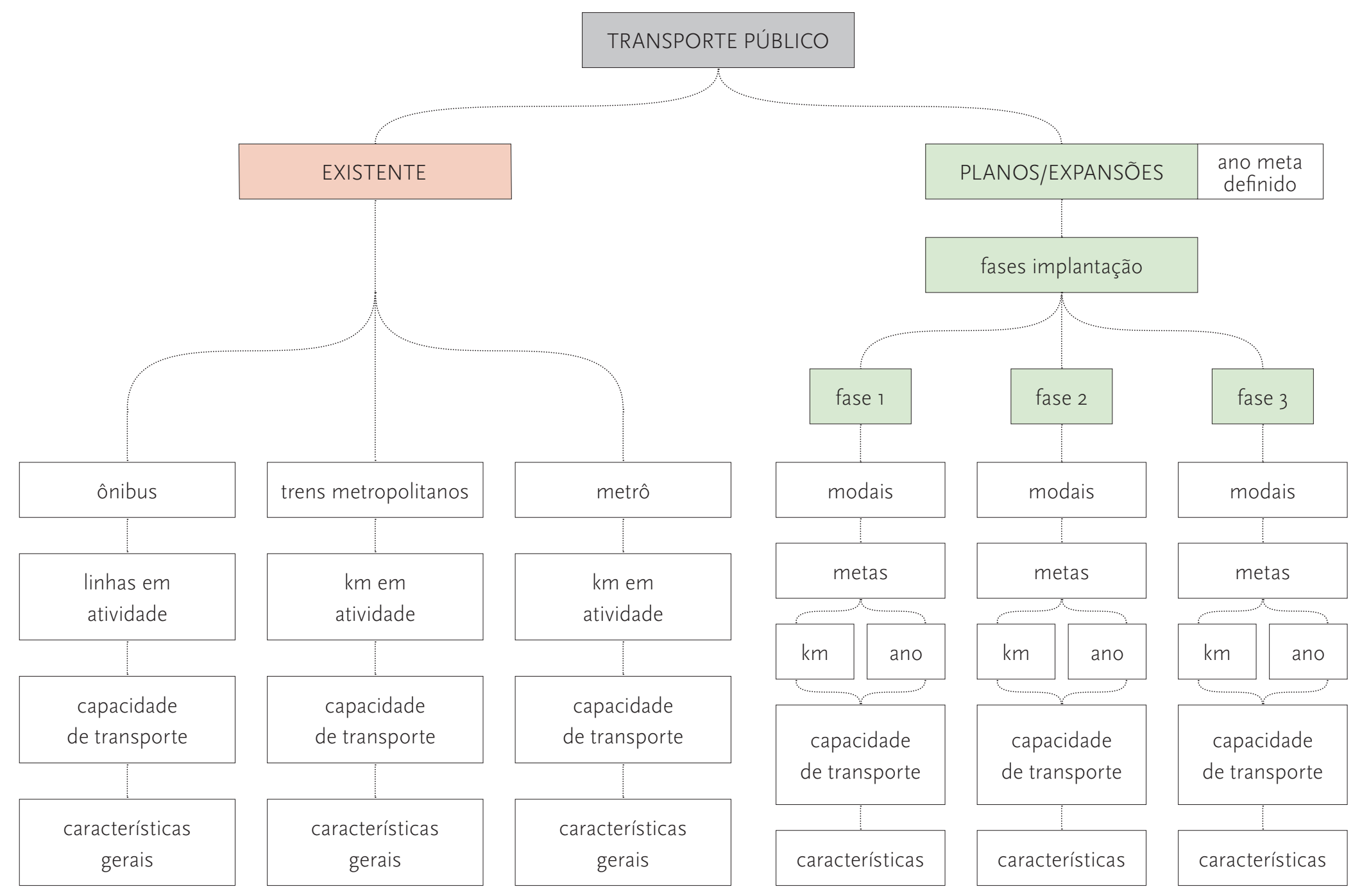

DiAGRAMA DE DADOS DO TRANSPORTE PÚBLICO A SEREM INSERIDOS EM MODELOS MATEMÁTICOS 
rodoferroviário existente e o sistema em fase de planejamento. Ambos devem ser considerados na entrada de dados no sistema TRANUS em função do Ano Meta definido para uma período de pelo menos vinte anos, como sugerido anteriormente. Ambas as capacidades de transporte serão consideradas, desde que a meta de implantação do sistema ou parte dele tenha prazo de implantação compatível com o Ano Meta em questão. Exemplo: Cidade Tiradentes contará com a chegada do sistema Expresso Tiradentes, monotrilho no sistema Veículo Leve sobre Trilhos-VLT, com previsão para entrega em 2014 e que já tem sua primeira etapa implantada há anos a partir do Centro de São Paulo na forma de via elevada exclusiva para ônibus, mudando sua tipologia a partir da Vila Prudente. O distrito de cidade Tiradentes conta também com linhas de ônibus e suas rotas poderão ser alteradas ou complementadas em razão dos resultados do TRANUS, no caso de um plano de bairro ser desenvolvido para esse distrito.

Transportes alternativos não devem substituir os transportes convencionais rodoferroviários, por serem uma escolha opcional tanto diária como esporádica. Devem sim ser consideradas as estruturas para estimular e propiciar que eles sejam uma alternativa. O diagrama ao lado representa um resumo orientativo do disposto acima.

\section{LEVANTAMENTOS TERRITORIAIS}

Para obter-se um perfil realista das condições territoriais para um bairro objeto de implantação de um Plano de Bairro é necessário:
- Quantificar a área total do bairro em quilômetros quadrados;

- Quantificar o número de lotes e a área de cada um;

- Quantificar a área construída total sobre cada lote;

Tem-se como resultado o Coeficiente de Aproveitamento praticado em cada lote, fator muito variável que ora fica aquém de 0,5 vez a área do terreno e ora várias vezes a área do terreno, ou seja, o fator pode ser quatro ou cinco vezes.

Em seguida deve-se:

- Localizar os terrenos urbanos vazios existentes;

- Verificar na LUOS, como está classificado o uso e potencial construtivo para cada terreno vazio;

As informações acima devem ser solicitadas à prefeitura do município, no caso de São Paulo, no Cadastro Imobiliário Municipal.

Outro levantamento importante para a definição de novas centralidades a criar ou observar vizinhanças a preservar é o das tipologias de tecido urbano, combinação entre uso do solo atual, tipologias do traçado viário e o gabarito das edificações o que leva a uma grande diversidade de tipologias em uma mesma área de estudo, além dos espaços disponíveis para atividades ao ar livre. São feitos os levantamentos de Uso e Ocupação do Solo por predominância (em mapas oficiais) ou lote a lote, em pesquisa de campo; levantamento de terrenos vazios ou glebas disponíveis para implantação de habitações para as populações de baixa e média renda que para essas áreas se pretende transferir. 


\section{LEVANTAMENTOS POPULACIONAIS}

Para conhecer-se e atender as necessidades básicas da população residente com a maior precisão possível são necessários os seguintes dados:

- População total do bairro e por faixa etária em relação aos equipamentos de educação, centros de convivência para idosos, atendimento pelo sistema de saúde, educação profissionalizante etc;

- População idosa, população infantil e juvenil etc.,

Um Plano de Bairro para o Município de São Paulo com planejamento para um determinado futuro deve fazer a projeção de crescimento populacional para um ano meta que deve ser definido de acordo com as outras diretrizes. Devem ser levantados dados específicos, como consumo de terreno por habitante e consumo de área construída por habitante, o que pode ser visto de forma detalhada no Quadro 6 (det.) Análise das características territoriais e populacionais (p.217) e no Quadro 7: Área de terreno, área construida e número de lotes por unidades territoriais (p.216)

\section{LEVANTAMENTOS SOCIOECONÔMICOS}

Para o levantamento socioeconômico, são necessárias projeções econométricas do crescimento econômico e análises demográficas, ambos no âmbito estadual, macrorregional, metropolitano e regional realizadas por demógrafos e economistas, o que deve ser um trabalho encomendado caso não haja uma publicação oficial desses dados. Desse levantamento surge o número de empregos para os dois cenários: tendencial e desejado. Devem ser definidas as atividades existentes locais e como estão distribuídas no espaço, em dois grupos: 1. atividades indutoras a partir da implantação de grandes polos de postos de trabalho, como centros de compras, universidades, áreas de ZEIS, que induzem a instalação de outros serviços e comércio em seu entorno e, 2. atividades induzidas, que são as que foram induzidas pelas indutoras. (moradias de aluguel para estudantes, lojas e pequenos serviços, oficinas mecânicas etc.)

Com os dados socioeconômicos, o sistema TRANUS distribui as futuras moradias no território disponível em função do sistema de transporte e os empregos que existem na região usando também, inicialmente como parâmetro e depois como meta, a distância da moradia até onde estão os empregos O modelo também simula a distribuição de serviço e comércio local.

\section{População eCONOMICAMENTE ATIVA E ESCOLARIDADE}

A escolaridade da população é um tema muito especifico que deve ser elaborado por profissionais especialistas da disciplina como dito acima. $O$ mes mo ocorre em relação à população economicamente ativa na metrópole paulistana, mas existem um parâmetro que atribui a taxa de 40\% da uma região ou área de estudo, inserida nesse tecido urbano metropolitano.

\section{EQUIPAMENTOS PÚBLICOS}

Elaborar levantamento completo em relação aos equipamentos públicos existentes para conhecimento da oferta de vagas, por exemplo, em escolas 
diferenciadas por tipo e faixa etária e por localização. Podem ser levantados a partir das Secretarias Municipais de cada especialidade, para:

\section{EDUCAÇÃO}

Segundo a Secretaria Municipal de Educação, existem instalações para os seguintes tipos de ensino para: Educação Infantil, Ensino Fundamental I e II, Ensino Médio, Educação de Jovens e Adultos; Educação Especial, CEUs, Bibliotecas Paradidáticas e Bibliotecas Pedagógicas. Em todas as áreas acima, deve-se levantar o número de vagas disponíveis ocupadas e ociosas. Siglas: Escola Municipal de Educação Infantil-EMEl; Centro Educacional Unificado/Escola Municipal de Ensino FundamentalCEU EMEF; Centro Educacional Unificado/Centro de Educação Infantil-CEU CEI; Escola Municipal de Ensino Fundamental-EMEF; Creche Particular Conveniada-CR P CONV; Centros de Educação Infantil Direta-CEI DIRETA; Movimento de Alfabetização-MOVA; Escola Técnica-E TECNICA.

\section{SAÚDE}

A Secretaria de Estado da Saúde de São Paulo conta com diferentes áreas técnicas conforme relacionadas abaixo, responsáveis por formular políticas públicas e apoiar tecnicamente os municípios. A elaboração de políticas públicas para a saúde deve estar atenta para a identificação de problemas prioritários para as populações em situação de vulnerabilidade individual, social, programática, física ou psicossocial, aos riscos sociais de doença e para as necessidades específicas de distintos grupos sociais.

As áreas de atuação do Sistema Público de Saúde na prevenção e tratamento na Saúde estão divididas em: Saúde bucal, Saúde da Mulher, Saúde da Pessoa Idosa, Saúde das Pessoas Privadas da Liberdade, Saúde da População Indígena, Saúde da População Negra, Saúde Mental, Saúde do Homem, Saúde da Criança, Saúde da Pessoa com Deficiência, Saúde do Trabalhador, Saúde dos Usuários de Álcool e Drogas e Saúde do Adolescente. Dentro das áreas acima listadas existem as especialidades e as variações nas instalações de cada centro específico, cujas normas devem ser consideradas na fase de projeto urbano, em função das dimensões mínimas das edificações onde esses serviços serão prestados. Siglas: Assistência Médica Ambulatorial-AMA; Centro de Atenção PsicossocialCAPS; Centro de Especialização Odontológica-CEO; Núcleo Integrado de Reabilitação-NIR; Centro de Testagem e Aconselhamento-CTA.

\section{ESPORTE E LAZER}

Segundo a Secretaria Municipal de Esporte, Lazer e Recreação, existem os seguintes tipos de equipamentos: Os Clubes Esportivos Municipais que são estruturas públicas que oferecem diversas atividades para a saúde, bem-estar, lazer e recreação da todas as regiões de São Paulo, com campos de futebol, ginásios esportivos, quadras poliesportivas abertas, piscinas de vários tamanhos, quadras de tênis, basquete e até canchas de bocha. Existem também os Clubes Escola.

\section{Cultura}

Segundo a Secretaria Municipal Educação, existem instalações públicas para: Bibliotecas Públicas, Bibliotecas Temáticas, Bibliotecas dos CEUs, Ônibus-biblioteca, Museus, Teatros, Pavilhões para exposições e Centros Culturais. 


\section{OUTROS EQUIPAMENTOS INSTITUCIONAIS}

Distritos Policiais, Batalhões de Bombeiros,

Mercados Municipais etc.

\section{USO E OCUPAÇÃO DO SOLO}

Áreas construídas e áreas disponíveis - a fonte disponível para obterem-se esses dados é o Cadastro Imobiliário Municipal, que apresenta as áreas totais, áreas construídas e terrenos vazios por lote de cada distrito de São Paulo. (cf. Quadro 7 (p.216))

\section{DIRETRIZES GERAIS BÁSICAS PARA PLANOS URBANOS}

Como mencionado anteriormente, diretrizes urbanas são políticas públicas que definem intervenções urbanas de qualquer tipo e prioridade. As diretrizes urbanas para planos urbanísticos de qualquer tipo Requalificação, reestruturação, expansões urbanas devem ser agrupadas por tema e, dentro destes, por prioridade.

Diretrizes para Planejamento Urbano podem ocorrer desde a esfera federal até a escala local. O Governo Federal, por exemplo, aprovou o Estatuto da Cidade em 2001, Lei Federal derivada da Constituição Brasileira de 1988 e que afetou de forma positiva os municípios brasileiros com mais de vinte mil habitantes, levando-os a preparar Planos Diretores Municipais. Na esfera do Estadual podemos citar um exemplo já apresentado no Capítulo IV, como o Hidroanel de âmbito metropolitano. Na esfera municipal, pode-se citar as Operações Urbanas Consorciadas, as Áreas de Intervenção Urbana, Lei de Uso e Ocupação do Solo etc.

\section{DIRETRIZES GERAIS}

As diretrizes de um plano em escala municipal ou local, por exemplo, podem surgir de políticas públicas para:

- Reversão da desvalorização imobiliária e recuperação da função social das propriedades urbanas;

- Implantação de usos diversificados, como o cultural, educacional, saúde, segurança pública, hoteleiro e o habitacional, este com prioridade para a Habitação de Interesse Social - HIS e Habitação para o Mercado Popular;

- Estimular o uso habitacional, atividades culturais e de lazer e a diversidade social incentivando a diversidade de usos;

- Garantir os usos adequados de espaços públicos e privados a todos os habitantes, inclusive aos portadores de qualquer tipo de necessidade especial;

- Resgatar o espaço público para a apropriação coletiva;

- Recuperar áreas degradadas, em especial aquelas ocupadas por habitações precárias;

- Intervir em áreas desocupadas ou ocupadas por usos inadequados;

- Melhorar a gestão e o ordenamento dos espaços públicos nas principais ruas comerciais através de programas específicos para isso;

- Garantir uma mobilidade urbana eficiente; 
- Estimular o desenvolvimento econômico local, através da permanência de atividades de médio e pequeno porte, geradoras de empregos que utilizem insumos produzidos na região;

- Transformação do perfil econômico e social, por meio de ações de fomento da pluralidade econômica, da inclusão social, da segurança urbana e da cultura;

- Reconhecer, na logística das atividades, a existência de grupos organizados marginalizados, tais como ambulantes ou catadores de lixo e criar programas para sua reinserção na sociedade e na vida profissional;

- Criação de conjunto de parâmetros para fiscalização e controle de imóveis com usos conflitantes, garantindo o direito de todos a um ambiente urbano com qualidade;

- Garantir a despoluição ambiental e a descontaminação de solos;

- Criação e aplicação de conjunto de normas e ações de forma a implantar áreas verdes ou espaços abertos para lazer e contemplação;

- Garantir a proteção aos mananciais, florestas e matas.

\section{DIRETRIZES DE USO E OCUPAÇÃO DO SOLO}

As diretrizes de Uso e Ocupação do Solo são contempladas dentro da LUOS, de acordo com os espaços intraurbanos de uma cidade ou região e determinam o uso, a verticalização e o potencial construtivo de cada lote urbano. As questões em relação aos efeitos da definição de Coeficientes de Aproveitamento como direito adquirido do lote e de seu proprietário já foram discutidas ao longo desta tese. Abaixo, seguem os usos do solo geralmente encontrados nas LUOS:

\section{RESIDENCIAL}

- Predominantemente residencial;

- Estritamente residencial;

- Zonas Especiais de Interesse Social-ZEIS.

\section{Comercio e serviços}

- Serviços e comércio de âmbito Local;

- Serviços e comércio diversificados;

- Serviços e comércio diversificados sofisticados;

- Serviços e comércio especializados.

\section{INSTITUCIONAL}

- Educação pública;

- Saúde pública;

- Cultura;

- Esporte em instalações públicas;

- Lazer em áreas públicas como praças e parques;

- Segurança pública.

\section{INFRAESTRUTURA URBANA}

- Transporte público multimodal;

- Sistema rodoviário hierárquico;

- Vias e equipamentos públicos para apoio ao transporte alternativo como ciclovias; 
- Modernizar e tornar mais eficiente o sistema de iluminação pública.

\section{DIRETRIZES AMBIENTAIS}

- Recuperação da mata nativa original e a recuperação de áreas degradadas, com a reprodução e reposição das espécies originais;

- Criação de áreas verdes consistentes e equipadas para uso público controlado;

- Recuperação de áreas contaminadas, conhecidas internacionalmente como Brownfields através da descontaminação dos solos, subsolos e lençóis freáticos principalmente os localizados em áreas de atividade industrial desativada que deixaram para trás solos contaminados, por meio do tratamento de resíduos sólidos recicláveis, promover a recuperação dessas áreas contaminadas e estipular compensações ambientais, através de instrumentos legais existentes ou criados para esse fim;

- Permitir a ocupação de áreas contaminadas somente após a sua recuperação ou remediação;

- Elaborar um plano de drenagem de águas pluviais incluindo a criação de cisternas para captação de águas pluviais para reuso e minimização do risco de enchentes;

- Aumento significativo de áreas permeáveis através da não ocupação de áreas ociosas nos lotes industriais a requalificar e em outros pontos da área, eliminando os riscos ambientais; (inundações, deslizamentos, desabamentos e outros)
- Buscar novas soluções para bacias de contenção, evitando-se a impermeabilização total;

- Criar áreas verdes e aumentar a arborização com o objetivo de obter queda na temperatura de superfície da região e aumento da área de sombreamento;

- Aplicar instrumento de faixa non edificandi nas margens dos corpos d’água e fiscalizar de forma eficiente seu cumprimento, não permitindo a ocupação dessas faixas sob nenhuma circunstância.

\section{PARÂMETROS MAIS FREQUENTES}

Os parâmetros mais frequentes para inserir no sistema de modelagem matemática são Densidade de Uso do Solo gerador a partir de uso Residencial-R e atraidor a partir de Não Residencial-NR, das viagens compatíveis com a capacidade do sistema de transporte previsto medidos, em metros quadrados de uso residencial $\mathrm{R}$ e metros quadrados de uso não residencial NR por distrito ou bacia de tráfego. A densidade de pessoas é correlacionada com o padrão de renda, usualmente em quatro faixas, alta, média, baixa e muito baixa no que se refere ao consumo de área residencial para terrenos e a moradia. Consequentemente, teremos os CAs associados. No que se refere ao uso NR, teremos também metros quadrados de terreno e de edificação. Os usos do solo são distinguidos entre os que são estruturadores do espaço urbano, denominados usos indutores, e os usos induzidos pelos indutores. Desse modo, a própria estruturação urbana é reproduzida pela modelagem, como já se disse. E, concomitantemente, o sistema de circulação previsto ou planejado é definido enquanto capacidade de suporte. Parâmetros 
de congestionamentos são obtidos através da modelagem por região ampla, por distrito e até por via. Esse parâmetro de congestionamento é definido pela proporção de veículos pela capacidade V/C, no caso do viário. No caso do transporte coletivo, de passageiros por metros quadrados no interior dos veículos.

Assim, esses parâmetros, se traduzidos em normas legais, conferem ao planejamento qualidade ambiental, visando um espaço publico de vias e praças controlado enquanto proporção adequada de veículos, de um lado, e de pedestres e ciclistas, de outro, como estudaram, por exemplo, Gehl e Appleyard, que convida a um usufruto do espaço produtivo culturalmente, de convívio prazeroso, de protesto.

Esses parâmetros devem ser então absorvidos pelo Plano Diretor em seu plano de uso do solo, que é a lei de zoneamento, inclusive com a utilização dos instrumentos extra fiscais como o solo criado e o IPTU progressivo no tempo atuante sobre imóvel subutilizado. E com o Plano de Transporte, agora chamado de Mobilidade Urbana. Esse controle do volume e qualidade de tráfego no sistema principal de circulação para que se obtenham vias tranquilas em bairros de moradia, deve ser acrescido de um controle adicional propiciado pelas Unidades Ambientais de Moradia-UAMs. Estas, além de impedir um tráfego de veículos em volume que degrade as vias locais, também garantem a adequada localização dos equipamentos sociais a serem acessados por pessoas fragilizadas por idade (crianças e idosos) ou por saúde, que devem se situar em meio a "ilha de tranquilidade" das UAMs.

Uma tese secundaria é que essas mesmas técnicas de planejamento asseguram a imprescindível concretude dos Planos Diretores. Muitos Planos Diretores, por não serem concretos, isto é, permanecerem no nível das diretrizes gerais, na verdade não são Planos Diretores. Constituem as políticas orientadoras do planejamento, como, aliás, exige a Constituição Federal. Assim as técnicas que se propõe nesta tese para dar concretude aos planos são muito importantes para elucidarem essas confusões conceituais que ainda persistem em planos diretores, inclusive no chamado Plano Diretor Estratégico do Município de São Paulo.

\section{CENTRALIDADES: CONCEITO}

Voltando aos conceitos que devem ser do conhecimento dos planejadores e urbanistas para o desenvolvimento dos planos de bairro: O que são centralidades? Quais são os tipos de centralidades? Como são formadas as centralidades e o que as compõem?

Centralidades são vias estruturais ou coletoras que congregam uma série de estabelecimentos de serviços e comércio diversificados ao longo delas. São dois tipos de centralidades: as lineares, as vias estruturais e coletoras mencionadas, e as polares, que agrupam um número variável de estabelecimentos em torno de estações de embarques rodoferroviários.

\section{CIDADE TIRADENTES: HISTÓRIA, CARACTERÍSTICAS TERRITORIAIS, POPULACIONAIS E SOCIOECONÔMICAS}

Ao analisar o recorte territorial oficial divulgado para a OUC-RV), chegou-se à conclusão de que o distrito de Cidade Tiradentes é o melhor exemplo para ilustrar nossa metodologia para desenvolvimento 
de conjunto de diretrizes a partir de um cálculo de capacidade de suporte, pelos motivos expostos no Capítulo V.

Quais são as necessidades primordiais para a vida do cidadão comum, principalmente o de baixa renda e que vive em áreas extremas da metrópole, onde os serviços são rarefeitos e a moradia conseguida com muito sacrifício?

Para responder à questão acima sobre as recorrentes carências crônicas em todas as capitais e metrópoles brasileiras em maior ou menor grau, recorreu-se à teoria de Maslow, muito usada em estudos sobre motivação, mas que não estava relacionada a preocupações com eficiência e produtividade laboral, mas com estudos da personalidade e desenvolvimento humano. Maslow considera que o ser humano tem necessidade complexas e as hierarquiza dentro do comportamento humano dirigido primeiro à satisfação de necessidades fundamentais que são essenciais e se relacionam à fisiologia e à segurança do ser humano, como abrigo, comida e dinheiro. Em seguida vêm as necessidades mais complexas, superiores às básicas e para as quais o indivíduo só deslocará energia depois de satisfeitas as básicas. Seguindo a hierarquia de Maslow, em segundo lugar vêm as necessidades sociais, como filiação a grupos informais, de aceitação e de associação. As necessidades mais complexas são as sociais, autoestima e autorrealização, esta última a mais difícil de ser realizada. (Maslow, 1943 em MotTA E VASCONCELOS, 2006, p.65/66)

Para qualquer grupo social, a alimentação, seguida do trabalho e da educação infantil são necessidades básicas e de realização imediata. Para realizá-las, há a necessidade do trabalho, emprego muitas vezes em número insuficiente nas periferias de São Paulo, como visto no Capítulo V. Em relação às populações de menor renda, há grande ou total dependência da provisão do Estado em relação à moradia, educação e saúde, setores de qualidade variável no atendimento diretamente relacionados com localização, políticas e empenho da administração pública para implementar os planos que esta aprova em leis.

As demais necessidades, como lazer, esporte e cultura, são preenchidas pela programação de televisão e pelos campinhos de futebol de terra batida em meio aos conjuntos habitacionais, na maioria das vezes, improvisados pelos próprios moradores, com recursos próprios.

Para garantir a alimentação, o chefe familiar procura por trabalho onde este esteja, mesmo que tenha que sacrificar-se a viajar dezenas de quilômetros de seu local de moradia até o local de trabalho. O tempo de deslocamento, por tão longas distâncias, Ihe rouba o tempo que poderia ser produtivo ou de lazer, e essa é a realidade para a maioria da população economicamente ativa e moradora da Região Leste 2 Paulistana.

A Operação Urbana Consorciada Rio Verde-Jacu na Zona Leste 2, mencionada no Capítulo IV, prevê, segundo seu edital preliminar de licitação de projeto, incentivos para promover a criação de uma centralidade de usos diversificados ao longo do conjunto formado pelas Avenidas Jacu Pêssego e Nova Trabalhadores, recentemente implantado ao longo do Córrego Jacu. Essa nova via de uso rodoviário tem importância estrutural porque funcionará por alguns anos como a parte Leste do Rodoanel, ligando o $A B C$ a Guarulhos e ao Aeroporto Internacional de São Paulo, localizado em Cumbica, no Município 
de Guarulhos. Mesmo depois de inaugurado o Trecho Leste do Rodoanel, essa ligação entre os municípios que formam o ABCD e o Município de Guarulhos e seu Aeroporto Internacional permanecerá como um caminho alternativo de menor extensão, muito importante entre essas duas regiões da metrópole. Deverá, por isso, manter forte papel estruturante dos tecidos urbanos ao longo de seu traçado.

\section{BREVE HISTÓRIA DE CIDADE TIRADENTES}

O Distrito de Cidade Tiradentes abriga o maior complexo de conjuntos habitacionais da América Latina, com cerca de quarenta mil unidades, a maioria delas construídas na década de 1980 pela Companhia Metropolitana de Habitação de São Paulo$\mathrm{COHAB}$, Companhia de Desenvolvimento Habitacional e Urbano do Estado de São Paulo-CDHU e por grandes empreiteiras que, inclusive, aproveitaram o último financiamento importante do Banco Nacional da Habitação-BNH, antes de seu fechamento.

O bairro foi planejado como um grande conjunto periférico e monofuncional do tipo "bairro dormitório" para deslocamento de populações atingidas pelas obras públicas, assim como ocorreu com a Cidade de Deus, no Rio de Janeiro. No final da década de 1970, o poder público iniciou o processo de aquisição de uma gleba de terras situada na região, que era conhecida como Fazenda Santa Etelvina, então formada por eucaliptos e trechos da Mata Atlântica. Prédios residenciais começaram a ser construídos, modificando a paisagem e o local começou a ser habitado por enormes contingentes de famílias, que aguardavam na "fila" da casa própria de Companhias habitacionais. Além da vastidão de conjuntos habitacionais que compõem a chamada "Cidade Formal", existe também a "Cidade Informal," formada por favelas e pelos loteamentos habitacionais clandestinos e irregulares, instalados em áreas privadas.
A Cidade Tiradentes possui, portanto, uma 219.868 mil habitantes num único distrito. A alta concentração populacional, 16.309,67 habitantes por quilômetros quadrados, é acrescida de uma das maiores taxas de crescimento da cidade e de graves problemas sociais. Esta população contabiliza um total de 52.875 famílias residentes no território abrangido pela respectiva subprefeitura. Deste total, 8064 famílias encontram-se em situação de alta ou muito alta vulnerabilidade. (grifo nosso) ${ }^{126}$

As áreas ocupadas pela população da "Cidade Informal" são lacunas deixadas na construção dos prédios da COHAB; ocupações nas bordas dos conjuntos e também de expansão da mancha urbana.

A identidade dos moradores de Cidade Tiradentes está diretamente ligada ao processo de constituição do bairro, feita sem um planejamento pré-estabelecido, que levasse em conta as necessidades básicas da população.

Muitas pessoas vieram para a Cidade Tiradentes em busca da realização do sonho da casa própria, embora boa parte tenha se deslocado a contragosto, na ausência de outra opção de moradia. O fato de não terem encontrado no local uma infraestrutura adequada ás suas necessidades e da região oferecer escassas oportunidades de trabalho, fez com que passassem a ter Cidade Tiradentes, como bairro dormitório e de passagem e não de destino. ${ }^{127}$

\section{BREVE DIAGNÓSTICO SOBRE CIDADE TIRADENTES}

Localizado no extremo leste do município de são Paulo, o distrito de Cidade Tiradentes está dentro da Região leste 2 e possui grande área de proteção ambiental, ainda que em grande parte ocupada por aglomerações urbanas formadas por moradias precárias. Sua maior característica são os conjuntos
126. De acordo com a Fundação SEADE, que utiliza dados do IBCE, a Cidade Tiradentes em 2010 era de 211.309, a densidade demográfica era de $13.829,89$ habitantes por quilômetro quadrado e a área territorial de 15,12 quilômetros quadrados. (cf. Quadro 6 (det.) (p.217))

127. Subprefeitura de Cidade Tiradentes. Disponível em <http:// www.prefeitura.sp.gov.br/cidade/ secretarias/subprefeituras/ cidade_tiradentes/historico/index. php? $p=94>$. Acesso em 21 jun. 2013 


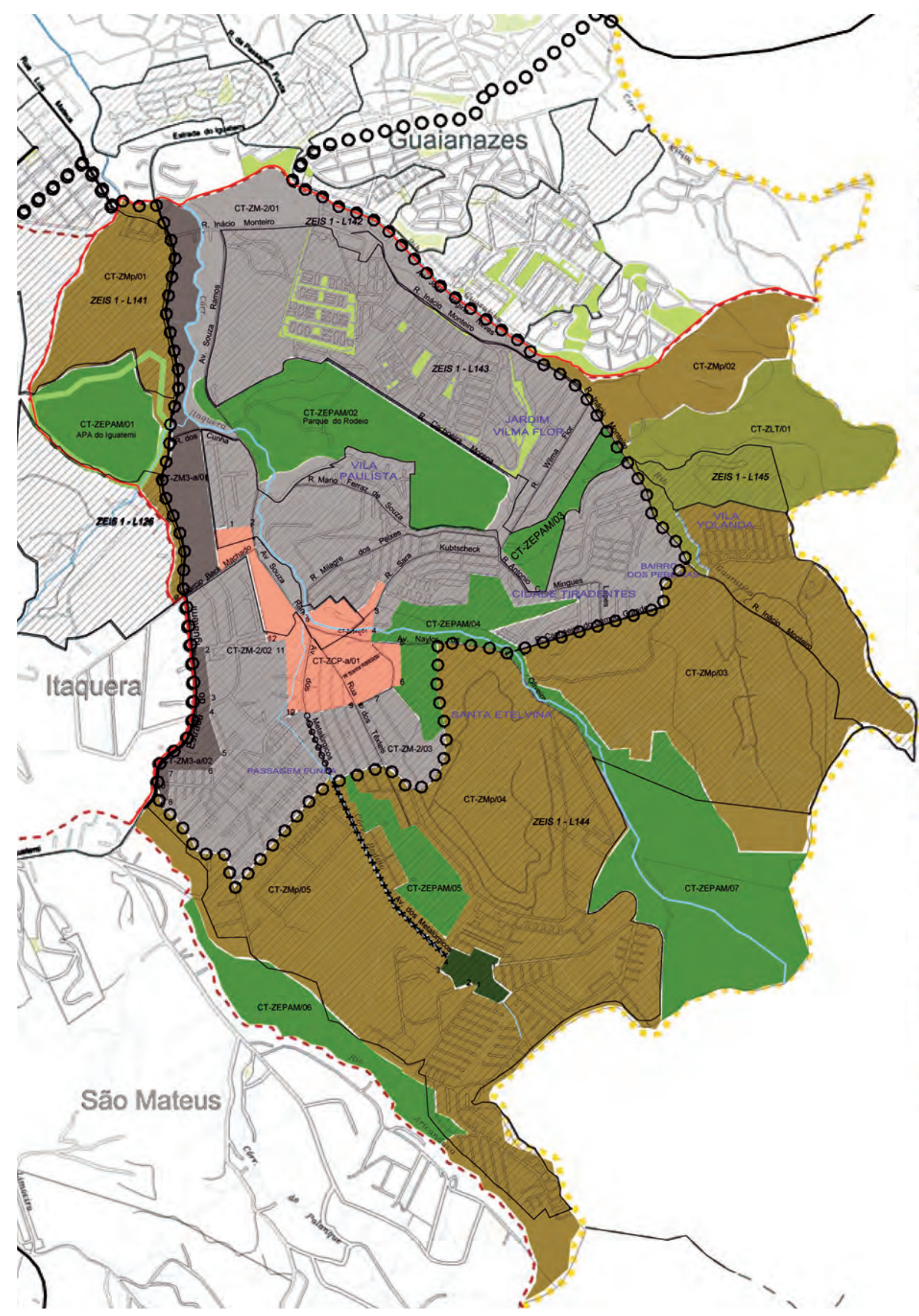

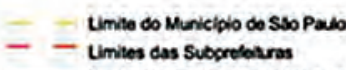

Limito des Municlios Vermes do Sso Paco

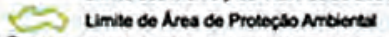

OOOO Uimito do Macrozena do Probecsio Artionta

$\longrightarrow$ Rodoand

- Sistoma Visto Eatrers

Finoria

- Mibrograss

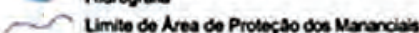

SSTEMM DE AREAS VERDES DO MUNICIPO

Parques o droes munidipals

vise Comeditio

tion Cuso Esportivo Socla

000 cunco do carmos

\section{zONUS ESPECWUS}

zEPAN Zona Espocial do Protecso Antionta

zapio Zona Espocial do Producto Noricola o de Extraplo Mren

zerec Zona Espocial co Proservacto Canard

zoe zona de caseoceso Especial

MUCROZONU DE PROTECAONMEENTN

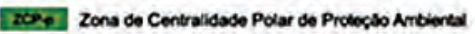

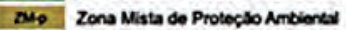

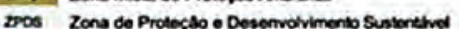

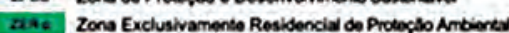

axi Zona de laver e Turamo

II. Zona Espocial do Presenrecsto

MUCROZONU DE ESTRUTURUGAOE QUNUACAGAO URBUWU

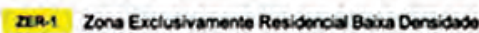

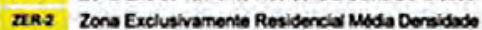

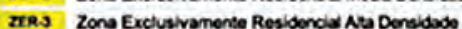

2B. Zona Procominantemente hostr

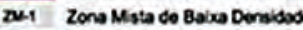

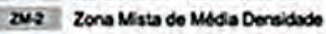

Desere Zona Mata do Na Densidacto -a

ais Z Zona Mista de Att Densiduche -b

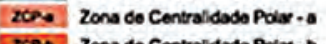

zoces zona de Centraldase Polex - 0

TRECHOS DE LOGRNDOUROS PÚBUCOS ENOUNDRUDOS EM ZONUS DE CENTRUUONDES UNENRES

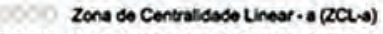

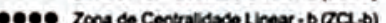

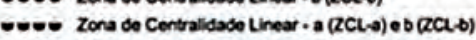

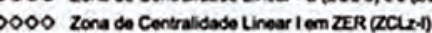

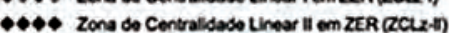

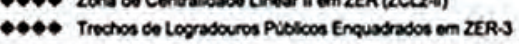

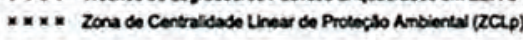

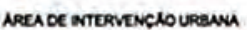

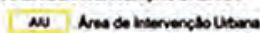

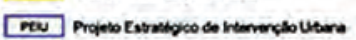

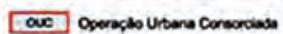

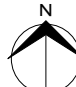

Mapa 47: Cidade TiRadentes-LUOS

PMSP/SEMPLA. PDR-Cidade Tiradentes, 2004 
habitacionais construídos ali a partir da década de 1970, conforme histórico colhido no site da Subprefeitura de Cidade Tiradentes que administra apenas esse distrito, uma rara exceção dentre as 31 subprefeituras.

Cidade Tiradentes tem imensas áreas de proteção ambiental ocupadas por aglomerações urbanas com construções precárias e com infraestrutura urbana deficiente, apesar de ter um grupo grande de equipamentos públicos para a saúde e educação, segundo uma breve avaliação preliminar.

Como informado pela Subprefeitura de Cidade Tiradentes, existem nesse distrito paulistano cerca de quarenta mil unidades habitacionais em edifícios multifamiliares com início de construção na década de 1980 pela COHAB e pela CDHU.

Como pode ser avaliado na leitura dos mapas, visitas ao local e outros dados, existe dentro de Cidade Tiradentes uma "cidade informal" formada por construções precárias em terrenos invadidos e loteamentos irregulares, em grande parte sobre áreas de proteção ambiental e onde provavelmente vivem mais trinta mil pessoas, aproximadamente, considerando-se uma média 4,5 pessoas por família nos conjuntos habitacionais.

O Mapa 47 apresenta a LUOS de Cidade Tiradentes, que tem uma subprefeitura própria, com grandes áreas delimitadas abaixo da linha limite entre área urbanizada e áreas de proteção ambiental, com áreas reservadas para Zonas Especiais de Interesse Social-ZEIS, Zonas Mistas de Proteção Ambiental e baixa densidade, onde o lote mínimo deve ter 250 metros quadrados e frente mínima de dez metros; o CA máximo é de 1 e a área permeável mínima é de
0,3. Mas, nessas condições de atendimento à LUOS, são poucos os exemplos que se podem encontrar porlá.

Isto mostra que um plano de bairro para Cidade Tiradentes deveria transferir essas famílias para outros edifícios residenciais novos em locais permitidos, de forma a dar condições para a recuperação do meio ambiente local. A área urbanizada de Cidade Tiradentes, com um contingente de mais de 220 mil moradores (Censo 2010) e um CA real de 0,54, poderia passar por um adensamento, mas há de se conferir junto a outras fontes que não somente o Cadastro Municipal qual é realmente a quantidade de metros quadrados construída no local.

Analisando-se o tecido urbano, (cf. Figura 9o: Cidade Tiradentes-Ortofoto (p.210)) é clara a visão que se tem das duas principais tipologias existentes: conjuntos habitacionais e vilas sobre loteamentos regulares ou não, mas sem condições mínimas de qualidade urbana, como também mostram as fotos a seguir. 


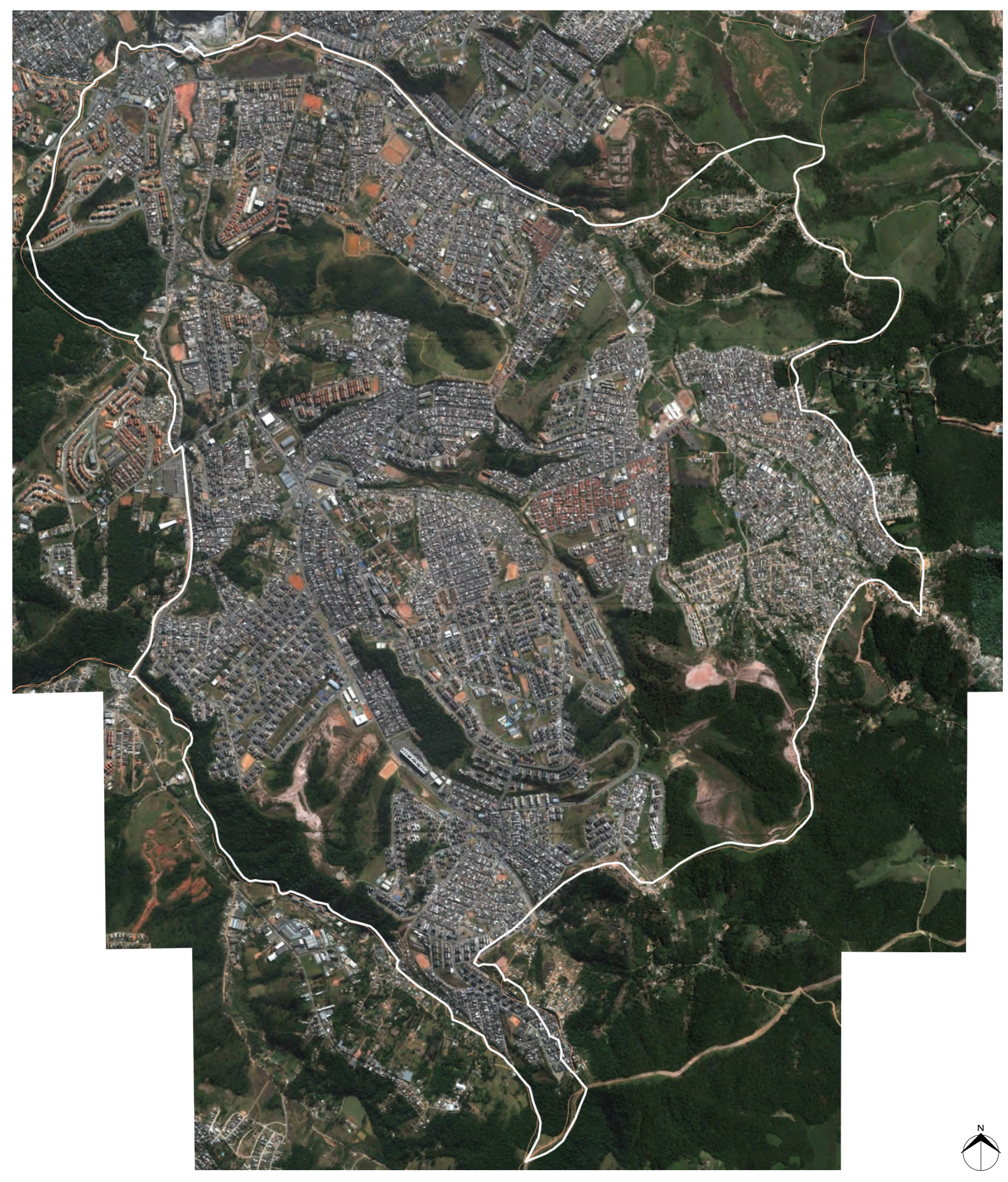

Figura 90: Cidade Tiradentes-Ortofoto Google Earth, 2013 

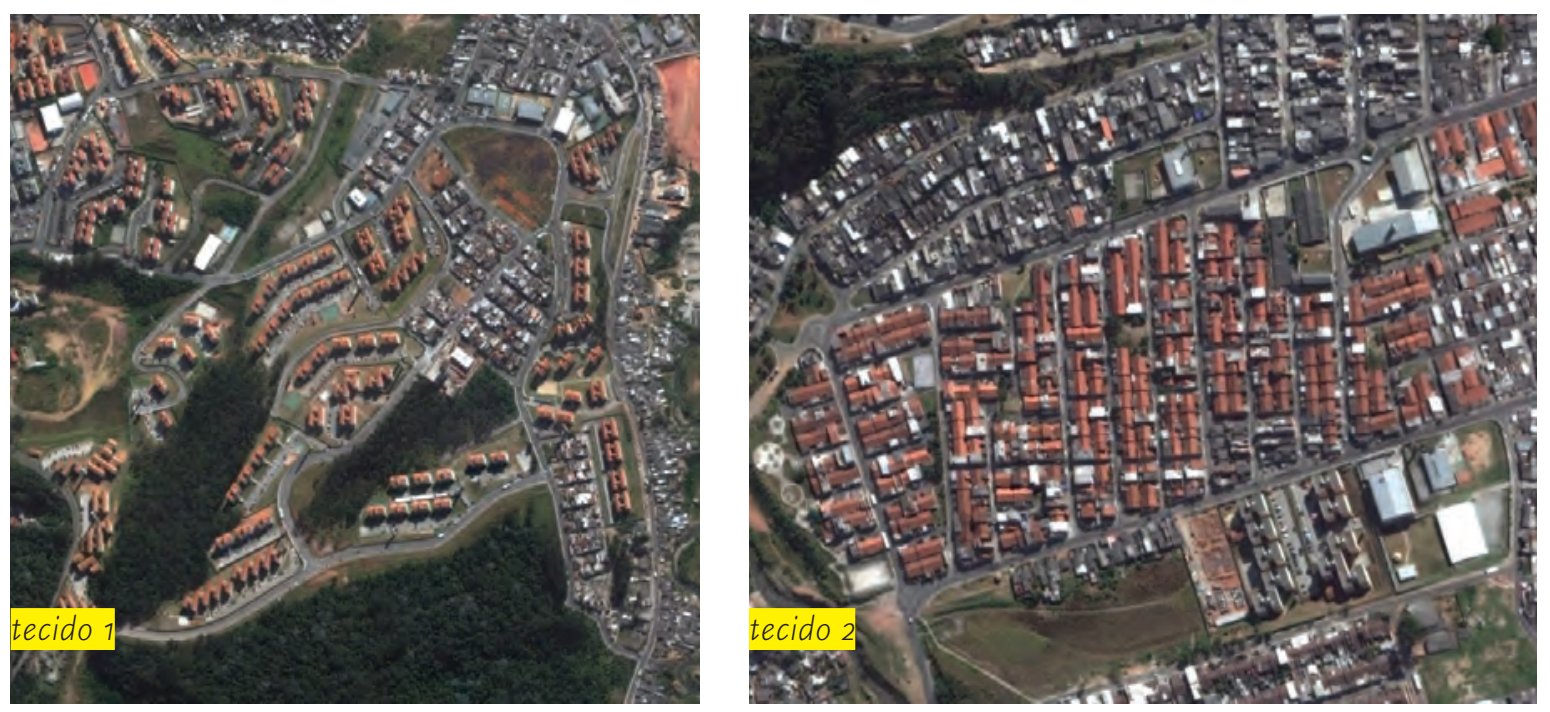

análise de tecido urbano

levantamento das tipologias

tecido 1

traçado viário orgânico

uso residencial

vertical

média densidade no lote produção estatal

tecido 2

traçado viário ortogonal

uso residencial

vertical

alta densidade no lote

produção estatal
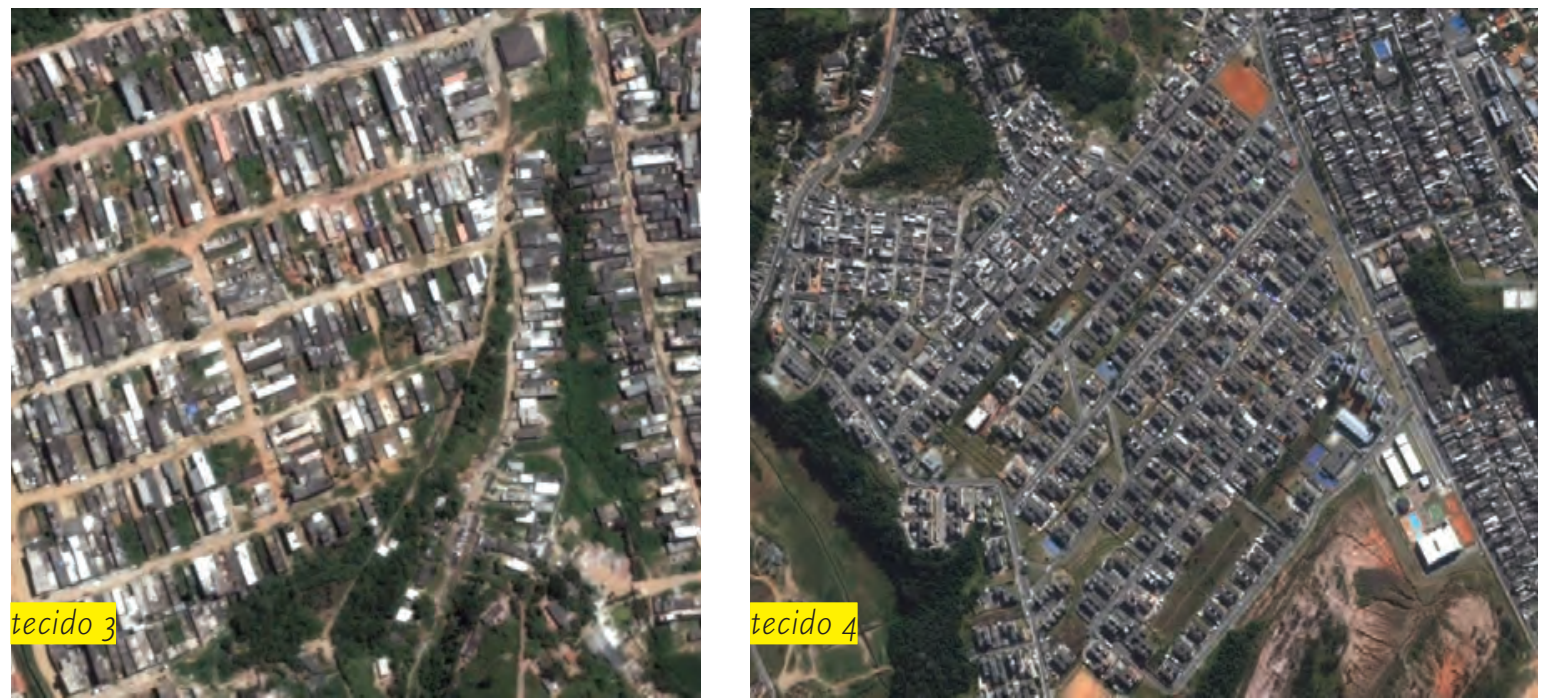

tecido 3

traçado viário irregular vias sem calçamento uso predominantemente residencial

autoconstruções precárias alta densidade no lote

gabarito baixo, 2 a 4 andares

tecido 4

traçado viário ortogonal

uso residencial

vertical

alta densidade no lote

produção estatal

tecido 5

traçado viário irregular uso predominantemente residencial

autoconstruções precárias alta densidade no lote

gabarito baixo, 2 a 4 andares
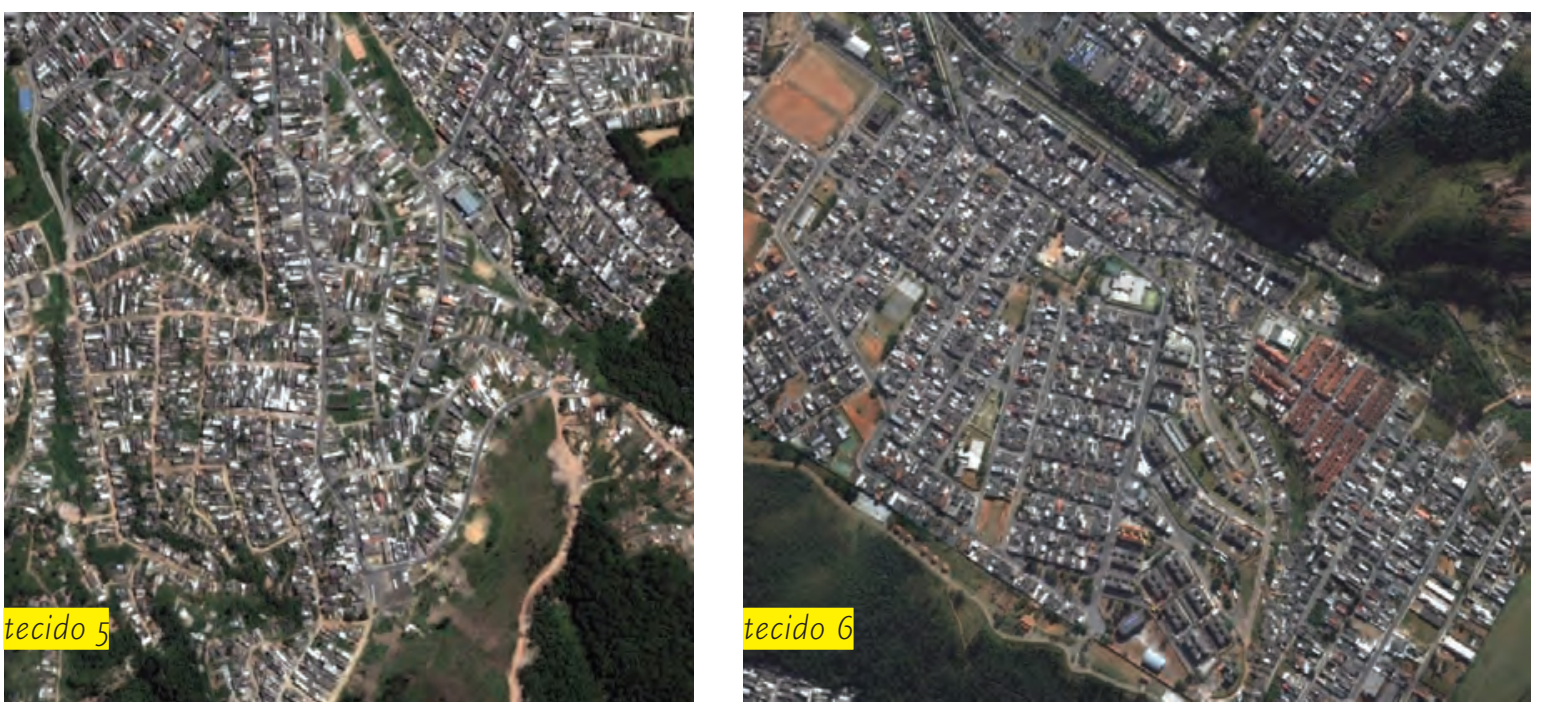

tecido 6

traçado viário irregular

uso residencial

autoconstruções precárias

alta densidade no lote

Figuras 91 a96: Cidade TiRadentes-Ortofotos Google Earth, 2013 


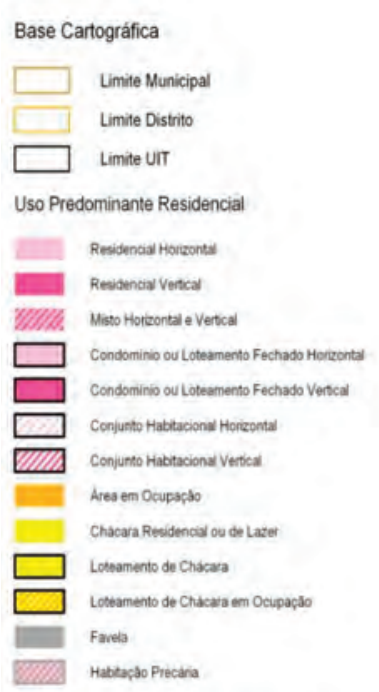

Uso Predominante Comercial / Servicos

comercibe servicos

Shosping Hipermercasto ou Alacadist:

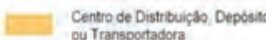

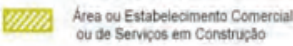

Uso Predominante Industrial

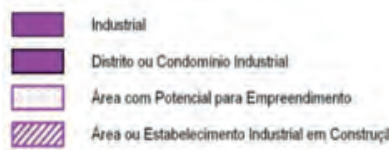

Uso Predominante Misto

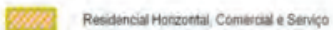

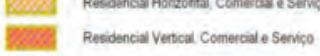

TIISA Ressonoal e inoustra

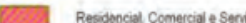

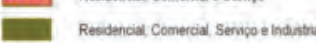

Equipamento de Infraestrutura

Tiltresturuara de Transpone

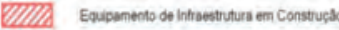

Equipamentos Sociais e de Servicos

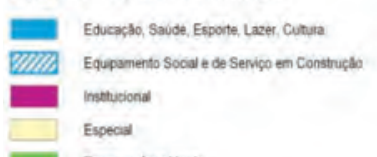

Praca ou dea Verto

Usos Năo Urbanos / Áreas Protegidas

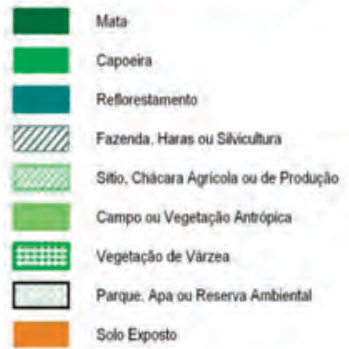

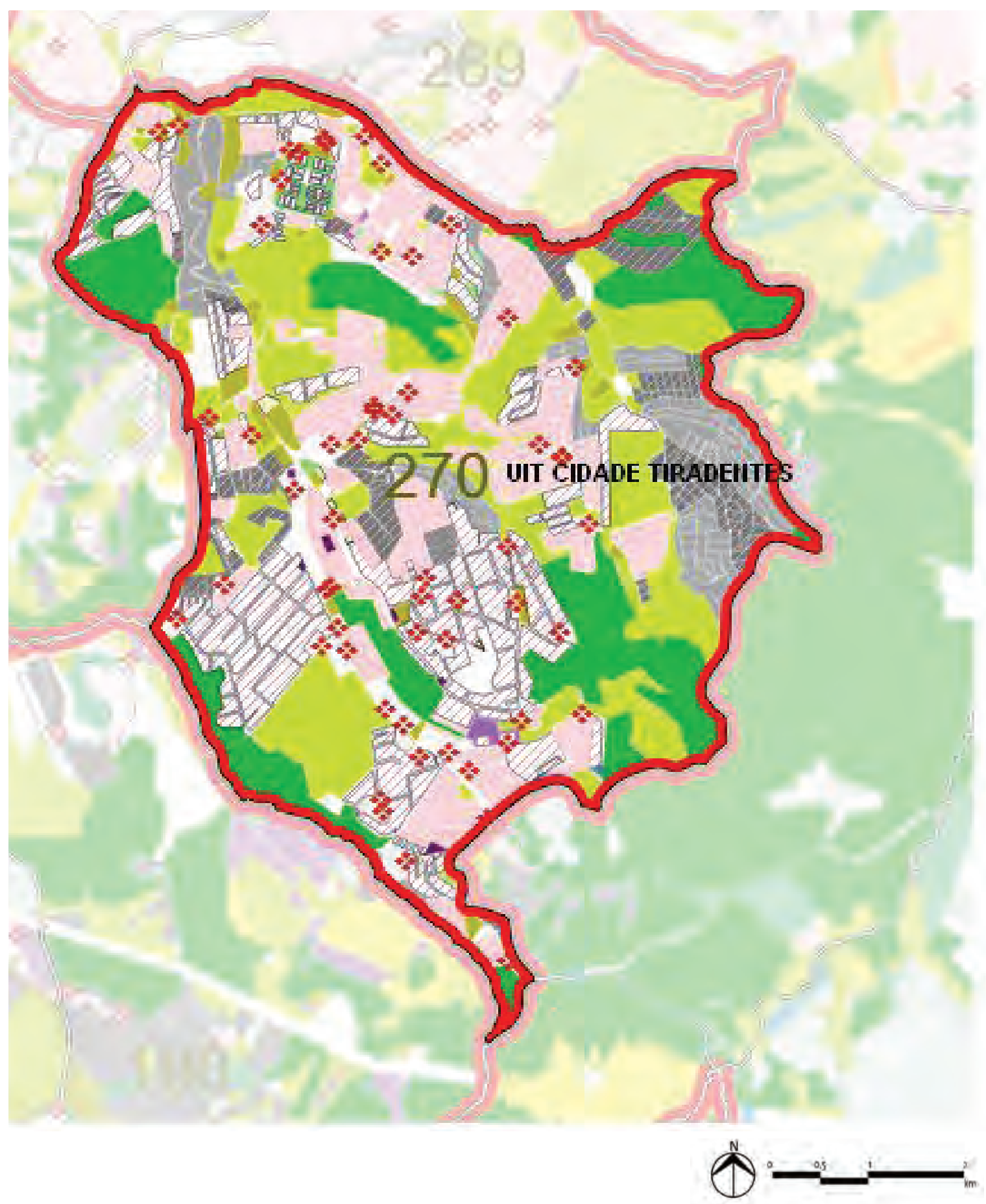

Mapa 48: Cidade Tiradentes-Uso e Ocupação do Solo Emplasa

EMPLASA, EMPLASAGEO, UITS 


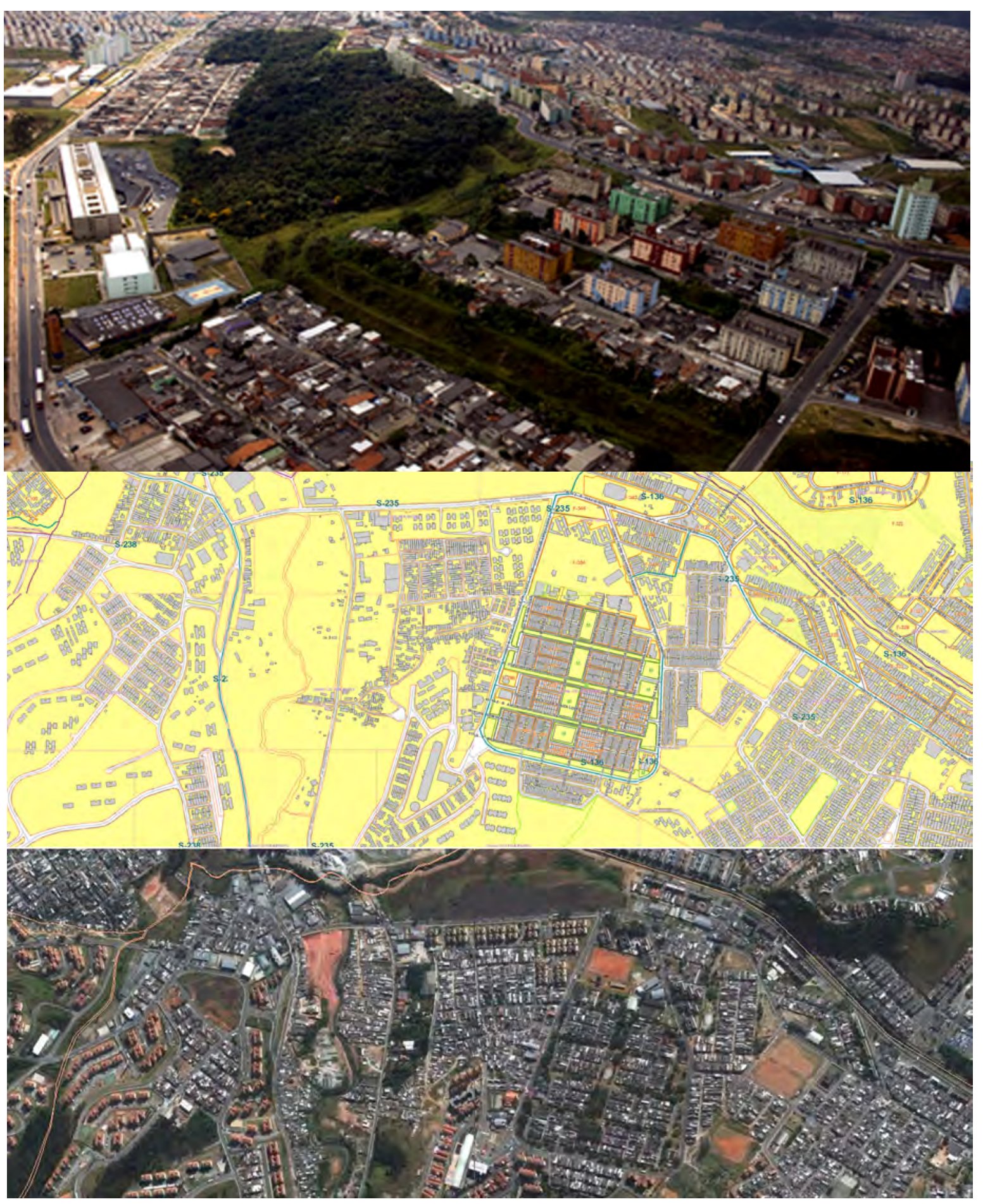

Figuras 97: Região Leste Paulistana-sobrevôo MEPR, 2013

FIGURAS 98 E 99: LEVANTAMENTO OFICIAL E ORTOFOTO REAL PMSP, Mapa Digital da Cidade/Google Earth certas ocupações não foram consideradas pela prefeitura 


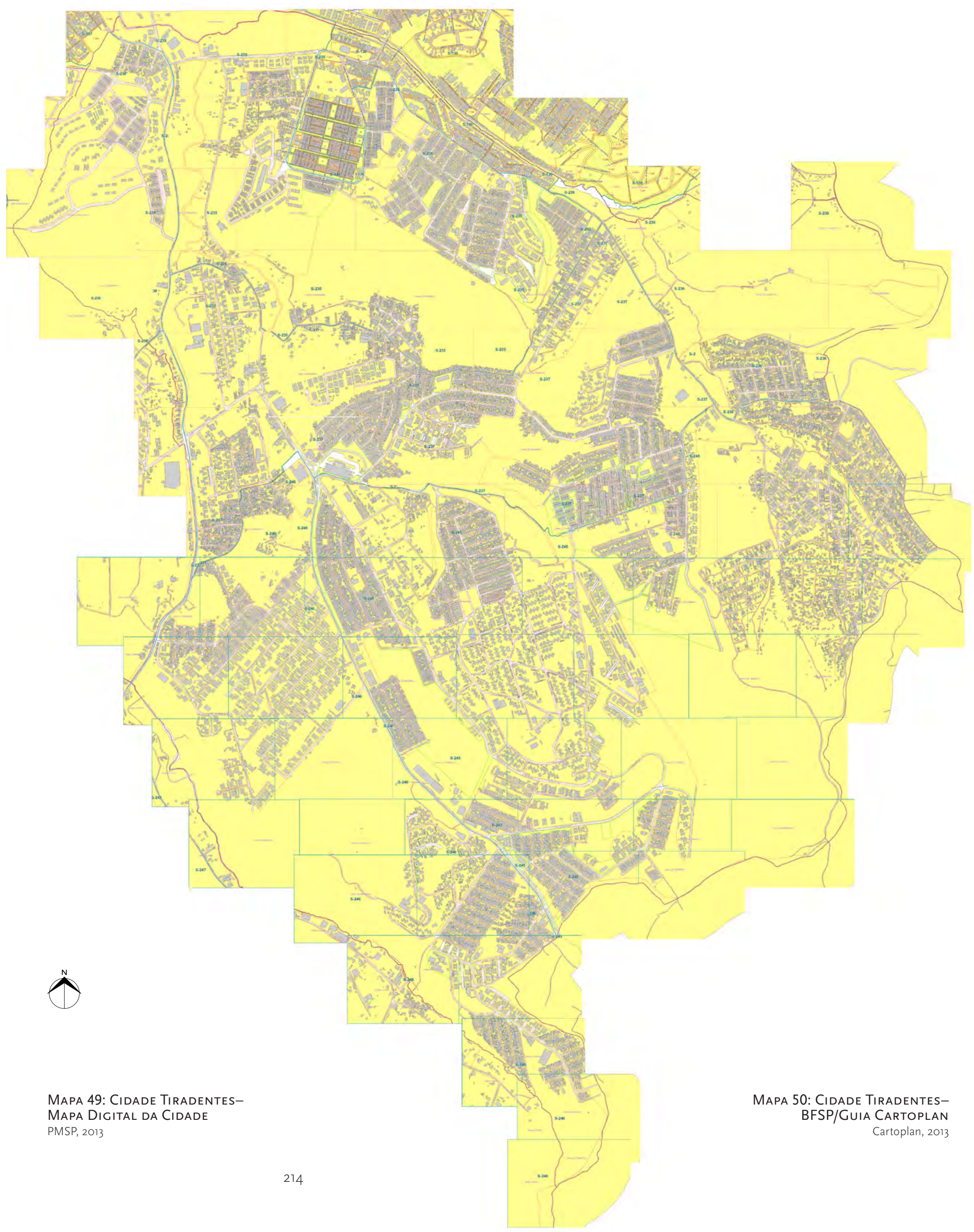




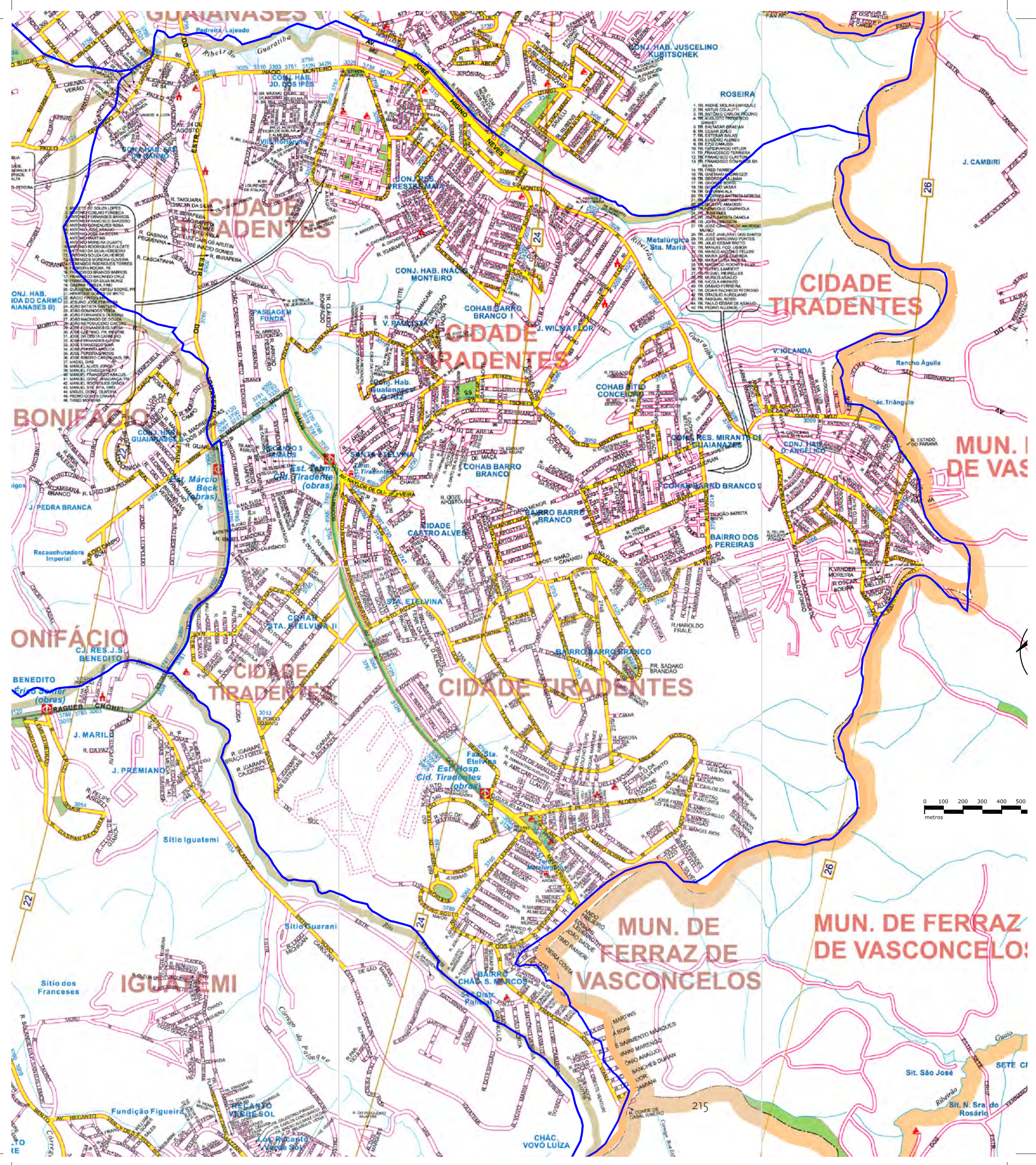


QUADRO 7

ÁREA DE TERRENO, ÁREA CONSTRUÍDA E NÚMERO DE LOTES POR UNIDADES TERRITORIAIS TPCL-Cadastro Imobiliário da PMSP 2010

Uso H A. Terreno A. Construída Nolotes $\quad$ No. Praticado

\begin{tabular}{|c|c|c|c|c|c|c|}
\hline & & & & & & \\
\hline São Paulo & 1 & 117.545 .037 & 51.914 .917 & 587.748 & Uso Residencial Horizontal Baixo Padrão & 0,4417 \\
\hline \multirow{4}{*}{$\begin{array}{l}\text { da } 14 \% \\
\text { da área de } \\
\text { São Paulo é } \\
\text { formada por } \\
\text { terrenos vazios }\end{array}$} & 2 & 112.604 .047 & 82.369 .139 & 548.042 & Uso Residencial Horizontal Médio Padrão & 0,7315 \\
\hline & 3 & 28.492 .838 & 17.919 .552 & 51.716 & Uso Residencial Horizontal Alto Padrão & 0,6289 \\
\hline & 4 & 16.934 .534 & 74.534 .869 & 757.294 & Uso Residencial Vertical Médio Padrão & 4,4014 \\
\hline & 5 & 9.274 .442 & 48.935 .229 & 218.225 & Uso Residencial Vertical Alto Padrão & 5,2764 \\
\hline \multirow[t]{12}{*}{0,14} & 6 & 81.231 .318 & 59.711 .427 & 222.528 & Uso Comércio e Serviço Horizontal & 0,7351 \\
\hline & 7 & 13.406 .049 & 40.241 .735 & 153.551 & Uso Comércio e Serviço Vertical & 3,0018 \\
\hline & 8 & 28.669 .837 & 18.784 .844 & 13.369 & Uso Industrial & 0,6552 \\
\hline & 9 & 12.560 .733 & 7.275 .557 & 7.616 & Uso Armazéns e Depósitos & 0,5792 \\
\hline & 10 & 26.654 .570 & 11.230 .799 & 29.404 & Uso Especial (Hotel, Hospital, Cartório, Etc.) & 0,4213 \\
\hline & 11 & 18.023 .992 & 9.329 .200 & 6.638 & Uso Escola & 0,5176 \\
\hline & 12 & $24 \cdot 434.300$ & 9.314 .638 & 9.791 & $\begin{array}{l}\text { Uso Coletivo (Cinema, Teatro, Clube, Templo, } \\
\text { Etc.) }\end{array}$ & 0,3812 \\
\hline & 13 & 84.534 .476 & O & 116.668 & Terrenos Vagos & 0,0000 \\
\hline & 14 & 8.194 .807 & 11.074 .357 & 167.380 & Uso Residencial Vertical Baixo Padrão & 1,3514 \\
\hline & 15 & 2.682 .187 & 1.191 .342 & 12.296 & Uso Garagens não-residenciais & 0,4442 \\
\hline & 99 & 7.173 .586 & 5.711 .559 & 19.760 & Outros usos (Uso e padrão não previsto) & 0,7962 \\
\hline & Total & 592.416 .753 & $449 \cdot 539.164$ & 2.922 .026 & & 0,7588 \\
\hline \multirow{2}{*}{$\begin{array}{l}\text { Cidade } \\
\text { Tiradentes }\end{array}$} & Uso H & A. Terreno & A. Construída & No Lotes & C.A. praticado & \\
\hline & 1 & 546.946 & 176.276 & 3.928 & Uso Residencial Horizontal Baixo Padrão & 0,3223 \\
\hline \multirow{4}{*}{$\begin{array}{l}24 \% \text { da área } \\
\text { de Cidade } \\
\text { Tiradentes é } \\
\text { formada por } \\
\text { terrenos vazios }\end{array}$} & 2 & 15.158 & $5 \cdot 975$ & 33 & Uso Residencial Horizontal Médio Padrão & 0,3942 \\
\hline & 3 & 283 & 410 & 1 & Uso Residencial Horizontal Alto Padrão & 1,4488 \\
\hline & 4 & $\mathrm{O}$ & $\mathrm{O}$ & $\mathrm{O}$ & Uso Residencial Vertical Médio Padrão & 0,0000 \\
\hline & 5 & $\mathrm{O}$ & $\mathrm{O}$ & $\mathrm{O}$ & Uso Residencial Vertical Alto Padrão & 0,0000 \\
\hline \multirow[t]{10}{*}{0,24} & 6 & 57.961 & 20.932 & 124 & Uso Comércio e Serviço Horizontal & 0,3611 \\
\hline & 9 & 1.130 & 800 & 1 & Uso Armazéns e Depósitos & 0,7080 \\
\hline & 10 & 8.709 & 3.859 & 5 & Uso Especial (Hotel, Hospital, Cartório, Etc.) & 0,4431 \\
\hline & 11 & 21.224 & 5.370 & 5 & Uso Escola & 0,2530 \\
\hline & 12 & 38.507 & 10.955 & 19 & $\begin{array}{l}\text { Uso Coletivo (Cinema, Teatro, Clube, Templo, } \\
\text { Etc.) }\end{array}$ & 0,2845 \\
\hline & 13 & 557.755 & $\mathrm{O}$ & 565 & Terrenos Vagos & 0,0000 \\
\hline & 14 & 1.038 .161 & 1.015 .474 & 20.381 & Uso Residencial Vertical Baixo Padrão & 0,9781 \\
\hline & 15 & O & $\mathrm{O}$ & $\mathrm{O}$ & Uso Garagens não-residenciais & 0,0000 \\
\hline & 99 & 4.487 & 3.226 & 6 & Outros usos (Uso e padrão não previsto) & 0,7190 \\
\hline & Total & 2.291 .061 & 1.243 .627 & 25.070 & & 0,5428 \\
\hline
\end{tabular}




\section{CARACTERÍSTICAS GERAIS DE CIDADE TIRADENTES}

\section{TERRITÓRIO E DEMOGRAFIA}

O quadro ao lado traz um detalhamento do consumo de território por uso residencial e não residencial no distrito de Cidade Tiradentes

\section{Sistema de transporte público em CidAde TIRADENTES}

O Expresso Tiradentes é Monotrilho do Metrô Linha Prata (pode-se chamar de VLT) no trecho entre Vila Prudente e São Mateus. (trechos 1 e 2 previstos para 2014) O trecho entre São Mateus a Cidade Tiradentes (trecho 3) tem previsão de conclusão para depois de 2014. (Metro)

\section{EQUIPAMENTOS URBANOS PÚBLICOS}

\section{EducaçÃo}

Cidade Tiradentes conta com um número de unidades de educação aparentemente completo, mas isso deve ser calculado em função da população em idade escolar por faixa etária. Unidades educacionais em Cidade Tiradentes:

Adoniran Barbosa, EMEl; Inácio Monteiro, CEU EMEl; Água Azul CEU EMEF; Irene Manke Marques Profa., CEU EMEl; Água Azul CEU CEl; José Augusto Cesar salgado Dr. EMEF; Amaral e Tolentino CR. P. CONV; José Roberto de Castro Ribeiro Prof., EMEI; Amor Perfeito C.E.I; CR. P. CONV; Klaus Reinach Eng., EMEl; Ana Rosaria, CR. P. CONV; Mãos Estendidas,CR. P. CONV; Ana Mirian ABC para Crescer Grande Vitória, CR. P. CONV; Margarida

QUADRO 6 (det.; cf. p.182)

ANÁLISE COMPARATIVA DAS CARACTERÍSTICAS TERRITORIAIS E POPULACIONAIS comparativo município de São Paulo e RLP SEADE/IBGE 2010/PMSP

\begin{tabular}{|c|c|c|}
\hline TIPO DE DADO INFORMADO & UNIDADE & $\begin{array}{c}\text { CIDADE } \\
\text { TIRADENTES }\end{array}$ \\
\hline \multirow{2}{*}{ População total } & habitantes & 211.501 \\
\hline & $\%$ & $1,88 \%$ \\
\hline \multirow{2}{*}{ Área territorial } & $\mathrm{km}^{2}$ & 15,0 \\
\hline & $\%$ & $0,99 \%$ \\
\hline \multirow{2}{*}{ Densidade habitacional } & habitantes $/ \mathrm{km}^{2}$ & 14.100 \\
\hline & $\%$ & $189,07 \%$ \\
\hline \multirow{2}{*}{ Nº de domicílos } & totais & 60.740 \\
\hline & $\%$ & $1,70 \%$ \\
\hline \multirow{4}{*}{$\mathrm{N}^{\circ}$ de lotes } & vagos & 3.962 \\
\hline & residenciais & 20.543 \\
\hline & não residenciais & 25.070 \\
\hline & totais & 49.575 \\
\hline \multirow{4}{*}{ Área de terrenos } & $\mathrm{m}^{2}$ vagos & 562.387 \\
\hline & $\mathrm{m}^{2}$ residenciais & 1.170 .919 \\
\hline & $\mathrm{m}^{2}$ não residenciais & 2.291 .061 \\
\hline & $\mathrm{m}^{2}$ totais & 4.024 .367 \\
\hline \multirow{3}{*}{ Área construída total } & $\mathrm{m}^{2}$ residenciais & 1.060 .966 \\
\hline & $\mathrm{m}^{2}$ não residenciais & 1.243 .627 \\
\hline & $\mathrm{m}^{2}$ totais & 2.304 .593 \\
\hline \multirow{3}{*}{ Área construída por lote } & $\mathrm{m}^{2}$ residenciais & 52 \\
\hline & $\mathrm{m}^{2}$ não residenciais & 50 \\
\hline & $\mathrm{m}^{2}$ totais & 51 \\
\hline \multirow{2}{*}{$\begin{array}{r}\text { Área construída por } \\
\text { domicílio }\end{array}$} & $\mathrm{m}^{2}$ residenciais & 17 \\
\hline & $\%$ & $35,91 \%$ \\
\hline \multirow{2}{*}{$\begin{array}{c}N^{\circ} \text { de pessoas } \\
\text { por domicílio }\end{array}$} & residenciais & 3,48 \\
\hline & $\%$ & $110,60 \%$ \\
\hline \multirow{2}{*}{$\begin{array}{r}N^{\circ} \text { domicílios } \\
\text { por lote }\end{array}$} & residenciais & 2,96 \\
\hline & $\%$ & $53,14 \%$ \\
\hline \multirow{3}{*}{$\begin{array}{l}\text { Coeficiente de } \\
\text { Aproveitamento }\end{array}$} & $\mathrm{m}^{2}$ residenciais & 0,906 \\
\hline & $\mathrm{m}^{2}$ não residenciais & 0,543 \\
\hline & totais $(*)$ & 0,666 \\
\hline
\end{tabular}


Maria Alves, EMEl; Astride Gondim de Souza, CR. P. CONV; Maria Augusta de Paula Profa., CEI DIRET; Aureliano Leite, EMEF; Marielcia Florêncio de Morais Profa., CEI DIRET; Barbara Heliodora, CEI DIRET; Marília de Dirceu, CEI DIRET; Cantinho Carinhoso, CR. P. CONV; Marli de Jesus Aparecida, CR. P. CONV; Carlota Pereira de Queiroz, EMEI; Mauricio Goulart, EMEF; Casinha da Vovó II, CR. O. CONV; Nossa Senhora do Divino Pranto, CEI INDIR; Casp Central de Assoc. e Soc. Pop Unid. II G, MOVA; Novo Amanhecer Anjo Gabriel II, CR. P. CONV; CASP central de Assoc. e Soc. Pop Unid. III, G MOVA; O Pequeno Mundo de Ellen - Unid. II, CR. P. CONV CASP; central de Assoc. e Soc. Pop Unid. VI G, MOVA; Olinda Menezes serra Vidal Profa. EMEF. Cidade Tiradentes, CEI DIRET; Oswaldo Aranha Bandeira de Mello, EMEFM; COHAB Santa Etelvina V, A CEI DIRET; Pássaro Azul, CEI INDIR; Dulce Salles Ferraz Profa. EMEl; Pássaro Azul VI, CR. P. CONV; Elisa Kauffmann Abramovich. EMEI, Pássaro Azul VII, CR. P. CONV; Elite CR. P. CONV; Querubins da Vitória, CR. P. CONV; Ernesto Cerreti, CR. P.C ONV; Renascer CR. P. CONV; Escola técnica de Saúde Publica Prof. Makiguti, E TECNICA

\section{SAÚdE}

Segundo lista divulgada pela Subprefeitura de Cidade Tiradentes, nesse distrito existem os seguintes equipamentos de saúde:

AMA Castro Alves, AMA Fazenda do Carmo, CAPS ADULTO - Cidade Tiradentes, Centro de atenção à saúde sexual e reprodutiva Maria Auxiliadora Lara B, CEO/ NIR Cidade Tiradentes, CTA DST/AIDS Cidade Tiradentes, HM Carmen Prudente Cidade Tiradentes, NIR/ CEO Cidade Tiradentes, UBS Barro Branco, UBS Carlos Gentile de Melo, UBS Castro
Alves, UBS Cidade Tiradentes I, UBS Dom Angélico, UBS Fazenda do Carmo, UBS Ferroviários, UBS Gráficos, UBS Inácio Monteiro, UBS Jardim Vitória, UBS Prefeito Prestes Maia, PA Glória Rodrigues dos Santos Bonfim, UBS Profeta Jeremias.

\section{Cultura}

Foram encontrados no site da Secretaria de Cultura da Prefeitura de São Paulo, os seguintes equipamentos culturais em Cidade Tiradentes e teatros em distritos próximos:

Centro de Formação Cultural de Cidade TiradentesCidade Tiradentes; Ponto de Leitura André VitalCidade Tiradentes; Ponto de Leitura Juscelino Kubitschek-Cidade Tiradentes; Ponto de Leitura Parque do Rodeio-Cidade Tiradentes; Teatro Zanoni Ferrite-Vila Formosa; Teatro Flávio ImpérioCangaíba. Região Leste.

\section{ESPORTE, LAZER E RECREAÇÃO}

Clube Escola Cidade Tiradentes:

Avenida dos Metalúrgicos, 2255-Tiradentes

Estrutura: Área: 16.398 m² $^{2}$

1 Ginásio esportivo

1 quadra Poliesportiva aberta

1 Quadra poliesportiva fechada

2 Salas de Ginástica. Modalidades: Karatê, Judô, Ginástica Geral, Futsal, Tai Chi Chuan, Capoeira, Step, Jump, Educação Física Infantil.

\section{Meio ambiente}

A subprefeitura de Cidade Tiradentes informa que há sete áreas de risco em Cidade Tiradentes. Existe um Ecoponto em Cidade Tiradentes chamado Nascer do Sol. 
PeRfIL SOCIOECONÔMICO

\section{EMPREGABILIDADE}

Como mencionado, a População Economicamente

Ativa de uma localidade é de 40\% aproximadamente da população total de um distrito ou bairro. Como em Cidade Tiradentes a população é de 211 mil pessoas aproximadamente, o número de postos de trabalho oferecidos localmente deveria ser de 85 mil, mas na realidade, o número de empregos nesse distrito é de apenas 27 mil postos de trabalho, o que atende menos de $13 \%$ da PEA. Apenas 13\% da população local podem trabalhar nas proximidades de sua moradia. Há necessidade de geração de pelo menos 58 mil postos de trabalho a mais e se possível em certa medida, de acordo com o perfil de sua população residente.

Segundo o Projeto UITs da EMPLASAGEO, as Tipologias de Ocupação do Solo em Cidade Tiradentes são de lotes urbanizados e conjuntos habitacionais para população de rendas média e baixa. Os usos predominantes por quadra são: Residencial, Comercial, Serviços, Industrial, Misto e Rural.
QUADRO 8

Distrito Cidade Tiradentes-População por faiXa etária Fundação Seade/IBGE 2012

\begin{tabular}{|c|c|c|c|c|}
\hline \multirow[t]{2}{*}{$\begin{array}{l}\text { VARIÁVEL } \\
\text { IDADE }\end{array}$} & \multicolumn{3}{|c|}{$\begin{array}{l}\text { POPULAÇÃO EM NÚMERO DE } \\
\text { HABITANTES }\end{array}$} & \multirow[t]{2}{*}{ \% тOtAL } \\
\hline & FEMININA & MASCULINA & TOTAL & \\
\hline oa 4 & 8.565 & 8.505 & 17.070 & $8,08 \%$ \\
\hline 5 a 9 & 9.570 & 9.965 & 19.535 & $9,24 \%$ \\
\hline 10 a 14 & 10.975 & 11.013 & 21.988 & $10,41 \%$ \\
\hline 15 a 19 & 10.088 & 9.704 & 19.792 & $9,37 \%$ \\
\hline 20 a 24 & 10.063 & 9.677 & 19.740 & $9,34 \%$ \\
\hline 25 a 29 & 10.525 & 9.801 & 20.326 & $9,62 \%$ \\
\hline 30 a 34 & 9.872 & 8.687 & 18.559 & $8,78 \%$ \\
\hline 35 a 39 & 8.475 & 7.646 & 16.121 & $7,63 \%$ \\
\hline 40 a 44 & 7.410 & 6.593 & 14.003 & $6,63 \%$ \\
\hline 45 a 49 & 6.854 & 5.437 & 12.291 & $5,82 \%$ \\
\hline 50 a 54 & 6.089 & 4.746 & 10.835 & $5,13 \%$ \\
\hline 55 a 59 & 4.819 & 3.633 & 8.452 & $4,00 \%$ \\
\hline 60 a 64 & 3.173 & 2.244 & 5.417 & $2,56 \%$ \\
\hline 65 a 69 & 1.923 & 1.318 & 3.241 & $1,53 \%$ \\
\hline 70 a 74 & 1.153 & 769 & 1.922 & 0,91\% \\
\hline 75 e mais & 1.421 & 596 & 2.017 & $0,95 \%$ \\
\hline $\begin{array}{r}\text { população total } \\
\text { do distrito }\end{array}$ & 110.975 & 100.334 & 211.309 & $100 \%$ \\
\hline \multicolumn{4}{|c|}{ população com menos de 15 anos (em \%) } & $27,73 \%$ \\
\hline \multicolumn{4}{|c|}{ população com 60 anos e mais (em \%) } & $5,96 \%$ \\
\hline \multicolumn{4}{|c|}{ índice de envelhecimento (em \%) } & $21,50 \%$ \\
\hline
\end{tabular}

QUADRO 9

Distrito Cidade TIRADENTES POPOULAÇÃO POR NÍVEL DE ESCOLARIDADE Fundação Seade/IBGE 2012

\begin{tabular}{ccc}
$\begin{array}{c}\text { POLULAÇÃO EM } \\
\text { IDADE ESCOLAR }\end{array}$ & $\begin{array}{c}\mathrm{N}^{\circ} \text { DE } \\
\text { HABITANTES }\end{array}$ & \% TOTAL \\
\hline O a 3 anos & 13.541 & $16,48 \%$ \\
\hline 4 a 6 anos & 10.944 & $13,32 \%$ \\
\hline 6 anos & 3.772 & $4,59 \%$ \\
\hline 7 a 10 anos & 16.422 & $19,99 \%$ \\
\hline 11 a 14 anos & 17.686 & $21,53 \%$ \\
\hline 15 a 17 anos & 12.034 & $14,65 \%$ \\
\hline 18 a 19 anos & 7.758 & $9,44 \%$ \\
\hline população total de o a 19 anos & $\mathbf{8 2 . 1 5 7}$ & $\mathbf{1 0 0 , 0 0 \%}$ \\
\hline
\end{tabular}




\section{CONCLUSÃO}

Após mais de quatro décadas de prática em planejamento urbano onde as políticas públicas não culminam em planos urbanos, o Brasil entra na segunda década do século 21 com suas metrópoles enfrentando a mesma questão urbana, agora agravada pela complexidade de suas cidades e da forma de usufruir delas: a localização da moradia, do trabalho, do estudo, do lazer dependente de uma mobilidade urbana comprometida pelos sistemas de transporte público e do esgotamento da capacidade de suporte de suas vias e rodovias.

Conhece-se a história e a evolução urbana, conhece-se o modus operandi do planejamento urbanístico praticado durante décadas, com erros e acertos. Adquiriram-se mais habilidades para o estudo e aprimoramento deste através de novas ferramentas também aprimoradas ao longo do tempo. Pode-se planejar melhor o futuro das cidades brasileiras e deve-se cuidar do meio ambiente e do meio urbano.

Citando o urbanista espanhol Solà-Morales,

Toda a questão está em medir o tempo com o espaço. Como em uma dança em que se descrevem anéis e distâncias no espaço como formas pelas quais representamos o ritmo, os passos do tempo musical em que a concepção urbanística, temos que nos atrever também a medir o tempo sobre o espaço. (Solà-Morales, (1986) 1997, p.19)

O urbanista compara à música a perfeição da métrica do tempo para incorporar sua importância ao projeto urbanístico. Na dança de Solà Morales existem "participantes paralisados que não compreendem os tempos de uma obra urbana, longos demais à miude e confundem o projeto com a construção de uma maquete ou objeto industrial."

Relativisando-se as palavras de Solà Morales com a questão da qualidade urbana paulistana, conclui-se que é inadiável que os planos urbanos alcancem os planos locais como política urbana e não acabem nela, para reparar erros urbanísticos e sociais cometidos em nome de um determinado objetivo que não esteve devidamente fundamentado com o cálculo das possibilidades e limitações de nossos espaços urbanos e por isso, fadado ao fracasso. Mas, a reversão desses processos tão impregnados em nosso planejamento urbano pode ser alcançada congregando-se a técnica à participação das comunidades nas decisões e definições de ações de melhoria para seus bairros ou vizinhanças, democraticamente. 


\section{BIBLIOGRAFIA}

APPLEYARD, Donald. Livable streets, protected neighborhoods. California: University of California Press, 1981.

AUGÉ, Marc. Não-lugares: introdução a uma antropologia da supermodernidade. Maria Lúcia Pereira. (trad.) Campinas: Papirus, 2008.

AZEVEDO, Aroldo. Estudos de geografia urbana. São Paulo: Companhia Editora Nacional/Associação dos Geógrafos Brasileiros: Seção regional de São Paulo, 1958.

BRESSER PEREIRA, Luis Carlos. (1982) Economia brasileira: uma introdução crítica. São Paulo: Editora 34, 1998, $3^{\text {a }}$ edição.

CAMPOS FILHO, Candido Malta. Um desenho para São Paulo: o corredor metropolitano como estrutura urbana aberta para a grande São Paulo. Tese (Doutorado em Planejamento Urbano e Regional). FAUUSP, São Paulo, 1972.

A Grande São Paulo: trabalhos e entrevistas de 1965 a 1973. São Paulo: FAUUSP, 1978.

(1989). Cidades Brasileiras: seu controle ou o caos. São Paulo: Studio Nobel, 2001.

Reivente seu Bairro. São Paulo: Editora 34, 2003
CESTARO, Lucas Ricardo. Urbanismo e humanismo: a SACMACS e o estudo da estrutura urbana da aglomeração paulistana. Dissertação de Mestrado. Escola de Engenharia da USP. São Carlos, 2009 COGEP. Série Políticas Globais 4. São Paulo, 1980. FELDMAN, Sarah. Planejamento e zoneamento de São Paulo: 1847/1972. São Paulo: Edusp/Fapesp, 2005.

FERNANDES, Edésio. (2002) Um novo estatuto para as cidades brasileiras apud OSÓRIO, Letícia Marques. (org.) Estatuto da cidade e Reforma Urbana: novas perspectivas para as cidades brasileiras. Porto Alegre: Sergio Antonio Fabris Editor, 2002, p.7-13.

GEHL, Jan (1971). Life between buildings: using public spaces. Washington: Island Press, 2011.

GOVERNO DE SÃO PAULO. Secretaria dos Transportes Metropolitanos. Montagem e avaliação de um cenário equilibrado para o Desenvolvimento Urbano de São Paulo através de uma estratégia combinada de transporte e uso do solo. São Paulo: FUPAM, 2009.

GRAZIA, Grazia de. (2002) Estatuto da Cidade: uma longa história com vitórias e derrotas apud OSÓRIO, 
Letícia Marques. (org.) Estatuto da cidade e Reforma Urbana: novas perspectivas para as cidades brasileiras. Porto Alegre: Sergio Antonio Fabris Editor, 2002, p.15-37.

JACOBS, Jane. (1961) Morte e vida das grandes cidades. São Paulo: Martins Fontes, 2000.

JARAMILLO, Samuel. (1980) Las formas de produción del espacio construído en Bogotá in PRADILLA, Emilio. (org.) Ensayos sobre el problema de la vivienda en México. Cidade do México: Latina/UNAM, 1982, p.149-212.

LANGENBUCH, Juergen Richard. A estruturação da Grande São Paulo: estudo de geografia urbana. Rio de Janeiro: Instituto Brasileiro de Geografia da Fundação IBCE, 1971.

Modelistica (2007). TRANUS: Integrated Land Use and Transport Modeling System. Disponível em <http://cdn.bitbucket.org/apalala/tranus/downloads/ GeneralDescriptionTranus.pdf $>$. Acesso em 12 jun. 2013

MORGADO, Maria Aparecida e MOTTA, Manoel Francisco de Vasconcelos. (orgs.) Juventude de classe média e educação: cenários, cenas e sinais. Brasília: Líber Livro/EdUFMT, 2006.

NADALIN, Vanessa Gapriotti e IGLIORI, Danilo Camargo. Evolução urbana e espraiamento na Região Metropolitana de São Paulo. Rio de Janeiro: IPEA, 2010.

Plano Diretor Estratégico do Município de São Paulo 2002/2012. Secretaria Municipal de Planejamento Urbano do Município de São Paulo-SEMPLA. (org.) São Paulo: Editora Senac, 2004.
Plano Urbanístico Básico. 1969.

RABAT, Márcio Nuno. A Federação: centralização e descentralização do poder político no Brasil. Brasília: Biblioteca Digital da Câmara dos Deputados, 2002, p.9. Disponível em <http://bd.camara.gov.br/bd/ bitstream/handle/bdcamara/1460/federacao_centralizacao_rabat.pdf?sequence=1>. Acesso em 19 maio 2013.

RODRIGUEZ, Maria Elizabeth Paez. Radial Leste, Brás e Mooca: diretrizes para requalificação urbana. Dissertação (Mestrado em Planejamento Urbano e Regional). FAUUSP, São Paulo, 2006.

ROLNIK, Raquel. A cidade e a lei: legislação, política e territórios na cidade de São Paulo. São Paulo: Studio Nobel/Fapesp, 1997.

SÃO PAULO. (cidade) Secretaria Municipal do Verde e Meio Ambiente. Atlas Ambiental do Município de São Paulo: o verde, o território, o ser humano-diagnóstico e bases para a definição de políticas públicas para as áreas verdes no Município de São Paulo. 2004. Disponível em <atlasambiental.prefeitura. sp.gov.br/?id=7> Acesso em 28 jun. 2013.

SEMPLA. Olhar São Paulo: Contrastes Urbanos, 2008.

SOLÀ-MORALES i Rubió. Manuel de. Las formas de crecimiento urbano. Barcelona: Edicions UPC, 1997.

VILLAÇA, Flávio. Espaço intraurbano no Brasil. São Paulo: Studio Nobel/Fapesp/Lincoln Institute, 1998.

WILHEIM, Jorge. São Paulo Metrópole 65: subsidios para seu plano diretor. São Paulo: Difusão Europeia do Livro, 1965. 
XII Congreso Mundial de la Union Internacional de Arquitectos, 1975, Madrid. Saconia: Dehesa de la Villa (apresentação do projeto). Madrid: Artes Graficas Coimoff, 1975.

\section{PERIÓDICOS}

CASTRO, Ruy. Pelos olhos do cidadão. Folha de S. Paulo, São Paulo, 9 set. 2011. Primeiro Caderno, P.2.

CAMPOS FILHO, Candido Malta. Editorial. Revista Acrópole, n. 356, p.18, nov. 1968.

CERQUEIRA CESAR, Jornal da Tarde, 20 out. 1971 apud FELDMAN, 2005, p.243.

PEQUENO, João. Viagem é até 60\% mais demorada no pico. Folha de S. Paulo, São Paulo, 21 abr. 2008. Caderno Cotidiano, $\mathrm{C}_{4}$ e $\mathrm{C}_{5}$.

\section{ÓRGÃOS CONSULTADOS}

Empresa Planejamento Urbano SA

Instituto Brasileiro de Geografia e Estatística

Instituto de Pesquisa Econômica Aplicada

Metrô

Prefeitura Municipal de São Paulo

Fundação SEADE

Secretaria Municipal de Planejamento

\section{LEGISLAÇÃO}

Brasil. Lei n. 10.257 de 10 de julho de 2001. Estatuto da Cidade. Regulamenta os artigos 182 e 183 da Constituição Federal, que estabelecem diretrizes gerais da política urbana e dá outras providências. Estimulou e orientou a criação de Planos Diretores para municípios com mais 20 mil habitantes no Brasil.

Prefeitura do Município de São Paulo. Elaboração: Sempla/Dipro. Nota: Distritos Lei n. 11.220/19922003. Subprefeituras Lei n. 13.399/2002, alterada pela Lei n. 13.682/2003.

Prefeitura do Município de São Paulo. Legislação. Lei n. 13.885 de 25 de agosto de 2004. Estabelece normas complementares ao Plano Diretor Estratégico, institui os Planos Regionais Estratégicos das Subprefeituras, dispõe sobre o parcelamento, disciplina e ordena o Uso e Ocupação do Solo do Município de São Paulo.

\section{VÍDEOS}

Construyendo la identidad: El Pozo del Tío Raimundo. Delia López Fuentes. Espanha, data desconhecida.

Flores de Luna. Juan Vicente Córdoba. Espanha, 2008. 


\section{VIRTUAIS}

ANELLI, Renato Luiz Sobral. (2007) Redes de Mobilidade e Urbanismo em São Paulo: das radiais/ perimetrais do Plano de Avenidas à malha direcional PUB. Vitruvius: Arquitextos, São Paulo, 07.082 Disponível em <http://www.vitruvius.com.br/ revistas/read/arquitextos/07.082/259>.

Cambridge University. Professor Marcial Echenique OBE MA DArch RTPI RIBA. Disponível em <http:// www.arct.cam.ac.uk/people/me15@cam.ac.uk>. Acesso em 25 maio 2013.

Plano Diretor de Bairro, Branca Flor Itapecerica da Serra. Disponível em <wWw.candidomaltacamposfilho.com.br: Plano de Bairro Branca Flor: http://www.candidomaltacamposfilho.com.br/ PDBBrancaFlor/pdb_brancaflor .html>. Acesso em 28 fev. 2013.

Plano Diretor de Bairro, Distrito de Perus, São Paulo. Disponível em <http://www.candidomaltacamposfilho.com.br/PDBPerus/pdbperusı.html> Acesso em 28 fev. 2013.

Disponível em <http://www. www.candidomaltacamposfilho.com.br/RevisaoPDE/RPDEo1. html>. Acesso em 18 mar. 2013.

CEPAM. Faria Lima. Disponível em <http://www. cepam.sp.gov.br/index.php?option=com_content\&task=view\&id=2\&ltemid=3>. Acesso em 19 maio 2013

Ciclofaixa. Circuitos. Disponível em <http://www. ciclofaixa.com.br/circuitos/>. Acesso em 8 jun. 2013.
Cidades Paulistas. Salesópolis. Disponível em <http://www.cidadespaulistas.com.br/cid/?c=507>. Acesso em 21 jun. 2013

EMPLASA. Emplasa. Disponível em <http://www. emplasa.sp.gov.br/emplasa/empresa/aempresa. asp>. Acesso em 3 jun. 2013.

EMTU. Rede de Transporte: Expresso TiradentesSacomã. Disponível em <http://www.emtu.sp.gov. br/emtu/redes-de-transporte/corredores-terminais/ expresso-tiradentes-sacoma.fss>. Acesso em 25 maio 2013.

FEHR \& PEERS. Traffic Calming: History. Disponível em <http://trafficcalming.org/history/>. Acesso em 8 jun. 2013.

GOVERNO DO ESTADO DE SÃO PAULO. Secretaria de Logística e Transportes. Ações. Disponível em: <http://www.transportes.sp.gov.br/programas-projetos_/acoes.asp>. Acesso em 19 maio 2013

\section{GOVERNO DO ESTADO DE SÃO PAULO/FAUUSP.}

Hidroanel Metropolitano. 2011. Disponível em <http://www.prefeitura.sp.gov.br/cidade/secretarias/ upload/desenvolvimento_urbano/arquivos/arco-tiete/DH-Seminario-ArcoTiete-20130404.pdf>. Acesso em 21 jun 2013.

HOV POD. Hovercraft. (2004) Disponível em <http://www.hovpod.com/index.html>. Acesso em 20 jun. 2013.

PADCO. Housing issues and impacts: a review of the literature and guidelines for rapid assessment of housing projects. Washington, 1981. Disponível em <http://pdf.usaid.gov/pdf_docs/PNAAU150.pdf>. Acesso em fev. 2012. 
PMSP. Legislação. Lei n. 13.872, de 12 de julho de 2004. Disponível em <http://www.prefeitura.sp.gov. br/cidade/secretarias/habitacao/plantas_on_line/ legislacao/index.php?p=10572>. Acesso em 5 jun. 2012.

PMSP. Cepac. Disponível em <http://www.prefeitura. sp.gov.br/cidade/secretarias/desenvolvimento_urbano/sp_urbanismo/cepac/index.php?p=19456>. Acesso em 13 jun. 2013.

PMSP. Concorrência n. 01/2011/SMDU (Edital). Disponível em <http://www.prefeitura.sp.gov. br/cidade/secretarias/upload/chamadas/edital_1310218121.pdf>. Acesso em 18 mar. 2013.

PMSP. Operações Urbanas. Disponivel em <http:// www. prefeitura.sp.gov.br/cidade/secretarias/desenvolvimento_urbano/sp_urbanismo/operacoes_urbanas/index.php? $p=19525>$. Acesso em 20 fev. 2013.

PMSP-SMDU. Arco Tietê. Disponível em <http:// www.prefeitura.sp.gov.br/cidade/secretarias/desenvolvimento_urbano/noticias/index.php? $p=142556$ > . Acesso em 13 abr. 2013.

PMSP. Operação Urbana Consorciada Rio verde-jacu. Termo de referência para contratação de empresa ou consórcio de empresas para elaboração de estudos urbanísticos e estudos complementares de subsídio para atualização da lei n. 13.872/2004 Operação Urbana Consorciada Rio Verde-Jacu. Disponível em <http:// www.prefeitura.sp.gov.br/cidade/secretarias/upload/ chamadas/ouc_rvj_tr_1308775998.pdf>. Acesso em 18 mar. 2013.
Ministério dos Transportes. Barragens e eclusas. Disponível em <http://www2.transportes.gov.br/bit/ O4-hidro/barra-eclu.html> Acesso em 21 jun. 2013. Rastrosdearquitectura. Construyendo la identidad: El Pozo del tio Raimundo. Publicado em 16 abr. 2012. Disponível em <http://rastrosdearquitectura.wordpress.com/2012/04/16/construyendo-la-identidad -el-pozo-del-tio-raimundo/>. Acesso em maio 2013.

São Paulo de Piratininga: de pouso de tropas a metrópole. O Estado de S. Paulo/Editora Terceiro Nome, 2004. CD-ROM.

SEMPLA. Zoneamento da Cidade de São Paulo: Características das Zonas de Uso: Histórico. Disponível em <http://www.prodam.sp.gov.br/sempla/zone.htm>. Acesso em 19 maio 2013. 


\section{DEPOIMENTO}

CAMPOS FILHO. Notas da disciplina Teoria

do Desenvolvimento e do Planejamento (Área:

Estruturas ambientais) no curso de Pós-Graduação

da Faculdade de Arquitetura e Urbanismo da USP,

em 2002.

Depoimento à autora, 5 maio 2012.

Depoimento à autora, 12 out. 2012.

Depoimento à autora, 18 fev. 2013.

Depoimento à autora, 1 mar. 2013.

Depoimento à autora, 4 mar. 2013.

Depoimento à autora, 5 mar. 2013.

Depoimento à autora, 7 mar. 2013.

Depoimento à autora, 12 mar. 2013.

Depoimento à autora, 15 mar. 2013.

Depoimento à autora, 24 maio 2013.

Depoimento à autora, 17 jun. 2013. 


\section{SIGLAS}

ATCP

Assessoria Técnica de Coordenação e Planejamento

ASPLAN

Assessoria em Planejamento S/A

BRT

Bus Rapid Transit

CA

Coeficiente de Aproveitamento

CBTU

Companhia Brasileira de Trens Urbanos

CMTC

Companhia Municipal de Transportes Coletivos

\section{COGEP}

Coordenadoria Geral de Planejamento

COHAB

Companhia de Habitação de São Paulo

CPTM

Companhia Paulista de Trens Metropolitanos de São Paulo

\section{CODEGRAN}

Conselho de Desenvolvimento da Região

Metropolitana da Grande São Paulo

\section{CONSULTI}

Conselho Consultivo Metropolitano de

Desenvolvimento Integrado

\section{EMPLASA}

Empresa Planejamento Urbano SA

FATEC

Faculdade de Tecnologia

FHWA

Federal Highway Administration

\section{GEGRAN}

Grupo Executivo da Grande São Paulo

GEP

Grupo Executivo de Planejamento

GPI

Grupo de Planejamento Integrado

IBGE

Instituto Brasileiro de Geografia e Estatística

IPEA

Instituto de Pesquisa Econômica Aplicada

LRT

Light Rapid Transit

LUOS

Lei de Uso e Ocupação do Solo

OUC

Operações Urbanas Consorciadas

OUC-RVJ

Operação Urbana Consorciada Rio Verde-Jacu

PADCO Inc

Planning and Development Collaborative International

PDDI

Plano Diretor de Desenvolvimento Integrado

PDDT

Plano Diretor de Desenvolvimento de Transportes

PDE

Plano Diretor Estratégico

PMDI

Plano Metropolitano de Desenvolvimento Integrado

PPP

Parceria Publico Privada 
PUB

Plano Urbanístico Básico de São Paulo

RLP

Região Leste Paulistana

$\mathrm{RLP} 1$

Região Leste 1 Paulistana

RLP2

Região Leste 2 Paulistana

RMSP

Região Metropolitana de São Paulo

RFFSA

Rede Ferroviária Federal S/A

FEPASA

Ferrovia Paulista S/A

\section{SAGMACS}

Sociedade para Análises Gráficas e Mecanográficas Aplicadas aos Complexos Sociais

Fundação SEADE

Fundação Sistema Estadual de Análise de Dados

\section{SECOVI}

Sindicato da Indústria da Construção Civil

\section{SEHAB}

Secretaria Municipal de Habitação

SEMPLA

Secretaria Municipal de Planejamento

SERFHAU

Serviço Federal de Habitação e Urbanismo

Secretaria de Estado dos Negócios Metropolitanos

SPAM

Sistema de Planejamento e Administração

Metropolitana

STU/SP

Superintendência de Trens Urbanos de São Paulo
TAV

Trem de Alta Velocidade

TO

Taxa de Ocupação

UAM

Unidade Ambiental de Moradia

VLT

Veículos Leves sobre Trilhos

ZRA

Zona de Reserva de Área 
MAPAS

\section{ApresentaçÃo}

Mapa 1: Regiões, Subprefeituras e DistritosMunicípio de São Paulo 2009 (p.3)

PMSP/SEMPLA/Dipro

Mapa 2: Uso do Solo Predominante-Distritos de São Paulo 2010 (p.8) (Secretaria Municipal de Finanças/Dep. de Rendas Imobiliárias-PGV 2005 Agregação por Quadra Fiscal e TCPL 2005. IBCE Censo 2000

Mapa 3: Taxa de crescimento anual da populaçãoMunicípio de São Paulo 1991/2006 (p.14)

IBGE, Censos 1991 e 2000, SEMPLA/DIPRO,

Estimativa populacional para 2005

Mapa 4: Segmentos sociais mais vulneráveis (p.15) Região Leste do Município de São Paulo

SEADE. Índice paulista de vulnerabilidade social, 2005

Mapas 5 a 7: Empregos formais segundo setor de atividade 2004 (p.17)-Indústria, Comércio e Serviço Ministério do Trabalho e Emprego. Rais, 2004

Mapa 8: Área para análise territorial na Região Leste Paulistana (p.24)

Região Leste, rodoferrovias, Operações Urbanas.

Montagem sobre ortofoto GoogleEarth 2013

\section{Capítulo}

Mapa 9: Plano de Bairro de Perus-Síntese das diretrizes estruturais (p.6o)

Candido Malta Campos Filho (Acervo pessoal do autor)

Mapa 10: Plano de Bairro de Perus-Diretrizes para o anel viário e sua envoltória AIU-11 (p.60)

Candido Malta Campos Filho (Acervo pessoal do autor)

Mapa 11: Plano de Bairro de Perus-UAMs (p.61) Candido Malta Campos Filho (Acervo pessoal do autor)
Mapa 12: Plano de Bairro de Perus-Detalhamento AIU 2 (p.61)

Candido Malta Campos Filho (Acervo pessoal do autor)

\section{Capítulo II}

Mapa 13: Arredores da cidade de São PauloMovimento pendular por trem (p.70)

Langenbuch, 1971, Encarte

Mapa 14: Caminhos e ferrovias do século XIX (p.75) tentativa de reconstrução cartográfica Langenbuch, 1971, Encarte

Mapa base: Carta dos Excursionistas - Primeira

Secção, Comissão Geográfica e Geológica, 1923

Mapa 15: Caminhos e ferrovias do séc. XIX sobre a GSP 1961 e RMSP 1973 (p.77) montagem sobre Langenbuch, 1971, Encarte

Mapa 16: Arredores da cidade de São Paulo-Colônias oficiais 1875/1900 (p.78)

Langenbuch, 1971, Encarte

Mapa 17: Planta geral da cidade de São Paulo 1897 (p.80)

Comissão do IV Centenário da cidade de São

Paulo-Plantas da cidade de São Paulo, 1954

Mapa 18: Loteamento da Vila Prudente-primeiros proprietários (p.80)

Disponivel em <http://lemad.fflch.usp.br/

node/354>. Acesso em 1 jun. 2013

Mapa 19: Expansão da área arruada da cidade de São Paulo 1881/1914 (p.81)

montagem sobre Planta Ceral da Cidade 1897

Mapa 20: Levantamento topográfico do Parque São Jorge e entorno 1930-Sara Brasil (det.) (p.81) PMSP. Sara Brasil S/A Mapa topográfico do município de São Paulo; Sr. Dr. Prefeito José Pires do Rio, Diretor de Obras Eng. Arthur Saboya, 1930 
Mapa 21: Levantamento viário de São Paulo 1952Falk (p.82)

Cia. Melhoramentos, 1952, 3a edição. Projeção

hiperbolóide com rede quilométrica

Mapa 22: Arredores de São Paulo-ônibus urbanos intermunicipais 1965 (p.85)

Langenbuch, 1971, Encarte

observações efetuadas pela autora

Mapa 23: Evolução do espraiamento em São Paulo até 2002 (p.89)

PMSP, SEMPLA

\section{Capítulo III}

Mapas 24 a 29: Comparação da área urbanizada de São Paulo com a de outras metrópoles: Chicago, Londres, Paris, Tóquio e Moscou 1965 (p.96 e 97) PUB, 1969

Mapa 30: Distribuição da população e do emprego 1965 (p.103)

PUB, 1969, p.70

Mapa 31: Distribuição proposta da população e do emprego-Modelo 2 (p.103)

PUB, 1969, p.71

Mapa 32: Linhas expressas de ônibus urbanos propostas e terminais de embarque (p.112)

Governo de São Paulo. Programa de acção

imediata de transportes e tráfego-PAITT, 1971.

Redesenhado com inclusão da RLP

Mapa 33: Diretrizes de Estrutura Urbana (p.118)

COGEP, Série Políticas Globais, 1980, Mapa 6: Diretrizes de

Estrutura Urbana-Área preferencial de adensamento 1980

Mapa 34: Rede Viária Estrutural (p.122)

PDE 2002/2012, Mapa 2 (det.)

Mapa 35: Centralidades Polares e Lineares na RLP (p.123)

PDE 2002/2012, Mapa 4 (det.)

\section{Capítulo IV}

Mapa 36: Localização da RLP em São Paulo e na RMSP (p.130)

MEPR, 2013

Mapa 37: Pitu 2025 (p.133)

Governo de São Paulo. STM/CPG, 2006
Mapa 38: Hidroanel Metropolitano-Integração com Rodoanel e Ferroanel (p.137)

Governo de São Paulo/FAUUSP, Grupo Metrópole Fluvial

Mapa 39: Projetos e Operações Urbanas (p.151)

PMSP/SMDU, 2013

Mapa 40: OUC-RVJ Setores/Macrozoneamento

(p.152)

PMSP/SMDU, 2013

Mapa 41: OUC-RVJ recorte territorial oficial (p.157) MEPR, 2013

Mapa 42: OUC-RVJ Recorte territorial proposto alternativo 1 (p.159)

MEPR, 2013

Mapa 43: OUC-RVJ Recorte territorial proposto alternativo 2 (p.159)

MEPR, 2013

Mapa 44: OUC-RVJ recorte territorial proposto alternativo 3 (p.161)

MEPR, 2013

\section{CApítulo V}

Mapa 45: Cortiços e loteamentos irregulares 2006 (p.176)

PMSP. Cadastro Unificado SEHAB/COHAB/

CDHU; SEHAB/RESOLO 2006

Mapa 46: Transportes coletivos (p.180)

PMSP. SEMPLA/DIPRO/IBGE. Transportes

coletivos 2004. Censo 2000

\section{CAPÍtulo VI}

Mapa 47: Cidade Tiradentes-LUOS (p.208) PMSP/SEMPLA. PDR-Cidade Tiradentes, 2004

Mapa 48: Cidade Tiradentes-Uso e Ocupação do Solo Emplasa (p.212)

EMPLASA, EMPLASAGEO, UITS

Mapa 49: Cidade Tiradentes-Mapa Digital da Cidade (p.214)

PMSP, 2013

Mapa 50: Cidade Tiradentes-BFSP/Guia Cartoplan (p.214)

Cartoplan, 2013 
FIGURAS

\section{Apresentação}

Figura 1: Cenário ocorrido entre 1950 e 2010 (p.6) MEPR, 2013

Figuras 2 a 12: Estações de trem e terminais de ônibus das Regiões Sul e Leste de São Paulo (p.26)

Baixa acessibilidade, desconforto e falta de ambientes de

estar em espaços públicos de circulação. MEPR, 2012

Figura 13: Estação Guaianases CPTM (p.26) loão Paulo Chagas

\section{CAPÍtulo}

Figura 14: Conceito 1-Agregação de propostas parciais (p.34)

Campos Filho, 1972

Figura 15: Conceito 2-Corredores Metropolitanos (p.34)

Campos Filho, 1972

Figura 16: Conceito 3-PUB (p.34)

Campos Filho, 1972

Figura 17: Sistema viário centro expandido (p.35) Campos Filho, 1972

Figura 18: Periculosidade por nivel de tráfego

(p.48)

Appleyard, 1981, p.17

Figura 19: Relacionamento de vizinhança por nível de tráfego (p.49)

Appleyard, 1981, p.21

Figura 20: Extensão do lar no espaço urbano por nível de tráfego (p.50)

Appleyard, 1981, p.23
Figura 21: Antes dos impactos do tráfego (p.52)

Appleyard, 1981, p.29

Figura 22: Impactos da intrusão do tráfego (p.52) Appleyard, 1981, p.30

Figura 23: Soluções para adaptação aos impactos (p.52)

Appleyard, 1981, p.30

Figura 24: TRANUS-exemplo de apresentação de rotas num SIG (p.56)

Modelistica, 2007, p.22

Figura 25: Tipos básicos de Macrorregiões na Metrópole de São Paulo (p.57)

Campos Filho, 1972, p.16

Figuras 26 a 43 (exceto 27 e 33): El Pozo del Tío Raimundo (p.64 a 66)

Disponíveis em em <http://rastrosdearquitectura. wordpress.com/2012/04/16/construyendo-la-identidad el-pozo-del-tio-raimundo/>. Acesso em maio de 2013

Figuras 27: O poço que deu nome ao bairro (p.63) Disponivel em <http://www.flickr.com/photos/7299278@ No5/423434333/>. Acesso em maio de 2013

Figura 33: El Pozo del Tío Raimundo-localização (em azul) (p.64)

Google Maps, maio 2013

Figuras 44 a 52: Saconia (p.67 a 68) (p.67)

XII CONGRESO..., 1975, passim

\section{CApítulo II}

Figuras 53 a 57: São Paulo antiga 1860/1930 (p.76) São Paulo de Piratininga..., 2004

Figura 58: Linha de bonde em construção (p.76) Acervo Eletropaulo 
Figuras 59 a 62: Antigas estações de ferroviárias em cidades dos arredores de São Paulo (p.76)

Disponivel em <http://www.flickr.com/photos/7299278@

No5/423434333/>. Acesso em 18 maio de 2013

Figura 63: Estação Ferroviária de Mogi das Cruzes (p.78)

Autor indefinido. Data incerta. Disponivel em $<w w w$. estacoesferroviarias.com.br/m/mcruzes $/ \mathrm{htm}>$. Acesso em 1 ju. 2013

Figuras 64 a 66: Ortofotos das áreas de mananciais ocupadas ao sul do Município de São Paulo (p.90) Google Earth, 2013

Figura 67: Detalhe do mapa de zoneamento do Plano Diretor Regional da Subprefeitura de Capela do

Socorro (p.90)

PMSP. Subprefeitura de Capela do Socorro. Mapa 4. Disponível em <http://www.prefeitura.sp.gov.br>. Acesso em 2 jun. 2013

\section{Capítulo III}

Figura 68: Acesso à Estação do Metrô Vergueiro (p.125)

MEPR, 2013

Figura 69: Ciclovia na Av. Faria Lima (p.125) MEPR, 2013

Figuras 70 e 71: Faixas exclusivas para pedestres e para ciclistas na Brooklin Bridge, NY, EUA (p.126) Mashcare/Farm 2, Flicker

Figura 72: Ponte estaiada (p.127)

Fernando Donasi, Folha Imagem

Figura 73: Sinalização no acesso à ponte estaiada (p.127)

André Pasqualini

\section{Capítulo IV}

Figura 74: Rede de transporte Metropolitano 2014 (p.132)

Metrô, 2013

Figura 75: Eclusa entre rios Pinheiro e Tietê (p.138) FAUUSP, Grupo Metrópole Fluvial, 2011

Figura 76: Triportos, Transportos e Ecoportos (p.139)

FAUUSP, Grupo Metrópole Fluvial, 2011
Figura 77: Projeto Várzeas do Tietê (p.140)

Governo de São Paulo/FAUUSP, 2011

Figura 78: Eclusa da Penha (p.140)

Governo de São Paulo/FAUUSP, 2011

Figura 79: Arco do Futuro-Arco Tietê em evidência

(p.147)

PMSP/SMDU, 2013

Figuras 80 a 82: Complexo Viário Jacu Pêssego-Nova Trabalhadores (p.148)

Disponíveis em <http://www.geometrica.com.br/portfolio/ projeto/complexo-viario-jacu-pessego/33><http://www dersa.sp.gov.br/empresa/jacupessego_tipo.asp $>$. Acesso em 18 maio 2013. <http://www.saopaulo.sp.gov.br/spnoticias/ lenoticia. php $? \mathrm{id}=216789 \& \mathrm{c}=5356$ > . Acesso em 6 jun. 2013

Figura 83: OUC-RVJ • Polos institucional, Tecnológico e Econômico (p.154)

\section{CAPítulo V}

Figura 84: Composição da CPTM sob o viaduto Aricanduva, em São Paulo (p.177)

Disponível em <www.skyscrappercity.com>. Acesso em abr. 2012

Figuras 85 a 88: Exemplos de análise de tipologias de tecido (p.178)

Google Earth, 2013

\section{CAPÍtulo VI}

Figura 89: Ilhas de Tranquilidade esquema (p.191) Campos Filho, 2003, p.23

Figura 90: Cidade Tiradentes-Ortofoto (p.210) Google Earth, 2013

Figuras 91 a 96 (p.211)

Google Earth, 2013

Figuras 97: Região Leste Paulistana-sobrevôo (p.213)

MEPR, 2013

Figuras 98 e 99: Levantamento oficial e ortofoto real (p.213)

PMSP, Mapa Digital da Cidade/Google Earth 